\title{
China:
}

\section{new engine of}

world growth 



\section{China:}

\section{new engine of world growth}

Ross Garnaut and

Ligang Song (editors)

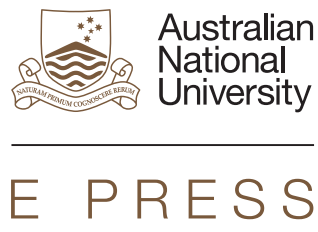




\section{ANU \\ E PRESS}

Published by ANU E Press

The Australian National University

Canberra ACT 0200, Australia

Email: anuepress@anu.edu.au

This title is also available online at http://epress.anu.edu.au

National Library of Australia Cataloguing-in-Publication entry

Title: China : new engine of world growth / Ross Garnaut and Ligang Song, editors.

ISBN: 9781922144546 (pbk.) 9781922144553 (ebook)

Subjects: Commerce.

China--Commerce.

China--Economic conditions--1976-2000..

China--Economic policy--1976-

Other Authors/Contributors::

Garnaut, Ross.

Song, Ligang.

Dewey Number: 330.951

All rights reserved. No part of this publication may be reproduced, stored in a retrieval system or transmitted in any form or by any means, electronic, mechanical, photocopying or otherwise, without the prior permission of the publisher.

Book and cover design by Jude Shanahan

Printed by Griffin Press

First published by Asia Pacific Press, 2003

This edition $\odot 2012$ ANU E Press 


\section{Contents}

Tables

vii

Figures

$x$

Boxes

xii

Symbols

xiii

Abbreviations

xiii

Contributors

xvii

Macroeconomic performance and new challenges

1 China: new engine of world growth

Ross Garnaut

2 The impact of SARS

Jong-Wha Lee and Warwick J. McKibbin

3 The travails of current macroeconomic and exchange rate management

Wing Thye Woo

4 The changing pattern of economic growth

Yiping Huang

Financial system reform: an unfinished task

5 Transforming the banking sector

Yiping Huang

6 Financial opening and eocnomic growth: a quantitative assessment

94 Jordan Shan

7 Rural financial markets and institutions: new developments

Enjiang Cheng

Foreign trade, trade policy and FDI

8 Entry into the WTO: commitments and implementation

Geoff Raby

9 WTO commitment: further marketisation and trade liberalisation

Jiadong Tong

10 A changing role in world trade 
11 China and the world economy: the FTA strategy

Christopher Findlay

Sectoral impact and policy adjustment

12 Location determinants and provincial distribution of FDI

Chen Chunlai

13 The impact of urbanisation on economic growth Xiaolu Wang and Ronald Duncan

14 Trade reform, macroeconomic policy and sectoral labour movement Jennifer Chang and Rod Tyers

15 Internet development

Fang-Fang Tang

Income distribution and social security

16 Accession to WTO and foreign pharmaceutical firms'

business opportunities

Yifeng Wu

17 Political capital and wealth accumulation

Meng Xin

18 Reforms and challenges of the social security system

Qun Shỉ

\section{Enterprise reform and regional development}

19 The National Social Security Fund Tim Murton

20 Building modern enterprises: challenges and requirements Mei Wen

21 Challenges facing small private enterprises

\section{Kim Houghton and lan Davies}

22 Industrial location and regional development

Jane Golley

23 Government transfer payments and regional development

Tingsong Jiang and Zhiyun Zhao

\section{China's role in the world}

24 A new engine for pragmatism in the international security order? 


\section{TABLES}

1.1 Output growth and inflation performance in China, 1979-2003 4

2.1 Cumulative number of reported probable cases of SARS, 2003 21

2.2 Health expenditure and sanitation indicators for selected countries 22

2.3 Chronology of SARS and major responses by the Chinese government, November 2002-July $2003 \quad 24$

2.4 Percentage change in GDP in 2003 due to SARS, 1993-2003 28

2.5 Forecasts for China's GDP growth 30

3.1 Employment in China's industries, 1978-2001 39

3.2 Growing fiscal spending $\quad 42$

3.3 Investment trends by ownership 45

3.4 Rising fragility of China's banking sector 47

3.5 Contingent liabilities in China, end of $2001 \quad 50$

4.1 Investment by the state and non-state sectors 66

4.2 China and Asian economies: growth of GDP components and investment-GDP ratio 69

4.3 Contingent liabilities $\quad 69$

4.4 Selected Asian economies, long-term growth potential 77

4.5 Citigroup estimates of long-term growth potential, selected Asian economies 77

5.1 China committed to open up banking sector after WTO accession 84

5.2 Estimated contingent liabilities for China 84

5.3 The new policy framework for banking reform 86

5.4 Loan provisioning standards for Chinese banks 87

6.1 Variance decomposition percentage of 36-month error variance 103

$\begin{array}{ll}6.2 \text { Granger causality test } & 106\end{array}$

7.1 Changes in rural deposit savings and loans 113

7.2 Changes in real institutional rates of interest 115

9.1 Imports and exports by different types of enterprise, $2002 \quad 145$

9.2 Selected Chinese tariff rates prior to WTO accession, 1987-2000 147

10.1 Shifting patterns of export specialisation in selected industrial sectors, 1970-2000 154

10.2 Foreign direct investments in China, 1980-2002 156

12.1 Actual FDI inflows into China, 1979-2002 190

12.2 Actual FDI inflows into China's provinces, 1983-2002 193 
12.3 Accumulated FDI stock in China's provinces, 1983-2002 196

12.4 List of variables of provincial FDI inflow equation 205

12.5 Regression results of provincial FDI inflow equation 208

12.6 Provincial FDI attractiveness index 211

13.1 Growth of the agricultural sector and rural population in the pre-reform and reform periods, 1952, 1978 and 2002

13.2 Agricultural sector, share of GDP, employment and population, 1952-2002 218

13.3 Agriculture as a source of rural income, 1990-2002 220

13.4 Rural-urban income disparity, 1980 and $2000 \quad 220$

13.5 Modelling results: urbanisation and economic growth 227

14.1 Official price level changes since the Asian crisis 241

$\begin{array}{ll}14.2 \text { Model structure } & 247\end{array}$

14.3 Chinese equivalent import tariff and export tax rates 250

14.4 Ancillary effects of WTO trade reforms 252

14.5 Simulated long-run effects of a unilatera/ liberalisation of China's 2001 trade policy regime 253

$\begin{array}{ll}\text { 14.6 Short-run closure } & 255\end{array}$

14.7 Simulated short-run effects of a unilateral liberalisation of China's 2001 trade policy regime: by macroeconomic policy regime 258

14.8 Comparing simulated trade reform-driven labour relocation demand with historical experience $\quad 264$

A14.1 Chinese labour relocation $\quad 275$

15.1 Growth of networked computers 282

15.2 International bandwidth distribution 282

15.3 Distribution of domain names under ' $C N$ ' 283

15.4 Growth of online users 284

15.5 Demographics of online users 285

15.6 Education level of online users 286

15.7 Geographic distribution of online users 287

15.8 Methods of financing online access 288

15.9 Monthly income distribution of online users 290

15.10 Main location of going online 292

15.11 Time of usual online use 293

15.12 Hardware used to go online 293 
15.13 Main purpose for going online 295

15.14 Type of information users read online 296

15.15 User perception of important problems of online transactions 296

15.16 Goods or services purchased online $\quad 297$

15.17 Proportion of users who purchased 298

16.1 Structure of the Chinese pharmaceutical industry in $2000 \quad 303$

16.2. Research and development expenditures, of large and medium-sized pharmaceutical enterprises $\quad 305$

16.3 International trading competitiveness indices of chemical raw medicines and pharmaceutical products $\quad 307$

16.4 Price indices of chemical raw medicines and pharmaceutical $\begin{array}{ll}\text { products } & 308\end{array}$

16.5 Number of patent applications in the field of medicine 311

17.1 Summary statistics and inequality measures of real income and wealth, 1995 and $1999 \quad 319$

17.2 Effect of housing reform on housing ownership, 1988-99 319

17.3 Determinants of net total wealth, 1995 and $1999 \quad 323$

17.4 Determinants of financial wealth, 1995 and 1999

17.5 Determinants of net housing wealth, 1995 and 1999

17.6 Direct and indirect effects of unemployment and party membership on wealth

18.1 Employment structure by ownership in urban China, 1980-99 332

18.2 Number of retrenched workers of SOEs, 1997-2001 333

18.3 Summary of Chinese unemployment insurance reforms in the 1980s and 1990s 335

18.4 A summary of public pension reforms in the 1980s and 1990s 336

18.5 Retiree/employee ratios by ownership structure in China, 1982-98 337

18.6 Selected aggregate figures for the UMLS program, 1998-2002 340

18.7 Contributions, employment and replacement rate of pensions 346

21.1 Siying Qiye and Getihu in Harbin and Qingdao, 2002

21.2 Responses by business type and survey mode 391

21.3 Distribution of respondents by industry and legal structure, by city 391

21.4 Age of businesses, by city 392

21.5 Average hours worked per day, by legal structure 392

21.6 Sources of start-up capital, by city 394 
21.7 Registered capital, by legal structure, Siying Qiye

21.8 Main barriers in starting up businesses, by city

21.9 Use for expansion capital in next 12 months, by city

21.10 Sources of expansion capital, by city

21.11 Difficulties expected in accessing expansion capital, by city

21.12 Business skills sought in next 12 months, by city

21.13 Preferred skills training delivery modes, by city

22.1 NRC, SC and LC combinations

22.2 Rankings of GDP growth, GVIO shares and changes in per capita GDP

22.3 Gini coefficients

22.4 NRCs, SCs and types for each province and sector

22.5 Summary of types

23.1 Composition of local government revenues by region, 2001

23.2 Coefficients of variation for per capita revenue and expenditure across provinces, 1982-92

23.3 Trends in the inter-regional distribution of fiscal resources, 1990-2001

23.4 Summary of simulations

23.5 Simulation results of increasing transfer payments to inland regions

\section{FIGURES}

2.1 Impacts on China of temporary versus permanent SARS shock

3.1 Credit conditions

3.2 Consumption and investment growth

4.1 Annual GDP growth, China, Hong Kong, Taiwan, Korea, Japan and India

4.2 Average shares of various components of GDP

4.3 Contributions to GDP growth of various components

4.4 High investment growth and rising investment-GDP ratio

4.5 Annual GDP growth and share of TFP in GDP growth, 1997-2002

4.6 China's fiscal deficits, 1997-2002, 1997-2002

4.7 Growth of inventories by industry, end April 2003

4.8 Retail sales, 1994-2003

4.9 Bank deposits, 1998-2003 
4.10 Consumer Price Index and money supply (M2) growth 80

6.1 Growth of GDP, credit and investment in China 96

6.2 Credit and investment in GDP in China 96

6.3 EG responses to a 'shock' in TC, LAB, INV and TRADE 105

6.4 TC responses to a 'shock' in EG, LAB, INV and TRADE 106

10.1 China's average tariff rate, 1986-2003 153

10.2 Major countries' share in world trade, $2002 \quad 158$

10.3 Destination of Chinese exports, $2003 \quad 158$

10.4 Change of export markets, 1980-2001 159

10.5 Source of Chinese imports, $2003 \quad 159$

10.6 Changes in import sources, 1980-2001 160

10.7 Trends in export composition, 1965-2000 161

10.8 Composition of exports, $2000 \quad 162$

10.9 Composition of imports, $2000 \quad 163$

10.10 Trends in import composition, 1965-2000 163

10.11 Share of labour-intensive products in total exports, 1970-2000 165

10.12 China's cumulative exports, 1965-2000 166

10.13 Changes in export composition and specialisation, 1965-2000 167

10.14 Changing share of some East Asian economies in total labour-intensive manufactured exports, 1970-2000 168

12.1 Actual FDI inflows into China, 1979-2002 190

12.2 FDI inflows into China, by region, 1984-2002 197

12.3 FDI stocks in China, by region, 1983-2002 197

13.1 Relationship between rural industrialisation and rural income, $2000 \quad 223$

13.2 Relationship between urbanisation and rural household income, 2000226

14.1 Per capita annual income of urban and rural households 234

14.2 Gap between urban and rural incomes, 1978-2001 236

14.3 Employment by industry group, 1990-2001 238

14.4 Official growth rate of real GDP, 1990-2001 240

14.5 Official growth rate of the average real manufacturing wage, 1996-2001 241

14.6 The domestic capital market without capital controls 248

14.7 The domestic capital market with capital controls 248

14.8 Trade reform with capital controls 262

14.9 Trade reform without capital controls 263

15.1 Average hours online per week 292 
15.2 Time users usually go online

15.3 Number of people using mobile devices and info home appliances to access internet

16.1 Output of chemical raw medicines and traditional Chinese medicines

16.2 Growth rates of net asset profits and output value, pharmaceutical and total industry

302

16.3 Imports and exports of Chinese medicines

304

16.4 Medicine patents in China: proportion granted to foreign applicants

17.1 Lorenz curves of wealth

17.2 Net wealth distribution by percentile of permanent income

17.3 Actual and predicted net total wealth by income percentile 326

18.1 Expenditure of major social security programs in China, 1999

18.2 World population aging, 1950-2050

18.3 The UN projected old-age dependency ratio and the PAYGO tax rate

18.4 Optimal payroll tax rate between 2001-50 to pay off historical pension debts up to 2000 , but not beyond

19.1 Reporting structure of the National Social Security Fund

19.2 Funding of the National Social Security Fund

22.1 Pattern of agglomeration

23.1 Per capita GDP, 1978-2000

23.2 Composition of transfer payments by region, 2001

23.3 The relationship between regional income and transfer payments, 2000

23.4 Provincial average tax rate versus per capita GDP, 2001

23.5 Regional average tax rate, 2001

23.6 Structure of CERD

23.7 National migrant labour market

\section{BOXES}

19.1 Qualifying conditions to manage funds in the NSSF 
CSRC China Securities Regulatory Commission

DFN Deutsche Forschungsnetz [German Research Network]

DPP Democratic Progressive Party

EEFSU Eastern Europe and the former Soviet Union

EEM electronic equipment and machinery

ETE electronic and telecommunications equipment

FDI foreign direct investment

FPC Funding the Poor Cooperation

FTA Free Trade Agreement

GATT General Agreement on Tariffs and Trade

GDP gross domestic product

GLS generalised least squares

GTAP Global Trade Analysis Project

HRS Household Registration System

HSBC Hong Kong and Shanghai Banking Corporation

ICBC Industrial and Commercial Bank of China

LDC less developed country

LIR labour insurance regulations

MCA Ministry of Civil Affairs

MFI microfinance institution

MFN most-favoured nation

MNE multinational enterprise

MOF Ministry of Finance

MOFERT Ministry of Foreign Economic Relations and Trade

MOFTEC Ministry of Foreign Trade and Economic Cooperation

NBS National Bureau of Statistics

NGO non-governmental organisation

NATO North Atlantic Treaty Organisation

NIE newly industrialised economy

NPC National People's Congress

NPL non-performing loans

NRC net relative change

NSSF National Social Security Fund

NYSE New York Stock Exchange 


\section{SYMBOLS}

.. not available

n.a. not applicable

zero

insignificant

\section{ABBREVIATIONS}

$\begin{array}{ll}\text { ABC } & \text { Agricultural Bank of China } \\ \text { ADB } & \text { Asian Development Bank } \\ \text { ADBC } & \text { Agricultural Development Bank of China } \\ \text { AEC } & \text { ASEAN Economic Community } \\ \text { AMC } & \text { asset management corporation } \\ \text { APEC } & \text { Asia Pacific Economic Cooperation } \\ \text { ASEAN } & \text { Association of Southeast Asian Nations } \\ \text { BOC } & \text { Bank of China } \\ \text { BVAR } & \text { Bayesian vector autoregression } \\ \text { CANET } & \text { China Academic Network } \\ \text { CAR } & \text { capital adequacy ratio } \\ \text { CBC } & \text { Construction Bank of China } \\ \text { CBRC } & \text { China Banking Regulatory Commission } \\ \text { CERD } & \text { Chinese economy with regional details } \\ \text { CES } & \text { constant elasticity of substitution } \\ \text { CESG } & \text { cultural, educational and sports goods } \\ \text { CET } & \text { constant elasticity of transformation } \\ \text { CGAP } & \text { Consultative Group to Aid the Poorest } \\ \text { CIA } & \text { Central Intelligence Agency } \\ \text { CNY } & \text { Chinese yuan } \\ \text { CNNIC } & \text { China Internet Network Information Centre } \\ \text { CPC } & \text { Communist Party of China } \\ \text { CPI } & \text { consumer price index } \\ \text { CRN } & \text { China Research Network }\end{array}$


OECD Organisation for Economic Cooperation and Development

PAYGO pay-as-you-go

PBOC People's Bank of China

PECC Pacific Economic Cooperation Council

PEO Pacific Economic Outlook

$\mathrm{PPI} \quad$ producer price index

PRC People's Republic of China

RCA revealed comparative advantage

RCC rural credit cooperative

RCCU Rural Credit Cooperative Union

RCF rural credit foundation

RFI rural financial institution

RIETI Research Institute of Economy, Trade and Industry

RMB Renminbi

RPI retail price index

RPS rural postal savings

SARS Severe Acute Respiratory Syndrome

SASAC State-Owned Asset Supervision and Administration Commission

SCO Shanghai Cooperative Organisation

SCORES China Society for Research on Economic Systems

SITC Standard International Trade Classification

SME Small and medium enterprise

SEZ special economic zone

SOB state-owned bank

SOCB state-owned commercial bank

SOE state-owned enterprise

SSF social security fund

TFP total factor productivity

TIFA Trade and Investment Framework Agreement

TRQ tariff-rate quota

TVE township and village enterprise

UHIDS Urban Household Income Distribution Survey

UMLS Urban Minimum Living Security Program

UNCTAD United Nations Conference on Trade and Development 
VAR vector autoregression

VAT value added tax

VECM vector error correction model

WHO World Health Organization

WTO World Trade Organization

XUAR Xinjiang Uighur Autonomous Region 


\section{Contributors}

Greg Austin is Principal Research Fellow at the Centre for International Cooperation and Security, Department of Peace Studies, Bradford University.

Jennifer Chang researches at the School of Economics in the Faculty of Economics and Commerce at The Australian National University.

Enjiang Cheng is a Senior Research Fellow at The Centre for Strategic Economic Studies, The Victoria University of Technology, Melbourne.

Chen Chunlai is a lecturer at The Asia Pacific School of Economics and Government, The Australian National University.

lan Davies is an international business consultant specialising in development cooperation and a former United Nations diplomat.

Ronald Duncan is Emeritus Professor at the School of Economics, The Australian National University, and Executive Director of the Pacific Institute of Advanced Studies in Development and Governance, University of the South Pacific.

Christopher Findlay is Professor of Economics in the Asia Pacific School of Economics and Government, The Australian National University.

Ross Garnaut is Professor of Economics at the Research School of Pacific and Asian Studies, The Australian National University, and Chairman of the China Business and Economy Program, The Australian National University.

Jane Golley is a Lecturer in the Faculty of Economics and Commerce, The Australian National University.

Kim Houghton is the Director of Strategic Economic Solutions, a consulting company specialising in regional and small business development.

Yiping Huang is the Chief Economist for Greater China at Citigroup.

Tingsong Jiang is a Senior Economist at the Centre for International Economics. Jong-Wha Lee is a Professor at Korea University and The Australian National University. 
Warwick J. McKibbin is a Professor of International Economics in the Economics Division, Research School of Pacific and Asian Studies, The Australian National University and a Senior Fellow at The Brookings Institution.

Xin Meng is a Fellow with the Department of Economics at the Research School of Pacific and Asian Studies, The Australian National University.

Timothy Murton is Assistant Director of Capacity Building in the International Branch of the Australian Department of Family and Community Services.

Geoff Raby is First Assistant Secretary of the International Organisations and Legal Division of the Department of Foreign Affairs and Trade.

Jordan Shan is an Associate Professor in the Faculty of Business and Law, Victoria University, and also holds a Professorship at Guanghua School of Management, Peking University.

Qun Shi is a Postdoctoral Research Fellow at the School of Economics, Faculty of Economics and Commerce, The Australian National University.

Ligang Song is a Fellow at the Australia-Japan Research Centre, Asia Pacific School of Economics and Government, The Australian National University and Director of the China Economy and Business Program at The Australian National University.

Sizhong Sun is a Visiting Fellow in the Asia Pacific School of Economics and Government, The Australian National University, and also holds a position at the Department of International Trade at Xiamen University.

Fang-Fang Tang is an Associate Professor of Marketing at the Chinese University of Hong Kong.

Jiadong Tong is a Professor at the School of Economics in Nankai University.

Rod Tyers is Professor of Economics, Faculty of Economics and Commerce, The Australian National University.

Xiaolu Wang is the Deputy Director of the National Economic Research Institute at The China Reform Foundation and a Research Fellow at the National Centre for Development Studies, The Australian National University.

Mei Wen is a Research Fellow with the Division of Economics, in the Research School of Pacific and Asian Studies, The Australian National University. 
Wing Thye Woo is a Professor in the Economics Department, The University of California

Yifeng Wu is a Professor at the School of Business, China Pharmaceutical University, Nanjing, China.

Zhiyun Zhao is Director of the Research Centre for Finance and Taxation at the Chinese Academy of Social Sciences, Beijing. 



\section{1 \\ China: new engine of world growth}

\section{Ross Garnaut}

China is now the centre of attention for international business. For the main global producers of travel and financial services, resources, electronic products, aeroplanes and machines, the annual reports this year contain statements about the importance of the China market to growth.

There is good reason for the focus on China. Since the eve of financial crisis in Korea and much of Southeast Asia in 1996, China has contributed one quarter of global growth in output and international trade. In the sluggish world economy since the Clinton-era boom in the United States ended in late 2000, China has contributed the whole of the global expansion in international trade. Over these years it has supplanted the United States as the world's largest recipient of direct foreign investment, with annual levels exceeding US $\$ 50$ billion.

These are immediate causes of the current international excitement about China. More important than these indicia of recent relative success, however, is an older reality. Over the quarter century since Deng Xiaoping won decisive control of the Central Committee of the Chinese Communist Party and moved policy decisively towards reform and opening to the outside world in 1978, economic output and international trade have expanded much more rapidly in China than in any other country, even through periods of exceptional prosperity in Asia, North America and Australasia.

These last half dozen years have been but one stage in what is inevitably a long and difficult Chinese journey towards the emergence of a productive modern economy. The last half dozen years have actually seen the lowest average growth for any 
period of comparable duration in the reform era, most importantly because the external environment has been exceptionally difficult.

The world is noticing Chinese economic success now not because economic reform and growth are different and more impressive in China (although the increase in economic mass that comes with sustained growth itself increases China's impact on the rest of the world, even if growth rates are a bit below earlier heights). The world is noticing now because the rest of the world is different. The rest of the world is growing more slowly, a weakened international trading system is supporting less growth in trade, and the United States is going through a period in which it is inclined to see China as a strategic partner rather than a rival. And the modernisation of China is a project of such immense dimension that those who turn their minds to it now and then have difficulty keeping it in perspective, with a consequence that expectations overshoot in both positive and negative directions.

The contemporary international excitement about China's economic performance should be a cause for caution rather than exuberance. The Chinese reality of reform and economic growth since 1978 has been much more stable than foreigners' perceptions of them.

The Chinese economy is likely to continue to perform relatively strongly on the pattern of the past quarter century. But as at each stage of the reform journey so far, success may be broken at any time by inadequate responses to immense challenges. Policy and institutional innovation of historic dimension on a world scale will continue to be necessary, to overcome barriers to growth as their importance becomes apparent through the process of reform. China's reform, international integration and growth will continue to make extreme demands on the quality of Chinese leadership and the energy and capacity for transformation within the Chinese people. It could not ever have been otherwise in an economic, political and social transformation on a scale that is unprecedented in human history.

It is not in the nature of Western businesspeople to reflect on what has gone before. But it takes little reflection to appreciate the volatility of Western expectations of China. It is only a year since books by Joe Studwell and Gordon Chang became bestsellers and part of every American business conversation about China predicted the imminent collapse of the Chinese economy and the Chinese Communist Party.

Australians over the past quarter century-officials, businesspeople and citizenshave been steadier than Americans in their perceptions of China. For the most part, they have been closer to the reality-less apocalyptic; less alarmist in the difficult 
times and less extreme in their enthusiasm in the better times. Less downbeat in the periodic inflationary crises of the first fifteen years of reform, in the dark days after the split in the Chinese leadership over management of the Tian An Men crisis and through the external challenges of the Asian financial crisis. A bit less excited in the periods of exceptional growth in domestic demand, Chinese ferment over political change, and more obvious identity between Chinese and Western strategic interests.

It is possible that the current Australian mood on China is absorbing more of the amplitude of the American, through the contemporary tendency for Australian business to look at its international opportunities through lenses ground in New York, California and Washington DC. This new assessment, in China: new engine of world growth, will help to place the Chinese reality into perspective.

The reality is much as it has been for the last 25 years of reform. Nothing is more important to the health of the global economy and especially of Australia's Asia Pacific neighbourhood than the success of China's efforts to build a productive market economy, deeply integrated into the international economy through mechanisms that promote trade on the basis of global comparative advantage. The good progress so far augurs well for the future of reform and growth in China. The challenges that remain are less daunting than some that have already been overcome. But the challenges of today and tomorrow are nevertheless immense.

\section{THE KEYNESIAN EXPANSION}

These last six years, since the collapse of the Thai baht heralded financial dislocation in much of East Asia and recession in more, have been more challenging for Chinese economic growth than any similarly extended period in the reform era. Growth has been sustained at rates comfortably above the 7.2 per cent that doubles output each decade and which has been an unheralded official target since Deng Xiaoping in 1980 promised that Chinese output would quadruple by the end of the century (Table 1.1). But this success was built on a risky strategy of Keynesian fiscal expansion with a fixed exchange rate that has costs for systemic efficiency and long-term growth. It was built on risks that no-one could define at all clearly when there was great uncertainty about the depth and duration of the Asian financial crisis and after that of the United States' recession. Now that we know how things turned out, we know that the risks were worth taking, although we also know that the costs that must be paid for in the period ahead were real and large. 
Table 1.1 Output growth and inflation performance in China, 1979-2003

\begin{tabular}{|c|c|c|c|}
\hline & $\begin{array}{c}\text { Gross Domestic } \\
\text { Product }\end{array}$ & $\begin{array}{l}\text { Retail Price } \\
\text { Index }\end{array}$ & $\begin{array}{c}\text { Consumer Price } \\
\text { Index }\end{array}$ \\
\hline 1979 & 7.6 & 2.0 &.. \\
\hline 1980 & 7.8 & 6.0 & .. \\
\hline 1981 & 5.2 & 2.4 & .. \\
\hline 1982 & 9.1 & 1.9 & .. \\
\hline 1983 & 10.9 & 1.5 & .. \\
\hline 1984 & 15.2 & 2.8 & .. \\
\hline 1985 & 13.5 & 8.8 & 9.3 \\
\hline 1986 & 8.8 & 6.0 & 6.5 \\
\hline 1987 & 11.6 & 7.3 & 7.3 \\
\hline 1988 & 11.3 & 18.5 & 18.8 \\
\hline 1989 & 4.1 & 17.8 & 18.0 \\
\hline 1990 & 3.8 & 2.1 & 3.1 \\
\hline 1991 & 9.2 & 2.9 & 3.4 \\
\hline 1992 & 14.2 & 5.4 & 6.4 \\
\hline 1993 & 13.5 & 13.2 & 14.7 \\
\hline 1994 & 12.6 & 21.7 & 24.1 \\
\hline 1995 & 10.5 & 14.8 & 17.1 \\
\hline 1996 & 9.6 & 6.1 & 8.3 \\
\hline 1997 & 8.8 & 0.8 & 2.8 \\
\hline 1998 & 7.8 & -2.6 & -0.8 \\
\hline 1999 & 7.1 & -3.0 & -1.4 \\
\hline 2000 & 8.0 & -1.5 & 0.4 \\
\hline 2001 & 7.3 & -0.8 & 0.7 \\
\hline 2002 & 8.0 & -1.3 & -0.8 \\
\hline Jan-Jun 2003 & 8.2 & -0.4 & 0.6 \\
\hline Average $1979-2002$ & 9.40 & 5.53 & .. \\
\hline Average 1979-1996 & 9.92 & 7.84 &.. \\
\hline Average 1997-2002 & 7.83 & -1.39 & 0.16 \\
\hline Variance 1979-1996 & 11.239 & 42.412 & .. \\
\hline Variance 1997-2002 & 0.348 & 1.846 & 2.307 \\
\hline $\begin{array}{l}\text { t-statistic for difference in the } \\
\text { of } 1979-96 \text { and } 1997-2002\end{array}$ & 2.521 & 5.661 & \\
\hline
\end{tabular}

Source: State Statistical Bureau, various years. Zhongguo Tongji Nianjian [China Statistical Yearbook], Zhongguo Tongji Chubanshe, Beijing. Created by Wing Thye Woo, Chapter 3 , this volume 
The systemic costs of heavy reliance on public expenditure to maintain growth since 1996 have been substantial, and future growth must contend with the legacy of expanded direct and contingent public debt.

However, some other elements of the policy response to the past six years of difficult external economic conditions have been helpful to long-term growth. The years in which growth has been sustained by fiscal expansion have also been the years in which China prepared for and then achieved entry into the World Trade Organization. WTO entry supported the continuation of the radical trade liberalisation of the reform era when the political economy of change might have been expected to force some easing of the pace. These were also the years in which the legitimacy of the private sector's role in the economy was recognised by constitutional amendment, in which legislative and governmental reform was implemented to facilitate private sector growth, and in which rapid and extensive growth in the private sector came to contribute a majority of the country's economic output for the first time.

Thus two major elements of the policy response to external weakness pulled in opposite directions. The maintenance of growth in aggregate demand through increased direct public expenditure and lending by the state-owned banks to other state-owned enterprises was a step backwards into a larger role for unproductive entities. But the recognition at this time that the state sector could deliver neither the rapid increase in productivity nor the strong employment growth necessary to sustain political stability through rapid structural change led to the removal of many constraints on private business activity.

The resultant of these powerful developments was a state sector absorbing a high proportion of investment resources but contributing proportionately less on the supply side through employment and productivity growth.

There are several senses in which the Keynesian expansion of the past six years is unsustainable. It is unsustainable in the public finances. Huang (Chapter 4) and Wing (Chapter 3 ) in this book discuss the challenge of servicing the public debt and above all of managing the new contingent liabilities of the banking system.

The Keynesian expansion is unsustainable in its concentration of investment resources in the parts of the economy that use it least productively. If it continued much longer, it would be associated with increasingly disappointing growth performance. 
It is unsustainable in political economy terms. Reform has been a long struggle against the vested interests that have inevitably grown around the state sector, and these have been strengthened at a time when further reduction of their power is essential for continued success of the reform process.

Fortunately, the other developments have made it possible now to withdraw the Keynesian stimulus without stopping growth. The growth in scale of the private sector, with policy and institutional reform supported by high rates of direct foreign investment, has generated new sources of demand growth. The inevitable monetisation of part of the external payments surplus is boosting private consumption and investment demand. The recent stronger and more broadly based demand expansion has tightened the utilisation of productive capacity in many areas, and has ended the deflation that has troubled policymakers since the Asian financial crisis. The end of deflation itself has provided a boost to private consumption.

For the moment and for a while it seems, and will seem, that productive capacity and demand are broadly in balance. But this may turn out to be the appearance of a stopped clock showing the correct time twice each day. If there were no withdrawal of the Keynesian stimulus in the near future, the momentum in demand growth would be likely to push the economy into unsustainable over-expenditure, manifested in the re-emergence of inflationary pressures and rapid movement of the current account of the balance of payments from surplus into deficit. Developments along these lines were postponed in the first half of 2003 by the negative effects of SARS (analysed by McKibbin and Lee, Chapter 2), but will re-emerge now as the effects of the epidemic pass into history.

In these circumstances, the rate of expansion in public expenditure and investment by state-owned enterprises could be cut back without endangering growth performance. If this step were taken now, the emerging problems of public debt and contingent liabilities, of wasteful over-investment within large state enterprises, and of emerging excess domestic demand can be corrected before they damage longterm macroeconomic performance.

\section{THE UNDERVALUED YUAN}

The exuberance about Chinese growth, the external payments surplus and above all the bilateral trade surplus with the United States have led in 2003 to calls from foreign business and Governments for China to abandon the nine-year-old peg of the yuan against the US dollar. The call has mostly been for the floating of the 
currency in the expectation that this would lead to a large appreciation. Some calls have been for an appreciation of the yuan within the framework of the established peg against the US dollar.

The current official peg against the US dollar was adopted in early 1994 as part of a currency reform that embodied the integration of official and 'grey market' foreign exchange rates. Prior to these developments, the yuan had been loosely pegged to the US dollar, but uninhibitively devalued from time to time to correct recurrent external payments weakness that had there origins in rates of demand expansion and inflation that were high relative to the rest of the world, at a time of rapid trade and payments liberalisation. Since the 1994 reforms, the yuan has been firmly fixed to the US dollar, although in the year immediately preceding the Asian financial crisis there was discussion of moving to a floating rate by the end of the twentieth century.

In the lead-up to the foreign exchange market unification, the yuan had been going through one of its more pronounced periods of overvaluation, on the back of the huge boom in domestic investment triggered by Deng Xiaoping's exhortations to accelerate reform and growth on his famous last journey to the south of China. The overvaluation was reflected in large premia over the official rate on the black market and the officially-sanctioned grey market. The unification of the foreign exchange market at a rate close to the 'grey market' level represented a substantial devaluation for firms operating at the official exchange rate (principally the large state-owned corporations) but not for the foreign joint ventures and many others who had access to the officially-sanctioned 'grey market'. This partial devaluation was seen as underpinning China's competitiveness through a period of accelerated trade liberalisation, and in practice had this effect.

The unified official exchange rate, pegged against the US dollar, came under downward pressure through the Asian financial crisis, when the East Asian economies went into recession and experienced large devaluations of their own. These economies together absorbed almost half of China's exports and were China's most intense competitors in exports to global markets. China's payments came under pressure, prompting large efforts to accelerate reform to make China more attractive for direct foreign investment and to raise productivity in the export industries. There was frequent comment through 1998 that the yuan would need to be devalued. The Chinese authorities responded that such action would not be helpful to the Chinese economy and would undermine the attempts by other East Asian economies to restore stability in the aftermath of financial crisis. 
From time to time through 1998 the peg against the US dollar came under speculative attack, directly, and by proxy through speculative sale of the more exposed HK dollar. The attacks on the HK dollar could be resisted because of the Special Administrative Region's exceptional levels of fiscal and monetary reserves. Speculation directly against the yuan was never effective because of China's retention of foreign exchange controls on international capital movements. Some controls on use of foreign exchange were made more restrictive. This episode, and parallel observation of the contribution of large-scale fluctuations in capital movements to macroeconomic instability elsewhere in East Asia at this time, led the Chinese authorities to announce indefinite postponement of any movement towards a floating exchange rate and a more open capital account.

China's strategy of seeking to maintain growth through the Asian financial crisis with public sector demand expansion and a fixed exchange rate worked well for China and the international economy. Import growth remained positive in China when it was contracting elsewhere in East Asia. This helped to moderate the downward spiral of import contraction and slower economic growth that was at the centre of the contagion that continued after the initial recessionary impetus from the financial markets. Until 2001 , the only questions about the sustainability of the peg focussed on yuan weakness.

The strategy depended on the judgment that the East Asian economies would in a relatively short period-no more than a couple of years-emerge from recession, have their currencies stabilise and then strengthen against main currencies outside the region, and return to import expansion. These developments would have to occur early enough for China to ease the domestic stimulus before the macroeconomic imbalances that they would produce had themselves caused major problems for sustainable growth in China.

In the event, the judgment was validated by the trajectory of East Asian recovery from late 1998. The sustainability of the strong yuan policy was supported by Chinese deflation, which generated some depreciation of the real exchange rate even at a time of low inflation in industrial countries. The macroeconomic strategy had been proven to have been successful before the depreciation of the US dollar, and with it the yuan, against most currencies between late 2002 and mid 2003 added to emerging concerns that the Chinese currency may have entered a period of undervaluation.

Both exports and imports have increased rapidly since 1998. Chinese import expansion accounted for around one-quarter and exports for the whole of the world 
total in the two years from 2000. The faster export expansion has been associated with a significant current account surplus, amounting to US $\$ 21$ billion or 1.7 per cent of GDP in 2002.

This is the context of the growing clamour for appreciation of the yuan. The claim that rapid export growth deriving from an undervalued yuan is causing unwarranted pressure for manufacturing production and employment to decline in the rest of the world has become part of United States' electoral politics in 2003 , with dangerous implications for the political economy of protection in that country. The pressure on Chinese exchange rate policy reached a new height during the visit of United States Treasury Secretary Snow to Beijing in late August 2003. The Secretary's representations were met by a Chinese response that it would eventually free up the foreign exchange market, but not yet.

If China had had a freely floating currency, it would probably have depreciated with its East Asian neighbours in 1997 and 1998, and appreciated with the tendency towards payments surplus since 2001 . China with a freely floating and at first a depreciating currency would have found it neither necessary nor feasible to embark on the huge Keynesian fiscal expansion of these last six years. China would have contributed less to holding up East Asian and global trade through and in the immediate aftermath of the East Asian crisis, but would probably have placed less strain on the global trade and payments system in the current, less inherently dangerous circumstances.

Would it make sense for China now to liberalise capital transactions in its foreign exchange markets and float the yuan? Not unless and until China has taken reform of its financial system to the point where its financial institutions can be expected to respond with foresight and flexibility to the huge flows of capital and their reversal over short periods that is a normal feature of contemporary international financial affairs. China is not yet at that point. Priority needs to be given to financial system reform, including facilitation of the emergence of strong private banks, and to effective imposition of hard budget constraints on state-owned enterprises generally through privatisation or other means. Important aspects of financial sector reform are discussed in the contributions to this book by Huang (Chapter 5 ), Shan (Chapter 6) and Cheng (Chapter 7).

Pending the necessary progress on reform, would discrete revaluation of the yuan, without liberalisation of the foreign exchange markets, be helpful to Chinese and international macroeconomic stability? 
It is hard to see how a minor adjustment, achieved through widening the band in which the yuan exchange rate is set against the US dollar, would be at all helpful. But is there a case for a larger, discrete revaluation?

Perhaps, if the current tendency towards external payments surplus were expected to be of large dimension over a long period. However, the current account surplus does not seem to have these characteristics. It is likely to fall quickly as the acceleration in domestic demand expansion, itself deriving to a considerable extent from monetisation of part of the external payments surplus, together with recent measures to liberalise trade and payments, flow quickly into increased imports. Indeed, in the first seven months of 2003, the import growth of 43 per cent in US dollars exceeded export growth of 33 per cent over the corresponding period of 2002. The time that China has bought in its discussions with the Treasury Secretary will probably be enough for the fragility of the current account surpluses to become widely apparent.

The capital account surpluses are contributing a large component of China's accumulation of foreign exchange reserves. Since the capital inflow takes the form of direct foreign investment to an unusual degree, it seems at first sight that this element of the external payments surplus would be more durable, and therefore make a stronger case for yuan appreciation. Closer analysis raises questions as well about the durability of this element of the payments surplus. When high levels of direct foreign investment were associated with weak external payments generally and speculation about yuan devaluation during and in the aftermath of the Asian financial crisis, they were accompanied by high levels of net capital outflow in other forms. Speculators ultimately found ways around the capital controls through leads and lags in current payments and variations in the ratios of locally sourced to imported capital associated with direct foreign investment. All of these mechanisms have gone into reverse in the current period of speculation about yuan appreciation. The capital controls inhibit but do not completely block the speculative movement of capital, and the residual movements are closely correlated with the balance and direction of change of the current account. The large contemporary surpluses on the capital account are likely to diminish as the current account moves from large surplus towards deficit.

To the extent that the downward adjustment of the Chinese external payments surplus as a result of the processes described as being too slow or incomplete, there is a stronger case for China to accelerate the growth in imports through faster 
trade and payments liberalisation rather, than through currency appreciation. The pace of trade liberalisation is currently impressive, as China meets the far-reaching conditions on its entry into the WTO. But the barriers to international trade at China's borders will remain considerable after the completion of the currently agreed program. It is open to China to accelerate the implementation of the current WTO commitments, and to move beyond them. China has done something of each of these things, most recently with the announcement of liberalisation of restrictions on money taken abroad by tourists and other travellers. Going further in this direction would contribute to macroeconomic adjustment in much the same way as currency appreciation. However, it would have a more favourable impact on the efficiency with which domestic resources were used. And it would have a favourable effect on global discussions of trade liberalisation at a time when the Doha round of multilateral trade negotiations is experiencing trouble for want of trade liberalisation leadership in any major economy.

\section{CHINA'S GROWTH AND THE WORLD COMMUNITY}

As China, with a fifth of the world's people, moves towards the average productivity levels of industrialised countries, it inevitably comes to assume a large place in the fortunes of other countries and of the world economy. This is a natural and inevitable process. It should take no-one by surprise, although it does involve radical rearrangement of power relationships in the global economy and eventually the world's political system.

If China's reform and economic growth proceed broadly along the lines of the past twenty five years-and that is the most likely course, despite the bumps in the road, the detours and dead-ends that will inevitably be part of such a long and complicated story - then China will catch up with the United States in total economic size more quickly than is commonly supposed. I discussed the economics and the arithmetic of catching up with the United States in chapter one of China 2002: WTO entry and world recession (Garnaut and Song 2002). It would not be at all surprising if China were the world's largest economy by all the relevant way of measuring economic size within a few decades.

China's foreign trade and investment have been growing even more rapidly than its economic output, absolutely and in comparison with the rest of the world. This follows partly from the reform and growth strategy, which from the beginning have emphasised deep integration into the global economy. The tendency is also promoted 
by the considerable and increasing concentration of Chinese economic activity and population in coastal cities and provinces and up the Yangtze River with relatively easy access to the coast. It is reinforced by the highly skewed nature of China's resource endowments relative to other major participants in international trade, endowments which expand opportunities for profitable international exchange. China's growing and changing role in international trade are discussed by Song and Sun (Chapter 10), Tong (Chapter 9), Tang (Chapter 15), Wu (Chapter 16), and Chang and Tyers (Chapter 14). Some implications for the world and Asia Pacific trading systems are the focus of the contributions by Raby (Chapter 8 ) and Findlay (Chapter 11).

The emergence of China as an increasingly large and internationally oriented economy generates opportunities and challenges for the rest of the world. There are opportunities for incomes growth through greater specialisation by other countries in what they do best. Utilisation of this opportunity is especially valuable at a time of diminished economic dynamism in much of the world. The challenges are the other side of the same coin. The utilisation of opportunity requires the transfer of resources from activities that compete directly with emerging comparative strengths of China, into others in which China's trading partners have stronger comparative advantage as a result of the growth of China and its increased participation in international exchange. There are short-term adjustment costs, and negative domestic political reactions.

Geography matters in international trade, and the largest positive and negative effects of China's emergence as a major trading economy are close to China in the Western Pacific region. Pacific Economic Outlook 2003 discusses major effects of mainland China's growth on the economic outlook for Japan, Korea, Hong Kong, Chinese Taipei and the economies of Southeast Asia (PECC 2003). Australians are closely aware that elements of recent strength in international markets for minerals, metals, petroleum and agricultural products and services (notably education and tourism) have origins in Chinese demand.

East Asian economies are also experiencing tendencies towards 'hollowing out' of old manufacturing industry, as competitive productive capacity expands in China. Most analysts as well as political leaders in the Western Pacific have taken the view that the net effects are positive, but there are still costs and negative perceptions to be managed. 
More recently, there has been wider international concern about the shift of global manufacturing capacity to China. Some political discussion in the United States in 2003 has identified growing imports from China as a significant factor in the decline in manufacturing employment, and the under-valuation of the yuan as a contributing cause. While the arithmetic of increased imports from China and decline of manufacturing employment in large industrial countries does not suggest strong causation, there is no doubt that the issue has political traction.

China's growth and integration into the international economy can go badly wrong if reactions to the costs of adjustment to rapid structural change become influential in political processes at home or abroad. The nature of domestic and international institutions through which political reactions to structural change are mediated can therefore have an important influence on the sustainability of growth.

China's institutions for managing resistance to structural change are weak. That partly reflects the traditions of a highly centralised political system, in which leaders have not had to pay attention to day to day community reactions to policy. Improvements in education and in communications amongst Chinese, greater freedoms of movement and association and what could be described as the democratisation of daily life (as distinct from the democratisation of the political superstructure) are increasing the openness of policymaking processes to community pressures. The chances of political resistance leading to partial retreat from open policies would be reduced if China developed domestic institutions that had credibility as sources of independent (from government and business direction) and transparent analysis of the costs and benefits of trade policy changes (see Carmichael and Garnaut (2003) for more general articulation of this point).

The WTO is the most important of the international institutions in mediating pressure for restrictive reactions to adjustment pressures arising from the rapid growth of Chinese foreign trade. Chinese (and Chinese Taipei) membership from late 2003 has reduced the risk that reactions to domestic political pressures in China or in its trading partners would ever block expansion of profitable trade relations between China and the rest of the world. The value of China's WTO membership for productive expansion of trade has been enhanced by several innovations in the Uruguay Round of multilateral trade negotiations. The most important of the Uruguay Round developments for China were the strengthened disputes settlements mechanism, 
the constraints on agricultural subsidies, and the complete phasing out of the multifibres arrangement and with it quantitative restrictions on imports of textiles and clothing by 2005 in the high-income countries of the North Atlantic.

China's membership of the WTO has delivered the benefits for China and the world that had been sought in negotiations on entry conditions. China has been disappointed at the extent of other countries' recourse to anti-dumping devices and has responded by making more use of them itself. This is a development with potential significantly to reduce benefits to China and its trading partners of internationally oriented growth in China. Constraints on protectionist uses of antidumping arrangements are an important Chinese interest in the new, Doha Round of multilateral trade negotiations, alongside the expansion of market access in many areas that is necessary to maintain international interest in and support for the multilateral system. China has been inclined so far to take a back seat in the Doha Round, in the belief that the substantial liberalisation which it has effected in recent years or to which it has already committed will be recognised as a substantial contribution that obviates the need for further initiatives ahead of a comprehensive settlement of the issues. However, China's economic dynamism in a world that is struggling for sustained growth, and its external payments surpluses, place it in a good position to take a lead in global trade liberalisation in the Doha Round, at a time when the WTO is lacking clear leadership on trade liberalisation from other countries.

Findlay (Chapter 11) discusses one surprising and troubling feature of contemporary Chinese trade policy: the recent interest in discriminatory trading arrangements, especially with East Asian trading partners. It is surprising because the dimensions of Chinese trade expansion suggest the advantages of specialisation in line with global comparative advantage Trade on a non-discriminatory basis in China and its trading partners allows the adjustment stresses of Chinese trade expansion to be spread broadly through the international community. This would seem to be the logic of China's recent membership of the WTO, the benefits of which have been explained extensively within China.

Preferential trading arrangements concentrate pressures of adjustment disproportionately amongst favoured partners. To the extent that discriminatory trading arrangements were with East Asian partners, it would compound the tendency for economic geography to concentrate adjustment costs in this region. The absorption of the huge expansion in Chinese trade that follows naturally from China's open 
policies is accommodated most easily within a global trading system. The breakdown of the multilateral trading system into small-group free trade areas, with East Asian and some other Asian partners inside, and the United States, the European Union and some others outside, would greatly complicate international accommodation to internationally oriented growth in China. It would increase the chances that protectionist response to the costs of adjustment in China or elsewhere would bring slow the productive process or even bring it prematurely to an end.

The implications of Chinese growth for the international political system are even more complex. Two years ago, it seemed that feelings of strategic rivalry with a rapidly growing China in the young administration of George W. Bush in the United States may lead to such serious conflict that productive economic relations would be at risk. These risks subsided with the United States focus on the war against terrorism, in which China was seen as a helpful ally, and the security crisis on the Korean peninsular, in which China was seen as an essential contributor to any satisfactory solution. China has worked to build a less problematic relationship with the United States more generally in this new context, and the United States has reciprocated the efforts. Austin discusses these important developments in Chapter 24.

\section{RESPONSES TO GROWING INEQUALITY}

Of the many innovations in doctrine and policy that were necessary conditions for the success of the reforms from 1978, none were more important or difficult than the acceptance of wider dispersion in the distribution of incomes and wealth amongst the people of mainland China.

Three aspects of the Chinese reforms made their effects on inequality of wealth and incomes benign in the early years.

First, China's reforms had their first large impact on farming, with the rapid replacement of almost all the People's Communes by the household responsibility system in agriculture between 1978 and 1984. Alongside the institutional transformation, the removal of the bias against agriculture in the old central planning system was associated with an increase in the price of farm products relative to manufactured goods purchased by farmers. Agricultural output and real farm incomes rose rapidly all over China. This was highly favourable to equitable income distribution in the early years of reform.

Second, China is a relatively densely populated country, especially in coastal areas, with comparative advantage in labour-intensive products in the early stages 
of development. This meant that opening up to foreign trade generated exceptionally strong growth in labour-intensive industries. This caused many of the early gains from trade to be passed directly to labour and therefore distributed widely through the community through the operation of the labour market.

Third, the provinces with the highest average incomes at the beginning of the reform period were the favoured locations for heavy industry and other activities which were concentrated in large, state-owned enterprises. These included Shanghai and the provinces of Northeast China. By contrast, the early beneficiaries of reform were provinces with opportunities to take full advantage of agricultural reform, growth in township and village industries and international exports of labour-intensive products. These were led by Guangdong, Zhejiang and Jiangsu, the rapid growth of which for a few years involved catching up with some other provinces.

So until the mid eighties, reform was favourable to equitable income distribution. For a few years after that, it was, at worst, ambiguous in its effects.

That all changed in the 1990s and the early twenty first century. The further development of the market economy has greatly widened the dispersion of the distribution of personal incomes and wealth. At the top of the distribution, and inevitably in a market economy, there are concentrations of wealth. Meng (Chapter 17) shows that these are correlated with political privilege. Rural-urban income gaps have widened markedly, exacerbated by a partial retreat from the use of market mechanisms to allocate resources within agriculture, and by the favoured position of large-scale state-owned enterprises through the period of Keynesian fiscal expansion. The distribution of income amongst provinces has widened as the more successful coastal provinces have continued to grow rapidly after their average incomes have come to exceed those of the provinces that had been favoured by central planning.

Many elements of the contemporary economic reform program are widening still further the interpersonal, inter-sectoral and interprovincial income gaps. Loss of jobs associated with restructuring of state-owned enterprises has made unemployment a significant contributor to inequality amongst individuals and households. Inequality in the interpersonal distribution of income continues to widen as the private sector matures and expands its role (Mei, Chapter 20). Direct foreign investment is concentrated in coastal provinces with high average incomes (Chen, Chapter 12). The opportunities for incomes growth that are created by trade 
liberalisation are concentrated disproportionately in coastal China-even in agriculture, where WTO entry favours the labour-intensive production of the coastal provinces and forces contraction in the land-intensive production of the inland.

These developments have the potential to undermine political support for reform and productivity-raising structural change. They have generated much discussion of and some action on policy change to moderate adverse effects of reform on income distribution. Recent developments in policy with implications for the moderation of income inequality are discussed in Wang and Duncan (Chapter 13), Qun (Chapter 18), Murton (Chapter 19), Golley (Chapter 22), Houghton and Davies (Chapter 21) and Jiang and Zhao (Chapter 23).

\section{THE PATH AHEAD}

China's reform and growth have recently emerged from a sustained period of adverse external conditions. Chinese economic strategy was successful in maintaining domestic growth momentum during this period, and in the process was helpful to economic activity abroad at a difficult time for East Asia and much of the world economy.

The current environment appears to be more benign. In some senses it is. But it is dangerous to forget the dimensions of the reform task that lies ahead. Focus in the policy discussion is containing larger components on measures to moderate the income distribution of effects of contemporary reform. It is inevitable that the debate on the income distribution issues will become intertwined with a debate on the more sensitive question of the distribution of political power. The maintenance of reform momentum and political stability will require wise leadership and steady achievement in these areas.

The outstanding agenda of reform of economic institutions, with the financial system first of all, contains immense challenge. There is unlikely to be a dramatic financial crisis, but failure to make steady process is likely to be associated with attrition of economic performance to an extent that soon shows up in the growth statistics.

The current over-excitement about China in international business will be brought to heel as realisation spreads that China's external strength is of modest dimension, as the strong domestic demand growth is instrumental in turning a current account surplus into a deficit over a short time. Observers who hold the view that China's 
economic success is a positive development for people everywhere will then be glad that Chinese economic leaders kept their feet on the ground when foreigners talked of the need for huge exchange rate appreciation in mid 2003. Maybe this time the foreign misperception can be corrected without over-reaction. Because, for all the problems and risks which lie ahead, China's emergence as a modern, internationally oriented economy will remain the big story of world economic history for some time yet.

\section{REFERENCES}

Carmichael, B. and Garnaut, R., 2003. Open Letter to the Prime Minister and Leader of the Opposition, The Australian National University, Canberra.

Garnaut, R. and Song, L., 2002. China 2002: WTO entry and world recession, Asia Pacific Press, Canberra.

Pacific Economic Cooperation Council, 2003. Pacific Economic Outlook 2003-04, Asia Pacific Press, Canberra.

State Statistical Bureau, various years. Zhongguo Tongji Nianjian [China Statistical Yearbook], Zhongguo Tongji Chubanshe, Beijing. 


\section{2 \\ The impact of SARS}

\section{Jong-Wha Lee and Warwick J. McKibbin}

The outbreak of SARS (severe acute respiratory syndrome) has had an important impact on the People's Republic of China (hereafter referred to as China). When the virus was at its most virulent, from November 2002 to July 2003, it had a direct impact on economic activity. But it has also had a more fundamental and long lasting impact on possible political and economic reforms in China.

The first outbreak of SARS was in Guangdong Province, the source of annual cycles of disease for over a century. China has been criticised for its initial response, in which lack of transparency and attempts to minimise the impact of the disease, in apparent violation of World Health Organization (WHO) guidelines, were a primary cause of the propagation of SARS to the world. The experience of SARS has illuminated weaknesses in China's public health system and raised questions about the ability of the government to respond to serious crises and coordinate responses between the central government and regional authorities. These issues have potential impacts on the political system as well as on the economy because of the possibility of future diseases and resulting impact on FDI flows into China.

This chapter gives an overview of the SARS outbreak, presents some estimates of the economic costs to date and possible costs over the medium term and draws some lessons for policy in China. Our empirical estimates of the economic effects of the SARS epidemic are drawn from our earlier paper, which was based on a global model called the G-cubed (Asia Pacific) Model. A few recent studies including Chou, Kuo and Peng (2003), Siu and Wong (2003), Hanna and Huang (2003) and Wen (2003) provide some estimates of the economic effects of SARS on individual 
Asian countries such as China, Hong Kong and Taiwan. But these studies focus mostly on assessing the effects of SARS on industries such as tourism and the retail service sector. However, merely calculating the effects on the number of cancelled tourist trips or declines in retail trade does not provide a full picture of the impact of SARS because such a calculation ignores links across sectors, and across economies through international trade and capital flows. The multi-sector multi-country model captures important links across sectors, as well as across countries, through goods and services trade and capital flows.

The G-cubed model also incorporates individuals' expectations and their forwardlooking intertemporal behaviour. We are interested in distinguishing the effects of a temporary shock from those of a persistent shock, for instance, when foreign investors expect that SARS or other epidemics of unknown etiology may break out in some Asian countries not just this year but at some time in the future, they demand a greater risk-premium from investing in affected economies. Long-term impacts of this type would have far more devastating consequences for China than the shortterm cost of SARS.

\section{CHINA'S RESPONSES TO SARS}

The SARS virus is contagious and often fatal. In the eight months after its first outbreak in China in Guangdong province on 1 November 2002, the SARS disease spread to 30 economies, infecting 8,437 people and causing 813 deaths worldwide (Table 2.1).

By July 2003, SARS seemed to have disappeared, andWHO declared that SARS outbreaks had been contained worldwide (Table 2.3). Yet scientists still do not know details about the coronavirus that causes SARS. The precise mechanism by which this atypical pneumonia is spread is still unclear. Many countries have successfully contained the SARS outbreaks and local transmission, but the disease may recur later in 2003. ${ }^{1}$ There is speculation that even if it diminishes in the Northern Hemisphere summer, it could re-emerge in an even more fatal form in the next influenza season. Experts assess that the likelihood of discovering a vaccine or treatment for SARS in the foreseeable future is very low. Crowds of anxious patients may overwhelm the hospitals during the next flu season (Enserink 2003).

SARS has posed a big challenge to China. Hong Kong and Taiwan were worst hit. As of 14 July 2003, 5,327 people had been infected with SARS in China and 813 of those had died. This represented 63.1 per cent of SARS cases and 42.8 per cent of 
Table 2.1 Cumulative number of reported probable cases of SARS, 11 July $2003^{1}$

\begin{tabular}{|c|c|c|c|c|c|}
\hline & $\begin{array}{c}\text { Cumulative } \\
\text { number } \\
\text { of case }(s)^{2}\end{array}$ & $\begin{array}{c}\text { Number of } \\
\text { deaths }\end{array}$ & $\begin{array}{l}\text { Number } \\
\text { recovered }\end{array}$ & $\begin{array}{l}\text { Date last } \\
\text { probable case } \\
\text { reported }\end{array}$ & $\begin{array}{r}\text { Date for which } \\
\text { cumulative } \\
\text { number of cases } \\
\text { is current }\end{array}$ \\
\hline Canada & 250 & 38 & 194 & 9 Jul 2003 & $10 \mathrm{Jul} 2003$ \\
\hline China & 5327 & 348 & 4941 & 25 Jun 2003 & $11 \mathrm{Jul} 2003$ \\
\hline China, Hong Kong & 1755 & 298 & 1433 & 11 Jun 2003 & 11 Jul 2003 \\
\hline China, Macao & 1 & - & 1 & 21 May 2003 & 10 Jul 2003 \\
\hline China, Taiwan & 671 & 84 & 507 & 19 Jun 2003 & 11 Jul 2003 \\
\hline Malaysia & 5 & 2 & 3 & 20 May 2003 & 4 Jul 2003 \\
\hline Mongolia & 9 & - & 9 & 6 May 2003 & 2 Jun 2003 \\
\hline Philippines & 14 & 2 & 12 & 15 May 2003 & $11 \mathrm{Jul} 2003$ \\
\hline Republic of Korea & 3 & 0 & 3 & 14 May 2003 & 2 Jul 2003 \\
\hline Singapore & 206 & 32 & 172 & 18 May 2003 & 7 Jul 2003 \\
\hline Thailand & 9 & 2 & 7 & 7 Jun 2003 & 1 Jul 2003 \\
\hline United States & 75 & - & 67 & 23 Jun 2003 & 9 Jul 2003 \\
\hline Viet Nam & 63 & 5 & 58 & 14 Apr 2003 & 7 Jun 2003 \\
\hline Other countries & 49 & 2 & 45 & & \\
\hline Total & 8437 & 813 & 7452 & & \\
\hline
\end{tabular}

Notes: ${ }^{1}$ Cumulative number of cases includes number of deaths. As SARS is a diagnosis of exclusion, the status of a reported case may change over time. This means that previously reported cases may be discarded after further investigation and follow-up. As of 14 July, WHO no longer publishes a daily table of the cumulative number of reported probable cases of SARS.

${ }^{2}$ Decrease in the number of cumulative cases and discrepancies in the difference between cumulative number of cases of the last and the current WHO update are attributed to the discarding of cases. ${ }^{3}$ Includes cases who are 'discharged' or 'recovered' as reported by the national public health authorities.

Source: World Heath Organization, n.d. CSR Severe Acute Respiratory Syndrome (SARS) homepage, World Health Organization, Geneva. Available online at http://www.who.int/csr/sars/en/.

deaths worldwide. Hong Kong reported 1,755 cases and 298 deaths. Taiwan had 671 cases and 84 deaths.

The SARS outbreaks have highlighted several sociopolitical problems in Chinese society, including lack of transparency, inaccurate information, and lack of coordination between central and local authorities. The response by the Chinese government to the epidemic has been fragmented and opaque. Only on 11 February did the Chinese Ministry of Health inform the WHO of an outbreak of acute respiratory syndrome for the first time (Table 2.3). There is even later evidence that the Chinese 
government was attempting to hide the epidemic, making only minimal information available. As a result, public fears began to rise as rumours spread by telephone and email. Responding to mounting criticism of its lack of transparency, the government quickly adapted to encourage more open reporting. On 20 April, Chinese leaders removed the mayor of Beijing and the Minister of Health from their posts.

The quick spread of SARS has raised doubts about the capability of China's medical system to deal with major epidemics. Overall healthcare spending is not low as a proportion of GDP in China, amounting to about 5 per cent of GDP, but health expenditure per capita is only US $\$ 45$ in China (Table 2.2). About one-third of the population has no access to improved sanitation. The government announced a comprehensive scheme to set up a nationwide health network to fight SARS and prevent other diseases. The response to SARS could represent a breakthrough for the improvement of the health care system in China.

The slow government response to this previously unknown disease raises grave concerns about China's institutional quality and its potential for growth. Although it

Table 2.2 Health expenditure and sanitation indicators for selected countries

\begin{tabular}{lccc}
\hline & $\begin{array}{c}\text { Health expenditure, } \\
\text { total } \\
\text { (per cent of GDP) }\end{array}$ & $\begin{array}{c}\text { Health expenditure } \\
\text { per capita } \\
\text { (Current US\$) }\end{array}$ & $\begin{array}{c}\text { Improved } \\
\text { sanitation facilities } \\
\text { (per cent of population) }\end{array}$ \\
China & 5.3 & 45 & 29 \\
Hong Kong & 4.4 & 950 & 100 \\
India & 4.9 & 23 & 16 \\
Indonesia & 2.7 & 19 & 47 \\
North Korea & 2.1 & 18 & 99 \\
South Korea & 6.0 & 584 & 63 \\
Malaysia & 2.5 & 101 & n.a. \\
Philippines & 3.4 & 33 & 74 \\
Singapore & 3.5 & 814 & 100 \\
Thailand & 3.7 & 71 & 79 \\
Vietnam & 5.2 & 21 & 29 \\
United States & 13.0 & 4499 & 100 \\
Japan & $n . a$. & $n . a$. & n.a. \\
High income OECD & 10.2 & 2771 & 55 \\
World & 9.3 & 482 & n.a. \\
\hline
\end{tabular}

Source: CEIC, 'World development indicators', presented in Hanna, D. and Huang, Y., 2003. SARS Impact on Asian Economies, Paper presented at Asian Economic Panel, Keio University, Tokyo, 11-12 May. 
is difficult to quantify the impact of the disease on the decisionmaking of foreign investors, they must surely have lost some degree of confidence in China. The impact of SARS on FDI has been relatively minor but its recurrence, or that of another epidemic, in China could have disastrous impacts on future foreign investment flows.

\section{MODELLING ECONOMIC IMPACTS OF THE SARS EPIDEMIC}

Most earlier studies on the economic effects of epidemics focus on direct medical costs or incomes forgone as a result of disease-related morbidity and mortality. Costs include private as well as public expenditures on diagnosing and treating the disease. Costs are increased by the need to maintain sterile environments, implement prevention measures, and do basic research (Commission on Macroeconomics and Health 2002).

Previous researchers have also focused on the long-term demographic consequences of epidemics. The first impact of epidemics is a negative shock to the population and labour force. Epidemics can have further effects on demographic structures by influencing fertility decisions of households. Another important mechanism by which a disease has an adverse impact on the economy's long-term growth is the destruction of human capital (Lee and McKibbin 2003).

However, the direct consequences of the SARS epidemic in terms of medical expenditures or demographic effects seem to be rather small, in particular compared to such major diseases as HIV/AIDS or malaria (see Bloom and Mahal 1997; Commission on Macroeconomics and Health 2002; Haacker 2002).

The number of probable SARS cases is still small compared to other major historical epidemics. Unlike AIDS, the duration of hospitalisation of the infected patients is short, with more than 90 per cent of patients soon recovering fully, so medical costs are low. The SARS-related demographic or human capital consequences are also currently estimated to be insignificant. But SARS has had detrimental economic effects in other ways.

SARS influences the global economy in three ways. First, fear of SARS leads to a substantial decline in consumer demand, especially for travel and in retail since the fast rate of contagion makes people avoid social interactions. The decrease in consumption has a more detrimental effect on regions with more service industries and higher population densities, such as Beijing and Hong Kong. 


\section{Table 2.3 Chronology of SARS and major responses by the Chinese government}

16 November 2002

11 February 2003

14 February 2003

12 March

17 March

26 March

30 March

2 April

3 April

4 April

16 April 2003

18-20 April

20 April
First known case of atypical pneumonia occurred in Foshan City, Guangdong Province, China, but was not identified until much later. The Chinese Ministry of Health informed the WHO of an outbreak of acute respiratory syndrome with 300 cases and 5 deaths in Guangdong Province.

The Chinese Ministry of Health informed WHO that the outbreak in Guangdong Province was clinically consistent with atypical pneumonia. The outbreak was said to be coming under control.

WHO issued a global alert about cases of severe atypical pneumonia following mounting reports of spread among staff at hospitals in Hong Kong and Hanoi.

China provided a first brief report to WHO about the Guangdong outbreak. The outbreak was said to have tapered off.

China reported a cumulative total of 792 cases and 31 deaths in Guangdong Province from 16 November 2002 to 28 February 2003. Officials had previously reported 305 cases and 5 deaths from mid November to 9 February.

Hong Kong announced the closure of schools until 6 April and placed 1,080 people under quarantine.

Chinese authorities reported SARS cases in other parts of China. China joined WHO collaborative networks.

Hong Kong health authorities announced that 213 residents of the Amoy Gardens housing estate had been hospitalised with SARS since reporting on the disease had begun.

WHO recommended that persons travelling to Hong Kong and Guangdong Province considered postponing all but essential travel until further notice. This was the most stringent travel advisory issued by WHO in its 55-year history.

WHO team arrived in Guangdong and started work immediately. All team requests for access to sites and interviews with health staff at all levels were granted.

China began daily electronic reporting of cases and deaths nationwide by province.

WHO announced that a new pathogen, a member of the coronavirus family never before seen in humans, is the cause of SARS.

China's top leaders advised officials not to cover up cases of SARS. The mayor of Beijing and the Minister of Health were removed from their Communist Party posts. The State Council cancelled the week-long May Day holidays. 
23 April

3 May

8 May

11 May 2003

21 May

23 May

13 June

23 June

24 June

5 July
The government established a national SARS task force headed by VicePremier Wu Yi, and a national fund of two billion yuan (US $\$ 243$ million) for SARS prevention and control. Beifing officials suspended all primary and secondary schools for two-weeks.

Chinese authorities reported a cumulative total of 2305 probable cases of SARS and 106 deaths, including 693 probable cases in Beijing.

WHO sent a team to Taiwan, which was reporting a cumulative total of 100 probable cases.

Travel recommendations were extended to Tianjin and Inner Mongolia in China and to Taipei, Taiwan.

The Ministry of Finance announced that it would allocate an additional 812.6 million yuan (US\$98.3 million) to improve the infrastructure and capacity of local medical institutes in a bid to prevent SARS from spreading to rural areas, which was on top of 1.55 billion yuan (US\$187 million) already channelled to the construction of a nationwide disease prevention and control network. It also announced that taxes and administrative fees levied by the government on some industries affected by the outbreak of SARS would be waived or reduced.

Travel recommendations were extended to all of Taiwan.

Travel recommendations for Hong Kong and Guangdong Province were removed.

Research teams in Hong Kong and China announced detection of a SARS-like virus in the masked palm civet and racoon-dog.

Travel recommendations for Hebei, Inner Mongolia, Shanxi and Tianjin provinces, China, were removed. Guangdong, Hebei, Hubei, Inner Mongolia, Jilin, Jiangsu, Shaanxi, Shanxi and Tianjin provinces were removed from the list of areas with recent local transmission.

Hong Kong was removed from the areas with recent local transmission. Travel recommendations were removed for Beijing, the last remaining area subject to WHO travel advice. Beijing was also removed from the list of areas with recent local transmission.

Taiwan, the last area with recent local transmission, was removed from the list.

WHO declared that SARS outbreaks had been contained worldwide, but called for continued vigilance.

Sources: Compiled from World Health Organization, n.d. CSR SARS homepage, 'SARS:

Chronology of a Serial Killer', World Health Organization, Geneva. Available online at http:// www.who.int/csr/don/2003_07_04/en/; and Asian Development Bank, n.d. Asia Recovery Information Center, SARS WATCH homepage, 'Chronology of Country Responses', Asian Development Bank, Manila. Available online at http://aric.adb.org/infocus/sars/ chronology_sars_policy.asp. 
Second, uncertainty concerning any future epidemics reduces confidence in the future and this effect is very important, particularly in China, which has been a key recipient of foreign investment.

Third, SARS undoubtedly increases the cost of disease prevention, especially in the most affected industries, such as travel, retail and the service industries. As long as the disease is transmitted only by close human contact, this cost may not be substantial, but if it were found to be transmitted by other channels, such as international cargo, the global cost would be enormous.

\section{ESTIMATING THE ECONOMIC IMPACT OF SARS}

We use the G-Cubed (Asia Pacific) Model to quantify the effects of SARS on China. ${ }^{2}$ We first generate a baseline projection of the world economy from 2002 to 2100 under assumptions about exogenous inputs such as productivity growth rates by sector and country, population growth rates by country and settings for fiscal and monetary policies by country. ${ }^{3}$ We then apply the shocks outlined below to this underlying baseline projection.

\section{Design of simulation}

We make two alternative assumptions about the duration of SARS. In an original paper we assumed in the first scenario that the shock would last a year. In reality, it lasted only six months so we have scaled down the shocks by 50 per cent. This is called a temporary shock. The second assumption is that future shocks are of the same magnitude in the first year as the temporary shock but are more persistent in that they fade out proportionally over ten years. This gives some insight into what might happen to the region if the SARS virus were the beginning of a series of annual epidemics emerging from China.

We first calculate the shocks to the Chinese and Hong Kong economies and then develop some indices summarising how these shocks would be likely to occur in other economies. There are three main shocks based on financial market analysts' observations about the data emerging from China and Hong Kong.

Initial shock to China and Hong Kong. In our representation of SARS, we assume three broad shocks to China and Hong Kong. These are

- a sector-specific demand shock to retail sales: a 15 per cent drop in demand for the exposed industries in the service sector

- a 5 per cent increase in costs in the exposed activities in the service sector

- a 200 basis point increase in the country risk premium. 
These shocks are scaled to last six months (by dividing by two) rather than a year, which is the frequency of the model.

We could also consider several other shocks, such as the impact on health expenditure and fiscal deficits. It is not clear how large this would be or for the persistent shock. Nor is even the direction of change clear. Since SARS kills a higher proportion of vulnerable people in a short time it follows that a large amount of expenditure for these people would thereafter be reduced. We might also anticipate the effect of the reaction of medical authorities with substantial investments in public health.

Shocks to other countries. In Lee and McKibbin (2003) we note that the transmission of SARS, as distinct from the economic transmission through global markets, depends on a number of factors. We refer to this as the global exposure to SARS. The speed of spread is likely to depend, among other things, on

- tourist flows

- geographical distance to China (and Hong Kong)

- health expenditures and sanitary conditions

- government response

- climate

- per capita income

- population density.

We develop indices that enable us to estimate the likely transmission of SARS to other countries. We do not present these in this chapter but use them in the simulations.

\section{Simulation results}

We apply the shocks outlined in the previous section to the global economy. We begin the simulation in 2003 , assuming that the SARS outbreak was completely unanticipated. Both the temporary and persistent shocks are assumed to be understood by the forward-looking agents in the model. Clearly this is problematic when it comes to a new disease like SARS, which is likely to be associated with a period of learning about the nature of the shock. In this case, an assumption of rational expectations might not be justified. Yet there is no clear alternative. In our modelling we presume that only 30 per cent of agents have rational expectations and 70 per cent of agents are using a rule of thumb in adjusting to contemporaneous information about the economy.

Table 2.4 sets out results for the percentage change in GDP in 2003 as a result of the temporary and permanent SARS shocks, as well as the contribution of each 


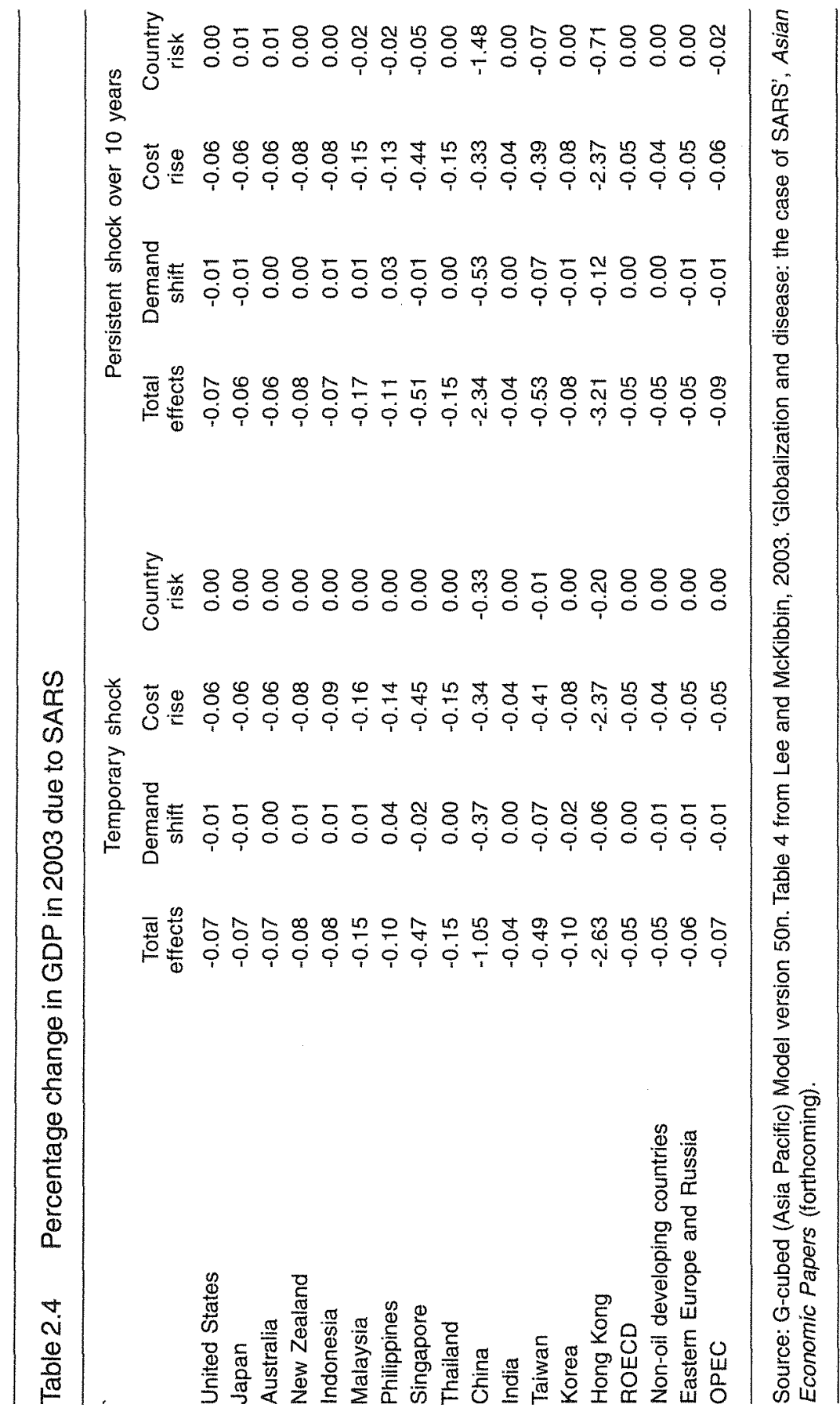


component (that is, demand decline for services, cost increase for services and country risk premium).

The full dynamics of adjustment will be outlined shortly. Focusing on the effects on GDP, there are interesting differences between the various components of the overall shock as well as between the temporary and permanent shocks. The temporary shock has the largest impact on China and Hong Kong. The loss to Hong Kong of 2.63 per cent of GDP is much larger than the 1.05 per cent for China. This reflects the larger role of the service sector in Hong Kong and Hong Kong's greater reliance on trade. Taiwan is next most affected, losing 0.49 per cent of GDP in 2003, followed closely by Singapore, with a loss of 0.47 per cent. For Hong Kong, the increase in costs in the service sector is by far the largest contributing factor to the loss of GDP. In China, the contributions are evenly spread across the three factors.

A persistent SARS shock would be much more serious for Hong Kong and China. The primary impact would be from the rise of the country risk premium. Although the initial shock in 2003 is the same as for the temporary shock, persistent elevation of the country risk premium causes a much larger capital outflow from China and Hong Kong. This results in a sharp contraction in investment and an ongoing decrease in production. The growth of capital stock declines, which in turn further reduces investment.

The results for GDP just illustrated how the costs of SARS can be very different in 2003 depending on expectations of how the disease will unfold. It could also be instructive to examine the economic impact over time on other variables.

Figure 2.1 compares the adjustment over time for China under the two scenarioswhen SARS is temporary, and when it is expected to be persistent. This figure contains six panels. Results for real GDP, investment, net capital outflows, real effective exchange rates, real interest rates and price levels are presented. Detailed discussion of these dynamics can be found in Lee and McKibbin (2003). The more persistent SARS is expected to be, the larger the impact on expectations, the larger the capital outflow and the larger the negative effects on investsment and real GDP. With an exchange rate pegged to the US dollar, the real exchange rate adjustment is achieved through a fall in the price level induced by a spike in real interest rates. Thus the exchange rate regime causes a larger GDP loss than would be the case if the Chinese exchange rate were flexible.

Other studies have estimated the potential effects of SARS, but it is difficult to compare their results directly with our own. Table 2.5 contains the various forecasts 
Table 2.5 Forecasts for China's GDP growth

\begin{tabular}{lccc}
\hline & $\begin{array}{c}\text { Pre-SARS } \\
\text { forecast }\end{array}$ & $\begin{array}{c}\text { Height of SARS } \\
\text { forecast }\end{array}$ & $\begin{array}{c}\text { Post-SARS } \\
\text { forecast }\end{array}$ \\
Asian Development Bank & 7.5 & 7.3 & 7.3 \\
World Bank & 8.0 & 7.5 & n.a \\
JP Morgan Chase & 8.0 & 7.4 & 7.4 \\
Morgan Stanley & 7.0 & 6.5 & 7.5 \\
Goldman Sachs & 7.5 & $6-7$ & n.a \\
Citigroup & 7.6 & 7.0 & 7.5 \\
\hline
\end{tabular}

Source: Asian Development Bank, 2003. 'Social and economic impacts of SARS in the PRC', Asian Developement Bank, Manila. http://aric.adb.org/infocus/sars/SARSImpact_PRC.pdf

of Chinese GDP growth made before SARS and after SARS from a recent ADB study. There are more changes in the forecasts than just the impact of SARS. Nonetheless our estimate for temporary SARS of a cost of around 1 per cent of GDP in 2003 is larger than the results in this table. Our estimates are, however, a touch lower than those of Garnaut and Findlay (2003).

\section{Policy lessons}

The large short-run economic impact of SARS on China is not the consequence of the disease itself for the affected people, but of effects on the behaviour of many people within China and abroad. Estimation of impacts also depends on the adjustment of expectations as reflected in real and financial markets. The more persistent SARS is expected to be, the larger the negative economic impacts will be in 2003 and in the future in affected economies.

There are some important lessons for policy. Transparency is vital, especially when dealing with uncertainty (Grant 2003). The experience of SARS has moved China towards more transparency, but much more could be done. It is important to manage unnecessary public fears and maintain people's confidence. Transparency is more important in a globalised world in which a loss of foreign investors' confidence could have large impacts on foreign investment flows and consequently economic growth. This is shown in our simulations. It also emphasises the need to strengthen international cooperation regarding disease response. ${ }^{4}$

There is a strong economic case for the improvement of public health in China. Public health expenditure has been inadequate and there has not been enough investment in research into disease prevention. 
Figure 2.1 Impacts on China of temporary versus persistent SARS shock

Real GDP

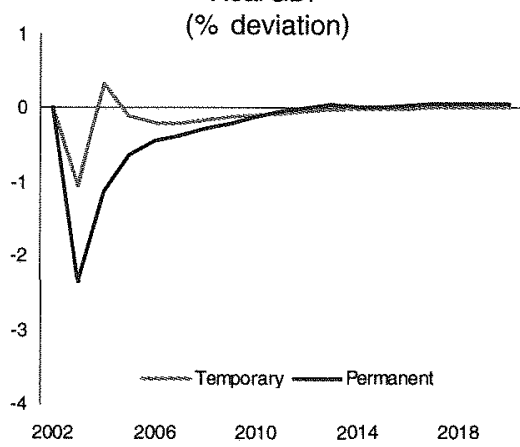

Net capital outflow

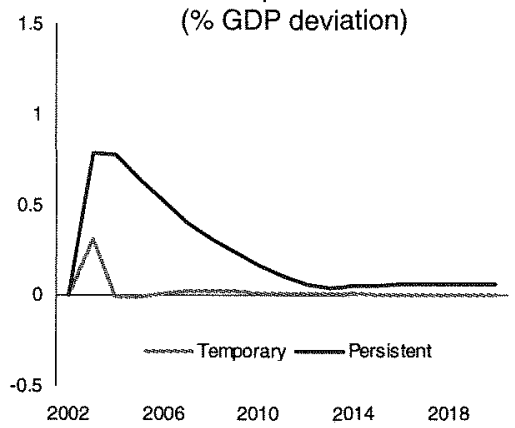

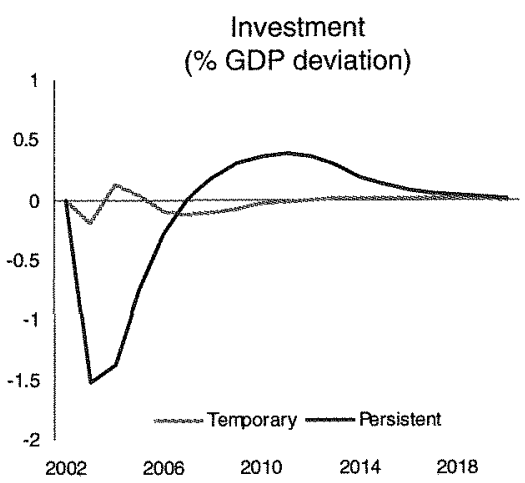

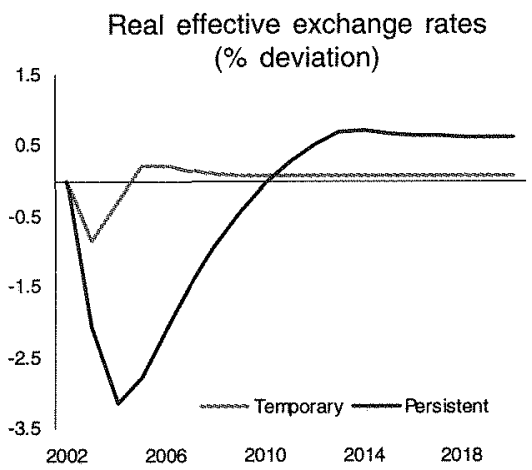

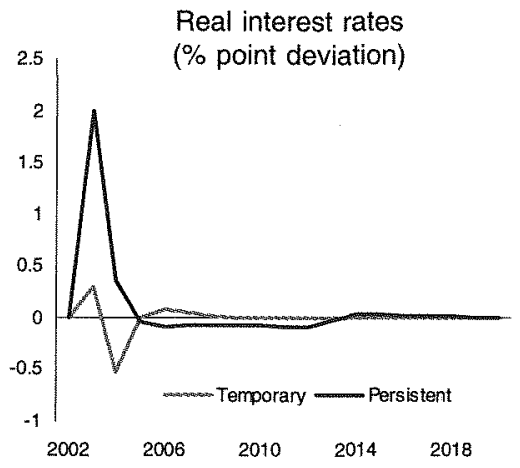

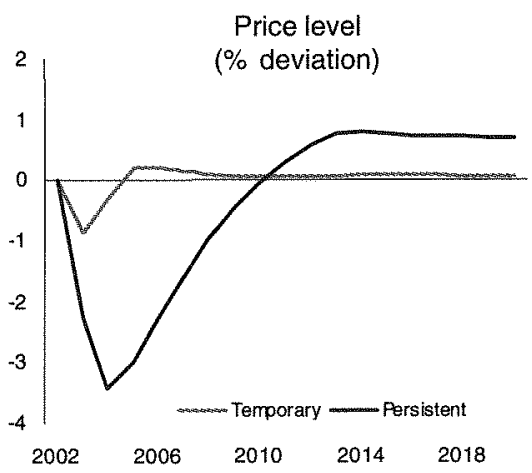

Source:APG3 model version $50 \mathrm{~N}$ 
There is a need to improve the quality of government responses such as coordination between agencies and between central and local governments in China. A large part of the short-term costs that we estimate derive from the rigidity of the exchange rate. Given the underlying pressure for an appreciating yuan in the baseline, the lack of a depreciation may have been less pressing in practice, but still causes the costs of SARS to the larger in China and Hong Kong.

Finally, the outbreak of SARS has reinforced the idea that an important role of governments in an interdependent but uncertain world is to manage risk; to establish processes for responding appropriately to unforeseen events, and to coordinate policy responses and information sharing globally.

\section{NOTES}

t See WHO SARS website (www.who.int/csr/sars/en/).

2 See McKibbin and Wilcoxen (1998) for the theoretical specification and McKibbin and Vines (2000) for an overview of key features and applications of the model.

3 See Bagnoli et al. (1996) for an overview.

4 A point made by Richard Cooper in Cooper (1989).

\section{REFERENCES}

Bagnoli, P., McKibbin, W. and Wilcoxen, P., 1996. ‘Future projections and structural change', in N. Nakicenovic, W. Nordhaus, R. Richels and F. Toth (eds), Climate Change: integrating economics and policy, International Institute for Applied Systems Analysis, Austria:181-206.

Barro, R. and Sala-I-Martin, X., 1995. Economic Growth, McGraw-Hill, Massachusetts. Bloom, D.E. and Mahal, A.S., 1997. 'AIDS, flu, and the black death: impacts on economic growth and well-being', in D.E. Bloom and P. Godwin (eds), The Economics of HIV and AIDS: the case of South and South East Asia, Oxford University Press, Oxford.

Chou, J., Kuo, N. and Peng, S., 2003. The Potential Impacts on the Taiwanese Economy of the Outbreak of SARS, Ppaper presented at Asian Economic Panel, Keio University, Tokyo, 11-12 May.

Commission on Macroeconomics and Health, 2002. Macroeconomics and Health: investing in health for economic development, Report of the Commission on Macroeconomics and Health to the World Health Organization, Geneva. 
Cooper, R., 2003. 'International cooperation in public health as a prologue to macroeconomic cooperation' in R.N. Cooper, G. Holtham, C.R. Henning, B. Eichengreen and R.D. Putnam (eds), Can Nations Agree? Issues in international economic cooperation, Brookings Institution, Washington, DC:178-254.

Enserink, M., 2003. 'The big question now: will it be back?', Science, 301 (5631):299. Garnaut, R. and Findlay, C., 2003. 'Overview', in Pacific Economic Cooperation Council (ed.), Pacific Economic Outlook 2003, Asia Pacific Press, Canberra:2-6. Grant, S., 2003. Risk Assessment and SARS, Public lecture, National Institute of Economics and Business, The Australian National University, 28 July. Available online http://ecocomm.anu.edu.au/nieb/SGrant_NIEB_LectureNotes030728.pdf. Haacker, M., 2002. The Economic Consequences of HIVIAIDS in South Africa, Working Paper WP/02/38, International Monetary Fund, Washington, DC.

Hanna, D. and Huang, Y., 2003. SARS Impact on Asian Economies, Paper presented at Asian Economic Panel, Keio University, Tokyo, 11-12 May.

Lee, J.W. and McKibbin, W., 2003. 'Globalization and disease: the case of SARS', Asian Economic Papers (forthcoming).

McKibbin, W.J. and Vines, D., 2000. 'Modelling reality: the need for both intertemporal optimization and stickiness in models for policymaking', Oxford Review of Economic Policy, 16(4):106-13.

McKibbin, W. and Wilcoxen, P., 1998. 'The theoretical and empirical structure of the G-cubed Model', Economic Modelling, 16(1):123-48.

Obstfeld, M. and Rogoff, K., 1996. Foundations of International Macroeconomics, MIT Press, Cambridge, Massachusetts.

Siu, A. and Wong, R., 2003. Ravaged by SARS: the case of Hong Kong SARS, Paper presented at Asian Economic Panel, Keio University, Tokyo, 11-12 May. Wen, H., 2003. China in the Eye of the Storm, Paper presented at Asian Economic Panel, Keio University, Tokyo, 11-12 May. 


\title{
3
}

\section{The travails of current macroeconomic and exchange rate management}

\author{
Wing Thye Woo
}

The quandary in macroeconomic management that the Chinese government is currently facing cannot be seen more clearly than in the following two newspaper headlines. On 18 August 2003, an article in Singapore's Straits Times under the headline 'Hu calls for more work creation as jobless rate rises' reported that the Secretary-General of the Chinese Communist Party, Hu Jin Tao, had called for 'stronger measures... [including] fiscal subsidies, tax incentives, insurance subsidies and credit opportunities' to spur economic growth. On 19 August 2003, Hong Kong's South China Morning Post carried an article with the headline 'Investments soar amid reluctance to rein in growth', reporting that the Chairman of the State Development and Reform Commission, Ma Kai, had 'urged the nation to be wary of overheating and unveiled measures to cut back lending at state-run banks.'

Have China's recent macroeconomic policies been too cautious? Or have they been too inflationary? Evidence in favour of the first assessment can be found in the successive negative inflation rates since 1997, and continued weak aggregate demand is suggested by the -0.4 per cent inflation rate in the first half of 2003. The case for overheating is based on the following facts: first, the GDP growth rate in the first quarter of 2003 was 8.9 per cent; second, fiscal and monetary stimuli were greatly ramped up in the March-June period to offset the negative consequences of 
SARS 2 ; third, the price index for intermediate input has risen by five per cent since the beginning of 2003; and, fourth, inflation has traditionally lagged behind excessive growth by $9-12$ months.

The cost of erring on the conservative side is certainly a high one. The official growth target of seven per cent in 2003 could only create 10 million new urban jobs, while there are 24 million urban job-seekers. ${ }^{3}$ In addition, 150 million of China's 500 million rural workers are 'effectively' unemployed-and this is the most conservative estimate. ${ }^{4}$ The cost of overheating could also be very big because high inflation in the past has sometimes undermined social stability. Furthermore, overheating is often a sign that the state credit system has been undermining economic restructuring objectives by bailing out inefficient state enterprises and funding investments in sectors with excess capacity.

As if China's macroeconomic managers were not already sufficiently vexed by the confusing signals of 'overheating' and 'below-potential growth', they now face tremendous political pressures from Japan, Western Europe and the United States to substantially revalue the renminbi (RMB). ${ }^{5}$ The current indignation over an undervalued RMB was set off on 1 December 2002 when two senior officials of Japan's Ministry of Finance wrote in the Financial Times that 'China is exporting deflation...through export growth and a combination of price deflation and an exchange rate pegged to the dollar', and asked China 'to allow the currency to appreciate' (Kuroda and Kawai 2002). This call to mobilise international opinion for action on the RMB appears to have succeeded. By mid 2003, South Korea, Western Europe and the United States had joined Japan in urging an appreciation of the RMB, probably in response to the adamant charges levied by their domestic industries about unfair competition from cheap Chinese imports. ${ }^{6}$ How China will respond to this foreign clamour for RMB revaluation will, not surprisingly, depend on its diagnosis of the current macroeconomic situation. The Chinese leaders are more likely to agree quickly to making the RMB much more expensive if they are convinced that the economy is overheated, and unlikely to go beyond the immediate introduction of a minor trading band around the current RMB-US dollar exchange rate if they conclude that deflation is a more plausible threat to China's economic growth.

In assessing the two contradictory desired stances of macroeconomic policies, the relevant analytical issue for an economist is whether China is already at its 'natural' rate of unemployment. An output growth rate that pushes the actual 
unemployment rate above the natural unemployment rate would not be unsustainable but would also risk generating a high inflation rate. The point is that, at any given moment, there is a maximum value on the sustainable output growth rate that is determined by the existing material and institutional conditions of the economy (and of the outside world). Thus, unless the higher growth rate desired by the policymaker is below the 'natural' growth rate, more expansionary macroeconomic policies will not deliver the desired higher growth rate.

The operational difficulty for macroeconomic management is that the natural growth rate of an economy is not immutable. For example, a rise in the rate of technological innovation would increase the natural growth rate, while the steady convergence of a formerly autarkic developing country to the frontier of modern science would cause a steady decline in the natural growth rate. Because of the latter phenomenon of growth slowdown as a consequence of economic maturation, it is not so straightforward to claim that China's annualised growth rate of 8.2 per cent in the first half of 2003 is below the natural output growth rate despite two crucial facts. The first fact is that the 2003 growth rate is more than a percentage point below the 9.4 per cent average growth rate of the 1979-2002 period; the second is that the inflation rate of -0.4 per cent in the first half of 2003 is substantially below the 5.5 per cent average of the 1979-2002 period. ${ }^{7}$ One needs a more compelling argument against the alternative explanation that the lower 2003 growth rate simply reflects a lower natural output growth rate and that slightly negative inflation is compatible with being on the natural growth path.

While it is important to manipulate aggregate demand via monetary and fiscal policies to keep the actual unemployment rate close to the natural unemployment rate, fortunately China is a position to implement other economic policies that will move the natural unemployment rate downward-that is, increase the natural output growth rate. To use a production analogy, the biggest gain comes not only from keeping an engine running at peak efficiency but also from having the engine with the largest capacity. The most important economic task for China is to adopt the best economic growth engine that world economic history has identified-a market economy where competitive private enterprises constitute the norm, and where the state focuses mainly on the provision of public goods and social insurance. The case for making this type of market economy the new growth engine is obvious 
when one recognises that China's remarkable growth in the post 1978 period has come from deregulation that has allowed Chinese economic institutions to converge with those of private market economies, especially those of the East Asian variety. ${ }^{8}$

My second argument is that many of the major macroeconomic challenges facing the Chinese government have their roots in China's inadequate marketisation and continued discrimination against the domestic private sector. Because of bureaucratic incentives within the state-controlled banks which monopolise the financial system, the large volume of savings is inefficiently intermediated into investment (with the private component of investment particularly deprived of bank loans). The significant consequence of inadequate intermediation is a level of aggregate demand that expands slower than the natural output growth rate. The state has thereby responded to deflationary tendencies by undertaking massive public investment to soak up excess savings in the banks. While increased public-directed investment can be a satisfactory solution in the short run, it is a disaster in the long run. The point is that an efficient banking system is an indispensable component of the new growth engine that China needs to put in place.

My third argument is that China's persistent trade surplus is fundamentally linked to the deflation phenomenon, and successful solution of one will mean successful solution of the other. A chronic trade surplus means that national savings are chronically larger than domestic investments, which is exactly the malaise of inadequate financial intermediation. An alternative to revaluing the RMB would therefore be increasing the level of domestic investment, especially targeting investment projects that require large amounts of imported capital equipment. It is hard to over-emphasise that it is extremely anomalous for a developing economy like China to be exporting capital to the rest of the world the counterpart of a current account surplus. Something must be fundamentally flawed when capital-short China is investing abroad in the same way as capital-abundant Japan.

My fourth argument is that the state-owned sector and state-controlled companies are still a serious threat to sustained high growth, banking sector solvency, and price stability. Worse yet, corruption within state enterprises undermines social stability. The switch to the new growth engine necessitates continued privatisation of non defence-related state enterprises that are not natural monopolies, and the elimination of legal discrimination against private sector activities. 


\section{A SLOWER GROWTH PHASE, AND ATTEMPTS AT MACROECONOMIC STIMULATION}

Towards the end of the 1990s, the partially reformed Chinese economy entered a slower growth phase, having largely exhausted the growth potential created by significant economic deregulation and internationalisation (Table 1.1). The average annual growth rate in the 1997-2002 period was 9.4 per cent, and growth rates from 1997-2002 were below 9.4 per cent. This extended period of below-average growth was unprecedented in the market reform period. When I compared mean growth rates for 1979-96 (9.9 per cent) with mean growth rates for 1997-2002 (7.8 per cent), I found the difference between them to be statistically significant. The tstatistic is 2.52 .

The analytically difficult question is whether lower growth rates for 1997-2002 reflect inadequate growth in aggregate demand or a reduction in the growth potential of aggregate supply. The fact that there was a statistically significant downward shift in the inflation rate between the two subperiods-the t-statistic is 5.6-with price changes negative for 1997-2002, raises the possibility that inadequate demand contributed to the lower growth rates in the second subperiod. This implication follows because, in the absence of a drop in aggregate demand growth, a fall in supply growth would have produced an outcome of lower growth-cum-higher inflation (that is, stagflation) rather than the observed outcome of lower growth-cum-deflation. The evidence suggests that the natural output growth rate at present is likely to be higher than 7.8 per cent.

The explanation for the lower growth-cum-deflation phenomenon for 1997-2002 is that there was not only a slowdown in supply-side growth but also a slowdown in aggregate demand growth. In the next section I will develop the argument that China's dysfunctional banking system has created a deflationary bias in the economy.

In thinking about the growth of aggregate supply there is little justification for the belief that there is a positive relationship between the actual growth rate and the inflation rate for all values of the growth rate. It is more likely that, if a positive relationship exists at all within any short period, it will be limited to a small range clustered around the natural growth rate-say, half a percentage point on each side of the natural growth rate. ${ }^{9}$ My estimate is that the natural output growth rate in 2003 , as permitted by China's material conditions and institutional structure, is 8 per cent. My estimate is higher than the 7.5 per cent in Huang (2003) and the official growth target of 7 per cent, and is at the high end of the 7-8 per cent range in $\mathrm{Yu}$ 
(2003). I also estimate that, in the absence of substantial reforms enabling the rapid emergence of a dynamic private sector, the natural growth rate will decline to 7.5 per cent at the end of the decade as the catching-up process proceeds further. If the necessary comprehensive reforms are implemented, however, the natural growth rate at the end of the decade will be 8.5 per cent.

The hypothesis that China has entered into a slower growth phase is consistent with employment data (Table 3.1). Average annual employment growth in the industrial sector was 2.8 per cent during the 1992-97 period, with a minimum of 2.1 per cent in 1997. Employment growth fell significantly after 1997-0.3 per cent in 1998, -1.1 per cent in 1999, -1.2 per cent in 2000, and 0.4 per cent in 2001. Employment in manufacturing had actually turned bad earlier in 1996. Manufacturing employment growth was negative throughout the 1996-2000 period, with a particularly large decline of 13.5 per cent in 1998.

Table 3.1 Employment in China's industries, 1978-2001

\begin{tabular}{|c|c|c|c|c|c|c|}
\hline \multirow[b]{4}{*}{1978} & \multirow{2}{*}{\multicolumn{2}{|c|}{$\begin{array}{c}\text { Employment level } \\
\text { Secondary Manufacturing }\end{array}$}} & \multirow{2}{*}{\multicolumn{2}{|c|}{$\begin{array}{l}\text { Employment share } \\
\text { Secondary Manufacturing }\end{array}$}} & \multirow{2}{*}{\multicolumn{2}{|c|}{$\begin{array}{l}\text { Growth in employment } \\
\text { Secondary Manufacturing }\end{array}$}} \\
\hline & & & & & & \\
\hline & \multicolumn{2}{|c|}{ (in millions) } & \multicolumn{2}{|c|}{ (percent of total employment) } & (percent per year) & $\begin{array}{l}\text { sector } \\
\text { er year) }\end{array}$ \\
\hline & 69.5 & 53.3 & 17.3 & 13.3 & & \\
\hline 1988 & 121.5 & 86.5 & 22.4 & 15.9 & $5.8^{*}$ & $5.0^{*}$ \\
\hline 1989 & 119.8 & 85.5 & 21.6 & 15.4 & -1.4 & -1.2 \\
\hline 1990 & 138.6 & 86.2 & 21.4 & 13.3 & 15.7 & 0.9 \\
\hline 1991 & 140.2 & 88.4 & 21.4 & 13.5 & 1.1 & 2.5 \\
\hline 1992 & 143.5 & 91.1 & 21.7 & 13.8 & 2.4 & 3.0 \\
\hline 1993 & 149.6 & 93.0 & 22.4 & 13.9 & 4.2 & 2.1 \\
\hline 1994 & 153.1 & 96.1 & 22.7 & 14.3 & 2.3 & 3.4 \\
\hline 1995 & 156.5 & 98.0 & 23.0 & 14.4 & 2.2 & 2.0 \\
\hline 1996 & 162.0 & 97.6 & 23.5 & 14.2 & 3.5 & -0.4 \\
\hline 1997 & 165.5 & 96.1 & 23.7 & 13.8 & 2.1 & -1.5 \\
\hline 1998 & 166.0 & 83.2 & 23.5 & 11.8 & 0.3 & -13.5 \\
\hline 1999 & 164.2 & 81.1 & 23.0 & 11.4 & -1.1 & -2.5 \\
\hline 2000 & 162.2 & 80.4 & 22.5 & 11.2 & -1.2 & -0.8 \\
\hline 2001 & 162.8 & 80.8 & 22.3 & 11.1 & 0.4 & 0.5 \\
\hline
\end{tabular}

Note: * Annual compound growth rate between 1978 and 1988.

Source: State Statistical Bureau, various years. Zhongguo Tongji Nianjian [China Statistical Yearbook], Zhongguo Tongji Chubanshe, Beijing. 1990-2001 data from 2002 edition, earlier data from 2001 edition. 2002 and 2003 GDP growth rates are from Citigroup, 2003. China Economics, Citigroup, 6 March. 
Price deflation appeared in the Retail Price Index (RPI) in October 1997, and in the Consumer Price Index (CPI) in February 1998. When it became apparent in the middle of 1998 that the economy was slowing significantly, the government implemented monetary and fiscal measures to boost aggregate demand (Figures 3.1 and 3.2, Table 3.2). Interest rates have been reduced eight times in less than six years, with the latest rate reduction on 21 February 2001, bringing the one-year deposit rate to 1.98 per cent and the one-year lending rate to 2.34 per cent (Figure 3.1). However, financial growth rates followed a declining trend in 2001. The central bank then began not only to increase reserves more aggressively but also to lean even more on the state banks to extend credit.

The annualised (year-on-year) growth rate of fixed asset investment of the state sector was kept above 15 per cent from July 1998 to July 1999, then lowered as exports to the other East Asian economics recovered (Figure 3.2). Fiscal stimulus

Figure 3.1 Credit conditions (money growth and interest rates, per cent)

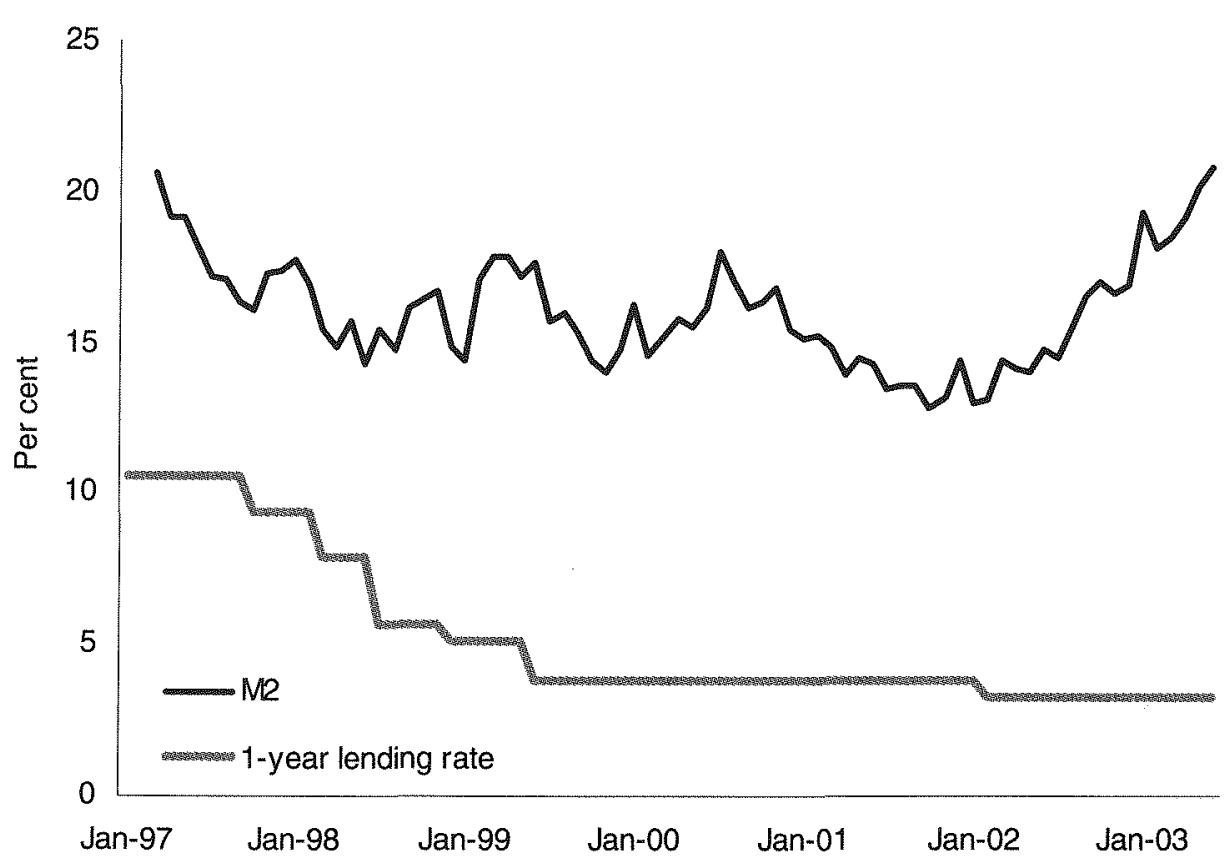

Source: Citicorp Database. 
was renewed in 2001. State spending on capital construction jumped from 209.5 billion yuan in 2000 to 251.8 billion yuan in 2001 , keeping the annualised growth rate of state sector fixed asset investment above 15 per cent for 11 of the 12 months in 2001. When the CPI slipped again into negative growth rates, (falling in November 2001 and reaching -1.3 per cent in April 2002), the Chinese government increased the intensity of the fiscal stimulus; for example, the growth rate of state sector fixed asset investment was above 23 per cent in the January 2002 - November 2002 period, and was 17 per cent in December 2002. Apart from investment in capital construction, the government also implemented several pay rises in this period. The increased government spending meant the fiscal deficit increased substantially from 1.1 per cent of GDP in 1998 to 1.9 per cent in 1999, 2.5 per cent in 2000, 2.7 per cent in 2001, and 2.9 per cent in 2002 (Table 3.2). ${ }^{10}$ Most government economists, for example Jia (2002), believe that investment funds raised through the issuing of treasury bonds contributed about 2 percentage points to GDP growth each year in the 1999-2002 period.

With the encouragement of the central bank, especially with the onset of SARS in early 2003 , the state banks greatly expanded their loans, especially to the real estate sector, and financial growth went from 16.8 per cent in the fourth quarter of 2002 to reach 20.0 per cent in the second quarter of 2003. Additional fiscal and monetary stimuli created to offset the deleterious effects of SARS on aggregate demand caused the rate of fixed asset investment to jump from 21.6 per cent in the fourth quarter of 2002 to 32.4 per cent in the first quarter of 2003 and 31.7 per cent in the second quarter of 2003 . The unfortunate feature about encouraging stateowned enterprise (SOE) investments, as emphasised by Fan and Woo (1996), is that, in a partially reformed centrally planned economy, there are many institutional features that motivate SOE investments to veer out of control and overheat the economy.

\section{THE DEFLATIONARY AND TRADE ACCOUNT CONSEQUENCES OF INADEQUATE FINANCIAL INTERMEDIATION}

At a superficial level, systemic deflationary pressures that have plagued China since 1997 have their sources in a shrinking money multiplier (a phenomenon that many Chinese economists have called 'the liquidity trap'), and a slowing down in the growth of consumption (a phenomenon commonly known as the paradox of 
Figure 3.2 Consumption and investment growth (year-on-year, per cent)

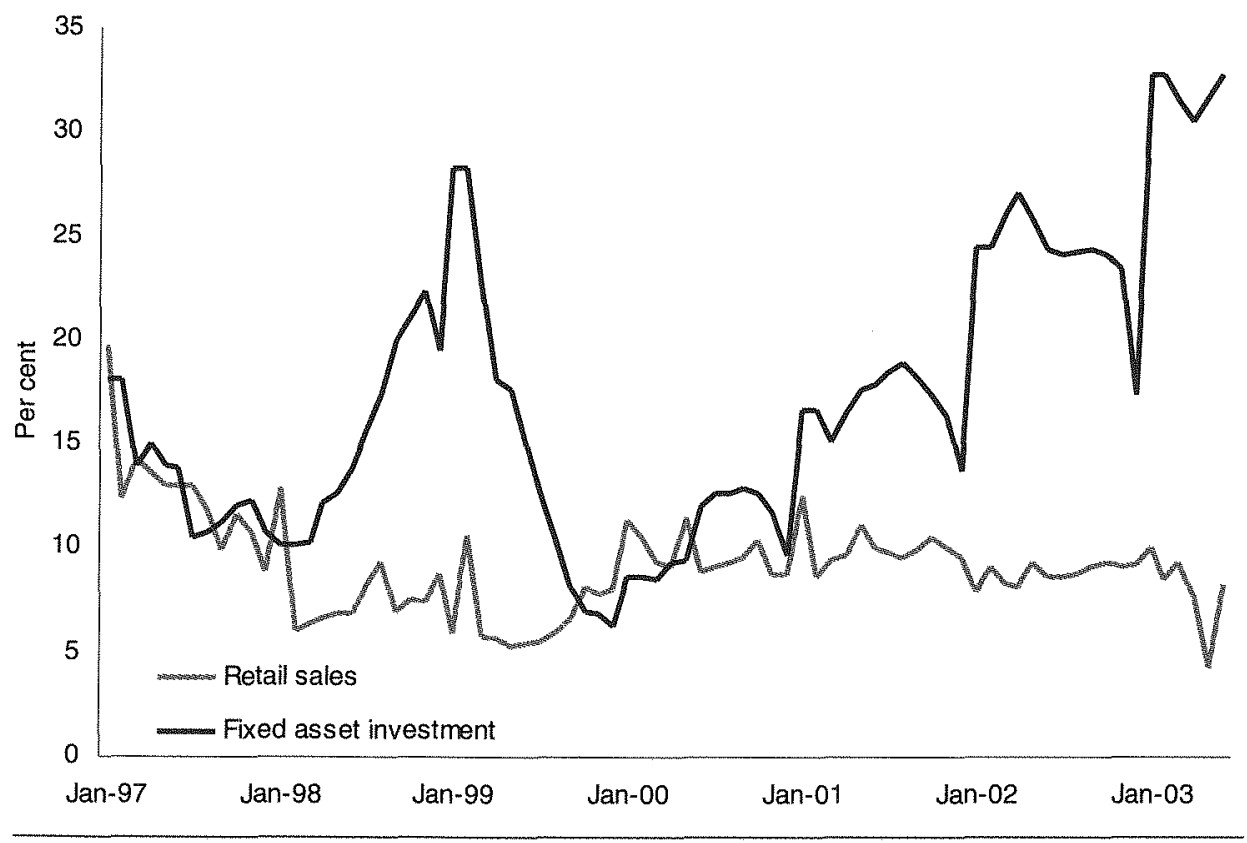

Source: Citicorp Database

Table 3.2 Growing fiscal spending

\begin{tabular}{lcccccc}
\hline & & & \multicolumn{3}{c}{ Spending } \\
Fiscal & $\begin{array}{c}\text { Fiscal } \\
\text { revenue } \\
\text { (RMB bn) }\end{array}$ & $\begin{array}{c}\text { Fiscal } \\
\text { (RMB bn) }\end{array}$ & $\begin{array}{c}\text { Share } \\
\text { (Ralance } \\
\text { of GDP }\end{array}$ & $\begin{array}{c}\text { (RM bn) } \\
\text { construction } \\
\text { (RMB bn) }\end{array}$ & $\begin{array}{c}\text { Share } \\
\text { of GDP } \\
(\%)\end{array}$ \\
1997 & 865.1 & 923.4 & -58.2 & -0.7 & 102.0 & 1.4 \\
1998 & 987.6 & 1079.8 & -92.2 & -1.1 & 138.8 & 1.8 \\
1999 & 1144.4 & 1318.8 & -174.4 & -1.9 & 211.7 & 2.6 \\
2000 & 1339.5 & 1588.7 & -249.1 & -2.5 & 209.5 & 2.4 \\
2001 & 1637.1 & 1884.4 & -247.3 & -2.7 & 251.8 & 2.6 \\
2002 & 1891.4 & 2201.2 & -309.8 & -2.9 & & \\
2003 & & & -319.8 & -2.8 & & \\
\hline
\end{tabular}

Source: Citigroup. 
thrift'). ${ }^{11}$ China has tried to boost the domestic economy with successive cuts in interest rates, but the rise in credit creation has been much lower than expected, except for the periods when the central bank has leaned heavily on the banks. ${ }^{12}$ The paradox of thritt refers to the low level of private aggregate demand due to increased private savings. The savings rate increased from almost 20 per cent of GDP in 1981 to 30 per cent in 1988 and almost 40 per cent in 2001.

At a deeper level, however, both these phenomena spring from the same causethe absence of adequate financial intermediation in China. The liquidity trap made its appearance in the mid 1990s when Zhu Rongji called for the removal of the state bank manager if the ratio of NPLs in her bank were to rise two years consecutively. As the majority of state enterprises are either in the red or just breaking even, the banks became unwilling to lend money to SOEs. Lending more to private enterprises was not really an option, however, since their legal status was lower than that of state enterprises and there was no reliable way to assess their balance sheets. The only activity to which the banks were happy to allocate their funds is the purchase of state bonds - that is, the financing of the government's deficit. ${ }^{13}$ The elimination of the liquidity trap requires the state to remove barriers to lending to the private sector, ending legal discrimination against private activities and establishing uniform accounting and auditing standards with credible enforcement mechanisms.

In discussions about the increasing savings rate, a common view is that it reflects uncertainty about the future. Many SOE workers feel this uncertainty in the face of widespread privatisation of loss-making SOEs. This explanation is incomplete, because there has also been a rise in the rural saving rate, even though rural residents have little to fear about the loss of jobs in the state-enterprise sector because none of them are employed there. On the basis of the work of Liu and Woo (1994) on savings behaviour, I conjecture that the desire to invest is an important reason for the rural sector's increased savings rate. The most dynamic industrial expansion in China during the period 1984-94 occurred in the rural areas. Since non-state firms in rural areas cannot borrow from the bank, the only way they could establish themselves was through self-financing, requiring would-be entrepreneurs to save first.

In the very first phase of rural industrialisation, the amount of capital needed to start a factory workshop was very small. After a decade of rapid industrial growth, the Chinese countryside is saturated with labour-intensive enterprises. As competition among rural enterprises is fierce at present, it no longer makes economic sense to 
invest and open the same type of factory workshop. Rural enterprises must therefore move up to the next stage of value-added production to be more profitable.

The new generation of rural enterprises is much more capital-intensive, thus it requires larger startup funds. Rural residents have responded to the higher capital requirements by increasing their savings. Since the phenomenon of investmentmotivated saving must also be present within the Chinese urban community, pessimism-based explanations for the rise in urban savings are only partially correct. In fact, with the steady relaxation of regulations against the establishment of private businesses in rural and urban areas, the amount of investment-motivated savings in China could only have risen more. According to Williamson's (1988) summing up of the historical record of Western Europe and North America, "investment demand seems to have been the driving force behind private saving and accumulation, past and present.'

Total fixed investment has increased spectacularly as a proportion of GDP, with annual averages of 28.8 per cent in 1984-88, 34.0 per cent in 1992-96 and 36.3 per cent in 1997-2001. SOE investment increased in 1992-96 (19.8 per cent), then returned to its initial 1984-88 level (18.7 per cent) (Table 3.3). However, the amount of state-directed investment in 1997-2001 could be more than three percentage points higher than 18.7 per cent of GDP, because many of the big SOEs of 1988 had by 1999 converted themselves (or components of themselves) to shareholding companies listed on the stock exchanges, while remaining state-controlled. Furthermore, many SOES have formed joint-venture firms with domestic and foreign companies, with themselves as the controlling shareholders.

In contrast to the spectacular rise in total investment and the probably equal rise in state-directed investment, rural investment has fallen from 8.2 per cent in 198488 to 7.7 per cent in 1992-96 and 7.5 per cent in 1997-2001. My hypothesis is that a major reason for the decline in the rural investment ratio is that the traditional labour-intensive factory is no longer profitable, and rural entrepreneurs have been unable to borrow the money to undertake the more capital-intensive investments required for the next generation of rural enterprises. ${ }^{14}$ The investment-GDP ratio rose at the national level because FDI rose while state investments (through the budget, SOEs and state-controlled enterprises) fully utilised higher domestic savings.

Inow turn to show that another outcome of inadequate financial intermediation is a chronic current account surplus. To see this point, consider the following accounting relationship: 
Current account surplus $=$ (government budget surplus)

+ (savings of SOEs - investments by SOEs)

+ (savings of the non-state sector - investments of the non-state sector). ${ }^{15}$

The facts for the recent period are that the current account surplus (or, loosely speaking, the trade surplus) is positive, the government budget surplus is negative at an unprecedented level, and SOE savings are less than SOE investments. This means that the savings of the non-state sector must greatly exceed the investments of the non-state sector. As documented earlier, the government has sought to fight

Table 3.3 Investment trends by ownership (per cent of GDP)

\begin{tabular}{lccc}
\hline & Total & Rural & SOE \\
1981 & 19.8 & 5.1 & 13.7 \\
1982 & 23.2 & 6.2 & 16.0 \\
1983 & 24.1 & 7.0 & 16.0 \\
1984 & 25.6 & 7.7 & 16.5 \\
1985 & 28.4 & 7.6 & 18.7 \\
1986 & 29.6 & 8.0 & 20.4 \\
1987 & 30.4 & 8.9 & 19.2 \\
1988 & 30.1 & 8.9 & 18.5 \\
June 4th Tian An Men disruption, $1989-91$ & & \\
1992 & 29.5 & 7.5 & 19.8 \\
1993 & 36.0 & 8.0 & 22.1 \\
1994 & 36.4 & 7.5 & 20.6 \\
1995 & 34.2 & 7.5 & 18.6 \\
1996 & 33.8 & 7.9 & 17.7 \\
1997 & 33.5 & 7.7 & 17.6 \\
1998 & 36.3 & 7.5 & 19.6 \\
1999 & 36.4 & 7.5 & 19.4 \\
2000 & 36.8 & 7.5 & 18.5 \\
2001 & 38.8 & 7.5 & 18.4 \\
Average 1984-88 & 28.8 & 8.2 & 18.7 \\
Average 1992-96 & 34.0 & 7.7 & 19.8 \\
Average 1997-2001 & 36.3 & 7.5 & 18.7 \\
\hline
\end{tabular}

Notes: Investment refers to fixed asset investment. 1984 was the year when the central government gave the clear signal that it had no ideological objection to the formation of rural enterprises. Rural $=$ rural collectives and rural individuals. SOE = state-owned units only, does not inciude state-controlled units listed as various types of joint-owned units (for example, shareholding units, joint-venture units).

Source: State Statistical Bureau, various years. Zhongguo Tongji Nianjian [China Statistical Yearbook], Zhongguo Tongji Chubanshe, Beijing. 
deflation by increasing public works (that is, running record budget deficits) and encouraging SOE investments to soak up the excess savings. The rise in total investments has not been sufficient to use up the excess savings, however, and these residual excess savings have leaked abroad in the form of an aggregate trade surplus. Inadequate financial intermediation has made China a capital-exporting country!

This perverse current account outcome is not new. Taiwan had exactly this problem up to the mid 1980s when all Taiwanese banks were state-owned and operated according to the civil service regulation that the loan officer had to repay any bad loan that he had approved. The result was a massive failure in financial intermediation that caused Taiwan's current account surplus to amount to 21 percent of GDP in 1986.

China's tendency to generate persistent current account surpluses manifested itself only after 1994 because of major policy changes implemented in that year. Before 1994, with the government budget deficit being usually small, the voracious absorption of bank loans by SOEs, in the soft-budget environment, to invest recklessly kept the current account usually negative. In 1994, Zhu Rongji implemented stricter controls on the state-owned banks (SOBs) to reduce the then 24 percent inflation rate and the explosion of NPLs. This lower growth rate in SOE investments from 1995 onward is the reason China's built-in propensity for current account surpluses revealed itself only from 1995 onward. This propensity is mainly caused by the secular rise in the savings of the non-state sector for the reasons identified earlier, for example, secular rise in the required amount of start-up capital, secular improvement in the official attitude toward market capitalism. ${ }^{16}$ China is not producing the gargantuan current account surpluses seen in Taiwan in the mid 1980 s because of its record budget deficit and still overly large amounts of SOE investments.

Obviously, increasing budget deficits and SOE investments to counter deflation and reduce the trade surplus can only be a satisfactory solution in the short run. In the long run, the increased public investments could follow an increasingly rentseeking path that is wasteful as in Japan (where, for example, a second big bridge would be built to a lowly populated island almost solely to benefit a politically connected construction company), and the increased SOE investments could convert themselves into non-performing loans at the SOBs.

The solution to the problem of excess saving is not for the government to absorb it by increasing its budget deficit but to establish an improved mechanism for 
coordinating private savings and private investment. This solution is correct regardless of my hypothesis about investment-motivated savings.

\section{THE BANKING SYSTEM AS A SINKHOLE}

Undeniably, China's banks are in serious financial straits. According to the People's Bank of China (PBOC), the proportion of NPLS of the four big SOBs is presently about 26 per cent, about 2 percentage points lower than a year ago. However, recent scandal over improper loans given to a Shanghai developer by the Hong Kong branch of the Bank of China suggests undiscovered problems. Citigroup (2002) suggests that NPLs amount to 35 per cent of outstanding loans to the four big SOBs at the beginning of 2002, and that the average capital adequacy ratio (CAR) of these four banks is 5.0 per cent (Table 3.4).

Bank reform efforts of the past several years have failed. The proportion of NPLS declined from its record high of 48 per cent in 1998 , but this reduction was achieved mainly by the transfer of NPLs to the state-owned asset management corporations (AMCs). Most NPLs still need to be dealt with and are the responsibility of the People's Bank of China or the Ministry of Finance. ${ }^{18}$ Worse still, most of the problematic SOEs remain the clients of the parent banks and continue to create new NPLs. New NPLs have been created by intermittent pressure on the banks from the government to expand investment credit to combat deflation, and to expand social stability loans to reduce firm closures. This may be an important reason for the deterioration in the quality of banking assets in recent years, causing the capital adequacy ratio to fall to 5 per cent in early 2002 from the more than 8 per cent in late 1998 after the recapitalisation of the banks.

Table 3.4 Rising fragility of China's banking sector

\begin{tabular}{lccc}
\hline & End-1996 & End-1998 & Beginning-2002 \\
Proportions of NPLs (\%) & & & \\
Big four banks & 40.0 & 48.0 & 35.0 \\
Ten joint-stock banks &.. & 13.5 & 15.5 \\
Average CAR (\%) & 4.4 & $>8.0$ & 5.0 \\
Big four banks & 4.4 & \\
\hline
\end{tabular}

Notes: CAR: capital adequacy ratio. Proportion of NPLs for the four major banks for 1996 and 1998 are re-estimated on the basis of new information made available at the beginning of 2001 . The proportion for 2001 excluded the Rmb1.4 trillion transferred to the AMCs in the previous year. Source: Citigroup, 2002. Greater China Insights, 14 June. 
However, it is possible that a large part of the post 1998 NPLs may actually be pre 1998 NPLs that were not recognised during the 1998 recapitalisation. At that time, the SOBs might not have wanted to reveal the actual NPL situation because this would have revealed previous official NPL estimates to have been wildly inaccurate. In any case, the state banks are now in need of another round of recapitalisation.

With such a fragile banking system, China has committed itself to opening up the banking system completely after five years of joining the WTO. Foreign banks have been able to conduct transactions in foreign currencies from the beginning of WTO membership (December 2001), conduct transactions with the local corporate sector in renminbi after two years, and conduct transactions with local households in local currencies after five years. Although foreign banks are likely to compete only in the coastal cities, the pressure on domestic banks would be great, as the big four banks extract about 95 per cent of their profits from about half a dozen coastal cities (Shanghai, Beijing, Xiamen, Shenzhen, Guangzhou, and Tianjin). Because there is no depositor insurance in China, the obvious question is whether depositors will believe that foreign banks cause SOBs to bankrupt, and rush to withdraw their savings from the SOBs, setting in motion the vicious downward spiral of credit contraction, leading to business failures, rendering sound financial institutions insolvent, and contracting credit further.

Even if pressure on the state banks does come from depositor withdrawals, there will not necessarily be a full-blown crisis, since the central bank will be able to issue currency to the state banks to meet withdrawals. This expansion of high-power money cannot be easily translated into a loss of foreign reserves because capital controls, which I support, remain in place and are likely to do so for the foreseeable future. The resulting expansion of high-power money will not have an impact on inflation because it represents a shift from bank deposits to cash, or from some banks to others, and not a shift to goods. In the current deflationary atmosphere, a run from bank deposits to goods would be stabilising. The government has the technical ability to accommodate shifts in bank deposit preferences, even a modest bank run, without risking exchange rate collapse or runaway inflation.

If the banking system is plagued by frequent bank runs, its role as a financial intermediary will be greatly reduced, and economic growth could suffer significantly. The real issue is not whether depositor shifts or a run on a bank could be accommodated, but how a banking crisis could be prevented from occurring in the first place. The government must keep the banks adequately capitalised at all times. 
Another reason for the banks to be recapitalised is that this will lower the lending rate, and hence spur capital formation. To see how NPLs raise lending rates, note that the cash-flow constraint that a bank (regardless of solvency) must meet in the absence of state subsidies, operating costs, and a reserve requirement is given by

$$
r_{D} D=r_{L}[D-N P L]
$$

where $r_{D}=$ deposit rate, $r_{L}=$ lending rate, and $D=$ amount of deposit.

This means that if an NPL equals one-third of deposits, then the lending rate has to be at least 50 per cent higher than the deposit rate. The significant implication, however, is that a new bank (domestic or foreign) can undercut the lending rate of the existing $S O B$ because it will not have any NPLs on its books. Since the government recapitalised the banks in 1998, and needs to do so again now, the important question is whether there are technical and political obstacles that can prevent China from implementing another round of bank recapitalisation. How many more rounds of bank recapitalisation can China afford without generating a fiscal crisis?

\section{HOW SERIOUS IS THE THREAT OF FISCAL INSOLVENCY?}

The prolonged use of loose fiscal policy carries two major risks. The first risk is low economic efficiency of state investment, especially of many infrastructure projects implemented in the last four years. Almost all these projects were implemented hurriedly, with some projects approved even before the feasibility reports were completed. In 1998 and 1999 there were frequent reports about the collapse of recently built bridges and roads. This risk of fiscal inefficiency has been confirmed by an internal study by the Ministry of Finance, which found that the amount of investment required to create one additional unit of GDP has increased significantly in recent years (Gao 2002).

The second, and possibly more serious, risk to fiscal management is fiscal sustainability. Proactive fiscal policy contributes to fiscal risks in two ways, directly by increasing both fiscal deficits and public debts, and indirectly by increasing the amount of NPLs through influencing banks' lending decisions. A higher debt-GDP ratio means more debt servicing in future periods, and this could require expenditure cuts to prevent an upward spiral of the debt-GDP ratio-a development that could convince financial markets that the state is resorting to the Ponzi scheme (or pyramid scheme) to finance its deficits. 
Fiscal sustainability lies at the heart of whether a banking crisis would actually occur. As long as the state is perceived as able and willing to bail out failing SOBs, depositors will retain their confidence in the SOBs, regardless of the actual state of their balance sheets. The stock of publicly acknowledged government debt is 16 per cent of GDP, and it is common to hear official assurances that current fiscal deficits of less than 3 per cent of GDP do not pose a problem for debt servicing by the state. Analytically, however, the correct measure of public debt should be the consolidated debt of the state sector, including at least some part of contingent liabilities (for example, foreign debts of SOEs and SOBs, and unfunded pension schemes in the SOE sector). If an analyst counts NPLs as contingent liabilities, then she is really computing what the public debt will be after one more round of bank recapitalisation. According to Fan (2003), consolidated public debt at the end of 2001 amounted to 72 per cent of GDP; according to Citigroup (2002), it could be as high as 115 per cent (Table 3.5). So, is China's present debt-GDP ratio too low or too high?

In 1995, central government debt-GDP ratios in Italy, Sweden and the United States were, respectively, 117.6 per cent, 70.8 per cent, and 50.5 per cent in $1995 .{ }^{19}$ So, if China undertakes its second bank recapitalisation, its public debt will still be within the range of advanced OECD countries that are not experiencing fiscal crises. However, two important points show that this finding is not optimistic.

First, the forthcoming recapitalisation of China's banks appears to be the last major one that the government could implement in the short term without risking the

Table 3.5 Contingent liabilities in China, end of 2001

\begin{tabular}{lcc} 
& RMB billion & $\begin{array}{c}\text { Per cent } \\
\text { of GDP }\end{array}$ \\
Accumulated public debts & 1,550 & 16.2 \\
Special T-bonds in 1998 for recapitalisation & 270 & 2.8 \\
Estimated costs for bank restructuring & 4,500 & 46.9 \\
Estimated costs for social security funds & 2,500 & 26.1 \\
Municipal government contingent debt & 700 & 7.3 \\
External debts & 1,500 & 15.6 \\
Total & 11,020 & 114.9 \\
& & \\
Note: This is an updated estimation based on new information available on both gaps in social \\
security funds and municipal government contingent debts for which the central government is \\
the guarantor. These were estimated on the basis of communication with government economists. \\
Source: Citigroup, 2002. Greater China Insights, 14 June. \\
\hline
\end{tabular}


stability of the domestic financial markets and its credit standing in the international financial markets. A third recapitalisation (since 1997) would push the debt-GDP ratio to over 150 per cent, well above the OECD norm.

Second, if China recapitalises the SOBs a second time, it will have to compromise the expansionary fiscal policy that has been keeping GDP growth above 7 per cent since 1997. This is because China raises much less state revenue (as a share of GDP) than the OECD countries, and hence has a much lower capacity to service its public debt. The revenue-GDP ratio was 16.2 per cent for China in 2001, 30 per cent for Italy in 1995, 38 per cent for Sweden in 1995, and 21 per cent for the United States in $1996 .^{20}$ China's additional debt service from the second bank recapitalisation will be about 1.5 to 2.5 per cent of GDP. ${ }^{21}$ If China increases tax collection or reduces infrastructure spending to cover this increased debt service, then this second recapitalisation of the SOBs will reduce the fiscal stimulus that has been keeping GDP growth rate above 7 per cent. Between these two options, expenditure reduction cannot be considered the less likely outcome, because in China's experience during the reform era frequent changes to the tax system have not been able to raise revenue significantly for sustained periods. The reason for the low revenue-GDP ratio could be that increasing tax collection is as much a political as an administrative challenge.

If the issue of fiscal sustainability is viewed in the broader context of debt dynamics, one might be tempted to be more optimistic about the present situation, and thus dismiss the existence of a trade-off between bank recapitalisation and fiscal stimulus. Such an optimistic assessment is based on the assumption that China's annual growth trend over the next decade and a half will continue to be at least 7 per cent, meaning that the high debt-GDP ratio of 115 per cent of today would be reduced over time by the high rate of output growth. There would be no need to cut back on the fiscal stimulus to service the additional debt from the new round of bank recapitalisation. China could just borrow more to cover the additional debt service, and wait for the economy to 'grow' out of its debt.

This optimism is based on the evolution of the debt-GDP ratio as given by

$$
d(\ln [D e b t / G D P]) / d t=r+p+b-y
$$

where $r=$ real interest rate on government debt; $p=$ primary fiscal deficit rate $=$ [state expenditure excluding debt service - state revenue]/GDP; $b=$ NPL creation rate $=$ [change in NPL in SOB] / GDP; and $y=$ trend growth rate of real GDP. 
For convenience, I assume y to be 8 per cent, and $p$ to be 2 per cent. (According to Deutsche Bank (2003), p was 1.8 per cent in 2001 and 2.2 per cent in 2002, and is likely to be 2.1 per cent in 2003.) One seemingly plausible estimate of the real interest rate $(r)$ is 4 per cent, obtained by combining the government bond rate on 25 March 2003 at .65 per cent, and a negative 1 per cent inflation. If we now add the unrealistic assumption of $b=0$ to this example, we see that $y$ exceeds the sum of $r$ and $p$ by 2 percentage points, implying that the debt-GDP ratio declines over time.

However, this safety margin of 2 percentage point for China's debt situation is based on the wrong assumption of $b=0$. The fact that China must now undertake another recapitalisation after 1998 to solve the problem of NPLs valued at 35 per cent of GDP suggests that $b=7$ per cent! If we make the assumption that the SOBs will be able to reduce the annual NPL creation rate (b) to 2 per cent of GDP after this second recapitalisation, can we reach the optimistic conclusion that China can simply grow out of its debt without having to face the trade-off between bank recapitalisation and fiscal stimulus?

This optimistic conclusion is also dependent on two other highly unrealistic assumptions

- that there will not be another round of bank recapitalisation in the future-an assumption about state banks that has been falsified not only by international experience but also by China's own experience since 1998

- that China can promote the development of its financial sector without freeing state-set interest rates.

Because the real interest rate of 4 per cent (used above) is the product of interest rate ceilings, the shadow interest rate is likely to be substantially higher. As China is a capital-shortage country, the real rate of return on physical capital in China must be higher than in the United States, suggesting that it is likely to be over 15 per cent. Thus, if there were an efficient government bond market in China today, the lower boundary of the real government bond rate could be at least 6 per cent.2? This two percentage point rise in the real interest rate is made more plausible by the fact that the state would have to issue new bank recapitalisation bonds that amount to 40 per cent of GDP. In short, under interest rate liberalisation and with $b=2$ per cent, the primary fiscal deficit $(p)$ would have to be cut from two per cent to zero, that is, the fiscal stimulus would have to be eliminated in order for the debt-GDP ratio not to spiral uncontrollably upward. 
As international experience shows interest rate liberalisation to be crucial to the increasing sophistication of financial markets, I really see no reason to feel assured about the sustainability of China's fiscal situation. The lesson from this debt dynamics exercise is that we have to be very cautious about a benign scenario for China's fiscal situation. Even with the optimistic assumption that NPLs equal two per cent of GDP, China has no margin of safety to ensure fiscal solvency. There is a trade-off between maintaining its fiscal stimulus to reduce unemployment and liberalising interest rates to promote financial sector development.

In summary, China's consolidated debt-GDP ratio would be relatively high by international standards after a second bank recapitalisation, while its revenue-GDP ratio would remain relatively low. The threat to the stability of China's financial markets is fiscal sustainability, and the threat to fiscal sustainability is successive rounds of bank recapitalisation. This precarious outcome is a systemic feature of the current banking system, a relic from the era when central planning was the preferred engine of economic growth. We cannot attribute the creation of NPLs entirely to the SOBS; their chief customers, the SOEs, deserve an equal share of the blame. The fact is that the problem of NPLs cannot be solved unless the SOE problem is also solved. ${ }^{23}$

\section{MACROECONOMIC AND SOCIAL INSTABILITY FROM THE STATE ENTERPRISE SECTOR}

The inflationary problem generated by the traditionally biggest macroeconomic destabiliser (the SOE sector) still exists. If anything, the SOE sector in 2003 has not only become a potential source of more macroeconomic instability, but also emerged as a source of socio-political instability. To see the origin of these negative developments, we review the Fan and Woo (1996) argument that the reform strategy for the SOE sector during 1978-93 was inherently inflationary. ${ }^{24}$

The crux of the 1978-93 SOE reform strategy was to transfer decision-making power from the industrial bureaus to the state enterprises. The increased operational autonomy of the SOEs reduced the ability of the industrial bureaus to monitor the financial situation within the SOEs, and hence created the incentive for SOEs to greatly increase their demand for investment funds. The reduction in bureaucratic oversight of SOEs in a soft-budget environment allowed the SOEs to use creative accounting to privatise profits from good investment projects, and to receive state subsidies to cover losses from bad investment projects. Until about 1996, SOEs 
were generally able to satisfy their large appetite for investment because the local governments, in the interest of local development, inevitably lobbied local branches of the state banks to grant the SOEs' applications for investment loans. The evidence is overwhelming that local bank branches, at least until 1995, were unable to resist the demand for easy money. ${ }^{25}$

Losses at SOEs exploded after 1992 with the fall of the former Soviet Union, when many Chinese SOE managers saw the same fate for China and concluded that this was their last chance to steal. SOE losses skyrocketed, even though GDP grew in the range of 10-14 per cent annually in the 1992-95 period. By 1995, it was common to summarise the SOE situation in terms of one-third losing money and another one-third making no money. From the vantage point of 2003 , it seems that continued inefficiency and de facto asset-stripping and embezzlement of profits by managers and workers were the primary causes of the general decline in SOE profits, with the latter being the more important. Devolution of financial decisionmaking power to the SOEs, and steady reduction in discrimination against the private sector have made it increasingly easy for the managers to transfer state assets to themselves. Of the 327 cases of embezzlement, bribery and misuse of public funds that were tried in Beijing in 1999, '76 per cent took place in SOEs'. ${ }^{26}$

Increasing public outrage over the inequity of the informal privatisation of the SOE sector is well captured by He Qinglian who wrote that the SOE reform has amounted to

a process in which power-holders and their hangers-on plundered public wealth. The primary target of their plunder was state property that had been accumulated from forty years of the people's sweat, and their primary means of plunder was political power. ${ }^{27}$

By 1994, the Chinese leadership had recognised the increasingly serious economic and political problems created by the principal-agent problem innate in its decentralising reforms of market socialism. thus it announced that the clarification of property rights of SOEs would be added to the SOE reform program. In July 1997, the Communist Party of China (CPC) publicly committed to convert most of the SOEs to publicly traded shareholding corporations-a form of industrial organisation that originated in capitalist economies. Employment growth in the industrial sector (Table 3.1) fell from 2.1 per cent in 1997 to 0.3 per cent in 1998, then became negative in the following years. The restructuring of state manufacturing industries had occurred even earlier, in 1996. 
The state's decision to accelerate diversification of the ownership structure of the SOEs in 1997 was a bold move, because experiences with mass privatisation in Eastern Europe and the former Soviet Union (EEFSU) demonstrated that the task was extremely difficult and outcomes consistently fell below initial expectations. In Russia, 'loans-for-shares' privatisation transferred the country's enormous mineral wealth to a group of oligarchs, and the weak administrative and legal structures allowed many managers to take effective control of the privatised firms and loot them instead of improving their operations. Furthermore, the EEFSU experiences warn that mass privatisation is an exceedingly dangerous business politically, since it generates great amounts of rent and the resulting corruption inevitably affects government. The governments of both Vaclav Klaus and Boris Yeltsin were affected in this way.

Privatisation has been going forward in China (albeit with occasional stops) for two main reasons. The first reason comes from John Nellis (1999), who points out that 'governments that botch privatisation are equally likely to botch the management of state-owned firms'. The answer is not to avoid privatisation but to implement more careful privatisation: governments in transition economies should 'push ahead, more slowly, with case-by-case and tender privatisations, in cooperation with the international assistance community, in hopes of producing some success stories that will lead by example.'

The second reason lies in the fact that delaying privatisation would be costly to China's government politically. The maintenance of the status quo has become increasingly difficult because SOE managers in China know from the EEFSU experience that they are in an endgame situation. Widespread spontaneous privatisation by SOE managers could create grave social instability.

The solution to the SOE problem in China is not privatisation per se, but a transparent, legal privatisation process that society at large can accept. Because an adequate privatisation program must compensate retired and laid-off workers, permit takeover by core investors, and respect the rights of minority shareholders, it is important that legal reforms be carried out simultaneously. Only with a transparent, equitable privatisation process overseen by an adequate legal framework would China be likely to avoid a state-created Russian-style kleptoklatura.

Recently, there has been some questioning about whether the case for privatisation has been overstated. ${ }^{28}$ When Zhu Rongji was designated the new premier in 1997, 
he announced that he would solve the SOE problem in three years. In 2000, he declared victory on the SOE front when the profits of the industrial SOEs leaped from 53 billion yuan in 1998 to 241 billion. Zhou and Wang (2002) quantified the sources of the financial turnaround, and found that

- the lower interest rate in 2000 increased profits by 52 billion yuan (28 per cent of the increase in SOE profits)

- the higher oil prices boosted overall SOE profits by 79 billion yuan because almost all oil companies are state-owned (42 per cent of the increase) $)^{29}$

- the conversion of the bank loans of SOEs into equities held by state asset management companies raised profits by 10 billion yuan ( 5 per cent of the increase).

About 75 per cent of the increase in the profits of industrial SOEs in the 19982000 period was not due to actions taken within these enterprises but to external factors. When Zhou and Wang (2002) calculated the profit rate after deducting the profits from the more favourable external environment, they found profits had increased from 0.7 per cent in 1998 to 1.2 per cent in 2000 for the SOE sector, and from 2.8 per cent to 4.8 per cent for the non-SOE sector. Despite the recent good news on SOE profitability, the fact remains that the SOE sector still lags considerably behind the non-SOE sector in efficiency.

While the recent rise in profits gives some breathing space, the capacity of SOES to 'dissipate rents' through high payments to managers and workers, if not illegal transfer of assets, should remain clearly in the policymakers' minds, otherwise any gains could be squandered, if not reversed, in a relatively short period of time. It is important for China to replace uncontrolled (and uncontrollable) asset stripping in the SOE sector with transparent and equitable privatisation in order to improve macroeconomic stability and defuse socio-political instability.

\section{CONCLUSION}

I have argued that China's dysfunctional financial system has imparted a deflationary bias to the economy and made China a capital-exporting country by constraining the growth of aggregate demand to a lower level than the growth of aggregate supply. The government has been actively trying to neutralise deflation through an aggressive fiscal policy. I recommend that it should now expand its investment program to incorporate large import-intensive infrastructure projects so that the trade surplus can be reduced as well. This move would be a better alternative to the appreciation 
of the RMB as suggested by China's foreign friends. The additional infrastructure construction would create jobs, relieve production bottlenecks, and, on top of all this, preserve employment in China's export-oriented sectors. However, the most efficient solution is for private investment rather than public investment to recycle the pool of private savings back into the economy. The key to eradicating the deflation bias and the tendency towards current account surplus lies in establishing an efficient financial intermediation mechanism.

If the Chinese government decides to keep the SOBs as the dominant financial intermediation mechanism, there is really little to be gained by recapitalising the SOBs. This suggests that an effective way to slow the pace of NPL creation in an SOB-dominated financial system and to sustain the fiscal situation might be to keep the NPLs on the books of the SOBs, and 'the financial status of these loans should be constantly watched and openly discussed' in the public media (Fan 1993).

For Fan Gang's suggestion to work, it is necessary that foreign banks (which by 2008 will face no more restrictions than Chinese banks) will not expand aggressively out of the big coastal cities. If the foreign banks do expand rapidly, then their lower costs from the absence of NPLs will allow them to charge lower lending rates than the SOBs. This will eliminate the SOBs, because WTO regulations make it illegal for the government to subsidise SOBs against foreign competition. Fan Gang's method should work for 7-10 years because only HSBC and Citibank are likely to expand their banking network actively in China in the next decade, and even then only in the main coastal provinces.

The most important priority for financial sector reform is the establishment and growth of competitive domestic banks. As China is required by its WTO accession agreement to allow foreign banks to compete against its SOBs on an equal basis by 2007 , it would be ridiculous not to allow the formation of truly private banks of domestic origin. There is no reason to favour foreign private banks over domestic private banks, and no reason why China should not allow its best financial minds compete with the best foreign financial minds. I therefore recommend that, after recapitalisation of the big four state banks, at least two be broken into regional banks, and that the majority of these regional banks be privatised..$^{30}$ At the same time, the laws on the establishment of new banks should be loosened, and interest rates deregulated. However, it is crucial that the speed of financial sector liberalisation should proceed no faster than the development of the financial regulatory ability of the state. Even then, the danger of substituting financial crash for financial repression 
is still a real one. A modern financial system requires a modern system of financial supervision and prudential regulation for its proper functioning.

It would be a good idea to sell a few of the regional state banks to foreign banks. This would facilitate the transfer of modern banking technology to Chinese banks. The more local staff foreign bankers train, the larger will be the pool of future managers for Chinese-owned banks. An accelerated process of promoting the growth of sound domestic private financial institutions and allowing the entry of foreign financial institutions would certainly shorten the time it would take for Shanghai to assume its rightful place among the major international financial centres, and to contribute to more efficient intermediation in the world's savings.

Entry of Western banks into China's financial markets is not the same as liberalisation of the capital account in the balance of payments. China would not be well served by a rapid opening of the capital account, since that could subject China to the same rapid swings of short-term capital that shattered the economies of Southeast Asia and Latin America. Capital account opening should also proceed gradually, because it must be accompanied by sophisticated financial market regulation, something that is clearly not in place now. Foreign banks could become conduits for large-scale capital flight, or for rapid swings in short-term lending and repayments, or facilitators of bank runs (in which depositors do not merely switch banks, or switch from domestic banks to domestic currency, but actually switch from domestic deposits to foreign assets).

Besides successive rounds of bank capitalisation, other shocks could also undermine the fiscal sustainability of the state. One such shock would be an AIDS pandemic that would necessitate increased state spending on public health; another would be massive construction to offset a major ecological disaster and significant climatic changes (for example, water shortages in the northern provinces, alternative energy systems to traditional methods of burning coal). The SARS epidemic is an important reminder that macroeconomic stability depends on more than just traditional shocks. The economic costs of SARS have been greatly magnified by an inadequate public health system and by structural weaknesses in information dissemination. China's new leaders should take a more comprehensive view of economic growth and the implications of socio-political influences on macroeconomic management.

There can be no greater confirmation of China's determination to make the private sector its new growth engine than the tenacity with which it pursued WTO membership. 
The WTO is limited to private market economies, and it requires that the economic institutions of its members converge within a specified period to some broadly defined norms compatible with the main forms of market capitalism. The challenge to China's new leaders is the proper management of institutional convergence in the wake of low, or negative, employment growth in the industrial sector in the four years leading up to WTO accession. ${ }^{31}$ The fiscal burden of installing the new economic growth engine is a heavy one, and my analysis shows that China can just afford it. The absence of a safety margin in fiscal management highlights the importance of competent economic management. This does exist in China, however the absence of a safety margin also highlights the importance of continued good luck. While the many reform tasks ahead are challenging, we take heart from the fact that during 1979-2002 many other challenges were faced and overcome.

\section{NOTES}

1 This chapter emerged from an ongoing project on Economic Growth in China conducted by the East Asian Program of the Center for Globalization and Sustainable Development at Columbia University. I am grateful to Fan Gang, He Liping, Huang Yiping, and Yu Yongding for sharing their insightful analyses on the Chinese economy with me. I am deeply indebted to the Citigroup office in Hong Kong for assistance in data compilation.

2 Employers in SARS-affected areas were also ordered 'not to lay off workers'. See 'China tries to stanch economic fallout as disease, worry spread: emergency policies boost public spending', Washington Post, 9 May 2003.

3 If realised, the official urban employment rate would rise from 4 per cent at the end of 2002 to 4.2 per cent at the end of 2003. Data are from 'Economy not working hard enough', South China Morning Post, 16 August 2003. However, it is well known that the official data on urban unemployment tend to understate the problem. When the official urban unemployment rate was 3.6 per cent in June 2002, a Chinese Academy of Social Studies report estimated the actual urban unemployment rate to be 7 per cent, and Liu Wei of Beijing University estimated it to be 14.6 per cent. See 'China jobless figures enter danger zone', Straits Times, 15 June 2002.

4 'Budget and job woes threaten stability', South China Morning Post, 19 December 2002.

5 For example, 'Snow calls on Beijing to let currency float', Financial Times, 2 September 2003.

' See, for example, 'Behind the debate over China's currency', Barrons, 28 July 2003; 'US job losses blamed on China's currency', The New York Times, 26 August 2003; and 'Economic ministers discuss Chinese currency', Pacific Business News, 23 July 2003. 
7 The inflation rate is calculated from the retail price index (RPI). The average inflation rate according to the consumer price index (CPI) (available from 1985) is 0.6 per cent for the first of 2003 and 7.7 per cent for 1985-2002. CPI is broader than RPI because it also covers services and housing. The 2003 GDP growth rate is from 'National economy faces a string of challenges', China Daily, 26 August 2003.

8 This interpretation of China's economic performance after 1978 is elaborated in Woo (1999) and Woo (2001).

9 Graphing the growth-inflation relationship, with the inflation rate on the $y$-axis, the relationship is a vertical line at each endpoint of the range. This does not mean that the positive portion of the graph could be exploitable for macrostabilisation, since changes in expectations could shift it up and down very quickly.

${ }^{10}$ Citigroup (2003) has projected the budget deficit to be 2.8 per cent in 2003 . The scale of the fiscal stimulus has evoked comparisons with the New Deal, and provoked catchy headlines in the media, for example, 'China gambles on big projects for its stability', New York Times, 13 January 2003, and 'Public spending explodes', Far Eastern Economic Review, 30 January 2003.

$"$ Keynes coined these both terms. Strictly speaking, the Chinese characterisation of the liquidity trap as a 'shrinking money multiplier' does not correspond to Keynes's original meaning. Keynes was referring to the situation where the interest rate would not fall despite the addition of reserves because of the predominant expectation held by investors that the interest rate would rise soon. In brief, the difference is 'the shrinking money multiplier' versus the non-falling interest rate.'

12 For example, during the SARS period, the banks faced intense pressure from the central bank to extend credit.

13 The Chinese government has sought to increase bank lending to private individuals by encouraging banks to establish mortgage loans, which are perceived as less risky because of their seemingly fully collateralised nature. While it is still early to tell, it appears that the enthusiasm for real estate lending in 2002 might have started a speculative bubble in that sector.

${ }_{14}$ Woo (2000) presents a proposal of how to meet investment financing needs in rural China.

15 It is important to note that this equation applies only to China's total trade surplus, not to any bilateral trade surplus between China and another country. The equation in standard textbook notation is

$C A=(T-G)+(S-1)$.

${ }^{16}$ Of course, just as the current account outcome is the product of the three terms in the equation, multi-variable causation also applies to the savings outcome, for example, demographic features, 
expected future income growth. Our discussion has concentrated on how one of these variables, the type of financial intermediation mechanism, can affect the savings rate.

17 It appears that the AMCs have started by concentrating on the NPLs with the best prospect for recovery', and that the 'average cash-recovery rate' on the small amount processed by June 2002 is 21 per cent. This recovery rate is expected to drop substantially when the more difficult loans are processed. See 'On the road to ruin', Far Eastern Economic Review, 14 November 2002.

18 The US ratio is for 1996. Ratios were constructed from the IMF's International Financial Statistics.

19. The revenue-GDP ratio for China is from Deutsche Bank (2002) which estimated that it will rise to 16.4 per cent in 2002 and 16.6 per cent in 2003. Debt-GDP and revenue-GDP ratios for other countries are from the IMF database.

2 This assumes a bond rate of four-six per cent-an assumption discussed in the next paragraph.

21 According to Solow (1991), the stylised fact for the real interest rate in the United States is that it is $5-6$ per cent.

22 See Wen (2003) for a recent analysis of the joint reform of the SOBs and SOES.

$\approx$ See Huang et al. (1999) for an account of the failure of SOE reform.

${ }^{24}$ The institutional reforms of the central bank and the state banks implemented in July 1993 as part of an austerity campaign have not been successful in changing the situation. Chen Yuan (1996), Deputy Governor of the Central Bank, reported that 'the enthusiasm for economic growth in some localities is so strong that it is very difficult to stop completely excessive investment financed through forced bank credit' (emphasis added).

25 'Judicial attention to SOEs pledged,' China Daily, 19 February 2000.

${ }^{26}$ He Qinglian, Zhongguo de Xianjing, (China's Pitfall), Mingjing Chubanshe, Hong Kong. The translated quote is from Liu Binyan and Perry Link, 'China: the great backward?', The New York Review of Books, 8 October 1998:19.

27 See Nolan and Wang (1999) for a recent assertion of a turnaround in SOE performance.

28 This estimate has taken into account the additional production cost of the non-oil SOEs.

29 Partial recapitalisation is likely to occur soon, and it is likely that the target will be the reduction of the NPL ratio from 35 per cent to 15 per cent. The cost is estimated to range from 700 million yuan to 1 trillion yuan (7 to 10 per cent of GDP)--see 'Massive bailout proposed for banks', South China Morning Post, 26 August 2003.

30 Recent insightful discussions on the conditions for meeting this challenge successfully, and on the impact of WTO accession on the Chinese economy can be found in Lu et al. (2003), Song (2002a), Song (2002b), and Yu (2003). 


\section{REFERENCES}

Chen, Y., 1996. 'Opening remarks', in M. Guitian and R. Mundell (eds), Inflation_and Growth in China, International Monetary Fund, Washington, DC:23-28.

Citigroup, 2002. Greater China Insights, Citigroup, 14 June.

-, 2003. China Economics, Citigroup, 6 March.

Deutsche Bank, 2002. Emerging Markets Monthly, Deutsche Bank, 4 September. - , 2003. Emerging Markets Monthly, Deutsche Bank, 6 March.

Fan, G., 2003. 'China's NPLs and national comprehensive liability', Asian Economic Papers, 2(1):145-52.

- and Woo, W.T., 1996. 'State enterprise reform as a source of macroeconomic instability', Asian Economic Journal, 10(3):207-24.

Gao, J., 2002. China's financial system and financial market reform:WTO participation and its challenge to China's financial sector, Paper presented at the Citigroup Investors' Seminar, Shanghai, 8 May.

Huang, Y, 2003. 'What will drive China's growth?', Macro China, Citigroup, 13 June.

—-, Woo, W.T. and Duncan, R., 1999. 'Understanding the decline of China's state sector', MOCT-MOST: economic policy in transitional economies, 9(1):1-15.

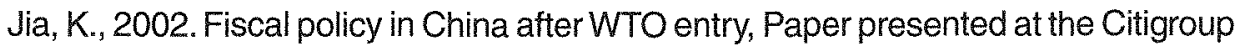
Investors' Seminars, Shanghai, 8 May.

Kuroda, $H$. and Kawai, M., 2002. 'Time for a switch to global reflation', Financial Times, 1 December.

Liu, L.Y. and Woo, W.T., 1994. 'Saving behavior under imperfect financial markets and the current account consequences', Economic Journal, 104(424):512-27.

Lu, D., Wen, G.J. and Zhou, H. (eds.), 2003. China's Economic Globalization through the WTO, Ashgate, Aldershot.

Nellis, J., 1999. Time to Rethink Privatisation in Transition Economies?, Discussion Paper No. 38, International Finance Corporation, World Bank.

Nolan, P. and Wang, X., 1999. 'Beyond privatization: institutional innovation and growth in China's large state-owned enterprises', World Development, 27(1):169200.

Solow, R., 1991. 'Sustainability: an economist's perspective', the 18th J. Seward Johnson Lecture to the Marine Policy Center, Woods Hole Oceanographic Institution. Reprinted in R.N. Stavins, 2000. Economics of the Environment: selected readings, 4th edition, W.W. Norton, New York:131-38. 
Song, L., 2002a. 'Conditions and prospects for sustaining China's economic growth', in L. Song (ed.), Dilemmas of China's Growth in the Twenty-First Century, Asia Pacific Press, Canberra: $1-10$.

- (ed.), 2002b. Dilemmas of China's Growth in the Twenty-First Century, Asia Pacific Press, Canberra, Australia.

State Statistical Bureau, various years. Zhongguo Tongji Nianjian [China Statistical Yearbook], Zhongguo Tongji Chubanshe, Beijing.

Wen, M., 2003. Further reform of SOEs and state banks, Paper presented at the China Update Conference, The Australian National University, Canberra, 25 September.

Williamson, J., 1988. 'Comments on Reflections on Development, in G. Ranis and T. P. Schultz (eds), The State of Development Economics: progress and perspectives, Blackwell, Oxford and New York:24-30.

Woo, W.T., 1999. 'The real reasons for China's growth', The China Journal, 41(January):115-37.

- 2000. 'Improving access to credit in rural China', in B. Chen, J.K. Dietrich and Y. Feng (eds), Financial Market Reform in China: progress, problems and prospects, Westview Press, Boulder, Colorado:321-45.

- 2001. 'Recent claims of China's economic exceptionalism: reflections inspired by WTO accession', China Economic Review, 12(2-3):107-36.

- and Liu, L.Y., 1995. 'Investment-motivated saving and current account malaise', Asia-Pacific Economic Review, 1(2):55-68.

Yu, Y., 2003. Fiscal stability and the road to prosperity, Institute for World Economics and Politics, Chinese Academy of Social Sciences, Beijing (unpublished).

Zhou, F. and Wang, X., 2002. The Way of State-Owned Enterprise Reform in China, National Economic Research Institute, Beijing, China. 


\section{4 \\ The changing pattern of economic growth}

\section{Yiping Huang}

\section{STRONG GROWTH PERFORMANCE UNDER PREMIER ZHU}

Five years ago, when Zhu Rongji became premier, he launched a comprehensive and ambitious package of reforms, including improving the profitability of SOEs, reducing financial risks, and downsizing the government.

Wen Jiabao's first battle after becoming premier in early 2003 was to control the SARS epidemic. Now that the outbreak is effectively under control, the new government is likely to shift its focus to the reform agenda. The economic challenges facing the new government today are still similar to those of five years ago: lossmaking SOEs, huge bad loans, rising unemployment rate, and so on.

We should nonetheless not underestimate Zhu's contribution to the Chinese economy, made mainly in two areas-WTO entry and strong growth. China's successful conclusion of the negotiations on WTO accession, under Zhu's leadership, has set the direction and pace for future economic reforms.

China's growth performance over the past five years has been very impressive, particularly in comparison with growth of other Asian economies during the same period (Figure 4.1).

Over the past five years, most Asian economies' growth rates have been volatile because of the East Asian financial crisis in 1998 and then a significant slowdown in the US economy in 2001. China's GDP growth rate, however, has stayed between 
7.1 and 8 per cent. Interestingly, the growth performance of the Indian economy was also quite consistent during this period, suggesting that there might be a largeeconomy factor.

Some economists have questioned the reliability of China's official statistics. We believe, however, that even after taking into account possible data problems, China's GDP was still strong and steady.

What was the main contributor to China's extraordinary growth performance? This is one of the key questions. The most important question now is whether the growth pattern of recent times is likely to change or persist under the new leadership.

\section{GROWTH DRIVEN MAINLY BY STATE INVESTMENT}

China's fixed asset investment is still dominated by the state. There are two definitions of state sector investment.

Figure 4.1 Annual GDP growth, China, Hong Kong, Taiwan, Korea, Japan and India, 1998-2002 (year-on-year, per cent)

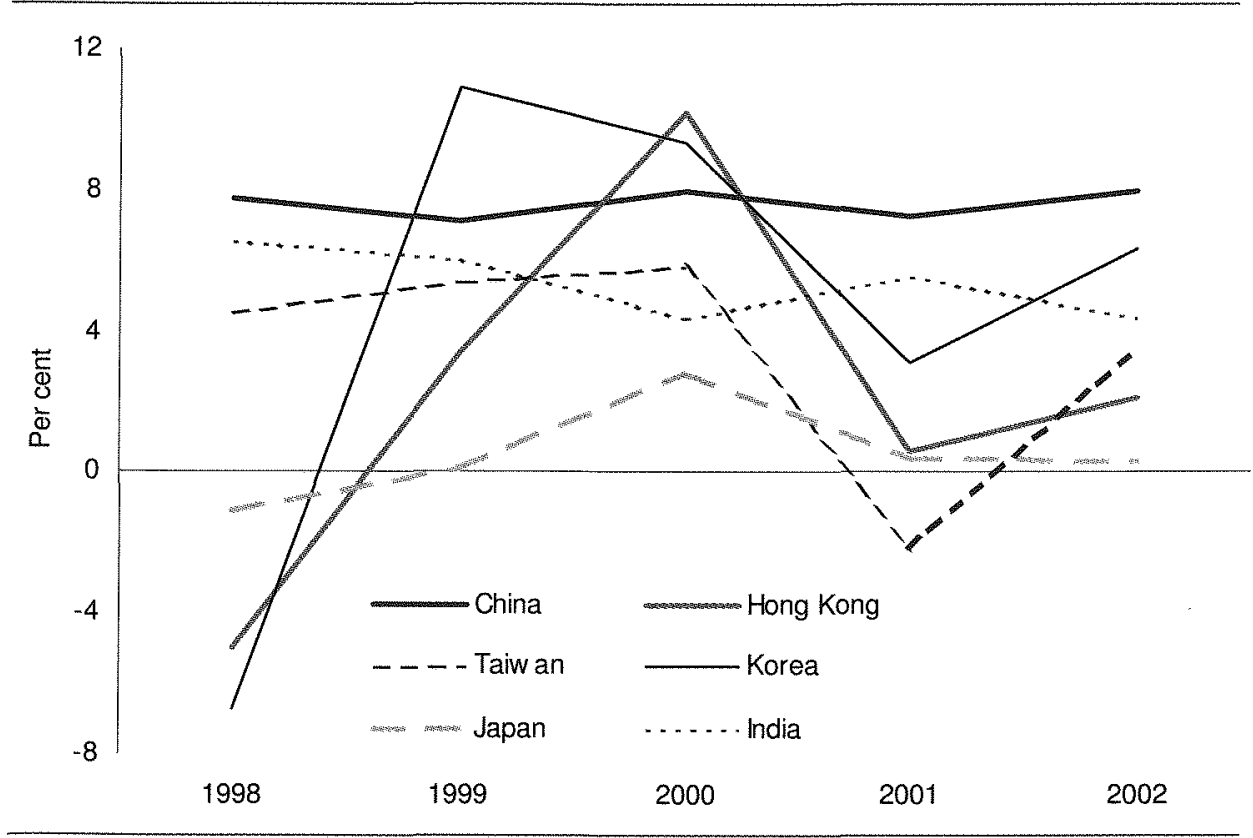

Source: CEIC. 
1 If only SOEs are considered, the share of the state sector in total investment was 48 per cent in 2002.

2 If the state sector is taken to include shareholding and listed companies controlled by the state, its share in total investment was 76.3 per cent in 2002.

This indicates that 'marketisation' proceeds much more slowly in investment than in the goods markets. There are three main channels for the financing of broadly defined state sector investment.

- Direct investment under the budget. Over the past five years, the government has issued RMB 650bn in treasury bonds to finance the construction of large infrastructure projects; another RMB 140bn is earmarked for direct investment in 2003.

- Financing of state-sponsored projects through either bank loans or bond issuance. The government has often called on the banks to provide loans for state-sponsored projects to supplement projects run directly by the state, and over the past five years an estimated RMB 3 trillion in loans has been provided for such projects.

- Bank loans for the state sector. While banks should in theory treat the state and non-state sectors equally in loan applications, in practice they still favour the state sector in their lending decisions, sometimes under pressure from local governments.

Broadly defined state sector investment may also include some investment by foreign investors in joint ventures. But this contribution is probably still limited. The

Table 4.1 Investment by state ${ }^{\star}$ and non-state sectors, 1997-2002 (per cent)

\begin{tabular}{ccccc}
\hline & $\begin{array}{c}\text { Growth of } \\
\text { total investment }\end{array}$ & $\begin{array}{c}\text { Growth of state } \\
\text { sector } \\
\text { investment }\end{array}$ & $\begin{array}{c}\text { Growth of } \\
\text { non-state sector } \\
\text { investment }\end{array}$ & $\begin{array}{c}\text { Share of state } \\
\text { sector in total } \\
\text { investment }\end{array}$ \\
1997 & 8.8 & 8.1 & 11.3 & 75.3 \\
1998 & 13.9 & 12.3 & 18.8 & 74.3 \\
1999 & 5.1 & 6.2 & 1.8 & 75.1 \\
2000 & 10.3 & 8.1 & 16.7 & 73.6 \\
2001 & 13.0 & 14.8 & 8.2 & 74.8 \\
2002 & 16.1 & 18.4 & 9.3 & 76.3 \\
\hline
\end{tabular}

Note: * Here state sector investment is taken to be fixed asset investment by SOEs and statecontrolled units.

Source: CEIC. 
average growth rate of actual FDI has only been 3.1 per cent during the past five years, and FDI accounted for 11 per cent of total investment.

How important is state sector investment for China's GDP growth? We can do some simple calculations. First, recall that GDP includes consumption, investment and net exports:

$$
G D P=C+I+\Delta X
$$

We can further decompose consumption into household and government consumption, and investment into state sector and non-state sector investment. Therefore, we can express GDP growth as a weighted average of growth in

1 household consumption

2 government consumption

3 state sector investment

4 non-state sector investment

5 net exports.

The weights used in this calculation are their respective shares in GDP over the past five years. State-related activity (government consumption and state sector investment) accounts for roughly 40 per cent of GDP, while net exports' share was only 2.8 per cent (see Figure 4.2).

Average GDP growth was 8.1 per cent in the period 1998-2002. Of this, 1.3 percentage points were contributed by government consumption, 2.7 by state investment, 3.4 by household consumption and 0.8 percentage points by non-state sector investment (Figure 4.2).

In other words, state sector-related activity accounted for half of GDP growth over the past five years (4 percentage points out of 8.1 per cent). This is the secret of China's growth success, but it is also one of our main concerns for the future.

\section{WHY THE CURRENT GROWTH PATTERN MAY NOT BE SUSTAINABLE}

\section{Investment-GDP ratio already unusually high}

In recent years, growth in fixed asset investment has accelerated and has consistently outpaced GDP growth. As a result, the investment-GDP ratio increased to the unusually high level of 42 per cent in 2002 from 34 per cent in 1997 (Figure 4.4). In other words, a smaller proportion of GDP was spent on consumption. How much longer can this continue? 
Investment-GDP ratios for many other Asian economies range between 20-30 per cent (Table 4.3).

Thus there is very little room for China to raise the share of investment in GDP further in the coming years, even if the government doesn't change its behaviour. In fact, the investment-GDP ratio is likely to fall, meaning that at some point in the future investment growth may be slower than GDP growth.

\section{Inefficiency of state investment}

State-dominated investment is often inefficient. China is no exception. In the past, when the government aimed at a minimum 7 per cent GDP growth, the inefficiency of the state sector investment became evident. When the proactive fiscal policy was introduced in 1998 and 1999, there were frequent reports of the poor quality of state-financed infrastructure projects.

More recently, there has been a visible improvement in construction quality, but low returns remain a general problem as projects are concentrated in less developed areas.

Figure 4.2 Average shares of various components of GDP, 1998-2002 (per cent)

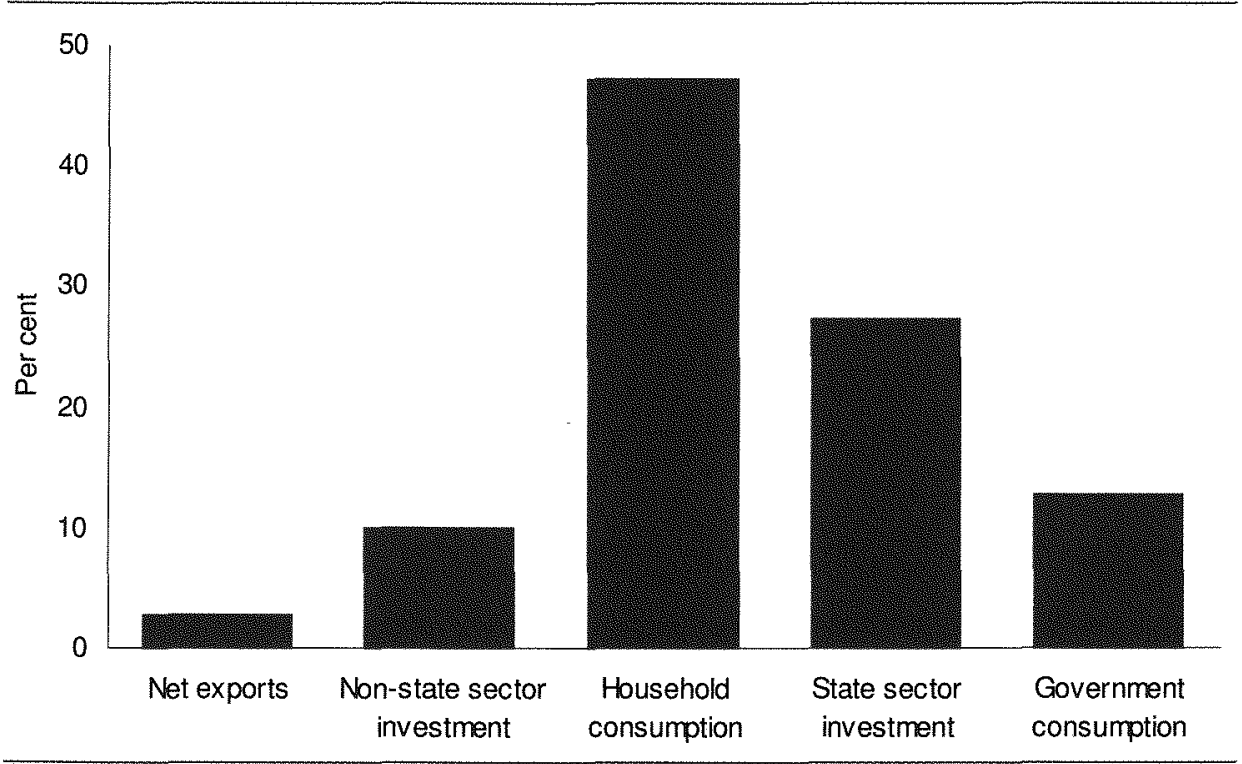

Source: Citigroup estimates. 
According to our estimates, while GDP growth has remained stable, the contribution of total factor productivity (TFP) to GDP growth has declined from 37 per cent in 1997 to 25 per cent in 2002 (Figure 4.5). In other words, growth has become increasingly reliant on the mobilisation of resources rather than on productivity improvement.

This is perhaps the strongest signal that China's past growth pattern may not be sustainable. This argument may sound odd given current strong growth momentum in China, but the former Soviet Union provides a good example. The Soviet Union's economic growth was attributable mainly to resource mobilisation, supported by central planning. In the early stages, particularly in the 1930s and 1950s, it was one of the world's fastest-growing economies. Such growth was not sustainable, however, because of the lack of productivity improvement.

Table 4.2 China and Asian economies: growth of GDP components and investment-GDP ratio, 2002 (per cent)

\begin{tabular}{lcccc}
\hline GDP & $\begin{array}{c}\text { Consumption } \\
\text { growth }\end{array}$ & $\begin{array}{c}\text { Gross capital } \\
\text { formation growth }\end{array}$ & $\begin{array}{c}\text { Investment-GDP } \\
\text { ratio }\end{array}$ \\
China & 8.0 & 8.8 & 16.0 & 42.2 \\
India & 5.5 & 6.1 & 3.8 & 24.2 \\
Korea & 6.3 & 6.2 & 4.3 & 24.3 \\
Malaysia & 4.2 & 6.4 & 8.8 & 30.1 \\
Taiwan & 3.5 & 1.5 & -2.0 & 18.3 \\
Thailand & 5.2 & 4.1 & 6.3 & 19.9 \\
\hline
\end{tabular}

Note: Data for India are for fiscal year 2001-02.

Source: CEIC and Citigroup estimates.

Table 4.3 Contingent liabilities

\begin{tabular}{lcc}
\hline & RMB & Per cent \\
& billion & of GDP \\
Accumulated public debt & 1,550 & 16.2 \\
Special T-bonds in 1998 & 270 & 2.8 \\
Costs for bank reform & 4,500 & 46.9 \\
Costs for Social Security Fund & 2,500 & 26.1 \\
Municipal contingent debt & 700 & 7.1 \\
External debt & 1,500 & 114.9 \\
Total & & \\
\hline
\end{tabular}

Source: Citigroup estimate. 
Figure 4.3 Contributions to GDP growth of various components, 1998-2002 (percentage points)

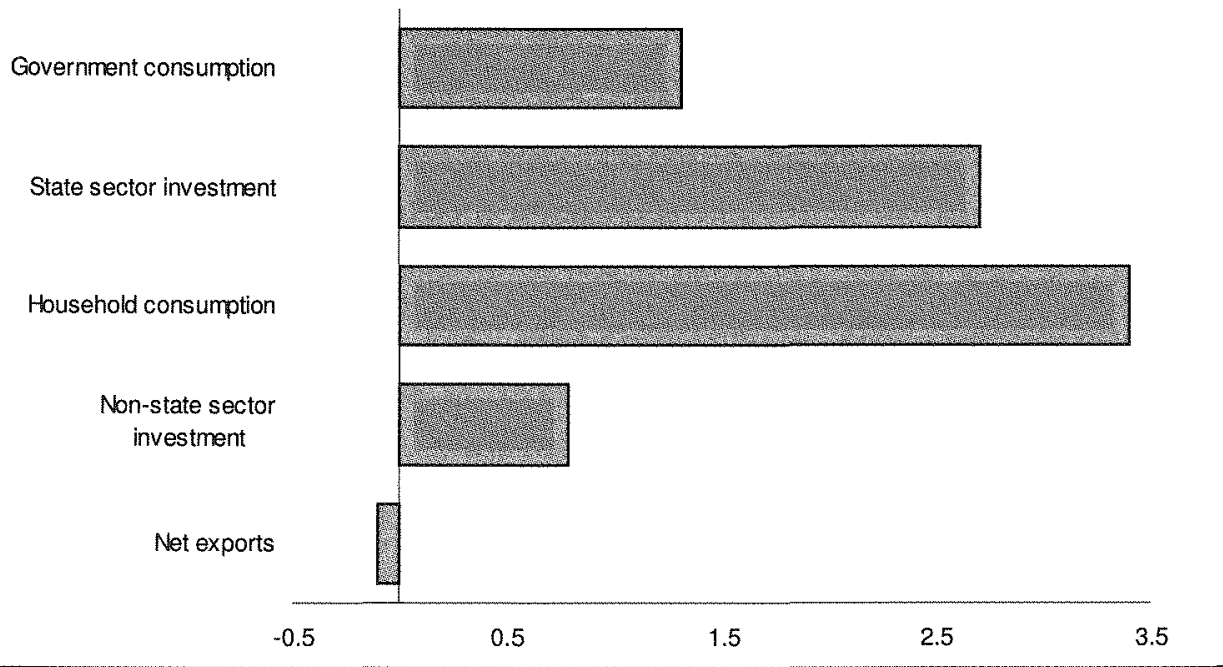

Source: Citigroup estimates.

Figure 4.4 High investment growth and rising investment-GDP ratio (per cent)

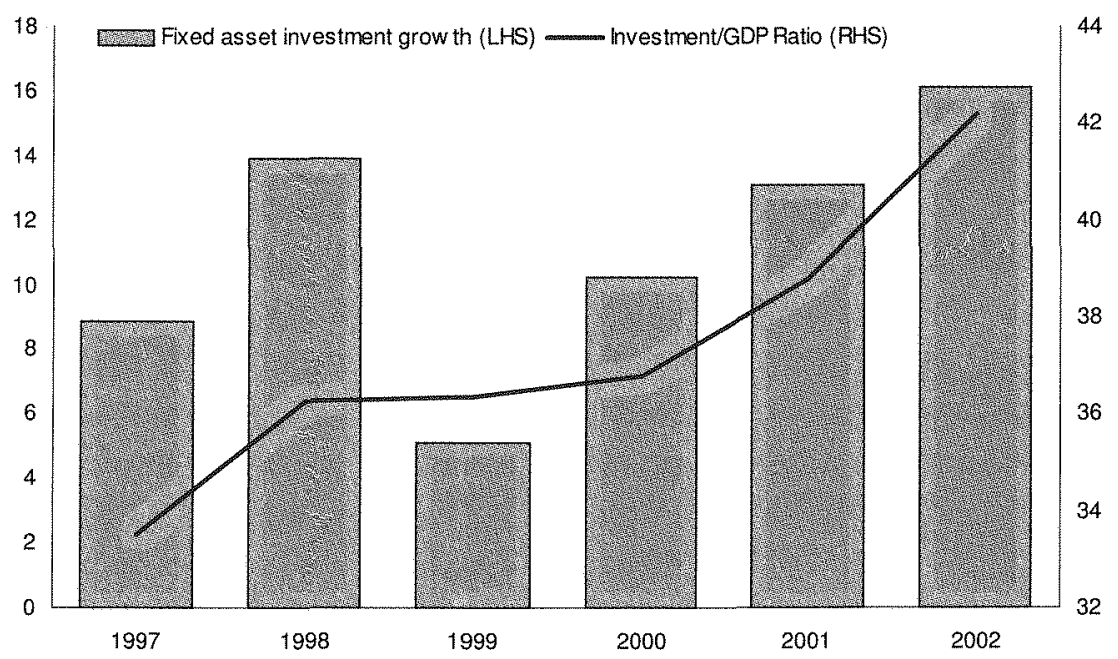

Source: CEIC. 
Usually, economists consider a growth pattern sustainable if TFP growth contributes more than one-third of GDP growth. According to this criterion, there is a large question mark over China's growth sustainability.

\section{Limited ability to obtain financing}

China's ability to maintain state investment-driven growth is also constrained by its ability to finance. The fiscal deficit grew from less than 1 per cent of GDP in 1997 to 3 per cent in 2002 as a result of the proactive fiscal policy in operation during the period (Figure 4.6).

While the current fiscal deficit is not necessarily dangerously high, the level of contingent liabilities is more alarming. Taking into account the potential cost of restructuring the banks and financing the social security fund, total liabilities are probably around 115 per cent of GDP. This is already comparable to those of Japan and some of the Scandinavian countries.

The government can continue to rely on bank lending to boost investment, as most of the banks are still state-owned. With a bad loan ratio above 20 per cent, however, the banks themselves are also under enormous pressure to improve asset quality.

\section{Accelerated boom-and-bust cycles for industries}

Another side-effect of state investment-driven growth is a build-up of inventories. Indeed, since the beginning of 2003 , inventories have been accumulating rapidly in the electronics and communication, and transport equipment sectors.

A consequence of this is that the growth of the whole economy is always dependent on a small number of industries and the boom-and-bust cycles of such industries are accelerated when state investment is involved. Since the beginning of economic reform, we have already seen several cycles.

- In the mid 1980s, the textile industry was the growth engine, but excess capacity became a serious problem, and later the government ordered the closure of many textile factories across the country.

- In the early 1990s, the electronics industry (particularly producers of televisions, refrigerators, and so forth) became a hotspot, but in the late 1990s price wars became endemic in the markets. 
- From 1998, the government promoted the property sector as one of the main growth drivers. In late 2002, however, policymakers voiced concerns about a possible bubble in the market and, in mid June this year, the central bank introduced a series of new measures to cool property investment.

- Now, the only growth engine is the automobile industry. Growth in car production should stay at around 100 per cent this year. Our question is how long it will be before collapse in this market, too, becomes necessary or inevitable.

Of course, both private sector investment and FDI have also played important roles in these industry booms. But policies designed to encourage pillar industriesparticularly with the involvement of state investment, which usually means less attention paid to efficiency and returns-are also responsible for the accelerated boom-and-bust cycles. This often leads to the waste of scarce investment resources.

Figure 4.5 Annual GDP growth and share of TFP in GDP growth, 1997-2002 (per cent)

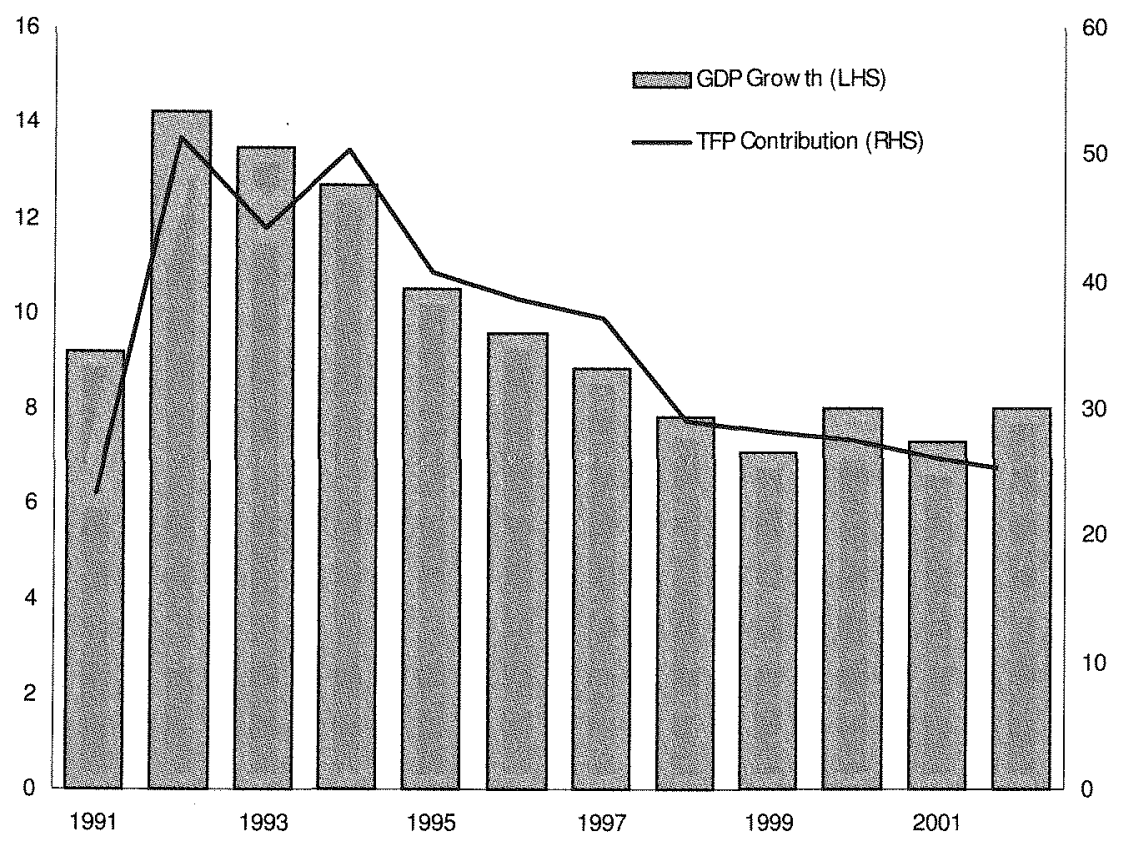

Source: Citigroup estimates. 


\section{PROMOTING PRIVATE SECTOR INVESTMENT AND IMPROVING INVESTMENT EFFICIENCY}

\section{Long-term growth potential}

In the absence of any major disruption, China should be able to maintain GDP growth at 7.5 per cent per annum for at least another 10 years. Only India and Malaysia can match this potential.

Our optimism is based mainly on China's expected ability to achieve productivity growth. On one hand, the expected structural reforms, particularly those to which China is committed in the agreements on WTO accession, should lead to more efficient use of resources. On the other hand, China is still a relatively poor country with GDP per capita at US $\$ 1,000$. In other words, China is far from the world's economic

Figure 4.6 China's fiscal deficits, 1997-2002 (RMB billion, per cent)

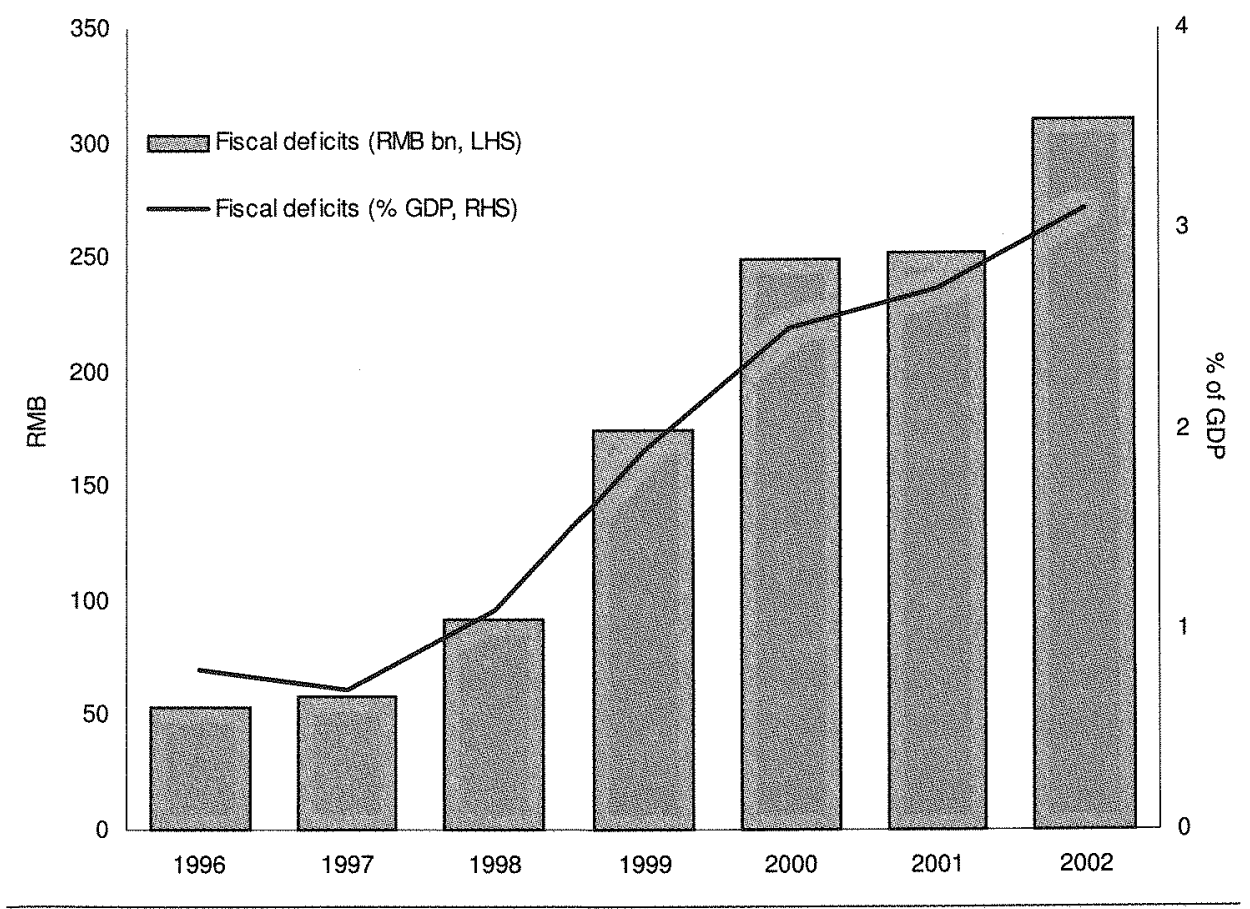

Source: Citigroup estimates. 
and technological frontiers, which makes the growth highly visible as it catches up. This is typically described as the 'advantage of backwardness' in growth literature.

\section{Promoting private sector investment}

Before this long-run growth potential can materialise, China will need to change its growth pattern. At the centre of this transformation will be the rise of private sector investment. The share of the state sector in overall investment should decrease significantly from the current 75 per cent as a natural part of the process of structural reform. Specifically, the following changes need to be made to ease such a transition

- The government needs to cut back on budget-supported investment projects and loan-financed state sector investment programs.

- The state-owned commercial banks need to extend more loans to the more profitable non-state sectors.

- The authorities need to create more favourable conditions for private enterprises to access the capital markets, both stock and bond markets.

Most importantly, however, policymakers need to abandon their obsession with achieving GDP growth rates above 7 per cent. In 1998, Zhu Rongji's government set 7 per cent as its GDP growth target. The result was that every province reported GDP growth of more than 7 per cent that year. The government recognised the political incentive for local leaders to exaggerate their growth performance and thus gave up setting any growth target after that. Nonetheless, the critical level of GDP growth remains 7 per cent in many policymakers' minds. Whenever GDP growth falls toward this level, the government tries to support growth, mainly through increased fiscal spending and state sector investment. The implicit reasoning is that slowing growth would lead to higher unemployment, which has broader social and political implications. In reality, however, state-backed growth has not had the desired effect as far as job creation is concerned.

Once more efficient private sector investment starts to take a more dominant role, the pressure for continued rapid investment growth should begin to ease off. Indeed, over time, sustainable rapid GDP growth may be compatible with a slowly declining investment/GDP ratio.

\section{Bullish on consumption in the long run}

A falling investment-GDP ratio is equivalent to a rising consumption-GDP ratio. This is the first reason we believe that in the long run China's GDP growth will be driven by consumer spending. 
The second reason is that we are confident that China's high growth is sustainable, and thus that household income is likely to increase rapidly. Assuming GDP growth of 7.5 per cent and population growth of 1.5 per cent, China should easily be able to achieve 6 per cent growth in per capita income. Chinese households' purchasing power should grow even faster if the renminbi appreciates. Something similar has happened in most newly industrialised East Asian economies over past decadesa strong economy leads to currency appreciation, and income catches up with GDP growth faster than predicted.

Figure 4.7 Growth of inventories by industry, end-April 2003 (per cent change, year-on-year)

Petroleum processing \& coking

Eectronic \& communication equipment Chemical fibre industry Transportation equipment Ferrous metals of smelting \& pressing Metal products Plastic products Raw chemical materials \& products Food manuf acturing Textile industry Ordinary machinery Garment \& other Fibre products Furniture manufacturing Eectric machinery \& equipment Medical \& pharmaceutical products Petroleum \& natural gas extraction Rubber products Coal mining $\&$ dressing Beverage manufacturing Tobacco processing Non ferrous metal mining \& dressing

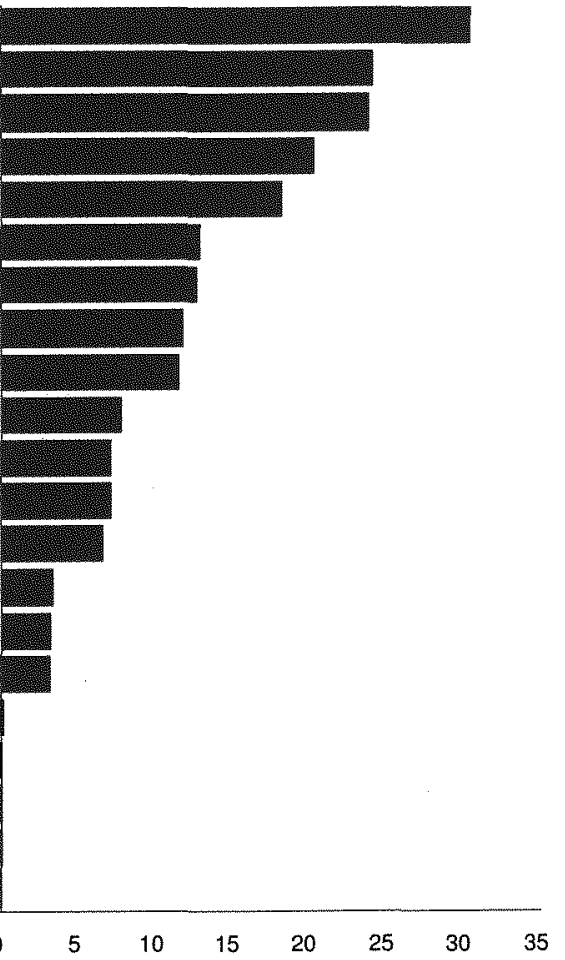

Source: Citigroup. 
Last, given China's family planning policy, it is also likely to have a more severe problem with population aging than other populous Asian economies. Over time, this will lower households' savings ratio.

\section{NEAR-TERM OUTLOOK AND IMPLICATIONS}

Reforms under the new government are likely to facilitate the promotion of privatesector investment. Specifically, the new administration has established two new organisations

1 The China Banking Regulatory Commission (CBRC) aims at the speedy restructuring of the state-owned commercial banks. This should lead to bank lending being guided more by commercial considerations than by government fiat.

2 The State-Owned Asset Supervision and Administration Commission (SASAC) takes under its control about 196 large companies with assets worth RMB 6.9 trillion (US $\$ 834$ billion). It is likely to speed the restructuring process, through public listings, foreign strategic investors. We expect the establishment of the SASAC to lead to a new wave of privatisations nationwide.

Growth will continue to depend on state sector investment, FDI and exports in the near term

No immediate end is foreseeable to the economy's heavy reliance on state sector investment for growth

- For one thing, the SARS epidemic probably strengthened rather than weakened the state investment mechanism. As some officials are worried about the implications of the SARS outbreak for growth, the government may consider increasing stimulus measures to support economic growth.

- Since 2002, the state banks have become more aggressive in extending loans to the corporate sector, particularly private enterprises. But this process may be reversed. China recently revealed a number of cases of corruption among senior bank officials, all involving high-profile private entrepreneurs. This is likely to discourage banks from lending to the private sector. For most bank managers, the same old principle still applies-if a loan turns bad with an SOE, it may be a bad commercial decision; but if a loan turns bad with a private enterprise, it may be a criminal act. 
Table 4.4 Selected Asian economies, long-term growth potential (per cent)

\begin{tabular}{lccc} 
& Avg. output growth & \multicolumn{2}{c}{ Long-term growth potential } \\
China & $1960-99$ & Citigroup & Consensus \\
India & 9.8 & 7.5 & 7.3 \\
Indonesia & 5.8 & 7.5 & 6.4 \\
Korea & 7.1 & 5.0 & 5.0 \\
Malaysia & 9.8 & 5.5 & 4.8 \\
Philippines & 8.6 & 7.0 & 6.2 \\
Singapore & 4.8 & 5.0 & n.a. \\
Thailand & 10.5 & 6.0 & 5.5 \\
Taiwan & 8.7 & 4.5 & 4.0 \\
Japan & 10.7 & 5.0 & 4.4 \\
United States & 6.2 & 2.7 & 2.0 \\
& 4.3 & 3.7 & 3.4 \\
\hline
\end{tabular}

Source: Adapted from Citigroup, 2002. Asian Economic Outlook and Strategy: accounting for growth, Citigroup, Hong Kong, 28 March.

Table 4.5 Citigroup estimates of long-term growth potential, selected Asian economies

\begin{tabular}{lccc}
\hline & $\begin{array}{c}\text { Young workers' } \\
\text { share in total } \\
\text { labour force (\%) }\end{array}$ & $\begin{array}{c}\text { Share of aged } \\
\text { population (\%) }\end{array}$ & $\begin{array}{c}\text { Age dependency } \\
\text { ratio }\end{array}$ \\
China & 60.3 & 9.0 & 0.5 \\
1990 & 44.6 & 11.8 & 0.5 \\
$2010 \mathrm{E}$ & & & \\
India & 61.4 & 8.0 & 0.8 \\
1990 & 57.4 & 8.4 & 0.6 \\
$2010 \mathrm{E}$ & & & 0.7 \\
Indonesia & 62.1 & 6.3 & 0.6 \\
1990 & 55.1 & 8.9 & 0.6 \\
$2010 \mathrm{E}$ & & & \\
\hline
\end{tabular}

Notes: Young workers are those aged between 15 and 39 ; the aged population includes those above 60 . The age dependency ratio is the proportion of the population of under 15 and above 60 to that aged 15-60.

Source: World Bank, various. World Population Projections, World Bank, New York. 
- Consumption will probably recover, as SARS is under control. But could household consumption become a major driver in the near term? Probably not. Over the past five years, growth in retail sales has fluctuated between 6-10 per cent, much lower than during the pre-1998 period (Figure 4.8).

The reason consumers became more cautious in 1998 was that accelerated structural reforms, including reforms to the social welfare, education and medical insurance systems, significantly increased uncertainty. Although income growth was high, households saved more money in the bank in anticipation of reduced support from the state in coming years. This explains why bank deposits have grown at around 20 per cent year-on-year recently.

This situation is unlikely to change before the social security system reform is completed, and will not happen soon.

Figure 4.8 Retail sales, 1994-2003 (year-on-year, per cent change)

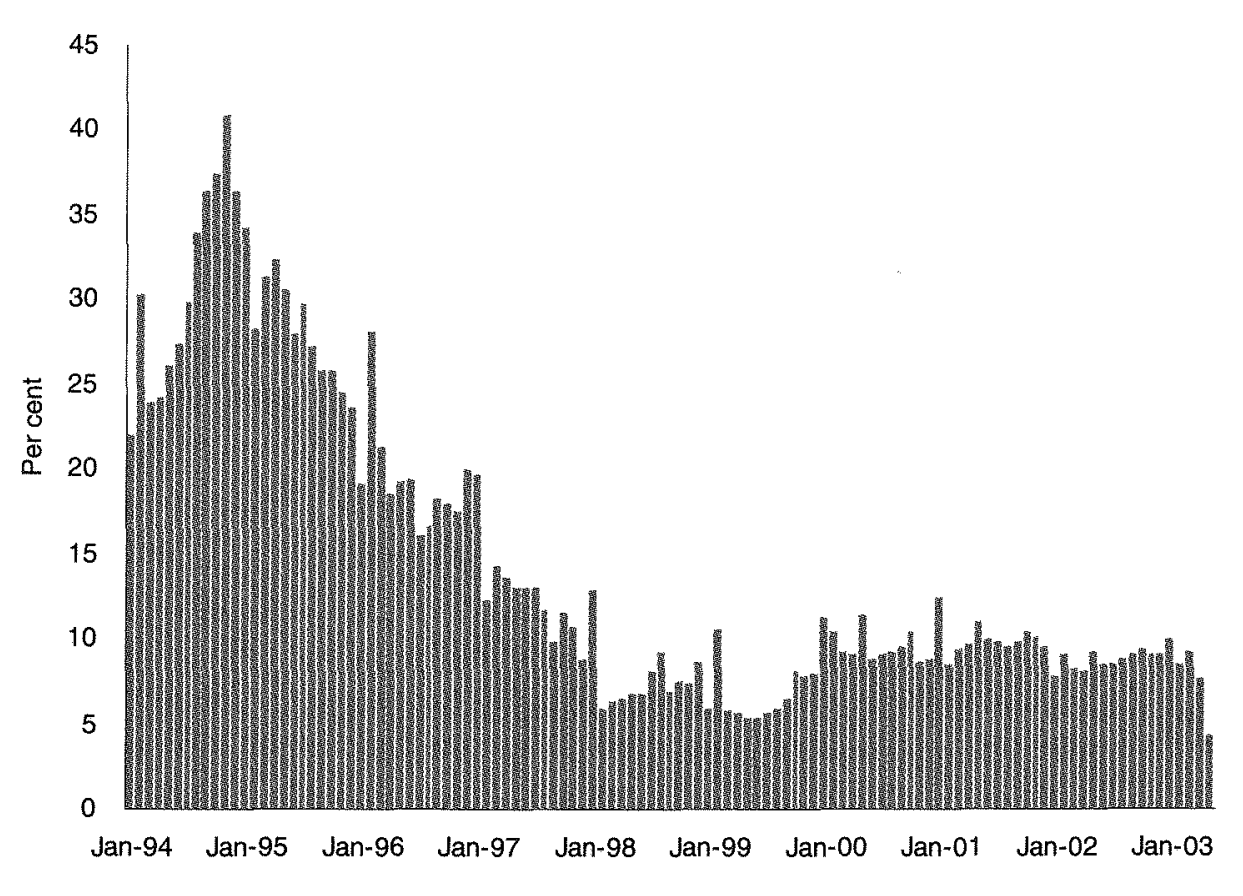

Source: CEIC. 
Retail sales are growing faster in the cities than in the countryside. This supports our view that growth is generally stronger in high-income household spending than in low-income household spending. However, if we look more closely at high-income household expenditure, there is a strong concentration in a small number of goods, particularly housing, automobiles and tech products. This pattern will probably continue in the coming years.

Mild monetary tightening possible but no change likely in exchange rate policy change

There are some concerns that the economy is overheating. The producer price index (PPI) has stayed around 4 per cent year-on-year in recent months, compared with negative growth in 2002. The main increase, however, came from the PPIs for

Figure 4.9 Bank deposits, 1998-2003 (year-on-year per cent change)

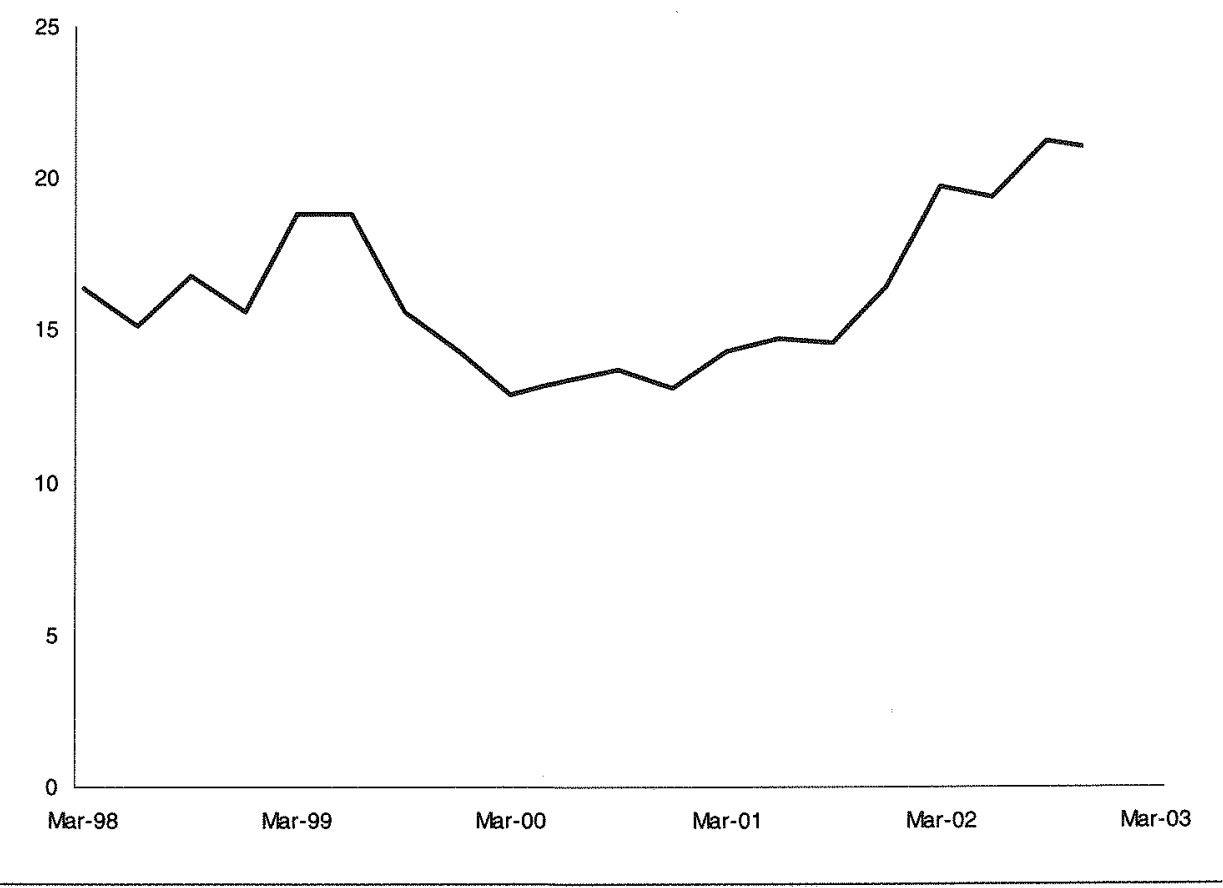

Source: CEIC. 
Figure 4.10 Consumer Price Index and money supply (M2) growth (per cent year-on-year)

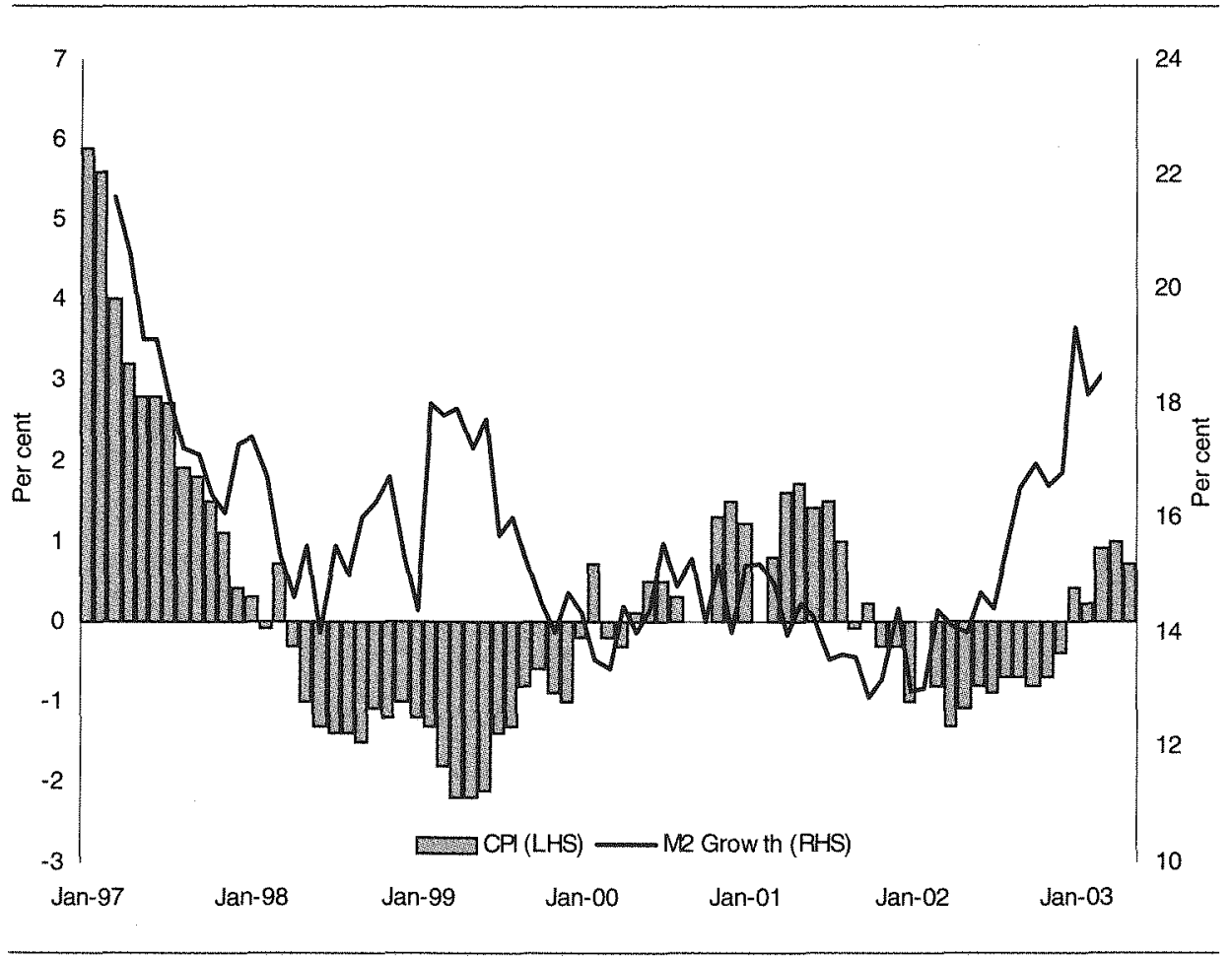

Source: CEIC.

heavy industry (up 8-10 per cent year-on-year in February-April) and producer goods (up 5-7 per cent). This is probably related to the high prices for energy and basic materials. In fact, the PPI for light industry and consumer goods is still falling.

But the acceleration of money supply (M2) growth in recent months is very clear (Figure 4.10). This probably reflects the PBOC's efforts to fight deflation since late 2002. With the currency probably undervalued, the central bank should be able to expand its money supply significantly. Also, the CPI returned to positive territory in 2003.

Concerns about possible overheating may lead to some mild monetary tightening; and the central bank has indicated that it might raise the provision requirements for commercial banks. The central bank is likely to be very cautious, given that the 
economy is newly out of deflation and the near-term outlook for the economy is not very clear. If there is any tightening in the near term, it is likely to be mild.

Another issue that has drawn attention lately is exchange rate policy. Some analysts have even predicted that the currency will appreciate by 2.5 per cent within six months.

Some flexibility will eventually be introduced to the exchange rate regime, but this probably will not occur any time soon.

Two crucial conditions will need to be in place before Chinese policymakers begin to consider widening the band

- a stable outlook for the economy, including exports

- a significant ratcheting up of US pressure (lobbying by Japanese officials does not seem to carry much weight in Beijing).

US government officials have on various occasions recently mentioned a possible need for Yuan revaluation, suggesting that US policymakers probably already have the issue in their sights. This does not yet appear to be a top policy priority for the United States in bilateral relations.

More importantly, Chinese policymakers are still more concerned about the condition of the domestic economy. First, it is not yet clear whether the SARS outbreak will have any delayed effect on the economy, particularly on exports, in coming months. Second, the unemployment situation appears to have deteriorated lately, with at least one-third of new university graduates failing to find jobs. Finally, there are also concerns that CNY appreciation might lead to renewed downward pressure on wages and prices.

It is unlikely that Yuan revaluation will happen in 2003. If all situations develop favourably, the earliest possible time for a policy change would be early 2004 . Even then, a major effect on the foreign exchange market is not likely, as the new band will probably only be $+/-3$ per cent. 


\title{
5
}

\section{Transforming the banking sector}

\author{
Yiping Huang
}

\section{MASSIVE BURDENS IN THE BANKS}

The health of the Chinese banking system has come under the spotlight since the beginning of the East Asian financial crisis in 1997. In early 1998, the People's Bank of China (PBOC) estimated the average proportion of the non-performing loans (NPLs) at 24 per cent in the four major state-owned commercial banks (SOCBs)the Bank of China (BOC), the Industrial and Commercial Bank of China (ICBC), the Construction Bank of China ( $C B C)$ and the Agricultural Bank of China $(A B C) .{ }^{\text {T This }}$ was much bigger than those of pre-crisis Thailand, South Korea, Indonesia and Malaysia (Huang and Yang 1998). But China maintained strong GDP growth in the following years without major financial instability. ${ }^{2}$

China's entry to the WTO on 11 December 2002 revived anxieties about the sustainability of its banking system. China promised, within five years of joining the WTO, to grant foreign banks market access and to remove geographic and client restrictions. Two years after entry to the WTO, foreign banks will be allowed to do local currency business for Chinese firms, and after five years they will be able to do local retail business. The WTO agreements became effective on 1 February 2002.

Can Chinese banks survive the foreign competition? For some China watchers like Chang (2001), the answer is definitely negative. Others, however, take comfort in the belief that foreign banks will not be able to build branch networks as widespread as those of the domestic banks' within a short period. This is true. What is also true 
is that the SOCBs generate 95 per cent of their profits from about half a dozen coastal cities, including Shenzhen, Guangzhou, Xiamen, Shanghai, Tianjin and Beijing. Unfortunately, these are the battlefields where the foreign banks will come and fight.

There is concern that the banking sector's problems have grown during recent years. Official data, which are based on the recently implemented international loan classification system, show an average NPL ratio in the four SOCBs of around 24 per cent in mid 2003. ${ }^{3}$ This ratio, however, still excludes the 1.4 trillion yuan already transferred to the four Asset Management Companies (AMCs) affiliated to the four SOCBs. Therefore, the NPLs of the whole banking system actually still account for about 35 per cent of total outstanding loans. In 1998, the government injected 270 billion yuan into the four major banks by issuing a special Treasury bond to raise their average capital adequacy ratio (CAR) from 4.6 per cent to above 8 per cent. By the end of 2001, however, the average CAR had come down to around 5 per cent again.

Banking problems represent one of the biggest risks for the Chinese economy now that China has gained entry to the WTO. Whether or not China can escape a financial meltdown depends on how quickly the government can eliminate, or at least contain, the banking problems and improve competitiveness.

\section{BANK MELTDOWN UNLIKELY}

While pessimists often compare China's banking situation to those of pre-crisis countries like Thailand or Mexico, we believe that such comparison ignores some important institutional differences between China and those crisis-affected countries, especially in terms of capital account control and blanket guarantee of deposits.

Given the problems of state-owned enterprises (SOEs) and SOCBs, capital account control is a second-best policy. It reduces efficiency and welfare by restricting domestic enterprises and households' direct access the international capital market. But it also prevents the external speculative attacks that triggered financial crises in some countries. Even if there are problems with some banks, depositors still need to put money into other banks in the country because of restrictions on capital mobility. This ensures that local problems do not lead to systemic disasters. In fact, capital account control was a key factor that enabled China to ride out the storm of the Asian financial crisis in 1998-99 (Huang 2001).

The entry of foreign banks may change the situation. ${ }^{4}$ In March 2002, several foreign bank branches were already receiving US dollar deposits from Chinese 
residents. Of course, full competition from foreign banks is still four years away. In a way, the WTO commitments have served to accelerate banking reforms. In the forseeable future, foreign competition will be mainly in the form of taking wealthy and profitable clients away from local banks (Bonin and Huang 2002). Foreign banks are not likely to build matching networks any time soon. The experiences of other emerging markets suggest that too much foreign competition is not often the major problem. Instead, it is usually too difficult for foreign banks to expand their businesses in the new market. Despite the policy commitments, the Chinese authorities still have plenty of flexibility to restrict foreign competition if domestic banks are not yet ready. A recent example is the new rule introduced by the PBOC that foreign banks' total borrowing from local interbank market cannot exceed 40 per cent of their assets. This rule, while not in violation of the national treatment principle, severely limits

Table 5.1 China committed to open up banking sector after WTO accession

$\begin{array}{ll}\text { Scheduled time } & \text { Expansion of foreign bank businesses } \\ \text { On accession (effective 1 Feb 02) } & \text { Foreign currency business with all companies } \\ & \text { Local currency business with foreign companies } \\ \text { Two years after accession } & \text { Local currency business with all companies } \\ \text { Five years after accession } & \text { Local currencies with all Chinese consumers } \\ & \text { No geographical restriction }\end{array}$

Source: Compiled by Citigroup.

Table 5.2 Estimated contingent liabilities for China, 2002

\begin{tabular}{lcc} 
& & Per cent of \\
& RMB billion & GDP \\
Accumulated public debts & 1,550 & 16.2 \\
Special T-bonds in 1998 for recapitalisation & 270 & 2.8 \\
Estimated costs for bank restructuring & 4,500 & 46.9 \\
Estimated costs for social security funds & 2,500 & 26.1 \\
Municipal government contingent debt & 700 & 7.3 \\
External debts & 1,500 & 15.6 \\
Total & 11,020 & 114.9 \\
\hline
\end{tabular}

Note: This is an updated estimate based on new information available on both gaps in social security funds and municipal government contingent debts for which the central government is guarantor. These were estimated based on discussions with government economists. Source: Citigroup estimates. 
foreign banks' potential in local currency business in the near term and thus shelters the domestic banks from competition pressure.

Another factor that helps keep depositors with the banks is the blanket guarantee of deposits by the state. The guarantee could cause a moral hazard problem if depositors do not discriminate against bad banks. But it maintains the faith of depositors in the shaky state banks. Does the government really have the ability to sustain guarantees? We believe that it has both the fiscal and monetary means to settle bank runs. China's formal public debts accounted for only 17 per cent of GDP at the end of 2002. If we take into account the estimated costs for restructuring banking system and the potential expenditure to finance the pension fund, 47 per cent and 26 per cent of GDP respectively, the contingent liabilities are around 90 per cent of GDP.

This ratio is very high according to any international standards but still does not pose any immediate threat to fiscal sustainability. The Chinese economy has been growing at a remarkable rate, even after adjusting for exaggeration in the official data. Fiscal revenues have been increasing at 15-20 per cent per annum, and fiscal deficits have been kept below 3 per cent of GDP in recent years. But the share of fiscal revenue in GDP is still below 20 per cent and has the potential to rise further. Thus, it should not be difficult for China to absorb the existing contingent liabilities over an extended period. Moreover, the government can also print more money if extra cash is needed to restore confidence in the banking system. Printing money can have adverse macroeconomic impacts, but such impacts are likely to be minimal given the current low inflation.

\section{A COMPREHENSIVE REFORM AGENDA}

The pace of banking reforms accelerated in the wake of the East Asian financial crisis, especially as WTO entry drew closer. From early 2001, policymakers were divided into eight groups exploring various reform options in different areas. The Central Financial Works Conference was held in early February 2002 to put together a blueprint for reform of the financial sector. Although the outcomes of the policy conference were less ambitious than expected, the policy framework for banking reforms encompassing three key areas became clear.

The first area is resolution of existing non-performing loans. The four AMCs will continue to deal with 1.4 trillion yuan of bad loans already transferred from the parent banks. We estimate the overall recovery rate to be 25 per cent at best (Bonin 
and Huang 2001). More worrying are the 3 trillion yuan or more of NPLs still in the banks. The PBOC's current policy is that no more NPLs will be transferred to the AMCs and that the banks should aim to reduce their NPL ratios by $2-3$ percentage points every year over the next five years in order to lower the average NPL ratio to below 15 per cent.

The second area is financial supervision. One of the main decisions at the February policy conference was to create a relatively independent body in charge of financial supervision within the PBOC. This body is expected to introduce international standard bank supervision practices gradually.

The third area is reform of the SOCBs through a three-step approach. Step one continues the reforms to improve internal management systems, including implementation of accounting, auditing and risk assessment systems. These will probably not bring about breakthrough changes but are necessary for the success of the later steps. Step two includes both corporatisation of the banks and introduction of strategic investors. The government intends to introduce a share-holding system in the major banks within two to three years, with the Ministry of Finance (MOF) as the sole owner initially. The MOF will then sell some equity to domestic and foreign strategic investors. Currently, foreign interests are capped at 25 per cent. Finally, step three aims at public listing of the large banks within about five years. The detailed forms of listing still need to be worked out case by case.

Table 5.3 The new policy framework for banking reform

Areas

Resolving the non-performing loans (NPLs)

Bank supervision

Reform of the state-owned commercial banks (SOCBs)
Key measures

The Asset Management Companies (AMCs) continue to absorb the RMB1.4 trillion in NPLs transferred from the four SOCBs The SOCBs are called to lower their NPL ratios by $2-3$ percentage points each year to reach an average of 15 per cent in 2005.

The China Banking Regulatory Commission (CBRC) is separated out from the People's Bank of China (PBOC) to strengthen bank supervision and reform

First step: continue reforms to improve the internal management system. Second step: implement the shareholding system and introduce foreign and domestic strategic investors. Third step: list the banks.

Source: Compiled by Citigroup. 
The dynamism of the reform, rather than the existing program itself, makes us reasonably confident that banking problems can be resolved. Five years ago, privatisation of the SOCBs would not have been acceptable to most policymakers. Today, however, it is already policy that the SOCBs will either be listed or sold soon to foreign strategic investors. China's practical reform approach, popularly characterised as 'crossing the river by groping for the stones', suggests that necessary reform measures will be adopted in order to improve the competitiveness of the banks.

\section{ARE RECENT DECLINES IN NPLS SUSTAINABLE?}

According to official statistics, the average NPL ratio of the four banks has been edging down for the past two years: from 32.9 per cent in December 2000 to 29.9 per cent in December 2001, 28 per cent in June 2002 and 24 per cent in May 2003. This improvement has been impressive, given the extremely negative perceptions of outsiders.

But is this process sustainable? Past successes were mainly attributable to the following factors

- writing off the NPLs using bank profits

- controlling NPLs in newly extended loans

- expanding the outstanding loan base.

Many officials, particularly bank managers, appear to be confident that NPLs should continue to decline for a number of reasons. First, the international standard five-category loan classification system has been implemented through the entire banking system, so bank managers now have a better means to monitor and control credit risks.

Table 5.4 Loan provisioning standards for Chinese banks

Loan category

Special mention

Sub-standard

Doubtful

Loss
Provision requirement

(per cent)

1

25

50

100

Source: People's Bank of China. 
Second, the PBOC system also devised the requirements for loan provisions and demanded that all banks achieve those requirements within three to five years. This system can effectively prevent further build-up of NPLS.

Third, the PBOC granted autonomies to commercial banks that identified and wrote off NPLs. This gave banks almost the same treatment as the AMCs that have so far worked out about one-third of their NPLs with an average recovery rate of 1820 percent.

Fourth, to improve the banks' financial position-and ability to further facilitate workout of the NPLs-the PBOC drafted 'management rules for service-based fee charging of commercial banks'. Currently, fees account for less than 10 per cent of revenues for most Chinese banks. In many other countries, this can be as high as 30-40 per cent.

Fifth, the banks will continue institutional reforms, particularly reform to their ownership structures through shareholding systems, strategic investors or public listings.

While we are encouraged by the past and current changes in the banking sector, we are still not fully convinced that these are sufficient. Banks made limited NPLS in recent years by investing in state-sponsored projects, treasury bonds, and mortgage and consumer loans rapidly. During the past five years, for instance, SOCBs extended about 2 trillion yuan loans to state-sponsored projects. This accounted for about half of the increased loans of that period. The banks also bought a huge amount of government/financial bonds, which now account for about 7 per cent of these banks' total capital utilisation. This does not really represent an improvement in banks' credit culture.

More worrying is the recent pace of credit expansion, at about 20 per cent. From mid 2002, many bank managers were encouraged to extend loans as a way of lowering the NPL ratios. Increasing proportions of the new loans went to the property and automobile industries, which were growing very rapidly. Unfortunately, both of these industries face serious risks of excess capacity. In fact, in mid June 2003, the central bank issued a new policy to restrict lending to the property sector.

\section{THE CASE FOR BREAKING UP THE LARGE BANKS}

We believe that breaking up some of the SOCBs might be a necessary step towards effective reform and transformation. Here we outline five reasons in more detail to support that argument. 
To avoid the 'too big to fail' problem. Although China shares the East Asian characteristic of being 'over-banked' (total bank loans account for 130 per cent of GDP), the individual SOCBs are also too big relative to GDP. The total assets of the Industrial and Commercial Bank of China (ICBC), for instance, were equivalent to 45.3 per cent of China's GDP in 2001. The proportions were slightly lower for the Bank of China (31.4 per cent), China Construction Bank (281 per cent) and the Agricultural Bank of China (25.9 per cent). They were all way above the equivalent proportions for global banks such as Citigroup (6.4 per cent) and Deutsche Bank (5.1 per cent). The relative size of the Chinese banks constitutes not only a financial risk but also a moral hazard ('too big to fail').

The breaking up of the SOCBs, at least the vulnerable ones, could help eliminate this problem. It would be much more feasible, politically and economically, to close down small, inefficient banks than to close a giant bank. More importantly, splitting the big banks into smaller ones could also break down monopolies and promote competition in the banking sector.

To improve the effectiveness of reform. Smaller banks would also mean a shorter chain of information transmission and more effective implementation of policy changes. A counter-argument would be that large banks have the potential to achieve scale efficiencies. But we have already learned from the Chinese experience that scale efficiency does not automatically come with size.

The SOCBs are among the world's largest banks. For instance, ICBC's assets are about half the size of Citigroup's, but its workforce (about half a million) is almost twice as big. The history of central planning has made it even more difficult for SOCBs to implement any policy changes consistently. Breaking up the banks could reduce the level of bureaucracy within them and improve the effectiveness of any reform measures. Increased competition pressure would certainly help promote swifter change.

To help fight the 'liquidity trap'. The essence of China's current 'liquidity trap' is that the banks do not lend, particularly to small and medium-sized private companies. This is partly a reflection of ideological discrimination (bad loans made to the state sector are more justifiable than bad loans made to private companies) and partly due to banks' lack of pricing flexibility (banks cannot charge much higher interest rates for riskier loans extended to small private firms). One problem, however, is that the SOCBs are too big, and large banks across the world basically deal only with large clients. 
Of course, China will need some large banks because it has some large companies. On the whole, however, private small and medium-sized enterprises will probably play a bigger role in China's economic growth in coming years. This is not compatible with the current banking structure, where the four SOCBs account for 70 per cent of total assets. Breaking up the banks would make it easier for them to deal with small and medium-sized companies and enhance financial intermediation.

To help with signing up strategic investors and public listing. The decision to introduce strategic investors into the banks and to list the banks in stock markets was an important policy breakthrough in banking reform. But the feasibility of attracting investors to buy into the SOCBs may be affected by two factors. One, foreign interests are still capped at 25 per cent of equity. This will significantly reduce foreign investors' interest because they will only be minority shareholders. Two, given the size of SOCBs, not many institutions could afford to hold even a small proportion of their equity. The BOC's equity at the end of 2001 was US $\$ 26.3$ billion, therefore a 10 per cent stake-a minority shareholding position-in the BOC would be US $\$ 2.6 \mathrm{bn}$. While some analysts are encouraged by the recent surge of foreign investment in Chinese banks, such as the Bank of Shanghai, Pudong Development Bank and Shenzhen Development Bank, we believe it will be much more difficult to attract investors to the SOCBs in their current form.

Breaking up the SOCBs could improve the banks' quality and affordability for investors, although the 25 per cent cap will remain a constraint. The size of the SOCBs will probably also pose difficulties for public listing, especially if the government aims at listing all the big four.

To smooth the flow of contingent liabilities. The SOCBs have been the main source of China's contingent liabilities. Our estimate of the total cost of restructuring the banking sector is around 46 per cent of GDP - on top of the public debt at 16 per cent of GDP, local government bad debt at 7 per cent of GDP, and pension fund deficits estimated to range between 25-100 per cent of GDP. With a strongly growing economy and steadily rising fiscal revenues, the risk of fiscal crisis is muted as long as the flow of new bad debts is contained.

If the government still attempts to introduce strategic investors to the SOCBs and list them without splitting, the Ministry of Finance will need to clean up the banks' books quickly and take over the bad debts. An instantaneous increase in the debt burden could result in rapid growth in interest payments and weaken investors' 
confidence. Thus the probability of fiscal crisis would rise. If the banks are broken up, however, the government can clean up the banks' balance sheets step by step and streamline the absorption of the contingent liabilities.

\section{RECENT POLICY DEVELOPMENT}

After the leadership transition in late 2002 and early 2003, the government appeared to step up efforts to resolve the banking problems.

The first move was the establishment of the new China Banking Regulatory Commission (CBRC) at the $10^{\text {th }}$ National People's Congress in March 2003, by separating the banking regulatory departments from the PBOC. A well-respected Chinese banker, Liu Mingkang, former president of the BOC, was appointed as the first chairman of the CBRC.

The regulators continue to require the SOCBs to lower their NPL ratios by $2-3$ percentage points each year. Policymakers decided that there would be no further transfer of NPLs to the AMCs. Instead, the regulators would grant necessary policy treatments to the banks in order to facilitate direct identification and writing off of NPLs by banks.

While the commercial banks' aim is still to ve listed publicly at the earliest possible date, policymakers are now more inclined to design different strategies for individual banks. One such proposal is that the ICBC should prepare for listing wholly in the domestic stock market, the BOC should aim at listing wholly overseas, and the $\mathrm{CBC}$ and $\mathrm{ABC}$ should be split up according to either business lines or geographic blocks.

The need for another round of capital injection to these SOCBs is widely recognised among policymakers; the disagreements lie in the size and timing of recapitalisation. Early in 2003, there was much speculation about an expected capital injection of US $\$ 40$ billion, slightly greater than the 1998 capital injection (270 billion yuan). But opponents argued that hasty recapitalisation might cause serious moral hazard, based on experiences of bank restructuring in other countries.

The banking sector is also expected to open the door wider to both foreign and private banks. There is currently a proposal to open five private banks in China, but so far it remains a non-government activity. Policymakers are instead focusing more on introducing foreign banks to the domestic system. The current policy restricting foreign interests in domestic banks to no more than 25 per cent (and 
single investors to no more than 15 per cent) is under review. In other words, foreign investors may be able to acquire higher stakes in Chinese banks in the near future. This may help stimulate foreign investor interest.

Finally, the PBOC is experimenting with interest rate reform in rural credit cooperatives in Guangdong, Guangxi, Hainan and Zhejiang. Interest rates for household and enterprise deposits can be floated upward by a maximum of 50 per cent, while those for all kinds of loans can be floated upward by a maximum of 100 per cent or downward by a maximum of 10 per cent. But the introduction of marketbased interest rates to the wider banking system will probably take years.

\section{NOTES}

1 'China central bank governor on financial situation', People's Daily, March 7, 1998, Beijing.

2 There were several incidents of bank runs in the southwestern and northeastern provinces in 1998 and 1999, but all of them were settled quickly.

3 In our earlier analysis, we noted that the average NPL ratio of the three SOCBS, excluding the $A B C$, was 23 per cent in mid 2002 (Huang 2002). ABC recently reported its NPL data, which was still around 30 per cent in mid 2003. This brought up the average ratio for the four SOCBs.

4 WTO agreements on entry of the foreign banks do not automatically require liberalisation of the capital account, but significant participation of foreign banks in the market does make it more difficult to maintain the control.

\section{REFERENCES}

Chang, G., 2001. The Coming Collapse of China, Random House, New York. Bonin, J.P. and Huang, Y., 2001. 'Dealing with the bad loans of the Chinese banks', Journal of Asian Economics, 12(2):197-214.

Bonin J.P. and Huang, Y., 2002. 'Foreign entry into Chinese banking: does WTO membership threaten domestic banks?', The World Economy, 25(8):1077-93.

Bottelier, P., 2003. Managing China's transition debt: challenges for sustained development, Johns Hopkins University, Baltimore (unpublished).

Hanna, D. and Huang, Y., 2002. 'Bank restructuring in post-crisis Asia', Asian Economic Papers, 1(1):3-42.

Huang, Y., 2001. China's Last Steps Across the River: enterprise and bank reforms, Asia Pacific Press, Canberra.

Huang, Y., 2002. 'Is meltdown of the Chinese banks inevitable?', China Economic Review, 13(4):382-7. 
Huang, Y. and Yang, Y., 1998. 'China's financial fragility and policy responses', AsianPacific Economic Literature, 12(2):1-9.

$\mathrm{Li}, \mathrm{W} ., 2000$. Dealing with Problem Banks in the Context of Bank Restructuring in China, Master Thesis, National Centre for Development Studies, The Australian National University, Canberra.

Lardy, N.R., 1998. China's Unfinished Economic Revolution, Brookings Institution Press, Washington, DC.

$\mathrm{Li}, \mathrm{D} ., 2000$. 'Beating the trap of financial repression in China', Cato Journal, 21(1):7790.

Woo, W.T., 2002.'Some unorthodox thoughts on China's unorthodox financial sector', China Economic Review, 13(4):388-93. 


\title{
6
}

\section{Financial opening and economic growth: a quantitative assessment}

\author{
Jordan Shan
}

This chapter sheds further light on the much-debated question of whether financial development leads, in a Granger causality sense, to economic growth. This is an important question because it helps to evaluate the extent to which the financial deregulation that has occurred in many western countries has spurred economic growth. Further, it gives some guidance about whether financial sector development is necessary to increase growth rates in developing countries.

These questions are particularly relevant in China, where swift change and reform in the financial sector-aimed at deregulating China's financial system further and opening up the domestic financial market-has brought about significant financial development. China's financial sector has been liberalised substantially with permission being granted for foreign entities to participate in the sector (Figure 6.1).

Net credit is a one indicator of financial development. ${ }^{\text {The }}$ There has a significant increase in net credit since early 1990s, along with strong real GDP growth and investment growth during the same period. ${ }^{2}$ However, investment as percentage in GDP has been stable despite a significant increase in the ratio of credit to GDP (Figure 6.2). This result diverges from the finance-led growth literature, which argues that financial development will promote investment and hence increase economic growth.

Does financial growth promote economic development in China? This chapter contributes to the finance-growth debate by investigating the relationship between 
financial opening and economic growth in China in a VAR econometric context (using the innovation accounting and Granger-causality methodology). This is the first attempt to use this methodology to investigate the hypothesis that financial development 'leads' economic growth in China.

In the literature, the question of causality between financial development and economic growth has been addressed both theoretically and empirically. The recent focus has been on empirical analysis, where research has been equivocal regarding the hypothesis that financial development leads economic growth. King and Levine (1993) concluded that financial development leads economic growth, and Levine and Zervos (1998) found that stockmarket and banking development lead economic growth. In contrast, Arestis and Demetriades (1997), Shan and Morris (2002) and Shan, Sun and Morris (2001) found that the hypothesis was supported in only a few of the countries surveyed and, therefore, that no general conclusions could be drawn.

The positive view of the finance-led growth hypothesis normally focuses on the role played by financial development in mobilising domestic savings and investment through a more open and liberalised financial system, and in promoting productivity through the creation of an efficient financial market. Chen (2002), for example, has examined the causal relationship between interest rates, savings and income in the Chinese economy over the period 1952-99 using the cointegration test and Bayesian vector autoregressions (BVAR) model. He argues that it is therefore important to establish well-developed financial institutions-particularly the independence of the Central Bank-interest rate liberalisation and sound financial intermediation, all of which are important for the efficient allocation of capital, which, in turn, can help to establish sustainable economic growth' (Chen 2002:59).

Ansari (2002:72), who used a vector error correction model (VECM) to analyse the impact of financial development, money and public spending on Malaysian national income, argues that Malaysian experience has shown 'an unambiguous support for the supply-leading view of financial development, implying the importance of financial sector development'. Strong government ownership of banks, a typical phenomenon in countries such as China, is said to be one of the causes of slow economic growth around the world. La Porta et al. (2002) have assembled data on government ownership of banks around the world and concluded that 'higher government ownership of banks is associated with slower financial development and slower growth of per capita income and productivity' (La Porta et al.2002:265). 
Figure 6.1 Growth of GDP, credit and investment in China

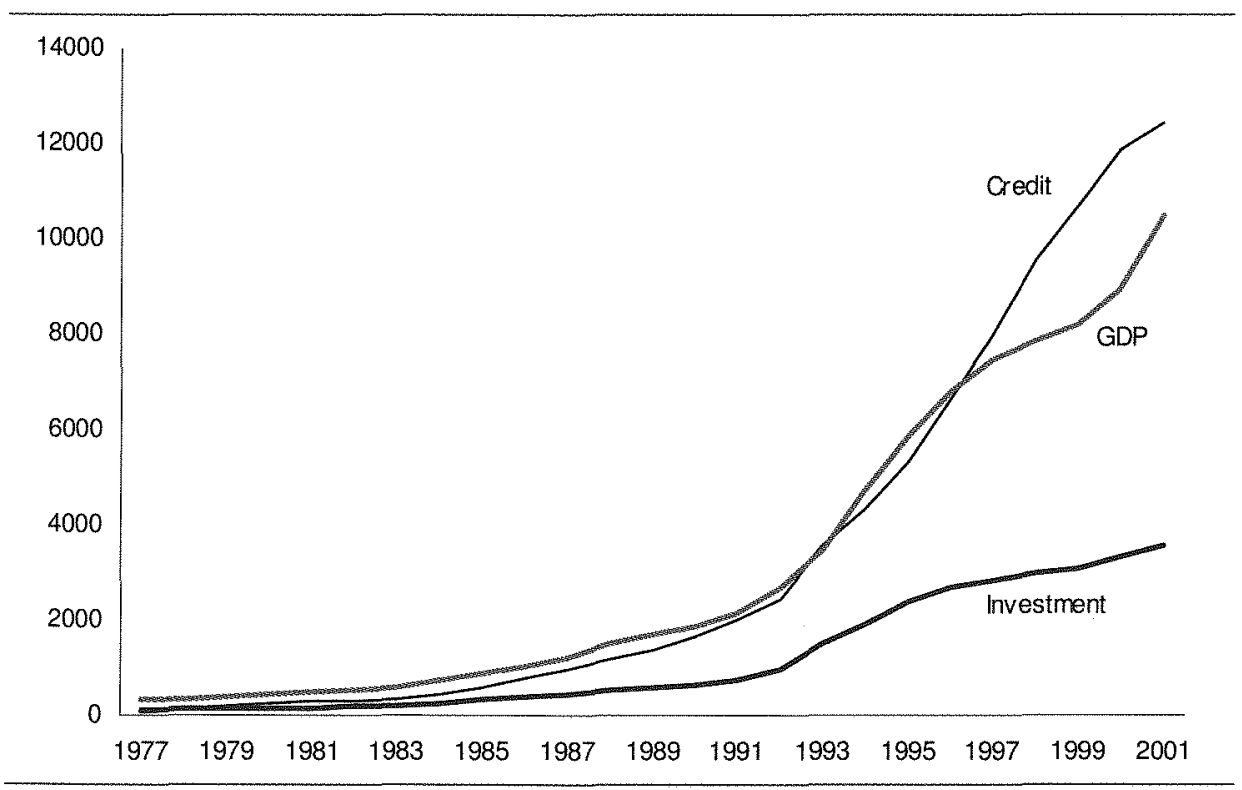

Figure 6.2 Credit and investment in GDP in China (per cent of GDP)

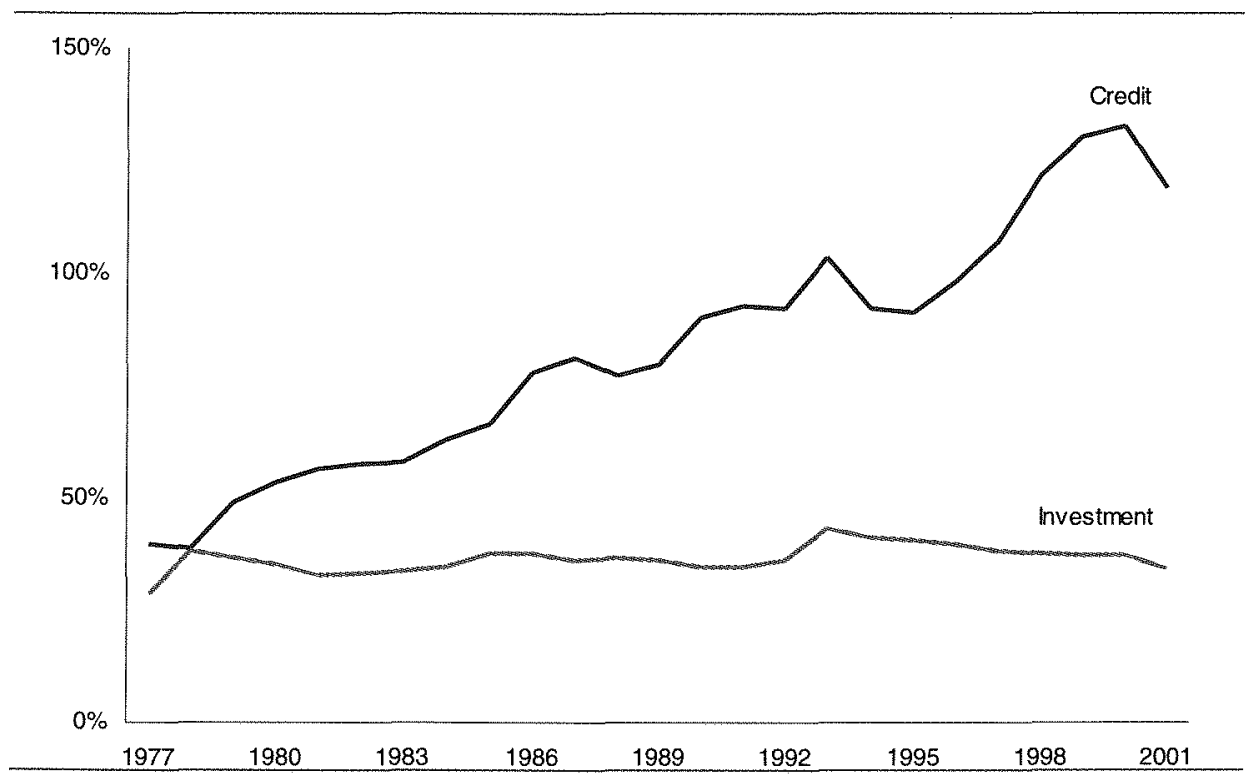

Source: Calculated using data from Statistical Yearbook of China 
In the cases of industrial economies, Schich and Pelgrin (2002) have applied panel data for 19 OECD countries from 1970 to 1997 to examine the relationship between financial development and investment levels. Their conclusion indicates that financial development is significantly linked to higher investment levels. Deidda and Fattouh (2002), who used a model allowing a non-linear and non-monotonic relationship between financial development and economic growth, have supported the hypothesis of King and Levine (1993).

Nourzad (2002) has also used panel data from a stochastic production function to investigate the impact of financial development on productive efficiency and concludes that 'financial deepening reduces productive inefficiency in both developed and developing countries, although the effect is larger in the former' (2002:138). Further, some literature suggests that financial sector development contributes to poverty reduction in developing economies (see, for example, Jalilian and Kirkpatrick 2002).

However, there is a large volume of literature which provides empirical evidence against the finance-led growth hypothesis. Al-Yousif (2002) has used both time series and panel data from 30 developing economies to examine the causal relationship between financial development and economic growth. He found that 'financial development and economic growth are mutually causal, that is, causality is bidirectional. The findings here accord with the view of the World Bank and other empirical studies that the relationship between financial development and economic growth cannot be generalised across countries (Al-Yousif 2002:131).

More empirical evidence is found for developing economies where no causal relationship exits from financial development to economic growth. Using the Granger causality and cointegration approach for selected Arab countries, Al-Tamimi et al. (2001) found no clear evidence that financial development affects or is affected by economic growth. Cargill and Elliot (2001) discussed the dangers and consequences of financial liberalisation with reference to the experiences in Japan and provided a summary of lessons that China's reformers should learn from the recent financial experiences of their Asian neighbours.

In the case of industrial economies, Luintel and Khan (1999) investigated the finance-growth nexus in a multivariate VAR model and found a bi-directional causality between financial development and economic growth in all the sample countries. Arestis (2002) demonstrated that financial liberalisation is a much more complex process than has been assumed by earlier literature and that its effects on economic 
development are ambiguous. Arestis et al. (2001) suggested, after an econometric assessment, that the contribution of stockmarkets to economic growth may have been exaggerated by studies that utilise cross-country growth regressions.

Finally, the East Asian financial crisis has cast further doubt on the hypothesis. The rapid economic growth of the 'Asian Tigers' has decreased (and in some cases, turned negative) following the East Asian 'meltdown', yet this slowing of growth was preceded by considerable, perhaps excessive, development of their financial sectors. In short, financial development appears to have led to reduced growth rates and, arguably, was partly responsible for the meltdown.

Empirical studies adopt either of two general broad econometrics methodologies. Gelb (1989), King and Levine (1993), Fry (1995), Levine (1997, 1998), Levine and Zervos (1998) and Rajan and Zingales (1998) used a cross-sectional modelling approach, and their work tends to support the hypothesis.

Others, including Sims (1972), Gupta (1984), Jung (1986), Demetriades and Hussein (1996), Demetriades and Luintel (1996), Arestis and Demetriades (1997), Arestis et al. (2001) and Shan, Sun and Morris (2001), and Shan and Morris (2002) have used time-series modelling to test the hypothesis. Arestis and Demetriades, in advocating time-series modelling, argued that a cross-sectional approach is based on the implicit assumption that countries have common economic structures and technologies. This, quite simply, is not true. The time-series studies have been equivocal in their conclusions regarding the hypothesis. Demetriades and Hussein observed that causality patterns differ between countries and it follows that any inferences drawn are about 'on average' causality across the sample. ${ }^{3}$ Shan et al. found that in most of their sample of nine OECD countries and China, financial development did not 'lead' economic growth except in a small minority of the countries studied.

Cross-sectional studies have failed to address the possibility of reverse causality from economic growth to financial development. Levine (1998) and Levine and Zervos (1998) examined causality from the development of banking, the legal system and the stockmarket to economic growth. Both noted that a case could be made for reverse causality but did not test this empirically and concluded, instead, that banking development leads economic growth. Ahmed (1998) argued that, whilst the direction of causality is an important matter, cross-sectional studies are not capable of revealing the dynamic relationships necessary to establish it. 
Gujarati (1995) and Shan and Sun (1998) noted that the neglect of reverse causality in either a cross-sectional or time-series modelling framework might introduce simultaneity bias. Earlier, Cole and Patrick (1986) had observed that the relationships between financial development and economic growth are complex and are likely to contain 'feedback interactions'.

Perhaps the most serious shortcoming of cross-sectional analysis is that it is inherently incapable of examining lagged relationships and, therefore, is inappropriate for testing Granger causality. Notwithstanding the increasing globalisation of national economies, there appears to be sufficient diversity remaining to render invalid the implicit assumption of cross-sectional analysis that the same constant parameters apply to all countries in the sample.

\section{MODELLING FRAMEWORK}

This work uses a Vector Autoregression (VAR) modelling framework to capture the dynamics of the relationship between financial development and economic growth whilst avoiding the pitfalls of endogeneity and integration of the variables. It differs from previous Granger causality literature, however, in investigating the financegrowth nexus by using the innovation accounting technique (impulse response function and variance decomposition) to investigate causality.

Enders (1995) proposed that forecast error variance decomposition permits inferences to be drawn regarding the proportion of the movement in a particular time-series that is attributable to its own earlier 'shocks' and the proportion attributable to 'shocks' arising from other variables in the VAR. After estimating the VAR, the impact of a 'shock' in a particular variable is traced through the system of equations to determine the effect on all of the variables, including future values of the 'shocked' variable. ${ }^{4}$ The technique breaks down the variance of the forecast errors for each variable following a 'shock' to a particular variable. In this way, it is possible to identify which variables are strongly affected and which are not. If, for example, a 'shock' in total credit leads subsequently to a large change in economic growth in the estimated VAR, but a 'shock' in economic growth has only a small effect on total credit, we would have support for the hypothesis that financial development leads economic growth. ${ }^{5}$

Impulse response function analysis, on the other hand, traces out the time path of the effects of 'shocks' of other variables contained in the VAR on a particular 
variable. In other words, this approach is designed to determine how each variable responds over time to an earlier 'shock' in that variable and to 'shocks' in other variables. Together, these two methods are termed innovation accounting and permit an intuitive insight into the dynamic relationships among the economic variables in a VAR.

We use variance decomposition to break down the variance of the forecast errors for economic growth, GDP growth ( $E G$ ), into components that can be attributed to each of the other variables including the measure of financial development, total credit (TC). If total credit explains more of the variance amongst the forecast errors for economic growth than is explained by other variables, we would find support for the hypothesis that financial development Granger-causes economic growth. Similarly, we would find support for the hypothesis that economic growth Grangercauses financial development if the economic growth variable explains more of the variance in the forecast errors for total credit.

We use the impulse response function to trace how the economic growth variable responds over time to a 'shock' in total credit and compare this to responses to 'shocks' from other variables. If the impulse response function shows a stronger and longer reaction of economic growth to a 'shock' in total credit than 'shocks' in other variables, we would find support for the hypothesis that financial development 'leads' economic growth. Similarly, if the impulse response function shows a stronger and longer reaction of total credit to a 'shock' in economic growth than 'shocks' in other variables, we would find support for the hypothesis that economic growth 'leads' financial development.

The particular VAR model in which the innovation accounting technique is applied is motivated by Feder's two-sector model concerning exports and growth. This article proposes a dynamic framework based on the production function theory and consists of two-sectors (the financial sector and the real sector), and extends it by combining financial development, external openness and factor inputs.

Therefore, the VAR model considers factor inputs such as labour and physical capital as well as trade sector and a monetary factor, for example, total credit, deriving from the theory of money in the production function. Similar treatment can be found in Wang (2000), Kang and Sawada (2000) and Evans, Green and Murinde (2002).

From growth theory we define economic growth $(E G)$ as the rate of change of real GDP, and investment (INV) as the rate of change of net investment. In accordance 
with modern growth theory, we propose that openness to international trade may facilitate economic growth by enlarging the markets of domestic firms and by permitting them to purchase inputs at world prices. To capture openness, we use the rate of change of the trade ratio (TRADE), defined as the ratio of the sum of imports and exports to GDP. Further, because economic output depends on inputs, and labour in particular, we include the rate of change of the labour force $(L A B)$ in the model.

The literature suggests a considerable range of choice for measures of financial development. Sims (1972), King and Levine (1993) and Cole et al. (1995) have used monetary aggregates, such as M2 or M3 expressed as a percentage of GDP. Recently, Demetriades and Hussein (1996) and Levine and Zervos (1998) have raised doubts about the validity of the use of such a variable to test the hypothesis that financial development 'leads' economic growth because GDP is a component of both focus variables.

Following Levine (1997) and the World Bank (1998) we use total credit to the economy (TC) as a measure of financial development. Credit is an appropriate measure of financial development because it is associated with mobilising savings to facilitate transactions, providing credit to producers and consumers, reducing transaction costs and fulfilling the medium of exchange function of money. In recent years, financial sectors have undergone rapid changes resulting from deregulation, technological innovation, new financial products (including widespread use of credit cards, telephone banking and internet banking). These changes, in particular the abandonment of credit rationing, seem likely to have facilitated greater volumes of credit being created by financial systems.

Juttner (1994:110), in arguing against the use of monetary aggregates to measure financial development, noted that 'credit creation does not necessarily entail money creation and vice versa'. This suggests that M2/GDP and M3/GDP are not appropriate measures of financial development if the researcher is seeking to investigate how financial development might bring about economic growth. Levine and Zervos (1998:542) argued that M3/GDP only measures financial depth and 'does not measure whether the liabilities are those of banks, the central bank or other financial intermediaries, nor does this financial depth measure identify where the financial system allocates capital'. In other words, they suggest that increases in M3/GDP are not necessarily associated with increases in credit, and credit is clearly one of the aspects of financial development that might generate economic growth. ${ }^{6}$ 
Our arguments suggest that financial development is unlikely to be more than a contributing factor and probably not the most important in increasing economic growth rates. Our VAR framework also accommodates the hypothesis that rising levels of real income give rise to demands for financial services from both the household and business sectors. The so-called reverse causality hypothesis is that increases in the demand for financial services lead businesses in the financial sector to expand their activities and/or governments to ease restrictions on the financial sector.

In view of the considerations outlined above, we establish a VAR system that takes the following form

$$
V_{t}=\sum_{i=1}^{k} A_{i} V_{t-i}+\varepsilon_{t}
$$

where $V_{t}=$ á $E G_{t}, T C_{t}, I N V_{t}, L A B_{t}, T R A D E_{t} \tilde{n}$,

$$
e_{t}=a \mu_{E G t}, \mu_{\text {INVEt }}, \mu_{\text {TCt }}, \mu_{\text {LABt }}, \mu_{\text {TRADEt }} \tilde{n}_{\text {, }}
$$

$A_{1}-A_{k}$ are five by five matrices of coefficients and $e_{t}$ is a vector of error terms. $E G_{t}$ $=$ real GDP in logarithm, $T C_{t}=$ total credit to the economy in logarithm, $L A B_{t}=$ labor force in logarithm, INV $=$ net investment in logarithm and $T R A D E_{t}=$ total trade as per cent of GDP in logarithm.

We use annual data from China for 1978-2001 to construct VAR models to examine the causality hypotheses between financial development and economic growth. The data was obtained from the World Bank's World Tables through DX-Data, Australia.

\section{EMPIRICAL EVIDENCE}

It is important to note that restrictions need to be imposed on the VAR to identify the particular 'shocks' and account for correlations in innovations across equations and to decompose the forecast error variances to identify the impulse responses. We use Cholesky's decomposition method to impose identification restrictions since it precludes contemporaneous correlations between time-series in the system and ensures that the variance-covariance matrix of the residuals is block recursive and provides a minimal set of restrictions that identify the primitive model. ${ }^{\text {? }}$

We first report the results of using Cholesky's method, which demonstrates how the forecast error variance of our focus variables can be broken down into components that can be attributed to each of the variables in the VAR. In particular, we examine 
the relationships between total credit and economic growth, compared to the contributions to GDP from investment, trade openness and labour. The forecast error variance decomposition of unrestricted VAR(3) models were estimated over a three year forecast horizon (results are shown in Table 6.1).

As expected, each time series explains the preponderance of its own past values: for example, GDP growth explains over 60 per cent of its forecast error variance, whereas total credit explains nearly 70 per cent of its forecast error variance. The fact that GDP growth is explained predominately by its past values suggests that current period economic growth influences future growth trends or that the phenomenon is due to a strong 'lag effect' in the business cycle.

For the purpose of our study, however, we are more interested in the contribution of total credit to GDP growth as compared to other variables such as TRADE, INV and $L A B$. It is interesting to note that labour input explains 15.5 per cent of the forecast error variance of GDP $\left(E G_{t}\right)$ and is thus the most important influence on economic growth. Total credit $\left(\mathrm{TC}_{\mathrm{t}}\right.$ ) comes second, explaining 12.2 per cent of forecast error variance of GDP, followed by trade openness (TRADE $t^{\prime} 7.1$ per cent) and investment (INV $\mathrm{t}, 4.8$ per cent).

Interestingly, we also found that trade openness had a larger effect on GDP growth (TRADE, explains 7.1 per cent of forecast error variance of $E G_{t}$ ) than investment (INV explains only 4.8 per cent of forecast error variance of $E G_{t}$ ). This clearly supports the hypothesis that economic openness promotes economic growth.

Trade and investment both appear to have strong lagged effects and are, to a large extent, explained by their own past values (Table 6.1).

The fact that labour contributes the most to GDP growth in China suggests that the Chinese economy is still a labour-intensive economy and that its primary source of growth comes from the extensive use of labour. At the same time, this study

Table 6.1 Variance decomposition percentage of 36-month error variance

\begin{tabular}{lccrcrc}
$\begin{array}{l}\text { Percentage of } \\
\text { forecast error }\end{array}$ & \multicolumn{5}{c}{ Typical shock in } \\
variance in & Variables & EGt & TCt & INVt & LABt & TRADEt \\
GDP & EGt & 60.3 & 12.2 & 4.8 & 15.5 & 7.1 \\
Total credit & TCt & 14.6 & 65.1 & 10.4 & 3.7 & 6.5 \\
Investment & INVt & 15.7 & 8.9 & 67.2 & 3.0 & 5.3 \\
Labour & LABt & 12.6 & 2.8 & 3.2 & 80.5 & 1.1 \\
Trade openness & TRADEt & 16.2 & 2.0 & 4.1 & 10.3 & 78.5 \\
\hline
\end{tabular}


suggests that financial development has indeed promoted GDP growth in China and the swift change in Chinese financial system has brought about significant credit inputs to the Chinese economy. The fact that total credit contributes more than net investment to GDP growth in China implies that its primary source of growth also comes from extensive use of credit/resources at the expense of productive net investment.

To investigate further the impact of credit on GDP growth compared with other variables, we have used an impulse response function to trace the time paths of GDP in response to a one unit shock to variables such as credit, investment, labour and trade. An illustration of an impulse response function can provide an intuitive insight into dynamic relationships because it shows the response of a variable to a 'shock' in itself or another variable over time. For example, it allows us to examine how GDP growth responds over time to a 'shock' in total credit and compare it with the effects on other variables.

The responses of the variables can be judged by their strength and the length over time. If the response of economic growth to a 'shock' in total credit exhibits a larger and longer effect than the response of total credit to a 'shock' in economic growth, we would find support for the hypothesis that financial development 'leads' economic growth.

Figure 6.3 depicts the time paths of the responses of GDP growth to 'shocks' in total credit, investment, trade and labour. Credit again ranked as the second most important input after labour - the response of GDP to a shock in labour has a longer and stronger effect than the response of GDP to total credit. The effect of labour on GDP lasts until the seventh year, whereas credit's impact on economic growth is smaller and 'dies out' quickly from the third year.

After labour and credit, trade is the next most important factor in GDP. The impact of net investment on GDP is small and not dynamically longer. This is consistent with the earlier finding in this study.

Therefore, we could argue financial development, as measured by total credit, does promote economic growth in China. However, two things are worth mentioning here: first, credit was only one of several sources of innovations in economic growth and was not the most important factor (setting aside past values of economic growth). The innovations in total credit were not the most important source of the variance of forecast errors for economic growth. Similarly, economic growth was found to have a greater impacts on investment $\left(E G_{t}\right.$ explained 15.7 per cent of forecast error 
variance of $\mathbb{N N V}_{t}$ ) than did total credit (TC explains 8.9 per cent of forecast error variance of INV). This suggests that economic growth has a greater influence on investment behaviour than the availability of funds.

Second, if one looks at the impact of GDP on credit, we can see that GDP growth also affects financial development; that is, total credit. GDP growth $\left(\mathrm{EG}_{\mathrm{t})}\right.$ explains about 14.6 per cent of forecast error variance of total credit, and is the most important influence on total credit over a three year forecast horizon (Table 6.1). Economic growth also affects financial development because the response of credit to a shock in GDP has a longer and stronger effect than to shocks in any other variables in the VAR system (Figure 6.4). The effect of GDP growth (EG) on credit lasts until the ninth year whereas the impacts of investment, trade openness and labour on credit are smaller and 'die out' quickly from the second year.

Therefore, the above findings suggest that the causality between GDP growth and financial development in bi-directional. In other words, the empirical evidence provided in this study supports the view in the literature that financial development and economic growth exhibit a two-way causality and hence is against the so-called 'finance-led' growth hypothesis. However, it is also clear that the impact of GDP on credit is stronger than the reverse situation as suggested by the above impulse response function analysis.

Figure 6.3 EG responses to a 'shock' in TC, LAB, INV and TRADE

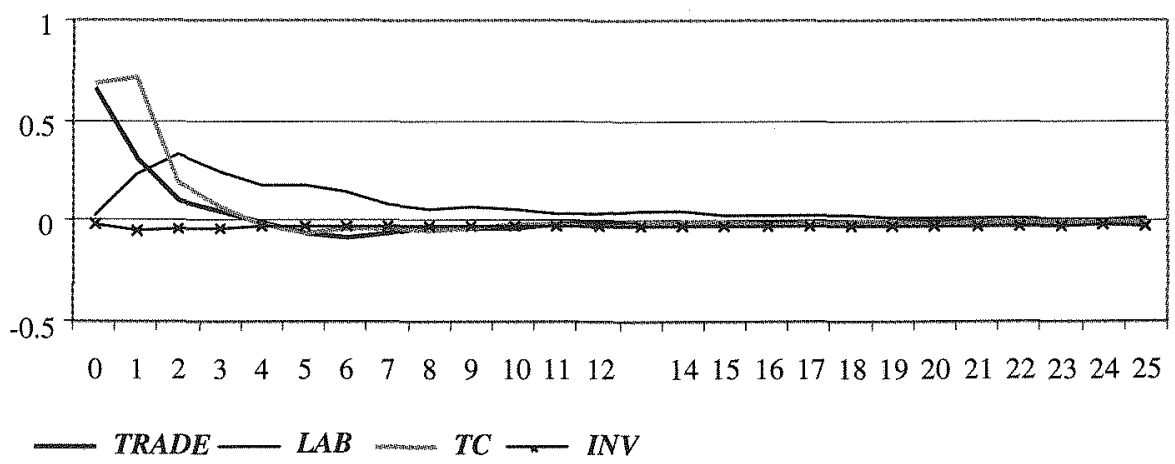


To further verify this finding, we have conducted a Granger causality test, which is a modified Wald test proposed by Toda and Yamamoto (1995). Financial development and GDP growth are mutually affected and this clearly suggests that one cannot overestimate the impact of financial development on economic growth in China (Table 6.2)

Financial development in China was found to be the second most important factor after labour affecting economic growth. Given this, swift reform and change in the Chinese financial system have brought significant credit resources to the economy and hence contributed to GDP growth in China. However, we also found that strong economic growth in the last 20 years has had a significant impact on financial development by providing a solid credit base (through rising personal income and

Figure 6.4 TC responses to a 'shock' in EG, LAB, INV and TRADE

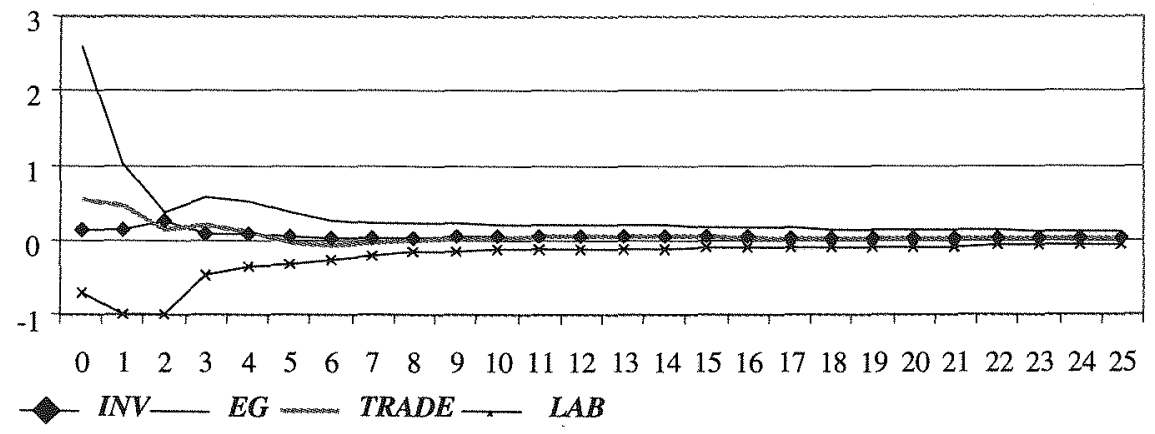

Table 6.2 Granger causality test

\begin{tabular}{lc}
\hline Variables & P-values \\
$T C \Rightarrow>$ GDP & $0.05^{\star}$ \\
$G D P=>T C$ & $0.01^{\star *}$ \\
$E G=>$ INV & $0.05^{\star}$ \\
$I N V=>E G$ & $0.06^{* \star}$ \\
$I N V \Rightarrow$ TC & $0.04^{\star}$ \\
$T C \Rightarrow$ INV & $0.05^{\star *}$
\end{tabular}

Note: $\Rightarrow>$ indicates the direction of causality. * significant at 5 per cent; ${ }^{* *}$ significant at 1 per cent. 
private and public resources) in China. This indicates a two-way causality between finance and growth in the context of the so-called 'finance-led growth' debate.

We also found that trade promotes GDP growth in China but that credit growth has not helped increase the growth of net investment. Labour is the most important factor affecting economic growth in China.

To a limited extent our findings suggest some support for the hypothesis that financial development 'leads' economic growth in China. It seems clear, however, that financial development is no more than a contributing, and almost certainly not the most important, factor in GDP growth.

Whatever causality may exist, it is not uniform in direction or strength, and highlights the inappropriateness of cross-sectional analysis. The results provide evidence, from a different methodological perspective, that the hypothesis that financial development 'leads' economic growth is not generally supported by time-series analysis, at least not from the experience of China.

\section{NOTES}

1 The choice of using credit as the indicator of financial development will be discussed in the model building section.

2 Investment is defined here as the net investment where gross investment minus fixed investment.

3 Any significant 'on average' relationship across different countries is likely to be sensitive to the addition or deletion of a few observations in the sample.

4 The Microfit program sets the 'shock' equal to one standard deviation of the particular time-series used to 'shock' the VAR system.

5 This is not a test of hypothesis in the manner of a Granger causality test that has well defined test statistics and critical values.

6 Our measure is slightly different from Levine and Zervos (1998) who differentiate between credit to the public and private sectors. Because of data limitations, we use total credit.

7 For details, see Lutkepöhl (1991).

\section{REFERENCES}

Ahmed, S., 1998. 'The legal environment, banks, and long-run economic growth', Journal of Money, Credit, and Banking, 30(3):614-20.

Al-Tamimi, H., Al-Awad; M. and Charif, H., 2001. 'Finance and growth: evidence from some Arab Countries', Journal of Transnational Management Development, $7(2): 3-18$. 
Al-Yousif, Y.K., 2002. 'Financial development and economic growth: another look at the evidence from developing countries', Review of Financial Economics, 11(2): $131-50$.

Ansari, M. I., 2002. 'Impact of financial development, money, and public sending on Malaysian National Income: an econometric study', Journal of Asian Economics, 13(1):72-93

Arestis, P. and Demetriades, P., 1997. 'Financial development and economic growth: assessing the evidence', Economic Journal, 107(442):783-99.

Arestis, P., Demetriades; P., Luintel, K., 2001. 'Financial development and economic growth: the role of stock markets', Journal of Money, Credit, and Banking, 33(1):16-41.

Arestis, P., 2002. 'The impact of financial liberalisation policies on financial development: evidence from developing economies', International Journal of Finance and Economics, 7(2):109-21.

Cargill, T. and Elliott, P., 2001.'Financial liberalisation in China: imitations and lessons of the Japanese regime', Journal of the Asia Pacific Economy, 6(1):1-21.

Chen, C.H., 2002. 'Interest rates, savings and income in the Chinese economy', Journal of Economic Studies, 29(1):59-73.

Cole, D. and Patrick, H.T., 1986. 'Financial development in the Pacific Basin market economies', in A.H.H. Tan and B. Kapur (eds), Pacific Growth and Financial Interdependence, Allen and Unwin, Sydney.

Cole D.C., Scot, H.S. and Wellons, P.A. (eds), 1995. Asian Money Market, Oxford University Press, Oxford.

Deidda, L. and Fattouh, B., 2002. 'Non-linearity between finance and growth', Economics Letters, 74(2):339-45.

Demetriades, P. and Hussein, K.,1996. 'Financial development and economic growth: cointergration and causality tests for 16 countries', Journal of Development Economics, 51(2):387-411.

Demetriades, P. and. Luintel, K. 1996. 'Financial development, economic growth and banking sector controls: evidence from India', Economic Journal, 106(435):359-74.

Enders, W., 1995. Applied Econometric Time Series, Wiley, New York.

Evans, A.D., Green, C. and Murinde, V., 2002. 'Human capital and financial development in economic growth: new evidence using the translog production function', International Journal of Finance and Economics, 7(2):123-40. 
Fry, M.J., 1995. Money, Interest and Banking in Economic Development, Johns Hopkins University Press, Baltimore.

Gelb, A.H., 1989. Financial Policies, Growth and Efficiency, Policy Planning and Research Working Papers 202, World Bank, Washington, DC.

Gujarati, D., 1995. Basic Econometrics, McGraw-Hill, New York and Washington, DC.

Gupta, K.L., 1984. Finance and Economic Growth in Developing Countries, Croom Helm, London.

Jalilian, H. and Kirkpatrick, C., 2002. 'Financial development and poverty reduction in developing countries', International Journal of Finance and Economics, 7(2):97108

Jung, W., 1986. 'Financial development and economic growth: international evidence', Economic Development and Cultural Change, 34(2):333-46.

Juttner, D.J., 1994. Financial markets, Interest Rates and Monetary Economics, Longman Cheshire, Sydney.

Kang, S.J. and Sawada, Y., 2000. 'Financial repression and external openness in an endogenous growth model', Journal of International Trade and Economic Development, 9(4):427-43.

King, R.G. and Levine, R., 1993. 'Finance and growth: Schumpeter might be "right"', Economic Journal, 107:771-82.

La Porta, R., Lopez-de-Silanes. F. and Shleifer, A., 2002. 'Government ownership of banks', Journal of Finance, 57(1):265-301.

Levine, R., 1997. 'Financial development and economic growth: views and agenda', Journal of Economic Literature, 35(2):688-726.

Levine, R., 1998. 'The legal environment, banks, and long-run economic growth', Journal of Money, Credit, and Banking, 30(3):596-613.

Levine, R. and Zervos, S., 1998, 'Stock markets, banks, and economic growth', American Economic Review, 88(3):537-58.

Lutkephl, H., 1991. Introduction to Multiple Time Series Analysis, Springer-Verlag, New York.

Luintel, K. and Khan, M., 1999. 'A quantitative reassessment of the finance-growth nexus: evidence from a multivariate VAR', Journal of Development Economics, 60(2):381-405.

McKinnon, R., 1993. The Order of Economic Liberalization, Johns Hopkins University Press, Baltimore. 
Nourzad, F., 2002. 'Financial development and productive efficiency: a panel study of developed and developing countries', Journal of Economics and Finance, 26(2):138-49.

Rajan, R.G. and Zingales, L., 1998. 'Financial dependence and growth', American Economic Review, 88(3):559-86.

Schich, S. and Pelgrin, F., 2002. 'Financial development and investment: panel data evidence for OECD Countries from 1970 to 1997', Applied Economics Letters, $9(1): 1-7$.

Shan, J.Z. and Sun, F., 1998. 'On the export-led growth hypothesis: further econometric evidence from China', Applied Economics, 30(8):1055-65.

Shan, J.Z., Sun, F. and Morris, A., 2001. 'Financial development and economic growth', Review of International Economics, 9(3):443-54.

Shan, J.Z. and Morris, A., 2002. 'Does financial development 'lead' economic growth?', International Review of Applied Economics, 16(2):153-68.

Sims, C.A., 1972. 'Money, income and causality', American Economic Review, 62(4):540-52.

Toda, H.Y. and Yamamoto, T., 1995. 'Statistical inference in vector autoregressions with possibly integrated processes', Journal of Econometrics, 66(1-2):225-50.

Wang, E.C., 2000. 'A dynamic two-sector model for analyzing the interrelation between financial development and industrial growth', International Review of Economics and Finance, 9(3):223-41.

World Bank, 1998. World Development Report, Oxford University Press, Oxford. 


\section{7}

\section{Rural financial markets and institutions: new developments}

\section{Enjiang Cheng}

Continuous declines in the growth rate of farmers' incomes and widening income gaps between urban and rural areas since the early 1990 s have renewed interest in China's agricultural and rural development. Rural fiscal and taxation policies, including the massive debts owed by the township and village administrations, and rural financial policies have topped the agenda for further rural economic reforms in 2003. The Central government has been urged to reduce the ever-increasing burdens on farmers through fiscal and taxation reforms and to provide more credit for rural development by introducing new reforms to rural financial institutions and markets.

China's rural financial market is dominated by formal rural financial institutions, especially in the savings markets, as the deposits of formal financial institutions are insured by the state. The formal financial market and its institutions are highly regulated, with government regulations on rates of interest, market entry and exit, financial products and lending methodologies. Like their counterparts in urban areas, China's rural financial institutions have for a long time been marred by poor financial performance and high proportions of non-performing loans.

Rural financial institutions in China can be divided into formal and informal institutions. Formal rural financial institutions in China consist of the Agricultural Bank of China $(A B C)$, the Agricultural Development Bank of China (ADBC), rural credit cooperatives (RCCs) and Rural Postal Savings (RPS). Of them, ADBC is a 
policy bank in agriculture and RPS are savings-only financial institutions attached to Post Offices. Rural credit cooperatives are credit cooperatives based at township level, and township rural credit cooperatives are profit centres and legal persons. Informal finance in rural China, defined as the financial intermediaries and transactions unregulated by the People's Bank of China (PBOC), consists mainly of credit transactions among relatives and friends, by moneylenders, and informal financial mechanisms organised by rural households, such as revolving savings and credit associations, as well as institutional informal finance (Cheng and $\mathrm{Xu}$ 2003). Institutional informal finance includes rural credit foundations (RCFs) and other financial institutions organised by local governments, as well as donor-funded microfinance institutions (MFIs). ${ }^{1}$

This chapter focuses on the operation of formal rural financial institutions, mainly rural credit cooperatives, the $A B C$ and formal financial markets in China. The major challenges to China's rural financial system since the middle 1990 s and the attempts by the Chinese government and others to create an efficient rural financial system responsive to the demand from farmers and rural enterprises are reviewed in the chapter.

\section{THE CHALLENGES}

\section{Declines in credit supply}

The outflow of funds from rural areas channelled through formal rural financial institutions and declines in the supply of rural credit have been identified as major obstacles to China's rural development (Zhang 2003). The shortage of rural formal credit has been blamed for the slow pace of rural structural adjustment in developed areas of China (Xinhua News Agency, 27 April 2002). Woo (2003) argued that the slowdown of TVE growth, which has contributed to a slower growth in China since 1996 , has been closely related to the operation of the rural financial system. The shortage in the supply of institutional credit has also been blamed for the problems in the major agricultural areas of China. For example, in a report submitted to the Monetary Policy Committee of the People's Bank of China, Wen (2001) argued that, in poor areas, a growing number of poor households have been trapped in a debt cycle and forced to provide labour to moneylenders to cover interest repayments.

Using official statistics, we found that the actual supply of institutional credit as a proportion of rural deposits in rural China has declined significantly since the mid 
1990s. This is despite continuous increases in year-end loans outstanding in rural financial institutions (Cheng and Xu 2003). In Table 7.1, we attempt to track the actual flows of rural credit funds by considering deposits from rural households to be rural deposits and the ABC's loans to agriculture and TVEs and all rural credit cooperative loans as rural lending. In Table 7.1, rural household deposits include deposits from the rural household sector to all formal financial institutions in China, including rural postal savings. We further assume that it is annual loan disbursements rather than year-end loans outstanding that affect the supply of institutional credit, and, second, that the ADBC loans should not be counted as rural lending because they are not provided to rural households and enterprises.

As a proportion of total household deposits, the institutional lending in rural China has halved in the last decade (Table 7.1). The decline has been consistent over time, and the steeper declines in the ABC's agricultural lending have been offset to some extent by lending from rural credit cooperatives. As a consequence, over 70 per cent of total rural institutional lending has been from rural credit cooperatives, which makes the $A B C$ a relatively insignificant player in financing households and TVEs in rural China. Moreover, the decline in the ratio of rural lending to rural deposits

Table 7.1 Changes in rural deposit savings and loans, 1991-2001 (Billion yuan at current prices)

\begin{tabular}{ccccccc}
\hline & $\begin{array}{c}(1) \\
\text { Total rural } \\
\text { deposits }\end{array}$ & $\begin{array}{c}(2) \\
\text { ABC annual } \\
\text { disbursement }\end{array}$ & $\begin{array}{c}(1) /(2) \\
\text { (per cent) }\end{array}$ & $\begin{array}{c}\text { RCCs annual } \\
\text { disbursement }\end{array}$ & $\begin{array}{c}\text { ABC \& RCC } \\
(4) /(1)\end{array}$ & $\begin{array}{c}\text { disbursement } \\
\text { (pent) }\end{array}$ \\
1991 & 611 & 170.6 & 27.9 & 259.4 & 42.5 & 70.4 \\
1996 & 1848 & 317.2 & 17.2 & 794.3 & 43.0 & 60.1 \\
1997 & 2282 & 344.1 & 15.1 & 879.9 & 38.6 & 53.6 \\
1998 & 2660 & 270.7 & 10.2 & 796.5 & 29.9 & 40.1 \\
1999 & 3011 & 234.6 & 7.8 & 871.8 & 29.0 & 36.7 \\
2000 & 3428 & 179 & 5.2 & 952.4 & 27.8 & 33.0 \\
2001 & 4106 & 201.5 & 4.9 & 1087 & 26.5 & 31.4 \\
\hline
\end{tabular}

Notes: ${ }^{1}$ Total household deposits by all RFIs in China. ${ }^{2}$ Annual loan disbursement by the ABC for Agriculture and TVEs, including the poverty loans. ${ }^{4}$ Annual RCC loan disbursement. $5=(2+4) / 1 * 100$.

Sources: Calculated from Statistical Yearbooks of China's banking and Finance, People's Bank of China, 1992 to 2002. 
would be more drastic if loan refinancing and rescheduling were taken into account. It is also important to note that the aggregate rural lending figures conceal regional variations and flows of funds from poorer to richer areas, a topic deserving further study.

\section{Financial performance and historical burdens}

Declines in the supply of institutional credit in rural China have been caused largely by the deteriorating financial performance of rural financial institutions and the pressure for commercialisation of the Agricultural Bank of China. According to rural credit cooperatives, most losses and non-performing loans have been caused by historical factors and other developments beyond their control. Hence, the cumulative financial losses and non-performing loans of rural credit cooperatives are called historical burdens. $\mathrm{He}(2001)$ reported that about half of all rural credit cooperatives in China have been operating at a financial loss. It was further estimated that the ratio of non-performing loans in the rural credit cooperative system has exceeded 35 per cent ( $\mathrm{Li} 2000$ ). The performance of rural financial institutions in poor and major agricultural areas was usually worse than the national average. Our field investigations show that the performance of many branches of the Agricultural Bank of China's, especially those in poor areas, is not necessarily better than that of the rural credit cooperatives in these areas.

According to a study by the PBOC branch in Tongren Prefecture of Guizhou Province, the cumulative financial losses of rural credit cooperatives in the prefecture had reached 81 million yuan and the ratio of non-performing loans had reached 53.7 per cent by the end of 2000 . In Dejiang County of the prefecture, the ratio of nonperforming loans had reached 87.8 per cent. Cumulative financial losses had reached 20.7 million and were increasing at a rate of 1 million per annum (Tongren PBOC 2001). Our field investigations in China indicate that the rural credit cooperatives in Tongren could be regarded as representative of many rural credit cooperatives in the poor areas of China. We also found that, following the increases in non-performing loans and financial losses, many rural credit cooperatives have negative net worth and are technically bankrupt.

Because the Agricultural Bank of China was a state-owned bank, the Central Government accepted responsibility for its historical burdens and shifted its bad loans to an asset management company. It is unclear, however, who will be responsible for the massive historical burden of the rural credit cooperatives. Owing 
to problems with the definition of, and collection of information on, non-performing loans, no one knows the actual amount of uncollected loans and the true financial losses of rural credit cooperatives in China. It will be difficult for rural financial institutions to increase their rural lending if the so-called historical burdens are not resolved.

\section{Distortions in rural financial markets}

Since the early 1990s, the Chinese government has made progress in relaxing direct state control over interest rates and removing market distortions caused by negative real rates of interest. Real deposits and lending rates rose from 1989 to 1998 and declined slightly thereafter (Table 7.2). Moreover, the difference between the rates for demand deposits and time deposits has narrowed consistently, and the term structure for deposit rates has become less skewed. Real lending rates for rural lending have also turned from negative to positive in the last decade. The major officially subsidised loans are poverty loans and the agricultural on-lending provided by rural credit cooperatives. The rate differential between one-year lending and deposits has increased over time, leaving a higher margin for rural financial institutions. These changes do suggest a process of financial deepening (McKinnon 1973; Shaw 1973), which is thought to have contributed to the increases in savings deposits and resource allocation in rural China.

Table 7.2 Changes in real institutional rates of interest, 1989-2002 (per cent)

\begin{tabular}{lccccccc}
\hline & Feb 89 & Apr 91 & Jul 93 & Jul 95 & Jul 97 & Jun 99 & Feb 02 \\
Deposits & -12.7 & -1.1 & -8.9 & -11.2 & 0.9 & 4.1 & 2.0 \\
Demand & -7.5 & 2.4 & -3.7 & -8.2 & 3.3 & 5.3 & 3.2 \\
6 month & -5.5 & 4.5 & -2.0 & -6.4 & 4.8 & 5.4 & 3.3 \\
12 month & -4.0 & 5.2 & -0.8 & -5.7 & 5.4 & 5.9 & 3.9 \\
3 years & -2.4 & 5.9 & 0.6 & -5.1 & 5.8 & 6.1 & 4.1 \\
5 years & & & & & & & \\
Loans & -5.5 & 5.1 & -3.7 & -4.1 & 6.8 & 8.8 & 6.4 \\
6 months & -5.5 & 5.6 & -2.0 & -2.4 & 7.8 & 9.1 & 6.7 \\
12 months & -5.5 & 4.7 & -2.8 & -3.2 & 6.9 & & \\
Agriculturalprocurement & -12.7 & 0.0 & -9.1 & -10.4 & 2.1 & 6.2 & 4.4 \\
Subsidised poverty loans & 17.8 & 2.9 & 13.2 & 14.8 & 0.8 & -3 & -1.3 \\
Inflation (p) & & & & & & & \\
\hline
\end{tabular}

Notes: Real rates of interest are calculated using the formula: $r=(i-p) /(1+p)$, where $r=$ real interest rates, $i=$ nominal rate of interest, $p=$ annual increase in general retail prices.

Sources: PBOC, 2002. Almanac of China's Finance and Banking, 1990-2002, People's Bank of China, Beijing. 
Nevertheless, distortions in China's rural financial market remain, as institutional rates of interest are still determined administratively, with little regard for the costs and risks of lending. Real rural lending rates (Table 7.2), although raised over time, have been low compared with the market rate of interest, as reflected by rates in the informal financial markets (around 20-25 per cent nominal). Moreover, the rates have been lower in terms of the high costs and high risks for rural lending in China. I project sustainable lending rates for rural financial institutions of 8.8 per cent in coastal areas, 11.5 per cent in major agricultural areas and 16 per cent in poor areas of China, all of which are much higher than official lending rates. Clearly, institutional lending in rural China is generally not profitable under the current structure of institutional interest rates. ${ }^{2}$ in other words, the more rural financial institutions lend, the more losses they will incur. Low lending rates of interest have already contributed to financial losses in rural financial institutions, and these are accumulating over time. Moreover, low lending rates and low interest margins have limited the volume of operational funds available for rural financial institutions, leading in turn to rises in the proportion of non-performing loans and hence declines in the supply of rural funds for lending. On the assumption that rural financial institutions are responsive to interest rate signals, rural financial institutions will reduce their rural lending and shift the funds out of rural areas unless the government regulates their lending and use of funds.

\section{Ownership structure and corporate governance}

Soft budget constraints and implicit deposit insurance give rise to a moral hazard problem for rural financial institutions in China. Xie Ping (2001) argued that rural credit cooperatives are not real credit cooperatives. The ownership of rural credit cooperatives is further complicated by the fact that many have a negative equity. In other economies, where banks have a more clearly defined ownership structure, bankruptcy is a hard constraint for any financial institution. But rural credit cooperatives face soft budget constraints. Chinese regulators have been very cautious about closing rural credit cooperatives and have sometimes bailed individual cooperatives out when they have had a payment problem.

Rural credit cooperatives in China face soft budget constraints for several reasons. First, given state regulation of the rate of interest and barriers to market entry, rural 
credit cooperatives have become predominant in the supply of financial services to farmers following the gradual withdrawal of the Agricultural Bank of China from rural townships. Closure of poorly performing rural credit cooperatives could lead to the complete absence of formal financial services in some rural areas. Second, with the collapse of producers and marketing cooperatives and recent difficulties with agricultural extension services, rural credit cooperatives-as a link between the state and farmers - have become one of the major vehicles for the Central Government to carry out its agricultural support policies. Third, with large amounts of deposits from low income farmers and the absence of explicit deposit insurance from the government or any other body, closure of rural credit cooperatives could cause serious political and social unrest. Therefore, bankruptcy of rural credit cooperatives is socially and politically unpalatable (Xie Ping 2002).

With soft budget constraints and deposit insurance implicitly provided by the state, rural credit cooperatives definitely face a moral hazard problem. Moral hazard has occurred at the following three levels. At the local level, local governments tend to adopt the strategy of levying high taxes and fees on rural credit cooperatives because they are aware that the Central Government will not let rural credit cooperatives go bankrupt. At the cooperative level, management and staff of rural credit cooperatives may not be concerned about performance and profitability and may extend risky loans. At the borrower level, borrowers, especially enterprise borrowers, find it easier to persuade loan officials to soften their loan terms. The possibility of collusion between RCC management and local governments and between the loan officials and their clients for mutual benefit, at the cost of the state, cannot be ruled out.

The same moral hazard problem occurred with the Agricultural Bank of China. The Agricultural Bank of China has been trapped in a cycle of centralisation and decentralisation of lending decisions. Decentralisation, which allows institutions to process and use local information more effectively, gave rise to local government intervention on loan decisions and possible collusion between loan officials and clients. But centralisation makes the loan application process long and complicated, which discourages rural enterprises and households from applying. In addition to the interest rate distortions, the moral hazard problem is an important reason for the continuous decline in the Agricultural Bank of China's lending to rural enterprises and households. ${ }^{3}$ 


\section{Lack of competition in rural financial markets}

Competition in China's rural financial markets is constrained by state regulation on the entry and exit of financial institutions. The Agricultural Bank of China, the Agricultural Development Bank of China and rural credit cooperatives are the only state-sanctioned legal rural financial institutions. Of them, the Agricultural Bank and the Agricultural Development Bank are government-owned financial institutions and rural credit cooperatives, albeit defined as cooperatives, are subject to PBOC regulation and management and have a corporate governance structure similar to those of state-owned financial institutions. Entry by new financial institutions is next to impossible. ${ }^{4}$ Moreover, there is no defined mechanism for individual lossmaking rural credit cooperatives with negative equities to exit the market. ${ }^{5}$ Restrictions on competition and exit are expected to contribute to the moral hazard problems for rural financial institutions in China (Cheng and Xu 2003).

It is difficult for the central authorities to tackle individually any of the challenges discussed above, as many problems are interrelated and the rural financial market is closely related to other markets in China. An immediate issue facing the Central Government is the historical burden of rural credit cooperatives. To mitigate moral hazard, it is necessary for the government to classify and remove these historical burdens. Otherwise, the rural credit cooperatives will pool the newly generated nonperforming loans and financial losses into historical burdens. ${ }^{6}$

Due to problems with reporting, monitoring and auditing it is extremely difficult for the government to distinguish between non-performing loans and financial losses of rural credit cooperatives caused by policy factors, and those caused by mismanagement. Given the scale of the problem the government would have to issue more bonds to write off all the historical burdens of rural credit cooperatives. ${ }^{7}$ Even if the government can write off all the bad loans by issuing more bonds, simply writing off the historical burdens of rural credit cooperatives will exacerbate the already serious moral hazard problem among rural financial institutions in China. In terms of the sustainable rate of interest, when the lending rate of interest is liberalised the rate charged by rural financial institutions will tend to jump higher in the less developed areas of China, precisely the areas where farmers can least afford it. Moreover, interest rate liberalisation alone can hardly improve the performance of rural financial institutions. Changes in corporate governance and the introduction of effective monitoring and supervision are required. 


\section{FINANCE FOR POVERTY ALLEVIATION: EXPERIMENTS IN MICROFINANCE}

Up to the mid to late 1990 s, the reforms of China's rural financial system were characterised by institutional changes, with little change in financial prices and lending methodologies. The fundamental changes to financial prices and lending methodologies were initiated by donors with the introduction of the Grameen Model microfinance in China in the early and mid $1990 \mathrm{~s}^{8}$ As the central and local authorities in China have adopted a non-interventionalist policy towards donor-supported microfinance programs, these programs have been in a unique position to set higher lending rates and test new lending methodologies for rural loans in China. ${ }^{9}$

Microfinance programs conducted experiments in new lending methodologies ahead of both the formal and informal financial institutions in China. The loans provided by rural financial institutions in China prior to the late 1990s were mainly term loans with low interest rates and relatively large loan sizes, and these loans were backed with neither collateral nor guarantees for loans. Other mechanisms for loan repayment, such as dynamic incentives and the targeting of women, were not in place. Loans provided by the microfinance programs in China (modified Grameen replicates) have been characterised by small loan sizes (about 500-3,000 RMB per loan), relatively high interest rates, frequent centre meetings and loan repayments, dynamic incentives and the targeting of women borrowers. Some programs have adopted group guarantees, deducting five per cent of the principal as a group fund deducted at the time of loan disbursement and initiating compulsory savings programs. Compulsory savings and group funds could be regarded as substitutes for collateral substitutes. Some new lending methodologies, such as dynamic incentives, the targeting of women and frequent loan repayment, have proved effective in raising loan repayment rates for small-size loans to rural households. These experiments also show that market mechanisms, such as market rates of interest, direct screening, peer selection and peer monitoring are useful means for delivering and collecting loans for poverty alleviation.

Microfinance programs have also tested higher lending rates for poverty alleviation loans. Most donor-funded programs in China charge an effective rate of interest from 12-18 per cent per annum, which is much higher than the rate charged by rural financial institutions in China (3-8.5 per cent per annum). The experiments with microfinance show that the current lending rates of interest regulated by the People's 
Bank of China are not able to cover the full costs for small scale rural financial institutions that provide small-size loans to the poor. The microfinance experiments in Henan and Hebei provinces of Central China undertaken by Funding the Poor Cooperatives (FPC) indicate that, in order to be viable, microfinance institutions in these areas need to charge an effective nominal lending rate of about 15 per cent. ${ }^{10}$ Moreover, microfinance institutions in China like the Funding the Poor Cooperative have no historical burdens or tax obligations, and the loan repayment rates of the Funding the Poor Cooperative's programs are much higher than those of the average rural credit cooperative in China (Cheng 2003).

A significant but less evident contribution of the microfinance movement is the creation of new forms of institution and a new approach to poverty alleviation, social welfare and financial development in China. The conventional approach in China is that the provision of financial services, poverty reduction and social welfare are the responsibility of governments and their institutions. The development of the microfinance movement in China demonstrates that semi-official institutions and NGOs can be equally effective, and in some cases more effective and innovative, in delivering public benefits.

The experiments in China's microfinance also show a number of constraints for financial development and poverty alleviation in rural China. First, it is difficult for any credit programs and institutions to be operationally and financially viable in the poor and remote mountainous areas of China's southwest and northwest, because they face very high transaction costs and a lack of income generation and investment opportunities in these areas. Second, China's microfinance experiments so far are largely program based rather than institution based, and many are run by temporary project management offices. In other words, the microfinance movement so far has failed to test a new form of institution based on a clearly identified ownership structure and good corporate governance, and committed to providing long-term sustainable financial services to the poor and others in rural China. Finally, there has not been effective external monitoring, supervision and auditing of microfinance programs and institutions, which makes the long-term development of the microfinance movement in China difficult. Good corporate governance and effective external monitoring and supervision are also two major obstacles to institutional development in China's rural financial markets. 


\section{REFORMS TO FORMAL FINANCIAL MARKETS}

Parallel to the development of microfinance a number of reforms to the formal financial markets have been undertaken. The overall objective of these reforms was to separate policy, cooperative and commercial finance in order to commercialise the operation of the Agricultural Bank of China, and hence to improve the operation of rural financial institutions in China. "In 1994, the Agricultural Development Bank of China was created and charged with the responsibility of managing policy loans, which at that time comprised of loans for agricultural procurement, storage and processing and integrated agricultural development and poverty alleviation (ADBC 1994). The comprehensive financial reforms launched in 1996, which separated rural credit cooperatives from the Agricultural Bank of China, advanced the Agricultural Bank of China towards commercialisation. The management of rural credit cooperatives was shifted first to a newly established Inter-ministerial Coordination and Leading Group for Rural Financial Reforms in 1996, which then joined the People's Bank of China in 1997 (Almanac of China's Finance and Banking 1998). After the separation, rural credit cooperatives were supervised and managed by the People's Bank of China, however, after a marked deterioration in loan quality, the Agricultural Bank of China took back the management of subsidised poverty loans (an important part of Chinese agricultural policy) in 1998.

To commercialise its operations the Agricultural Bank of China not only rationed credit supply in rural areas but also transferred its funds from relatively poor to richer areas. From 1995 to 2001 , it reduced its staff by around 13 per cent and its branches and business offices by 34 per cent. Many of the closed branches and business offices were located in rural townships. By reducing its rural lending the Agricultural Bank of China has diversified its portfolios, shifted its lending focus to urban and coastal areas and developed its off balance sheet transactions. According to the President of the Agricultural Bank of China consumer loans have increased substantially since 1997 (Almanac of China's Banking and Finance 2002:30), including mortgage loans, automobile loans and loans for house renovations. The major losers of the Agricultural Bank of China's credit rationing are township and village enterprises and those rural households engaging in off-farm production and investment (Cheng and Xu 2003). 
The Agricultural Bank of China was forced to take over the poverty loans from the Agricultural Development Bank of China in 1998, a setback on the institutional reforms initiated by the Central Government from the early 1990s. Since then, the Agricultural Bank of China has adopted a number of microfinance methods in some areas to reach the poor and raise repayment rates. These methods include providing small size loans for short terms (usually less than a year) and group guarantees. The overall repayment rate on Agricultural Bank of China's poverty loans is still very low, as it has insufficient staff and other resources at the township level to deal with thousands of individual borrowers. With a ceiling of three per cent per annum the Agricultural Bank of China is not allowed to raise the lending rate of poverty loans.

Another major event in rural finance since the mid 1990s is the closing of rural credit foundations. ${ }^{12}$ Since the financial reforms in the mid 1990 s, there have been increasingly frequent reports of a payment crisis with rural credit foundations. In 1999 the State Council ordered a nationwide termination of rural credit foundations. This was accompanied by a thorough auditing of rural credit foundation deposits and loans, which revealed serious problems with uses of the funds by the foundations in some parts of China. According to a study in Chongqing (Chen et al. 1999), of the total loan portfolio of rural credit foundations in the city ( 8.6 billion RMB), nearly 90 per cent should be regarded as non-performing when measured according to the bank standard and RCF rules. The same study indicates that local governments in the city borrowed more than one billion RMB from rural credit foundations and used the funds to invest in rural infrastructure. A high proportion of these loans to local governments were non-performing.

Nationwide, governments dealt with rural credit foundations in the following two ways. First, according to their financial position and loan quality: they merged the better-managed foundations with rural credit cooperatives, and the cooperatives took over all their loans and deposits. Second, they closed the other foundations and made local governments responsible for the repayment of deposits to small farmers. Because local governments have been forced to pay for the deposits of rural credit foundations, the closure of the foundations has had a large impact on local budget and local government debts, and, therefore, on the operation of local governments and government investment in rural infrastructure. Many local governments negotiated with the People's Bank of China and rural credit cooperatives and attempted to shift some of their financial burdens to the rural credit cooperatives. 
Consequently, there has been enormous pressure from some local governments for rural credit cooperatives to take over both the loans and deposits of rural credit foundations.

Since the early 1990 s, the central authorities have also relaxed direct control over interest rates for rural financial institutions. The central piece of the reform allows financial institutions to adjust their lending rates. In 1992, state banks and financial institutions were allowed to float their lending rates around the base rate for working capital loans, with an upper band of 20 per cent and a lower band of 10 per cent. On 1 June 1996, the state removed its control over the rates on the inter-bank money market rates (Dai Xianglong 1997:58). Then in 1998, they increased the interest band for the loans to SMEs from 10 to 20 per cent and the band for RCC lending from 40 to 50 per cent. ${ }^{13}$ In 1999, all the financial institutions and their branches operating at or below the county levels were allowed to float their lending rate by a maximum of 30 per cent, and the band for loans to SMEs was also raised from 20 to 30 per cent. As discussed above, despite the changes, the official lending rate was still far below the sustainable lending rate for rural financial institutions in many areas of China.

These institutional and market changes had a large impact on rural credit cooperatives in China. ${ }^{14}$ First, the gradual withdrawal of the Agricultural Bank of China from rural areas and the closure of rural credit foundations made rural credit cooperatives the dominant supplier-and in many agricultural areas the sole supplier - of institutional credit in rural China. Second, the quality of loans in the rural credit cooperative system deteriorated further as some rural credit cooperatives were persuaded or forced by local governments to take over RCF loans and obligations. Rural credit cooperatives were also under pressure from the Ministry of Agriculture and local governments to provide more loans to increase rural incomes and output. For example, the Ministry of Agriculture (2002) proposed to raise the amount of agricultural lending by setting the minimum amount of agricultural loans to be disbursed by financial institutions and increasing the variety and quantity of policy loans for agriculture. It also proposed to extend the loan duration and reduce the loan rate (so as to reduce the costs to borrowers) for rural lending in China.

Many rural credit cooperatives, especially those in poor and major agricultural areas of China, are struggling to survive. It is not possible for these rural credit cooperatives to increase their loans for agriculture. As a result, the People's Bank of China in 1998 had to introduce an agricultural on-lending program by providing 
cheap loans to rural credit cooperatives (at 2 per cent per annum). The value of these on-lending funds grew from 15 billion in 1999 to 20 billion RMB in 2001. The People's Bank of China stipulates that the on-lending fund can only be used for micro-loans to rural households for income generation activities. To reduce their costs, the rural credit cooperative system had undergone similar changes to the Agricultural Bank of China. From the mid 1990s to 2000, the number of township level rural credit cooperatives in China fell by about a quarter (He 2001).

\section{REFORMS OF RURAL CREDIT COOPERATIVES_PILOTS}

In an effort to tackle the deeply rooted problems in China's rural credit cooperatives, the Central Government and the People's Bank of China have launched a number of experiments for rural credit cooperative reforms since 2000. These experiments include the Pilot Rural Credit Cooperative reforms in Jiangsu Province, partial interest liberalisation for rural credit cooperatives in a number of provinces and promotion of microfinance within the rural credit cooperative system. ${ }^{15}$

\section{Pilot reforms in Jiangsu}

The pilot reforms in Jiangsu have three major objectives. First, to improve the corporate governance and management of rural credit cooperatives. Second, to eliminate the historical burdens and third, to make rural credit cooperative operations financially viable. The pilot reforms in Jiangsu Province, a relatively developed province in coastal China, include

- merging township level rural credit cooperatives into county rural credit cooperative unions and making rural credit cooperative unions the legal person and profit centre so as to expand the operational scale for rural credit cooperatives and reduce the tax burden

- in coastal areas of the province, turning the rural credit cooperative unions with good management and financial performance into rural commercial banks (RCBs)

- establishing the Provincial Rural Credit Cooperative Federation ${ }^{16}$

- providing interest free on-lending to the rural credit cooperatives in Jiangsu for five years to help reduce historical burdens.

By merging individual rural credit cooperatives into the county Rural Credit Cooperative Union and establishing the provincial Rural Credit Cooperative Federation, the PBC would be able to transfer its management function to the Rural Credit Cooperative Union and the provincial federation. This would allow the PBC to 
concentrate on monitoring and supervising rural credit cooperatives. By merging into rural credit cooperative unions, rural credit cooperatives would be able to allocate their funds in a county and achieve economies of scale in their operations. The experiment on the cooperative-to-stock conversion in the three counties (privatisation) was aimed at improving corporate governance and eliminating the moral hazards faced by rural credit cooperatives in rich areas of China.

Pilot reforms were initiated in Jiangsu in 2000. By early 2003, all township rural credit cooperatives had been merged into rural credit cooperative unions and the provincial Rural Credit Cooperative Federation had been established and had begun to function. The rural credit cooperative unions of Chagshu, Jiangyin and Zhangjiagang counties have been converted into rural commercial banks. ${ }^{17}$ It was reported that, following the reforms, the deposits and loan portfolio in the province have grown and the proportion of non-performing loans was falling. The full impact of the pilot reform on rural credit cooperative efficiency, the operation of rural financial markets in Jiangsu and the suitability of the pilot for rural credit cooperatives in other parts of the country remain to be studied.

\section{Partial interest rate liberalisation}

At the beginning of 2002, the People's Bank of China selected eight counties in rural China for a pilot on partial interest rate liberalisation. In these pilot areas, rural credit cooperatives are allowed to float their deposit rate by up to 50 per cent around the official base rate and to float their lending rate by up to 100 per cent around the base lending rate. No financial institution in China is allowed to float the base deposit rate. Rural credit cooperatives are allowed to float their lending rate by 50 per cent only around the base lending rate. The major purpose of the experiment is for rural credit cooperatives to be able to retain rural funds in local areas for agricultural supports and to help rural credit cooperatives achieve financial viability. Following the reform, rural credit cooperatives should be able to organise more funds from local areas, expand their operations and push down the high rates of interest charged by moneylenders in these markets. This should reduce the cost of lending for farmers. By April 2003, the pilot reforms had been replicated in 92 counties across China (Cheng and Xu 2003).

However, this reform has its own problems. The increase in deposit rate for rural credit cooperatives has shifted savings deposits from other financial institutions to rural credit cooperatives. But rural credit cooperatives are restricted to lending to 
rural households and enterprises in their local townships. Some rural credit cooperatives, therefore, have difficulty lending out the high-cost funds profitably, as the increases in the lending rates of rural credit cooperatives are determined more by the competition on the local markets than the costs and risks of rural credit cooperative operations. In the townships where there is little competition from other formal financial institutions and informal sources of finance, rural credit cooperatives tend to raise their lending rate to the maximum 100 per cent over the base rate. Rural credit cooperatives have difficulties raising their rate to the maximum where they face extensive competition. Further research is needed to study the impacts of partial interest rate liberalisation on rural credit cooperatives, other financial institutions and the local economy.

\section{Microfinance}

With financial support from the Canadian International Development Agency, the People's Bank of China started its own microfinance experiment with rural credit cooperatives in Luoping County of Hebei Province. It also issued an official document to promote micro-credit-particularly group guarantees and repayment in installments-and the connection between savings and loans (People's Bank of China Document 245 1999). Microfinance, as defined by the People's Bank of China, also includes the credit rating to individual households.

\section{CONCLUSIONS}

Since the mid 1990s, there has been a decline in the supply of institutional credit in rural China, caused by deterioration in loan quality, distortion in financial prices, a lack of competition in rural financial markets and problems associated with the ownership structure and corporate governance of rural financial institutions. Declines in the supply of institutional credit have had a negative impact on Chiria's rural economic development, particularly on the development of TVEs and rural off farmproduction, which used to be supported by the Agricultural Bank of China.

The microfinance movement initiated and funded by donors has tested lending methodologies and sustainable lending interest for microfinance programs in China. The main lessons are that

- the poor in many areas of China are bankable

- the current lending rates as regulated by the People's Bank of China are far below the sustainable rate for the operation of rural financial institutions in many areas of China 
- the mechanisms of microfinance, such as group guarantee, dynamic incentives and the targeting of women, help loan repayment in rural China. However, the experiment in microfinance has not been tested for long enough to be able to tell whether the new institutional form for delivering sustainable financial services to the poor will be successful in the long term. The movement has not been able to develop an external monitoring and auditing system to ensure the healthy development of the movement in the long term.

Government-initiated rural financial reforms have focused on institutional changes: the separation of the Agricultural Development Bank of China and rural credit cooperatives from the Agricultural Bank of China, commercialisation of the latter's operations, relaxation of direct state control over lending rates and provision of agricultural support on-lending to rural credit cooperatives. The recent pilots for the reform of rural credit cooperatives aimed to resolve the problems associated with moral hazard for rural credit cooperatives, low lending rates and low margins for the operation of rural financial institutions, the separation of management from monitoring and supervision of rural credit cooperatives and historical burdens for rural credit cooperatives. It remains to be seen what effect the reforms in Jiangsu and other parts of the country will have, or indeed whether these reforms will be replicable elsewhere.

\section{NOTES}

1 Rural credit foundations emerged in mid 1985, with strong support from local governments. For more information about rural credit foundations, see Cheng, Findlay and Watson (1997).

2 Park (1998:25) also found that lending is not profitable in rural China based on his field investigations in China.

3 For more detailed analysis of problems with centralisation and decentralisation of the $A B C$ and rural credit cooperatives, see Shen Minggao (2002).

4 Rural credit foundations emerged in the mid 1980s with strong support-and billions of yuan in deposits-from the Ministry of Agriculture and local governments. They were not financial institutions and, by law, not allowed to raise deposits from the public.

5 Since the rural economic reforms, there have been no bankruptcy cases for rural financial institutions, including any of the township level rural credit cooperatives that are legal persons and profit centres. The only exception is the rural credit cooperatives and urban credit cooperatives in Enping City of Guangdong Province (see Cheng and Xu 2003).

6 The Grain Bureau system did the same (see Cheng 1997). 
7 Assuming 30 per cent of the current rural credit cooperative loans cannot be collected (a conservative estimate), the overall amount of loans that need to be written off for the rural credit cooperative system will be around RMB 360 billion (US $\$ 45$ billion).

8 For details on China's microfinance movement see Park and Ren (2001) and Cheng (1998; 2003).

9 Donor-funded microfinance programs are not allowed to organise voluntary savings from the public.

10 See CGAP 2000. Operational sustainability here refers to the incomes of microfinance institutions covering the operational costs, loan loss provisions and real fund costs (usually subsidised, not opportunity cost of capital).

11 For the problems with the mixed policy and commercial operation of the Agricultural Bank of China see Cheng 1997.

12 For the rural credit foundations and their collapse in the late 1990s see Cheng, Findlay and Watson 2003.

13 See PBOC Document 446, 1998.

${ }^{14}$ For detail on rural credit cooperatives and reforms see Watson 2003.

${ }^{15}$ For details on the Jiangsu pilot see Chu and Cheng 2003.

t6 In addition to Jiangsu, provincial rural credit cooperative federations were established in Beijing, Shanghai, Tianjin, Chonging and Ningxia on a pilot basis to separate bank monitoring and supervision from management.

${ }^{17}$ For rural commercial banks see Cheng and Chu 2003.

\section{REFERENCES}

Agricultural Development Bank of China, 1994. Zhongguo Nongye Fazhan Yinhang Jianjie [Annual Report], Agricultural Development Bank of China, Beijing.

Chen Jianbo, Feng Xiaoling and Yan Yuming, 1999. 'Guanyu Chongqingshi nongcun hezuo jijinhui qingli de diaocha [On the closure of RCFs in Chongqing City]', in Ma Hong and Wang Mengkui (eds), Zhongguo Fazhan Yanjiu [China Development Research], Zhongguo Fazhan Chubanshe, Beijing:447-52.

Cheng Enjiang, 1997. 'Market reforms and provision of credit for grain purchases in China', The China Quarterly, 151(September):633-53.

- 1998. 'Micro-finance', China Review, Spring:9-19.

- Findlay, C. and Watson, A., 2003. 'Institutional innovation without regulation: the collapse of Rural Credit Foundations and lessons for further financial reforms', in C. Findlay, A. Watson, Cheng Enjiang and Zhu Gang (eds), Rural Financial Markets in China, Asia Pacific Press, Canberra:89-104. 
_- 2003. 'Microfinance in Rural China', in C. Findlay, A. Watson, Cheng Enjiang and Zhu Gang (eds), Rural Financial Markets in China, Asia Pacific Press, Canberra:120-33.

- and Xu Zhong, 2003. Rates of Interest, Credit Supply and China's Rural Development, Working Paper, Centre for Strategic Economic Studies, Victoria University, Melbourne.

- and Chu Baojin, 2003. The Pilot Reforms in Jiangsu, an Introduction, Paper presented at the Workshop on China's Rural Finance, People's Bank of China, Beijing, 16-18 August 2003.

Chu Baojin and Cheng Enjiang, 2003. Co-operative to Stock Conversions: the case of three rural commercial banks in Southern Jiangsu, China, Paper presented at the Workshop on China's Rural Finance, People's Bank of China, Beijing 16-18 August 2003.

Consultative Group to Assist the Poorest (CGAP), 2000. Annual Report, Consultative Group to Assist the Poorest, World Bank, Washington, DC.

Dai Xianglong, 1997. Lingdao Ganbu Jinrong Chubanshe Zhishi Duben [Financial Knowledge for Leading Cadres], Zhongguo Jinrong Chubanshe, Beijing.

Findlay, C., Watson, A., Cheng Enjiang and Zhu Gang (eds), 2003. Rural Financial Markets in China, Asia Pacific Press, Canberra.

He Guangwen, 2001. 'Zhongguo nongcun jinrong gongqiu tezheng ji junheng gongqiu de lujing xuanze [The characteristics of supply and demand for rural finance in China and the choices of ways to balance them]', Zhongguo Nongcun Jingji [Chinese Rural Economy], 10:40-5.

Li Jing, 2000. 'Give more credit service to countryside - A survey in Tunwa village in Shanxi Province', China Rural Survey, 3.

McKinnon, R.I., 1973. Money and Capital in Economic Development, The Brookings Institution, Washington, DC.

Ministry of Agriculture, 2002. A report on rural financial services, Department of Industrial Policy, Law and Policy, Ministry of Agriculture (unpublished).

Park, A., 1998. Rural financial market development in China: a report to the World Bank, Working Paper, Department of Economics, University of Michigan, Ann Arbor (unpublished).

Park A., and Ren, C., 2001. 'Microfinance with Chinese Characteristics', World Development, 29(1):39-62.

Shaw, E.S., 1973. Financial Deepening in Economic Development, Oxford University Press, Oxford. 
Shen Minggao, 2002. Decentralization in financial institutions: theory and evidence from China, PhD Thesis, Stanford University, Stanford (unpublished).

Tongren PBOC (2001), 'The Development Path of RCCs in less developed areas', Financial Reference, September 2001.

Watson, A., 2003. Financing Farmers: the reform of the rural credit cooperative and the provision of financial services to farmers (unpublished).

Wen Tie-jun, 2001. The Increasing Rural Usuries: the current situation, problems and policy suggestions, Research Report, Monetary Policy Committee, People's Bank of China, Beijing.

Woo Wing Thye, 2003. China's Rural Enterprises in Crisis: the role of inadequate financial intermediation, Paper presented at the Financial Sector Reform in China conference, Kennedy School of Government, Harvard University, Harvard, 1113 September 2001.

Xie Ping, 2001. 'Zhongguo nongcun xinyong hezuoshe tizhi gaige de zhenglun [Debates on the structural reform of China's Rural Credit Cooperatives]', Jinrong Yanjiu [Journal of Financial Research], 1:1-13.

Xie Ping, 2002. Reforms of China's Rural Credit Cooperatives and Policy Options, Paper presented to the World Bank Workshop on China's Rural Finance, The People's Bank of China, Beijing, 2003.

Zhang Xiaoshan, 2003. 'Deepening Rural Reforms and Promoting Rural Economic Development', China's Rural Economy, 2003, $1^{\text {st }}$ Issue. 


\section{8 \\ Entry into the WTO: commitments and implementation}

\section{Geoff Raby}

Accession to the WTO is a major undertaking for any country. As with all treaties, countries must adjust domestic laws and regulations to bring themselves into conformity with their international obligations. In most cases, this is a difficult exercise involving complex political choices. As in the general case of trade liberalisation, over time all will benefit from the welfare gains from WTO membership, but in the short to medium term, income redistribution between groups in society is likely to take place. In other words, during the adjustment period, there will be winners and losers.

Managing the political economy of this process is difficult enough at the best of times. With the inevitably protracted negotiating process involved in WTO accession, this is all the more difficult to manage. Interest groups have plenty of lead time to work out what the implications of the proposed new obligations will mean for them and time to muster political support to head off unfavourable decisions.

Add to this the unique and legally binding nature of the WTO agreements, and the fact that some 140 or so countries need to reach mutually satisfactory results with the aspiring member, and it thus becomes a marvel of modern multilateral diplomacy that these days anyone can manage to join the WTO at all. In a country of China's domestic political complexity, with an economy still somewhere between plan and market, and with an international relations agenda that stresses China's independence from outside influence, China's accession to the WTO at the end of 2001 is a remarkable achievement for the international system. 
In trying to understand the commitments that China has entered into and what implementation may mean - though it is far too early to judge this with any certaintyit is necessary to know something of the negotiating history that led to the package of undertakings on which China's accession is based. The ebb and flow of the negotiations over so many years shaped the final balance of compromises made both by China and existing WTO members.

\section{A SKETCH OF THE NEGOTIATING HISTORY}

The full history of the negotiations is yet to be written, but it would be an endeavour well worth pursuing. It is a tale of the evolution of two systems and how their respective developments intersected at various points until they eventually meshed at the time of China's accession.

China initially advised its intention to 'resume' its status as a 'Contracting Party' of the GATT in 1986. China had been one of the 23 original parties to the GATT in 1948 , but after the revolution the government in Taiwan withdrew China's membership. As Beijing had never recognised this act by Taipei, much of the earliest period of China's efforts to join the GATT was largely a political discussion about whether China was 'resuming' its membership or seeking to 'accede'. This was largely an argument between Beijing and Washington. Although, at one stage in the early years, Japan began to insist that if China intended to 'resume' its membership rather than accede anew, then Beijing should be required to pay all past membership fees owed since 1947.

Over the subsequent 16 years of negotiations there may well have been times when officials in Beijing had wished they had been allowed simply to pay their past subscriptions and get on with their membership. In reality, that would have been neither a sufficient nor a desirable basis on which to decide on membership. This anecdote, however, does serve to underscore the confusion that often surrounded China's quest to enter the GATT and later the WTO. This confusion applied both to China's own approach as well as to the existing members trying to come to grips with an accession of China's size, especially in view of the fact that reform of the economic system was in its infancy and political commitment to the process was so uncertain.

In China's accession negotiations three periods stand out. First is the period of ambivalence, from 1986 until the Tian An Men Square events. Second is the period of estrangement following Tian An Men Square and lasting until 1995, when China applied 
to join the WTO. Third, the period of gradual mutual accommodation between China and existing WTO members, eventually leading to accession at the end of 2001.

Characteristic of the period of ambivalence is the debate discussed above over whether China was resuming membership or acceding. Such political concerns are really irrelevant for accession, which involves negotiating a contractual basis for membership. The fact that these political discussions were so dominant at the time reflected the political uncertainty within China over GATT membership at such an early stage in its economic reforms. It also reflected the uncertainty among contracting parties as to China's intentions. It is likely that China's initial interest in joining the GATT was driven mainly by foreign policy concerns to normalise China's international relations. The same imperatives led China into the World Bank, IMF and other international bodies. To be a great power, China had to take its place in the major international institutions, including, at the time, the GATT.

Nevertheless, during this period, useful work was done both in starting the long process of educating Chinese politicians and officials about the GATT system and in developing skills among China's negotiators. As early as 1986, under a bilateral aid program, Australia had placed an experienced trade lawyer in China's Ministry of Foreign Economic Relations and Trade MOFERT (forerunner of the Ministry of Foreign Trade and Economic Cooperation) to provide technical training and help start the process of drafting China's first information submission on which subsequent negotiations were based. Such aid continued throughout the process.

By the time of the Tian An Men Square massacre, little substantive progress had been made on China's accession to the GATT, despite continued substantial advance in China's domestic economic reforms and opening to the international economic system. The political turmoil of Tian An Men Square did not stem the domestic reforms or the ever deepening engagement with the international economy through increasing trade and investment flows. Meanwhile, the Uruguay Round of trade negotiations had been launched some months after China's GATT bid but was badly stalled by mid 1989. Ambivalence had turned to neglect on all sides.

Prior to June 1989, China's accession was becoming dormant. With the events of June 1989, and the subsequent political reaction in China, political attitudes hardened towards China among many in the West. China's accession now attracted highly charged political interest both within China and from many outside. On one hand, accession became a test of the international legitimacy of the post-Tian An Men regime and, on the other, part of the international reaction to events in China. With 
the rapid growth of China's exports during the early 1990s, particularly to highincome markets, the issues of moral concern and trade protection became increasingly entwined.

During this period of estrangement, China approached the negotiations largely as a test of its international weight and as a measure of its emergence as a major world power. Whereas negotiations for GATTMTO membership required agreement to be reached, at least in principle, with all members individually, China seemed to approach the negotiations as a test of will mainly between it and Washington and to a lesser extent Brussels. The smaller players, including Australia, were essentially sidelined during this time. China's negotiating strategy was to cut a deal with the United States and the European Union and then expect all other members to sign up to it. While there will always be a substantial element in any GATT/WTO negotiation of the majors doing a deal and then presenting it to the rest, the views of other members do have to be taken into account. At this time, China politely met with the smaller players, bilaterally and as part of the regular visits to Geneva for Working Party meetings, but it was not engaging seriously with them.

While China played superpower politics with its accession, the goal posts shifted. Not, as was often claimed, because the United States or other major negotiating partners had changed their positions unilaterally, although there was inevitably an element of this, but because the system China was seeking to join had itself changed fundamentally. With the conclusion of the Uruguay Round, the GATT was replaced by the WTO in 1995. From early in the 1990s it was increasingly evident that acceding countries would have to take on a range of obligations in new and challenging areas that had not existed under the GATT. The negotiations for the Uruguay Round were completed in December 1993 and from that time on acceding to the WTO system would require much more from China than under the old GATT.

With the formation of the WTO, whole new areas had to be negotiated covering services, intellectual property, agriculture, sanitary and phytosanitary measures and trade-related investment measures. At the same time, the negotiations had produced higher levels of commitments for liberalisation on a much wider range of products than ever before. A further significant complicating factor had also now entered the negotiations over China's (and everyone else's) accession and that was the new Dispute Settlement Body. This had far more power to enforce obligations and authorise retaliatory measures than under the old GATT. Henceforth, all negotiations took on a much more cautious, legalistic character for all parties. 
China made one last bid for membership on political grounds. It sought to rally international support and sympathy for its becoming a founding member of the WTO in 1995. It garnered a great deal of political support and the pressure on members to cut a quick and dirty deal was immense. China's offer did not meet the commercial interests of WTO members and, as with other deadlines before, China's accession was missed and the world was still the same the next morning.

After this, China's approach to negotiating its accession shifted in steps towards serious engagement, not only with the majors but, importantly, with the multitude of smaller members as well. China set about accommodating itself to the WTO, and other members to China's eventual accession on mutually acceptable terms. By this time, China was also well versed in the functioning of the WTO and had assembled an impressive team of negotiators. The negotiations were still difficult and sometimes highly fraught up until the end. Eventually, incremental progress resulted in a package of commitments as the legal basis of China's accession to the WTO.

\section{COMMITMENTS}

Unlike negotiations during a multilateral round, such as the current Doha Round, accession negotiations are non-reciprocal. An aspiring entrant is required to adjust its levels of protection to match those that generally apply for existing members at similar levels of development. The reasoning is that existing members have already 'paid' each other for the prevailing liberalisation extended to each other and new members are required to do the same.

The emphasis on reciprocity in the GATTMTO system is a major factor contributing to its stability and success but stands in sharp contrast to the economist's approach to liberalisation. Economists argue that countries liberalise because it is good for them to do so. With its voluntarism, APEC's approach to liberalisation is rather more like that of the economist than the trade negotiator.

WTO accession negotiations fall into two broad parts. One involves market access negotiations. These are essentially bilateral negotiations with individual members, or groups of members with a specific shared market access interest. The other part deals essentially with the domestic regulatory adjustments that must be made by the acceding member to bring its trading and related practices into conformity with WTO rules, including on subsidies.

Market access is the classic trade negotiation. It deals essentially with barriers at the border such as tariffs and tariff-rate quotas (TRQs) and non-tariff barriers. Since 
the creation of the WTO, it also includes negotiations on services. These involve domestic regulatory reforms to increase access to the domestic market for foreign services suppliers. All members of the WTO share in the results on the basis of the most-favoured nation principle; that is, one member is not allowed to discriminate against other members in terms of access to its market.

\section{MARKET ACCESS}

While negotiations are conducted on an individual tariff line basis, these may be summarised as follows.

In agriculture, China has agreed to average tariff cuts on most products from 23 per cent to 15 per cent, to be phased in by 2004 , albeit with considerable variation around the mean. All tariffs are bound. These cuts comprise a TRQ system for imports of bulk commodities, which is of particular value for products of interest to Australia, such as wool, sugar, wheat, rice, cotton and vegetable oils. The TRQ will provide guaranteed levels of increasing access at relatively low tariff levels.

China has also agreed to an administrative system for its TRQs which should help preserve their value to potential exporters to China. This includes increasing the share of TRQs available to private traders.

An additional commitment of major future value for agricultural exporters was agreement not to use export subsidies. Negotiations for this commitment were particularly tough. Whether or not China would at some stage have been in a position to subsidise agricultural exports is questionable, but the commitment is of important strategic and political, as well as commercial, advantage as efficient agriculture exporters seek to end all export subsidies. Similarly, China has agreed to limit tradedistorting domestic support to less than that normally available to developing countries.

For industrial products, average tariffs with few exceptions will be cut from 17 per cent to 8.9 per cent by 2005. All tariffs will be bound. Of course, there is considerable variation around this average as well, with industrial tariffs ranging from 0 per cent to 47 per cent. The remaining few quotas on industrial products will be eliminated by 2005. China has also undertaken to eliminate all export subsidies for industrial products, which was a long-standing requirement under the GATT Subsidies Code, strengthened in the Uruguay Round.

Services involved some of the most difficult negotiations of all, and this sector was the last to be settled. Much of the negotiation concentrated on four major areas: telecoms, banking and insurance, professional services, and distribution. 
Telecoms negotiations were particularly sensitive in view of the government's perception of the critical political function played by its existing regulatory regime in this area. The commitments involve a gradual expansion of access up to 2005. In the first phase, foreign suppliers will be permitted to establish joint-venture enterprises without quantitative restrictions in several cities but with foreign equity restricted to 25 per cent. Over the next three years, the areas open to foreign investment will gradually be expanded and equity limits raised to a maximum of 49 per cent. By 2005 all geographic restrictions will be removed.

On accession, foreign banks are to be permitted to provide foreign currency services without restrictions on clients. By 2004, foreign banks will be allowed to provide local currency services to Chinese enterprises. Within five years of accession, foreign financial institutions can extend this to all Chinese clients. Geographic restrictions will be phased out.

Foreign non-life insurers will be permitted to establish joint ventures with 51 per cent foreign ownership and within two years following accession wholly foreignowned subsidiaries will be allowed. In the case of life insurers, on accession 50 per cent joint-ventures will be permitted. Many other classes of insurers will be allowed to increase foreign equity from 50 per cent to 100 per cent over the next five years. Similarly, geographic restrictions will be phased out.

In the distribution sector, China will liberalise wholesale and retailing services for most products, including imported products, throughout China within three years.

Outside these sectors, geographic and numerical restrictions on foreign accountancy, legal and architecture service providers will be phased out. National treatment for foreign accountants will apply to those who have passed their Chinese CPA examinations. Foreign architect firms will be able to have majority ownership in joint ventures.

\section{SYSTEMIC COMMITMENTS}

While China's market access commitments are significant in every respect and will substantially increase China's integration into international markets, the commitments that touch on the fundamental structure of China's half-way house economic system promise to be the most profound aspect of its WTO accession. Advocates of economic reform in China have long argued for GATT/WTO membership as the surest way to lock in the reform process and to push it further into areas of deep political resistance. 
Within three years of entry, all enterprises will have the right to import and export any goods and trade them throughout China with limited exceptions.

China will retain state trading for a small range of products, including grains, cotton and sugar, but state trading enterprises will be required to act solely in accord with commercial considerations. For some products, private traders will be able to conduct an increasing share of imports.

China will progressively eliminate designated trading restrictions for wool and steel over three years.

Foreign exchange and trade balancing requirements, local content and export performance requirements will no longer apply to foreign or joint venture firms.

China will eliminate dual pricing practices as well as differences in treatment accorded to goods produced for sale in China in comparison with those produced for export. Price controls will not be used to provide protection.

China will reform its standards, technical barriers, conformity assessment procedures, and sanitary and phytosanitary regimes to conform with WTO requirements.

China will enhance protection of intellectual property rights.

\section{THE ADDITIONAL CONDITIONS}

China's size in terms of share of world markets, especially in some products like textiles, and the structure of its economic system led to a number of additional and unique conditions being attached to China's accession. These conditions, because they were special, were politically difficult for China to accept. They had their origins deep in the negotiating history of China's accession, particularly the initial ambivalence of both China and members to its accession and the subsequent period of estrangement.

A special Transitional Product-Specific Safeguard Mechanism will be available to WTO members for 12 years where imports from China cause or threaten disruption in the domestic market. A Textiles Safeguard will be available to WTO members to avoid market disruption until the end of 2008. WTO members will be able to continue to use non-market economy methodology to determine price comparability in antidumping cases.

China will increase transparency through publication of laws and regulations, establish impartial independent processes for review of administrative decisions, and uniformly administer the trade regime across China. 
China will submit to an annual review by the WTO of its implementation for a period of eight years, with a final review in the tenth year.

\section{Implementation}

The accession package that China now has to implement represents the result of hard fought compromises. The final package is also based on strong commitment to the continuation of fundamental reform of the Chinese economy. Indeed, accession may not have been possible until China's reforms and economic development had reached their current stage and sufficient political will had coalesced around their extension.

China has begun to take steps towards implementing its commitments and is preparing the way politically. China's accession to the WTO has been given almost as much national publicity and fanfare as its securing the right to host the 2008 Olympic Games. A visitor to Beijing after late 2001 would have been struck by the billboards hailing China's WTO accession. It may be that a larger share of the Chinese population has heard of the WTO than would be the case in Australia. The political seriousness of Beijing's approach to membership at this stage is very encouraging.

As with the negotiations, so it will be with implementation. Pressures are likely to arise domestically to trim and hedge on commitments. China at times is likely to disappoint other members in its implementation. At times this may be justified, at others not. Nothing in this would be unique to China's implementation of its commitments following accession. Other countries often struggle with their implementation following accession. China's sheer weight in a number of key sectors in international trade will, however, be likely to draw greater attention from trading partners than may occur for smaller members. The complexity of China's commitments, especially those involving systemic areas of reform, is also likely to lead to unrealistic expectations at times. This could increase dispute settlement actions and, unless restraint is shown, will place the still evolving Dispute Settlement Body under greater strain. Ultimately, China's continuing adherence to its economic reform policies will be the most sustainable guarantee of satisfactory implementation of its WTO commitments.

China's implementation will be monitored closely by other members. The realisation of the expected benefits for existing members from China's accession will depend on how completely China meets its commitments. It will therefore be in members' interests to work closely with China on implementation, especially by providing technical support to help it deliver on its commitments. 


\section{SOME CONCLUDING REFLECTIONS}

China's accession to the WTO has been largely a result of its two-decade long persistence with reform of its economic system and the resulting growth in its level of development. As a consequence of accession to the WTO, the reform policies are now entrenched in binding, legally enforceable, international treaties. WTO accession will therefore help to sustain further reform. This outcome has been possible because China's accession was a high quality one as set down in its package of commitments. A quick and dirty political fix, if one had ever really been possible, could have harmed China's reform and would certainly have harmed the WTO. Nonetheless, over time, China's membership will also have profound implications for the character and functioning of the WTO itself. The evolving symbiotic relationship between China and the GATT/WTO system which began in 1986 has now entered a new and important phase. 


\title{
9
}

\section{WTO commitment: further marketisation and trade liberalisation}

\author{
Jiadong Tong
}

Since becoming a member of the World Trade Organization (WTO) in December 2001, China has been carrying out the commitments included in the 'Protocol on the Accession of the People's Republic of China'. This has required major steps on unification and transparency of its trade system, and expanding market access. China's accession to the WTO has meant that rapid government reform has simplified rationalisation of government functions, liberalised trade and increased marketisation. Market forces have been increasingly important in resource allocation. Rapid development of the private economy is giving a new impetus to economic growth, but some difficulties concerning the modification of laws and regulations, and some tensions concerning other aspects of marketisation, remain.

\section{MARKET REFORM AND TRADE LIBERALISATION}

China has further advanced its marketisation and trade liberalisation according to the Protocol on the Accession since it entered the WTO. Two elements contained in the Protocol are liberalisation of foreign trade and continued marketisation. Progress has been made in both areas, showing the sincerity of China's commitment.

On trade liberalisation, China produced many legal documents concerning unification and transparency of trade systems. This represents a legal guarantee of the unification and execution of its trade system. Over 30 departments affiliated 
with the State Department revised related economic laws and regulations concerning foreign affairs. By 2002, China had nullified 830 laws and regulations and revised 325. At the same time, central government required local government to reconsider all of its existing regulations. Local government sorted out over 190,000 laws and regulations. In order to meet the requirements of the WTO, China drafted a series of laws and regulations consistent with WTO rules, such as the new 'antidumping ordinance', 'anti-subsidy ordinance', 'safeguard measure ordinance' and so on. The sorting out and revision of these legal documents provides a legal guarantee for the unification of China's foreign trade management.

Before 1978, China was a planned economy. Foreign trade policy and management was only a part of the government's economic planning management. The government's foreign trade management had to submit to economic planning needs. There was no effective foreign trade law that regulated trading activities. Foreign trade management, like other government functions, was subject to administrative command. China's accession to the WTO requires China to change the way in which government arranges and manages foreign trade, so that a uniform standard based on the law for foreign trade management can be established.

After 1978 , China gradually recognised that the only way to expedite economic growth was by opening to the outside world and making full use of its economic resources and markets. China also established four coastal areas as special economic zones. Central government granted corresponding rights and power to these regions, and implemented favourable policies concerning the introduction of foreign capital. As a result, variations in trade policy were created among different regions.

Since accession to the WTO, special zones, such as Shenzhen, Zhuhai, Xiamen and Hainan provinces, lost their special privileges regarding foreign trade policy. They must carry out the same uniform foreign trade policy as other regions, and can no longer adopt more favourable policies to attract foreign capital.

The second requirement of trade liberalisation is to enlarge market entry for foreign products. In the protocol for China's accession to WTO, China consented to eliminate trade barriers gradually and to make it convenient to import foreign goods. China affirmed a schedule of tariff and non-tarriff measures. Part of these tariff concessions was the reduction of custom duties for over 5,300 kinds of goods in 2002. As a result, China's average import tariff level decreased from 15.8 per cent in 2001 to 12.1 per cent in 2002 . In 2003, China will have an average import tariff level of 11.5 
per cent. The downward trend will continue. The average tariff levels of industrial products and farm produce will be cut 7.2 per cent and 9.6 per cent respectively, and the import tariff of over 110 kinds of goods will drop to zero in 2003. Tariff concessions for some goods were more dramatic. For example, tariffs for cars were cut by nearly 100 per cent on the eve of China's accession to the WTO.

As part its commitments to the WTO, China also reduced non-tariff barriers. During 2001-2, China's annual import permits and quotas for over 800 kinds of goods were reduced or abolished. The list included open-tender management of eight kinds of important goods such as cereal, wool, cotton, chemical fertilisers, and so on, which, under the planned economy, were classed as primary products critical to the national economy and the people's livelihood. The government also limited the scope of state trading or government monopoly on specified products.

To facilitate FDI, the government implemented the Interim Provisions on Guiding Foreign Investment Direction in 2002. At the same time, the new Catalogue for the Guidance of Foreign Investment Industries divided foreign investment projects into four groups: the encouraged, the allowed, the restricted and the prohibited. The amount of encouraged foreign investment projects increased from 186 to 262, and the amount of the restricted decreased from 112 to 75 in 2002. Commerce, banking and insurance, as well as foreign trade, tourism, telecommunications, transport, accounting, auditing and other industries were all opened up further. China will open these industries completely after some years of transition.

China has gradually opened trade rights and distribution rights to the outside world. Sales of 22 foreign-owned retailing enterprises in 2002 were estimated to make 100.9 billion yuan and to constitute more than 40 per cent of gross sales among China's top 100 chain retailers. The total number of foreign-owned stores rose to 2,285, accounting for 13.4 per cent of the total number of stores of China's top 100 chain retailers. China authorised 60 foreign banks to operate foreign exchange business with no limit on region or clients. Fifty-three banks were authorised to conduct RMB business in nine cities, such as Shanghai and Shenzhen. China granted market access to six foreign insurance corporations in 2002. At present, 34 insurance corporations from 12 countries and regions have established 54 business operation institutions in China.

China has established legal safeguards for intellectual property. On the eve of accession to the WTO in 2001, China passed a series of laws and regulations concerning the protection of intellectual property, for example, the Copyright Law of 
the People's Republic of China and the Trademark Law of the People's Republic of China, as well as regulations governing patent law and the protection of computer software.

China was rigorous in keeping the new legal system for protection of intellectual property consistent with the related clauses of the WTO and to fulfil the commitments in the protocol on China's accession to WTO. As a result, the number of applications for patents increased by 24 per cent in 2002 over 2001. In 2002, the patent department received 252, thousand applications for patents-205 thousand domestic applications, accounting for 81.3 per cent of the total, and 47,236 foreign applications, accounting for the remaining 18.7 per cent. In the same period 132,401 patent warrants were issued, of which 112,088 were domestic and 20,313 foreign. The total amount of applications for trademarks in 2002 was 372,000 , an increase of 37 per cent from 2001. In the meantime, central and local government strengthened investigation into intellectual property right infringementsand intensified the penalties for such infringements.

Collective, private and other non-state-owned economies have increased in China. Fixed asset investments from these now comprise over 40 per cent of the total in 2002 and are increasing at 30 per cent per annum. The $16^{\text {th }}$ National Congress of the Communist Party of China endorsed the government policy of encouraging development of the private economy. During the initial stage of economic reform, the state sector accounted for more than 90 per cent of the total. If the production of the collective economy production is included, the share of the state sector would have been around 98 per cent at that time. The government has taken a gradual approach to privatising the state-owned enterprises (SOEs). China's accession to WTO will accelerate the process by promoting the role of the non-state sector in the national economy.

In 2002, the non-state sector, including foreign firms, played an important role in China's foreign trade (Table 9.1). SOE exports made up less than one-third of total exports and imports made up slightly more than one-third of all imports. Imports and exports of foreign-owned enterprises made up about half each. The growth of foreign trade of private enterprises has grown the most rapidly, followed by that of foreign owned enterprises, although the weight of private enterprises in total imports and exports is still relatively small. The protocol on China's accession to WTO stipulates that foreign trade rights must be opened after three years of transition. There is no doubt that this will increase the proportion of foreign trade attributable to 
foreign-owned and private enterprises as the government grants more and more trading rights to private firms. The system is also changing from the examination and approval system to a standard registration system for conducting foreign trade.

To increase market competition, the government has started the process of breaking up state monopolies in some areas, for example, it has divided the telecom communication industry into northern and southern corporations. The north, the China Net Communication Group, is in charge of the telecom business of ten provinces in the north, while the former China Telecom is in charge of 21 provinces in the south. These two corporations compete with each other and have the right to do business in their counterpart's regions. China has also reconstructed the civil aviation industry, establishing three big airline companies-Air China, China Southern Airlines and China Eastern Airlines-in order to improve services and introduce competition.

In the fields of retailing, insurance and other traditional competitive industries, increased competition has occurred because of the liberalisation of services trade, increased private sector participation, and the accelerated reform of SOEs. China has enacted related laws for improving the environment of market competition-for example, in 2002 over ten laws diminishing unfair-competition were legislated.

The Chinese government now has less power to participate directly in the economy. According to institutional reform decided in the $16^{\text {th }}$ National People's Congress of the People's Republic of China, China incorporated and reformed ministries and commissions to make them more compatible with the operation of the market system.

Table 9.1 Imports and exports by different types of enterprise, 2002

\begin{tabular}{|c|c|c|c|c|}
\hline \multirow[b]{2}{*}{$\begin{array}{l}\text { Nature of } \\
\text { enterprise }\end{array}$} & \multicolumn{2}{|c|}{ Exports } & \multicolumn{2}{|c|}{ Imports } \\
\hline & $\begin{array}{c}\text { Value } \\
\text { (US\$100m) }\end{array}$ & $\begin{array}{l}\text { Year-on-year } \\
\text { growth rate } \\
\text { (per cent) }\end{array}$ & $\begin{array}{c}\text { Value } \\
\text { (US\$100m) }\end{array}$ & $\begin{array}{l}\text { Year-on-year } \\
\text { growth rate } \\
\text { (per cent) }\end{array}$ \\
\hline State-owned & 1228.6 & 8.5 & 1144.9 & 10.6 \\
\hline Foreign-owned & 1699.4 & 27.6 & 1602.7 & 27.4 \\
\hline Collective & 188.6 & 32.6 & 94.8 & 18.5 \\
\hline Private & 137.8 & 159.5 & 95.6 & 180.9 \\
\hline Others & 1.3 & -12.5 & 14.1 & -49.7 \\
\hline Total & 3255.7 & 22.3 & 2952.0 & 21.2 \\
\hline
\end{tabular}

Source: China Customs Administration, 2002. China Customs Statistics, Beijing. 
In particular, the State Assets Management Commission has been established to change the function of government from running SOEs to managing state-owned assets. The change will create the institutional condition for the government to retreat from microeconomic management of the economy. The State Planning Commission has been renamed the State Development and Reform Commission and its new responsibility is to reform economic management systems and to improve economic development. The government annulled the former State Economic and Trade Commission and Ministry of Foreign Trade and Economic Cooperation, and established the Ministry of Commerce to unite domestic and foreign trade and manage the economy as its primary function.

The adjustment of these ministries and commissions is not simply a change of names, but a significant reform by the government in the course of marketisation and liberalisation. It represents an important step towards development of market institutions and fundamental transformation of governmental functions. Following the central government's lead, local governments will also initiate institutional change and reform, laying an institutional foundation for China's marketisation

China has focused its attention on the following areas in the course of marketisation

- the privatisation of SOEs and enhancement of the private economy's role in national economy

- the elimination of state monopoly and creation of a free competitive environment

- the creation of a legal and regulatory system to protect property rights and support the market order

- institutional reform

- the transformation of government functions. When this process is finished China's transition from a nonmarket economy to a market economy country will be complete.

\section{THE WTO AND CONTINUED REFORM}

Marketisation and liberalisation have been occurring since reform started in the late 1970s. The process has been enhanced by China's efforts to become a member of the WTO. China has successively lowered its general tariff level since putting forward its application to the WTO (which was called re-entry into GATT) in 1986, and many tariffs were cut to a large extent (Table 9.2).

China's gradual tariff reductions were implemented with GATTMTO entry in mind, but at the same time, however, China also wished to benefit from an open economy 
policy. Apart from tariff reductions, non-tariff barriers also decreased markedly. The main achievement was a decrease in quota and license management. From 1992 to 2000 , the number of goods subject to import licenses and quotas decreased by two-thirds, and the number of enterprises that had foreign trade rights increased from approximately 30,000 to more than 350,000 .

Liberalisation has been a driving force in China's economic growth and development. China's dependence on foreign trade increased from 5 per cent at the beginning of reform to 50 per cent in 2000 . Authorities recognise that trade liberalisation in a nonmarket economy should be based on domestic marketisation in order for the liberalisation program to be effective.

China's accession to the WTO marked a new phase of marketisation and liberalisation in China, in which crucial parts of the reform program, such as government reform itself were carried out. The WTO not only exerts strong external pressure for reform, but also has restrictions on the content of marketisation and trade liberalisation, for example, its 'rewards and punishment' for compliance or

Table 9.2 Selected Chinese tariff rates prior to WTO accession, 1987-2000 (per cent)

\begin{tabular}{|c|c|c|c|c|c|}
\hline & 1987 & Dec 1992 & Dec 1993 & Apr 1996 & Dec 1997 \\
\hline Average tariff rate & 43.1 & 39.9 & 36.4 & 23.0 & 17.0 \\
\hline Agriculture & 37.7 & 34.5 & 34.4 & 27.2 & 17.2 \\
\hline Mining and quarrying & 22.0 & 20.2 & 20.4 & 6.0 & 3.4 \\
\hline Consumption goods in manufacturing & 65.8 & 63.9 & 60.5 & 35.5 & 25.3 \\
\hline Capital goods manufacturing & 29.5 & 36.2 & 32.9 & 21.6 & 17.2 \\
\hline Intermediate input in manufacturing & 28.8 & 21.7 & 29.0 & 17.1 & 15.1 \\
\hline Petroleum refining products & 17.6 & 16.0 & 13.9 & 8.1 & 7.6 \\
\hline $\begin{array}{l}\text { Raw chemical materials and } \\
\text { chemical products }\end{array}$ & 26.6 & 26.2 & 23.3 & 14.1 & 11.4 \\
\hline $\begin{array}{l}\text { Building materials and other nonmetal } \\
\text { products }\end{array}$ & 46.4 & 44.5 & 39.9 & 26.9 & 18.4 \\
\hline Products of smelting and pressing & 40.4 & 44.5 & 39.9 & 20.9 & 10.4 \\
\hline $\begin{array}{l}\text { of ferrous metals } \\
\text { Products of smelting and pressing }\end{array}$ & 13.3 & 14.1 & 14.3 & 9.6 & 9.1 \\
\hline of nonferrous metals & 16.2 & 16.2 & 15.4 & 10.0 & 7.8 \\
\hline Metal products & 43.0 & 42.8 & 38.5 & 20.4 & 13.5 \\
\hline
\end{tabular}

Source: Jin Xiangrong and Lin Chengliang, 1999. 'Positive analysis of China's all previous tariff adjustments and their effective protection structure', World Economy, 26(1):28-34. 
non-compliance. The protocol includes procedures to evaluate the process of China's market economy reform, supervise trade liberalisation and the transition on the part of marketisation. Under this system, China's economic reforms need to advance more quickly, especially in the area of reform and privatisation of SOEs, and in legislation and regulation.

However, while the construction of the legal system has been advancing rapidly, China is confronted with the problem of implementing the new laws. In the past five years, the Standing Committee of the National People's Congress (NPC) of China has passed 113 laws, a large number in the history of China's legal system. But passing a law is only part of the process; implementation is critical. Under the planned economic system, the administration of government mainly relied on various kinds of administrative decrees or regulations, and law was not the main foundation for the behaviour of individuals, enterprises and the government. Government officials and law enforcement authorities are not used to changing their long-enduring habit of administrative control, and business entities and residents are not accustomed to appealing to laws to defend their rights.

A second problem is that, in the course of implementation of the commitments in the protocol for China's accession to the WTO, some neglected links remain in terms of the functions and coordination of the government institutions which implement the commitments. The solution lies in strengthening the institutional reform. This was one of the key reform priorities put forward by the central government in 2003.

A third issue is that new trade protections may emerge to carry out China's commitments to the WTO, especially concerning efforts to normalise its trade protection measures. This could happen if China adopts transitional administrative measures that are not consistent with the basic principles of the WTO. Disputes may emerge as a result.

China faces some other problems as its participation in economic globalisation grows. For example, China could face some potentially detrimental treatment from a non-market economy country. The protocol on China's accession stipulates that the a member can adopt special safeguard measures against China. This clause is valid for 12 years. Such a clause makes a provision for every member to take certain measures if faced with increasing imports from China. It would be a shame for China to suffer unduly from other countries protecting themselves because this could persuade the Chinese government to take corresponding measures to protect 
its own industries. With an increasing degree of marketisation in China resulting from the reform and liberalisation, it would be advantageous to both Chinese and foreign firms when China is treated formally as a market-economy.

\section{PROSPECTS}

China's accession to the WTO has brought new opportunities for domestic reform and economic development. It provides favourable conditions for China and other countries in the world.

China is committed to lowering its tariff barriers gradually to an average tariff level of 8.9 per cent and to abrogating non-tariff barriers that contravene the WTO principles. China will push its trade liberalisation further after the new round of multilateral trade negotiations.

Besides multilateral commitments, China recently paid particular attention to the development of bilateral free trade cooperation in the hope that such a movement would further its China's liberalisation program. China has signed an agreement on the foundation of a free trade area with ASEAN, hoping to gain free trade between China and 10 countries of ASEAN within 10 years.

China's accession to the WTO has resulted in a significant increase in the overall scale of China's foreign trade. However, this also highlights the fact that protection measures from its trading partners are highly likely. These measures will have a negative impact on China's foreign trade, dampening the growth of its exports. Trade disputes are not conducive to the interests of China or its trading partners.

Trade liberalisation has had a significant effect on Chinese trade only after the achievement of a certain degree of marketisation in the Chinese economy. China has pinned its marketisation to trade liberalisation under the WTO. In the long run, the processes of marketisation and trade liberalisation will reinforce each other, bringing China closer to its goal of establishing a market system.

\section{CONCLUSIONS}

Since China's accession to WTO, China has reduced its import tariffs and abolished a series of non-tariff barriers. Elements of a private economy have emerged, and the state-owned sector has shrunk. China has reformed the government organisations and institutions to make them consistent with the requirements of the WTO. All these reforms have created the conditions necessary for the mechanism of market economy to operate successfully. 
Accession to WTO is a landmark in China's marketisation and trade liberalisation. Reforms will continue now that China has acceded to the WTO. This will continue to be a gradual process, and there will be resistance and problems. But the transient pain of adjustment and transition are unavoidable if China is to feel the benefits of marketisation and trade liberalisation.

\section{REFERENCES}

Chen Zongsheng, 1999. The Process of Marketization in the Chinese Economic System, People's Publishing House, Shanghai.

China Customs Administration, 2002. China Customs Statistics, Beijing.

Fan Gang, 1996. Political_Economic Analysis on Gradual Reform, Far Eastern Publishing House, Shanghai.

Neary, J.P., 1993. Domestic Distortion and International Trade, Policy Research Working Paper 1163, World Bank, Washington, DC.

Drysdale, P. and Ligang Song (eds), 2000. China's Entry to the WTO, Routledge, London and New York.

Qian Yingyi, 1999a. The Process of China's Market Transition (1978-1998): the evaluation, historical, and comparative perspective, Paper prepared for the Journal of International Economics Symposium, 'Big-Bang-Transformation of economic systems as a challenge to new institutional economics, Wallerfangen/Saar, 911 June.

Garnaut, R. and Ligang Song, 2002. China 2002: WTO entry and world recession, Asia Pacific Press, Canberra.

Sheng Bin, 2002. A Political Economic Analysis on Chinese Foreign Trade Policy, People's Publishing House, Shanghai.

Tong Jiadong, 1996. 'The reform of the Chinese foreign trade regime', Nankai Journal, 13(3):30-3.

- 2002. Trade Liberalization, Trade Protection and Economic Interest, Economic Science Publishing House, Beijing.

Wang Guang $\mathrm{Pu}$, 1999. Tariffs: theory, policy and practice, Foreign Economic and Trade University Press, Beijing.

World Bank, 1987, 2001, 2002. World Development Report, World Bank, Washington, DC. 


\section{0}

\section{A changing role in world trade}

\section{Ligang Song and Sizhong Sun}

The rapid growth of foreign trade during the past quarter century has fundamentally changed China's position in world trade. China is now a large, developing, and at the same time transitional, economy excelling in international economic activities through domestic reform and trade liberalisation. Relatively high export growth has been accompanied by a sustained process of GDP growth and rising per capita income at home. The combination of the size of the economy, sustained low production costs, and continued strong inflows of foreign direct investment means that China has had profound effects on regional and world production and consumption. China's changing role in world trade after its accession to the WTO in 2001 is much more than the increase in its share of world trade; its significance lies in the commensurate role it now has in promoting the multilateral trading system. A multilateral system provides the most appropriate framework for China to balance its domestic and international interests, and together with its trading partners, meet new challenges in globalisation.

\section{TRADE REFORM AND LIBERALISATION}

The domestic roots of the Chinese economy's remarkable international performance centre on the success of its domestic reform. On the macro level, successful economic reform has improved resource allocation, leading to rapid economic growth and rising income, causing both exports and imports to rise. On the micro level, continuing reforms have boosted the efficiency and productivity of domestic enterprises, which have been enhanced by foreign direct investment and the 
participation of domestic private enterprises in production and trade.

On the political level, decentralisation, enterprise and government system reform have produced domestic beneficiaries of open trade and who have pressured the government to lower the level of protection. In the regulatory area, legislation has been made to protect intellectual property rights and to ensure transparency in government policies and fair competition among firms.

To facilitate domestic firms' participation in international competition, the old trading system simply had to be reformed. Trading system reform has been carried out parallel to other reform programs such as price, enterprise, and administration reform. Initially, reform centred on removing state control over foreign trade and granting companies more autonomy. After China formally applied to rejoin the WTO (then GATT) in 1986, ${ }^{1}$ reform tackled the allocation of foreign exchange by establishing a dual exchange rate system and abolishing export subsidies.

Since the mid 1990s, the focus has been on reforming the granting of trading rights and setting up the rules for regulating trade. In 1994, the dual exchange rate system and the exchange retention system were abolished. The highly centralised foreign trading system has been replaced by a new system by which mandatory planning of imports and exports has been replaced by government guidance and indirect controls (Tseng et al. 1994; Song 2000). Controls over qualifications for participation in the foreign trade has been loosened, thus more and more domestic enterprises have been able to conduct trade directly with foreign counterparts.

China has been committed to continuously and unilaterally reducing tariff protection (Figure 10.1). From 1992 to 1997, China carried out six rounds of tariff cuts, and the average import tariff rate decreased from 43 per cent in 1992 to 17 per cent in 1997. In 1999, the average tariff rate was further reduced to 16 per cent, covering 1,041 items (15 per cent of the total) (MOFTEC Bulletin 1999). In 2001, the average tariff rate was cut down to 15 per cent, with an average decrease of 6.6 per cent (Foreign Trade Practice 2001).

In 2002, according to the commitments of the WTO accession, the average tariff rate was further reduced to 12 per cent, covering 5,300 items (75 per cent of the total), the average tariff rate for industrial manufactured goods was slightly below 12 per cent, and the average tariff rate for primary products was 15 per cent (China Petroleum and Chemical Industry 2002, and Du 2002). In 2003, the average tariff has been reduced to 11 per cent, covering 3,000 items (International Business Daily online 2002. 
Non-tariff barriers have also been reduced. In 1999, the number of import licenses was cut by 47 per cent (MOFTEC Bulletin: 1999). Overall, the coverage of non-tariff barriers fell from two thirds, to one third in 1996 and 22 per cent in 2001. Under WTO commitments, all non-tariff barriers will be phased out except for state trading, which is now subject to WTO rules, and is likely to cover less than 10 per cent of imports (Martin 2003).

Trade reform and liberalisation have directly affected China's foreign trade through increased specialisation, increased market size, and technological advancement through investment especially foreign investment (Table 10.2). From 1980 to 2002, China's foreign trade grew at an average annual rate of 13 per cent, well above the world average. In 2002, the value of China's foreign trade amounted to US $\$ 499$ billion, comprising exports of US $\$ 283$ billion and imports of US $\$ 216$ billion. China's total trade reached US $\$ 451$ billion in the first seven months in 2003 , up by 38 per

Figure 10.1 China's average tariff rate, 1986-2003

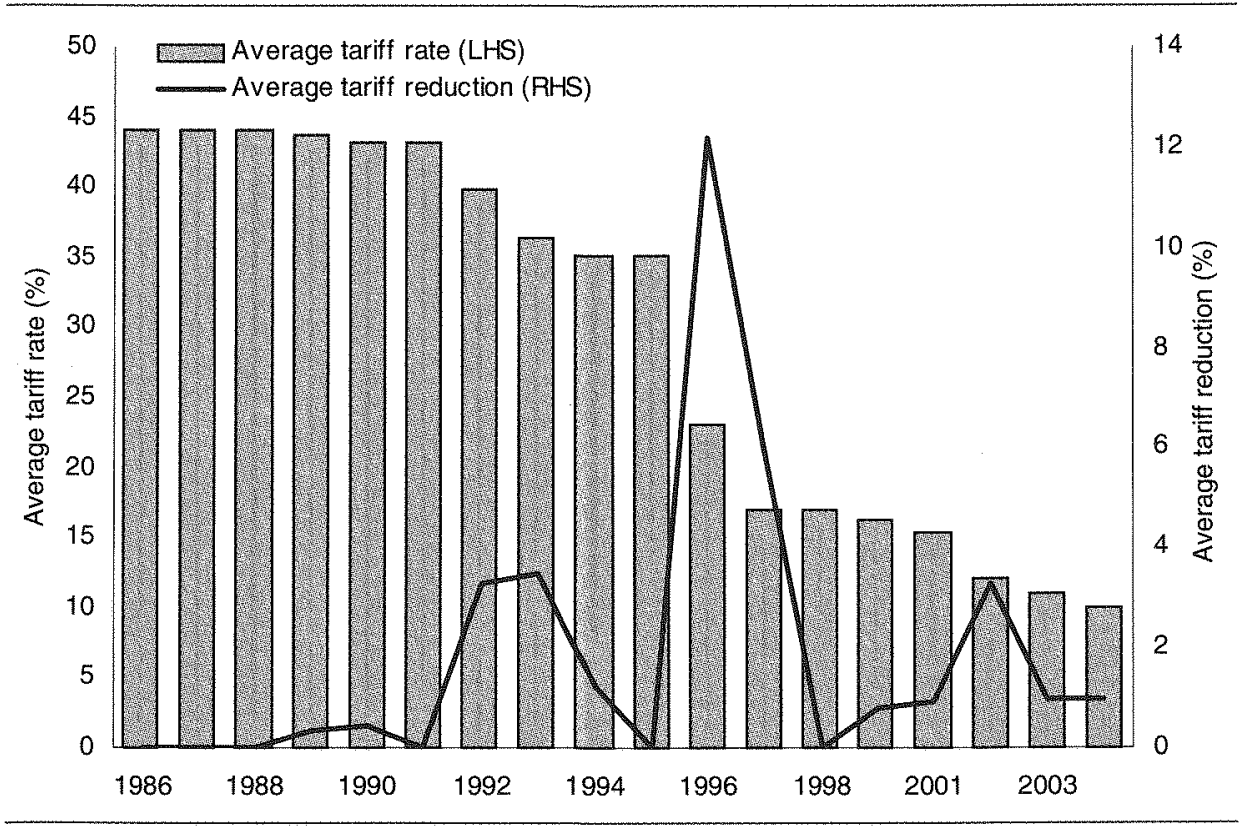

Note: The figure for 2005 is based on China's WTO commitments on tariff reduction for 2005 . Source: Made by using the data from International Business Daily online, 2002, People's Daily, 25 January 2002, MOFTEC Bulletin, 1999, and Lu, R.Z, and Yan, X.P., 2002. 'On the reform of China's tariff and nontariff barrier after WTO accession', Journal of Lujiang University, 10:34-39. 
Table 10.1 Shifting patterns of export specialisation in selected industrial sectors, 1970-2000 (index of revealed comparative advantage: RCA)

\begin{tabular}{|c|c|c|c|c|c|c|c|}
\hline & 1970 & 1975 & 1980 & 1985 & 1990 & 1995 & 2000 \\
\hline \multicolumn{8}{|c|}{ Chemicals (SITC 51) } \\
\hline China & 0.5 & 0.6 & 1.0 & 0.7 & 0.9 & 1.0 & 0.8 \\
\hline Japan & 1.1 & 1.2 & 0.9 & 0.6 & 0.8 & 1.0 & 1.0 \\
\hline NIEs & 0.1 & 0.2 & 0.3 & 0.2 & 0.3 & 0.6 & 0.7 \\
\hline ASEAN & 0.1 & 0.1 & 0.1 & 0.3 & 0.4 & 0.4 & 0.6 \\
\hline United States & 1.5 & 1.3 & 1.4 & 1.3 & 1.3 & 1.3 & 1.2 \\
\hline World & 1 & 1 & 1 & 1 & 1 & 1 & 1 \\
\hline \multicolumn{8}{|c|}{ Textiles (SITC 65) } \\
\hline China & 4.1 & 4.3 & 4.8 & 4.5 & 3.7 & 3.1 & 2.6 \\
\hline Japan & 2.2 & 1.7 & 1.4 & 1.0 & 0.6 & 0.5 & 0.6 \\
\hline NIES & 2.8 & 3.7 & 3.5 & 2.7 & 2.8 & 3.2 & 3.0 \\
\hline ASEAN & 0.3 & 0.4 & 0.5 & 0.6 & 0.8 & 0.8 & 0.8 \\
\hline United States & 0.3 & 0.5 & 0.6 & 0.4 & 0.4 & 0.4 & 0.6 \\
\hline World & 1 & 1 & 1 & 1 & 1 & 1 & 1 \\
\hline \multicolumn{8}{|c|}{ Iron and steel (SITC 67) } \\
\hline China & 0.2 & 0.2 & 0.4 & 0.1 & 0.6 & 1.2 & 0.8 \\
\hline Japan & 2.8 & 3.5 & 3.2 & 2.1 & 1.3 & 1.2 & 1.3 \\
\hline NIEs & 0.3 & 0.4 & 1.1 & 0.9 & 0.9 & 0.9 & 1.4 \\
\hline ASEAN & 0.1 & 0.1 & 0.1 & 0.2 & 0.2 & 0.2 & 0.3 \\
\hline United States & 0.6 & 0.4 & 0.4 & 0.2 & 0.3 & 0.3 & 0.4 \\
\hline World & 1 & 1 & 1 & 1 & 1 & 1 & 1 \\
\hline \multicolumn{8}{|c|}{ Metals (SITC 69) } \\
\hline China & 0.8 & 0.8 & 1.0 & 0.9 & 1.1 & 1.4 & 1.6 \\
\hline Japan & 1.7 & 1.5 & 1.6 & 1.0 & 0.8 & 0.8 & 0.7 \\
\hline NIEs & 1.0 & 1.2 & 2.0 & 2.3 & 1.7 & 1.8 & 1.5 \\
\hline ASEAN & 0.2 & 0.2 & 0.2 & 0.3 & 0.4 & 0.5 & 0.4 \\
\hline United States & 0.8 & 0.8 & 0.9 & 0.7 & 0.7 & 0.8 & 1.0 \\
\hline World & 1 & 1 & 1 & 1 & 1 & 1 & 1 \\
\hline \multicolumn{8}{|c|}{ Machinery (SITC 71) } \\
\hline China & 0.1 & 0.1 & 0.1 & 0.1 & 0.3 & 0.4 & 0.7 \\
\hline Japan & 0.9 & 1.0 & 1.4 & 1.4 & 1.6 & 1.7 & 1.5 \\
\hline NIES & 0.1 & 0.2 & 0.4 & 0.5 & 0.8 & 1.0 & 1.4 \\
\hline ASEAN & 0.1 & 0.2 & 0.2 & 0.4 & 0.8 & 1.2 & 1.4 \\
\hline United States & 1.6 & 1.7 & 1.9 & 1.7 & 1.3 & 1.4 & 1.4 \\
\hline World & 1 & 1 & 1 & 1 & 1 & 1 & 1 \\
\hline \multicolumn{8}{|c|}{ Elec. Machinery (SITC 72) } \\
\hline China & 0.2 & 0.2 & 0.2 & 0.3 & 0.7 & 0.9 & 1.1 \\
\hline Japan & 2.1 & 1.9 & 2.5 & 2.2 & 2.1 & 1.9 & 1.6 \\
\hline NIES & 1.8 & 2.0 & 2.3 & 1.8 & 2.0 & 2.0 & 1.8 \\
\hline
\end{tabular}




\begin{tabular}{|c|c|c|c|c|c|c|c|}
\hline ASEAN & 0.2 & 0.6 & 1.2 & 1.3 & 1.8 & 2.0 & 2.1 \\
\hline United States & 1.2 & 1.3 & 1.5 & 1.4 & 1.3 & 1.2 & 1.2 \\
\hline World & 1 & 1 & 1 & 1 & 1 & 1 & 1 \\
\hline \multicolumn{8}{|c|}{ Transport equipment (SITC 73) } \\
\hline China & 0.1 & 0.1 & 0.0 & 0.0 & 0.5 & 0.2 & 0.3 \\
\hline Japan & 1.7 & 2.5 & 3.0 & 2.4 & 2.0 & 1.8 & 1.8 \\
\hline NIEs & 0.1 & 0.2 & 0.4 & 0.8 & 0.5 & 0.7 & 0.8 \\
\hline ASEAN & 0.1 & 0.1 & 0.2 & 0.1 & 0.1 & 0.2 & 0.1 \\
\hline United States & 1.5 & 1.5 & 1.5 & 1.4 & 1.3 & 1.2 & 1.2 \\
\hline World & $t$ & 1 & 1 & 1 & 1 & 1 & 1 \\
\hline \multicolumn{8}{|c|}{ Travel goods (SITC 83) } \\
\hline China & 2.8 & 3.2 & 3.4 & 8.2 & 3.1 & 8.6 & 7.9 \\
\hline Japan & 2.0 & 0.5 & 0.3 & 0.2 & 0.1 & 0.0 & 0.0 \\
\hline NIES & 8.9 & 14.9 & 16.2 & 9.7 & 6.5 & 2.1 & 0.8 \\
\hline ASEAN & 0.4 & 0.7 & 0.4 & 0.3 & 1.2 & 1.1 & 1.2 \\
\hline United States & 0.2 & 0.3 & 0.3 & 0.1 & 0.2 & 0.2 & 0.3 \\
\hline World & 1 & 1 & 1 & 1 & 1 & 1 & 1 \\
\hline \multicolumn{8}{|c|}{ Clothing (SITC 84) } \\
\hline China & 2.0 & 2.4 & 4.7 & 5.2 & 4.9 & 5.1 & 4.6 \\
\hline Japan & 1.2 & 0.3 & 0.2 & 0.2 & 0.1 & 0.0 & 0.0 \\
\hline NIEs & 13.3 & 14.2 & 10.1 & 6.8 & 4.2 & 2.1 & 1.7 \\
\hline ASEAN & 0.3 & 0.6 & 0.9 & 1.1 & 1.8 & 1.4 & 1.2 \\
\hline United States & 0.3 & 0.2 & 0.3 & 0.1 & 0.2 & 0.4 & 0.4 \\
\hline World & 1 & 1 & 1 & 1 & 1 & 1 & 1 \\
\hline \multicolumn{8}{|c|}{ Footwear (SITC 85) } \\
\hline China & 1.3 & 1.6 & 1.8 & 1.6 & 3.8 & 6.1 & 6.4 \\
\hline Japan & 1.1 & 0.1 & 0.1 & 0.0 & 0.0 & 0.0 & 0.0 \\
\hline NIES & 3.6 & 6.2 & 7.8 & 6.5 & 5.1 & 1.1 & 0.3 \\
\hline ASEAN & 0.2 & 0.2 & 0.4 & 0.3 & 1.3 & 2.1 & 1.1 \\
\hline United States & 0.0 & 0.1 & 0.1 & 0.1 & 0.1 & 0.1 & 0.1 \\
\hline World & 1 & 1 & 1 & 1 & 1 & 1 & 1 \\
\hline \multicolumn{8}{|c|}{ Manufactures (total) } \\
\hline China & 0.7 & 0.7 & 0.8 & 0.8 & 1.0 & 1.1 & 1.1 \\
\hline Japan & 1.5 & 1.6 & 1.7 & 1.5 & 1.3 & 1.3 & 1.3 \\
\hline NIES & 1.4 & 1.5 & 1.6 & 1.4 & 1.3 & 1.2 & 1.2 \\
\hline ASEAN & 0.2 & 0.3 & 0.4 & 0.5 & 0.8 & 1.0 & 1.0 \\
\hline United States & 1.1 & 1.2 & 1.2 & 1.2 & 1.1 & 1.0 & 1.1 \\
\hline World & 1 & 1 & 1 & 1 & 1 & 1 & 1 \\
\hline
\end{tabular}


Table 10.2 Foreign direct investments in China, 1980-2002 (US\$ million)

\begin{tabular}{lccc}
\hline Year & Number of contracts & $\begin{array}{c}\text { Amount contracted } \\
\text { (US } \$ \text { million })\end{array}$ & $\begin{array}{c}\text { Amount used } \\
\text { (US } \$ \text { million) }\end{array}$ \\
$1979-82$ & 920 & 4,958 & 1,769 \\
1983 & 638 & 1,917 & 916 \\
1984 & 2,166 & 2,875 & 1,419 \\
1985 & 3,073 & 6,333 & 1,956 \\
1986 & 1,498 & 3,330 & 2,244 \\
1987 & 2,233 & 3,709 & 2,314 \\
1988 & 5,945 & 5,297 & 3,194 \\
1989 & 5,779 & 5,600 & 3,393 \\
1990 & 7,273 & 6,596 & 3,487 \\
1991 & 12,978 & 11,977 & 4,366 \\
1992 & 48,764 & 58,124 & 11,008 \\
1993 & 83,437 & 111,436 & 27,515 \\
1994 & 47,549 & 82,680 & 33,767 \\
1995 & 37,011 & 91,282 & 37,521 \\
1996 & 24,556 & 73,276 & 41,726 \\
1997 & 21,001 & 51,003 & 45,257 \\
1998 & 19,799 & 52,102 & 45,463 \\
1999 & 16,918 & 41,223 & 40,319 \\
2000 & 22,347 & 62,380 & 40,715 \\
2001 & 26,140 & 69,195 & 46,878 \\
2002 & 34,171 & 82,768 & 52,743 \\
$2003(1-7)$ & 22,245 & 59,924 & 34,252 \\
Total & 446441 & 887,985 & 482,222 \\
\hline
\end{tabular}

Source: MOFTEC, 2002. MOFTEC Bulletin, 2002. Ministry of Foreign Trade and Economic Cooperation, Beijing.

cent compared with the same period in 2002. Exports were up by 33 per cent, and imports 43 per cent. ${ }^{2}$ China's share of world trade was about 0.7 per cent in 1986 , but this rose to 5 per cent in 2002 when China became the fifth largest trading country (the fourth largest in terms of export) in the world (Figure 10.2).

\section{DIRECTION OF TRADE AND MARKET SHARES}

The effect of China's export growth becomes even more significant when direction of trade and changing market shares of its exports are considered. Increased openness of the Chinese economy has significantly changed China's business relationship with its major trading partners. China's exports focus heavily on the 
markets of the United States, the Asian newly industrialised economies (NIEs), Japan, the European Union, ASEAN, and to a much lesser extent, Australia, Canada, and Russia (Figure 10.3).

The proportion of exports to the US market has increased steadily, up from 5 per cent in 1980 to 24 per cent in 2002 (Figure 10.4). The Japanese market also takes a large proportion, but with a slight downward trend since the mid 1990s. Market shares of NIEs for China's exports have changed more dramatically. From 1980 to 1991, the relative importance of these markets grew sharply at about 51 per cent, falling to 24 per cent in 2002.

Rapidly falling market shares of China's exports to NIEs during the period under study largely reflect NIEs shift of their labour-intensive industries to China for labour cost advantages and the upgrade of their own industries towards producing more value-added products. High increases in China's trade with those industrialised countries is to a great extent due to the low costs of production in China.

China's imports mainly come from the United States, Japan, the European Union, NIEs, ASEAN, Australia, Canada, and Russia (Figure 10.5). China's imports from these countries appear to have fluctuated a great deal from 1980 to 1993, indicating a dramatic adjustment in China's import sources during that time (Figure 10.6). After 1993, the trend became much more stable, suggesting a relatively long-term restructure of import sources. ASEAN as a source of China's import sources has been steadily increasing, especially since the early 1990 s. The steadily increasing trend in ASEAN's exports to China is promising as it shows that ASEAN can benefit in the long term from the closer integration with China.

The proportion of US imports into China peaked in 1982 at a level of 22 per cent (exports were 24 per cent in 2002), and then decreased steadily. The gap reflects the degree to which trade imbalances exist between China and the United States. Japan remains China's most important import source. For the European Union, the trend of imports into China runs smoothly, indicating a stable trading relationship between China and the European Union. For NIEs, from 1980 to 1991, the proportion increased sharply, and peaked at 33 per cent in 1991. After that, the trend declines, but ASEAN remains an important source of imports for China.

China's emerging trade relations with its major trading partners in East Asia, North America and Europe have strengthened interdependence between China and these economies. Geographic closeness is an important factor, contributing to the formation of increasingly closed economic integration between China and other 
Figure 10.2 Major countries' share in world trade, 2002 (per cent)

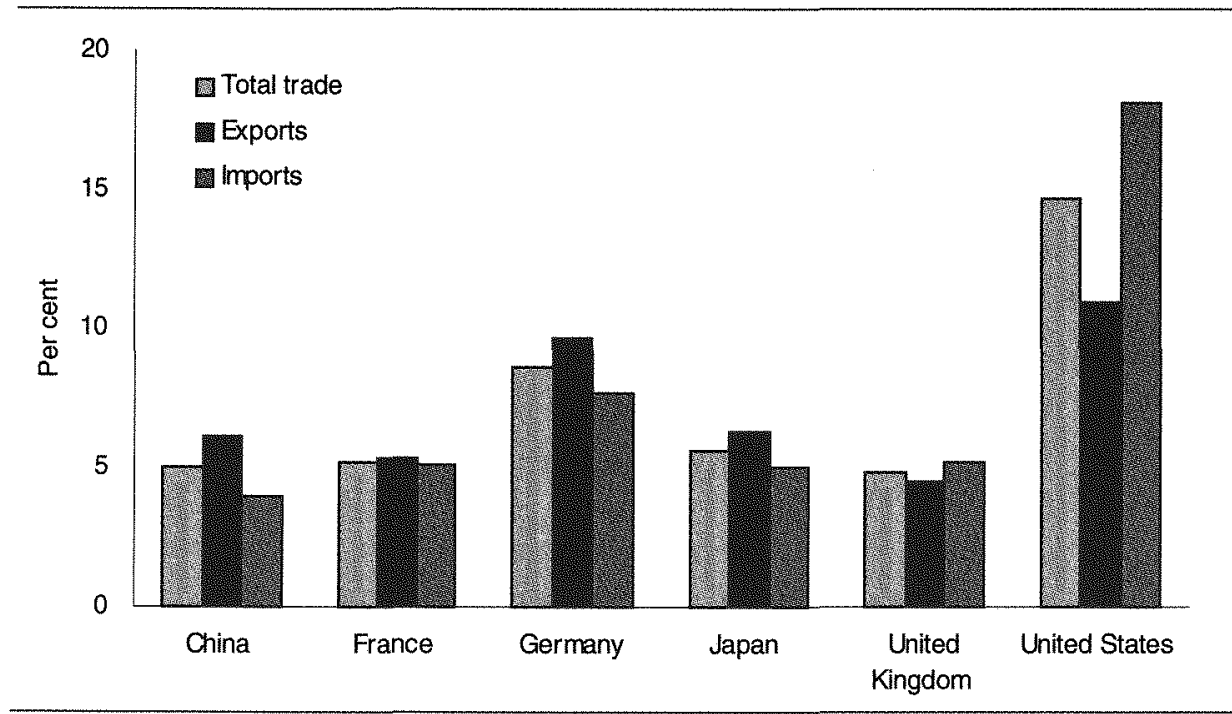

Source: Calculated using UN COMTRADE data, International Economic Databank, The Australian National University.

Figure 10.3 Destination of Chinese exports, 2003

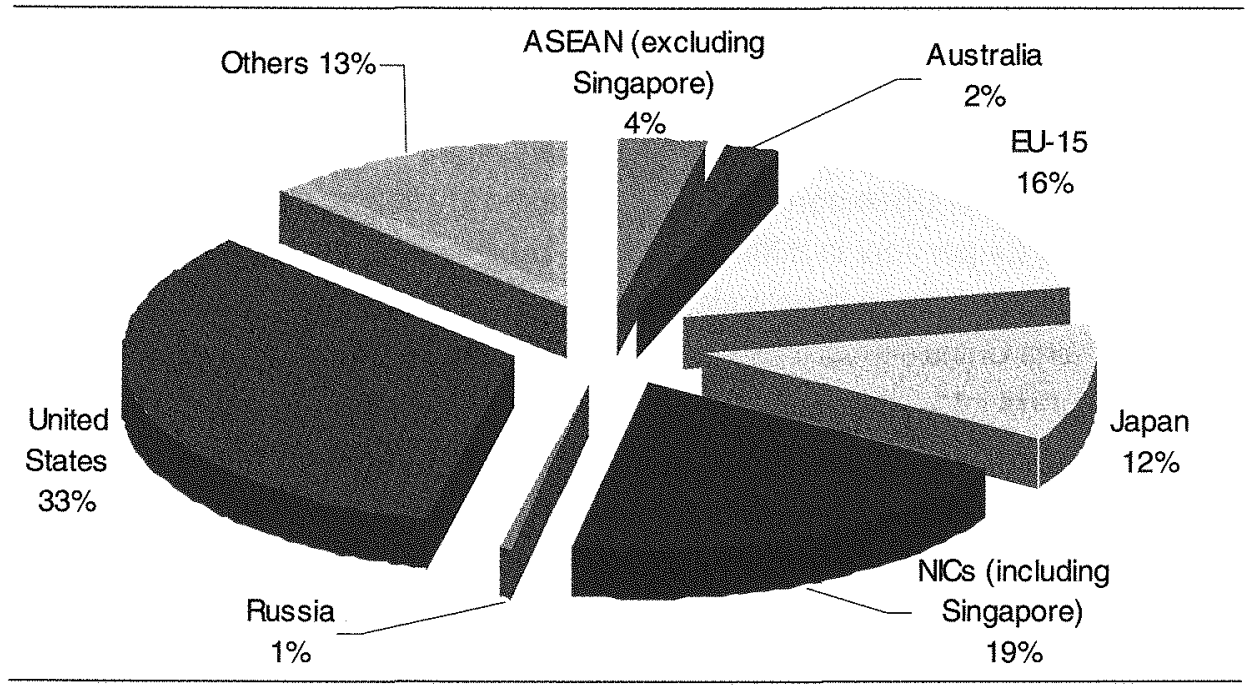

Source: Authors' calculation using data from IMF Direction of Trade (DOTS), International Economic Databank, The Australian National University. 
Figure 10.4 Change of export markets, 1980-2001 (per cent)

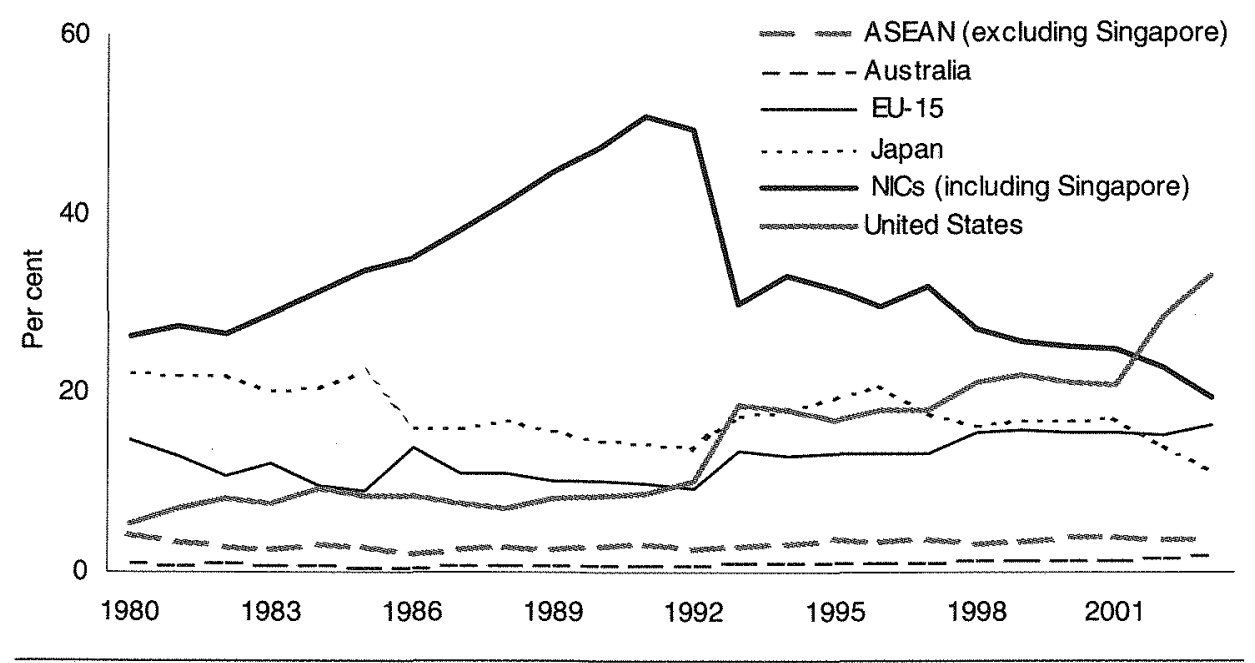

Source: Authors' calculation using IMF Direction of Trade data, International Economic Databank, Australian National University.

Figure 10.5 Source of Chinese imports, 2003

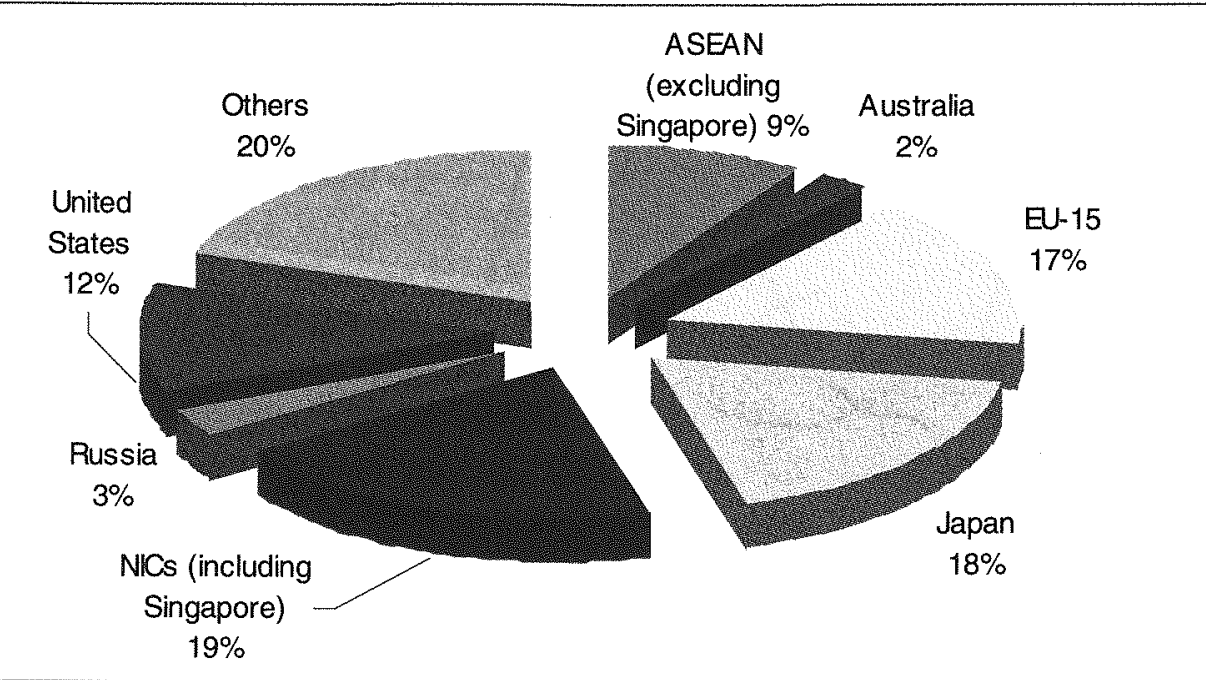

Source: Authors' calculation using IMF Direction of Trade data, International Economic Databank, Australian National University. 
East Asian economies such as Japan, NIEs and ASEAN. The relatively high share of exports from NIEs to China and the falling shares of exports from China to NIEs is an indication of China's close engagement with the process of industrial restructuring in East Asia since the 1980s. China's relationship with Japan and ASEAN has also been evolving in response to rapid increases in industrialisation levels and rapid structural change within China.

\section{COMPOSITION OF TRADE}

China has changed from being largely an exporter of primary products to largely an exporter of manufactured goods (SITC 5-8). Figure 10.7 shows that from 1965 to 1975 , China had to rely primarily on the exports of primary products, such as agricultural products, petroleum, and petroleum products, to earn much needed foreign exchange as the share of exports of primary products was larger than that of manufactured goods. But the gap was quickly narrowing. Exports of primary goods and manufactured goods were roughly the same during the early period of reform from 1975 to 1985 . After 1985, exports of primary products declined sharply, and

Figure 10.6 Changes in import sources, 1980-2001 (per cent)

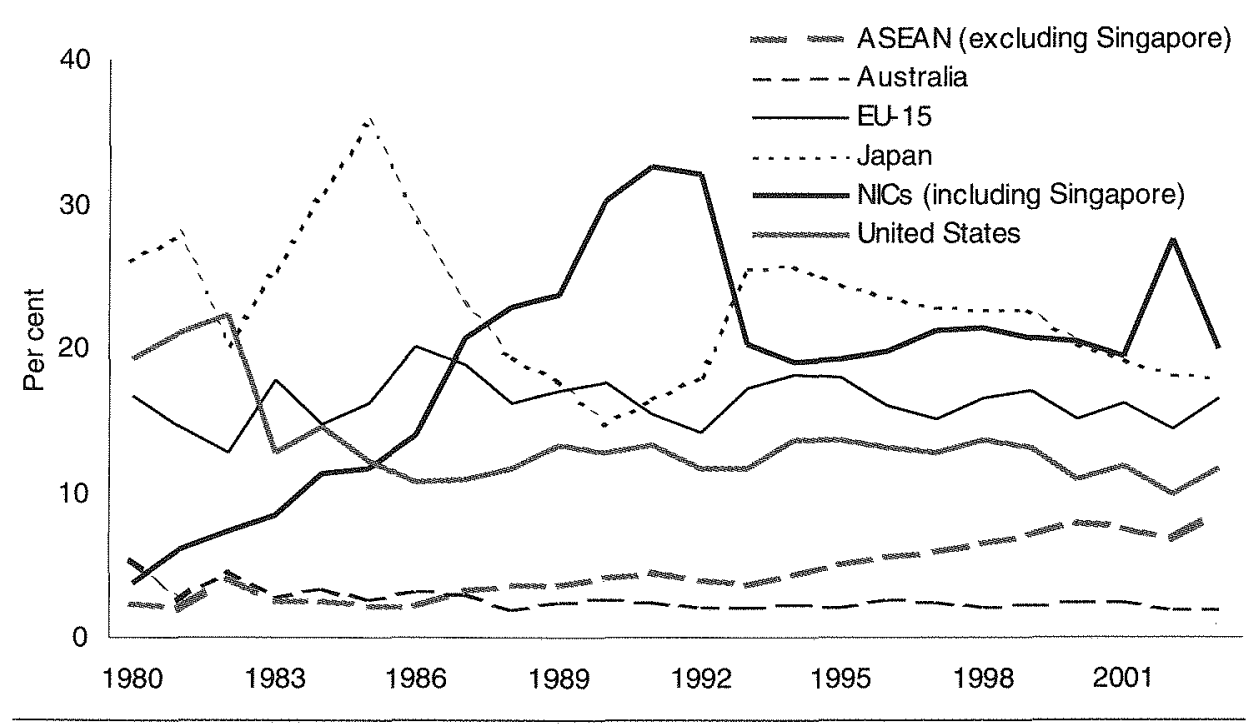

Source: Authors' calculation using the data from IMF, Direction of Trade, International Economic Databank, The Australian National University. 
exports of manufactured goods increased rapidly. The widening gap reflects the extent to which structural changes in export trade have been taking place, according to China's comparative advantage.

This changing pattern has become more evident since the mid 1980s. In 2000, China's exports of primary products (SITC 0-4) accounted for about 7 per cent of total exports, but exports of machines and transport equipment (SITC 7) and labourintensive manufactured products (SITC 8) accounted for 31 and 45 per cent of the total exports respectively (Figure 10.8).

Table 10.1 reports the international comparison of shifting patterns of export specialisation in ten selected industrial sectors (1970-2000) using the indices of revealed comparative advantage (RCA). ${ }^{3}$ The results show that by 2000 the products on which China had a strong comparative advantage ranked as follows: travel goods (7.9), footwear (6.4), clothing (4.6), and textiles (2.6). In comparison, China had less comparative advantage in machinery and transport equipment, although it had gained some ground in electronic machinery by the end of 1990s. This pattern of export specialisation is mirrored in China's composition of imports.

Figure 10.7 Trends in export composition, 1965-2000 (per cent)

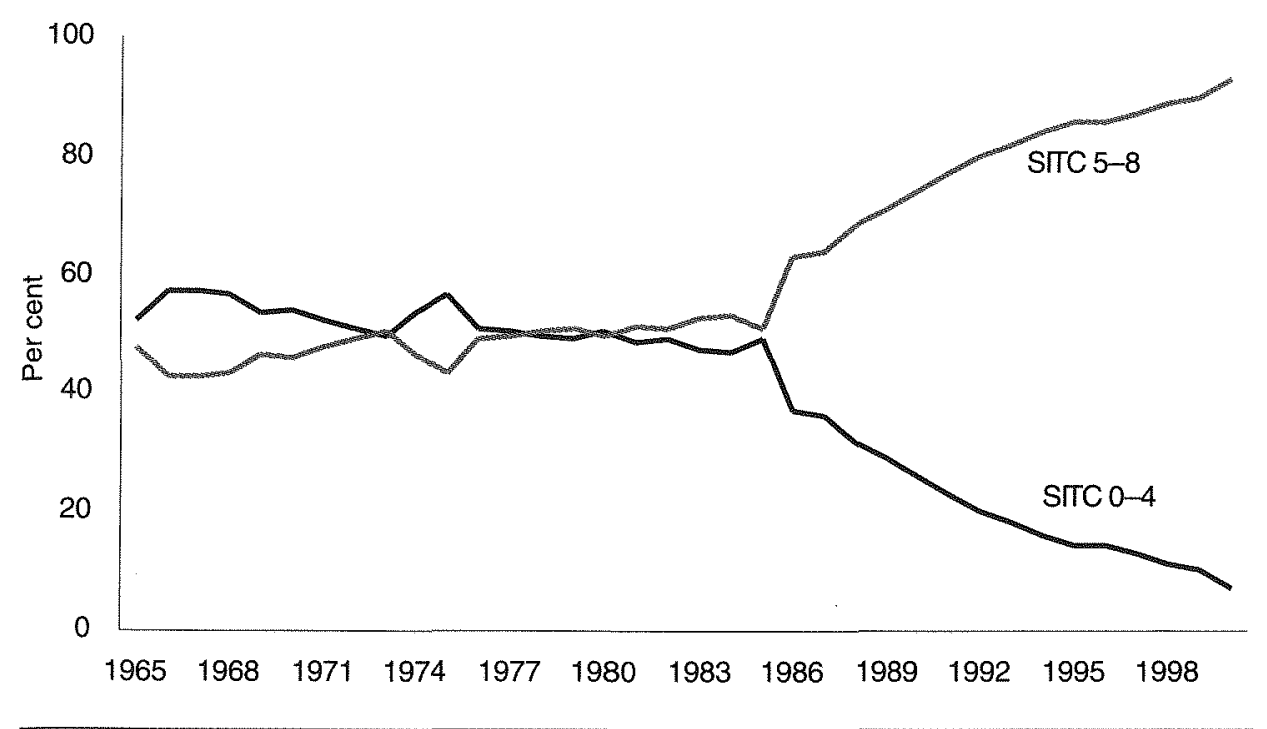

Source: Authors' calculation using UN COMTRADE, International Economic Databank, The Australian National University. 
China's imports initially focused on manufactured products, (especially SITC 7) as China needed manufactured products to meet both producer and consumer demand (Figure 10.9). Socialist legacies (heavy industry-oriented strategies) left a huge gap in both production and consumption (economic shortages), which had to be filled by imports. Figure 10.10 illustrates the composition of China's imports over time and shows that imports of manufactured products (SITC 5-8) were increasing while that of primary products (SITC $0-4$ ) were falling. From the mid 1980s, the imports of manufactured goods were an average of more than five times the imports of primary products. China had become less dependent on world markets for both exporting and importing primary products. Manufactured products have become dominant in China's foreign trade reflecting increased levels of industralisation in China.

Reflecting changes in the level of industrialisation in China, China's export shares of labour-intensive products have undergone important changes (Figure 10.11). The export shares of labour-intensive products in total exports reached a peak in mid 1994 and have fallen since then, although the absolute shares were still much higher than for all other East Asian economies. The declining trend of labour-intensive

Figure 10.8 Composition of exports, 2000 (per cent)
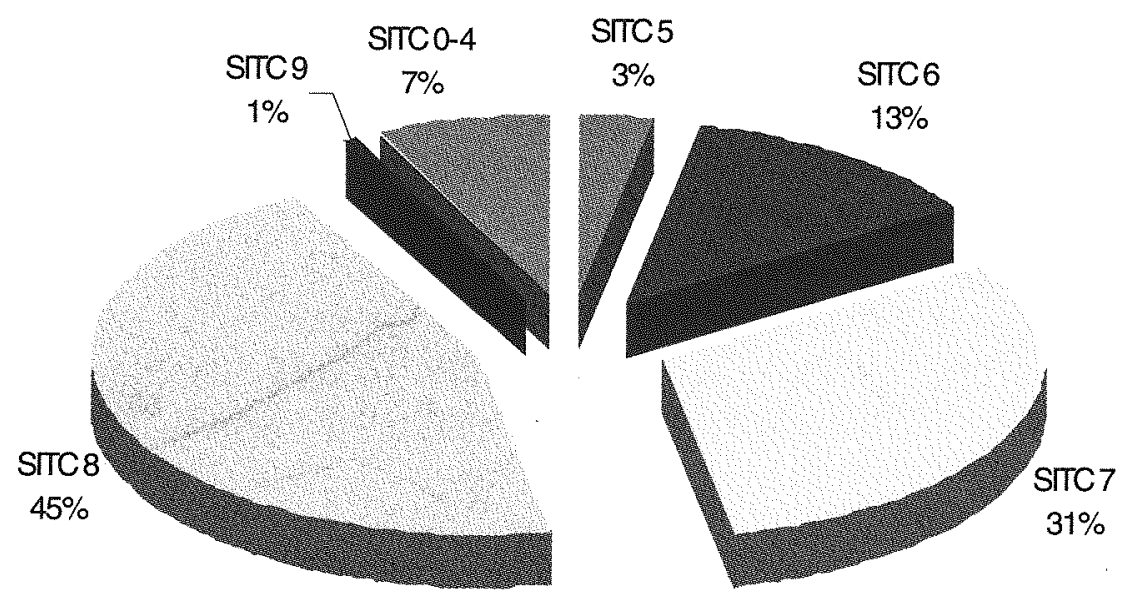

Source: Authors' calculation using UN COMTRADE, International Economic Databank, The Australian National University. 
Figure 10.9 Composition of imports, 2000 (per cent)

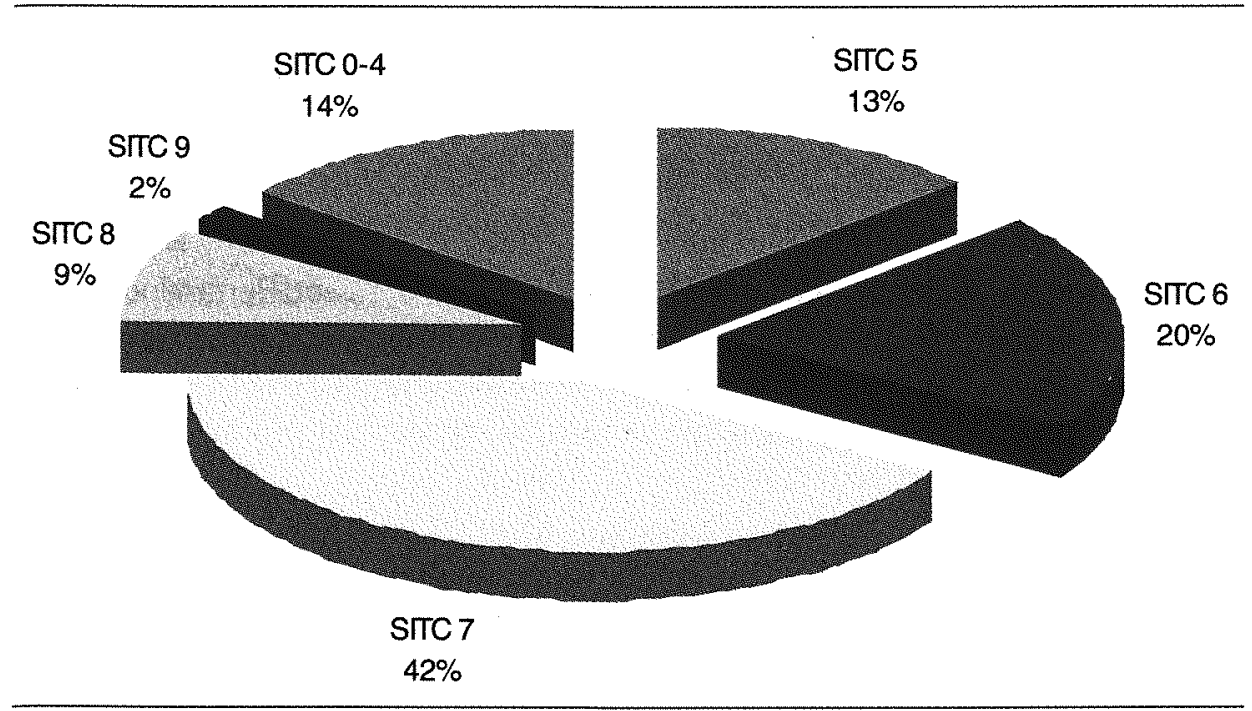

Source: Authors' calculation using UN COMTRADE, International Economic Databank, The Australian National University.

Figure 10.10 Trends in import composition, 1965-2000

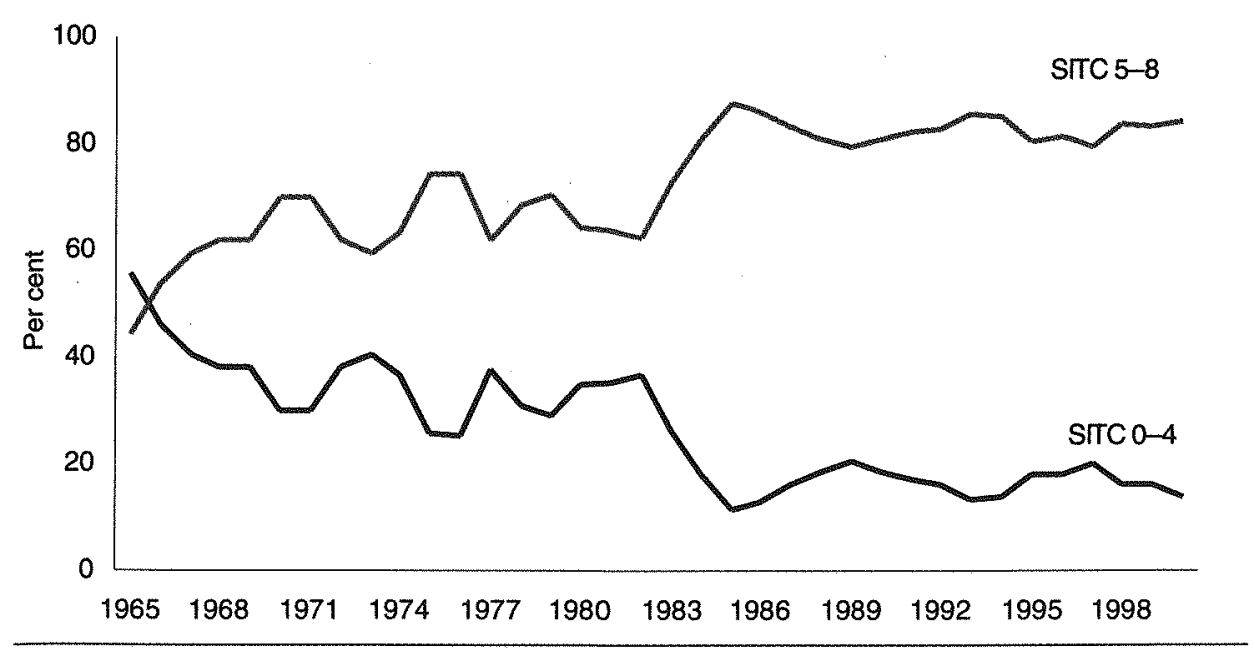

Source: Authors' calculation using UN COMTRADE, International Economic Databank, The Australian National University. 
products in China's total exports reflects China's efforts to change the composition of its exports towards more value-added products such as capital-intensive products. This trend does not necessarily mean that China will lose ground for exporting labour-intensive products in the future.

\section{EXPORT SPECIALISATION AND STRUCTURAL CHANGE}

To study the export specialisation and structural dynamics of China's exports, we follow the approaches adopted in Amin Gutierrez de Pineres and Ferrantino (1997) by first calculating a cumulative export experience function for each commodity following the formula:

$$
c_{i t}=\frac{\sum_{i=t_{0}}^{t} e_{i t}}{\sum_{i=t_{0}}^{t_{1}} e_{i t}}
$$

where $e_{i t}$ stands for export and $t_{0}$ and $t_{1}$ represent the initial and terminal periods of the sample: 1965-2000. The variable $c_{i t}$ has properties similar to that of a cumulative distribution function; it takes on values at or near 0 at the beginning of the sample period and rises to 1 in the final year. If values of $c_{i t}$ for two different industries were plotted together, an industry whose export experience was concentrated earlier in the period (a 'traditional' industry) would be differentiated from an industry whose export experience was concentrated later in the period (a 'non-traditional' industry) in that its export experience function would shift to the left.

Figure 10.12 presents cumulative distribution functions for eight of the most important Chinese export industries over the period under study. In general, the more rapidly real exports have grown in a given industry, the more the graph of $c_{i t}$ will shift to the right.

Figure 10.12 shows that the most traditional industries are textile fibres and live animals whose cumulative distribution functions are positioned to the left, indicating that a large proportion of the exports occurred relatively early in the sample period, and real exports are relatively constant over the period. For all other (non-traditional) industries, the functions shifted to the right, indicating more export experience in recent years. For example, the real export of clothing together with iron and steel experienced a rapid growth in more recent years. 
The second measure, CSX, is a measure of the change in export composition taking place in a single year.

$$
C S X=\sum_{i=1}^{61} \min \left(s_{i, t} s_{i, t-1}\right)
$$

where $s_{i t}=e_{i t} / \sum_{i \in(1,61)} e_{i t}$, the share of industry is exports in national exports in year $t$. CSX takes on a maximum value of 1 if there is no change in export composition while it takes on a minimum value of 0 if a country exports a bundle of products, none of which were exported in the previous year. High values of CSX indicate short-run stability in export composition (Amin Gutierrez de Pineres and Ferrantino 1997).

A static measure of specialisation, SPECL, can be calculated as

$$
\operatorname{SPECL}_{t}=\sum_{i=1}^{61}\left(s_{i, t}\right)^{2}
$$

Figure 10.11 Share of labour-intensive products in total exports, 1970-2000 (per cent)

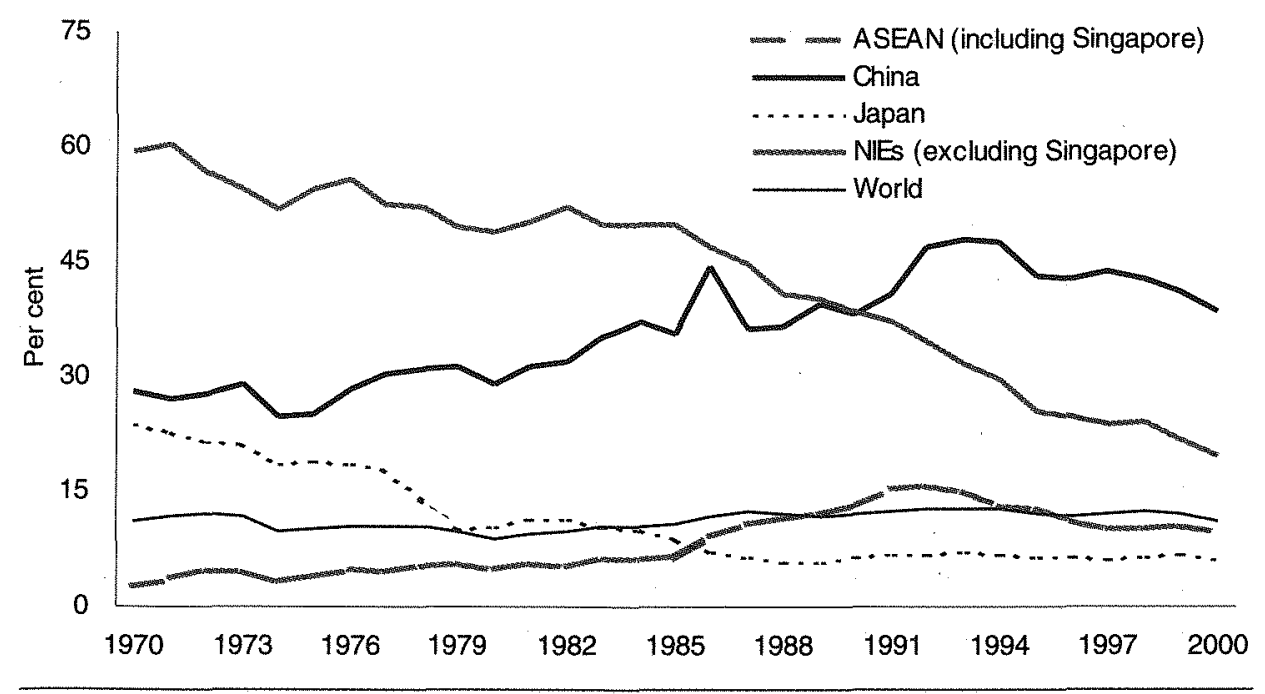

Source: Calculated using UN COMTRADE data, International Economic Databank, Australian National University. 
A score approaching 1 implies reliance on a single export (a high degree of specialisation) while a score approaching 0 implies a high degree of export diversification.

The results for both CSX and SPECL are plotted in Figure 10.13. On average, China maintained relatively high values of CSX throughout the period under study, although falls in the values can be observed for particular years. The results indicate that there has been an overall stability in the composition of China's exports although short-term fluctuations occurred over the period under study.

The value for 2000 marked a sharp fall from the normal level that had been more or less maintained in the 1990s. The fall may indicate that substantial change in structural adjustment with more export diversification occurred towards the end of $1990 \mathrm{~s}$.

The curve for SPECL shows the behaviour of the Chinese specialisation index over time (Figure 10.13). There are two periods in which a high degree of specialisation occurred: from the 1970 s to the early 1980 s, and from the mid 1980 s to the end of

Figure 10.12 China's cumulative exports, 1965-2000

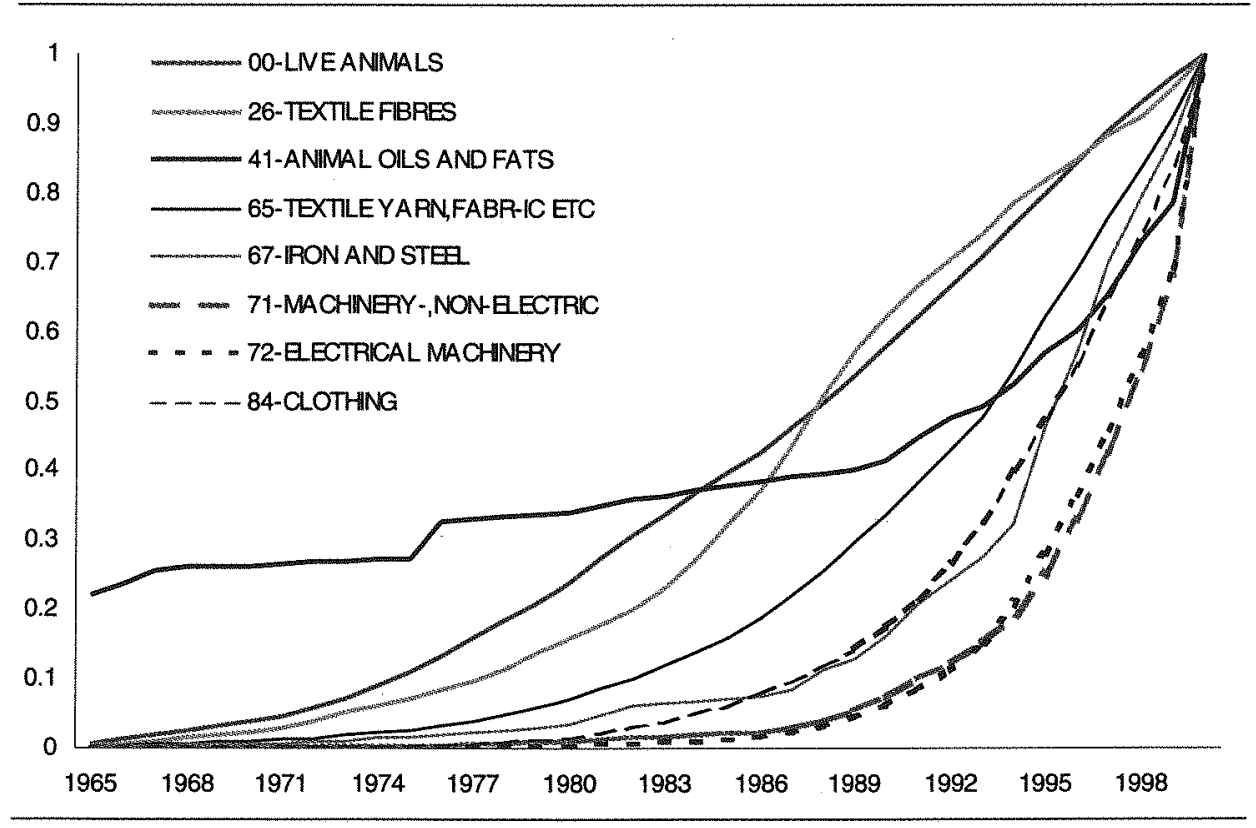

Source: Authors' calculation using UN COMTRADE, International Economic Databank, The Australian National University. 
1990s. The high degree of specialisation during the first period might be due to the distorted structure of trade caused by central planning. After the implementation of reform and trade liberalisation, a convergence of the pattern of trade and resource endowment occurred, generating trade expansion (Song 1996). The trend of the second period shows that trade expansion has been based primarily on a high degree of trade specialisation, namely its reliance on a few export items such as labour-intensive products.

This finding, together with the results shown in Figure 10.7, suggest that China has made great progress in restructuring its pattern of trade in terms of increasing the share of manufacturing products (SITC5-8) and reducing the share of primary products (SITC0-4) during the last quarter century. However, China had not achieved a high degree of export diversification manufacturing trade by the end of the 1990s. This can be seen from the increasing shares of China in world total labour-intensive manufactured exports from 1970 to 2000 (Figure 10.14), although the share of labour-

Figure 10.13 Changes in export composition and specialisation, 1965-2000

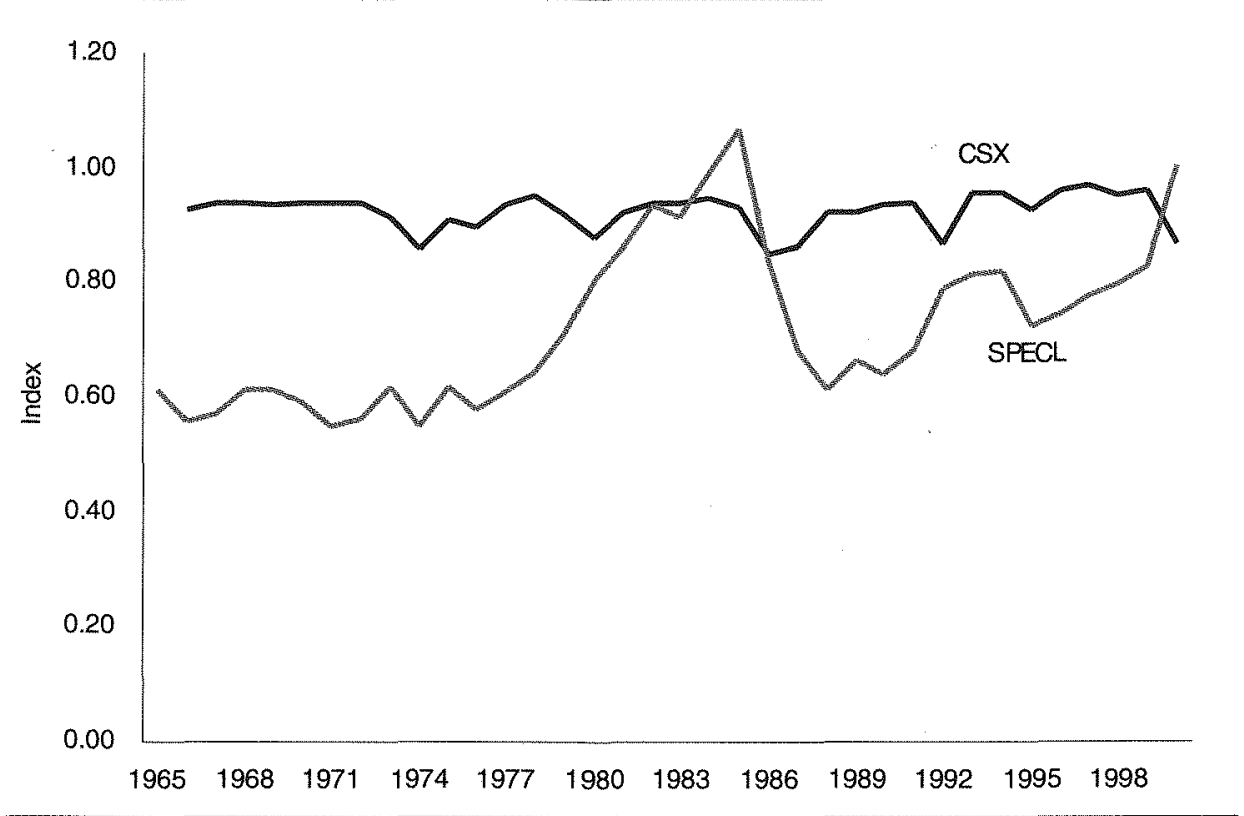

Source: Authors' calculation using UN COMTRADE, International Economic Databank, The Australian National University. 
intensive products in total exports began to fall after mid 1994 (Figure 10.11).

Faced with increasing pressure to ease tension with its trading partners over exports of labour-intensive products, the government has made efforts to diversify its exports by encouraging investment in high-tech areas and supporting the upgrading of existing industries. In doing so it increases the capital and technology content of its trade. The latest figures show that export values for high-tech products reached US $\$ 44$ billion during the first half of 2003 , up by 54 per cent compared with the same period in 2002, and accounting for 23 per cent of China's total exports. The growth rate was 21 percentage points higher than the average growth rate of the total exports in the same period. ${ }^{4}$

It is, therefore, predicted that the curve for SPECL in Figure 10.13 will soon reach a peak and then begin a sustained decline reflecting ongoing structural adjustment in exporting industries, leading to an increased degree of export diversification.

Figure 10.14 Changing share of some East Asian economies in total labourintensive manufactured exports, 1970-2000 (per cent)

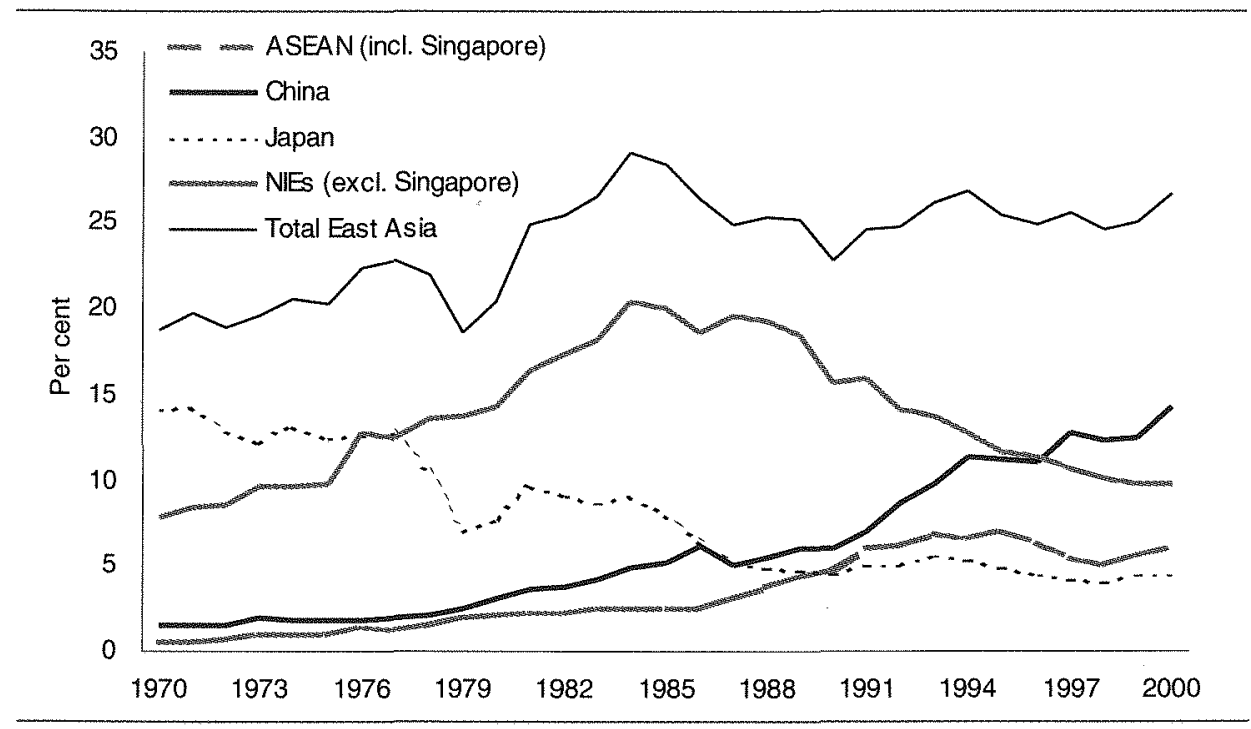

Source: Authors' calculation using UN COMTRADE, International Economic Databank, The Australian National University. 


\section{CHALLENGES AND OPPORTUNITIES}

China's emerging role in world trade has proved once again that outward-looking strategies have been successful. However, China faces challenges regarding the structural change and adjustment. Domestically, there are substantial weaknesses in China's agricultural and financial sectors. Unemployment has been exacerbated by the continuing reform of SOEs, and increased labour surpluses in rural areas result from a slowdown of township and village enterprises (TVEs). There has been an unequal distribution of benefits and costs of greater openness as far as regional economies are concerned. Macroeconomic stability has become a major concern with persistent domestic price deflation and oversupply of manufactured products. Under these circumstances, in fulfilling its WTO commitments, which in essence require more profound structural changes in the economy, the government's autonomy to decide the pace and depth of its reform has been diminished (Song 2003).

Regionally, competition between China and other Asian countries is likely to increase as China's relatively cheap and productive workforce provides it with comparative advantages on world markets across a range of labour-intensive products. China has an important place in the sale of many labour-intensive products in world markets, which are similar to those produced in ASEAN (Xu and Song 2000). Membership of the WTO makes China a more attractive place for FDI causing some diversion of capital flows away from ASEAN and other Asian economies.

China's rising trade has also forced NIEs to move more quickly in developing their capital intensive and technology intensive-industries in order to sustain a rapid growth of exports.

If they fail to respond adequately, they will suffer from lower competitiveness. China may not be content to attract lower levels of technology from them but may seek to challenge them directly in the most complex activities and functions. There is practically no activity in which China cannot build up a competitive edge; all evidence suggests that it is already doing so with amazing rapidity (Lall and Albaladejo 2002:106).

Globally, the increasing trade dependence makes the economy prone to various kinds of external shocks, which may complicate or interrupt the process of structural adjustments in the economy. Protectionism against the products in which China has comparative advantages such as textile and clothing increased especially in developed countries, which blame the cheap imports from China for loss of jobs in those traditional industries and more recently for causing deflation. The level of protection of labour intensive industries in those industrialised countries continues 
to be an important factor influencing the growth of exports from China although China is shifting quickly to diversify its exports in favour of more capital and technology-intensive industries.

China's accession to the WTO does not provide much relief in this regard as in two important areas-safeguards and antidumping-China was pressed to accept discriminatory treatment, that is, it is subject to WTO-plus requirements which were more onerous than those accepted by any other member of the WTO (Lardy 2002:80). After becoming a member of the WTO, China faces more cases of anti-dumping against its exports. Since 1979, China's exports have encountered more than 450 anti-dumping lawsuits with a total loss up to US $\$ 10$ billion (Wu 2002). Chinese enterprises have also begun resorting to anti-dumping measures against some foreign producers. The MOFTEC Bulletin shows that more firms have filed anti-dumping investigation applications against the imported goods after China joined the WTO. It is likely that increasing use of anti-dumping measures by both Chinese and foreign enterprises will negatively affect trade flows between China and its trading partners.

After a further surge in China's exports in 2002 and the first half of 2003 and the weakening of the US dollar, debate on whether China should revalue its currency have intensified. China has resisted the pressure to revalue its currency because of potentially detrimental effects on its export sector. China already devalued its currency substantially when it moved from a multiple exchange rate system where the official rate was 576.1 yuan to the dollar in 1993, to a unified rate of 861.8 yuan to the dollar by 1994 . The exchange rate appreciated slightly after that and since the Asian financial crisis has been fixed at around 8.28 yuan to the dollar. Currency depreciation played a role in boosting China's exports (Song 2000), but increasing trade from China is attributable to many other factors, especially to labour cost advantages, increased productivity resulting from domestic reform, and the role of FDI.

But given China's increasing share in world trade and the rapid increases in its foreign exchange reserves in recent years (US $\$ 356.5$ billion by July 2003$)^{5}$ it may be time for China to consider introducing exchange rate flexibility. A flexible exchange rate system would facilitate structural reforms and safeguard financial stability as the existing pegged regime is unlikely to cope with the mounting pressures of trade and capital account liberalisation (Hu 2003). Such a system would determine what the appropriate level of RMB would be, but more importantly, it would be a symbol of China's participation in the process of global adjustment, commensurate with China's increasing weight in the world economy. 
Meeting the challenges of accommodating China into the world economy will require effort by both China and its trading partners. China can best answer these challenges through unequivocal commitment to reform, to the eventual goal of free trade for China itself and the international community, and to the application of the rules of the international system (Garnaut and Huang 2000).

There is much more that needs to be done to strengthen reform in China. For example, it is argued that even after two decades of substantial reform, the trade and foreign investment regimes are still far from being transparent (Branstetter and Feenstra 2002), and price liberalisation is also far from being complete (Pomfret 1997). China needs to do more to honour international copyright and trademark laws (Behar 2000; Branstetter and Feenstra 2002). The role of government should also be changed for it to become more compatible with an open trade regime. Government's administrative capacity should be improved, and relevant legislation should be established or revised ( $X u$ 2001), as market mechanisms and open trade require a more transparent trading regime and efficient administration.

With the economy increasingly dependent on a high degree of trade, it is no longer in China's best interest to try to protect its industries by limiting imports.

Keeping imports out reduces the effective demand for, and consequently the price of, foreign exchange relative to the domestic costs of labour, capital, intermediate inputs, and so on that producers of export products must pay. Since exporters sell in foreign markets at this less favourable 'real' exchange rate, they are caught in a profit squeeze, which reduces traditional exports and blocks new export development-particularly of manufactures (McKinnon $1973 ; 134)$.

Domestic reform conforming with WTO requirements will further improve China's trading system, and help facilitate the expansion of trade through increased transparency and efficiency. One challenge is that prior to its accession to the WTO, the state provided support in many forms, such as export subsidies and easy credit to enhance the international competitiveness of domestic firms. Because of the WTO, the scope of such support will be limited and some, such as export subsidies, will have to be eliminated, with government procurement made in a more transparent way. The requirement of national treatment means that all firms, including both state and non-state firms, will be competing on an equal footing. It is therefore a matter of urgency to quicken the pace of reform of SOEs. ${ }^{6}$

Market-oriented reform in other areas, such as releasing controls over labour migration, the levelling of playing fields, privatising SOEs and enhancing regional 
growth by reducing cross-provincial barriers to trade, will have significant improvements in the overall efficiency of the Chinese economy, and thereby will further improve its export performance.

China can best maintain the balance between its domestic and international interests by pursuing a trade strategy within the multilateral framework and deepening market-oriented reform. China's remarkable performance in world trade so far has been achieved largely by following multilateral principles in the form of unilateral trade liberalisation in its attempt to become the member of the WTO. China's accession to the WTO has helped to facilitate structural change, implementing required changes in its institutions, increasing market competition through further deregulation and reform, attracting more FDls into the economy, and by opening foreign markets increasingly to China's exports.

When existing protective tariffs and quota restrictions on imports have been further reduced or eliminated according to WTO commitments, China will be in an excellent position to champion a multilateral course for further trade liberalisation. There are other approaches towards liberalisation, such as regional (subregional) and bilateral, but there are high costs associated with these approaches unless they follow the principles of multilateral arrangements such as non-discrimination. It would be counterproductive to emphasise reciprocity and appeal to bilateral negotiations (Uno 1991:29).

The potential impact of structural adjustment aimed at export diversification will be more profound than that achieved by export specialisation in that it will widen the scope of, and increase the intensities, of China's integration with the world economy. China's position in world trade will provide new opportunities for China's trading partners. Structural adjustment will be required to accommodate increased competition. There is room to raise capital and technology contents of the products within the existing labour-intensive industries such as clothing and consumer electronics. There is huge potential in developing intra-industry trade among regional economies through mutual investing (Lall and Albaladejo 2002:106).

\section{CONCLUSIONS}

As a result of the implementation of domestic reform and trade liberalisation (largely in the form of unilateral trade liberalisation) China has become an important player in world trade. China's increasing trade is a reflection of her progress with continuing structural change. A key force behind structural change is the working of China's 
comparative advantage of labour-intensive and, more recently, capital-intensive industries, supported by market-oriented reform and liberalisation. In the process, government's role in directing economic and trading activities has increasingly given way to market forces in guiding resource allocation, production and trade.

Prospects for further expansion of Chinese trade hinge on the success of continued structural adjustment in China and its trading partners. China needs further deregulation over control of labour movement, regional development, and privatisation of SOEs to increase the competitiveness and efficiency of Chinese enterprises. China will maintain its comparative advantage in labour-intensive industries for a long time to come. The matching of increased technological capability with labour cost-advantages will enlarge the scope for expansion of Chinese trade as it will contribute to producing a wider variety of products for exports.

The magnitude of the effects of China's integration with regional and world economy is reflected in the changing structure and pattern of China's trade.

Export diversification will, to a certain degree, ease trade tensions between China and those countries of a similar level of development, such as ASEAN economies, who are competing with each other in third markets for similar products, particularly labour-intensive products. A long-term solution would be to widen the scope of China's integration with the regional and the world economy so as to increase China's imports from and its investment flows to these economies.

China's changing role in world trade cannot be defined by mere increases in its weight, but by its role in championing open trade and promoting trading arrangements through the multilateral trading system. This system provides the most appropriate framework in which China can best balance its domestic and international interests and, together with its trading partners, meet the new challenges in globalisation for them to be able to continue to benefit from open trade.

\section{NOTES}

1 The General Agreements on Trade and Tariffs.

2 See People's Daily (Overseas Edition), 11 August 2003.

${ }_{3} R C A_{i k}=\frac{T_{i w}^{k} / T_{i w}^{t}}{T_{w w}^{k} / T_{w w}^{t}}$, where $T$ stands for exports, $i$ is country and $w$ represents world, $k$ is commodity. RCA $>1$ implies that a country tends to specialise in or has comparative advantage over the commodity concerned.

${ }^{4}$ See People's Daily (Overseas Edition), 24 July 2003. 
5 Reuters, Beijing, 26 August 2003.

6 See the Press release by Ministry of Commerce, People's Daily (Overseas Edition), 28 August 2003.

\section{REFERENCES}

Amin Gutierrez de Pineres, S. and Ferrantino, M., 1997. 'Export diversification and structural dynamics in the growth process: the case of Chile', Journal of Development Economics, 52(2):375-91.

Behar, R., 2000. 'Beijing's phony war on fakes, Fortune, 30 (October):189-208.

Branstetter, L., and Feenstra, R., 2002 'Trade and foreign direct investment in China:

a political economy approach', Journal of International Economics, 58:335-358

China Petroleum and Chemical Industry, 2002.'The declaration of customs general administration on tariff reduction', China Petroleum and Chemical Industry, 200202:21.

Du, H., 2002. 'How to distribute the cake of tax reduction?', Henan Taxation, 200202:12.

Garnaut, R. and Huang, Y., 2000. 'China and the future of the international trading system', in P. Drysdale and L. Song (eds), China's Entry to the WTO: Strategic Issues and Quantitative Assessments, Routledge, London:7-29.

Hu, F., 2003. 'A floating currency would be good for China', The Financial Times, Thursday, 29 May.

Lall, S. and Albaladejo, M., 2002. 'The competitive impact of China on manufactured exports by emerging economies in Asia', in C.A. Magarinos, L. Yongtu and F.C. Sercovich (eds), China in the WTO: The Birth of a New Catching-Up Strategy, Palgrave Macmillan, New York:76-110.

Lardy, N., 2002. Integrating China into the Global Economy, Brookings Institution Press, Washington, DC.

Lu, R.Z. and Yan, X.P., 2002. 'On the reform of China's tariff and nontariff barrier after WTO accession', Journal of Lujiang University, 10:34-39

Martin, W., 2003. China and the WTO: policy reform and poverty reduction, Special Report, World Bank Institute, July.

McKinnon, R.I., 1973. Money and Capital in Economic Development, The Brookings Institution, Washington, DC. 
Ministry of Foreign Trade and Economic Cooperation (MOFTEC), 2002. Report of China's Foreign Trade, Ministry of Foreign Trade and Economic Cooperation, Beijing. Available online at http://develop.hd.gov.cn/jjtt01.htm

- 1999. MOFTEC Bulletin, Ministry of Foreign Trade and Economic Cooperation, Beijing.

Pomfret, R., 1997. 'Growth and transition: why has China's performance been so different?', Journal of Comparative Economics, 25(3):442-40

Song, L., 1996. 'Institutional change, trade composition, and export supply potential in China', in M. Guitain and R. Mundell (eds), Inflation and Growth in China, International Monetary Fund, Washington DC:190-225.

,- 2000 . 'Trade liberalisation and development of China's foreign trade', in P. Drysdale and L. Song (eds), China's Entry to the WTO: strategic issues and quantitative assessments, Routledge, London:66-85.

- 2003. 'The state of the Chinese economy: structural changes, impacts and implications', in D. Cass, B. Williams and G. Barker (eds), China and the World Trade System: entering the new millennium, Cambridge University Press, London:83-92.

Tseng, W., Khor, H.E., et al. 1994. Economic Reform in China: a new phase, International Monetary Fund, Washington, DC.

Uno, K., 1991. Technology, Investment and Trade, Elsevier, New York.

Wang, H., 1993. China's Exports since 1979, St. Martin's Press, New York.

Wang, Z. and Zhai, F. 1998. 'Tariff reduction, tax replacement, and implications for income distribution in China', Journal of Comparative Economics, 26(2):358387.

Wu, Y. 2002. 'Anti-dumping after WTO accession and its countermeasures', Foreign Trade Practice, 2002-01:35-38.

Xu, J.2001. 'Entering WTO-what does government need to do?', Journal of Beijing Public Administration College, 2:13-17

$\mathrm{Xu}, \mathrm{X}$. and Song, L., 2000. 'Export similarity and the pattern of East Asia development', in P. Lloyd and Xiao-guang Zhang (eds), China in the Global Economy, Edward Elgar, Cheltenham:145-64. 


\section{1}

\section{China in the world economy: the FTA stategy}

\section{Christopher Findlay}

China made a huge international and domestic effort in multilateral trade liberalisation in the years leading up to its accession to the WTO in 2001. It is therefore at first surprising that China is now engaged in a vigorous strategy of using Free Trade Agreements. The sharp turnaround is in response to perceptions in the Chinese leadership that other Asia Pacific economies were moving away from most favoured nation commitments.

At the end of 2001, China and ASEAN reached an agreement on a framework to establish a free trade area and have agreed on a tariff elimination program which includes agriculture products in the early harvest component and which could begin as early as 2003 .

In June 2003, China and Hong Kong signed a Closer Economic Partnership Agreement which gives Hong Kong manufacturers duty free access in a large number of tariff lines in China and gives Hong Kong-incorporated services producers levels of access which exceed China's WTO commitments. ${ }^{12}$

China joined the WTO at the end of 2001. China's strong growth over the last few years has been attributed in part to accession, to the liberalisation associated with it, and to its contribution to attracting foreign capital to China.

What extra does China hope to gain from the FTA route to reform? Political considerations may have influenced thinking among the Chinese leadership about the change in their trade policy portfolio. 
Drysdale (2002) suggests that the ASEAN economies feared being crowded out by China's growth, a fear which could have been exaggerated by accession to the WTO. In the face of these uncertainties, China offered the FTA as way of providing some reassurance and as a vehicle for cooperation. Whether it does help resolve the uncertainties perceived in ASEAN is a question examined later.

The possibility of gains from preferential access by Chinese manufacturers into ASEAN markets may have been another motivation. From an ASEAN point of view, access to China's markets for raw materials or energy as well as manufactures could have been attractive. A free trade agreement involving all these economies, Zhang (2003) suggests, would also make the whole region more attractive to foreign investors-ASEAN members had been concerned about the effect of China's WTO entry on patterns of $\mathrm{FDI}$ flows.

According to some views, the reform program in ASEAN would also benefit from an FTA with China. The argument is that an agreement with China would accelerate ASEAN's own integration (the mechanism for this process is discussed in more detail below).

Zhang (2003) suggests that an agreement between China and ASEAN would hasten the efforts by Japan and Korea to form their own bilateral agreements with ASEAN, and push China, Korea and Japan themselves to make further progress on their own arrangements. A China-ASEAN FTA would therefore contribute to the building of agreements which can contribute to region wide cooperation. This process is similar to that of 'competitive liberalisation' promoted by US officials.

Zhang (2003) explains that a new interest in building regional cooperation emerged after the East Asian financial crisis. Drysdale (2002), in a similar vein, notes that another influence maybe the region's reaction to the role played by the United States in response to the crisis. Other factors he stresses that were driving new interest in smaller group regional cooperation in East Asia were the loss of faith in APEC's capacity to deal with the problems of that time and the failure to launch a new round of trade negotiations in the WTO at the Ministerial Meeting in Seattle.

Zhang (2003) attributes the first 'ASEAN plus three' meeting to this interest. Zhang stresses what he calls the vulnerability of market-based integration. He argues that the interest in a more formal institutional arrangement follows rationally from this concern but also from their emergence in Europe and the Americas.

The ASEAN plus three arrangement 'provides a framework for demonstrating East Asian leadership and influence on regional and international affairs' (Drysdale 
2002:141). Zhang (2003) is more specific. He refers to the ASEAN plus three agenda as, in addition to the establishment of an East Asian Free Trade Area, cooperation on macroeconomic policy and financial market strengthening, joint action on the provision of regional public goods. He refers to common challenges such as drug trafficking, piracy, illegal migration, environmental disasters, money laundering, international terrorism and other trans-boundary issues. Beyond these topics, there might be interaction in relation to defence and military affairs but that cooperation involves an even longer time horizon.

The FTA strategy is designed, from this perspective, to contribute to China's capacity to 'form at some point a counter power comparable to the United States and Europe by unifying Asian countries'. It is interpreted as part of an attempt by China to build a 'strategic partnership' with ASEAN which could be used to 'work closely on regional and international issues'. ${ }^{3}$ Whether the FTA component is actually required to achieve this goal is a question of interest.

Zhang (2003) also notes that other tensions within East Asia and other commitments in relation to security would inhibit the institutional integration process. He stresses that it is too early for China to consider a full East Asian arrangement, given that China is, in his view, not ready to negotiate an agreement with Japan or Korea, and given that the region cannot confront the issues that would arise from the treatment of Taiwan in a larger arrangement. So the agenda in the immediate term is actually a sub-regional one, with the focus on China and ASEAN. Whether an agreement of that scope contributes to East Asian regional interests is a further question of interest.

The trade and investment policy related components of the arrangements are seen as complementary to the interest in cooperation in the other fields. Cooperation starts in the economic area and spreads to other areas in this model. Zhang (2003:11) refers also to 'competitive regional cooperation' in which smaller groups of members in the region sign agreements which then 'help set up the legal foundation for regional institutional building'. These remarks highlight the view that a new legal and institutional framework is required to avoid the uncertainties of market-based integration.

What are the economic issues associated with the use of the FTA option, including its feedback onto the progress of the Doha Round? Does an FTA help resolve the uncertainties perceived in ASEAN about the emergence of China? is an FTA component required to build institutions for cooperation on the provision of regional 
public goods? What are the interests of China's trading partners in the Western Pacific in China's own strategic choices? These and other questions of interest are discussed in this chapter.

\section{ISSUES}

Two sets of issues are reviewed-one related to the structure of trade and the other the analysis of the dynamics of the competitive use of Free Trade Agreements.

\section{Production networks}

Garnaut and Findlay (2003), drawing on the Pacific Economic Cooperation Council's Pacific Economic Outlook (PEO) report, ${ }^{4}$ note that East Asia is again becoming increasingly interdependent in trade and growth. It was affected less by the international economic slowdown of 2001-02 than other world regions, with both exports and imports growing reasonably strongly in 2002. The period from mid $1980 \mathrm{~s}$ through to the mid 1990 s was characterised by increasing levels of regional integration. This period of growth in East Asian interdependence was driven by economic growth and structural change in Japan, supported by mutually reinforcing economic growth and trade liberalisation throughout the Western Pacific. The trend towards integration was broken temporarily by booming US markets in the mid and late 1990s. But now that earlier trend has been reinstated and is being driven by China's reform and growth.

There has been considerable relocation of the increment in production capacity to China from other economies which are losing competitiveness in labour-intensive manufacturing processes. This has created rapid growth in intermediate as well as final product exports to China.

Complex supply chains are likely to continue to change their character. New suppliers emerge to take over the positions vacated when established suppliers lose competitiveness in their original production and move to new niches. The transition of market shares supports the competitiveness of the region as a whole. The process of industrial restructuring associated with growth and changes in comparative advantage is a familiar theme in the literature on East Asian development. ${ }^{5}$

The risk is that the introduction of bilateral FTAs will retard the adjustment process. Sourcing may be diverted to institutionally preferred and away from commercially efficient partners. New suppliers may not have the opportunity to establish their market shares for either domestic market sales or re-export. ${ }^{6}$ This could be a special problem for the new members of ASEAN. 
Another interpretation of the growth of intra-regional trade is that East Asia is now more 'self reliant'. This is used as a further argument in favour of regional and preferential free trade arrangements (since the risk of diversion is smaller if trading relationships are already intense). Athukorala (2003) also notes the growth of regional trade but separates out the contribution of component trade from that associated with the demand for final products. He stresses that the fragmentation of the supply chain leads to growth in trade of components. He concludes that the data he examines show that

in a context where fragmentation based trade is expanding rapidly, the standard trade flows analysis can lead to misleading inferences regarding the ongoing process of economic integration through trade. When data on assembly trade are excluded from trade flows, our estimates suggest that extra-regional trade is much more important than intra-regional trade for continued growth dynamism of East Asia, both including and excluding Japan. Thus, the ongoing process of product fragmentation seems to have strengthened the case for a global, rather than a regional, approach to trade and investment policy making (Athukorala 2003:n.p.).

Athukorala (2003) also reports data which reinforce earlier observations about the importance of world markets for China's growth and, by extension, continuing reform. He reports that exports to North America and the European Union accounted for about 41 per cent of China's manufactured exports in 2000, up from 34 per cent five years earlier. China's share of exports to East Asia fell over that period. Access to markets in the rest of the world continue, therefore, to be a priority goal for China. These data support the observation made by Drysdale that over time, while China will most likely become more important to its East Asian neighbours as a destination for exports, they will become less important to China as it 'extends its global reach' (2002:143). Like Athukorala, Drysdale takes the point from this observation that "the protection of the WTO framework, and open regional arrangements, will assume far greater importance to China's partners in East Asia...' (2002:143).

The diversionary effects of free trade agreements are also important in markets for services. A free trade agreement has the effect of applying a particular sequence to the entry into markets for services. The first entrants may not be the world's most competitive suppliers but, once they are established, it becomes difficult to force them to exit the market, even if market access is made available on a non-preferential basis. This is because of the advantages of incumbency in services markets. The competitiveness of the rest of the economy suffers because of this effect of using FTAs to manage the sequence of entry. 
Another feature of China's position in regional production networks is the value of China's WTO commitments leading to benchmarking of bureaucratic processes against global standards. As a result of accession, China has rewritten large amounts of legal and regulatory documents to match expectations of other WTO members. Areas covered include customs procedures, quarantine, regulation affecting the service sector and government procurement. To add another layer of complexity to this new structure would be to discard one of the most important benefits of accession. The extra layer of rules required to implement preferential arrangements would add to the potential for bureaucratic discretion. Greater degrees of complexity and higher risks associated with bureaucratic discretion are not outcomes that international business wants in China.

\section{Dynamics of the competitive use of FTAs}

The other major trading partners of ASEAN have taken their own initiatives for regional cooperation. Japan has stepped up its expressions of interest in agreements with ASEAN members. Findlay et al. (2003) note that Japan appears to be giving higher priority to bilateral free trade agreements with individual ASEAN countries. In the APEC meetings in Los Cabos in 2002, President Bush announced the Enterprise for ASEAN initiative. India is also currently negotiating a framework agreement for a free trade area with ASEAN along the same lines as China, although the sectoral coverage is not expected to be as comprehensive. The European Union has approached ASEAN on the possibility of regional cooperation, although it is not clear what form it will take.

Individual ASEAN members are also negotiating bilaterally with trading partners. The more extensive interest in this effort in East Asia has been led by the shift in attitude in Japan and Singapore and to their Economic Partnership Agreement. Singapore's agreement with New Zealand was also an important prompt for action by others. Australia too is an active participant, and has just concluded an FTA with Singapore. Thailand is following Singapore's lead and is aggressively pursuing a parallel bilateral approach including separate negotiations with China, Japan and Australia. Malaysia, in a significant shift in policy, has started talks with Japan.

The dynamic process of the independent use of FTAs is well underway. While no agreements of economic significance have been signed as yet, China's participation adds to the range of activity and the intensity of effort. 
How might that process evolve? Is it automatic that the agreements made separately between members of a region will be sufficiently consistent to build to a region-wide arrangement? There are risks that this will not happen. The sectoral coverage of agreements is not likely to be consistent, given the variation in the sensitivity of various sectors. Rules of origin are likely to vary between agreements. Agreement up-front on consistency of rules is difficult to achieve in small group negotiations where the stakes are low.

The political economy effects are also complicated (Findlay et al. (2003) discuss these factors in more detail). The construction of regional agreements creates new interest groups that gain from preferential access to foreign markets. These groups may resist the extension of concessions to other economies, either in new FTAs or via the WTO negotiations. The dynamic effects within the FTA model are in other words uncertain and may undermine the political economy processes which are vital to success in the WTO process.

\section{ASEAN responses ${ }^{7}$}

Findlay et al. (2003) ask whether the extensive use of FTAs is a threat or opportunity for ASEAN. If ASEAN capitalises on this situation and becomes the hub of this set of agreements, it might be able to go even further and consolidate the regional agreements into one and so lead the response in the Western Pacific to any FTA development in the other hemisphere.

The problem is that ASEAN members may instead become the spokes rather than ASEAN as a whole being the hub. This can happen because of differences in sectoral coverage of agreements and differences in rules of origin. China (the hub) is a better choice of location for foreign investors than the spokes, since market access and sourcing is guaranteed with each spoke. Being located in a spoke provides less coverage. So one of the ASEAN's original motivations for stepping into this process with China would not be met, and China's relative competitiveness as a host for FDI might actually be even higher!

ASEAN is working on the specification of a new ASEAN Economic Community (AEC). The AEC can be seen as an attempt to maintain a coordinated approach to reform in the face of the risks posed by the hub and spoke structure with China. This is an example of the mechanism by which the agreement with China actually accelerates reform in ASEAN as a whole. Further assessment of the likelihood of that outcome will be possible after the Bali Summit of ASEAN Leaders later in 
2003. In the meantime, the vigorous and independent pursuit of trade agreements with China by individual members suggests that the risks remain high.

What are the implications of lack of cohesion for ASEAN as a whole and its capacity to deal with the other issues on its agenda, including the provision of regional public goods?

The provision of goods or services in which all members of a region have a common interest involves cooperation between those affected, but usually hinges on a leadership role being played by one or a sub-group of members. They do so because they reap a larger share of the benefits and, according to this assessment, they are willing to bear a larger share of the costs. Economies taking that decision are more likely to contribute in this way if they understand that in other closely related matters they will have the opportunity to ride on the contributions of others. The right agenda of activities supports the contribution of the package of activities, whereas the isolated treatment of any one issue may fail to yield a result.

Success in cooperation on these issues depends on a common understanding of the scope of the relevant agenda, and on a continuing discussion to refine that agenda. It also depends on the expectation that on different occasions various members will step into the leadership role so that over time, for any one member of the group, the benefits are more likely to exceed the costs of membership. It depends in other words on the development of trust in this behaviour by others. That trust is the basis of a grand bargain on regional economic cooperation.

ASEAN may not be exactly the right membership for any one issue of this type. Some may be dealt with effectively by smaller groups. Others require wider participation. But the proximity of ASEAN members, as well as common use of sea and air space, suggest that for many issues the membership is relevant.

A group like ASEAN is more likely to maintain its cohesion for these purposes when members commit not to take independent actions as a result of which other members incur a cost. The willingness of any one member to consider such an action could also lead others to question the commitment of that economy to the 'grand bargain'.

The FTA approach has been incorporated into this agenda of economic policy cooperation in the region. It may or may not generate benefits for the two parties involved, but it challenges the conditions for successful regional cooperation involving a larger group. The uncoordinated use of FTAs diverts trade and investment from non-members. It is not adding value from all members' points of view but instead 
imposes a cost on others. The willingness to adopt an independent approach to trade and investment policy may also affect the perceptions of members of the group about their ability to work together on other issues. It is not clear, therefore, that the FTA agenda will contribute to the capacity of the group to continue to commit to the agenda of cooperation.

Benefits from cooperation among the ASEAN economies are not confined to those economies. Work on piracy or terrorism or public health for example benefits others trading partners, including China. While China may have some other short term economic interests in fragmentation in ASEAN, as noted above, China too may also lose from a diminished capacity of ASEAN to continue to produce regional public goods.

\section{Reactions by other economies}

China and ASEAN are not the only relevant players in the FTA game. How will others react and how will their reactions affect the cooperation within ASEAN and feedback on the structure of agreements between China and ASEAN? Others will certainly react to the actions of such a big and growing economy, to avoid the risk of economic loss through the price effects of the diversion of trade. They may also be concerned about how to respond to the implications for them of any change in the political relationships between China and each of the ASEAN partners. Will the reactions of others take a form which offsets the challenges to ASEAN cohesion?

Findlay et al. (2003) note that the big economies in the Western Pacific could tussle to become the lead hub in the region. China would be the favourite to win that particular race. Japan currently has less to offer in terms of long-term market growth potential or as a host for FDI from relocating industry. The United States, indeed, may rank above Japan as a partner for ASEAN, particular as some members have established security ties with the United States. As Zhang (2003) notes, the development of a more specific institutional form of cooperation in East Asia may be constrained by these commitments with the United States.

Both the United States and Japan have taken their own FTA-related initiatives in East Asia, not with China, but with individual ASEAN countries. As noted above, Japan appears to be seeking a series of bilateral agreements that will give it the capacity to isolate its own sensitive sectors from the agreements.

In the Enterprise for ASEAN initiative, the United States and individual ASEAN members will together determine if they are ready to launch FTA negotiations. The 
United States expects potential FTA partners to be members of the WTO already (which excludes Cambodia, Laos and Vietnam) and to have concluded a Trade and Investment Framework Agreement (TIFA) with the United States (already in place for Indonesia, the Philippines, Brunei and Thailand). On 19 November 2002, the United States reached agreement with Singapore.

Japan and the United States therefore appear set to react to China's initiative, but to do so by signing separate agreements with individual ASEAN members. Apparently their actions are not a force for consolidation in ASEAN.

\section{TWO PATHS}

As noted, the downside risks in the scenarios examined here are largest with ASEAN. There are however also some risks for China in the fragmentation of the trading system, which in the short term means lack of progress in the Doha Round. There are also challenges for other economies with economic and political interests in the region, Japan in particular but also the United States.

Leadership by either ASEAN or China, not just with respect to agreements between them but with others in East Asia, could help solve the problem. However the dilemma is that the FTA strategy itself has weakened the capacity of ASEAN members to cooperate to avoid the risks that it poses. The weight of expectation is therefore placed more firmly on China but it too faces constraints on playing that role.

There are two tracks to resolving these issues, one within the institutional approach to regional cooperation and other involving a rediscovery of the market based approach.

The option which maintains the focus on formal institution building would be to strengthen the rules. This could involve seeking to specify what is meant by a 'good' FTA-that is, what constitutes a well-designed regional arrangement which would maximise the benefits and minimise downside risks already outlined. This framework would then be used for all negotiations. Likely features would be comprehensive coverage, a clear and bold tariff reduction program, a commitment to apply (according to some timetable) the tariff cuts on a non-discriminatory basis, standard, liberal rules of origin, recognition of the importance of non-tariff barriers, and inclusion of the normally sensitive agriculture sector (even if not immediately but according to schedule).

The problem is that it is not clear that the political economy of small group negotiations supports the maintenance of a tight set of rules. The actual outcome 
will more likely involve a hub and spoke structure, a series of agreements which do not mesh together, and a structure in which accession of new members stalls while interest in the WTO wanes. An 'ideal' agreement, including one with open accession, could be specified. Whether it can be implemented is not clear.

The alternative, even now that the FTA game is well underway, is to try to rediscover market-based integration. The key to that approach is an immediate commitment to apply any reductions in protection to all trading partners. An MFN application of reductions in tariffs would also remove the need to negotiate on rules of origin, compliance with which is likely to be the major source of higher transaction costs in the regional trading system. Coverage is also less of an issue (though on efficiency grounds a top-down approach is desirable). APEC principles of liberalisation are based on this approach.

This strategy is equivalent to a return to a market-based approach to regional integration. Commitments to reform under this approach are made at a global level in the WTO process. The relevant institutional structures for institutionalised cooperation on trade and investment policy lie in the WTO. New institutions at the regional level are not required for these purposes. Regional cooperation, both in APEC and at the level of smaller groups, is then designed to complement efforts at the global level. Issues are allocated to the best forum for consideration.

Meanwhile, patterns of trade and investment are worked out in market processes at the regional level. Business decisionmaking in a non-discriminatory rather than a preferential environment determines the patterns of trade and investment.

The expectations of leadership are greater on China. China could take such a position by confirming its interest in applying its tariff reduction schedule with ASEAN on an MFN basis. Application of cuts in all forms of protection as a result of regional arrangements on which basis is the best way to avoid the risks just described.

The market-based approach to cooperation on trade and investment does not rule out institutionalised cooperation on other matters. Those institutions may be specific to issues (for example, public health or the environment) or they may be established to run across a range of issues. The institution of 'ASEAN plus three' continues to play a role of projecting an East Asian position on current issues, especially with respect to cooperation on financial market development. 


\section{CONCLUSION}

These issues are not just matters of concern for China and ASEAN but for all the Western Pacific economies, because of the intensity of the trading relationships between them and because of the features of the supply chain in which they are all connected.

The the weight of leadership on these issues is expected to lie with China. At the same time, there are constraints on the capacity of China to take that role, given its stage of development and, as Zhang (2003) notes, its position in relation to other economies in the region. The political constraints faced by China in combination with the common economic interests in a regional approach to managing the risks associated with the FTA route to reform all suggest cooperation among a wider group of economies. Drysdale (2002) explains the value of APEC to China in that context.

The immediate focus of that cooperation could be work in the Doha Round. This could include a willingness to work on common positions on issues of interest to other WTO members, investment for example. But most importantly it means that the application of any reductions in protection negotiated at a regional level would be made part of a package of MFN measures which would later be bound in the Doha Round. Work on the scope and detail of this agenda is the priority for cooperation in the rejuvenation of the market based approach to regional economic integration.

\section{NOTES}

1 More detail on this agreement including the rules of origin applied to the services exports are available at www.tid.gov.hk/english.cepa

2 The Australian press made much of the Australian Prime Minister's statement on a visit to China in July, 2003, that the Chinese government had agreed to examine the merits of discussions on an Australia-China Free Trade Agreement. However, there has been no public reference to this matter by a Chinese official or in the Chinese media.

3 Naoko Munakata from the Research Institute of Economy, Trade and Industry (RIETI) in Tokyo, quoted in the Far Eastern Economic Review, 17 July 2003, p. 29.

4 For more information on the PEO, see www.pacificeconomicoutlook.com 
5 Findlay (2001) provides information on changes in the patterns of China's participation in world markets for labour-, capital- and technology-intensive products.

6 The significance of this effect also depends on the use of rebate schemes applied to intermediate products imported for re-export.

7 This section is based on Findlay, Haflah and Pangestu (2003).

\section{REFERENCES}

Athukorala, Prema-chandra, 2003. Product fragmentation and trade patterns in East Asia, Research School of Asian and Pacific Studies, The Australian National University (unpublished).

Drysdale, P., 2002. 'China, the WTO and East Asian economic diplomacy', in P. Drysdale and Kenichi Ishigake (eds), East Asian Trade and Financial Integration: new issues, Asia Pacific Press, Canberra:129-43.

Findlay, C., 2001. China's Admittance to the WTO and Industrial Structural Adjustment in the World Economy, Pacific Economic Paper 315, Australia-Japan Research Centre, The Australian National University, Canberra.

Findlay, C., Mohd. Haflah Piei, and Pangestu, M., 2003, Trading with Favourites: risks, motives and implications of FTAs in the Asia Pacific, Paper prepared for the East Asian Trade Policy Seminar, The Australian National University, Canberra, 20-21 March.

Garnaut, R. and Findlay, C., 2003. 'The Pacific Economic Outlook: slow to medium ahead', Asia Inc, September 2003:20-2.

Zhang Yunling, 2003. 'East Asian cooperation and integration: where to go?', in Zhang Yunling (ed.), East Asian Cooperation: progress and future, World Affairs Press, Beijing. 


\section{2}

\section{Location determinants and provincial distribution of FDI}

\section{Chen Chunlai}

Foreign direct investment into China has been one of the most important aspects of the overall economic reform program launched in China 25 years ago. The gradual but active liberalisation of the FDI regime and improvements in the investment environment greatly increased the confidence of foreign investors to do business in China. Consequently, FDI inflows into China increased rapidly after 1979 and particularly during the 1990s. In 2002, with its accession to the World Trade Organization (WTO), China surpassed the United States in becoming the largest FDI recipient in the world.

The eastern provinces account for nearly 90 per cent of the total. What are the causes of the uneven provincial distribution of FDI inflows into China, the provincial characteristics that determine FDI location decisions within China, and the relative attractiveness to FDI of mainland China's 31 provinces given their specific provincial characteristics?

\section{FDI INFLOWS INTO CHINA, 1979-2002}

Though China first started to attract FDI in late 1979, massive FDI inflows began after 1992. Table 12.1 and Figure 12.1 present data on FDI inflows into China from 1979 to 2002, a period characterised by two distinct phases: 1979-91 and 19922002.

In the initial period of the first phase, following the establishment of the four Special Economic Zones (SEZs) ${ }^{1}$ with their special incentives for FDI, inflows into China 
Table 12.1 Actual FDI inflows into China, 1979-2002

(US\$ million, current prices)

\begin{tabular}{lccc}
\hline Year & FDI inflow & Year & FDI inflow \\
1979 & 109 & 1992 & 11,007 \\
1980 & 195 & 1993 & 27,515 \\
1981 & 375 & 1994 & 33,767 \\
1982 & 440 & 1995 & 37,521 \\
1983 & 636 & 1996 & 41,725 \\
1984 & 1,258 & 1997 & 45,257 \\
1985 & 1,661 & 1998 & 45,463 \\
1986 & 1,874 & 1999 & 40,398 \\
1987 & 2,314 & 2000 & 40,715 \\
1988 & 3,194 & 2001 & 46,878 \\
1989 & 3,392 & 2002 & 52,743 \\
1990 & 3,487 & $1979-2002$ & 405,982 \\
1991 & 4,366 & &
\end{tabular}

Source: State Statistical Bureau, various issues, 1986-2002. Zhongguo Tongji Nianjian [China Statistical Yearbook], Zhongguo Tongji Chubanshe, Beijing.

Figure 12.1 Actual FDI inflows into China, 1979-2002 (current prices)

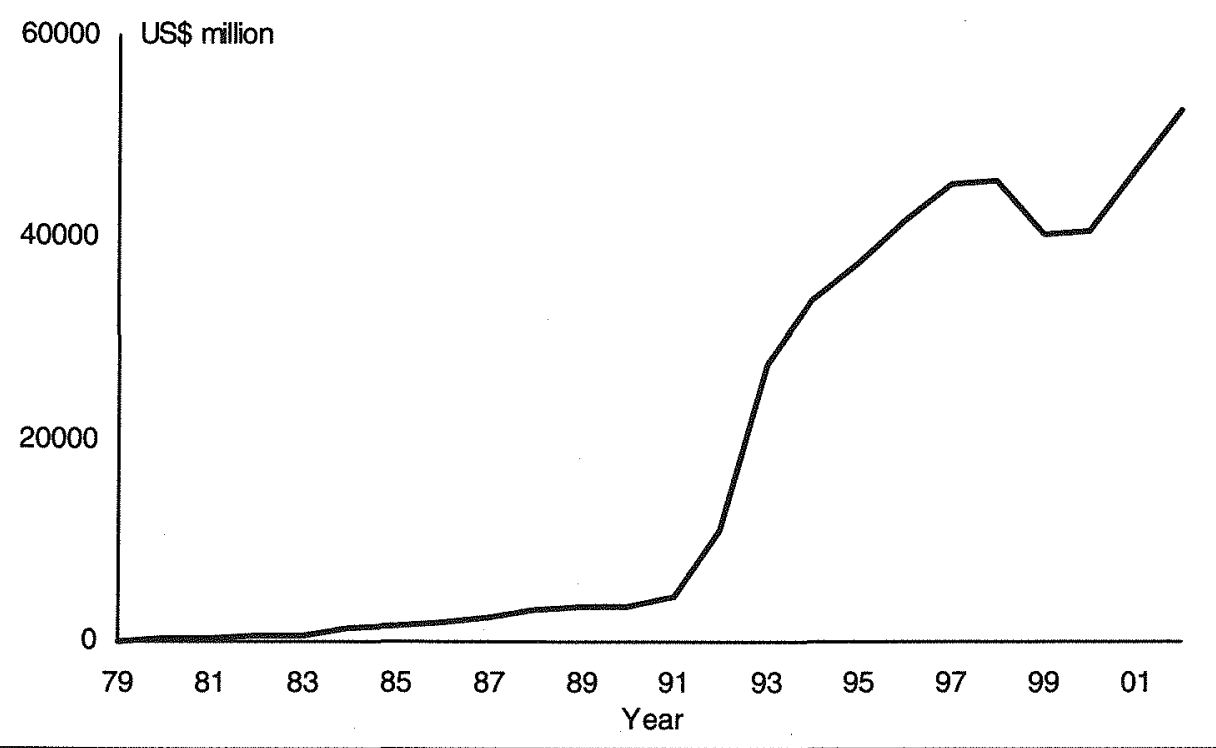

Source: As Table 12.1. 
were highly concentrated in Guangdong and Fujian provinces, and particularly in the four SEZs. The Chinese government was very cautious about introducing FDI into its domestic economy and foreign investors were also cautious about making investments in China in the initial stages of China's opening up to the outside world, so that initial FDI inflows were relatively small.

In 1984, Hainan Island and 14 coastal cities across ten provinces ${ }^{2}$ opened to FDI. Special economic policies were introduced in these open coastal cities. In 1984, inflows of FDI into China were double those of 1983. Major efforts were made over the next 7 years to attract FDI inflows. More and more areas and regions were opened to FDI, including the Yangzi River delta, the Pearl River delta, the Min Nan region, the Shanghai Pudong New Development Area and the entire coastal region. A series of new laws and regulations was introduced to encourage FDI, with considerable success.

In the Spring of 1992, Deng Xiaoping made a tour to the economically open areas and SEZs on China's southern coast. His aims were to push China's overall economic reform process forward, and to increase foreign investors' confidence in China's open-door policy and market-oriented economic reform. Deng praised the FDl-driven economic development in the economically open areas and SEZs, and called for acceleration of liberalisation. Deng's visit, which turned out to be a landmark, set the scene for China's move away from the uneven regional priority system towards nationwide implementation of open policies for FDI. The Chinese government then adopted and implemented a series of new policies and regulations to encourage FDI inflows. The response was astounding. From 1992, inflows of FDI into China increased dramatically, reaching US\$45 billion in 1998.

In 1999, mainly because of the impact of the East Asian financial crisis, FDI inflows into China dropped for the first time since 1979. When China acceded to the WTO in 2001 the situation changed dramatically: FDI inflows into China rose to US $\$ 47$ billion, an increase of 13 per cent over 2000. In 2002, FDI inflows increased by another 11 per cent from 2001 , reaching US $\$ 53$ billion. In 2002, China surpassed the United States to become the largest FDI recipient in the world.

\section{PROVINCIAL DISTRIBUTION OF FDI INFLOWS}

To facilitate the analysis of the regional and provincial distribution of FDI inflows into China, we group China's 31 mainland provinces into three regions-East, Central and West. ${ }^{3}$ 
Tables 12.2-12.3 and Figures 12.2-12.3 provide basic statistics on the distribution of FDI among China's 31 mainland provinces and three regions from 1983-2002. Several important features can be made out here. First, as Table 12.2 shows, FDI inflows into China in the 1980s were overwhelmingly concentrated in the four special economic zones (SEZs) and the two municipalities of Beijing and Shanghai. The combined shares of Guangdong, Fujian, Beijing and Shanghai accounted for about 70 per cent of the national total from 1983 to 1991.

With the development of overall economic reform and the nationwide implementation of open policies for FDI in the 1990s, FDI inflows into China gradually spread to other provinces. Increasingly, the most important areas for hosting FDI have been the Yangzi River Delta, including Shanghai, Jiangsu, and Zhejiang, and the Bohai Gulf, including Shandong, Hebei, Tianjin, and Liaoning. Several central provinces (Jilin, Heilongjiang, Jiangxi, Henan, Hubei and Hunan) and two western provinces (Sichuan and Shaanxi) also witnessed relatively large increases in FDI inflows from 1992 to 2002. Thus, since the early 1990s, FDI inflows have diffused from the initially concentrated southern coastal areas towards the southeastern and eastern coastal areas as well as inland.

Second, for the East region provinces, FDI inflows have increased steadily and remarkably quickly, particularly during the periods 1992-1998 and 2001-2002 (Figure 12.2).

Third, the East region has overwhelmingly dominated the other two province groups in stocks of FDI (Table 12.3 and Figure 12.3). The percentage shares of accumulated FDI stocks were 88 per cent for the East, 9 per cent for the Central region, and only 3 per cent for the West.

Guangdong's accumulated FDI stock from 1983 to 2002 was 28 per cent of the national total, far exceeding the secopnd, third and fourth provinces (Jiangsu, Fujian and Shanghai). However, Guangdong's dominance in attracting FDI inflows has declined gradually over the past two decades. Its share of China's FDI stock fell from 46 per cent in the 1980s to 27 per cent in the 1990s. In contrast, the shares of other coastal provinces, notably Jiangsu, Fujian, Zhejiang, Shandong, Tianjin and Hebei, have increased steadily.

The share of the Central provinces in national accumulated FDI stocks has increased gradually, from 5 per cent during the 1980 s to 9 per cent during the 1990s. The main contributors are Henan, Hubei, and Hunan; from the 1980 s to the 1990 s 
Table 12.2 Actual FDI inflows into China's provinces, 1983-2002 (millions of US dollars at 1995 prices)

\begin{tabular}{|c|c|c|c|c|c|c|c|c|c|}
\hline Province & 1983 & 1984 & 1985 & 1986 & 1987 & 1988 & 1989 & 1990 & 1991 \\
\hline Beijing & 116 & 52 & 126 & 208 & 142 & 648 & 393 & 325 & 274 \\
\hline Tianjin & 7 & 15 & 79 & 71 & 179 & 79 & 39 & 43 & 148 \\
\hline Hebei & 2 & 7 & 12 & 16 & 14 & 25 & 54 & 52 & 64 \\
\hline Shanxi & - & - & 1 & - & 7 & 8 & 12 & 4 & 4 \\
\hline Inner Mongolia & 5 & - & 4 & 10 & 7 & 8 & 5 & 12 & 2 \\
\hline Liaoning & 11 & 11 & 36 & 67 & 122 & 168 & 155 & 300 & 405 \\
\hline Jilin & - & - & 7 & 34 & 10 & 12 & 12 & 21 & 35 \\
\hline Heilongjiang & 1 & 2 & 6 & 34 & 19 & 89 & 71 & 33 & 23 \\
\hline Shanghai & 16 & 62 & 154 & 207 & 287 & 300 & 519 & 203 & 162 \\
\hline Jiangsu & 14 & 30 & 47 & 47 & 116 & 162 & 156 & 156 & 245 \\
\hline Zhejiang & 4 & 12 & 38 & 34 & 49 & 56 & 66 & 57 & 103 \\
\hline Anhui & - & - & 4 & 49 & 4 & 36 & 11 & 16 & 12 \\
\hline Fujian & 25 & 74 & 168 & 87 & 74 & 187 & 428 & 373 & 527 \\
\hline Jiangxi & 0 & 10 & 15 & 13 & 7 & 12 & 11 & $\theta$ & 22 \\
\hline Shandong & 4 & 7 & 51 & 91 & 87 & 116 & 200 & 217 & 242 \\
\hline Henan & - & - & 12 & 15 & 18 & 83 & 57 & 13 & 43 \\
\hline Hubei & - & - & 11 & 17 & 35 & 29 & 35 & 37 & 52 \\
\hline Hunan & 3 & 4 & 39 & 14 & 4 & 17 & 29 & 17 & 29 \\
\hline Guangdong & 612 & 953 & 922 & 1199 & 988 & 1,611 & 1,626 & 1845 & 2,174 \\
\hline Guangxi & 10 & 33 & 44 & 68 & 60 & 27 & 65 & 42 & 36 \\
\hline Hainan & - & - & - & - & - & 151 & 117 & 120 & 198 \\
\hline Chongqing & .. & .. & .. & .. & .. & .. & .. & .. & 72 \\
\hline Sichuan & 29 & 12 & 41 & 44. & 33 & 52 & 16 & 28 & 18 \\
\hline Guizhou & - & 1 & 14 & 17 & - & 13 & 15 & 12 & 16 \\
\hline Yunnan & - & - & 2 & 5 & 9 & 11 & 10 & 8 & 4 \\
\hline Tibet & - & - & - & - & . & - & - & - & - \\
\hline Shaanxi & 4 & 10 & 22 & 52 & 98 & 144 & 119 & 55 & 36 \\
\hline Gansu & 20 & - & 1 & 2 & - & 3 & - & 2 & 5 \\
\hline Qinghai & - & 1 & - & - & - & 4 & - & - & - \\
\hline Ningxia & - & - & - & - & - & - & 1 & - & - \\
\hline Xinjiang & " & 3 & 16 & 20 & 24 & 7 & 1 & 6 & " \\
\hline East region & 820 & 1256 & 1,677 & 2,095 & 2,118 & 3,530 & 3,818 & 3,733 & 4,578 \\
\hline Central region & 10 & 15 & 98 & 185 & 110 & 294 & 243 & 161 & 222 \\
\hline West region & 53 & 27 & 96 & 139 & 163 & 233 & 163 & 113 & 152 \\
\hline National total & 882 & 1299 & 1870 & 2420 & 2391 & 4056 & 4224 & 4007 & 4,951 \\
\hline
\end{tabular}


Table 12.2 Actual FDI inflows into China's provinces, 1983-2002 (continued)

\begin{tabular}{|c|c|c|c|c|c|c|}
\hline Province & 1992 & 1993 & 1994 & 1995 & 1996 & 1997 \\
\hline Beijing & 380 & 703 & 1410 & 1,080 & 1,508 & 1,512 \\
\hline Tianjin & 117 & 552 & 1044 & 1,521 & 1,948 & 2,385 \\
\hline Hebei & 123 & 418 & 538 & 547 & 802 & 1,045 \\
\hline Shanxi & 59 & 91 & 33 & 64 & 134 & 253 \\
\hline Inner Mongolia & 6 & 90 & 41 & 58 & 70 & 70 \\
\hline Liaoning & 561 & 1349 & 1481 & 1,425 & 1,687 & 2,093 \\
\hline Jilin & 82 & 290 & 249 & 408 & 438 & 382 \\
\hline Heilongjiang & 78 & 245 & 357 & 517 & 532 & 698 \\
\hline Shanghai & 536 & 3332 & 2543 & 2,893 & 3,826 & 4,012 \\
\hline Jiangsu & 1589 & 2998 & 3869 & 5,191 & 5,058 & 5,161 \\
\hline Zhejiang & 260 & 1088 & 1183 & 1,258 & 1,476 & 1,428 \\
\hline Anhui & 60 & 272 & 380 & 483 & 492 & 413 \\
\hline Fujian & 1546 & 3031 & 3818 & 4,044 & 3,966 & 3,985 \\
\hline Jiangxi & 108 & 220 & 269 & 289 & 292 & 454 \\
\hline Shandong & 1090 & 1976 & 2625 & 2,689 & 2,515 & 2,367 \\
\hline Henan & 58 & 322 & 398 & 479 & 508 & 657 \\
\hline Hubei & 221 & 570 & 619 & 625 & 660 & 750 \\
\hline Hunan & 144 & 461 & 341 & 508 & 683 & 871 \\
\hline Guangdong & 4019 & 7966 & 9730 & 10,260 & 11,285 & 11,119 \\
\hline Guangxi & 198 & 933 & 860 & 673 & 637 & 835 \\
\hline Hainan & 491 & 746 & 944 & 1,062 & 766 & 670 \\
\hline Chongqing & 31 & 209 & 418 & 259 & 212 & 365 \\
\hline Sichuan & 91 & 394 & 530 & 283 & 219 & 236 \\
\hline Guizhou & 22 & 45 & 65 & 57 & 31 & 47 \\
\hline Yunnan & 31 & 102 & 67 & 98 & 64 & 157 \\
\hline Tibet & - & - & - & - & - & - \\
\hline Shaanxi & 49 & 247 & 246 & 324 & 316 & 596 \\
\hline Gansu & - & 13 & 90 & 64 & 87 & 39 \\
\hline Qinghai & 1 & 3 & 3 & 2 & 1 & 2 \\
\hline Ningxia & 4 & 13 & 8 & 4 & 5 & 6 \\
\hline Xinijiang & - & 56 & 50 & 55 & 62 & 24 \\
\hline East Region & 10,909 & 25,090 & 30,043 & 32,641 & 35,474 & 36,612 \\
\hline Central Region & 814 & 2,560 & 2,686 & 3,429 & 3,810 & 4,546 \\
\hline West Region & 229 & 1,082 & 1,475 & 1,145 & 996 & 1,474 \\
\hline National Total & 11,953 & 28,731 & 34,205 & 37,216 & 40,280 & 42,631 \\
\hline
\end{tabular}


Table 12.2 Actual FDI inflows into China's provinces, 1983-2002 (continued)

\begin{tabular}{|c|c|c|c|c|c|}
\hline Province & 1998 & 1999 & 2000 & 2001 & 2002 \\
\hline Beijing & 2,026 & 1,881 & 1,490 & 1,544 & 1,474 \\
\hline Tianjin & 1,975 & 1,680 & 1,032 & 1,863 & 1,352 \\
\hline Hebei & 1,335 & 992 & 601 & 585 & 669 \\
\hline Shanxi & 229 & 373 & 199 & 204 & 181 \\
\hline Inner Mongolia & 85 & 62 & 94 & 94 & 151 \\
\hline Liaoning & 2,047 & 1,011 & 1,809 & 2,198 & 2,916 \\
\hline Jilin & 382 & 287 & 298 & 295 & 209 \\
\hline Heilongjiang & 492 & 303 & 266 & 298 & 304 \\
\hline Shanghai & 3,3656 & 2,702 & 2,797 & 3,748 & 3,652 \\
\hline Jiangsu & 6,198 & 5,788 & 5,686 & 6,039 & 8,709 \\
\hline Zhejiang & 1,232 & 1,174 & 1,427 & 1,932 & 2,629 \\
\hline Anhui & 259 & 249 & 282 & 294 & 328 \\
\hline Fujian & 3,937 & 3,832 & 3,037 & 3,422 & 3,281 \\
\hline Jiangxi & 435 & 306 & 201 & 346 & 925 \\
\hline Shandong & 2,059 & 2,151 & 2,629 & 3,075 & 4,046 \\
\hline Henan & 576 & 497 & 499 & 400 & 346 \\
\hline Hubel & 909 & 871 & 835 & 1,038 & 1,220 \\
\hline Hunan & 765 & 623 & 600 & 708 & 769 \\
\hline Guangdong & 11,234 & 11,102 & 9,983 & 10,421 & 9,687 \\
\hline Guangxi & 828 & 605 & 464 & 336 & 357 \\
\hline Hainan & 670 & 461 & 381 & 408 & 438 \\
\hline Chongqing & 403 & 228 & 216 & 224 & 167 \\
\hline Sichuan & 471 & 325 & 387 & 508 & 475 \\
\hline Guizhou & 42 & 39 & 22 & 25 & 33 \\
\hline Yunnan & 136 & 147 & 113 & 56 & 96 \\
\hline Tibet & - & - & - & - & - \\
\hline Shaanxi & 281 & 231 & 255 & 307 & 308 \\
\hline Gansu & 36 & 39 & 55 & 65 & 52 \\
\hline Qinghai & - & 4 & - & 32 & 40 \\
\hline Ningxia & 17 & 49 & 15 & 15 & 19 \\
\hline Xinjiang & 20 & 23 & 17 & 18 & 16 \\
\hline East Region & 36,907 & 33,381 & 31,337 & 35,570 & 39,209 \\
\hline Central Region & 4,131 & 3,569 & 3,274 & 3,675 & 4,432 \\
\hline West Region & 1,407 & 1,084 & 1,081 & 1,250 & 1,206 \\
\hline National Total & 42,444 & 38,033 & 35,693 & 40,495 & 44,847 \\
\hline
\end{tabular}

Sources: Data for 1983-91 are calculated from the State Statistical Bureau, 1992. Zhongguo Duiwai Jingji Tongji Daquan 1979-1991 [China Foreign Economic Statistics 1979-1991], China Statistical Information \& Consultancy Service Centre, Beijing. Data for 1992-2002 are calculated from the State Statistical Bureau, 1986-2002. Zhongguo Tongji Nianjian [China Statistical Yearbook], Zhongguo Tongji Chubanshe, Beijing. 
Table 12.3 Accumulated FDI stock in China's provinces, 1983-2002

(1995 constant US\$ prices)

\begin{tabular}{|c|c|c|c|c|c|c|}
\hline \multirow[b]{2}{*}{ Province } & \multicolumn{2}{|c|}{ 1983-1991 } & \multicolumn{2}{|c|}{ 1992-2002 } & \multicolumn{2}{|c|}{$1983-2002$} \\
\hline & $\begin{array}{l}\text { FDI stock } \\
\text { (US\$ mn) }\end{array}$ & $\begin{array}{c}\text { Share } \\
(\%)\end{array}$ & $\begin{array}{l}\text { FDI stock } \\
\text { (US\$ mn) }\end{array}$ & $\begin{array}{c}\text { Share } \\
(\%)\end{array}$ & $\begin{array}{l}\text { FDI stock } \\
\text { (US\$ mn) }\end{array}$ & $\begin{array}{c}\text { Share } \\
(\%)\end{array}$ \\
\hline Beijing & 2,284 & 8.75 & 15,009 & 3.79 & 17,293 & 4.09 \\
\hline Tianjin & 660 & 2.53 & 15,469 & 3.90 & 16,128 & 3.82 \\
\hline Hebei & 244 & 0.93 & 7,655 & 1.93 & 7,899 & 1.87 \\
\hline Shanxi & 36 & 0.14 & 1,818 & 0.46 & 1,854 & 0.44 \\
\hline Inner Mongolia & 54 & 0.21 & 819 & 0.21 & 872.39 & 0.21 \\
\hline Liaoning & 1,276 & 4.89 & 18,576 & 4.68 & 19,852 & 4.70 \\
\hline Jilin & 131 & 0.50 & 3,321 & 0.84 & 3,452 & 0.82 \\
\hline Heilongjiang & 278 & 1.06 & 4,091 & 1.03 & 4,368 & 1.03 \\
\hline Shanghai & 1,911 & 7.32 & 33,405 & 8.42 & 35,316 & 8.36 \\
\hline Jiangsu & 973 & 3.73 & 56,287 & 14.19 & 57,259 & 13.55 \\
\hline Zhejiang & 419 & 1.61 & 15,086 & 3.80 & 15,506 & 3.67 \\
\hline Anhui & 132 & 0.51 & 3,510 & 0.89 & 3,642 & 0.86 \\
\hline Fujian & 1,943 & 7.45 & 37,897 & 9.56 & 39,840 & 9.43 \\
\hline Jiangxi & 98 & 0.38 & 3,843 & 0.97 & 3,941 & 0.93 \\
\hline Shandong & 1,014 & 3.89 & 27,221 & 6.86 & 28,236 & 6.68 \\
\hline Henan & 240 & 0.92 & 4,738 & 1.19 & 4,978 & 1.18 \\
\hline Hubei & 217 & 0.83 & 8,318 & 2.10 & 8,535 & 2.02 \\
\hline Hunan & 153 & 0.59 & 6,472 & 1.63 & 6,625 & 1.57 \\
\hline Guangdong & 11,930 & 45.71 & 106,807 & 26.93 & 118,737 & 28.09 \\
\hline Guangxi & 385 & 1.47 & 6,725 & 1.70 & 7,109 & 1.68 \\
\hline Hainan & 586 & 2.24 & 7,037 & 1.77 & 7,623 & 1.80 \\
\hline Chongqing & 72 & 0.28 & 2,731 & 0.69 & 2,804 & 0.66 \\
\hline Sichuan & 273 & 1.04 & 3,918 & 0.99 & 4,191 & 0.99 \\
\hline Guizhou & 88 & 0.34 & 428 & 0.11 & 516 & 0.12 \\
\hline Yunnan & 49 & 0.19 & 1,067 & 0.27 & 1,116 & 0.26 \\
\hline Tibet & 0 & 0 & 0 & 0 & 0 & 0 \\
\hline Shaanxi & 539 & 2.06 & 3,159 & 0.80 & 3,698 & 0.88 \\
\hline Gansu & 32 & 0.12 & 542 & 0.14 & 574 & 0,14 \\
\hline Qinghai & 5 & 0.02 & 88 & 0.02 & 93 & 0.02 \\
\hline Ningxia & 3 & 0.01 & 155 & 0.04 & 158 & 0.04 \\
\hline Xinjiang & 76 & 0.29 & 340 & 0.09 & 416 & 0.10 \\
\hline East Region & 23,624 & 90.52 & 347,174 & 87.55 & 370,797 & 87.74 \\
\hline Central Region & 1,338 & 5.13 & 36,927 & 9.31 & 38,266 & 9.05 \\
\hline West Region & 1,137 & 4.35 & 12,428 & 3.14 & 13,565 & 3.21 \\
\hline Total & 26,099 & 100 & 396,528 & 100 & 422,627 & 100 \\
\hline
\end{tabular}

Sources: As for Table 12.2. 
Figure 12.2 FDI inflows into China, by region, 1984-2002 ( 1995 constant US $\$$ prices)

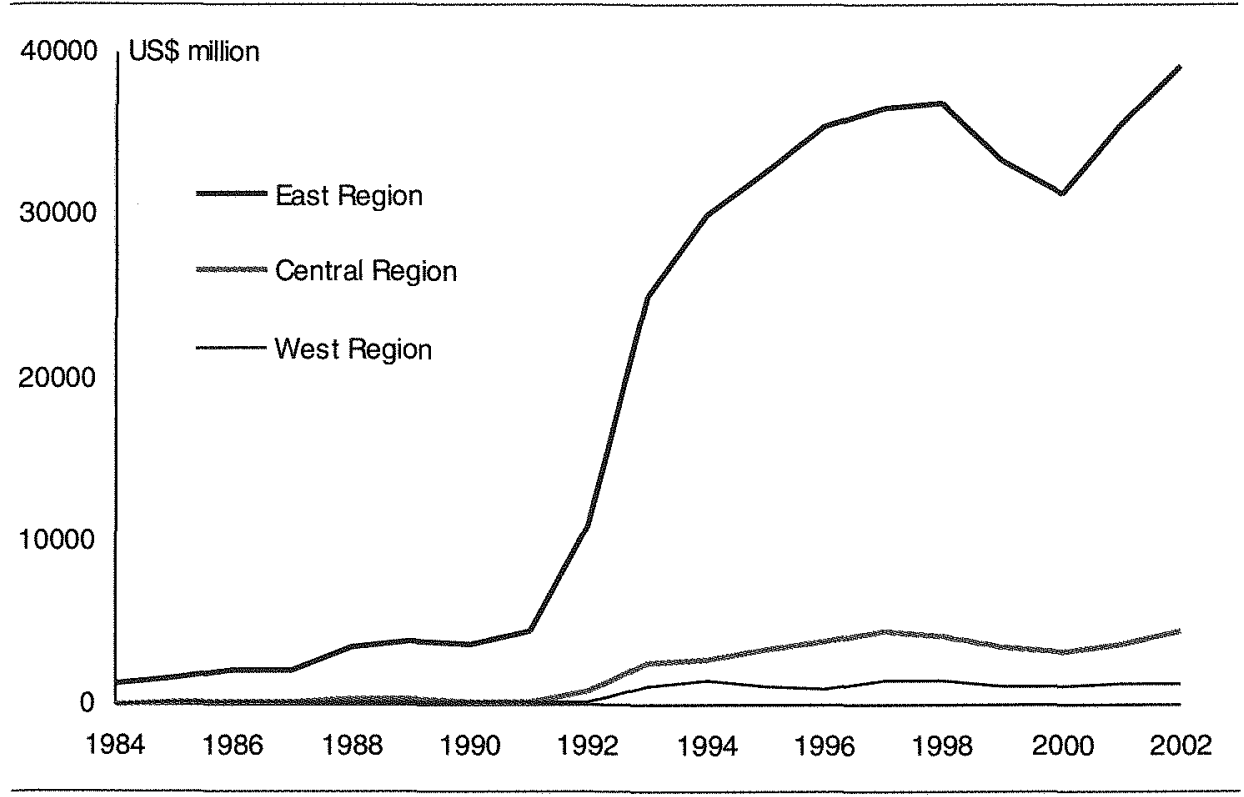

Figure 12.3 FDI stocks in China, by region, 1983-2002 (1995 constant US\$ prices)

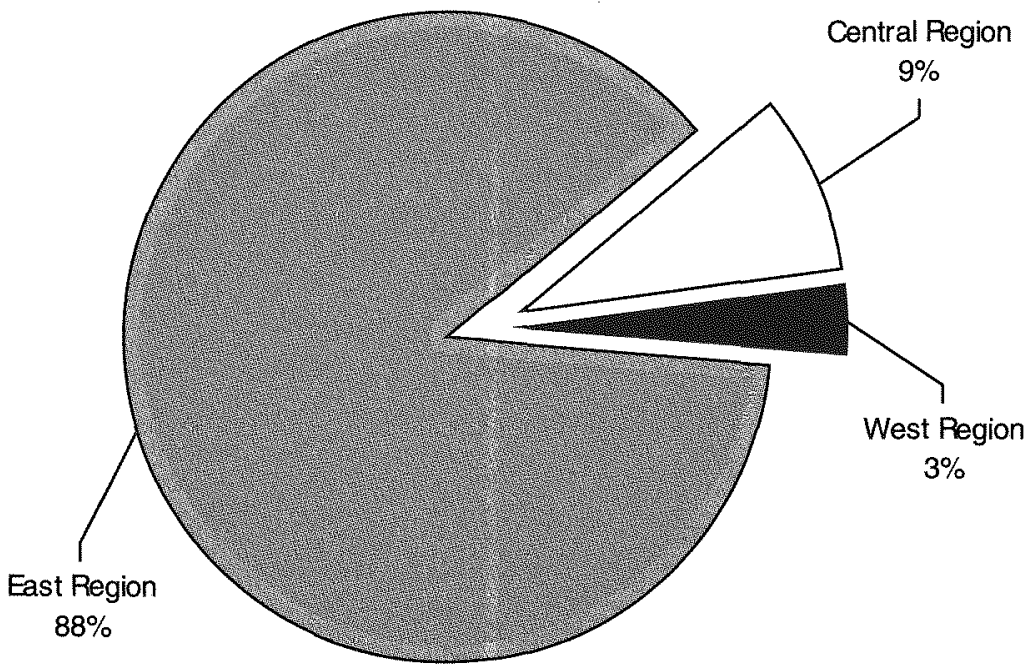


their shares of accumulated FDI in the national total doubled. This situation suggests that the provincial distribution of FDI inflows has spread from the opened coastal provinces to the inland provinces.

The less developed western provinces received little FDI. Their share in national accumulated FDI stocks declined from 4 per cent in the 1980 s to 3 per cent in the 1990s. Sichuan and Shaanxi, however, attracted more FDI inflows than other western provinces.

\section{LOCATION DETERMINANTS OF FDI DISTRIBUTION WITHIN CHINA: THE HYPOTHESES}

The theoretical framework adopted in this study is Dunning's 'OLl' explanation of FDI (Dunning 1993). According to the 'OLI' framework, for a firm to conduct FDI it must possess certain kinds of firm-specific ownership advantage. A firm's ownership advantage could be a product or a production process to which other firms do not have access, such as a patent or blueprint. It gives the firm valuable market power or cost advantage that outweighs the disadvantages of doing business abroad. In addition, the foreign market must offer a location advantage that makes it profitable for a firm to produce the product there rather than meeting demand from production at home. Location advantages include resource endowments and such economic and social factors as market size and structure, prospects for market growth and the cultural, legal, political and institutional environment, and government legislation and policies. Finally, the multinational enterprise must have an internalisation advantage. If a company owns a proprietary product or production process and it is advantageous for it to supply a foreign market through production in that market, it is still not obvious that the company should set up a foreign subsidiary. One alternative is to license a foreign firm to produce the product or use the production process. However, the product or process is exploited internally rather than at arm's length through markets because of failures in the transaction of such intangible assets. This is what is referred to as an internalisation advantage.

On the basis of Dunning's 'OLI' paradigm, the determinants of FDI can be classified into two groups-source-side and host-side factors. The source-side factors are ownership advantages and internalisation advantages and the host-side factors are location advantages. Empirically, scholars have tested the two sets of determinants either together or separately (Dunning 1993:148-79). Some empirical studies of host-side factors have shown that location determinants are very important in 
affecting the distribution of FDI inflows into host countries (Scaperlanda and Mauer 1969; Riedel 1975; Lim 1983; Nigh 1985; Torrisi 1985; Hultman and McGee 1988; Coughlin et al. 1991; Wheeler and Mody 1992; Balasubramanyam and Greenaway 1994; Milner and Pentecost 1994; Zhang Leyin 1994; Wei Shangin 1995; Chen ChienHsun 1996; Chen Chunlai 1997a, 1997b; Broadman and Sun 1997). Using the same methodology, this study will focus upon host-side factors to explore the location determinants of FDI inflows into each province.

The FDI literature suggests the general hypothesis that, facing the same set of sources of FDI in the world, provincial differences in FDI inflows are caused by differences in location factors. In this study, we examine five groups of location factors that affect FDI inflows into each of China's host provinces.

\section{Economic factors}

Economic factors include market size, level of economic development, growth rate of the economy, labour cost and productivity, openness of economy to the outside world, and past performance in attracting FDI inflows.

Market size of host province. We may hypothesise that FDI inflows will be greater where the market of the host province is larger. Numerous studies of FDI location determinants suggest that larger economies attract more FDI because of their greater potential market demand. However, this use of provincial market size as a location factor in the provincial distribution of FDI inflows within China needs to be qualified in that provincial market size can be seen to be important for both export-oriented FDI and FDI aimed at serving the whole national market. This is because larger economies can provide more opportunities for industries and enterprises to benefit from external economies of scale and spill-over effects. In these circumstances, the influence of provincial market size will still be positive on the inward FDI to host provinces. In addition, because of the increasing importance of FDI in service sectors, local market size is also a very important location determinant. The measure of market size used in this study is the gross domestic product (GDP) of the host province.

Level of economic development of host province. A province's economic development level is a comprehensive indicator of its economic and social conditions. A higher economic development level not only indicates good overall economic performance and higher purchasing power but also implies higher productivity associated with good labour quality and advanced technology, better local 
infrastructure, and an overall better investment environment. Because the economic development levels of China's provinces vary greatly, we expect that a higher provincial economic development level will have a positive impact on FDI inflows into a province. In this study, per capita GDP, denoted as PGDP, is used as a proxy for the provincial economic development level.

Economic growth rate of host province. A high rate of economic growth is an indicator of development potential. Clearly, markets that are expected to grow faster will tend to attract higher levels of inward FDI. Therefore, we hypothesise that there is a positive relationship between inward FDI and economic growth in the host province. In this study, the real growth rate, denoted by GR, is used as the measure of economic growth in the host province.

Labour costs and productivity in host province. In the FDI literature, the most important factor cost in the determination of FDI flows is the wage rate, especially when $\mathrm{FDl}$ is export-oriented. Therefore, we take the relevant factor cost in the decision to locate FDI in the host province as that of labour costs. In particular, we expect lower labour costs to imply higher levels of FDI inflows, especially for export-oriented FDI. However, a lower wage rate may also be accompanied by lower productivity, meaning the efficiency wage may not be low. The best measure of labour costs would therefore be the 'efficiency wage' rather than the absolute wage rate. In this study, we use the efficiency wage as a measure of labour costs in each host province. The efficiency wage as a measure of labour costs has the advantage of being unit free. It is expected to be negatively related to the level of FDI inflows.

The efficiency wage is measured as

$$
E W_{j}=\frac{W_{j}}{\Pi_{j}}
$$

where $E W_{j}$ is the average efficiency wage in host province $j, W_{j}$ is the average wage rate of all employees in host province $j$, and $\Pi_{j}$ is the overall labour productivity in host province $j$. The provincial overall labour productivity is measured as total valueadded (approximated by GDP) over total employees in each province.

Openness of provinces to the outside world. The level of openness of an economy indicates the intensity of economic interactions between it and the rest of the world. A higher level of openness represents a higher level of international exposure of an economy. Through trade, international business generally lays the ground for inward FDI and the international production that serves to substitute for or complement trade (UNCTAD 2002). In this study, we use two indicators for the openness of an 
economy - the trade to GDP ratio (TGDP) and the export to GDP ratio (EGDP). We expect the level of provincial openness have a positive impact on FDI inflows.

The level of accumulated FDI. Previous studies have found the level of accumulated FDI stock to be an important factor explanator of current FDI inflows (Chen Chunlai, 1997a, 1997b; Petri 1995; Dobson 1993; Mody and Shrinivasan 1991). On the basis of these previous studies, we argue that the level of accumulated FDI stock may have certain demonstration effects on the investment location decision of foreign investors. Consequently, our hypothesis is that a higher level of accumulated FDI stock indicates an overall better investment environment, which may generate demonstration effects and induce higher levels of FDI inflows. Thus, we expect the level of accumulated FDI stock to have a positive effect on attracting new FDI inflows. A province's accumulated FDI, denoted as FDIS, is its FDI inflows accumulated since 1983 at 1995 US dollar prices.

\section{Infrastructure and energy supply}

Intensity of transport infrastructure in host province. The level of transport infrastructure in each host province might be another important consideration for foreign investors. We expect relative length of highways, more railways and interior transport waterways to be positively related to FDI inflows. The proxy for the intensity of transport infrastructure used in this study is the ratio of the sum of the length of highways, railways and interior transport waterways divided by the size of the corresponding host province, denoted as TI. The unit of the intensity of transport infrastructure is kilometres per 100 square kilometres of the host province's land area.

Level of telecommunications of host province. Another important infrastructure variable might be level of telecommunications. Higher levels of telecommunications save time and reduce the costs of communication and information gathering, thus facilitating business activities. Therefore, we expect a province's level of telecommunications to be positively related to its FDI inflows. The level of telecommunications, denoted as TELCOM, is measured by the number of telephone sets per 100 persons in each province.

Energy supply of host province. Energy supply is an important input in many production activities. Therefore, it is expected that energy supply will be positively related to FDI inflows, particularly for manufacturing and efficiency-seeking FDI. In this study, we use electricity production, denoted as EL, as a proxy for energy supply. It is measured by $\mathrm{kWh}$ per capita. 


\section{Human resource endowment and labour quality}

Labour quality in host province. Since labour quality is directly related to labour productivity, it may be another important labour market variable affecting foreign investors' location decisions. In this study we use two measures for labour quality. One is the percentage of the population 15 years or older who are illiterate and semi-literate; the other is the percentage of the total population who are enrolled as university students. We expect the illiterate and semi-literate rate, denoted as NOREAD, to be negatively related to FDI inflows, and the university students enrolment rate, denoted as UNI, to be positively related to FDI inflows.

\section{Geographical location}

China is a large country with a very wide geographical distribution of provinces. Therefore, geographical location might also be an important factor affecting FDI inflows. As mentioned above, based on geographical location, China's 31 mainland provinces can be grouped into East (coastal), Central and West regions. The East coastal provinces are closest to the economic centres of the outside world. Therefore, we use a dummy variable, denoted as COAST, to test the impact of geographical location on FDI inflows. We give a value of one for the 12 provinces along the coastal line and a value of zero for the other provinces. ${ }^{4}$ We expect this dummy variable to have a positive impact on FDI inflows.

\section{Policy factors}

Since China adopted the open door policy more than two decades ago, increasing numbers of cities and areas have gradually opened up to attract FDI and an evolving series of policies towards FDI has been implemented. Have these policies had any significant impact on provincial distribution of FDI inflow? In this study we do not intend to test all policies implemented during the study period. The FDI policies we do test are the Special Economic Zone (SEZ) policies, the uneven regional open policies, and the nationwide FDI promotion policies implemented since the 1990 s.

The uneven regional open policies for FDI were implemented from the establishment of the four SEZs in 1979, to the opening up the 14 coastal cities in 1984, and the expansion of open policies to the eleven coastal provinces in 1988. Not until the early 1990 s did the Chinese government gradually move towards a more even national implementation of open policies for FDI. The policy change in the early 1990 s removed the unfair competition for FDI between the coastal and inland regions, but also 
offered more preferential treatment to foreign investors generally. Preferential policies gradually shifted from favouring some locations to accommodating national and local industrial development policies. Now, any FDI project, as long as it is in line with state or local industrial policy and involves high or new technology, is entitled to preferential treatment, regardless of its location. Second, 52 cities, including all the inland provincial capitals (except Lhasa in Tibet and Urumqi in Xinjiang) and the areas along the Yangzi River,were granted the same preferential policies given to the 14 coastal cities. Third, more than 15 border cities and counties in the southwest, northwest, north and northeast of China were declared open border cities. Fourth, FDI was allowed in certain service industries, such as aviation, telecommunication, banking, insurance and retail trade. Fifth, in order to further develop foreign trade and processing industries in the coastal areas, more duty free bonded zones were planned. Sixth, the government allowed foreign business people, both those intending to set up FDI firms at a later stage and land developers, to buy land use rights for building infrastructure, including residential, commercial, industrial and recreational real estate (Liu Xiangdong et al. 1993; United Nations 1994; Wei Jia 1994).

Since 1997, to reduce the negative impact of the East Asian financial crisis, the Chinese government introduced a series of FDI promotion policies, including the extension of import duty-free treatment of imported equipment for foreign investors, more preferential taxation and other financial policies to encourage foreign investors to invest in targeted industries and the West region further loosened restrictions on FDI in service sectors. The aim was not only to attract more FDI inflows into China but also to encourage foreign investors to invest in certain industries and regions in accordance with China's national economic development strategy (MOFTEC 1997, 1999).

China has made substantial commitments in trade and investment liberalisation with its accession to the WTO, which will have a positive impact on FDI inflows into China's economy.

Three dummy variables, denoted as SEZ, ROP and P, for the Special Economic Zone policy, the regional open policy and FDI promotion policies implemented since the 1990s, are tested for their impact on the inflow of FDI. For the dummy variable SEZ, we give a value of one for Guangdong, Fujian, Hainan and Shanghai, and a value of zero for other provinces. For the dummy variable ROP, we give a value of one for the 12 eastern provinces from 1986 to 2002, and values of zero from 1986 to 1991 and one from 1992 to 2002 for other provinces. For the dummy variable $P$, 
we give a value of zero for the years from 1986 to 1991 and a value of one for the years from 1992 to 2002 for all provinces.

\section{LOCATION DETERMINANTS OF FDI DISTRIBUTION WITHIN CHINA-AN EMPIRICAL ANALYSIS}

\section{Variable specification and the model}

The relationship between inflows of $\mathrm{FDI}$ and location variables in China's provinces is investigated over time and across provinces. The Kmenta Model, an approach (Pool) designed especially for pooled time-series and cross-section data in the SHAZAM econometrics computer program is used. As this method applies the Generalised Least Square (GLS) technique to pooled data, taking time-wise autocorrelation and cross-sectional heteroskedasticity into account, it will produce a more efficient regression estimation than other methods. Furthermore, with the pooled data, the observations are much larger than would be the case if just timeseries or cross-sectional data were employed. Consequently, the reliability of the estimates of the regression parameters can be greatly increased.

Data on 29 provinces for the period 1986-2002 are included. ${ }^{5}$ In this study, the dependent variable, denoted as $\mathrm{FDI}_{\mathrm{r}_{\mathrm{j}, \mathrm{t}}}$, is the aggregate inflow of actual FDI from all source countries and economies into China's host province j in year t. The value of FDI is at constant 1995 US dollar prices. There are 16 independent variables, as summarised in Table 12.4.

We establish the following equation to test the location determinants of the provincial distribution of FDI inflows into China.

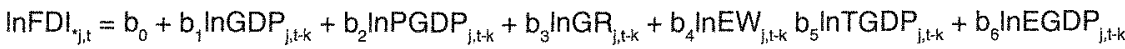

$$
\begin{aligned}
& +b_{7} \operatorname{InFDIS} S_{j, k-k}+\left.b_{8} \operatorname{lnT}\right|_{j,-k}+\left.b_{9} \operatorname{InTELCOM}\right|_{j, t-k}+b_{10} \ln E L_{j, k-k}+b_{11} \ln U N_{j, t, k} \\
& +b_{12} \operatorname{InNOREAD~}_{j, t-k}+b_{13} \text { COAST }_{j}+b_{14} S_{14} Z_{j}+b_{15} R^{2} P_{j, t}+b_{16} P_{t}+e_{j, t}
\end{aligned}
$$

where $e_{j, t}$ is stochastic disturbance, the $b s$ are the regression parameters to be estimated, and the variables are as defined above. The estimated coefficients of all variables except the dummy variables will be elasticities.

The independent variables, except for the dummy variables, are lagged $k$ years. This model assumes that the effect of the independent variables at time $t-k$ appears only within period $t$ and is fully completed within that period. The relationship shown in the above equation will be examined for $k=1$, the most likely appropriate lag. 
Table 12.4 List of variables of provincial FDI inflow equation

\begin{tabular}{|c|c|c|}
\hline Variable name & Specification of variables & $\begin{array}{l}\text { Expected impact } \\
\text { on } \mathrm{FDl} \text { inflow }\end{array}$ \\
\hline \multicolumn{3}{|c|}{ Dependent variable } \\
\hline $\mathrm{FDI}_{\mathrm{y}, \mathrm{s}}$ & $\begin{array}{l}\text { Aggregate FDI inflows from all source countries } \\
\text { into province } \mathrm{j} \text { in year t. Million US dollars at } 1995 \\
\text { constant prices. }\end{array}$ & \\
\hline \multicolumn{3}{|c|}{ Independent variables } \\
\hline $\mathrm{GDP}_{\mathrm{h}, \mathrm{t}}$ & $\begin{array}{l}\text { GDP of province } j \text { in year t. Renminbi million yuan } \\
\text { at } 1995 \text { constant prices. }\end{array}$ & Positive \\
\hline$P$ DDP $_{i, t}$ & $\begin{array}{l}\text { Per capita GDP of province } \mathrm{j} \text { in year t. Renminbi } \\
\text { yuan per capita at } 1995 \text { constant prices. }\end{array}$ & Positive \\
\hline $\mathrm{GR}_{\mathrm{i}, \mathrm{t}}$ & Real growth rate of GDP of province j in year $t$. & Positive \\
\hline$E W_{i, t}^{n+1}$ & Efficiency wage of province $\mathrm{j}$ in year $\mathrm{t}$. & Negative \\
\hline$T / G D P_{j, t}$ & Total trade to GDP ratio of province $j$ in year $t$. & Positive \\
\hline$E / G D P_{j, t}$ & Export to GDP ratio of province $\mathrm{j}$ in year $\mathrm{t}$. & Positive \\
\hline $\mathrm{FDIS}_{\mathrm{l}, \mathrm{t}}$ & $\begin{array}{l}\text { Accumulated FDI stocks of province j at the end } \\
\text { of year t. Million US dollars at } 1995 \text { constant prices. }\end{array}$ & Positive \\
\hline$T I_{j, t}$ & $\begin{array}{l}\text { Transport intensity index of province } j \text { in year t. } \\
\text { Kilometres per } 100 \text { square kilometres. }\end{array}$ & Positive \\
\hline TELCOM $_{\mathrm{j}, \mathrm{t}}$ & $\begin{array}{l}\text { Level of telecommunications of province } j \text { in year t. } \\
\text { Number of telephone sets per } 100 \text { persons. }\end{array}$ & Positive \\
\hline $\mathrm{EL}_{\mathrm{j}, \mathrm{t}}$ & $\begin{array}{l}\text { Level of electricity supply of province j in year t. } \\
\text { kWh per capita. }\end{array}$ & Positive \\
\hline$U N I_{j, t}$ & $\begin{array}{l}\text { University students enrolment rate of province } \\
\mathrm{j} \text { in year t. }\end{array}$ & Positive \\
\hline NOREAD $_{\mathrm{j}, \mathrm{i}}$ & $\begin{array}{l}\text { Illiterate and semi-literate rate of population } 15 \\
\text { years or older of province } j \text { in year } t \text {. }\end{array}$ & Negative \\
\hline COAST $_{\mathrm{j}, \mathrm{t}}$ & $\begin{array}{l}\text { Geographical location dummy variable. One for } \\
\text { the } 12 \text { provinces located along the coastline, and } \\
\text { zero for other provinces. }\end{array}$ & Positive \\
\hline$S E Z_{3, t}$ & $\begin{array}{l}\text { Special Economic Zone dummy variable. One for } \\
\text { Guangdong, Fujian, Hainan and Shanghai, zero for } \\
\text { other provinces. }\end{array}$ & Positive \\
\hline $\operatorname{ROP}_{j, 1}$ & $\begin{array}{l}\text { Regional open policy dummy variable. One for the } 12 \\
\text { coastal economically opened provinces. Zero from } \\
1986 \text { to } 1991 \text { and one from } 1992 \text { to } 2002 \text { for other } \\
\text { provinces. }\end{array}$ & Positive \\
\hline$P_{t}$ & $\begin{array}{l}\text { Policy dummy variable. Zero for the years } 1986 \text { to } \\
1991 \text {, one for the years } 1992 \text { to } 2002 \text {. }\end{array}$ & Positive \\
\hline
\end{tabular}

Note: All the variables are calculated from the State Statistical Bureau, 1986-2002. Zhongguo TongjiNianjian, [China Statistical Yearbook]. 


\section{Regression results and explanations}

Table 12.5 shows the regression results of the provincial aggregate FDI inflow equation with the explanatory variables, except for the dummy variables, lagged 1 year $(k=1)$ for 29 provinces for the period 1986-2002.

Since there are 16 independent variables, before running the regression, we conducted a correlation test for the independent variables. We found the correlation coefficients between some of the independent variables to be very high. The high correlation between these independent variables may incur high multicolinearity problems if we enter all the independent variables into the same regression equation. Therefore, we split the original equation into two independent models. The result is shown in Table 12.5 (model 1 and model 2). By using the Chow test, the F-statistic is equal to 1.390 , which is less than the critical value (5.89 at 5 per cent level). Thus, we accept the $\mathrm{H}_{0}$ : the decomposition of the equation is reasonable. Furthermore, we split the original model into five independent models. By using a similar method, the F-statistic to be equal to 1.936 , which is less than the critical value (18.5 at 5 per cent level). Thus, we accept the $\mathrm{H}_{0}$ : the decomposition of the equation is valid. ${ }^{6}$

Therefore, we ran seven separate regressions each with a different set of explanatory variables. The seven models performed well. All regressions have relatively high explanatory power and all the independent variables have the expected signs and are statistically significant.

The regression results show that provincial differences in FDI inflows can be explained by differences in provincial location factors. The provincial market size (GDP), the level of economic development (PGDP), the growth rate of provincial economy (GR), the trade and export to GDP ratios (TGDP and EGDP), the level of accumulated FDI stock (FDIS), the intensity of transport infrastructure (TI), the level of telecommunications (TELCOM), the level of energy supply (EL) and the university student enrolment rate (UNI) are positive and statistically significant location determinants of the provincial distribution of FDI. Meanwhile, the provincial efficiency wage $(E W)$, the proxy for labour costs adjusted for productivity, and the provincial illiterate and semi-literate rates are negative and statistically significant location determinants affecting FDI inflows. The geographical location (COAST), the Special Economic Zone policies (SEZ), and the regional differentiation in the timing of implementing the open policies (ROP) for FDI have had a strong impact on the provincial distribution of FDI inflows into China. This indicates that, apart from economic factors, FDI inflows into the East region were enhanced by the geographical 
location advantage, the special policies to the SEZs, and the implementation of the uneven regional open policies for FDI during the 1980s. The gradual but obvious diffusion of FDI inflows into the inland provinces after 1992 is also partly due to the nationwide implementation of open policies for FDI since the early 1990 s. Finally, the series of FDI promotion policies ( $P$ ) implemented in the early 1990 s had strong positive effects on inflows of FDI into China across all provinces. Therefore, the sharp increase in the inflows of FDI into China since 1992 can be explained partly by the major favourable policy towards FDI made in the early 1990s and the trade and investment liberalisation that continued throughout the 1990s.

\section{INWARD FDI ATTRACTIVENESS INDEX OF CHINA'S PROVINCES}

With the empirical test results, we can construct the inward FDI attractiveness index for China's provinces using the provincial location factors affecting FDI inflows. We adopt the same method used by UNCTAD (2002). ${ }^{7}$ The provincial inward FDI attractiveness index is the average of the scores on fifteen variables (including three dummy variables) for each province. The scores for each variable, except the dummy variables are derived from using the following formula

$$
\text { Score }=\left(V_{1}-V_{\min }\right) /\left(V_{\max }-V_{\text {min }}\right)
$$

where $V_{i}=$ the value of a variable for the province $i$

$V_{\text {min }}=$ the lowest value of the variable among the provinces

$V_{\max }=$ the highest value of the variable among the provinces.

According to the above formula, for each variable the province with the lowest value is given a score of zero and the province with the highest value is given a score of one. For dummy variables, the province with the value of zero is given a score of zero and the province with the value of one is given a score of one.

The variables used in the calculation of the provincial inward FDI attractiveness index include provincial GDP, per capita GDP, real economic growth rate, cost adjusted productivity (the inverse of the efficiency wage), trade to GDP ratio, export to GDP ratio, accumulated FDI stock, level of transportation infrastructure, level of telecommunications, electricity supply, university student enrolment rate, literacy rate (the opposite of the illiteracy rate), and three dummy variables, that is, the location dummy variable of COAST, the special economic zone policy dummy variable of SEZ and the dummy variable of $P$ representing the trade and FDI liberalisation policies implemented since 1992. 


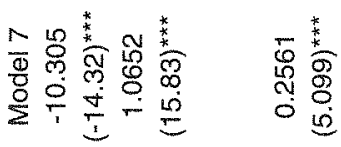

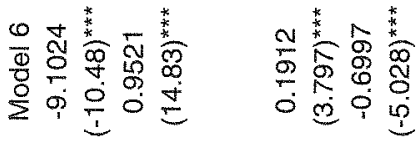

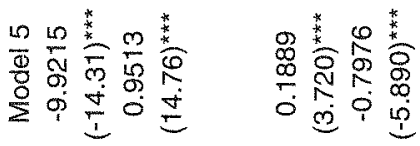

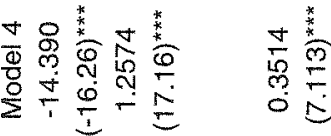

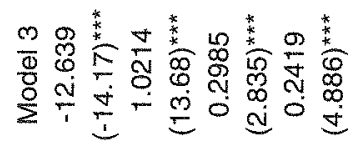

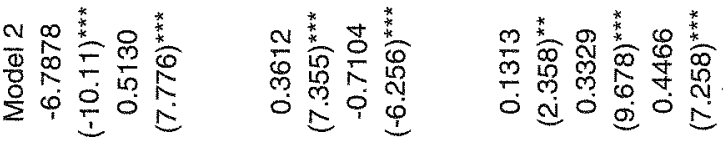

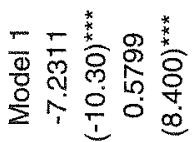

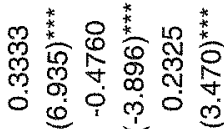

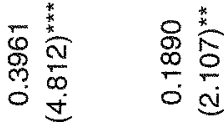

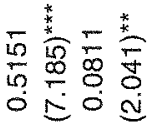

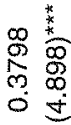

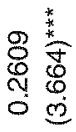

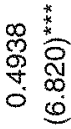

导 


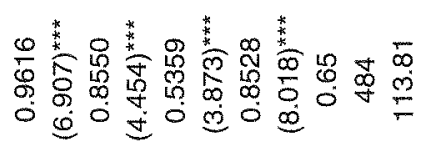

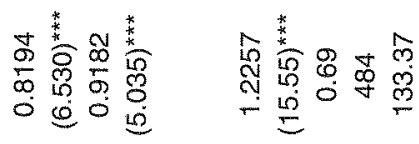

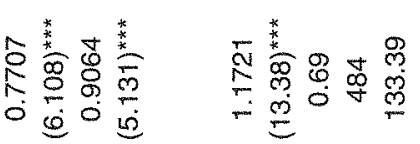

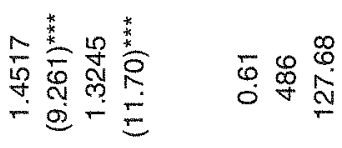

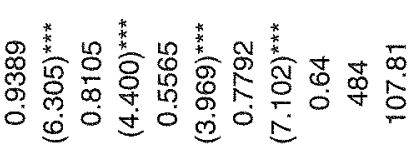

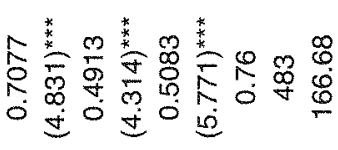

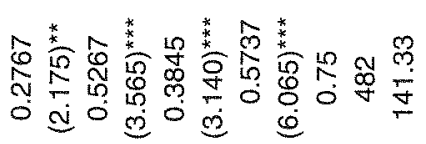

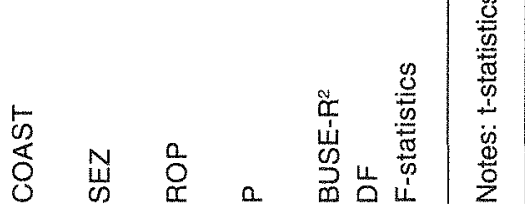


The provincial inward FDI attractiveness index is calculated for the four periods, 1985-89, 1990-94, 1995-99 and 2000-02 (Table 12.6). The interesting results of the calculation can be summarised as follows. First, index values among China's 31 mainland provinces differ greatly and are consistent with the provincial distribution of FDI inflows into China.

Second, for all four periods, Shanghai, Guangdong, Beijing and Tianjin have remained the top four provinces with the highest index values, while Tibet, Guizhou, Gansu, Yunnan and Qinghai have remained the bottom five provinces with the lowest index values.

Third, in terms of the inward FDI attractiveness index values, for all four periods, the top ten provinces are all located in the East region, while of the bottom ten provinces two are located in the Central region and eight in the West region. As a result, the East region has the highest index values, around two and two and a half times higher respectively than those in the Central and West regions.

Fourth, over time, the index values for all three regions and provinces have increased, indicating that for the last two decades or so, the investment environment for FDI has steadily improved across China. Among the provinces, the largest lifts in the ranks of the inward FDI attractiveness index are by Jiangsu and Zhejiang in the East region and Hubei in the Central region.

Finally, compared with the East region, although there has been some improvement in the investment environment for FDI, the Central and particularly the West regions still have very low FDI attractiveness in terms of location factors. On a comparable basis, the attractiveness to FDI of the Central and West regions lag 10-15 years behind that of the East region. Because the inward FDI attractiveness index values are largely based on structural economic factors that tend to change slowly over time, it is unrealistic to expect that the Central region and particularly the West region will attract large FDI inflows in the near future.

\section{CONCLUSION}

This paper has investigated empirically the provincial distribution of FDI inflows into China during the reform period, particularly since the late 1980s. The provincial distribution has been very uneven. The East region provinces received the overwhelming share, while the Central and West regions received only around 10 per cent of total FDI inflows into China during the period 1983-2002. The causes of 
Table 12.6 Provincial FDI attractiveness index $($ minimum $=0$, maximum $=1)$

\begin{tabular}{|c|c|c|c|c|c|c|c|c|}
\hline \multirow[t]{2}{*}{ Province } & \multicolumn{2}{|c|}{$1985-89$} & \multicolumn{2}{|c|}{$1990-94$} & \multicolumn{2}{|c|}{$1995-99$} & \multicolumn{2}{|c|}{$2000-02$} \\
\hline & Value & Rank & Value & Value & Rank & Rank & Value & Rank \\
\hline East region & 0.40 & 1 & 0.48 & 1 & 0.51 & 1 & 0.52 & 1 \\
\hline Beijing & 0.53 & 3 & 0.58 & 3 & 0.60 & 3 & 0.62 & 3 \\
\hline Tianjin & 0.45 & 4 & 0.49 & 4 & 0.57 & 4 & 0.61 & 4 \\
\hline Hebei & 0.28 & 10 & 0.33 & 11 & 0.38 & 10 & 0.37 & 11 \\
\hline Liaoning & 0.42 & 5 & 0.43 & 8 & 0.44 & 8 & 0.45 & 8 \\
\hline Shanghai & 0.65 & 1 & 0.76 & 1 & 0.81 & 1 & 0.83 & 1 \\
\hline Jiangsu & 0.37 & 7 & 0.43 & 7 & 0.50 & 6 & 0.53 & 5 \\
\hline Zhejiang & 0.32 & 9 & 0.41 & 9 & 0.45 & 7 & 0.48 & 7 \\
\hline Fujian & 0.38 & 6 & 0.49 & 5 & 0.54 & 5 & 0.51 & 6 \\
\hline Shandong & 0.32 & 8 & 0.40 & 10 & 0.43 & 9 & 0.45 & 9 \\
\hline Guangdong & 0.61 & 2 & 0.71 & 2 & 0.72 & 2 & 0.73 & 2 \\
\hline Guangxi & 0.21 & 15 & 0.29 & 12 & 0.29 & 14 & 0.27 & 16 \\
\hline Hainan & 0.25 & 11 & 0.45 & 6 & 0.38 & 11 & 0.40 & 10 \\
\hline Central region & 0.18 & 2 & 0.24 & 2 & 0.27 & 2 & 0.27 & 2 \\
\hline Shanxi & 0.17 & 19 & 0.24 & 17 & 0.27 & 16 & 0.27 & 15 \\
\hline Inner Mongolia & 0.17 & 21 & 0.22 & 20 & 0.24 & 20 & 0.27 & 17 \\
\hline Jilin & 0.22 & 12 & 0.27 & 14 & 0.28 & 15 & 0.30 & 14 \\
\hline Heilongjiang & 0.22 & 13 & 0.28 & 13 & 0.31 & 13 & 0.30 & 13 \\
\hline Anhui & 0.15 & 25 & 0.21 & 23 & 0.25 & 19 & 0.23 & 24 \\
\hline Jiangxi & 0.16 & 24 & 0.21 & 22 & 0.24 & 21 & 0.23 & 26 \\
\hline Henan & 0.18 & 17 & 0.23 & 18 & 0.27 & 17 & 0.27 & 18 \\
\hline Hubei & 0.21 & 14 & 0.27 & 15 & 0.31 & 12 & 0.30 & 12 \\
\hline Hunan & 0.18 & 18 & 0.22 & 19 & 0.26 & 18 & 0.25 & 20 \\
\hline West region & 0.13 & 3 & 0.18 & 3 & 0.20 & 3 & 0.21 & 3 \\
\hline Chongqing &.. & & . & & .. & & 0.23 & 25 \\
\hline Sichuan & 0.16 & 23 & 0.21 & 21 & 0.23 & 25 & 0.23 & 27 \\
\hline Guizhou & 0.09 & 29 & 0.14 & 29 & 0.17 & 29 & 0.18 & 29 \\
\hline Yunnan & 0.13 & 27 & 0.17 & 26 & 0.20 & 26 & 0.18 & 30 \\
\hline Tibet & 0.01 & 30 & 0.09 & 30 & 0.14 & 30 & 0.14 & 31 \\
\hline Shaanxi & 0.18 & 16 & 0.20 & 24 & 0.23 & 24 & 0.24 & 22 \\
\hline Gansu & 0.13 & 26 & 0.15 & 28 & 0.18 & 27 & 0.19 & 28 \\
\hline Qinghai & 0.11 & 28 & 0.16 & 27 & 0.18 & 28 & 0.23 & 23 \\
\hline Ningxia & 0.16 & 22 & 0.20 & 25 & 0.23 & 23 & 0.26 & 19 \\
\hline Xinjiang & 0.17 & 20 & 0.24 & 16 & 0.24 & 22 & 0.25 & 21 \\
\hline
\end{tabular}

Source: Author's calculation. 
this uneven provincial distribution were made the subject of theoretical explanation and empirical investigation.

Using Dunning's 'OLI' explanation of the causes of FDI with a focus on location advantages, our empirical analysis has shown that given the ownership advantages of source countries and the incentives for their multinational enterprises (MNEs) to internalise their ownership advantages in order to reduce transaction costs, the location advantages or determinants of host provinces are crucial in attracting FDI inflows. In other words, given the same set of source countries, provincial differences in FDI inflows are determined by differences in the location advantages of host provinces. Therefore, the uneven provincial distribution of FDI inflows into China is caused by the differences in provincial location factors.

Strong support for the hypotheses set out in the fourth section of this chapter was provided by the empirical regression analysis. To summarise, the provinces with larger GDP, higher per capita income, higher rate of economic growth, higher level of openness represented by trade and export to GDP ratios, higher level of accumulated FDI stock, more intensive transport infrastructure, higher level of telecommunications, higher level of electricity supply, higher level of labour quality and R\&D potential represented by higher ratio of university student enrolment, and coastal location attracted greater FDI inflows. Meanwhile, higher labour costs approximated by efficiency wages and lower labour quality approximated by illiterate and semi-literate ratios deterred FDI inflows. In addition, the SEZ policies and regional differentiation in the timing of implementation of the open policies for FDI had a strong impact on the provincial distribution of FDI inflows. Finally, the implementation of a series of trade and FDI liberalisation policies in the 1990s had a very strong positive effect on FDI inflows into China across all provinces.

Based on the empirical analysis, we constructed the provincial inward FDI attractiveness index for mainland China's 31 provinces. There are large differences among China's 31 mainland provinces in the attractiveness to FDI inflows. The most attractive provinces are the East region provinces, particularly Shanghai, Guangdong, Beijing, Tianjin, Jiangsu, Fujian, Zhejiang and Shandong. Although there have been some improvements in their investment environments, the Central region provinces, and particularly the West region provinces, remain less attractive to FDI than the East. The East region will continue to attract most of the FDI inflows into China, and uneven regional distribution of FDI inflows into China will persist. 
Two important implications for the provincial distribution of FDI in China can be drawn from this study. First, it is essential for each of the provinces to boost economic growth, to increase per capita income, to increase interaction with the world economy, to enhance education and labour training, to raise labour productivity, and to improve basic infrastructure in order to attract more FDI inflows. Though this will not be easy for all of the provinces, especially not for economically backward provinces in the West region, it is crucial if they are to attract more FDI to accelerate economic development. Second, since China launched the overall economic reform in the late 1979, the economic growth rates of the East region provinces, which benefited from regionally biased special policies, have been much faster than those of the less developed inland and West region provinces. This unbalanced economic growth between the coastal and the inland and western provinces has led to uneven economic development and the widening of the income gap between them. Though policies open to FDI have been followed throughout China since 1992, differences between the East region provinces and the Central and West region provinces resulting from time lag of policy implementation will not be eliminated in the near future. To hasten the economic development of inland provinces, particularly the less developed western areas, China should

- shift the preferential policies for FDI from regional priority to industrial priority, in order to support those FDI projects engaged in export-oriented, technologically advanced, transportation, communication, energy and raw materials industries

- adjust its regional development strategy by offering special economic and industrial development policies to the Central and West regions (the launch of the 'West Region Development Strategy' in 1998 was an important step in the right direction)

- encourage coastal areas to transfer managerial skills and technology accumulated and obtained from attracting and utilising FDI to the inland regions in order to benefit fully from FDI nationwide.

\section{NOTES}

1 Shenzhen, Zhuhai, and Shantou in Guangdong Province, and Xiamen in Fujian Province.

2 Liaoning, Tianjin, Hebei, Shandong, Shanghai, Jiangsu, Zhejiang, Fujian, Guangdong and Guangxi.

${ }^{3}$ The East region includes Beijing, Tianjin, Hebei, Liaoning, Shanghai, Jiangsu, Zhejiang, Fujian, Shandong, Guangdong, Guangxi, and Hainan. The Central region includes Shanxi, Inner Mongolia, 
Jilin, Heilongjiang, Anhui, Jiangxi, Henan, Hubei, and Hunan. The West region includes Chongqing, Sichuan, Guizhou, Yunnan, Tibet, Shaanxi, Gansu, Qinghai, Ningxia, and Xinjiang.

4 The twelve coastal provinces are Beijing, Tianjin, Hebei, Liaoning, Shanghai, Jiangsu, Zhejiang, Fujian, Shandong, Guangdong, Guangxi, and Hainan.

5 Tibet and Chongqing are excluded from the test because of insufficient data. Tibet attracted only US\$20,000 FDI inflow in 1988 and Chongqing was separated from Sichuan in 1997.

6 I would like to thank Mr Sheng Yu for his help in conducting the tests.

7 Though UNCTAD names it the 'inward FDI potential index', I prefer to call it the 'inward FDI attractiveness index'.

\section{REFERENCES}

Balasubramanyam, V. and Greenaway, D., 1994. 'East Asian foreign direct investment in the EC', in V. Balasubramanyam and D. Sapsford (eds), The Economics of International Investment, Edward Elgar, Brookfield, Vermont:103-28.

Broadman, G. and Sun Xiaolun, 1997. 'The distribution of foreign direct investment in China', The World Economy, 20(3):339-61.

Chen Chien-Hsun, 1996. 'Regional determinants of foreign direct investment in mainland China', Journal of Economic Studies, 23(2):18-30.

Chen Chunlai, 1997a. The Location Determinants of Foreign Direct Investment in Developing Countries, Working Paper, 12, Chinese Economies Research Centre, University of Adelaide, Adelaide.

$\longrightarrow$ - 1997b. Provincial Characteristics and Foreign Direct Investment Location Decision within China, Working Paper 16, Chinese Economies Research Centre, University of Adelaide, Adelaide.

Coughlin, C., Terza, J. and Arromdee, V., 1991. 'State characteristics and the location of foreign direct investment within the United States', Review of Economics and Statistics, 73(4):675-83.

Dobson, W., 1993. Japan in East Asia: trading and investment strategies, Institute of Southeast Asian Studies, Singapore.

Dunning, J., 1993. Multinational Enterprises and the Global Economy, AddisonWesley, Wokingham, England.

MOFTEC, 1997. Tax Exemption Policies on Importation of Equipment by MOFTEC Enterprises with Foreign Investment, Foreign Investment Administration, Ministry of Foreign Trade and Economic Cooperation, Beijing. 
MOFTEC, 1999. Measures for Further Encouraging Foreign Direct Investment, Foreign Investment Administration, Ministry of Foreign Trade and Economic Cooperation, Beijing.

Hultman, C. and McGee, L., 1988. 'Factors influencing foreign investment in the US, 1970-1986', Rivista Internazionale di Scienze Economiche e Commerciali, 35(1011):1061-6.

Lim, D., 1983. 'Fiscal incentives and direct foreign investment in less developed countries', The Journal of Development Studies, 19(2):207-12.

Liu Xiangdong, He Cun, Lu Zheng, Fan Baoqing and Zhou Jie (eds), 1993. Zhongguo Duiwai Jingji Maoyi Zhengce Zhinan [Guide to China's Foreign Economic and Trade Policies], Jingji Guanli Chubanshe, Beijing.

Milner, C. and Pentecost, E., 1994. 'The determinants of the composition of US foreign direct investment in UK manufacturing', in V. Balasubramanyam and D. Sapsford (eds), The Economics of International Investment, Edward Elgar, Brookfield, Vermont:85-102.

Mody, A. and Shrinivasan, K., 1991. Trends and Determinants of Foreign Direct linvestment: an empirical analysis of US investment abroad, World Bank, Washington, DC (unpublished).

Nigh, D., 1985. 'The effect of political events on United States direct foreign investment: a pooled time-series cross-sectional analysis', Journal of International Business Studies, 16(1): 1-17.

Petri, P., 1995. 'The interdependence of trade and investment in the Pacific', in E. Chen and P. Drysdale (eds), Corporate Links and Foreign Direct Investment in Asia and the Pacific, Harper Educational Publishers, Pymble:29-55.

Riedel, J., 1975. 'The nature and determinants of export-oriented direct foreign investment in a developing country: a case study of Taiwan', Weltwirtschaftliches Archiv, 111(3):505-28.

Scaperlanda, A. and Mauer, L.,1969. 'The determinants of US direct investment in the EEC', American Economic Review, 59(4):558-68.

State Statistical Bureau, various years. Zhongguo Tongji Nianjian 1986-2002 [China Statistical Yearbook], Zhongguo Tongji Chubanshe, Beijing.

State Statistical Bureau, 1992. Zhongguo Duiwai Jingji Tongji Daquan 1979-1991 [China Foreign Economic Statistics 1979-91], China Statistical Information \& Consultancy Service Centre, Beijing. 
Torrisi, C., 1985. 'The determinants of direct foreign investment in a small LDC', Journal of Economic Development, 10(1):29-45.

United Nations, 1994. World Investment Report 1994: transnational corporations, employment and the workplace, United Nations Publications, New York and Geneva.

United Nations, 1995. World Investment Report 1995: transnational corporations and competitiveness, United Nations Publications, New York and Geneva.

United Nations, 2002. World Investment Report 2002: transnational corporations and export competitiveness, United Nations Publication, New York and Geneva.

Wei Jia, 1994. Chinese Foreign Investment Laws and Policies: evolution and transformation, Quorum Books, Westport, Connecticut.

Wei Shangjin, 1995. 'Attracting foreign direct investment: has China reached its potential?', China Economic Review, 6(2):187-99.

Wheeler, D. and Mody, A.,1992. 'International investment location decisions: the case of US firms', Journal of International Economics, 33(1-2):57-76.

Zhang Leyin, 1994. 'Location-specific advantages and manufacturing direct foreign investment in south China', World Development, 22(1):45-53. 


\section{3}

\section{The impact of urbanisation on economic growth}

\section{Xiaolu Wang and Ronald Duncan}

With only 0.3 hectares of arable land per farmer, China's agriculture has successfully fed its 1.2 billion people. Economic reform during the 1980 s accelerated agricultural growth and lifted farmers' incomes. Growth of farmers' incomes was, however, far slower than the rapid growth of the whole economy and urban income growth, especially in the 1990s, which resulted in larger rural-urban income disparities. Meanwhile, the rural population and labour force continued to account for the major part of China's total population and labour force, while the share of agricultural product in GDP fell.

\section{RURAL DEVELOPMENT AND RURAL-URBAN INCOME DISPARITY IN CHINA}

The agricultural sector (including farming, forestry, animal husbandry and fisheries) has experienced relatively fast growth since 1978, as compared with the pre-reform period: 4.8 per cent versus 2.7 per cent in terms of the average growth rate of valueadded (Table 13.1). In the reform period, development of the agricultural sector has solved the long-term problem of food shortages, rural incomes have increased substantially, and rural poverty has been reduced significantly.

In spite of the significant improvement in agricultural production, the agricultural sector's dominant role in the economy has been lost to the industrial and service sectors, due to rapid industrialisation during the past half century. The share of the 
agricultural sector in GDP declined from 51 per cent to only 14 per cent over the period 1952-2002. Meanwhile, because of its large share, and the continued growth of the rural population, the employment structure of the agricultural and nonagricultural sectors has changed far more slowly than the output structure. Agricultural employment accounted for 84 per cent of total employment in 1952, and 50 per cent in 2002. Over the same period, agricultural employment increased from 173 to 369 million. During the past half century, the share of the rural population in the national total has declined even more slowly: from 85 per cent in 1953 to 61 per cent in 2002 (Table 13.2). ${ }^{1}$

Agriculture remains the most important source of rural incomes (that is, as compared with the rural industrial sector, the services sector, and remittances of rural-urban migrants), but its importance has declined due to the significant changes in the production structure of the economy. Within agriculture, the share of farm

Table 13.1 Growth of the agricultural sector and rural population in the prereform and reform periods, 1952, 1978 and 2002

\begin{tabular}{lccc}
\hline & $\begin{array}{c}\text { Agricultural value-added } \\
\text { (billion Yuan) }\end{array}$ & $\begin{array}{c}\text { Agricultural worker } \\
\text { (million persons) }\end{array}$ & $\begin{array}{c}\text { Rural population } \\
\text { (million persons) }\end{array}$ \\
1952 & 34 & 173 & $505^{* *}$ \\
1978 & 68 & 283 & 790 \\
2002 & 209 & 369 & 782 \\
Growth 1953-78 & 2.7 per cent & 1.9 per cent & 1.8 per cent \\
Growth 1979-2002 & 4.8 per cent & 1.1 per cent & 0.0 per cent \\
\hline
\end{tabular}

Notes: *In 1952 constant prices, deflated by the Price Index of Agricultural Products. For the few years when the index is unavailable, the rural CPI is used instead. ${ }^{* *} 1953$ data.

Source: Calculated from National Bureau of Statistics, various years. Statistical Yearbook of China, Statistics Press, Beijing.

Table 13.2 Agricultural sector, share of GDP, employment and population, 1952-2002 (per cent)

\begin{tabular}{lccc}
\hline & GDP & Employment & Population \\
1952 & 51 & 84 & 85 \\
1978 & 28 & 70 & 82 \\
2002 & 14 & 50 & 61 \\
\hline
\end{tabular}

Source: Calculated from Table 13. 1 and National Bureau of Statistics, various years. Statistical Yearbook of China, Statistics Press, Beijing. 
income has also fallen (Table 13.3). Grain production remains the major farming activity, especially in less developed regions, although it is gradually being replaced by other farming activities.

During the pre-reform period-from the 1950s to the mid 1970s-movement of the agricultural population to non-agricultural sectors was hampered by the restrictive migration policies. However, rural industrialisation and urbanisation have increased since the adoption of market-oriented reforms. Such developments have provided close to 200 million additional non-agricultural jobs to rural workers in rural and urban areas over the past 24 years. Despite this, the number of farmers has increased, and there appears to be more surplus agricultural labour than ever.

Table 13.4 shows the changes in annual income per capita in rural and urban areas in the three regions (East, Centre and West) from 1980 to 2000. Rural income per capita was 47 per cent of urban income per capita in 1980. By 2000 , this ratio had fallen to 35 per cent. The rural-urban income disparity increased in all three regions, but most seriously in the least-developed West region, where the ruralurban income ratio fell from 45 to 30 per cent over this period. In 2000 , the average rural income per capita in the West region was 1713 Yuan (or US\$207), whereas the urban income in the region was 5642 Yuan.

\section{THE IMPACT OF DOMESTIC POLICIES AND INTERNATIONALISATION ON AGRICULTURE AND RURAL INCOMES}

Agricultural reform, begun in the late 1970s, broke the long-term stagnation in rural development and turned food shortages into surpluses. Grain production was initially stimulated by increases in state purchasing prices in 1979, and subsequently fuelled by the introduction of the Household Responsibility System in the early 1980s, which converted the collective-based production system into a household-based system. Between 1978 and 1984, grain output increased nearly 50 per cent.

However, grain production was never fully liberalised. It was subject to three prices at that time- the state quota and above-quota prices, and the market price. Market prices only played a role at the margin while the volume of state purchases remained large. Because of the rigidity of the controlled prices, the real prices of major grains fell significantly in the late 1980s, a period of high inflation (Wang 2001). As a result, output growth stagnated in the mid and late 1980s. In the early 1990s, however, grain output reached 440 million tons (compared with 400 million tons in the late 
Table 13.3 Agriculture as a source of rural income, 1990-2002 (per cent)

\begin{tabular}{lccc}
\hline & 1990 & 1995 & 2002 \\
Agr. share (rural income $=100$ per cent ) & 74 & 63 & 47 \\
Farming share (agr. output=100 per cent) & 65 & 58 & 55 \\
\hline
\end{tabular}

Source: NBS (National Bureau of Statistics), 2003. Statistical Abstract of China, Statistics Press, Beijing.

Table 13.4 Rural-urban income disparity, 1980 and 2000

(Chinese Yuan in current prices)

\begin{tabular}{lccccccc}
\hline & Urban & $\begin{array}{c}1980 \\
\text { Rural }\end{array}$ & $\begin{array}{c}\text { Rural/urban } \\
\text { (per cent) }\end{array}$ & Urban & $\begin{array}{c}2000 \\
\text { Rural Rural/urban } \\
\text { (per cent) }\end{array}$ \\
East & 452 & 246 & 54.4 & 7940 & 3429 & 43.2 \\
Center & 386 & 191 & 49.5 & 5217 & 2091 & 40.1 \\
West & 383 & 172 & 44.9 & 5642 & 1713 & 30.4 \\
China & 413 & 193 & 46.7 & 6635 & 2301 & 34.7 \\
\hline
\end{tabular}

Note: incomes are calculated by the authors as weighted averages from urban disposable income and rural pure income at the provincial level.

Source: NBS (National Bureau of Statistics), 2000a, 2001. Statistical Yearbook of China, Statistics Press, Beijing.

1980s), probably because above-quota prices had become more flexible and moved closer to market prices.

The government attempted to liberalise the quota control system in grain production in 1993, but the policy was abandoned due to the sudden increase in market prices and supply shortages resulting from hoarding behaviour due to expectations of price increases. In place of the price liberalisation, the government increased the quota prices substantially between 1994-97 and also introduced a 'provincial governor responsibility system' to ensure local self-sufficiency of grain supply.

Stimulated by these measures, grain output increased by 15 per cent between 1994-98 and reached a historical high of 512 million tons in 1998. This level exceeded domestic demand and resulted in falls in market prices. From 1996 to 2000, the market prices of rice, wheat, corn and soybeans fell by 39-44 per cent, and remained low in 2001-02. Analysis has shown that the inflexibility of the government pricing system has caused serious price and output instability in grain markets (Wang 2001). 
Low grain prices had a seriously negative impact on farmers' incomes, especially the incomes of famers who relied heavily on grain production. Faced with this problem, the government decided in 1998 to purchase all traded grains at above-market prices. To limit the government subsidy, it was also decided that the retail price should not be lower than the support price. To ensure this, grain markets were monopolised and private businesses were prohibited from purchasing grain from farmers.

This policy failed to protect farmers' incomes for several reasons. Most importantly, it was impossible to monopolise the already partially liberalised grain markets; therefore there was downward pressure on the purchase prices. Second, the role of policy executants given to the state grain companies conflicted with their role as profit makers. To make profits or avoid losses, they tended to undergrade the quality of the grain they were purchasing to avoid paying anything more than market prices. This system also resulted in rent-seeking behaviour by the state grain agents. Finally, even if consumer prices could be monopolised, demand for grain cannot be controlled by the state and any surplus grain could not be sold. As a result, either the state or farmers had to bear the ensuing huge losses.

As a result of these problems, grain markets were re-opened in eight east coast provinces in 2001-02. In 2003, the central government conducted an experiment in some areas, paying the margin between the market price and the support price directly to farmers as a lump sum, and liberalised the local grain market at the same time. However, the support price system remains in a number of provinces. This policy is in conflict with the liberalisation of imports resulting from China's accession to the WTO.

China entered the WTO in 2001 and made a commitment to open its food markets substantially. The average tariff rate for all agricultural products was reduced from 22 per cent to 17.5 per cent. Export subsidies on agricultural products were eliminated, and China accepted a tariff rate quota (TRQ) for imports of major grains at a tariff rate of 1 per cent. The quota was set at 18 million tons for 2002, increasing to 22 million tons by 2004. Any unused quota of the state trading companies is to be transferred to non-state trading companies. This means that once domestic prices exceed international prices, the quota will be usedautomatically, which will reduce price levels. The tariff rate for soybeans is only 3 per cent and there is no quota (WTO 2001).

The import quota is large compared with the historical level of imports. In the 1990 s, the average annual level of grain imports was nine million tons. Given that 
half of all grain output is consumed by farmers and does not enter the formal market, the size of the domestic grain market is about half of the total output. Therefore, the 2004 TRQ accounts for 11.9 per cent of the domestic grain market. It is estimated that full utilisation of the TRQ in the short run-that is, without the full working through of the adjustment to any price changes-could mean the loss of nine million farming jobs; or alternatively, it implies a significant decline in grain farmers' incomes (Wang 2002).

In 2001 and 2002, grain imports (including soybeans) totalled 17.4 and 14.2 million tons. These large imports prevented domestic grain prices from recovering their previous levels. Grain output fell from the 1999 level of 508 million tons to 462 and 453 million tons in 2001 and 2002 respectively. Clearly, without adjustments in the agricultural sector, increased grain imports will adversely affect farmers' incomes and widen the rural-urban income gap.

The WTO accession commitments provide great opportunities for reforming China's agricultural sector, which could lead to positive long-run impacts on farmers' incomes. The liberalisation should push agricultural activity towards China's comparative advantages, leading to higher efficiency. For example, in 2002 the area sown to grain fell by 2 per cent but grain output increased by 1 per cent. New breeds of soybean with higher quality and higher oil content were introduced (CCTV 2003). Output of other agricultural products increased significantly. Sugarcane and beetroots together increased by 16 million tons in 2002, a 19 per cent increase over the 2001 level. Tea and fruit production increased by 6 per cent and 4 per cent respectively. These developments indicate that further increases in efficiency in agricultural production are possible in response to the WTO challenge.

Although grain market deregulation and structural adjustment in the agricultural sector are important, more is needed to reduce the rural-urban income disparity significantly. Given the huge labour surplus in the agricultural sector, further policy adjustments are needed in order to accelerate the transfer of the redundant agricultural labour force to non-agricultural rural and urban sectors.

\section{RELATIONSHIPS BETWEEN RURAL INDUSTRIALISATION AND URBANISATION AND RURAL INCOMES}

During the economic reform period, particularly in the 1980s and early 1990s, dramatic developments occurred in the rural industrial sector (the township and village enterprise (TVE) sector) that made a major contribution to China's rapid 
economic growth (see World Bank 1996; Cai et al. 2000; Wang 2000). Employment in the TVE sector increased from 28 million to 135 million during 1978-96, accounting for more than one-quarter of the total rural labour force. TVEs produce at least onequarter of total industrial output. In the earlier period, most TVEs were collectively owned. Most TVEs have been privatised since the 1990s.

Development of the rural industrial and services sectors also made a great contribution to increases in farmers' incomes. Nearly half of all rural household income now comes from the industrial and services sectors. Figure 13.1 shows clearly that the level of rural income per capita in China's 31 provinces is closely related to provincial achievements in rural industrialisation (as indicated by the share of TVE employment in the rural labour force).

Rural industries experienced substantial growth in the 1980s, partly because the rural reform created a better market environment while the urban economy was still

Figure 13.1 Relationship between rural industrialisation and rural income, 2000

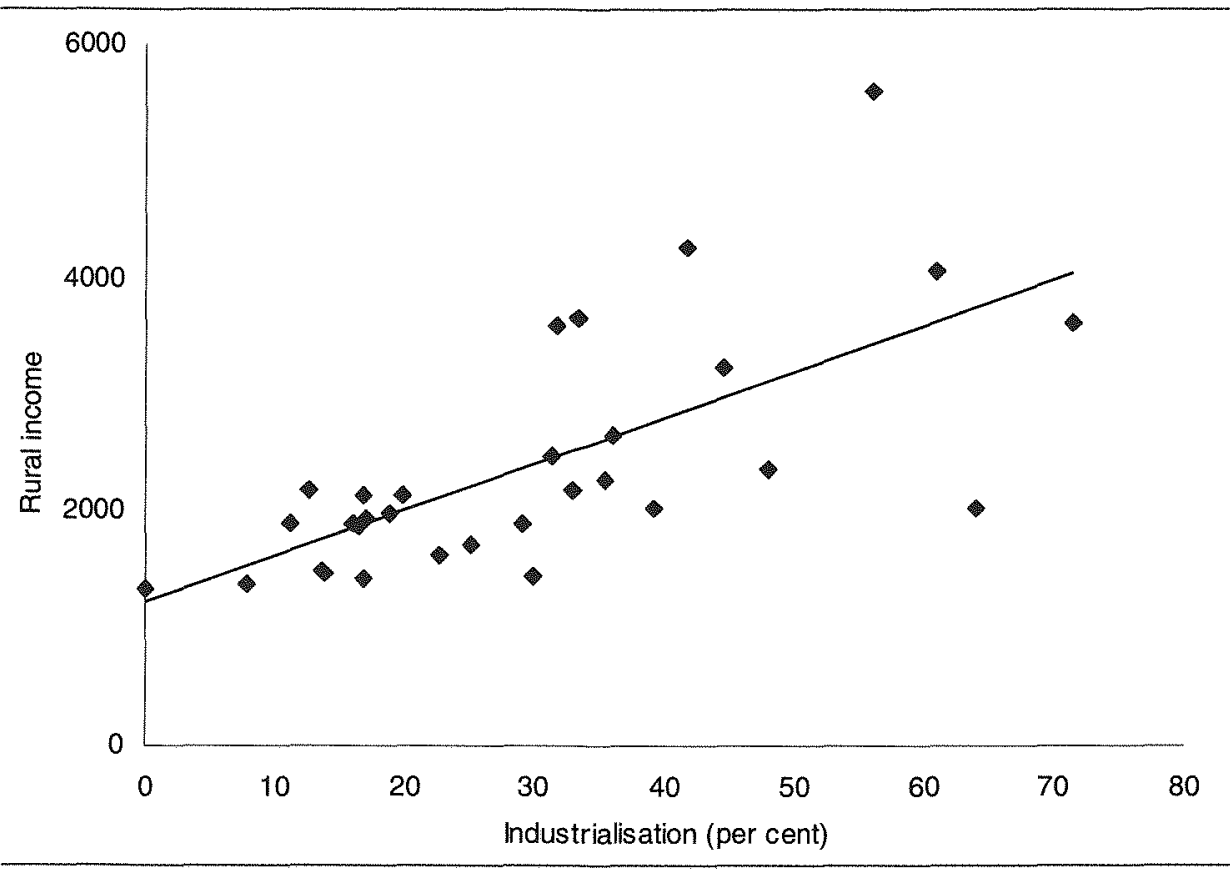

Note: Rural industrialisation is indicated by the share of TVE employment in rural labour, and rural income is defined as per capita rural pure income (yuan).

Source: Calculated from NBS (2000a, 2001). 
heavily subject to central control. Government policies also had an important influence during this period, encouraging development of TVEs in rural areas and discouraging rural-urban migration.

Development of rural industries slowed in the late 1990s, mainly due to sharper market competition, the unfavourable location of rural enterprises, difficulties in accessing external finance, and lack of infrastructure facilities, technical inputs, and human resources. Meanwhile, urbanisation accelerated. Large numbers of rural labourers migrated to urban areas in search of jobs. In 2001, the urbanisation rate (the ratio of urban to total population) in China reached 38 per cent, compared to 26 per cent in 1990 and 19 per cent in 1980. Increased availability of rural finance would help the development of rural industries. Nevertheless, the importance of rural industrialisation in the economy is likely to be replaced by urbanisation.

In spite of the acceleration of urban development, the urbanisation rate in China is on average 10-20 percentage points lower than in other countries at a similar income level (Wang and Xia 1999). In particular, there are relatively few medium and large cities given China's large population. In 2000, 121 million people, only 9.6 per cent of the national population, lived in cities of more than 0.5 million people. In the lessdeveloped West region, only 5.6 per cent of the population lived in cities of that size. If China had an urbanisation rate similar to that of other countries at the same income level, an additional 120-240 million people would be living in urban areas. ${ }^{2}$ This number may also be thought of as the excess supply of people in the rural economy.

The urbanisation rate and rural income of China's 31 provinces in 2000 suggests a positive relationship between rural income and urbanisation: provinces with a higher urbanisation rate have a higher rural income (Figure 13.2). This relationship may imply that urbanisation helps to liberate redundant rural labour from arable land and therefore increase agricultural productivity. Considering that half the Chinese labour force is still engaged in agricultural labour, further urbanisation is likely to have a significant impact on agricultural productivity.

\section{A CAUSALITY TEST ON THE IMPACT OF URBANISATION AND POLICY CONSIDERATIONS}

Urbanisation need not be the only explanation for the relationship (Figure 13.2); both urbanisation and higher rural incomes can be an outcome of economic growth. In the following, we introduce a growth model to test the causality between urbanisation and regional economic growth. This model has its origins in neoclassical growth 
models and endogenous growth models (see, for example, Solow 1956; Lucas 1988) but includes additional variables representing urbanisation.

$$
Y_{i t}=A+a^{7} K_{i t}+a^{2} H_{i t}+a^{3} D_{n i t}+a^{4} L+a^{5} U_{i t-1}+a^{6} D U_{i(t-1)}+\mu_{i t}
$$

where $Y_{i t^{t}} K_{i t^{t}} H_{i t^{t}} D_{i t}$ and $L_{i t}$ are growth rates of GDP, capital stock, human resources (indicated by workers' average years of schooling), cultivated land area and total employment, respectively, of the ith province in year $t . U_{i t-1}$ is the urbanisation rate with a one-year lag (the urbanisation rate used is the ratio of urban employment to provincial total employment). $D U_{i(t-1)}$ is the difference in $U_{i}$ between years $t-1$ and $t-$ 2. $\mu$ is the error term.

Lagged variables of $U$ and $D U$ are used for the causality test between urbanisation and economic growth. This specification identifies the effect of urbanisation on growth if either $U_{i t-1}$ or $D U_{i t-1}$ is positive and significant. Both $U_{i t-1}$ and $D U_{i t-1}$ are included in the model to distinguish between the possible growth effect (long-run effect) and the level effect (short-run effect) of urbanisation. A significant estimate of $U_{i t-1}$ indicates a continuing effect of urbanisation on growth (meaning that a higher urbanisation rate brings about higher productivity growth), whereas a significant estimate of $D U_{t-1}$ indicates an impact from changes in the urbanisation rate on growth, which is a short-run effect.

To impose the restriction of constant returns to scale $\left(a^{3}=1-a^{1}-a^{2}\right)$, both sides of Equation 13.1 were divided by $L_{t^{\prime}}$

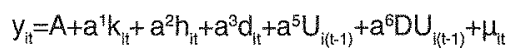

where $y, k, h$ and $d$ are $Y, K, H$ and $D$ divided by $L$, respectively.

To see the possible differences in the urbanisation effect at the different levels of economic development, $U_{i(t-1)}$ is replaced by three urbanisation variables for the East, Central and West regions in version 2 of the model. The East region is the most developed while the West region is the least developed of the three regions. Similarly, replacements are made to $D U_{i(t-1)^{\prime}}$.

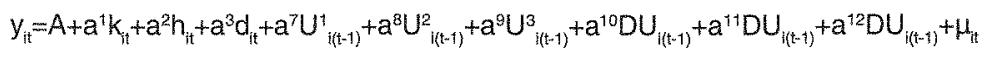

Panel data for 25 provinces covering the 20 years from 1979 to 1998 were used. The other six provinces were excluded due to incomplete data. Data were provided by Fang Cai and Dewen Wang (forthcoming) and the National Bureau of Statistics (StatisticalYearbook of China (various years) and 1999b). Capital stock was calculated from the historical data for capital formation in each province. 
Both fixed effects and random effects models were estimated. Hausman's test rejects the hypothesis that the random effects model is appropriate, therefore the results of the fixed eeffects model are reported in Table 13.5.

The two versions of the model produce similar results. Most coefficients are statistically significant at the 1 per cent level. According to version (13.1'), the elasticities of capital, human resources, employment and land with respect to economic growth are $0.348,0.431,0.205$ and 0.016 respectively, all in reasonable ranges. The elasticity of land is minor and insignificant, which is not surprising because the farming sector now contributes such a small share of total GDP and increased yields account for all of China's growth in agricultural output. The estimates of urbanisation $(U)$ are positive and significant. This result indicates that each percentage point increase in the urbanisation rate accelerates provincial economic

Figure 13.2 Relationship between urbanisation and rural household income, 2000

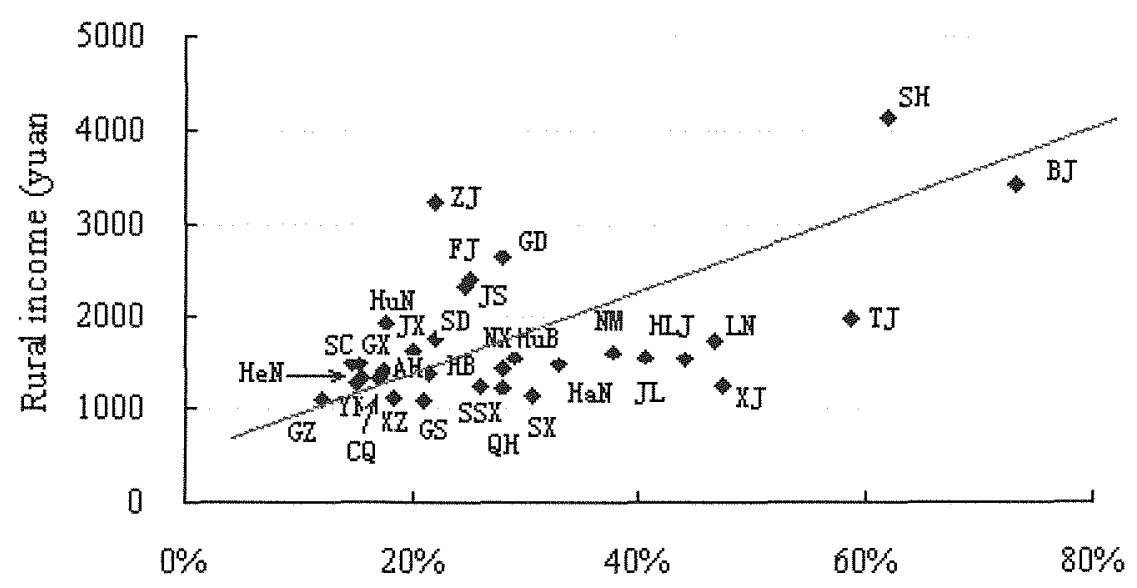

Urbanization rate

Note: The urbanisation rate used in this figure is the proportion of urban to total employment in each province. Symbols of provinces-BJ: Beijing, TJ: Tianin, HB: Hebei, SX: Shanxi, NM:

Neimenggu, LN: Liaoning, JL: Jilin, HLJ: Heilongjiang, SH: Shanghai, JS: Jiangsu, ZJ: Zhejiang, AH: Anhui, FJ: Fujian, JX: Jiangxi, SD: Shandong, HeN: Henan, HuB: Hubei, HuN: Hunan, GD:

Guangdong, GX: Guangxi, HaN: Nainan, CQ: Chongqing, SC: Sichuan, GZ: Quizhou, YN: Yunnan, XZ: Xizang, SnX: Shannxi, GS: Gansu, QH: Qinghai, NX: Ningxia, XJ: Xinjiang

Source: National Bureau of Statistics, 2001. Statistical Yearbook of China, Statistics Press, Beijing. 
growth by 0.37 percentage points over the already high 7-10 per cent growth rate. $D U$ is omitted from the model due to insignificant estimates in previous regressions. These results suggest that urbanisation has a long-run impact on economic growth.

For version 2, the results suggest a significant effect of urbanisation on economic growth in both the East and Central regions, but the effect is minor and insignificant for the less-developed West region. There may be two possible reasons for the latter result: the rate of urbanisation in the West has been low, and the urban economy in the West provinces, unlike the other regions, has not experienced much restructuring, and is therefore less market-oriented and less efficient.

In general, the results identify a contribution of urbanisation to economic growth via productivity changes. This implies that reallocating resources from rural to urban economies can result in higher growth rates in the productivity of the resources being reallocated. In addition, because this reallocation reduces the surplus labour in the rural sector, it can increase the productivity of the remaining rural labour and reduce the rural-urban income gap. Theoretically, this result would follow from an assumption of diminishing marginal product of labour in the rural sector.

The fact that urbanisation in China lags so far behind other countries is mainly a result of earlier central government policies restricting rural-urban migration and the growth of cities. Some of these restrictions have been removed over the past decade, but rural-urban migration is still partially restricted by the urban household registration

Table 13.5 Modelling results: urbanisation and economic growth

\begin{tabular}{lcccc}
\hline & \multicolumn{2}{c}{ Version $1^{\prime}$} & \multicolumn{2}{c}{ Version 2} \\
Variable & Coefficient & t-ratio & Coefficient & t-ratio \\
$\mathrm{k}$ & 0.3481 & $\left(8.891^{* *}\right)$ & 0.3552 & $\left(8.931^{* *}\right)$ \\
$\mathrm{h}$ & 0.4315 & $\left(5.122^{* *}\right)$ & 0.4261 & $\left(5.045^{* *}\right)$ \\
$\mathrm{d}$ & 0.0157 & $(0.903)$ & 0.0159 & $(0.911)$ \\
$\mathrm{U}_{\mathrm{t}-1}$ & 0.3753 & $\left(3.619^{* *}\right)$ & & \\
$\mathrm{U}^{1}$ & & & 0.3560 & $\left(2.698^{* *}\right)$ \\
$\mathrm{U}^{2}$ & & & 0.5525 & $\left(2.835^{* *}\right)$ \\
$\mathrm{U}^{3}$ & & & 0.0097 & $(0.031)$ \\
$\mathrm{Constant}^{*}$ & -0.0837 & $\left(-2.383^{*}\right)$ & -0.2119 & $\left(-2.265^{*}\right)$ \\
& Dependent var. & $\mathrm{y}$ & Dependent var. & $\mathrm{y}$ \\
& $\mathrm{R}^{2}$ & 0.3697 & $\mathrm{R}^{2}$ & 0.3726 \\
\hline
\end{tabular}

Note: $t$ ratios with * and ${ }^{* *}$ are significant at the 5 per cent and 1 per cent levels, respectively. Source: Estimation result. Original data are from NBS $(2001,1999 \mathrm{~b})$. 
system, job entry barriers, and non-access or harder access to services such as housing, schooling, health care benefits, and public security protection for rural migrants. The low level, or lack of, rural education, job training, and employment information services are also barriers to rural-urban migration. Policy changes to remove these restrictions, to improve rural education, and to provide government services in job training and employment information services are essential for accelerating urbanisation.

The current urban economies provide limited opportunities for rural migrants because the number of cities is limited, and their average size small. Expansion of the urban economy will provide more employment opportunities, especially in China's underdeveloped services sector, which accounts for a significantly higher percentage of GDP in the urban sector than the rural sector. It is the government's responsibility to improve urban planning and to provide urban infrastructure and public utilities in order to promote urban development. With these changes, many small cities and towns can be expected to become large or medium sized cities.

\section{CONCLUSION}

While China has experienced rapid economic growth in the reform period, rural incomes have grown slowly in recent years and the rural-urban income gap is growing. This outcome has been partly due to the non-market-oriented agricultural policies of the 1990s. WTO accession commitments have added new challenges for the rural economy and for agricultural policymaking. Reforms to liberalise the agricultural pricing system and promote market-oriented adjustment of the agricultural structure are essential, although they are not sufficient to yield significant reductions of the rural-urban income disparity.

The agricultural sector in China is seen as being labour-redundant, largely as the result of policies restricting the development of urban areas. These policies are also seen as a major reason for China's large and growing rural-urban income gap.

The urbanisation rate in China is far lower than in other countries at a similar level of GDP per capita. Our findings indicate that urbanisation has positive and significant effects on rural incomes and regional economic growth. Therefore, we recommend that urbanisation should be accelerated by deregulating rural-urban migration, developing urban infrastructure, improving rural education, job training, and enhancing the provision of employment information services. 


\section{NOTES}

1 Data used in this paper are from the National Bureau of Statistics (various years) unless otherwise noted

2 These calculations take into account estimates of the so-called 'floating population' that is living in urban areas but is still registered as rural.

\section{REFERENCES}

Cai Fang, Dewen Wang and Juwei Zhang, 2000. 'Economic growth in China: labour, human capital and employment structure', in Xiaolu Wang and Gang Fan (eds), The Sustainability of China's Economic Growth, Economic Science Press, Beijing. Cai Fang and Dewen Wang, forthcoming. 'Regional comparative advantage in China: differences, changes and its impact on regional disparity', in Xiaolu Wang and Gang Fan (eds), Regional Disparity in China: changing trends and influential factors, Economic Science Press, Beijing.

Lucas, R.E., 1988. 'On the mechanics of economic development', Journal of Monetary Economics, 22(1):3-42.

Ministry of Agriculture, various years. China Agricultural Development Report, Ministry of Agriculture, Beijing.

National Bureau of Statistics, various years. Statistical Yearbook of China, Statistics Press, Beijing.

- 2003. Statistical Abstract of China, Statistics Press, Beijing.

- 1999. Comprehensive Statistical Data and Materials on 50 years of New China, China Statistics Press, Beijing.

Solow, R.M., 1956. 'A contribution to the theory of economic growth', Quarterly Journal of Economics, 70(1):65-94.

Wang Xiaolu, 2000. 'The role of rural industrialization in China's economic growth', in Xiaolu Wang and Gang Fan (eds), The Sustainability of China's Economic Growth, Economic Science Press, Beijing.

2001. Grain Market Fluctuations and Government Intervention in China, Research Report for the ACIAR project 'China's Grain Market Policy Reform', The Australian National University, Canberra.

- 2002. 'The WTO challenge to agriculture', in R. Garnaut and L. Song (eds), China 2002: WTO entry and world recession, Asia Pacific Press, The Australian National University, Canberra:81-96. 
— and Xiaolin Xia, 1999. 'Optimum city size and economic growth', Economic Research, 9.

World Bank, 1996. The Chinese Economy: controlling inflation, deepening reform, World Bank, Washington, DC.

WTO (World Trade Organization), 2001. 'Accession of the People's Republic of China, Decision of 10 November 2001', World Trade Organization, Washington, DC. Available online at www.wto.org. 


\title{
14
}

\section{Trade reform, macroeconomic policy and sectoral labour movement}

\author{
Jennifer Chang and Rod Tyers
}

Although the Chinese economy continues to grow rapidly, since the late 1990 s there has been evidence of a slow down in per capita rural income growth. One explanation for this is that the relocation of labour from agriculture to manufacturing and services, essential in any growing developing economy, has been retarded. This could be due to policy disincentives designed to control urban congestion, such as the household registration or hukou system (lanchovichina and Martin 2002) or information asymmetries and transaction/infrastructural costs (Sicular and Zhao 2002). An alternative explanation is that comparatively poor performance in China's rural sector is due to economic reforms, and in particular to trade reform commitments made in the lead-up to the WTO accession (Anderson et al. 2002).

It is the central hypothesis of this chapter that this comparative decline in rural performance is due, at least in part, to a combination of China's adherence to a de facto fixed exchange rate regime and shocks that have tended to depreciate its real exchange rate. Most significant among these shocks was the surge of (largely illegal) outflows on the capital account and the associated private investment slowdown during the Asian financial crisis (Yang and Tyers 2001). Since then, however, numerous trade reforms have been implemented, all of which have tended to encourage Chinese consumption to shift towards foreign goods, thus reducing the price of home goods relative to pre-tariff prices of foreign goods and hence further depreciating the real exchange rate (Rees and Tyers 2002). 
By definition, a real depreciation must be accompanied either by a nominal depreciation, a domestic deflation, or a combination of both. The de facto peg to the US dollar has therefore necessitated China's deflation. When prices are falling there is downward pressure on wages. Even if wages fall only slightly more slowly than prices, however, other things being equal, employment growth in the wage sectors of the economy can be expected to decline. ${ }^{1}$ In the Chinese case this appears as high real wage growth but reduced labour demand growth in the modern sector and hence a 'bottling up' of workers in the rural sector and reduced rural income per capita.

This chapter examines the relevance of this story to China's comparatively poor recent per capita rural income growth performance using short and long-run comparative static analysis. The shocks considered are China's WTO accession commitments and the model used is a development of that introduced by Yang and Tyers (2000) and applied more recently by Rees and Tyers (2002). It is a multisector, multi-country comparative static macro model, the microeconomic components of which have their origins in GTAP. ${ }^{2}$ As in the application by Rees and Tyers, all countries have open capital accounts and forward-looking investor behaviour is represented in the short run via expectations formed from long-run simulations. The focus here, however, is on labour relocation and the short-run consequences of trade reform shocks for the uptake of labour in the manufacturing and services sectors. ${ }^{3}$ We examine the pace of such labour relocation historically and compare this with simulated changes in labour demand following WTO accession.

We observe a reversal in the rate of relocation of workers from agriculture to manufacturing after 1998 and a glut of workers in the rural sector (Dolven 2003). Our simulations confirm that the relocation slowdown has been been enhanced by China's broader macroeconomic policy regime. Indeed, the exchange rate regime, combined with capital controls, appears to have restricted the flow of workers into manufacturing and services by at least a full one per cent per year and into services by at least two per cent per year.

\section{Urban-rural inequality and worker relocation}

The pace of rural per capita income growth depends on the rate at which surplus labour is generated by agricultural change and the corresponding rate at which surplus workers in agriculture are absorbed into the manufacturing and services sectors. It is a common view that the economic reform of the early 1980 s, which brought de- 
collectivisation and the household responsibility system, along with associated increases in agricultural labour productivity, created a substantial rural labour surplus. ${ }^{4}$ Moreover, prior to that reform, wages were not market determined and there is evidence of considerable underemployment. This was due, in part, to the seasonal nature of agricultural activity, which meant that many workers were left idle in the off-peak parts of the agricultural cycle and yet were unable to take employment elsewhere (Banister and Taylor 1989).

An exacerbating factor on the supply side was rapid rural population growth in the pre-reform period. Even though rural population growth slowed in the 1970 s and 1980 s, the rural labour supply continued to grow strongly in the aftermath of the 'baby boom' periods of the 1950 s and 1960 s. $^{5}$ On the demand side, China's prereform economic strategy promoted relatively capital-intensive heavy industries. These two effects tended to raise underemployment in the rural sector, where, although rural communes were disbanded, all workers were still technically employed. ${ }^{6}$ The post-reform period therefore carried considerable potential for worker relocation from agriculture into other sectors. The subsequent volume of internal migration would depend, then, on economic incentives in the form of urban-rural income inequality and on both policy-induced and natural barriers to migration.

\section{Urban-rural inequality}

There is income inequality in China between urban and rural residents as well as within both urban and rural areas. Inequality also has a strong regional pattern, particularly between inland and coastal provinces. Of overall income inequality, Lozada (2002) estimates that 75-80 per cent is due to the urban-rural divide. Official estimates of the trends of rural and urban household incomes indicate a general upward trend in income for both areas while urban income has experienced comparatively sharp increases in the 1990s (Figure 14.1). The corresponding proportional difference between urban and rural household income is plotted in Figure 14.2. In the early 1980s, rural incomes grew relatively rapidly and there was a decline in urban-rural inequality. Since then, however, urban incomes have grown much more rapidly, most prominently since the early to mid $1990 \mathrm{~s}^{7}$

\section{Internal migration}

Were there no costs or barriers to internal migration, workers would be expected to respond to the widening income gap between rural and urban areas by migrating 
until wages were much closer. Although the estimated number of internal migrants has grown (by 100 million since the 1980s) these relocations have been insufficient to stem the growing inequality (Dolven 2003). Some of this apparent growth in inequality is due to a rise in skilled employment in urban areas, while some is due to reduced urban labour demand associated with real wage growth and to official migration barriers. Together, these factors appear to have left an expanding labour supply 'bottled up' in the rural sector. The key official barrier has been the Household Registration System (HRS).

Introduced in major cities in 1951 and extended to rural areas in 1955, the HRS was intended to deal with the escalating urban influxes of rural migrants at the time of the Great Famine of 1959-61 (Chan and Zhang 1999). The associated food shortages continued into the 1970s, only ending in the 1980s (Zhao 2000). The HRS

Figure 14.1 Per capita annual income of urban and rural households (yuan)

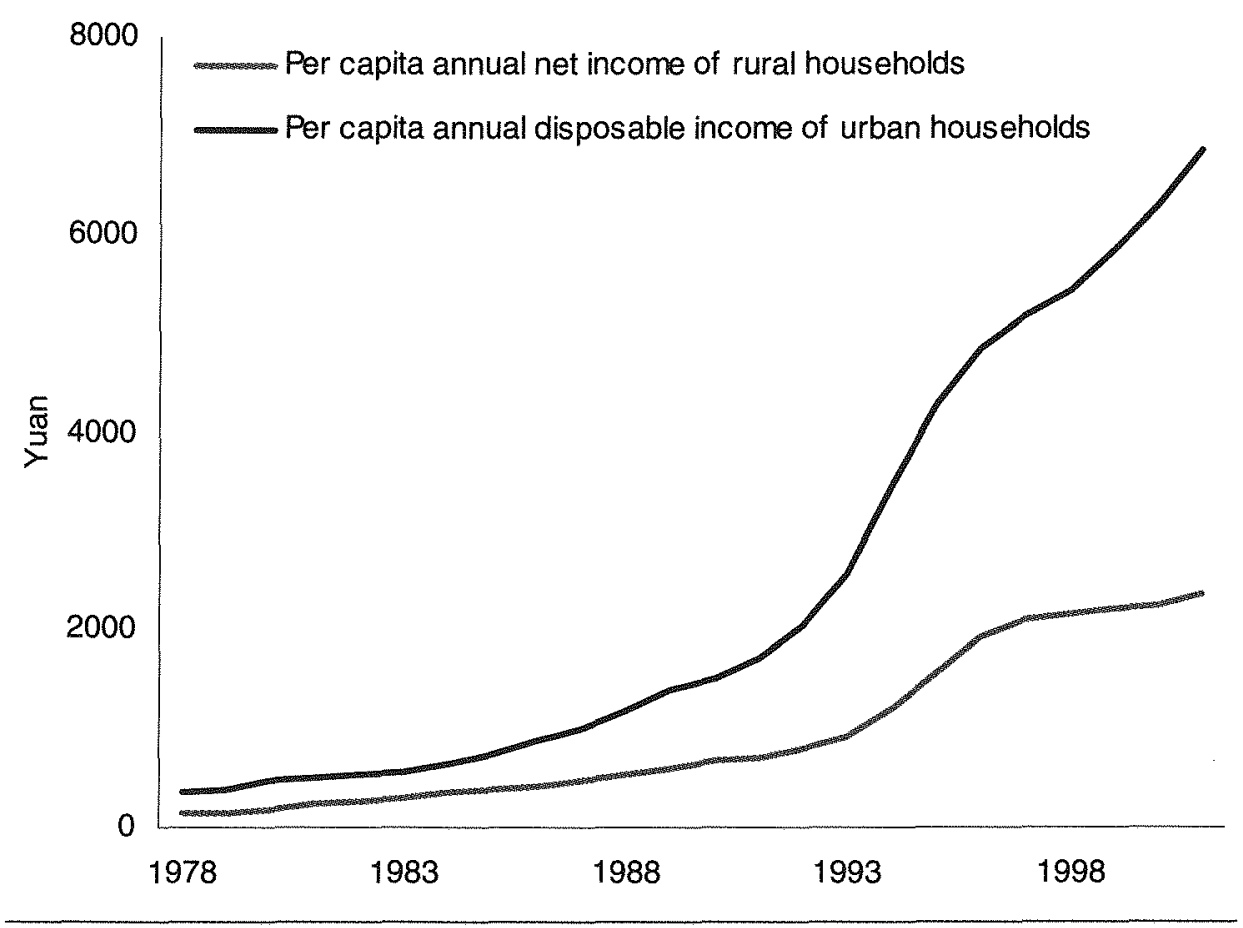

Source: National Bureau of Statistics, 2002. China Statistical Yearbook, 2002, China Statistics Press, Beijing. 
requires all citizens to register in their place of regular residence, often their birthplace. Moving from rural to urban areas requires a complex and costly application for a transfer to a local hukou. Prior to the reform in the 1980s this was a huge barrier, as without a proper hukou one would not qualify for government job assignment. Workers who ignored this requirement were denied social security benefits such as housing and other necessities, even food.

Decollectivisation in rural areas allowed income inequality to soften a little and non-farm rural industries to develop. This, and the household responsibility system that accompanied it, led to increased productivity in the agricultural sector. Thus, while rural incomes grew, so too did the proportion of workers considered redundant. ${ }^{8}$ The government began rewarding collective farms and cooperatives for production rather than quantified labour, so excess workers could be free to look for other jobs (Seeborg et al. 2000). The marketisation of food also meant that migrants were no longer restrained entirely by the need to obtain a local hukou to survive. Combined with the development of special economic zones and the increase in urban private and informal sectors, these conditions put the cities on a path of rapid development with growing demand for labour. Yet the HRS created ambiguous incentives for migrants. On the one hand it constrained people with access to land from migrating, since each was now responsible for his or her own land, which most saw as a form of social security (Chan 2000). On the other hand, individuals who had little or no access to land or who had specialised in what were to become low productivity rural activities were now less constrained.

Throughout the 1980s and 1990s, the HRS was gradually weakened by policy reforms and less stringent enforcement. Previously prohibited 'spontaneous' migration to jobs in urban centres was tacitly facilitated and tolerated, conditionally opening urban residency to rural workers and relaxing some of the strict controls. There has therefore been an increase in temporary urban migrants-workers going to cities and towns without official residential status, known as the 'floating population'. From the late 1980s onwards, transients made up over one-fifth of the population of such major cities as Beijing, Shanghai, and Guangzhou (Immigration and Refugee Board, Canada 2002). Many official restrictions remained, however, including the link between hukou status and welfare eligibility, the denial of education for migrant children and state job availability. In 1995, to re-assert control over internal migration, Zhao (2000) notes that tighter controls were imposed over the legality of urban residency and housing subsidies. ${ }^{9}$ 
As part of China's urbanisation strategy for the Tenth Five-Year Plan, Central Party Document No.11 of November 2000 allows a person and his or her immediate family to obtain urban hukous if he or she has fixed accommodation, stable work (in a job for more than one year) in the urban area. Urban hukou was also offered to those who would purchase a local commercial housing unit (to attract outside investment) and to holders of graduate degrees (attracting professionals). The focus of these reforms was still mainly small urban towns and small cities. Nonetheless, according to China's Committee to Restructure the Economy (SCORES), during 2001 about 600,000 rural residents acquired urban hukou in these small urban centres. More recently still, a State Council directive indicated that rural migrants have a legal right to work in cities. This directive prohibits job discrimination based on residency and orders that urban residency documents are to be provided to any

Figure 14.2 Gap between urban and rural incomes, 1978-2001 (per cent)

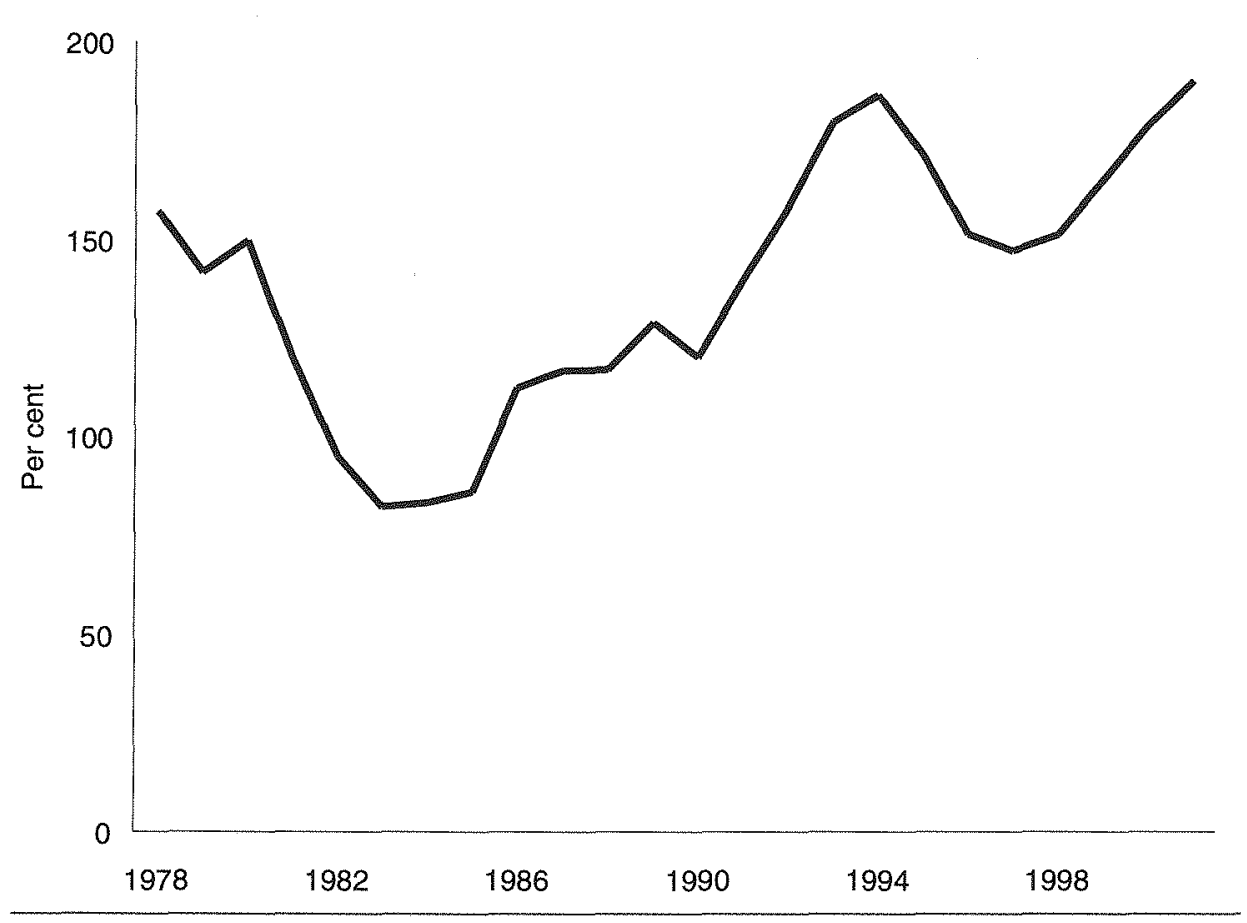

Source: Source: National Bureau of Statistics, 2002. China Statistical Yearbook, 2002, China Statistics Press, Beijing. 
workers who find employment. A further recent directive indicates that businesses should stop delaying wage payments to workers. This is a significant improvement for migrant workers as they often find that they are taken advantage of due to their uncertain legal status.

Official barriers to migration therefore appear to have had an ever diminishing effect in China, and least effect in the period since the Asian crisis of 1997. Other things being equal, then, we would expect an acceleration in the relocation of workers into jobs in the modern sector in that period. However, the evidence does not suggest that this has happened.

\section{Sectoral relocation of workers}

The early 1990s was a period of rapid industrial expansion during which workers relocated from the rural sector to the industrial and services sectors (Figure 14.3). Significantly, while the expected long-term rise in the share of services in total employment is borne out, industrial employment fell substantially during the Asian crisis period and failed to expand thereafter. Indeed, the farming and forestry sector shows annual declines in employment that peaked in 1993 and continued until 1996. In this period the Chinese economy grew at its highest rate ever. During the Asian crisis and in the period thereafter, however, relative declines in the growth rates of activity in manufacturing and services appear to have driven workers back to the rural sector. This back-flow appears to have continued in the post-crisis period.

\section{AGGREGATE PERFORMANCE SINCE THE ASIAN CRISIS}

In 1995, good weather and improved farming incentives brought a resurgence of the rural economy and the reform of state-owned industrial enterprises (SOES) was accelerated, precipitating substantial lay-offs (Meng 1998). These changed saving incentives, leading to a sudden increase in the private saving rate (Yang and Tyers 2000, 2001). The contractionary effects of these internal shocks were then worsened by the East Asian financial crisis, which saw the mostly illegal flight of a substantial part of China's additional private savings from the country, leading to a fall in private investment. At the same time, slowdowns and currency depreciations in other Asian economies made their exports relatively competitive, so that the dollar value of China's exports grew more slowly than in 1990-96 (Yang 1998).

Our macroeconomic policy story begins with the crisis and China's reaction to it. The shocks of that period-the rise in the domestic saving rate, the increased 
outflow on the capital account and the adverse change in the terms of tradedepreciated the real exchange rate. This can be seen from the following definition of the real bilateral exchange rate, for region $i$ with region $j$, as the common currency ratio of the price of a basket of region is goods and the price of a corresponding basket of region is goods:

$$
e_{i j}^{R}=E_{i j}\left(\frac{P_{i}^{Y}}{P_{j}^{Y}}\right)=\frac{P_{i}^{Y}}{\left(\frac{P_{j}^{Y}}{E_{i j}}\right)}
$$

where $E_{i j}$ is is nominal exchange rate with $j$, measured as foreign currency units per local unit, and the price index used is the GDP price, $P^{Y} .{ }^{10}$ This depreciates when the price of the basket of home goods falls relative to the corresponding basket of

Figure 14.3 Employment by industry group, 1990-2001 (million workers)

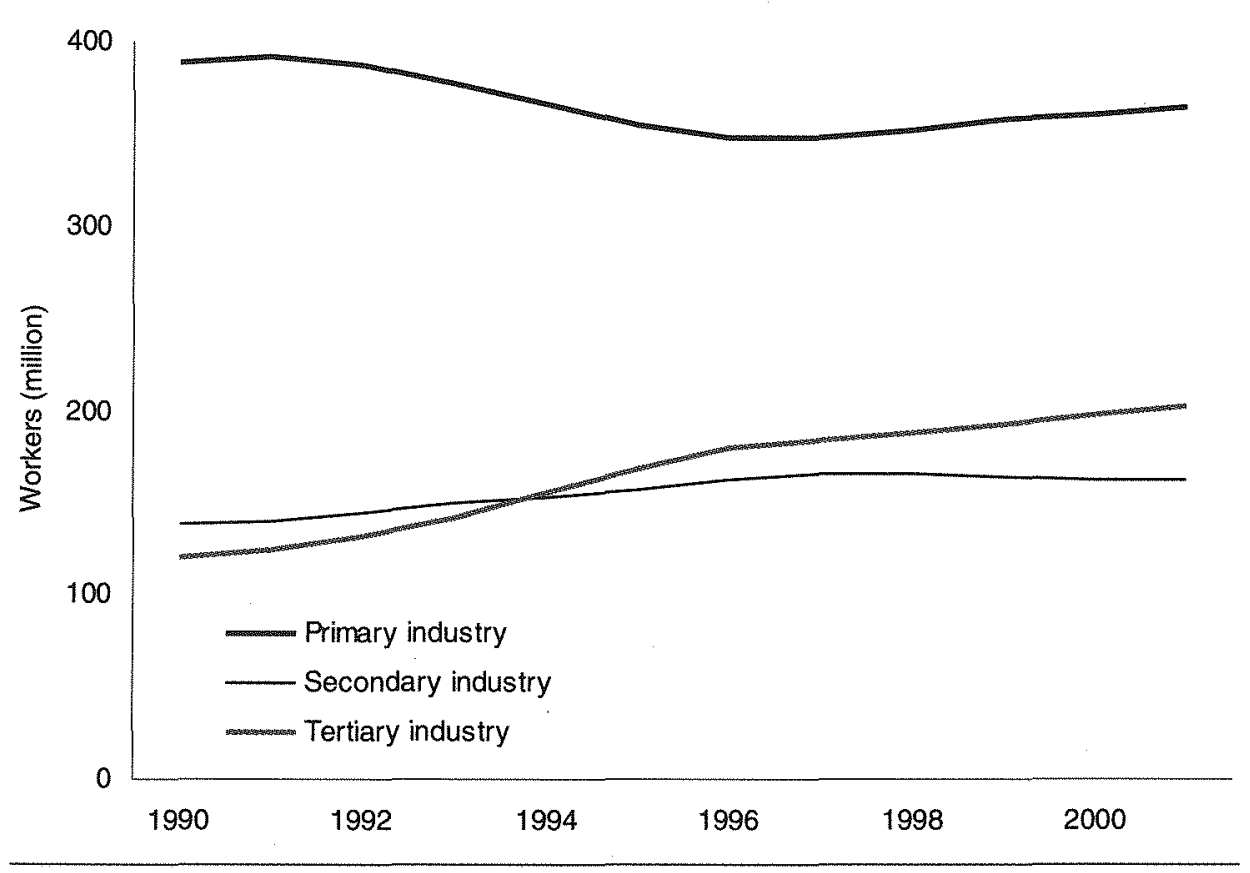

Source: National Statistical Bureau, 2002. China Statistical Yearbook (2002), China Statistics Press, Beijing. Primary industry: farming, forestry, animal husbandry and fishery. Secondary industry: mining, manufacturing, electricity, water, gas, construction. Tertiary: all other industries. 
foreign goods. The real depreciation during the crisis period, combined with the fixed nominal exchange rate, necessitated a monetary policy sufficiently restrictive to bring about a decline in the home price level relative to that in the United Statesa deflation. This was the first in a series of deflations in the crisis and post-crisis periods.

Shocks that cause real depreciations also include other elements of China's domestic reforms. By raising productivity, these factors reduce domestic costs relative to foreign costs and hence tend to reduce relative domestic prices. Similarly, trade reforms divert domestic demand away from home-produced goods towards imports and so they also tend to reduce the prices of domestic goods relative to the import prices of foreign goods. In the period 1997-2001, China embarked on substantial trade liberalisations, including the introduction of a duty drawback system on the imported inputs of export firms (Rees and Tyers 2002). Real depreciations due to such shocks would have occurred irrespective of China's exchange rate regime. But it is that regime which distributes the nominal effects of the real depreciations between falls in the home price level, or deflations, on the one hand and depreciations of the nominal exchange rate on the other.

The declines in China's prices indicate that, other things being equal, such deflations are contractionary (Table 14.1). ${ }^{11}$ This is because, even in the most flexible of industries, wage rates are renegotiated more rarely than product prices are adjusted. Lags in wage adjustment mean that deflation applies a profit squeeze that retards both employment growth and investment in the private sector. Consequently, real wage growth in China's modern sector has been extraordinarily high since 1996, (Figure 14.5) suggesting some deterrence of labour demand and overall growth in this sector. Weaker overall performance of the Chinese economy is indicated by its official GDP growth rates (Figure 14.4). These bottomed out in the crisis period at between seven and eight per cent per year, but have not recovered since.

Since 2001 China has embarked on a still more dramatic set of trade reforms as part of its WTO accession commitments. By themselves, these reforms will cause further real depreciations. Should there be no change in macroeconomic policy, growth and the relocation of workers into China's modern sector will continue to be retarded by deflation. In the remainder of the chapter we investigate the relationship between growth, labour relocation and macroeconomic policies in the aftermath of the WTO accession reforms. 
Figure 14.4 Official growth rate of real GDP, 1990-2001 (per cent)

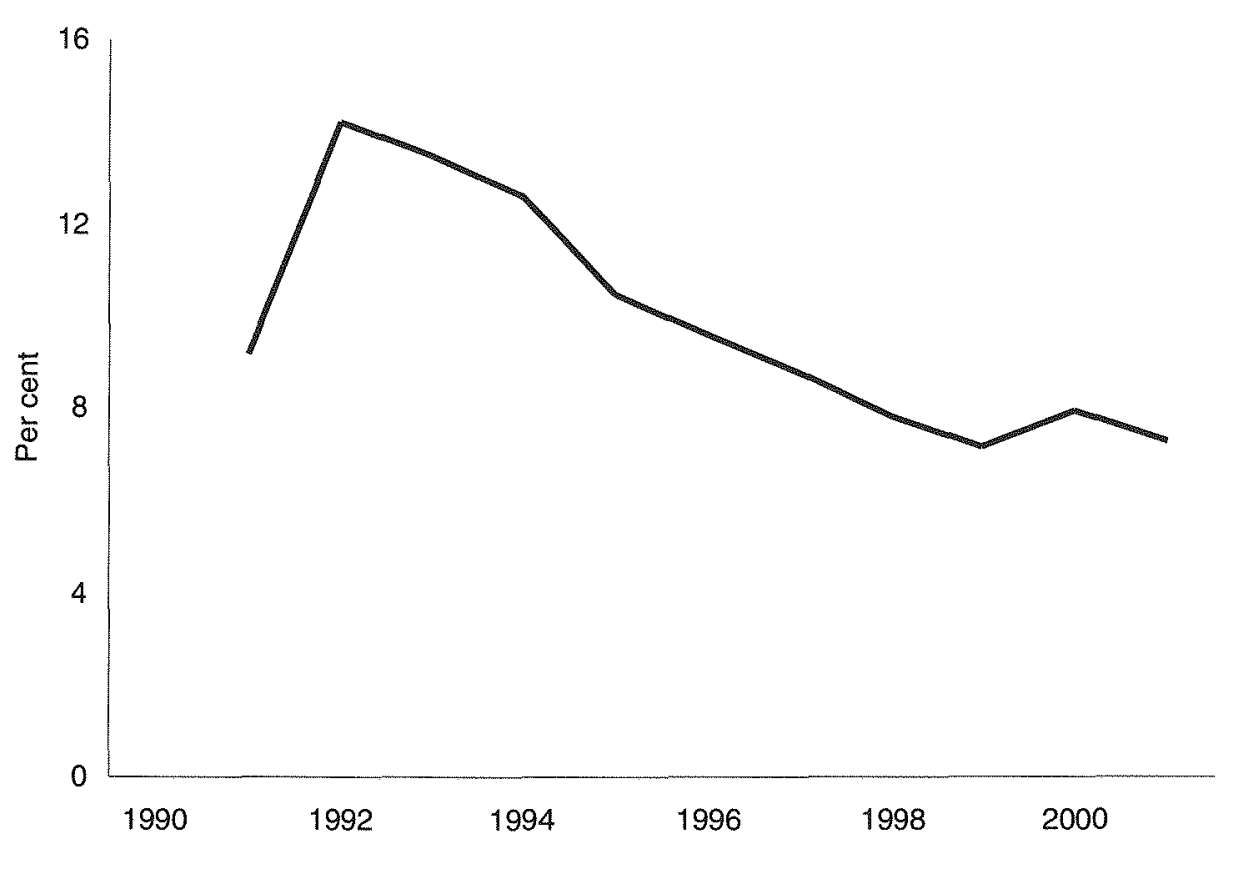

Source: National Statistical Bureau, 2002. China Statistical Yearbook 2002, China Statistics Press, Beijing.

\section{MODELLING EFFECTS OF TRADE POLICY REFORMS}

Here we complement the work of Rees and Tyers (2002) by simulating the short-run effects of trade reforms in China while accounting for the implications of services trade commitments as well as productivity changes associated with these reforms. As in Rees and Tyers (2002) and lanchovichina and Martin (2002), we make allowance for idiosyncratic trade policies, such as the duty drawbacks on imports used in the manufacture of exported goods. As befits a short-run analysis, we also allow for labour market rigidity and associated departures from full employment.

Following Yang and Tyers (2000), we use a comparative static global macroeconomic model, within which the microeconomic (supply) side is adapted from GTAP, ${ }^{12}$ a multi-region comparative static model in real variables with price-taking households and all industries comprising identical competitive firms. To this microeconomic 
Figure 14.5 Official growth rate of the average real manufacturing wage, 19962001 (per cent per annum)

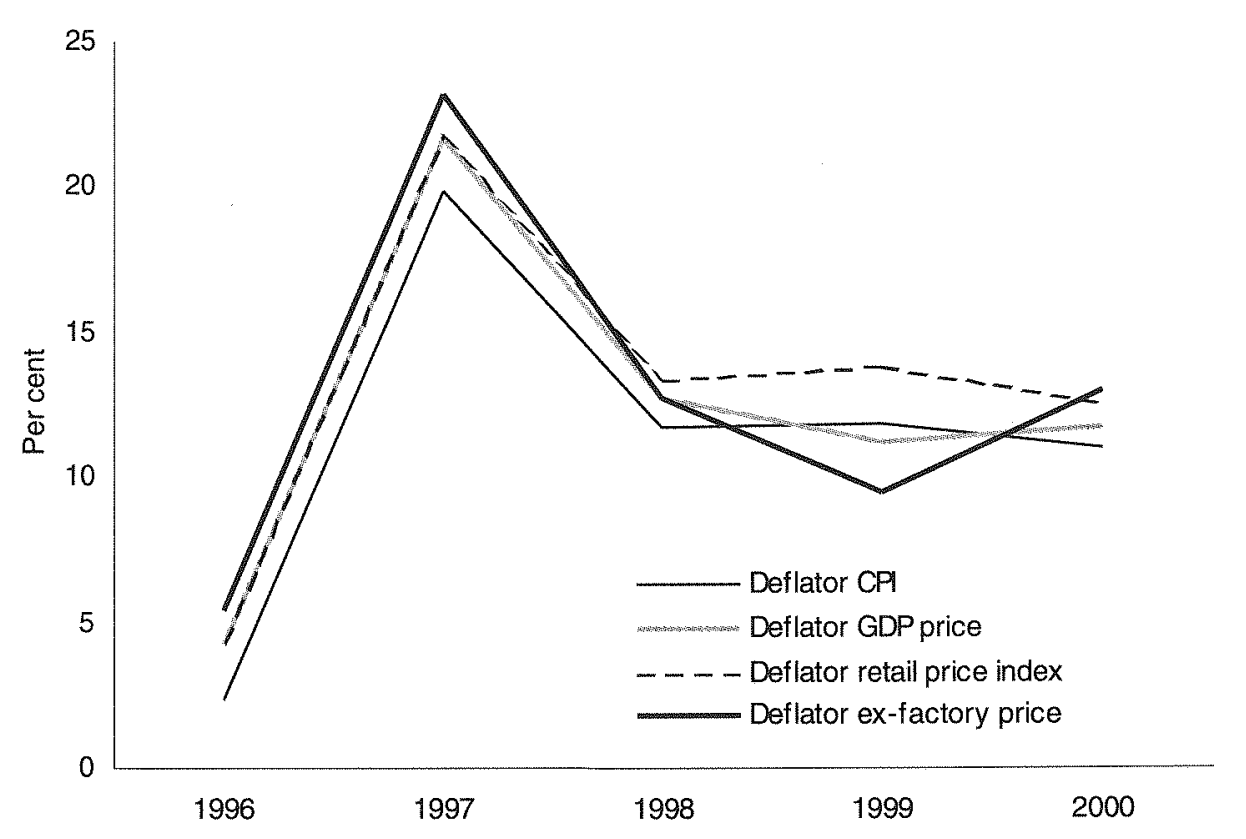

Source: National Statistical Bureau, 2002. China Statistical Yearbook, 2002, China Statistics Press, Beiling: Tables 5-22 and 9-1.

Table 14.1 Official price level changes since the Asian crisis

\begin{tabular}{lcccc}
\hline & Consumer prices & Retail prices & Ex-factory prices & GDP deflator \\
1997 & 2.8 & 0.8 & -0.3 & 0.9 \\
1998 & -0.8 & -2.6 & -4.1 & -2.6 \\
1999 & -1.4 & -3.0 & -2.4 & -2.4 \\
2000 & 0.4 & -1.5 & 2.8 & 1.0 \\
2001 & 0.7 & -0.8 & -1.3 & 0.0 \\
\hline
\end{tabular}

Source: Source: National Statistical Bureau, 2002. China Statistical Yearbook, 2002, China Statistics Press, Beijing: Tables 3-3 and 9-1. 
base are added independent representations of governments' fiscal regimes, with both direct and indirect taxation, as well as separate assets in each region (currency and bonds) and monetary policies with a range of alternative targets.

\section{The model}

The microeconomic side of the model is a modified version of that created by Hertel (1997). It offers the following useful properties

- a capital goods sector in each region to service investment

- explicit savings in each region, combined with open regional capital accounts that permit savings in one region to finance investment in others

- multiple trading regions, goods and primary factors

- product differentiation by country of origin

- empirically based differences in tastes and technology across regions

- non-homothetic preferences

- explicit transportation costs and indirect taxes on trade, production and consumption.

All individual goods and services entering final and intermediate demand are constant elasticity of substitution (CES) blends of home products and imports. In turn, imports are CES composites of the products of all regions, the contents of which depend on regional trading prices. Savings are pooled globally and investment is then allocated between regions from the global pool. Within regions, investment places demands on the domestic capital goods sector, which is also a CES composite of home-produced goods, services and imports in the manner of government spending.

To expand the model for macroeconomic analysis, the standard code is modified to make regional governments financially independent, thus enabling explicit treatment of fiscal policy. Direct taxes are incorporated at the observed average income tax rates for each region. Marginal tax rates are therefore assumed constant (say at $t$ ). Regional households then receive regional factor income, $Y_{F}$, and from this they pay direct tax $t Y_{F}$. The disposable income that remains is then divided between private consumption and private saving. Government saving, or the government surplus, $S_{G}=T-G$, is then simply revenue from direct taxes, $t Y_{F}$, and from the many indirect taxes already incorporated in the microeconomic part of the model ${ }^{13}, T_{p}$ less government spending, $G$, which could be exogenous or fixed as a proportion of GDP. Thus, $S_{G}=T_{1}+t Y_{F}-G$. The private saving and consumption decision is represented by a reduced form exponential consumption equation with 
wealth effects included via the dependence of consumption (and hence savings) on the interest rate. Each region then contributes its total domestic (private plus government) saving, $S_{D}=S_{P}+S_{G}$, to the global pool from which investment is derived. ${ }^{14}$

For each region, the above relations imply the balance of payments identity, which sets the current account surplus equal to the capital account deficit: $X-M=S_{p}+$ $S_{G}-1 .{ }^{15}$ From the pool of global savings, investment is allocated across regions and places demands on capital goods sectors in each region. In the short run however, investment does not add to the installed capital stock. Also at this length of run, nominal wages are sticky in some regions (the industrialised regions of the United States, the European Union, Canada and Australia, and those developing countries with heavily regulated labour markets: China and Vietnam) but flexible elsewhere. In the spirit of comparative statics, although price levels do change in response to shocks, agents represented in the model do not expect any continuous inflation and so there is no distinction between the real and nominal interest rates.

In allocating the global savings pool as investment across regions, we have opted for the most flexible approach, implying a high level of global 'capital' mobility. ${ }^{16}$ Where controls exist on international capital flows we introduce these explicitly. In the absence of capital controls, the allocation to region $j$ (net investment in that region) depends positively on the expected long-run change in the average rate of return on installed capital, $r_{j}^{\ominus}$, which, in turn, rises when the marginal product of physical capital is expected to increase. ${ }^{17}$ Net investment falls when the opportunity cost of financing capital expenditure, the region's real interest rate, $r_{f}$ rises. This rate depends, in turn, on a global capital market clearing interest rate, $r^{w}$, calculated such that global savings equals global investment $: \Sigma_{j} S_{j}^{D}=\Sigma_{j} I_{j}\left(r_{j}^{\theta}, r_{j}\right)$. Here $I_{j}$ is real gross investment in region $j .{ }^{18}$ The region's home interest rate is then $r_{j}=r^{N}\left(1+p_{j}\right)$ where $p_{j}$ is a region-specific interest premium, thought to be driven by risk factors not incorporated in this analysis. The investment demand equation for region $j$ then takes the form:

$$
I_{j}=\delta_{j} K_{j}+I_{j}^{N}=\delta_{j} K_{j}+\beta_{j} K_{j}\left(\frac{r_{j}^{e}}{r_{j}}\right)^{\varepsilon_{j}}=K_{j}\left[\delta_{j}+\beta_{j}\left(\frac{r_{j}^{e}}{r_{j}}\right)^{\varepsilon_{j}}\right]
$$

where $K_{j}$ is the (exogenous) base year installed capital stock, $d_{j}$ is the regional depreciation rate, $b_{j}$ is a positive constant and $e_{j}$ is a positive elasticity. Critically, investment in any region responds positively to changes that are expected to raise 
the sectoral average of a region's marginal product of physical capital and hence the regional average return on installed capital. ${ }^{19}$ Other things being equal, improvements in trans-sectoral efficiency, such as might stem from a trade reform, are thought to raise capital returns permanently and hence they raise $r_{j}^{e}$. If such a shock also causes the rate of unemployment to fall, this raises total labour use and hence the current return on installed physical capital. When the shock is a trade reform, such employment effects are also considered permanent and so they add positively to the expected future return on installed capital, $r_{j}^{\theta}$.

Investment decisions are made by forward-looking agents with access to a longrun version of the model. Thus, the expected change in the (long-run) rate of return on installed capital in each region, $r_{j}^{\theta}$, is exogenous in short-run simulations. It is calculated by first simulating the effects of the same shock but under long-run closure assumptions. These differ from the short-run closure in the following ways

- there are no nominal rigidities (no rigidity of nominal wages)

- larger production and consumption elasticities are used to reflect the additional time for adjustment

- physical capital is no longer sector specific; it moves across sectors to equalise rates of return

- capital controls are ignored

- in China, irrespective of short-run fiscal policy assumptions, in the long run any loss of government revenue associated with tariff changes is assumed not to be made up via direct (income) tax, with the result that the fiscal deficit expands; thus, the ratios of government revenue and expenditure to GDP are endogenous while the average direct tax rate is exogenous.

Note that the short-run comparative static analysis does not require the global economy to be in a steady state. When shocks are imposed, any change in the counterfactual return on installed capital, $r_{j}^{\theta}$, need not be the same as the corresponding change in the opportunity cost of capital expenditure, $r_{j}$ Most often, short-run shocks change income and savings and, therefore, expected returns in directions that differ from corresponding short-run changes in the global interest rate, particularly considering that physical capital is fixed in quantity and sectoral distribution at this length of run. Even in long-run simulations, the global distribution of physical capital at the outset does not equalise rates of return across regions, and redistribution through the regional allocation of one year's global savings is insufficient to redress such imbalances. 
To include asset markets, region-specific money and nominal bonds are introduced. Even though there is no interregional ownership of installed capital in the initial database, regional bonds are traded internationally, making it possible for savers in one region to finance investment in another. ${ }^{20}$ Cash constraints cause households to maintain portfolios including both bonds and non-yielding money and the resulting demand for real money balances has the usual reduced form dependence on GDP (transactions demand) and the interest rate. This is equated with the region's real money supply, where purchasing power is measured in terms of its GDP deflator, $P^{Y}$. Since all domestic transactions are assumed to use the home region's money, international transactions require currency exchange. For this purpose, a nominal exchange rate, $E_{j}$, is defined for each region. A single key region is identified (here the United States), relative to whose currency these nominal rates are defined. For the United States, then, $E=1$ and $E_{j}$ is the number of US dollars per unit of region $j$ s currency. In essence, we are adding to the real model one new equation per region (the LMcurve linking the real money supply to GDP and the interest rate) and one new (usually endogenous) variable per region, $E_{j}{ }^{21}$ The bilateral rate between region $i$ and region $j$ is then simply the quotient of the two exchange rates with the United States, $E_{i j}=E_{i} / E_{j}$. Quotients such as this appear in all international transactions.

Without nominal rigidities the model always exhibits money neutrality, both at the regional and global levels. Firms in the model respond to changes in nominal product, input and factor prices but a real producer wage is calculated for labour as the quotient of the nominal wage and the GDP deflator, so that $W=W / P^{Y}$. Money shocks always maintain constant $w$ when nominal rigidities are absent. To make possible some rigidity in the setting of the nominal wage, $W$, a parameter, $\lambda \in(0,1)$ is inserted, such that

$$
\frac{W}{W_{0}}=\Lambda\left(\frac{P^{C}}{P_{0}^{C}}\right)^{\lambda}
$$

where $W_{0}$ is the initial value of the nominal wage, $P_{0}^{C}$ is the corresponding initial value of the consumer price index (CPI) and $\lambda$ is a constant. Whenever $\lambda$ is exogenous and set at unity, the nominal wage carries this relationship to the CPI and the labour market will not clear except in the unlikely event that Equation 14.3 happens to yield a market-clearing real wage. The case where the labour market is fully flexible is represented by setting $\lambda$ as an endogenous slack variable and thereby rendering 
Equation 14.3 ineffective. At the same time, labour demand is forced to equate with exogenous labour supply to reflect the clearing market.

The representation of capital controls. Savings are assumed to be perfectly mobile between regions. The allocation of investment between them depends on regionspecific interest premia and, if they are present, capital controls. In the absence of capital controls, a region's domestic capital market might be represented as in Figure 14.6. Net inflows on the capital account $(K A)$, which comprise the net inflow of private foreign savings, less the net outflow associated with the accumulation of official foreign reserves, $\Delta R$, depend on the domestic bond rate, which deviates from a global capital market clearing interest rate by the risk premium factor $1+\pi .^{22}$ The KA curve slopes upward slightly in spite of the assumed perfect capital mobility because larger net inflows to the focus region drive up the global market-clearing interest rate.

The actual scale of net inflows depends on the net demand for foreign investment, $N F I=I-S_{D}$, where the relationship between $N F I$ and $r$ is shifted to the right by an increase in the expected future return on installed capital, $r$, via Equation 14.2, or by an increase in government spending, $G$, via its effect on domestic saving. It is shifted to the left by an increase in GDP ( $Y$ ), via its effect on consumption and tax revenue and hence on domestic savings, $S_{D}$. In the figure, net outflows on the capital account are determined by the intersection of the two curves shown. For a balance of payments, these outflows must then equate to net inflows on the current account, $C A$, and prices, and therefore real exchange rates, adjust to ensure that this is the case.

In this analysis, capital controls take the form of a rigid ceiling on net outflows on the capital account (Figure 14.7), severing the link between the home and global interest rates unless net foreign investment rises sufficiently for the controls no longer to be binding. To capture this in model simulations, the interest premium, $\pi$, is made endogenous while net flows on the capital account, $K A$, or, equivalently, on the current account, $C A$ (where $B O P=K A+C A=0$ ), are set as exogenous.

Data and parameters. The regions, primary factors and sectors identified in our analysis are listed in Table 14.2. Considering regions first, we draw on the now wellknown GTAP Version 5 global database for 1997, which divides the world into 66 countries and regions. Although this database separates mainland China from Taiwan, it amalgamates Hong Kong with the mainland. ${ }^{23}$ Our further aggregation of mainland China with Taiwan overlooks effects that are internal to these regions, but such 


\section{Table 14.2 Model structure}

\section{Regions}

1. China, including Hong Kong and Taiwan

2. Vietnam

3. Other ASEAN

4. Japan

5. Korea

6. Australia

7. United States

8. European Union ${ }^{a}$

9. Rest of world

\section{Primary factors}

1. Agricultural land

2. Natural resources

3. Skill

4. Labour

5. Physical capital

Sectors ${ }^{b}$

1. Paddy rice

2. Beverages (product 8 OCR, 'crops nec')

3. Other crops (wheat, other cereal grains, vegetables, fruits, nuts, oil seeds, sugar cane and sugar beet, plant-based fibres and forestry)

4. Livestock products (cattle, sheep, goats, horses, wool, silk-worm cocoons, raw milk, other animal products)

5. Fish (marine products)

6. Energy (coal, oil, gas)

7. Minerals

8. Processed food (meat of cattle, sheep, goats and horses, other meat products, vegetable oils and fats, dairy products, processed rice, processed sugar, processed beverages and tobacco products)

9. Light manufacturing (textiles, wearing apparel, leather products and wood products)

10. Other manufacturing (paper products and publishing, petroleum and coal products, chemicals, rubber and plastic products, other mineral products, ferrous metals, other metals, metal products, motor vehicles and parts, other transport equipment, electronic equipment, other machinery and equipment, other manufactures)

11. Transport (sea transport, air transport and other transport)

12. Infrastructure services (electricity, gas manufacturing and distribution, and water)

13. Construction and dwellings

14. Other services (retail and wholesale trade, communications, insurance, other financial services, other business services, recreation, other private services, public administration, defence, health and education)

Notes: ${ }^{a}$ The European Union of 15. ${ }^{\mathrm{b}}$ These are aggregates of the 57 -sector GTAP Version 5 database. 
Figure 14.6 The domestic capital market without capital controls

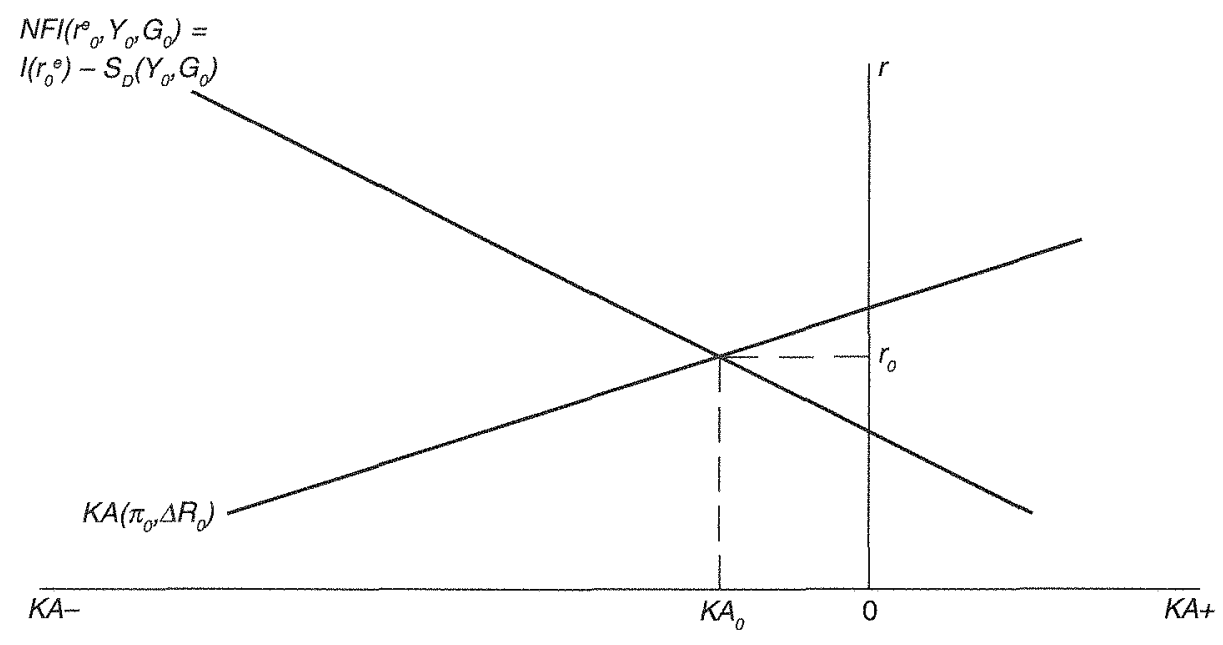

Figure 14.7 The domestic capital market with capital controls

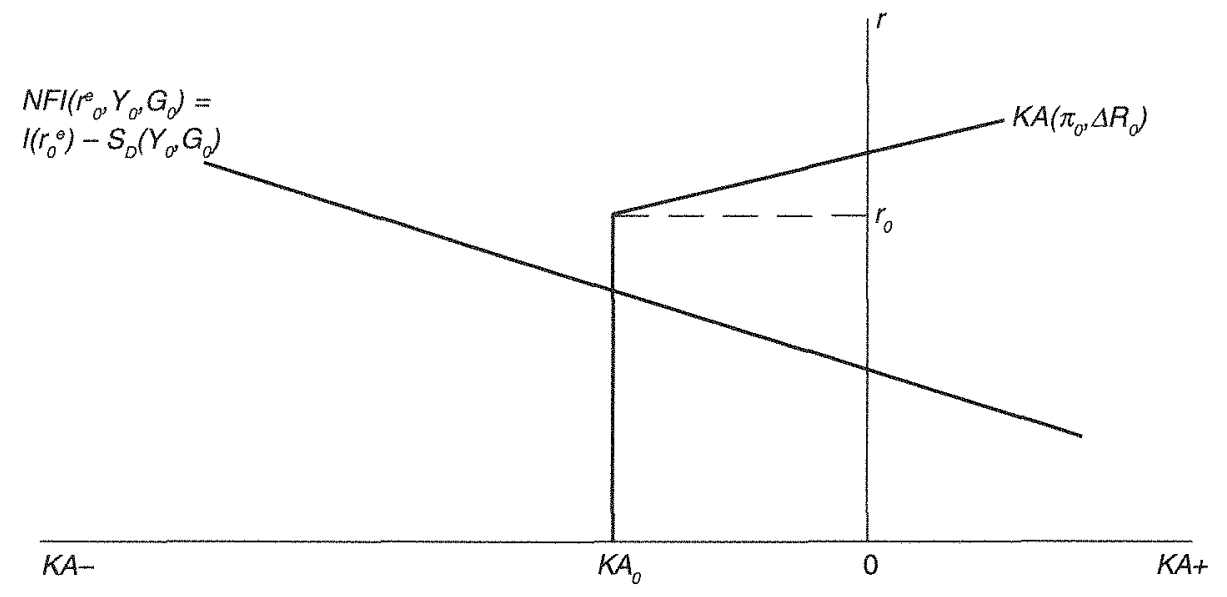


effects are not our focus. Instead, we seek to illustrate the strong interaction between trade reforms and macroeconomic policies, and, particularly, foreign exchange regimes. These interactions are important for all the economies of East Asia and particularly for those with regulated foreign exchange regimes. China is the largest developing economy to maintain, at least de facto, fixed US dollar parity and, in this respect, the macroeconomic policy regimes of Hong Kong (and to a much lesser extent) Taiwan have been compatible with that of the mainland.

Turning to primary factors, skill is separated from raw labour on occupational grounds, with the 'professional' categories of the International Labour Organisation (ILO) classification included as skilled. ${ }^{24}$ The structure of factor demand has skill and physical capital as complements. This enables the model to represent the links between skill availability, capital returns and investment that are important in China, which has large skilled and unskilled labour forces that are increasingly mobile between sectors. ${ }^{25}$ Finally, the sectoral breakdown we have chosen aggregates the 57 sectors in the database to our more manageable 14, offering the most delail in agricultural and marine products. This is because, amongst China's merchandise trade commitments for WTO accession, a key liberalisation is in the processed food sector, to which these commodities are inputs.

Because the length of run is short, the real part of the short-run model incorporates smaller-than-standard elasticities of substitution in both demand and supply. These are set on the basis of a short-run calibration exercise on the East Asian crisis, described in Yang and Tyers (2000). For further details of the model, its parameters and its structure, see Yang and Tyers (2000) and Tyers and Yang $(2000,2001)$.

\section{Representing post-crisis trade policies and reforms}

A key change since 1997 is the introduction of duty drawbacks offered to firms on the component of their imports that is used for export production. The approach taken is detailed in Tyers and Rees (2002). Table 14.3 presents the pattern of equivalent trade taxes and subsidies as of 2001 and as anticipated post-accession. To obtain the rates in Table 14.3, the industry classification used in the WTO list of tariff concessions was concorded with the cruder subdivision used in our model and average rates constructed for each sector. The information contained in the database was supplemented by details of the accession tariff rates provided by lanchovichina and Martin (2001). To represent the behavioural impacts of the changes in equivalent tariff rates as accurately as possible, emphasis was placed on preserving changes 
in the 'powers of the tariffs' rather than in the rates themselves. ${ }^{26}$

The equivalent Chinese tariff rates of the 1990s vary by country of origin. This means that the application of the same shock to the powers of these equivalent tariffs might have led to negative post-accession rates for some trading partners. The accession shocks to the equivalent bilateral tariff rates were therefore calculated so as to harmonise the post-shock tariff rates across countries of origin. The proportional changes in 'powers of equivalent tariffs' are the same as those implied by the changes in rates detailed in lanchovichina and Martin (2002). For our present purpose, these shocks are the same for both the long run and the short run. As indicated in the WTO database, China is committed to undertaking many of the tariff concessions immediately on accession. ${ }^{27}$

Table 14.3 Chinese equivalent import tariff and export tax rates ${ }^{\mathrm{a}}$

\begin{tabular}{lccc}
\hline \multicolumn{4}{c}{$\begin{array}{c}\text { Equivalent import tariff } \\
\text { (per cent) }\end{array}$} \\
Rice & \multicolumn{2}{c}{$\begin{array}{c}\text { Post-accession } \\
\text { Pre-accession }\end{array}$} & $\begin{array}{c}\text { Pqivalent export tax } \\
\text { (per cent) }\end{array}$ \\
Beverages & 0.04 & 0.04 & -0.13 \\
Other crops & 11.00 & 11.00 & -0.11 \\
Livestock & 22.00 & 16.00 & -0.25 \\
Food & 5.00 & 4.00 & -0.02 \\
Fish & 16.00 & 6.00 & -0.13 \\
Minerals & 8.00 & 8.00 & -0.19 \\
Energy & 0.40 & 0.40 & -0.32 \\
Light manufacturing & 3.00 & 3.00 & -0.32 \\
Heavy manufacturing & 14.00 & 8.00 & 2.63 \\
& 8.00 & 4.00 & -1.01 \\
\hline
\end{tabular}

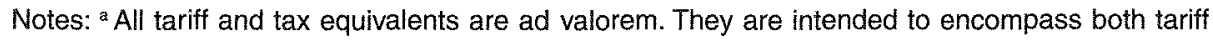
and non-tariff barriers, though the accounting for non-tariff barriers is incomplete. Services distortions are not generally included in the database. See text of a discussion of their representation in the analysis. ${ }^{b}$ Negative export tax rates indicate export subsidies. These incorporate the export subsidy equivalents of the duty drawbacks available on imported inputs by exporting firms, calculated as explained in the text.

Sources: The original 1997 numbers are aggregated from the 57 commodity categories in the GTAP Version 5 global database (as published in 2000). They are then modified using model simulations, as described in the text and based on the work of lanchovichina and Martin (2002), to obtain pre-accession estimates for 2001. Finally, the post-accession rates are based on the protocol for China's accession, as obtained from the WTO website at http://www.wto.org. 


\section{SIMULATED EFFECTS OF ACCESSION POLICY REFORMS}

The reasons for examining long-run implications first are twofold. First, the long-run results are useful in their own right, given that they may then be compared with the many other simulations of China's WTO accession reforms. Second, the long-run outlook is required in order that the expectations of investors can be formulated for short-run analysis. Recall that investors are assumed to take into account changes in long-run returns on installed capital in determining short-run changes in their investment behaviour.

Recapping the key elements of long-run closure

- there are no nominal rigidities (no rigidity of nominal wages)

- production and consumption elasticities of substitution are chosen at long-run levels to reflect the additional time for adjustment in the long run over the short run

- physical capital is no longer sector specific; it redistributes across sectors to equalise rates of return

- capital controls are ignored, and

- in China, irrespective of short-run fiscal policy assumptions, in the long run any loss of government revenue associated with tariff changes is assumed to not be made up via direct (income) tax, with the result that the fiscal deficit expands.

The key point of difference between our long-run analysis and that of Rees and Tyers (2002) is that we represent the effects of trade reforms on productivity. There is a substantial literature identifying this association (Chand et al. 1998; Chand 1999; Stoeckel et al. 1999). These studies use Australian data on the long-run effects of trade reforms to identify elasticities of total factor productivity to protection level by industry. We applied these elasticities to China's intended reforms, albeit with discounts for China's lower starting protection levels in some industries and adjustments to account for services sector reforms (Dee and Hanslow 2000; Verikios and Zhang 2001), to yield the one-off long-run productivity shocks listed in Table 14.4. Although these shocks are applied only in the long run, they are important for short-run behaviour (our object here) because they raise the return on installed capital and hence stimulate investment.

The results from the long-run simulation are provided in Table 14.5. They show the expected allocative efficiency gains, reflected here in a rise in GDP, aided by 
increased returns on installed physical capital that induce greater investment and therefore larger net inflows on the capital account in the long run. As home consumption switches away from home-produced goods, the relative prices of homeproduced goods fall yielding the predicted real depreciation. The principal downside of the reforms is the long-run shift of activity out of agriculture into manufacturing and services and the associated decline in land rents. Associated with this shift, further substantial relocation of workers from agriculture to the modern sector will therefore be required.

Although the trade policy regime of 2001 advantaged food processing, 'other crops', fisheries and light manufacturing, it is the manufacturing sectors that are the robust beneficiaries of the unilateral trade liberalisation. This is surprising given that the

Table 14.4 Ancillary effects of WTO trade reforms ${ }^{\mathrm{a}}$

\begin{tabular}{|c|c|c|}
\hline & $\begin{array}{l}\text { Long-run total } \\
\text { factor productivity } \\
\text { rises associated with } \\
\text { reduced protection } \\
\text { (per cent) }\end{array}$ & $\begin{array}{l}\text { Short-run effect of } \\
\text { reduced services } \\
\text { protection on capital } \\
\text { accumulation in } \\
\text { finance and } \\
\text { communications } \\
\text { (per cent/year) }\end{array}$ \\
\hline Rice & 1.0 & \\
\hline Beverages & 1.0 & \\
\hline Other crops & 1.0 & \\
\hline Livestock & 1.0 & \\
\hline Food & 2.0 & \\
\hline Fish & - & \\
\hline Minerals & - & \\
\hline Energy & - & \\
\hline Light manufacturing & 1.5 & \\
\hline Heavy manufacturing & 3.0 & \\
\hline Transport services & 1.0 & \\
\hline Infrastructural services (electricity, gas, water) & 1.0 & \\
\hline Construction and dwellings & 2.0 & \\
\hline Other (including financial and communications) & 5.0 & 2.0 \\
\hline
\end{tabular}

Notes: a These are supplementary exogenous shocks applied, where indicated, along with the tariff reductions. They incorporate the findings of other research, particularly on the effects of services reform. ${ }^{\circ}$ Estimates based on the results from research by Chand et al. (1998), Chand (1999) and Stoeckel et al. (1999). " Estimated one-year effect, based on the results from research by Dee and Hanslow (2000) and Verikios and Zhang (2001).

Sources: As specified in the notes above. 
Table 14.5 Simulated long-run effects of a unilateral liberalisation of China's 2001 trade policy regime ${ }^{a}$

\begin{tabular}{|c|c|c|}
\hline Change in & $\begin{array}{l}\text { No ancillary effects } \\
\text { on productivity or } \\
\text { services capital }\end{array}$ & $\begin{array}{l}\text { With ancillary effects } \\
\text { on productivity and } \\
\text { services capital }^{b}\end{array}$ \\
\hline Terms of trade (per cent) & -1.25 & -1.52 \\
\hline Real effective exchange rate, $e_{i}^{A}$ (per cent) & -1.98 & -2.56 \\
\hline Real exchange rate against USA, $e_{i j}{ }^{F}$ (per cent) & -1.81 & -2.37 \\
\hline Global interest rate, $r^{w}$ (per cent) & 0.10 & 0.05 \\
\hline Investment premium factor, $(1+\dot{A})$ (per cent) & 0.00 & 0.00 \\
\hline Home interest rate, $r$ (per cent) & 0.10 & 0.05 \\
\hline Return on installed capital, $r^{c}$ (per cent) ${ }^{c}$ & 1.30 & 4.98 \\
\hline Real domestic investment, I (per cent) & 0.95 & 3.85 \\
\hline Balance of trade, $X-M=-K A=-\left(1-S_{D}\right)$ (US\$ bn) & -10.87 & -5651 \\
\hline \multicolumn{3}{|l|}{ Real gross sectoral output (per cent) } \\
\hline Rice & -3.29 & -2.54 \\
\hline Beverages & 2.77 & 3.33 \\
\hline Other crops & -1.25 & -0.36 \\
\hline Livestock & 0.03 & 1.32 \\
\hline Food & -5.41 & -4.32 \\
\hline Fish & -0.17 & 0.35 \\
\hline Minerals & 0.88 & 2.38 \\
\hline Energy & 0.78 & 0.95 \\
\hline Light manufacturing & 1.49 & 2.26 \\
\hline Heavy manufacturing & 1.08 & 4.60 \\
\hline Transport & 1.44 & 2.87 \\
\hline Infrastructure services & 0.34 & 2.25 \\
\hline Construction and dwellings & 0.73 & 3.46 \\
\hline Other services & 0.76 & 4.96 \\
\hline Real GDP, $Y$ & 0.41 & 3.31 \\
\hline \multicolumn{3}{|l|}{ Unskilled wage and employment (per cent) } \\
\hline Nominal (unskilled) wage, $W$ & -0.42 & 1.85 \\
\hline Production real wage, $w=W / P^{r}$ & 1.51 & 4.53 \\
\hline Employment, $L^{D}$ & 0.00 & 0.00 \\
\hline \multicolumn{3}{|l|}{ Unit factor rewards CPI deflated (per cent) } \\
\hline Land & -2.65 & -1.39 \\
\hline Unskilled labour (those employed) & 1.27 & 4.08 \\
\hline Skilled labour & 1.38 & 4.22 \\
\hline Physical capital & 1.24 & 4.04 \\
\hline Natural resources & 1.20 & 2.65 \\
\hline
\end{tabular}

Notes: a All results in table are based on the assumption that government spending is held constant as a share of GDP; revenue lost from tariff reform is not made up in other taxes, so the fiscal deficit expands. Key exogenous variables are highlighted as per the long-run closure discussed in the text. ${ }^{b}$ For these additional shocks, see Table 14.4.

Source: Model simulations described in the text. 
protection of the manufacturing sectors is also set to decline. It is because both manufacturing sectors commit approximately half their total costs to inputs in the same product category and about 10-15 per cent of those committed to imports. Competing imports, even though they are from the same sector, are differentiated from home products (Rees and Tyers 2002). Under these conditions, the tariff reductions on imported intermediates have a direct effect on home industry total cost. Reductions to tariffs on competing, but differentiated, imports have only an indirect effect, the magnitude of which depends on the elasticity of substitution between the two. Indeed, for manufacturing, it turns out that the effect of tariff reductions on input costs is considerably greater than that of the loss of protection against competing imports. Cost reductions of similar origin are the reason for similar gains accruing to the domestic transport services sector.

The reforms cause the most substantial reductions in protection to China's food processing sector and therefore lead to long-run contractions in that sector and in the local supply of its inputs (especially rice and 'other crops'). The more income elastic and lightly protected agricultural sectors, the 'beverages' group and livestock, actually expand. Labour is assumed to be perfectly mobile between sectors, so that our results indicate the labour movement needed in order to achieve the maximum gain from the reforms. In the long run, employment in food processing falls by seven per cent, in rice production by four per cent and in 'other crops' by two per cent. Workers lost from these sectors are re-employed primarily in manufacturing and services.

When reform-driven productivity improvements are included in the long-run analysis, even though the assumed productivity changes are one-off and modest, the economic effects of the reforms are greatly amplified. The GDP increase is almost ten times larger, while domestic investment is four times larger, as is the return on installed capital, which will drive short-term investment. Increases in sectoral expansions are largest in manufacturing and services, the productivity of services having widespread effects through their role as intermediates. The overall contraction in the agricultural sector is much reduced, with the beverages, livestock and fisheries sectors now showing robust expansions.

\section{Simulated short-run effects}

In the short run, for all the regions represented, the standard closure is as indicated in Table 14.6. Monetary authorities in China, Vietnam and the rest of the world are 
assumed to maintain fixed exchange rates against the US dollar. The other regions identified adopt price level (CPI) targeting. Capital controls are assumed to be rigid in China and Vietnam, but non-existent in the other regions. In the labour markets of China and Vietnam nominal wages are assumed to be 'sticky'. Full short-run rigidity is assumed in the industrial countries, while nominal wages are assumed to be fully flexible elsewhere in Asia and the developing world. As to fiscal policies (not shown in Table 14.6), government spending in all regions is assumed to absorb a fixed proportion of GDP and the rates of direct and indirect tax are assumed to be constant, so that government deficits do vary in response to shocks.

As indicated earlier, three alternative macroeconomic policy regimes are considered.

\section{Table 14.6 Short-run closure ${ }^{a}$}

\begin{tabular}{|c|c|c|c|}
\hline Region & Monetary policy target ${ }^{b}$ & $\begin{array}{c}\text { Labour market } \\
\text { closure: nominal } \\
\text { wage }^{c o}\end{array}$ & $\begin{array}{l}\text { Capital controls: } \\
\text { capital account } \\
\text { net inflow } /-S_{D}{ }^{d}\end{array}$ \\
\hline China (1) & Nominal exchange rate, $E$ & Sticky $(l=0.5)$ & Rigid \\
\hline China (2) & Nominal exchange rate, $E$ & Sticky $(\mid=0.5)$ & Flexible \\
\hline China (3) & GDP price, $p^{r}$ & Sticky $(l=0.5)$ & Flexible \\
\hline Vietnam & Nominal exchange rate, $E$ & Sticky $(l=0.5)$ & Rigid \\
\hline Other ASEAN & Consumer price level, $P^{c}$ & Flexible $(l=1)$ & Flexible \\
\hline Japan & Consumer price level, $P^{c}$ & Sticky $(l=0.5)$ & Flexible \\
\hline Korea & Consumer price level, $P^{c}$ & Flexible $(=1)$ & Flexible \\
\hline Australia & Consumer price level, $P^{c}$ & Sticky $(l=0.5)$ & Flexible \\
\hline United States & Consumer price level, $P^{c}$ & Sticky $(l=0.5)$ & Flexible \\
\hline Europe (EU) & Consumer price level, $P c$ & Rigid $(l=0)$ & Flexible \\
\hline Rest of world & Nominal exchange rate, $E$ & Flexible $(l=1)$ & Flexible \\
\hline \multicolumn{4}{|c|}{$\begin{array}{l}\text { Notes: }{ }^{a} \text { The expected future return on installed capital is exogenous in the short run, determined } \\
\text { in a separate long-run solution. There are three macroeconomic policy regimes for China, with (1) } \\
\text { the most restrictive and ( } 3 \text { ) the most expansionary. }{ }^{b} \text { The nominal money supply is endogenous in } \\
\text { each case, the corresponding exogenous variable being the listed target. " When the nominal } \\
\text { wage is assumed flexible it is endogenous and the corresponding exogenous variable is the } \\
\text { employment level. When it is sticky or rigid, Equation } 14.2 \text { is activated and the employment level is } \\
\text { endogenous. }{ }^{d} \text { Capital controls are assumed to maintain a rigid net inflow of foreign investment on } \\
\text { the capital account. When } K A=I-S_{D} \text { is made exogenous to represent this, an interest premium } \\
\text { opens between the domestic and international capital markets. This premium becomes } \\
\text { endogenous. Effectively, the home and foreign capital markets are separated and clear at different } \\
\text { interest rates. Where the capital account is flexible (open), this implies that private flows on the } \\
\text { capital account are permitted at any level. } K A=1-S_{D} \text { is then endogenous and the home interest } \\
\text { premium is exogenous (unchanged by any shock). This means that the home interest rate then } \\
\text { moves in proportion to the rate that clears the global savings-investment market. }\end{array}$} \\
\hline
\end{tabular}


- The 'standard'-rigid capital controls with a fixed exchange rate.

- No capital controls and a fixed exchange rate.

- No capital controls, a floating exchange rate and monetary policy targeting the GDP price.

In addition, two alternative assumptions are made about investment and the services capital stock. In a pessimistic alternative, investors do not see the longrun benefits of productivity gains that would accompany trade reform, and there is no immediate effect from reforms in services trade. In an optimistic counterpart, investors are motivated by the long-run return on installed capital listed in the second column of Table 14.5. Moreover, drawing on the conclusions from studies by Dee and Hanslow (2000) and Verikios and Zhang (2001), service trade reforms are assumed to result in the short run bolstering of the capital stock in finance and communications indicated in Table 14.4. Not surprisingly, the short-run effects of China's WTO commitments prove to be heavily dependent on her macroeconomic policy regime and the associated productivity and capital stock changes. Indeed, the effects range from the contraction alluded to in the introduction through to a substantial short-run expansion.

\section{The effects of capital controls and the choice of monetary policy target}

The broad behaviour of the model in the short run with rigid capital controls retained can be represented as in Figure 14.8. The upper diagram represents the domestic capital market and the lower diagram the domestic market for foreign products. These markets are linked by the requirement that, for a balance of payments, net flows on the capital account must mirror those on the current account. Net demand for foreign products (the downward sloping line in the lower diagram, $N M=M-X$ ) depends on the relative price of foreign goods. For this purpose, we define the real exchange rate (Equation 14.1) as the common currency ratio of the price of home goods to the price of foreign goods. Net imports depend positively on this real exchange rate and negatively on its inverse (the common-currency foreign to home product price ratio). This excess demand curve is shifted to the right by an increase in GDP, $Y$, or a reduction in protection, $\tau$. The real exchange rate is then determined by the balance of payments requirement that net inflows on the capital account must equal net outflows on the current account, $K A=-C A=N M=M-X^{28}$ 
The trade liberalisation reduces $\tau$ and shifts $N M$ to the right. With tight capital controls, the current account balance cannot change. The shock therefore raises the relative price of foreign goods in the home market and thus depreciates the real exchange rate. If the nominal exchange rate is the target of monetary policy and the home economy is small by comparison with its trading partners ( $P^{*}$ is unaffected) then, from Equation 14.4, a fall in $P^{Y}$ (a deflation) is required. This must be brought about by a monetary contraction in defence of the exchange rate. To the extent that wages adjust more sluggishly than product prices, the deflation causes the real wage to rise. Were the real depreciation the only consequence of the liberalisation shock, its effects would therefore be contractionary. Fortunately, this need not be the case. The trade reform brings gains in allocative efficiency. ${ }^{29}$

When capital controls remain rigid and the exchange rate fixed, however, in the Chinese case these allocative gains are insufficient to offset the contractionary effects of the deflation. This can be seen from the first column of Table 14.7. The real depreciation is substantial and the deflation required is of the order of two per cent per year. The production real wage rises by half this and employment falls. In Figure 14.8, investment demand responds to the expectation of higher real returns to installed capital in the future by shifting outward. The loss of tariff revenue drives the government deficit higher, reducing domestic saving, further reinforcing the outward shift of the net foreign investment (NFI) demand curve. But the rigidity of the capital controls causes this to simply push up the domestic interest rate and so real private investment actually falls. Output falls in all sectors except beverages, energy, manufacturing and transport. Manufacturing gains in the short run for the same reasons it gains in the long run-cheaper imported inputs. Under these policy circumstances, then, the overall net gains from trade reform are not robust in the short run, at least when pessimistic assumptions are made about productivity effects and services reform.

If the capital controls are removed, the corresponding liberalisation shock is as depicted in Figure 14.9 and the results are shown in column 2 of Table 14.7. Here, reduced protection also yields a gain in allocative efficiency, but this time the increase is large enough to generate a net gain in GDP, reinforcing the rightward shift in the net imports curve in the lower diagram. In this case, however, the absence of capital controls allows investment to flow in, responding to the increase in the expected long-run return on installed capital. The increased inflow on the capital account 


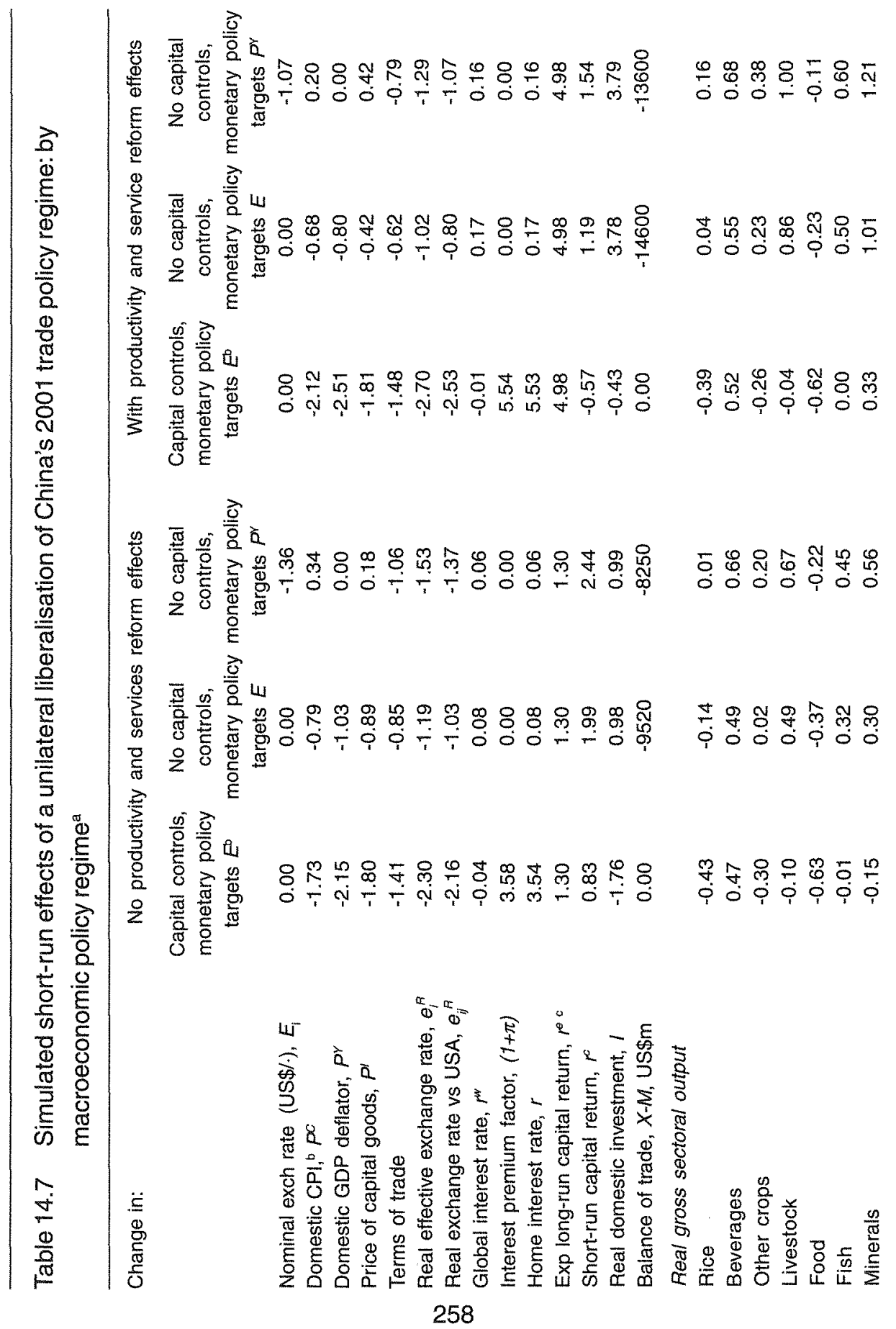




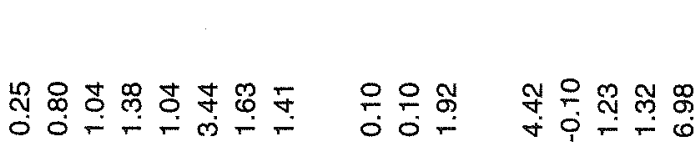

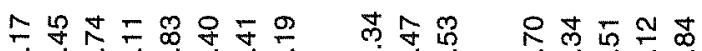

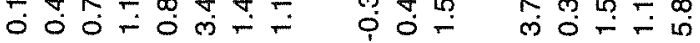

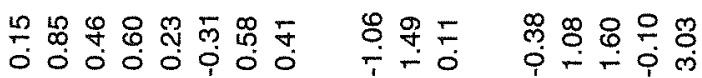

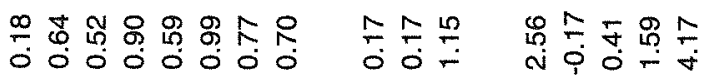

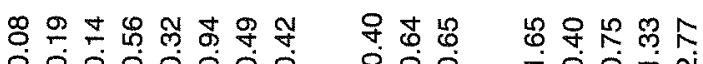

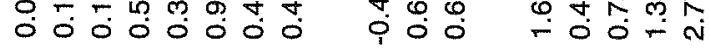

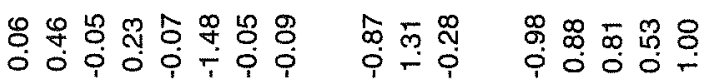

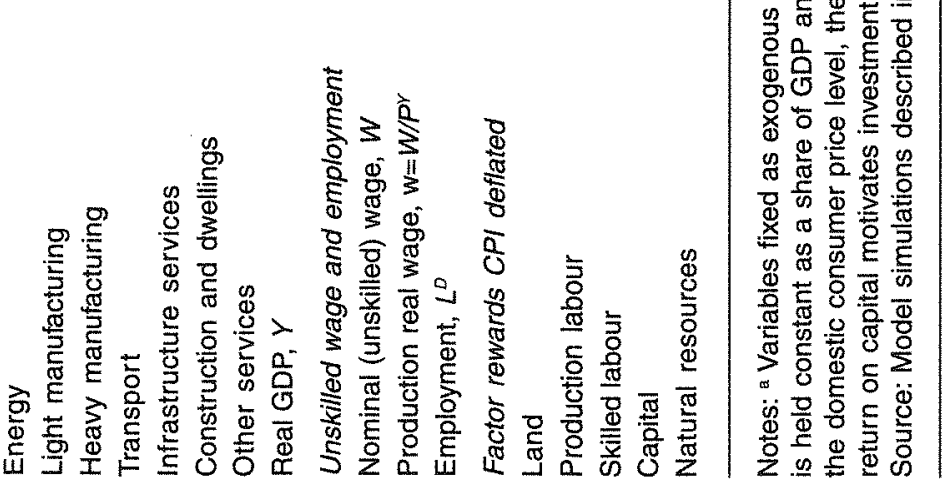


relaxes the balance of payments constraint in the lower diagram and allows a shift toward net imports. The net effect on the real exchange rate depends on whether the capital account shift, which raises the net supply of foreign goods, is larger or smaller than the increase in net demand for them due to the tariff reduction and the rise in domestic income. In the case of China, the rise in net demand is dominant and the real exchange rate still depreciates, albeit to a lesser extent than in the presence of capital controls. Thus, when capital controls are weak or nonexistent, the trade liberalisation is seen to attract increased inflows on the capital account and hence to mitigate the real depreciation and associated GDP price deflation that are its inevitable consequences.

In the third column of Table 14.7 the target of monetary policy is the GDP price, so that the nominal exchange rate is allowed to depreciate. This removes the deflation that must accompany a fixed exchange rate and hence reduces the rise in the production real wage due to the reforms. The GDP gain is therefore almost doubled and now only the processed food sector contracts in the short run. Interestingly, the additional investment and greater employment generated with the policy regimes of columns 2 and 3 ensure that real land rents actually rise in the short run.

Finally, the three right-hand columns of Table 14.7 indicate the short-run effects of the WTO accession reforms under the same three Chinese policy regimes but with the more optimistic ancillary effects of those reforms (Table 14.4) included. There are two key differences. First, investors are motivated by the effects of increased productivity in response to the reforms in the long run and, second, services reforms see a short-run increment to the capital stocks in the financial and communications sectors. These changes cause substantial rises in investment and, together, they cause larger net inflows on the capital account, boost the construction sector and reduce the cost of service inputs to other sectors. Overall expansions are therefore consistently larger in these cases, as is the demand for the sectoral relocation of workers. These are due, in part, to rises in overall employment which occur because of sticky nominal wages. The upward movement in nominal wages is slower than that in labour productivity, expanding aggregate labour demand by up to two per cent.

\section{Short-run sectoral impacts}

The key determinants of the sectoral mix of changes in the economy are the tariff reductions themselves, which reduce product prices in affected sectors, and the size of the resulting short-run real depreciation, which reduces non-traded (largely 
services) prices relative to traded goods prices. When capital controls are tight, the real depreciation is comparatively large. Traded sectors, such as light manufacturing, are advantaged, while non-traded services sectors, such as construction and dwellings, are disadvantaged. When capital controls are ineffective, manufacturing gains are smaller and the non-traded services sectors gain. Processed food suffers because of the decline in its protection, and other agricultural industries contract as that sector demands fewer local inputs. When the macroeconomic policy regime is expansionary, however, only the processed food sector contracts. If the optimistic ancillary effects are included the decline in the processed food sector becomes trivially small, ensuring gains to the agricultural sector as a whole. This result is quite important since, sensing losses due to reduced protection, the farm sector opposes the reforms. Yet if the reforms were embraced along with expansionary macroeconomic policy, the farm sector would be a net gainer, at least in the short run.

\section{Worker relocation demand in the short run}

The sectors defined for the purpose of our simulations (Table 14.2) are here aggregated for ease of comparison with the classification of employment by China's National Bureau of Statistics. The result is the seven sectoral groupings in Table 14.8. Also listed are the maximum and average annual changes in employment by sector, drawn from official statistics since 1978. The detailed official record of annual changes in employment by sector is provided in the Appendix. Some of these changes are of extraordinary magnitude, especially the growth in service sector employment in 1984. We discount these as due to changes in measurement in that year. There have also, however, been some extraordinary employment growth periods since then, including the service employment expansions of 1993 and 1994. Of course, the services sectors were considerably smaller then than they are now, and so the numbers of workers relocated to achieve those employment growth numbers were smaller than would now be required. Even so, these statistics suggest that China's capacity for the rapid sectoral relocation of workers has been considerable.

In the same table we show the range of simulated short-run worker relocation demands associated with China's WTO accession reforms. In interpreting these, it must be borne in mind that overall employment in China is endogenous in these simulations. From Table 14.7, depending on the macroeconomic policy settings, it either contracts by one-quarter of one per cent or expands by almost two per cent. 
Figure 14.8 Trade reform with capital controls

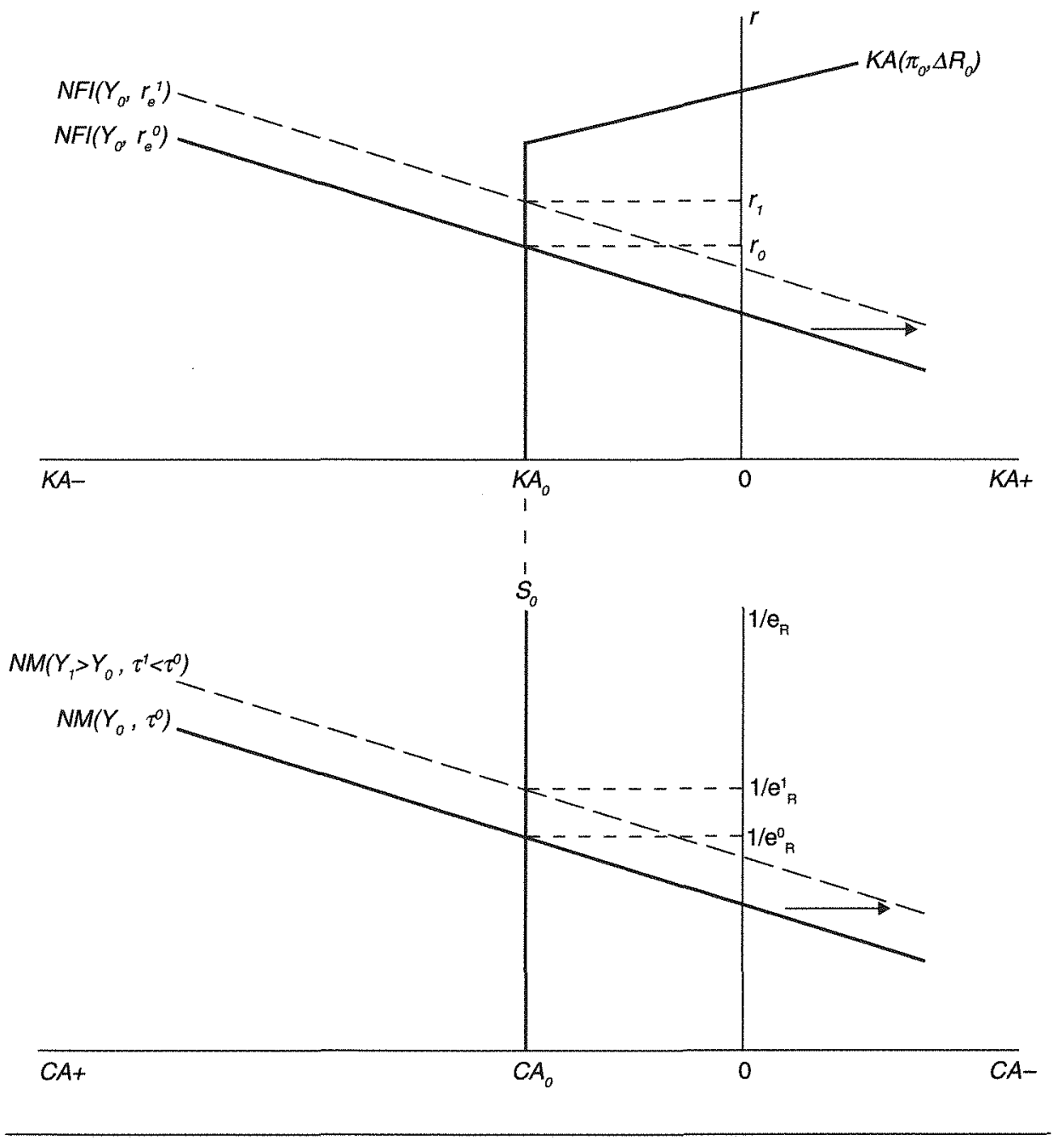


Figure 14.9 Trade reform without capital controls

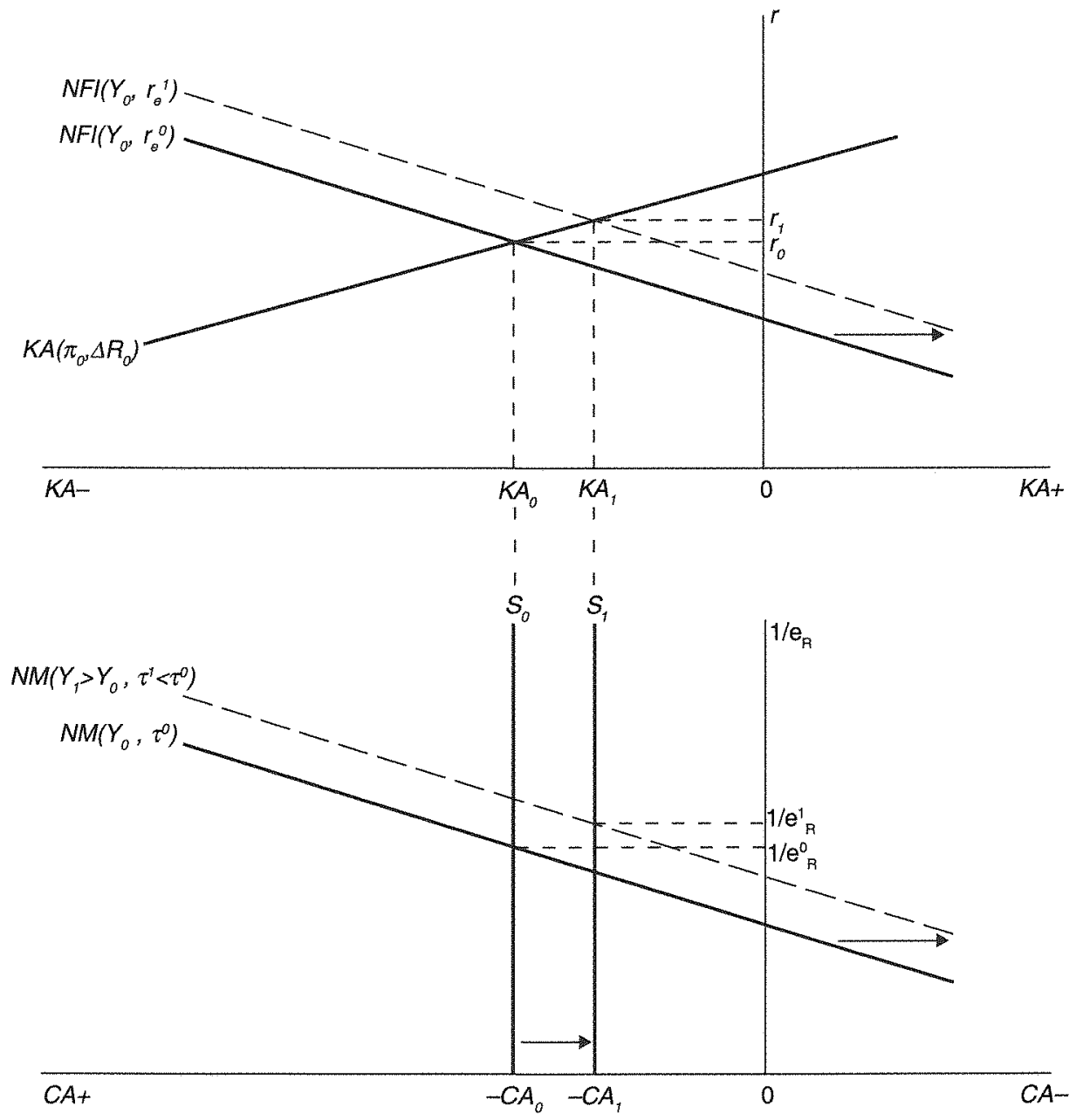




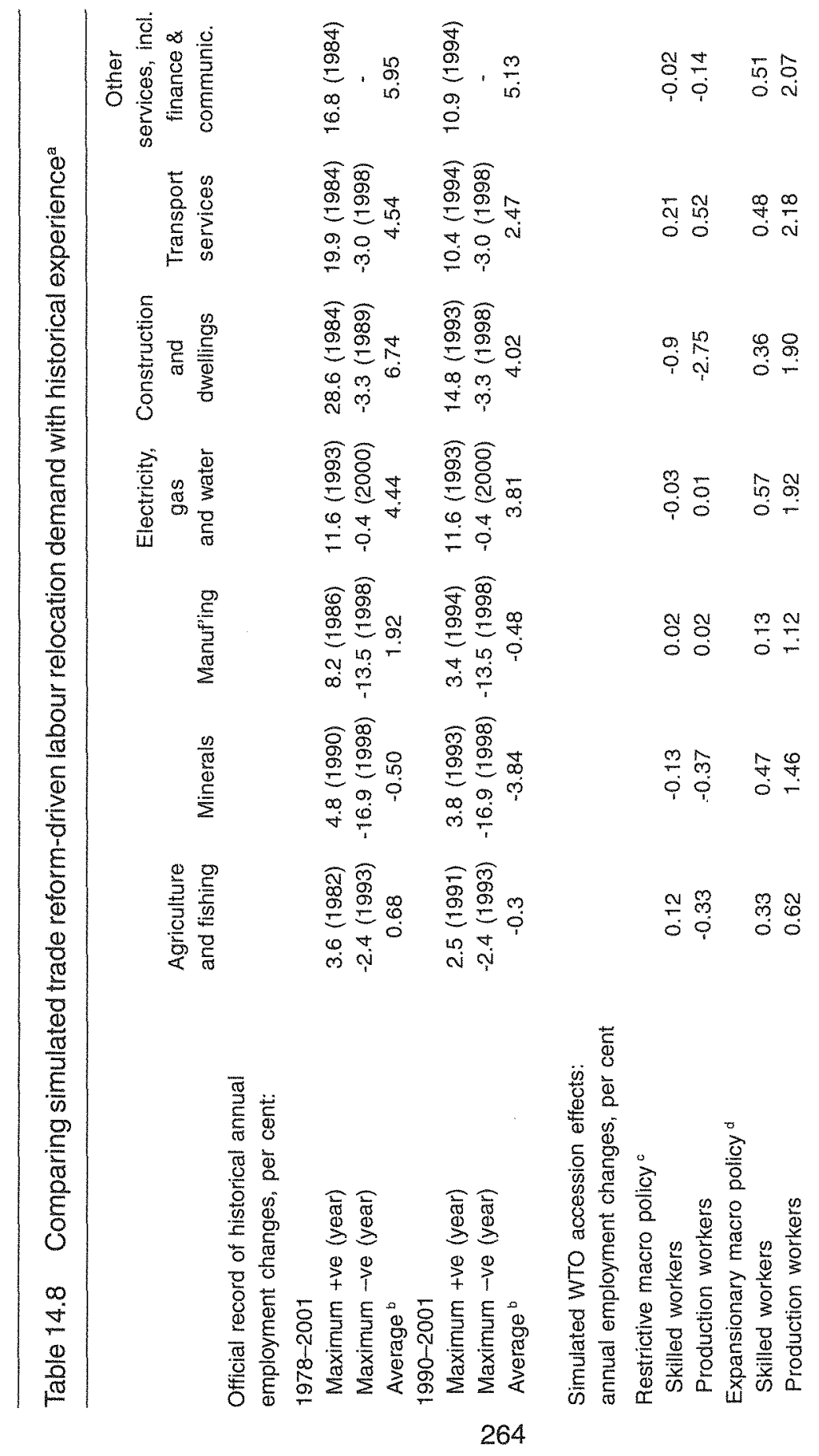




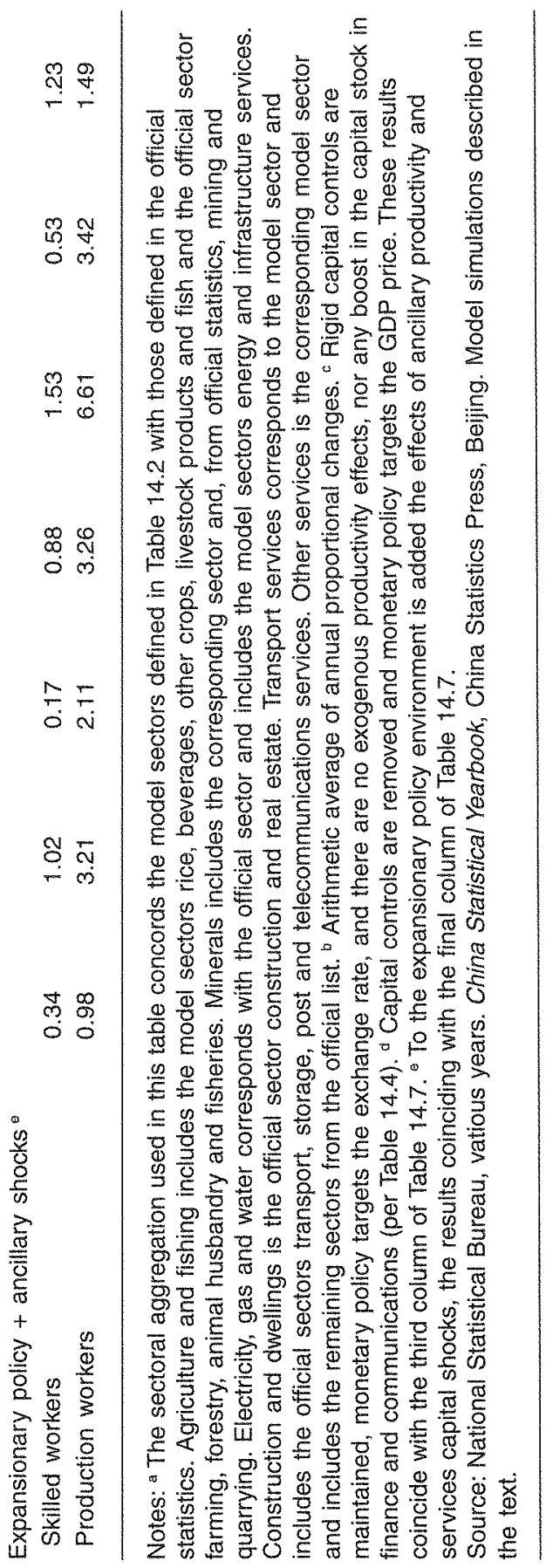


This opens the possibility that, at least in the short run, rural activity can expand at a sufficient pace to retain its workers. When we combine the most expansionary policy scenario with the ancillary effects of productivity and services reform (Table 14.4), the overall expansion permits employment in each sector to increase, as indicated in the final column of Table 14.8. Of course, there remains considerable redistribution of employment in these results, since the service sectors expand their labour use much more rapidly than does agriculture. Also, since we focus on the short run, we take no explicit account here of technical change in Chinese agriculture. In other countries at the same stage of development this change has been in labour saving, enabling the agricultural sector to shed workers more quickly (Anderson et al. 2003).

Our contention that the macroeconomic policy environment is important in determining the pace of worker relocation demand is borne out in these results. In all sectors there is a stark contrast between employment growth under tight capital controls and a fixed exchange rate regime on the one hand and an investment policy that renders the capital controls ineffective combined with a flexible exchange rate on the other. When the ancillary shocks to productivity and services capital are included, this gulf widens further. In the case of this most optimistic of scenarios, employment growth exceeds the average since 1990 in all but two sectors and the excess is largest in construction and dwellings and transport services. These strong worker relocation demands nonetheless fall short of the maxima achieved in a single year in all sectors, even since 1990.

Yet the WTO accession reforms are but a small part of the pantheon of China's overall reform program, the bulk of which is growth-enhancing. Not only do we exclude the trend of technology and associated organisational changes, as mentioned previously, but we take no direct account of the ongoing financial sector reforms and the continuing transformation of urban activity from the public to the private sector. Even in the case of China's WTO accession, we ignore commitments by China's trading partners to reduce protection against her labour-intensive exports. These changes will improve China's terms of trade and further stimulate its growth. Considering such omissions, worker relocation demand in a more expansionary policy environment could well approach, or even exceed, the high rates of change observed in the early 1990 s.

Finally, our simulations rest on the assumption that production and skilled workers in one sector are perfectly transformable into corresponding workers in other sectors. 
Because some workers have narrowly sector-specific education and training and because sectoral relocation attaches high transaction costs, particularly for rural families, the actual transformability of production workers will remain imperfect (Sicular and Zhao 2002). Our results therefore place upper bounds on the overall economic performance results from the WTO accession reforms and, more importantly for our purpose, upper bounds on worker relocation demands in the short run.

\section{CONCLUSION}

Our chronicle of changes in economic performance, income distribution and internal migration in China suggests a recent slowing of employment growth in the modern sector and the 'bottling up' of labour in rural activities, widening the income gap between urban and rural workers. This has happened in spite of what our review suggests is a considerable relaxation of the worker registration, or hukou, system which has constrained internal migration in the past.

To examine the hypothesis that the slowdown in overall growth, and the pace of worker relocation in particular, is due at least in part to a restrictive macroeconomic policy regime, we adapt a comparative static multi-product, multi-region macroeconomic model. We use the model to compare the economic effects of a key element of China's current economic reform program, namely its commitments associated with its accession to the WTO, under a variety of alternative macroeconomic policy regimes. These range from very restrictive capital controls combined with a fixed exchange rate to a regime with no capital controls (or the equivalent in FDI flexibility) and a flexible exchange rate. The results suggest these regimes make a difference of at least one per cent per year in overall GDP growth and at least two per cent per year in employment growth in the economy's modern sector. They therefore support our hypothesis, at least to the extent that the macroeconomic policy regime has contributed to a slowdown in the pace of expansion and worker relocation. Indeed, with an expansionary macroeconomic policy and optimistic assumptions about productivity effects associated with the WTO accession reforms and intersectoral worker transformability, simulated worker relocation demands from these reforms alone could exceed the average of China's recent experience.

While we are confident about our conclusion that China's macroeconomic policy regime has reduced economic performance relative to its theoretical potential, it 
does not follow that we advocate the immediate elimination of capital controls and the adoption of a floating exchange rate. The latter has been advocated recently by government representatives in Japan and the United States, including such significant players as the Chairman of the United States Federal Reserve. ${ }^{30} \mathrm{We}$ are more inclined to caution on the issue of the exchange rate, recognising that a float would be premature considering China's underdeveloped financial sector, its partially reformed banking industry and its still-vulnerable state-owned enterprises. ${ }^{31}$ The fact that more flexibility would enhance China's growth should be taken as indicating the need for acceleration of the financial sector reforms that are required before a floating rate regime can be implemented. ${ }^{32}$

\section{ACKNOWLEDGMENTS}

Funding for the research described comes, in part, from Australian Research Council Large Grant No. A201 and in part from ACIAR Project No.ADP/1998/128. Comments from Yongzheng Yang and assistance from Lucy Rees are appreciated.

\section{NOTES}

1 The contractionary effects of deflation do not end there. See Bordo and Redish (2003).

2 See Hertel (1997) for the original specification.

3 lanchovichina and Martin $(2001,2002)$ also examine the effects of WTO accession on labour relocation demand, and they offer an explicit analysis of the HRS. Their analysis, however, is strictly long run and ignores the short-run contractionary effects of macroeconomic policy emphasised here.

4 See Banister and Taylor (1989); Chai and Chai (1997); Hui (1989); Seeborg et al. (2000); and Multinational Monitor.

5 See Banister and Taylor (1989); Hul (1989); Seeborg, Jin and Zhu (2000).

6 See Banister and Taylor (1989); Hong Kong Liaison Office (IHLO). China's unemployment statistics measure only the urban unemployed.

7 Interestingly, just prior to the crisis (1995-96), the disparity actually narrowed. A grain shortage in 1994 had allowed a rise in prices for agricultural products relative to manufactures and hence a temporary improvement in the rural terms of trade. The effects of this on rural incomes were then bolstered by a return to good weather in 1995-96.

8 In 1984, it was estimated that about 40 per cent of workers in the countryside were redundant (Chai and Chai 1997). 
9 These restrictions tended to leave marginal urban residents underqualified for their jobs and migrants from rural areas overqualified. Meng and Zhang (2001) estimate these rates of under and over-qualification at 22 per cent for urban residents and 6 per cent for migrants from rural areas.

to Often quoted is the real effective exchange rate, which is a weighted average of bilateral real rates: $e_{i}^{R}=\sum_{j} E_{i j}\left(\frac{P_{i}^{Y}}{P_{j}^{Y}}\right)\left(\frac{X_{i j}+M_{i j}}{X_{i}+M_{i}}\right)$, where $X_{i}$ and $M_{i}$ are region $i s$ total values of exports and imports, respectively.

11 The analysis by Yang and Tyers $(2000,2001)$ suggests that the magnitudes of China's crisis period deflation might be understated by official statistics.

12 A detailed description of the original model is provided by Hertel (1997).

${ }_{13} T$, includes revenue from taxes on production, consumption, factor use and trade, all of which are accounted for in the original GTAP model and database.

${ }^{14}$ Private saving is derived as the difference between disposable income $(Y-T)$ and consumption expenditure, where real consumption is determined in a Keynesian reduced form equation that takes the form: $C=\gamma r^{\delta}[Y-T]^{\mu}$, where $r$ is the real interest rate.

15 Note that there is no allowance for interregional capital ownership in the starting equilibrium. At the outset, therefore, there are no factor service flows and the current account is the same as the balance of trade.

${ }^{16}$ By which it is meant that households can direct their savings to any region in the world without impediment. Installed physical capital, however, remains immobile even between sectors.

${ }^{\pi} r_{j}^{\theta}$ is the expected rental rate on physical capital (which, when physical capital is sector-specific, varies across sectors and thus is averaged), adjusted for depreciation and divided by the price of capital goods to yield a unitless net rate of return.

${ }^{18}$ Before adding to the global pool, savings in each region is deflated using the regional capital goods price index and then converted into US dollars at the initial exchange rate. The global investment allocation process is then made in real volume terms.

19 This investment relation is similar to Tobin's $Q$ in the sense that the numerator depends on expected future returns and the denominator indicates the current cost of capital replacement.

20 Since the initial database (GTAP Version 5) incorporates no 'net income' or factor service component in its current account, the initial equilibria must do likewise. This implies the assumption that, although there are no interregional bond holdings initially, the shocks implemented cause interregional exchanges of bonds and hence a non-zero net income flow in future current accounts not represented. 
21 More precisely, since for the US $E=1$, there is one less (usually endogenous) variable. Where nominal exchange rates are to be endogenous and nominal money supplies exogenous, one additional variable must be made endogenous. This could, for example, be balanced by making one price level exogenous, such as by having US monetary policy target the change in the US $C P I, P^{C}$.

22 The scope of monetary policy includes alterations in the rate at which official foreign reserves are accumulated. When there are no capital controls, however, the perfect capital mobility assumption implies that changes in reserves have no effect on net capital account flows. Where they are important is in the case where capital controls are effective. Because the manipulation of reserves offers only a short-term approach to exchange rate management that is only available if reserves are sufficient in the first place, $D R$ is held exogenous throughout the analysis in this chapter.

${ }^{2}$ Detailed descriptions of the GTAP database's content and sources as they relate to China are available in Gehlhar (2002), which describes the integration of the data for Hong Kong with that of the mainland and discusses the entrepot nature of some of Hong Kong's trade, Lin et al. (2002) for Taiwan and Wang et al. (2002) for the mainland.

${ }^{24}$ See Liu et al. (1998) for the method adopted.

$\approx$ For further discussion of the role and representation of skill-capital complementarity, see Tyers and Yang (2000).

2s Consequently, the rates in Table 14.3 tend to reflect the proportional changes in powers of tariffs implied by lanchovichina and Martin (2001) and the magnitudes as detailed in the protocol.

27 To the extent that some of the tariff reductions may in fact be phased in over several years, our analysis will tend to overstate the economic impacts in the short run.

$\approx$ The net factor income component of the current account is zero at the outset because that is the assumption embodied in the construction of the original database.

$\approx$ To see these at least partially offsetting gains in allocative efficiency it is necessary to use a multi-commodity general equilibrium framework such as that used in this chapter.

o Interestingly, this pressure has tended to be for a revaluation of the RMB, which would benefit both Japan and the US in the short run. The shocks we examine, however, yield real depreciations. Were these shocks dominant, we believe the fundamentals would be more likely to support a devaluation of the RMB. A revaluation would be justified only in the event of Chinese investment demand taking on 'bubble' characteristics, capital controls notwithstanding.

It See the discussion on this point by Edwards (2003).

32 See both Roberts and Tyers (2003) and Edwards and Levy-Yeyati (2003). 


\section{REFERENCES}

Anderson, K., Huang, J. and lanchovichina, E., 2002. Long-run Impact of China's WTO Accession on Farm-Non-farm Income Inequality and Rural Poverty, Paper presented at the World Bank Conference on China's WTO Accession, Policy Reform and Poverty Alleviation, Beijing, 28-29 June 2002.

Banister, J. and Taylor, J.R., 1989. 'China: surplus labour and migration', Asia-Pacific Population Journal, 4(4):3-20.

Bordo, M.D. and Redish, A., 2003. Is Deflation Depressing? Evidence from the classical gold standard, NBER Working Paper W9520, National Bureau of Economic Research, Cambridge, Massachusetts.

Chai, J.C.H. and Chai, B.K., 1997. 'China's floating population and implications', International Journal of Social Economics, 24(7-8-9):1038-51.

Chan, K.W., 2000. 'Internal migration in China: trends, determinants and scenarios', in China's Urbanization Strategy: opportunities, issues and policy options, World Bank and PRC State Development Planning Commission, Washington, DC and Beijing:56-63.

Chan, K.W. and Zhang, L., 1999. 'The Hukou system and the rural-urban migration in China: processes and changes', The China Quarterly, 160:818-55.

Chand, S., 1999. 'Trade liberalisation and productivity growth: time-series evidence from Australian manufacturing', The Economic Record, 75(228):28-36.

Chand, S., McCalman, P. and Gretton, P., 1998. 'Trade liberalisation and Manufacturing Industry Productivity Growth', in Productivity Commission and ANU Australian National University (eds), Microeconomic Reform and Productivity Growth, Ausinfo, Canberra:239-81.

Dee, P. and Hanslow, K., 2000. Multilateral Liberalisation of Services Trade, Productivity Commission, Melbourne.

Dolven, B., 2003. 'Take our workers, please', Far Eastern Economic Review, 27 February:24-26.

Edwards, S. 2003. 'China should not rush to float its currency', Financial Times, 3 August.

- - and Levy-Yeyati, E., 2003. Flexible Exchange Rates as Shock Absorbers, NBER Working Paper W9867, NBER, Cambridge, Massachusetts.

Garnaut, R., 1999. China After the East Asian Crisis, Paper presented to China Update 1999, National Centre for Development Studies, The Australian National University, Canberra, November. 
Gehihar, M.J., 2002.'Hong Kong's re-exports', in B.V. Dimaranan and R.A. McDougall (eds), Global Trade, Assistance and Production: the GTAP 5 Data Base, Center for Global Trade Analysis, Purdue University, West Lafayette. Available online at www.gtap.agecon.purdue.edu/databases/v5/v5_doco.asp.

Hertel, T.W. (ed.), 1997. Global Trade Analysis Using the GTAP Model, Cambridge University Press, New York.

Hong Kong Liaison Office (IHLO), 2002. China \& the WTO, Update and Analysis, Hong Kong Liaison Office, May 2002. Available online at http://www.ihlo.org/ item3/item3h-3.htm [accessed 4 December 2002].

Hui, D., 1989. 'Rural labour force transition and patterns of urbanization in China'. Asia Pacific Population Journal, 4(3):41-51.

lanchovichina, E. and W. Martin, 2001. 'Trade liberalisation in China's accession to the WTO', Journal of Economic Integration 16(4):421-45.

- 2002. Evaluating Accession to WTO by China and Chinese Taipei, Paper presented at the Fifth Annual Conference on Global Economic Analysis, Taipei, 5-7 June. Revised 11 December 2002. 'Economic Impacts of China's Accession to the WTO:'

Immigration and Refugee Board, Canada, 2002. China: internal migration and the floating population, Immigration and Refugee Board, Ottawa. Available online at http://www.irb.gc.ca/en/Researchpub/research/publications/chn11_e.htm [accessed 9 December 2002].

Lee, JW. And Rhee, C., 1999. Social Impacts of the Asian Crisis: Policy Challenges and Lessons, UNDP Working Paper 33, United Nations Development Programme, New York.

Lin, H.C., Chung, L., and Liou, R.W., 2002. 'Taiwan', in B.V. Dimaranan and R.A. McDougall (eds), Global Trade, Assistance and Production: the GTAP 5 Data Base, Center for Global Trade Analysis, Purdue University, West Lafayette:Chapter 11. Available online at www.gtap.agecon.purdue.edu/databases/v5/v5_doco.asp. Liu, J.N., Van Leeuwen, T., Vo, T., Tyers, R., and Hertel, T.W., 1998. Disaggregating Labor Payments by Skill Level in GTAP, Technical Paper 11, Center for Global Trade Analysis, Purdue University, West Lafayette. Available online at http:// www.agecon.purdue.edu/gtap/techpapr/tp-11.htm.

Lozada, C., 2002. 'Globalization reduces inequality in China', The NBER Digest, March:1. 
Meng, X., 1998. Recent Development in China's Labour Market, Paper presented at China Update 1998, National Centre for Development Studies, The Australian National University, Canberra.

Meng, X. and Zhang, J., 2001. The two-tier labour market in urban China: occupational segregation and wage differentials between urban residents and rural migrants in Shanghai', Journal of Comparative Economics, 29(3)485-504.

Multinational Monitor, 2000. Sewing up the Chinese market-The effect of WTO Entry on the Chinese Rural Sector, Multinational Monitor, Avalable online at www.multinationalmonitor.org/mm2000/00may/weil.html [accessed 4 December 2002].

National Bureau of Statistics, various years. China Statistical Yearbook. China Statistics Press, Beijing.

Rees, L. and Tyers, R., 2002. Trade Reform in the Short Run: China's WTO Accession, Working Papers in Economics and Econometrics 423, The Australian National University.

Roberts, I. and Tyers, R., 2003. 'China's exchange rate policy: the case for greater flexibility', Asian Economic Journal, 17(2):157-86.

Seeborg, M.C., Jin, Z. and Zhu, Y., 2000. 'The new rural-urban labour mobility in China: Causes and implications', The Journal of Socio-Economics, 29(2000):3956.

Sicular, T. and Zhao, Y., 2002. Labor Mobility and China's Entry to the WTO, Paper presented at the conference on WTO Accession, Policy Reform and Poverty Reduction, Beijing, June 26-28.

Stoeckel, A., Tang, K.K., and McKibbin, W., 1999. The Gains from Trade Liberalisation with Endogenous Productivity and Risk Premium Effects, Technical Paper prepared for the seminar Reasons versus Emotion: Requirements for a Successful WTO Round, Seattle, 2 December.

Tyers, R. and Rees, L. 2002. Trade Reform and Macroeconomic Policy in Vietnam, Working Papers in Economics and Econometrics 419, The Australian National University. Also presented at the Fifth Annual Conference on Global Economic Analysis, Taipei, June.

Tyers, R. and Yang, Y., 2000. 'Capital-skill complementarity and wage outcomes following technical change in a global model', Oxford Review of Economic Policy, 16(3):23-41. 
- 2001. Short Run Global Effects of US 'New Economy' Shocks: the role of capital-skill complementarity, Paper presented at the Fourth Annual Conference on Global Economic Analysis, Purdue University, West Lafayette, 27-29 June. Available online at http://ecocomm.anu.edu.au/people/rod.tyers.

Verikios, G. and Zhang, X., 2001. The Economic Effects of Removing Barriers to Trade in Telecommunications and Financial Services, Paper presented the Fourth Annual Conference on Global Economic Analysis, Purdue University, West Lafayette, 27-29 June.

Wang, Z., Zhai, F., and Xu, D., 2002. 'China', in B.V.Dimaranan and R.A. McDougall (eds), Global Trade, Assistance and Production: the GTAP 5 Data Base, Center for Global Trade Analysis, Purdue University, West Lafayette:Chapter 11C. Available online at www.gtap.agecon.purdue.edu/databases/v5/v5_doco.asp.

Yang, Y., 1998. China in the Middle of the East Asian Crisis: export growth and the exchange rate, paper presented at China Update 1998, National Centre for Development Studies, The Australian National University, Canberra.

Yang, Y. and Tyers, R., 2000. China's Post-crisis Policy Dilemma: multi-sectoral comparative static macroeconomics, Working Papers in Economics and Econometrics 384, The Australian National University, Canberra. Revised edition available online at http://ecocomm.anu.edu.au/people/rod.tyers.

- 2001. 'The Asian crisis and economic change in China', Japanese Economic Review, 52(4):491-520.

Zhao, Y., 2000. 'Rural to urban labour migration in China: past and present', in L.A. West and Y. Zhao (eds), Rural Labour Flows in China, University of California Press, Berkeley:15-33. 


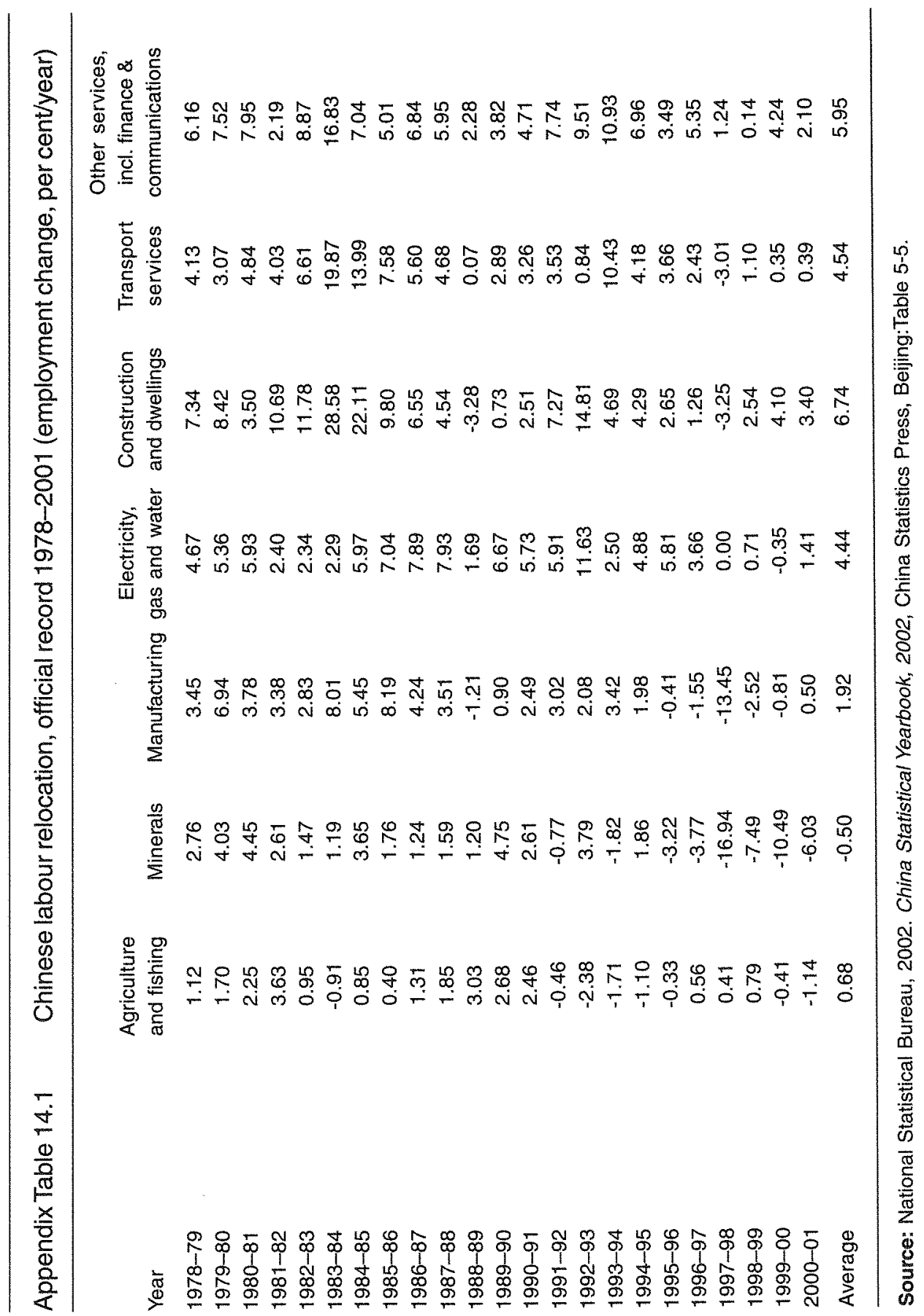




\title{
15
}

\section{Internet development}

\author{
Fang-Fang Tang
}

\section{A BRIEF HISTORY}

Internet use in mainland China has accelerated in recent years, reaching 68 million users by 30 June 2003, ${ }^{1}$ in sharp contrast to the slowdown in some of the industrialised economies. The latest survey conducted in Taiwan (31 December 2002) shows that the internet penetration rate on the island has reached 38 per cent, or 8.6 million users. A similar survey conducted by the City University of Hong Kong at the end of 2002 indicates that internet users in the Hong Kong number 2.8 million or 45 per cent of the Hong Kong population aged from 6 to 84 , according to the China Internet Network Information Centre (CNNIC) definition, or 2.4 million according to the WIP (World Internet Project) definition or 49 per cent of the population aged from 18 to 74. This chapter focuses on internet development in mainland China, with additional discussions of the situation in Hong Kong and Taiwan when relevant.

Internet development has been dramatic all over the world. Its brief history in China is even more dramatic because of the particular political and social factors.

On 20 September 1987, Professor Qian Tianbai, then in charge of the internet project of China Academic Network (CANET) initiated by the Beijing Municipal Computer Application Research Institute with collaboration with Karlsruhe University in West Germany, sent the first electronic mail, entitled 'Crossing the Great Wall to the World'. This email went through the PAD set up in Beijing by the Italian ATAPAC, routed by the German DATEX.P, at the speed of 300 bytes per second. It was slow and small but historic. Over a year later, in December 1988, Tsinghua University campus network in Beijing adopted the $\mathrm{X} 400$ Protocol, an email software package brought back by Professor Hu Daoyuan from the University of British Columbia 
(UBC), Canada, to connect to the UBC campus through the X.25 network. In the same year, the institute of High Energy Physics in the Academia Sinica in Beijing enacted its DECnet as an extension of the central DECnet in Western Europe through $X .25$, realising international computer networking and email communications with Europe and North America.

In May 1989, the China Research Network (CRN) was connected to the German Research Network (DFN) through the pilot X.25 net built by the then Ministry of Posts and Telecommunications. By that time, the CRN members comprised only a handful of research institutes and universities in Beijing, Shanghai, Chengdu, Shijiazhuang and Nanjing. Nevertheless, the CRN could provide services such as email, file transmission based on File-Transfer Access and Management (FTAM) standard, catalogue based on X.500 standard, and access to the Internet through the DFN. In April 1990, the State Planning Commission organised bidding for a project to build a pilot network of education and research (NCFC) in the Zhongguancun area in Beijing (now China's hi-tech computing centre), with loans from the World Bank and jointly supported by the State Planning Commission, State Science Commission, Academia Sinica, National Natural Science Foundation and State Education Commission. The project aimed to build a high-speed interconnected network connecting Academia Sinica, Peking University and Tsinghua University with a super-computing centre. World Bank loans played a positive role in the development process.

In October 1990, Professor Qian Tianbai, representing China, officially registered China's top domain name as CN in the Defense Data Network Network Information Center (DDN-NIC) of ARPANET (US Department of Defense) which was then in charge of allocation of global internet domain names and internet provider (IP) addresses before the Internet's Information Center (INTERNIC) was established. International email service using $\mathrm{CN}$ domain name started from that time. Since China was not yet formally connected to the internet, Karlsruhe University was commissioned to run the $\mathrm{CN}$ domain name server. At the International Networking (INET) Conference in June 1992 in Kobe, Japan, Qian Hualin, a research fellow at Academia Sinica, met the person in charge of the international network of the US National Science Foundation to discuss the issue of China's official connection to the internet. He was informed, however, that there were political hurdles because many US government organisations were connected to the internet. Nevertheless, that year saw the completion of the National Computing and Networking Facility 
(NCFC) college and institute network project, the CASNET, connecting dozens of research institutes of Academia Sinica and its headquarters, the TUNET of the Tsinghua University campus and the PUNET of the Peking University campus.

On 2 March 1993, the Institute of High Energy Physics, Academia Sinica leased a 64K dedicated line from AT\&T's international satellite channel to connect to the Stanford Linear Accelerator Center (SLAC). But it was only permitted a US Energy network because the US government still excluded 'socialist countries' since there was too much sensitive information about science and technology on the internet. Nevertheless, it was China's first dedicated line with partial access to the internet, so the China State Fund Commission strongly supported this initiative and allocated 300,000 RMB Yuan to enable all leaders of key research projects from various fields to access this line through dialing. Hundreds of scientists in China benefited, and email use within China in general was established. Ten days later, the then Deputy Premier Zhu Rongji put forward a proposal to establish the National Public Economic Information Network-the Golden Bridge Project. Next month the Computer Network Information Center of Academia Sinica brought together some of the network experts in Beijing to determine a framework for the China domain name system, after examining the domain name systems of other countries. In June 1993, NCFC specialists reiterated China's request to be linked to the internet at various possible occasions during the INET'93 conference and won the support of most participants from the international internet community. Qian Hualin discussed China's internet connection at the CCIRN conference and gained majority support.

On 27 August 1993, the then Premier Li Peng approved the use of US $\$ 3$ million of the Premier Reserve Fund to activate the Golden Bridge Project. The following month Deputy Premier Zou Jiahua established the National Joint Conference on Economy Informationalisation. In December, NCFC backbone network construction was completed with high-speed optical fibre wires and routers connecting the three networks of CASNET, TUNET and PUNET. At the beginning of 1994, before the China-America Network Symposium (CANS), US NSF agreed with the request of NCFC to connect to the internet officially. In March 1994, a 64Kbps dedicated line was tested and opened to the public.

In April, the Sino-American Federation of Scientific and Technological Cooperation met in Washington, DC, and Hu Qiheng, the then Vice President of Academia Sinica, reiterated China's request to be linked to the internet. NSF agreed. On 20 April 1994, the NCFC project leased and opened a dedicated $64 \mathrm{~K}$ line through SPRINT Co. of 
the United States to connect China with the internet. This represented official international recognition of China's internet access.

Young people now take internet access for granted but establishing links for China was a complicated process. The Chinese media ranked the country's full access to the internet among the top ten science and technology news items in 1994, and the State Statistics Bulletin ranked it among the major science and technology achievements in the same year.

On 15 May 1994, Academia Sinica's Institute of High Energy Physics set up the first web server with a set of web pages in China. The contents included exhibitions of China's hi-tech development and a window called 'Tour of China', which later extended to include graphics plus information on news, economy, culture, trade and so on, and was renamed as 'Window of China'. This development path is similar to the European integration process, which also began with collaborations in physics research. Soon after, Academia Sinica's Computer Network Information Center completed the installation of China's top domain name server $(\mathrm{CN})$. This was a historic moment.

In June 1994, the General Office of the State Council issued a notice to all provinces and municipalities to start the 'Three Golden Projects'. In September, China Telecom signed an agreement with US Chamber of Commerce to establish international internet links between China and the United States specifying that China Telecom would open two $64 \mathrm{~K}$ dedicated lines provided by the US Sprint Corporation, one line in Beijing and the other in Shanghai. Construction of China's public computer network (CHINANET) started. The following month the State Planning Commission invested in the China Education and Research Network (CERNET), supervised by the State Education Commission. This was a national infrastructure for education and research linking most colleges and middle schools for campus network interconnection and information resources. This was also the first year of the APNG (Asia Pacific Networking Group) Annual Meeting in Tsinghua University, the first international meeting in China on the internet.

In January 1995, China Telecom opened the two 64K lines to the United States provided by the Sprint Corporation and started to offer internet service to the general public through telephone lines, DDN and X.25 network. CERNET then put the journal 'Shen Zhou Scholar' (Chisacm) published by the State Education Commission on the internet. This was the first Chinese language e-journal. Soon after, CERNET opened a 128K dedicated line into the United States. In August 1995, CERNET 
opened the Tsinghua 'ShuiMu'(water-wood) the first internet bulletin board system (BBS) on mainland China.

In January 1996, China Telecom completed the national backbone network of CHINANET and opened nationwide internet access. Soon after, the State Council issued Decree 195 on 'Provisional Regulations of the People's Republic of China on the Management of International Interconnection of Computer Information Network' In September 1996, the China Golden Bridge Information Network (CHINAGBN) opened its $256 \mathrm{~K}$ dedicated line with the United States and announced provision of internet access, mainly for group users through dedicated circuits and for individuals through telephone lines. In November, CERNET opened its $2 \mathrm{M}$ international communication channel. In December, China Public Multimedia Communication Network (169 Net) began full operations, with the opening of its first group of websites, including Guangdong Shilington, Tianfu Online (Sichuan) and Shanghai Online.

The State Council held a National Informationalisation Workshop from 18-21 April 1997 in Shenzhen. This meeting defined the national information system framework, determined the essential factors, missions and guidelines, working principles, objectives and major tasks of such systems, and passed the 'National Informationalisation 95 Planning and Vision Goals of 2000'. It also categorised the internet into the construction agenda of national information infrastructure facilities and proposed the establishment of the National Internet Information Centre and the Internet Exchange Centre. On 20 May 1997, the State Council revised the Provisional Regulations on Internet Management. Ten days later, the Office of Informationalisation Leading Team of the State Council issued the Decree on 'Provisional Regulations of China Internet Domain Name Registration', commissioning Academia Sinica to establish and manage the CNNIC, and the China Education and Research Computer Network Center to contract with the CNNIC for management of the secondary domain names '.edu.cn'.

In November 1997, the CNNIC published its first Statistical Report on Internet Development in China. On 30 December 1997, the Ministry of Public Security issued 'Security Protection Management Regulations of International Interconnection of Computer Information Network', approved by the State Council. In 1997, connection between CHINANET, CSTNET (China Science and Technology Network), CENET (China Economics Network) and CHINAGSN networks was established. Early the following year, the National People's Congress merged several ministries to form the Ministry of Information Industries (MII), which would oversee nation-wide 
manufacturing of electronic and information technology products, telecommunications sector and software industry to advance the knowledge of the national economy and social services.

CERNET opened a satellite network and two satellite systems of CSTNET in January 1991, replacing the IP/X.25 and connecting more than 40 cities in China with high-speed satellite channels. Network speed was significantly improved. In February 1999, they launched the China National Information Security Testing Evaluation Centre (CNISTEC). Then MII cut various charges on internet access service by as much as 50 per cent and cancelled certain charges. China also opened its first ethnic minority website, the Tongyuan Xizhang (Tibet), on the platform of Western Space in Gansu Province in western China. Development of the internet in China was even more rapid after 2000.

\section{RESULTS}

CNNIC started to publish statistical reports on internet development in China in October 1997. This survey adopted international conventions by using a combination of networked computer search methods, user questionnaires and so on. The sampling and statistical methods and results are widely cited in China and internationally. It is one of the most reliable and authoritative surveys in China and has published results every January and July since 1998. A summary of the major findings from this series of reports follows. ${ }^{2}$

First, networked computers and international bandwidth have increased exponentially in mainland China during this period, about 80 and 732 times the October 1997 levels, respectively (Table 15.1). The slight decrease of international bandwidth in late 2002 and early 2003 was mainly due to the reduction of bandwidth by CHINANET and CNCNET (China Netcom Corporation Ltd.) (Table 15.2) although UNINET and CMNET expanded their bandwidth to a different extent. The reason was probably due to market fluctuations reflected in network use, since UNINET and CMNET represented the fast development of mobile telecommunications in China. The decrease of bandwidth gaps among the major service providers, particularly the telecoms, could mean more effective competition in this market.

Business application (com) under ' $\mathrm{CN}$ ' is still the main trend although it was stagnant in 2001-02 due to the burst of the internet bubble in global financial markets (Table 15.3). It should be noted that electronic government is rapidly becoming more common. Investment in e-government in 2002 was about RMB 40 billion and is 
Table 15.1 Growth of networked computers ('000)

\begin{tabular}{lcccc}
\hline & Total & Dedicated line & Dial-up & $\begin{array}{c}\text { International } \\
\text { bandwidth(M) }\end{array}$ \\
October 1997 & 299 & 49 & 250 & 25.4 \\
July 1998 & 542 & 82 & 460 & 84.6 \\
January 1999 & 747 & 117 & 630 & 143.2 \\
July 1999 & 1,460 & 250 & 1,210 & 241.0 \\
January 2000 & 3,500 & 410 & 3,090 & 351.0 \\
July 2000 & 6,500 & 1,010 & 5,490 & $1,234.0$ \\
January 2001 & 8,920 & 1,410 & 7,510 & $2,799.0$ \\
July 2001 & 10,020 & 1,630 & 8,390 & $3,257.0$ \\
January 2002 & 12,540 & 2,340 & 10,200 & $7,597.5$ \\
July 2002 & 16,130 & 3,070 & $12,000+1,060$ & 10576.5 \\
Jan. 2003 & 20,830 & 4,030 & in other ways & \\
July 2003 & & & $14,800+2,000$ & 9380 \\
& 25,720 & 5,150 & in other ways & \\
& & & in other ways & \\
\hline
\end{tabular}

Source: CNNIC Survey

Table 15.2 International bandwidth distribution (million yuan)

\begin{tabular}{lccc}
\hline & July 2002 & January 2003 & July 2003 \\
CSTNET & 55 & 55 & 55 \\
CHINANET & 6452 & 5147 & 10959 \\
CERNET & 257.5 & 259 & 324 \\
UNINET (China Unicom) & 693 & 1093 & 1435 \\
CNCNET (China NetCom) & 2870 & 2469 & 2112 \\
CHINA169 & $n . a$ & & 3465 \\
(broadband by China Netcom) & & $n . a$. & \\
CIETNET & 2 & 2 & 247 \\
(China International Economy and Trade Net) & 247 & 355 & \\
CMNET (China Mobile) & (under construction) & (under construction) \\
CGWNET (China Great Wall Net) & (under construction) & (under construction) \\
CSNET (China Satellite Group Net) & & & \\
\hline
\end{tabular}

Source: CNNIC Survey 
expected to reach RMB 50 billion in 2003. The number of websites has risen from approximately 1,500 in October 1997 to 15,153 in January 2000, 371,600 in January 2003 and 473,900 in July 2003. The geographic distribution of websites and domain names registered under ' $\mathrm{CN}$ ' has been reasonably stable during all surveys since 1997. The North (mainly Beijing), East and South parts of China have accounted for some 85 per cent or even more of the total, while the Northeast, Southwest and Northwest parts of China are still far behind. This pattern reflects disparities in economic development and also in the application of information technology between these regions.

The growth of online users is even more impressive, with rates in double digits in all the years, reaching 68 million in July 2003 (see Table 15.4). In July 2003, it was more than 110 times October 1997 and stands at the position of no. 2 internationally, only just behind the United States. ${ }^{3}$ On the other hand, online users account for merely 5.3 per cent of the population ( 1.3 billion in China), which indicates a huge potential in future growth. Further, it should be noted that dialing-up access maintains the main connection way for the majority of networked computers and also for online users. Broadband is only a recent phenomenon although its growth seems fast. Other economies, from the United States to Europe, and from Japan to South Korea, have put high priority on the development of broadband internet. The case of South Korea is particularly interesting (Tang 2002). The successful penetration of

Table 15.3 Distribution of domain names under ' $\mathrm{CN}$ '

\begin{tabular}{lccccccc}
\hline & COM & EDU & GOV & NET & ORG & others & Total \\
October 1997. & 2131 & 325 & 323 & 370 & 99 & 818 & 4066 \\
July 1998 & 6559 & 414 & 561 & 657 & 229 & 995 & 9415 \\
January 1999 & 13913 & 531 & 982 & 1223 & 409 & 1338 & 18396 \\
July 1999 & 22220 & 615 & 1663 & 2221 & 649 & 1677 & 29045 \\
January 2000 & 38776 & 731 & 2479 & 3753 & 940 & 2016 & 48695 \\
July 2000 & 78878 & 812 & 3665 & 10719 & 1912 & 3748 & 99734 \\
January 2001 & 96221 & 1127 & 4615 & 13291 & 2596 & 4249 & 122099 \\
July 2001 & 99922 & 1239 & 5181 & 15055 & 2864 & 4101 & 128362 \\
January 2002 & 99123 & 1354 & 5864 & 14045 & 2943 & 3990 & 127319 \\
July 2002 & 98835 & 1482 & 6686 & 12248 & 3031 & 3864 & 126146 \\
January 2003 & 133796 & 1629 & 7796 & 20234 & 9587 & 6502 & 179544 \\
July 203 & 341753 & n.a & 7876 & 60408 & 26292 & 35196 & 473900 \\
\hline
\end{tabular}

Source: CNNIC Survey 
broadband use has dramatically changed the way of life and business there. China should pay more attention in this strategically important area. Another worth mentioning is the growth of internet access from equipment other than computer, including mobile devices and home appliances, with users increasing from 200,000 in January 2000 to 1.53 million in January 2003 and to 1.8 million in July 2003. These figures represent a 9 times increase within three and a half years.

Clearly, the pattern of demographic distribution of online users has shifted from a mainly male activity to a more even one (Table 15.5). Male online users still count as 20 per cent more than female ones, but female users have been steadily increasing and have stabilised at about 40 per cent. The disparity has decreased from $7: 1$ in October 1997, to about 3:2 in 2003. Male users number 40.87 million in July 2003, a 16.6 per cent increase from the previous six months and close to 75 times the number in October 1997. Female users number about 27.13 million, a smaller increase of 12.8 per cent but still 358 times the number in October 1997. Nevertheless, male users account for 6.2 per cent of the male population in China and female users only 4.4 per cent of the female population, indicating a much lower Internet penetration rate in females than males in China.

Married people seem to have less time for such a novel hobby, reflected in the stable gap of 20 per cent fewer than unmarried users, although this gap may be narrowing. Clearly usage is linked to the fact that the internet appeals to people

Table 15.4 Growth of online users ('000)

\begin{tabular}{lrcccl}
\hline & Total & Dedicated line & Dial-up & Both ways & \\
October 1997 & 620 & 155 & 465 & n.a. & \\
July 1998 & 1,175 & 325 & 850 & n.a. & \\
January 1999 & 2,100 & 400 & 1,490 & 210 & \\
July 1999 & 4,000 & 760 & 2,560 & 680 & \\
January 2000 & 8,900 & 1,090 & 6,660 & 1,150 & \\
July 2000 & 16,900 & 2,580 & 11,760 & 2,560 & \\
January 2001 & 22,500 & 3,640 & 15,430 & 3,430 & \\
July 2001 & 26,500 & 4,540 & 17,930 & 4,030 & \\
January 2002 & 33,700 & 6,720 & 21,330 & 5,650 & \\
& & & & $1 S D N$ & Broadband \\
July 2002 & 45,800 & 16,060 & 33,420 & 3,150 & 2,000 \\
Jan. 2003 & 59,100 & 20,230 & 48,000 & 4,320 & 6,600 \\
July 2003 & 68,000 & 23,420 & 45,010 & 4,900 & 9,800 \\
\hline
\end{tabular}

Source: CNNIC Survey 
under 35. Married internet users reached 27.4 million by July 2003, or 3.4 per cent of the married population, while there were 40.6 million unmarried users, or 8.6 per cent of the unmarried population. Age seems to be the most important factor determining internet use so far, with the 18-24 year olds being most active, making up 40 per cent of all internet users. The proportion of 25-30 year olds has decreased sharply in the past three years, from 30.8 per cent in January 2000 to 17 per cent in January 2003, while users under 18 have risen rapidly, from 2.4 per cent to 17.6 per cent during the same period. This change has mainly to do with the recent trend of middle school students going online. The proportion of internet users over 35 has been fluctuating by about 2 per cent though generally increasing steadily, numbering 11.08 million in July 2003. The overall pattern seems to indicate that online activities are still more for information and fun than for business.

Table 15.6 summarises the educational level of online users from July 1998 , when this aspect was first surveyed. Obviously, the high school, professional school and three-year college level again account for the majority in recent years, although university-educated people were the main pioneers to use the internet. More specifically, by January 2003, high school and professional school education levels accounted for 30.9 per cent while three year college (Da Zhuan) level accounted for 27.1 per cent. The growth at undergraduate education level or above stood at 6.3 per cent or 1.14 million during the same period. The increasing supply and diversity of online content and lower costs of access services have surely contributed to this change.

Table 15.5 Demographics of online users (per cent)

\begin{tabular}{lcccccc}
\hline & Male & Female & Below 35 & Above 35 & Married & Unmarried \\
October 1997 & 87.7 & 12.3 & 84.1 & 15.9 & n.a. & n.a. \\
July 1998 & 92.8 & 7.2 & 91.1 & 8.9 & n.a. & n.a. \\
January 1999 & 86.0 & 14.0 & 89.8 & 10.2 & 36 & 64 \\
July 1999 & 85.0 & 15.0 & 88.9 & 11.1 & 37 & 63 \\
January 2000 & 79.0 & 21.0 & 88.2 & 11.8 & 36 & 64 \\
July 2000 & 74.7 & 25.3 & 87.6 & 12.4 & 33.4 & 66.5 \\
January 2001 & 69.6 & 30.4 & 83.8 & 16.2 & 37.0 & 62.9 \\
July 2001 & 61.3 & 38.7 & 79.8 & 20.2 & 41.5 & 58.5 \\
January 2002 & 69.0 & 40.0 & 79.9 & 20.1 & 43.1 & 56.9 \\
July 2002 & 60.9 & 39.1 & 82.0 & 18.0 & 41.1 & 58.9 \\
January 2003 & 59.3 & 40.7 & 82.1 & 17.9 & 42.2 & 57.8 \\
July 2003 & 60.1 & 39.9 & 83.7 & 16.3 & 40.3 & 59.7 \\
\hline
\end{tabular}

Source: CNNIC Survey 
Another useful category would be according to occupations or industries. Unfortunately, CNNIC surveys used different industry names or occupation titles at various stages so it is not feasible to summarise them in tables as above. In the latest surveys, January and July 2003, one can see that students account for 28 and 30.1 per cent of online users, more than the technical and professional people at 15.7 and 15.9 per cent. The third ranked are clerks, assistants, commerce and service people at 10.3 and 9.1 per cent, while the agriculture, forestry, cattle-raising and fishing personnel and the military personnel make up only 1, 0.9 and 0.8 per cent respectively of online users. Students are generally more open to novelty and the significant improvement in campus network infrastructure has certainly helped this trend. By January and July 2003, student online users account for 7.4 and 9 per cent of the total student population (including primary to postgraduate students), a 2 per cent increase during six months if one takes into account the vast base of student population in the enormous size of China.

By industry categorisation, personnel from public management and social organisations account for 12.5 per cent among online users, followed by wholesale and retailing personnel (11.8 per cent), manufacturing personnel (11.1 per cent), education and scientific researchers (10.6 per cent), IT personnel (10.3 per cent), financial industry personnel (6.1 per cent), warehousing and transportation workers (4.7 per cent), health, social security and welfare personnel ( 3 per cent) and so on.

Table 15.6 Education level of online users (per cent)

\begin{tabular}{lcccc}
\hline & $\begin{array}{c}\text { Below } \\
\text { high school }\end{array}$ & $\begin{array}{c}\text { College/ } \\
\text { University }\end{array}$ & Undergraduate & Postgraduate \\
July 1998 & 6.9 & 34.2 & 49.6 & 9.3 \\
July 1999 & 2.0 & 39.0 & 48.0 & 11.0 \\
January 2000 & 3.0 & 45.0 & 45.0 & 7.0 \\
July 2000 & 2.5 & 45.6 & 45.9 & 5.9 \\
January 2001 & 6.4 & 52.4 & 38.8 & 2.3 \\
July 2001 & 8.7 & 55.5 & 33.6 & 2.2 \\
January 2002 & 10.2 & 56.9 & 30.4 & 2.5 \\
July 2002 & 11.5 & 56.8 & 29.2 & 2.5 \\
January 2003 & 12.9 & 56.7 & 27.6 & 2.8 \\
July 2003 & 13.9 & 58 & 25.5 & 2.6 \\
\hline
\end{tabular}

Source: CNNIC Survey 
Internet use growth is highest among the health, social security and welfare personnel (83.2 per cent or 0.99 million during 6 months) followed by education personnel (39.8 per cent or 1.67 million) and manufacturing personnel (38.3 per cent during six months). Online user population becomes more and more diverse by occupations or industries, a healthy trend for Internet development in China. The fast growth of online users in manufacturing is interesting, since this sector is increasingly important in the Chinese economy, which is dominated by manufacturing. Increasing familiarity with internet use and e-commerce will enhance the competitiveness and productivity of its workforce and the whole sector.

Beijing, Shanghai and Guangzhou areas clearly dominated Internet use in the early years and still are the most important parts (Table 15.7). But other regions are catching up fast, especially the Northeast and Southwest regions. It would be interesting to make a comparison of users in the East and Northwest, the two ends of the spectrum. According to the CNNIC survey in January 2003, male Internet users account for 58 per cent in the East and female 38 per cent, but 67.5 per cent versus 32.5 per cent in the Northwest -51.9 per cent are unmarried users in the East and 45.3 per cent in the Northwest. The patterns are qualitatively different with sex ratio and marriage status reversed in these two regions. On the other hand, age distribution does not seem to differ between these two regions. Internet users at different age intervals in the East and Northwest were 19.5 per cent versus 19.6 per

Table 15.7 Geographic distribution of online users

\begin{tabular}{lcccccc}
\hline & North & Northeast & East & South & Southwest & Northwest \\
October 1997 & 41.0 & 5.2 & 27.1 & 29.5 & 4.3 & 1.9 \\
July 1998 & 31.6 & 9.6 & 29.3 & 22.6 & 4.2 & 2.7 \\
January 1999 & 28.7 & 6.7 & 24.0 & 30.5 & 5.9 & 4.0 \\
July 1999 & 26.7 & 6.6 & 32.0 & 21.2 & 7.9 & 4.7 \\
January 2000 & 28.0 & 7.4 & 31.6 & 23.6 & 6.0 & 3.2 \\
July 2000 & 25.1 & 6.4 & 35.0 & 22.9 & 6.2 & 4.3 \\
January 2001 & 19.9 & 9.5 & 34.4 & 21.8 & 9.3 & 4.9 \\
January 2002 & 17.7 & 8.4 & 36.0 & 24.3 & 9.0 & 4.6 \\
July 2002 &.. &.. &.. &.. &.. &.. \\
January 2003 & 21.9 & 11.0 & 26.4 & 25.0 & 10.3 & 5.4 \\
July 2003 &.. &.. &.. &.. &.. &.. \\
\hline
\end{tabular}

Note: CNNIC survey began to report by provinces. The author computed according to the traditional regional names (South includes South China and Middle China here).

Source: CNNIC Survey 
Table 15.8 Methods of financing online access

\begin{tabular}{lccc}
\hline & Public & Private & Both ways \\
July 1998 & 35.0 & 44.0 & 21.0 \\
January 1999 & 26.0 & 45.0 & 29.0 \\
July 1999 & 28.0 & 46.0 & 26.0 \\
January 2000 & 21.0 & 59.0 & 20.0 \\
July 2000 & 17.5 & 56.3 & 26.1 \\
January 2001 & 14.1 & 63.3 & 22.4 \\
July 2001 & 12.6 & 70.4 & 17.9 \\
January 2002 & 10.7 & 73.7 & 15.6 \\
July 2002 & 10.1 & 77.1 & 12.8 \\
January 2003 & n.a. & n.a. & n.a. \\
July 2003 & n.a. & n.a. & n.a. \\
\hline
\end{tabular}

Source: CNNIC Survey

cent for below 18, 31.3 per cent versus 23.4 per cent for 18-24, 18.9 versus 18.1 per cent for $25-30,10.8$ versus 17.5 for $31-35,8.2$ per cent versus 11.9 for $36-40,6.9$ per cent versus 6.5 per cent for $41-50,3.5$ per cent versus 1,8 per cent for $51-60$, and 1 per cent versus 1.2 per cent for above 60 . Internet users in the East were younger, 69.7 per cent below 31 while it is 61.1 per cent in the Northwest, not a qualitatively significant difference.

The distribution of educational levels among online users and online timing each day are also similar in these two regions. The frequency of internet use, however, is much higher in the East (11.3 hours and 3.6 days per week on average) than in the Northwest ( 8.4 hours and 3 days per week on the average) and consistently with this average, Eastern users spent more for internet connection than their non-Western counterparts. This pattern is also consistent with the economic development level in these two regions.

The proportion of non-users in the Northwest who wished to go online within a year was higher than in the East. Easterners went online more for information and for fun, while their Northwest counterparts more for education and making friends. The geographic remoteness of the Northwest is probably the contributing factor.

Ways of financing online access have changed dramatically, as reflected in Table 15.8. People have mainly spent their own money for internet access in recent years, and the CNNIC survey has stopped even collecting such data since 2003. It is not surprising, because internet access infrastructure becomes increasingly better and 
cheaper. When we consider that recently, private cars in China exceeded 10 million, it is clear that increasing numbers of people will also finance internet access.

In recent years, the CNNIC surveys started to collect information on the income distribution of internet users, an important improvement. See Table 15.9 for the years 2002 to 2003. Obviously, low income or even no income groups are the main users, thus online retailing in China still has a long to go, except for a few items such as books or online game services. In addition, the average spending on internet access is also rather low, mostly below 100 yuan per month, thus even ISPs must seriously think about their business models for sustainability facing such types of users (students and other young people without regular income). Fortunately, the growth rate of relatively high-income users (above 2000 yuan per month) seems higher than the low-income groups recently-16.6 per cent (from 9.2 per cent, an increase of 10.7 million from January to July 2003), versus 14.8 per cent (from 49.9 million to 57.3 million)-indicating a medium to long run market.

\section{ONLINE ACTIVITIES AND BEHAVIOUR}

Online activities and behaviour of Chinese internet users has evolved significantly, as in most other regions in the world. In the survey of October 1997, there were 10.3 per cent users who went online less than an hour per week, 43.3 per cent between one to five hours, 26.3 per cent five to 10 hours and 20.1 per cent above 10 hours. The distribution changed to 7.1 per cent, 25.3 per cent, 26.7 per cent and 40.9 per cent, respectively, in the survey of July 1998, and 4 per cent, 31 per cent, 29 per cent, and 36 per cent in January 1999. Heavy users increased sharply from about 20 per cent to over 40 per cent in a mere nine months, while the user population was exponentially rising. In the multiple choices of October 1997 survey, 80.4 per cent users wanted science and technology information, 42 per cent looking for social news, 39.6 per cent for commercial information, 32.8 per cent for financial information, and 24.8 per cent for leisure information. Clearly, most users were looking for science and technology information, probably due to the fact that 54.7 per cent users that year were professionals in research, education and IT industry and students, while the proportion of consumption-type users was relatively small. The situation changed dramatically nine months later, with 63.3 per cent users looking for leisure, entertainment and sports information, 67.2 per cent for science and technology, 45.1 per cent for economical and political news, 43.7 per cent for commercial information, 26.1 per cent for financial and securities information, and, interestingly, 
15.2 per cent interested in advertisements. This must be a good time for web portals with an advertisement-based business model.

Common complaints of users were the slow speed online (49.1 per cent in 1997 and 88.9 per cent in 1998), high connection charges (36.2 per cent in 1997 and 61.2 per cent in 1998), and too little information in Chinese language (7.3 per cent in 1997 and 45.5 per cent in 1998). In addition, users began to examine the service quality of ISPs as reflected in the 1998 survey, with 38.4 per cent users regarding the service providers as very good (patient with customers about problem solving and training), 55 per cent feeling so-so (nice at the beginning when attracting users but impatient later) and 6.6 per cent finding the ISPs very bad (no attempt at improving service quality).

Table 15.9 Monthly income distribution of online users (RMB, per cent)

January 2002

$\begin{array}{cccccc}\text { Below 500 } & 501-1,000 & 1,001-1,500 & 1,501-2,000 & 2,001-2,500 & 2,501-3,000 \\ 23.6 & 25.3 & 16.5 & 8.8 & 4.4 & 3.4 \\ 3,001-4,000 & 4,001-5,000 & 5,001-6,000 & 6,001-10,000 & \text { Above } 10,000 & \text { No income } \\ 2.3 & 1.1 & 0.8 & 0.7 & 0.8 & 12.3\end{array}$

July 2002

$\begin{array}{cccccc}\text { Below } 500 & 501-1,000 & 1,001-1,500 & 1,501-2,000 & 2,001-2,500 & 2,501-3,000 \\ 24.8 & 24.1 & 16.5 & 8.2 & 4.6 & 2.6 \\ 3,001-4,000 & 4,001-5,000 & 5,001-6,000 & 6,001-10,000 & \text { Above } 10,000 & \text { No income } \\ 2.7 & 1.3 & 0.7 & 0.6 & 0.9 & 13.0\end{array}$

January 2003

$\begin{array}{cccccc}\text { Below } 500 & 501-1,000 & 1,001-1,500 & 1,501-2,000 & 2,001-2,500 & 2,501-3,000 \\ 23.5 & 20.9 & 15.4 & 8.2 & 5.1 & 3.8 \\ 3,001-4,000 & 4,001-5,000 & 5,001-6,000 & 6,001-10,000 & \text { Above } 10,000 & \text { No income } \\ 3.1 & 1.3 & 0.7 & 0.7 & 0.8 & 16.5\end{array}$

July 2003

$\begin{array}{cccccc}\text { Below } 500 & 501-1,000 & 1,001-1,500 & 1,501-2,000 & 2,001-2,500 & 2,501-3,000 \\ 20.8 & 18.3 & 15.9 & 9.8 & 4.6 & 3.7 \\ 3,001-4,000 & 4,001-5,000 & 5,001-6,000 & 6,001-10,000 & \text { Above } 10,000 & \text { No income } \\ 2.4 & 2.0 & 0.7 & 1.0 & 1.1 & 19.5\end{array}$

Source: CNNIC Survey 
Since January 1999, surveys have collected information about where people go online (Table 15.10). The clear trend is that people are going online mainly in homes. Schools and Internet cafes have become important places for online access in recent years. This pattern corresponds to the increasing penetration of personal computers into Chinese homes, significant improvement in connection infrastructure both in schools and residential areas and a sharp reduction in connection charges. The broadband power and popularity in Internet cafes have been particularly attractive to young users.

The time people spent online exhibited an interesting pattern, dropping from a high 17 hours per week on average in early 2000 to 8.3 hours in mid 2002, but increasing sharply to 13 hours by July 2003 (Figure 15.1). The latest rise is attributed to the impact of SARS.

Survey data on the usual time people go online is shown in Table 15.11 in hour blocks (24 hour clock).

Figures $15.2 a-15.2 b$ show the survey results in January and July 2003, from which one can see that the curve fluctuates a good deal but the pattern has been quite similar from the known surveys in the past years. Fewest people go online between midnight to $7 \mathrm{am}$, and more activities start from $8 \mathrm{am}$. Predictably, the most active period is in the evening, with about 30-40 per cent of users going online during this time.

The hardware used to go online is constantly changing, and notebook computers are increasing rapidly (see Table 15.12). Even novel hardware such as mobile devices and info home appliances are becoming more acceptable to internet users (see Figure 15.3).

The main reasons users go online have also been surveyed (see Table 15.13). Clearly, the dominant purpose is to obtain information, followed by leisure and entertainment, then making friends. The internet has provided another channel for the traditionally conservative Chinese communities for more openness in personal lifestyles, although phenomena like one-night stands resulting from chat rooms are judged immoral by older generations. The fact that needs to be faced and researched is the profound changes accompanying the fast development in the economy and the widespread use of the internet, especially among the younger generation. The temporary setback in the stock trading online had much to do with the problems in the stock markets in China these years, rather than problems associated with the internet. 
Figure 15.1 Average hours online per week, 2000-03

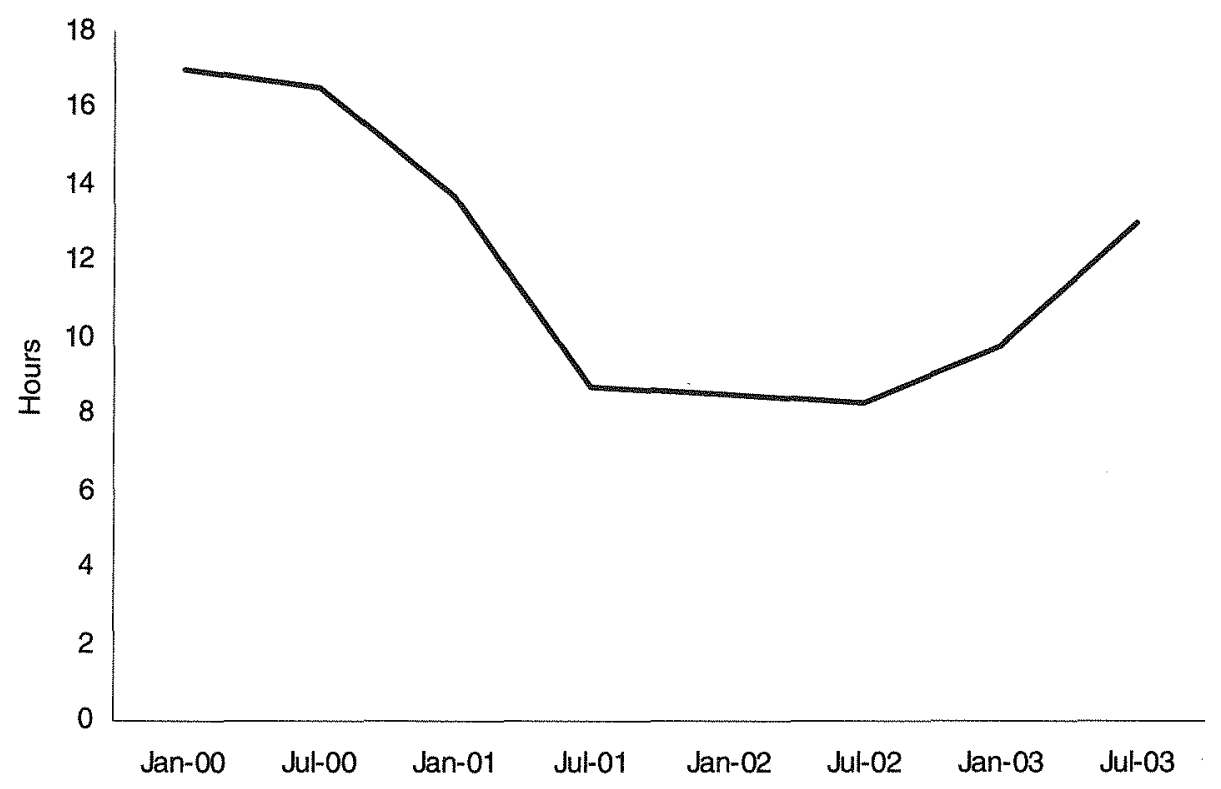

Table 15.10 Main location of going online (per cent)

\begin{tabular}{lccccccc}
\hline Year & Home & $\begin{array}{c}\text { Work } \\
\text { units }\end{array}$ & Schools & $\begin{array}{c}\text { Internet } \\
\text { cafes }\end{array}$ & Other & $\begin{array}{c}\text { Public } \\
\text { library }\end{array}$ & Mobile \\
January 1999 & 44.0 & 50.0 & n.a. & 3.0 & 3.0 &.. &.. \\
July 1999 & 44.0 & 47.0 & n.a. & 4.0 & 5.0 &.. &.. \\
January 2000 & 50.0 & 37.0 & n.a & 11.0 & 2.0 &.. &.. \\
July 2000* & 58.8 & 43.0 & n.a. & 20.9 & 8.8 &.. &.. \\
January 2001* & 60.3 & 43.9 & 19.7 & 20.6 & 4.1 &.. &.. \\
July 2001* & 61.0 & 45.1 & 18.3 & 15.2 & 0.2 &.. &.. \\
January2002* & 61.3 & 45.7 & 19.7 & 15.4 & 0.7 &. &.. \\
July 2002* & 62.1 & 43.3 & 21.8 & 17.3 & 0.5 & 0.7 & 0.9 \\
January 2003* & 62.6 & 42.5 & 20.2 & 19.4 & 0.4 & 0.6 & 0.5 \\
July 2003 & 65.9 & 43.0 & 22.6 & 18.1 & 0.7 & 0.4 & 0.5 \\
\hline
\end{tabular}

Note: Multiple choices possible.

Source: CNNIC Survey 
Table 15.11 Time of usual online use (multiple choice) (per cent)

\begin{tabular}{lcccc}
\hline Time & $0-1 \mathrm{am}$ & $2-3 \mathrm{am}$ & $4-5 \mathrm{am}$ & $6-7 \mathrm{am}$ \\
July 2000 & 24 & 11.05 & 6.38 & 13.02 \\
January 2001 & 10.58 & 2.9 & 1.68 & 3.32 \\
July 2001 & 14.1 & 4.1 & 3.3 & 3.7 \\
January 2002 & 14.9 & 5.0 & 2.8 & 3.5 \\
July 2002 & 15.2 & 6.4 & 3.9 & 4.8 \\
& & & & \\
Time & $8-9 \mathrm{am}$ & $10-11 \mathrm{am}$ & $12-1 \mathrm{pm}$ & $2-3 \mathrm{pm}$ \\
July 2000 & 43.1 & 37.3 & 36.1 & \\
38.77 & & & & \\
January 2001 & 17.4 & 22.0 & 21.9 & 17.85 \\
July 2001 & 24.4 & 30.8 & 29.3 & 42.1 \\
January2002 & 16.9 & 21.2 & 22.7 & 33.6 \\
July 2002 & 20.4 & 21.2 & 26.4 & 34.9 \\
& & & & \\
Time & $4-5 \mathrm{pm}$ & $6-7 \mathrm{pm}$ & $8-9 \mathrm{pm}$ & $10-11 \mathrm{pm}$ \\
July 2000 & 32.94 & 42.96 & 75.57 & 62.56 \\
January 2001 & 28.49 & 33.56 & 62.47 & 35.12 \\
July 2001 & 35.9 & 39.5 & 77.2 & 49.8 \\
January 2002 & 29.7 & 40.0 & 77.0 & 45.4 \\
July 2002 & 33.6 & 48.5 & 80.5 & 46.5 \\
\hline
\end{tabular}

Source: CNNIC Survey

Table 15.12 Hardware used to go online (per cent)

\begin{tabular}{lccc}
\hline Year & $\begin{array}{c}\text { Desktop } \\
\text { computer }\end{array}$ & $\begin{array}{c}\text { Notebook } \\
\text { computer }\end{array}$ & $\begin{array}{c}\text { Others } \\
\text { (millions) }\end{array}$ \\
July 2002 & 97.4 & 4.5 & 1.29 \\
January 2003 & 95.2 & 10.1 & 1.53 \\
July 2003 & n.a. & n.a. & n.a. \\
\hline
\end{tabular}

Note: * Including mobile devices and info home appliances.

Source: CNNIC Survey 
Figure 15.2(a) Times users usually go online, January 2003 (per cent)

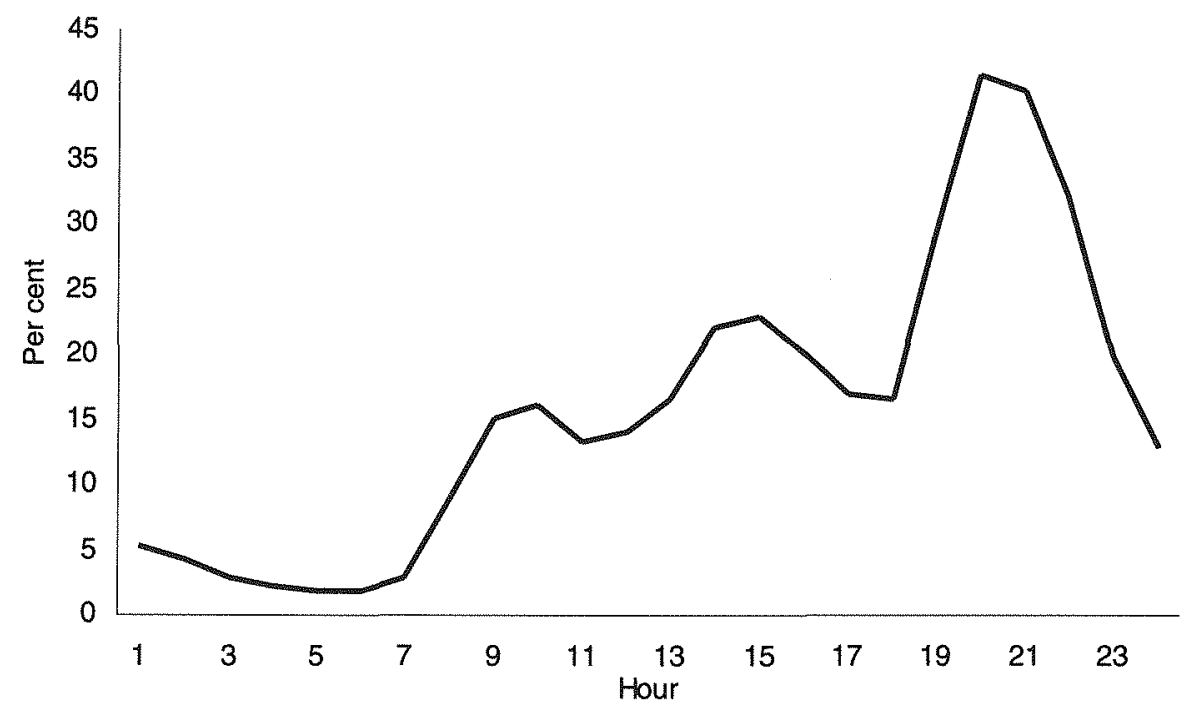

Figure 15.2(b) Times users usually go online, July 2003 (per cent)

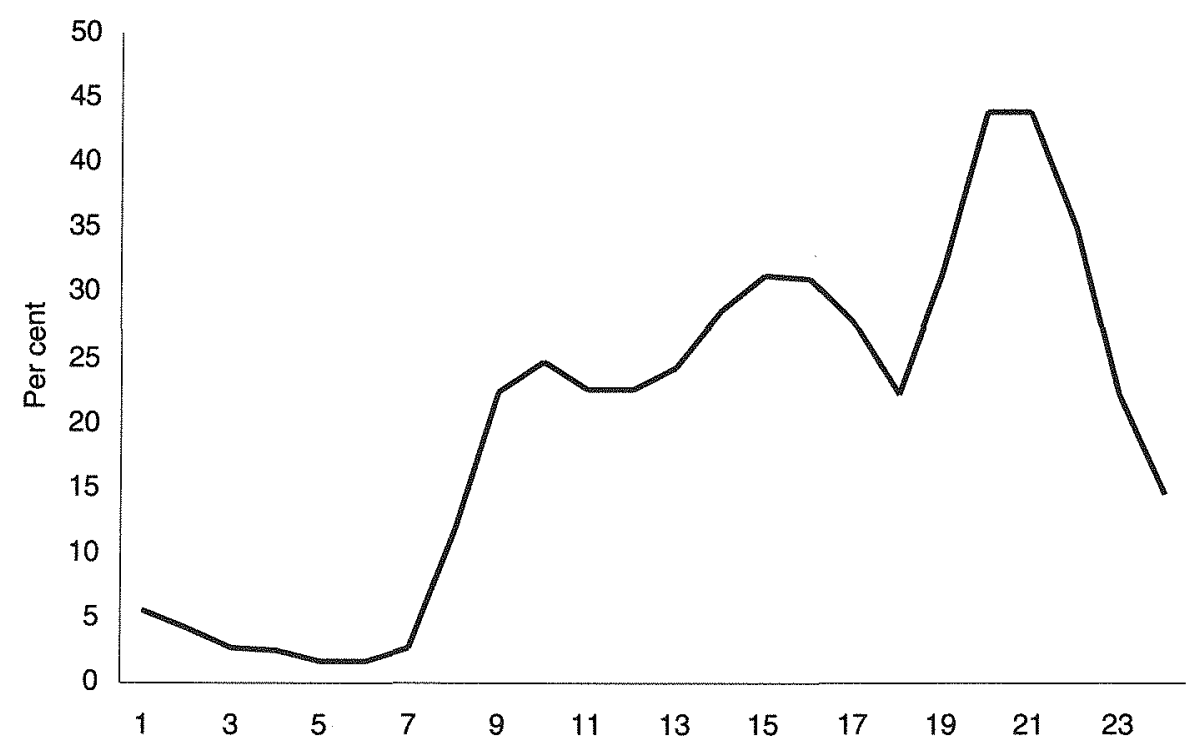


Table 15.13 Main purpose for going online (per cent)

\begin{tabular}{|c|c|c|c|c|c|c|}
\hline Year & Information & Study & Work & Leisure & $\begin{array}{c}\text { Emotional } \\
\text { needs }\end{array}$ & $\begin{array}{l}\text { Making } \\
\text { friends }\end{array}$ \\
\hline July 2001 & 42.9 & 4.3 & 5.8 & & $-34.4=$ & - \\
\hline January 2002 & 46.1 & 4.3 & 6.2 & - & $-31.1-$ & - \\
\hline July 2002 & 47.6 & 6.6 & 1.6 & 18.9 & 1.2 & 14.9 \\
\hline January 2003 & 53.1 & 4.8 & 2.0 & 24.6 & 1.1 & 7.0 \\
\hline July 2003 & 46.9 & 7.2 & 0.8 & 28.6 & 0.1 & 7.5 \\
\hline Year & $\begin{array}{c}\text { Obtain } \\
\text { free things* }\end{array}$ & $\begin{array}{l}\text { Commun- } \\
\text { ications }{ }^{\star \star}\end{array}$ & $\begin{array}{c}\text { Stock } \\
\text { trading }\end{array}$ & $\begin{array}{l}\text { Online } \\
\text { shopping }\end{array}$ & $\begin{array}{l}\text { Fashion, } \\
\text { curiosity }\end{array}$ & Others \\
\hline July 2001 & 3.1 & 4.1 & 4.1 & 0.3 & 0.5 & 0.5 \\
\hline January 2002 & 3.3 & 4.9 & 2.5 & 0.4 & 0.6 & 0.6 \\
\hline July 2002 & 1.2 & 4.4 & 0.9 & 0.3 & 0.3 & 2.1 \\
\hline January 2003 & 1.9 & 3.8 & 1.1 & 0.1 & 0.3 & 0.2 \\
\hline July 2003 & 1.7 & 3.2 & 2.1 & 0.2 & 06 & 1.1 \\
\hline
\end{tabular}

Notes: a Including free business activities abd academic research. ${ }^{b}$ Such as free email, personal homepage space, resources downloading, etc. ${ }^{c}$ Such as sending and receiving emails, short messages, faxes, etc.

Source: CNNIC Survey

Figure 15.3 Number of people using mobile devices and info home appliances to access internet

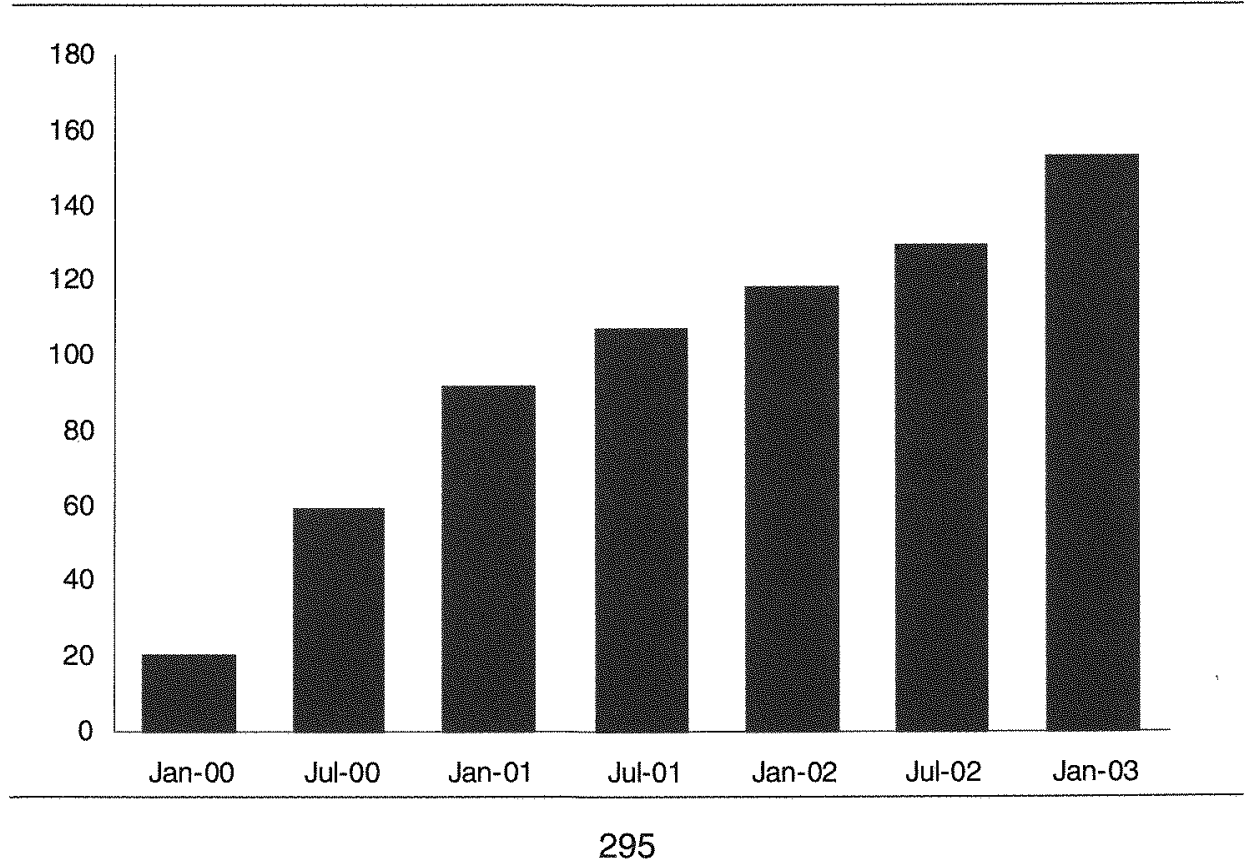


Language is obviously an issue in China, where most people do not speak any foreign language. It is thus not surprising to see that most people seek information, mostly domestic, in Chinese (see Table 15.14).

The overall picture of internet use in China indicates that business to consumer electronic commerce still has a long way to go, due to the youth and low incomes of most users. Nevertheless, it is still important to examine this aspect in more detail. Table 15.15 summarises people's view of online transaction problems. The internet

Table 15.14 Type of information users read online (per cent)

\begin{tabular}{|c|c|c|c|c|}
\hline & \multicolumn{2}{|c|}{$\begin{array}{l}\text { Information } \\
\text { in Chinese }\end{array}$} & \multicolumn{2}{|c|}{$\begin{array}{c}\text { Domestic } \\
\text { information }\end{array}$} \\
\hline January 2001 & \multicolumn{2}{|c|}{77.5} & \multicolumn{2}{|c|}{70.94} \\
\hline July 2001 & \multicolumn{2}{|c|}{78.7} & \multicolumn{2}{|c|}{71.3} \\
\hline January 2002 & \multicolumn{2}{|c|}{78.1} & \multicolumn{2}{|c|}{69.3} \\
\hline July 2002 & \multicolumn{2}{|c|}{81.4} & \multicolumn{2}{|c|}{71.4} \\
\hline \multirow[t]{2}{*}{ January 2003} & \multicolumn{2}{|c|}{81.3} & \multicolumn{2}{|c|}{71.1} \\
\hline & $\begin{array}{l}\text { Chinese info } \\
\text { mainland sites }\end{array}$ & $\begin{array}{l}\text { Chinese info } \\
\text { overseas site }\end{array}$ & $\begin{array}{l}\text { English info } \\
\text { mainland site }\end{array}$ & $\begin{array}{l}\text { English into } \\
\text { overseas site }\end{array}$ \\
\hline July 2003 & 80.9 & 7.7 & 5.0 & 5.8 \\
\hline
\end{tabular}

Source: CNNIC Survey

Table 15.15 User perception of important problems of online transactions (per cent)

\begin{tabular}{|c|c|c|c|c|c|c|c|}
\hline & Security & $\begin{array}{l}\text { Incon- } \\
\text { venience }\end{array}$ & $\begin{array}{l}\text { Product } \\
\text { quality }\end{array}$ & $\begin{array}{c}\text { Delivery } \\
\text { delay }\end{array}$ & $\begin{array}{l}\text { Price not } \\
\text { attractive } \\
\text { enough }\end{array}$ & $\begin{array}{l}\text { Online } \\
\text { into. not } \\
\text { reliable }\end{array}$ & $\begin{array}{l}\text { Other } \\
\text { factors }\end{array}$ \\
\hline July 1999 & 30.0 & 22.0 & 34.0 & 6.0 & 8.0 & n.a. & n.a \\
\hline January 2000 & 36.5 & 17.68 & 27.6 & 9.2 & 7.78 & n.a. & 1.1 \\
\hline July 2000 & 31.7 & 13.3 & 28.33 & 10.1 & 7.7 & 7.28 & 1.4 \\
\hline January 2001 & 31.2 & 12.59 & 32.0 & 9.8 & 7.39 & 5.9 & 1.0 \\
\hline July 2001 & 33.4 & 11.5 & 33.0 & 8.7 & 6.6 & 6.0 & 0.8 \\
\hline January 2002 & 31.0 & 11.8 & 30.2 & 13.9 & 6.3 & 6.3 & 0.5 \\
\hline July 2002 & 22.1 & 13.0 & 36.9 & 10.2 & 11.1 & 5.9 & 0.8 \\
\hline January 2003 & 23.4 & 10.8 & 39.3 & 8.6 & 10.8 & 6.4 & 0.7 \\
\hline July 2003 & 25.1 & 9.9 & 40.0 & 7.1 & 10.3 & 7.0 & 0.6 \\
\hline
\end{tabular}

Notes: 1 Product quality, after-sales service and merchant trustworthiness without guarantee. Source: CNNIC Survey 
security issue is universal so it is not surprising to see it in China. But people seem to worry less about this issue in recent years, and more (nearly 40 per cent) worry about quality control. This may be a result of fraud issues in the Chinese business environment. The credibility problem in the Chinese business world is so severe that this is more a business problem than a technological problem. Inconvenience of payment methods and unattractive pricing is also contributing to the online retailing stagnation.

A good sign of progress, if slow, is reflected in Table 15.16. Almost one third of Internet users had purchased goods or services online by January 2003. During the period of SARS in China, even more people (as reflected by the clear growth in the July 2003 survey) have switched to online shopping and found it satisfactory, to their surprise. Newspapers had reported people saying that they would not want to go to the crowded shopping malls after they had experienced pleasant shopping processes online, even for big-ticket items such as refrigerators. Ironically, the outbreak of SARS has given a good push for e-commerce development in China. The change of shopping habits will have a profound impact in China's retailing, although it may take some time.

The variety of goods and services purchased online is summarised in Table 15.17. One can see that books, music products and computer-related products are the major items, although computer-related products are declining. It is natural to search for computer-related products online, since online users will be more familiar with computers. The other two categories are small-ticket items, occupying a small portion of their respective markets. Internet market for consumer goods in China is still far behind other regions such as the United States and South Korea.

Table 15.16 Goods or services purchased online (per cent)

\begin{tabular}{lcc}
\hline & Yes & No \\
January 2000 & 8.8 & 91.2 \\
July 2000 & 16.3 & 83.7 \\
January 2001 & 31.7 & 68.3 \\
July 2001 & 31.9 & 68.1 \\
January 2002 & 31.6 & 68.4 \\
July 2002 & 31.2 & 68.8 \\
January 2003 & 33.8 & 66.2 \\
July 2003 & 40.7 & 59.3 \\
\hline
\end{tabular}

Source: CNNIC Survey 
Table 15.17 Proportion of users who purchased (multiple choice) (per cent)

\begin{tabular}{|c|c|c|c|c|c|c|}
\hline Year & $\begin{array}{l}\text { Books and } \\
\text { Magazines }\end{array}$ & $\begin{array}{l}\text { Computer } \\
\& \text { related }\end{array}$ & $\begin{array}{l}\text { Camera } \\
\& \text { related }\end{array}$ & $\begin{array}{l}\text { Telecom } \\
\text { \& related }\end{array}$ & $\begin{array}{l}\text { Music, } \\
\text { image, etc. e }\end{array}$ & $\begin{array}{l}\text { Home } \\
\text { electronics }\end{array}$ \\
\hline July 2000 & 45.1 & 37.2 & 7.5 & 17.1 & 15.6 & 9.4 \\
\hline January 2001 & 58.3 & 37.5 & 4.9 & 19.9 & 29.1 & 8.4 \\
\hline July 2001 & 58.7 & 35.5 & 4.8 & 18.0 & 29.5 & 7.4 \\
\hline January 2002 & 58.0 & 33.7 & 3.6 & 15.5 & 34.4 & 5.6 \\
\hline July 2002 & 69.0 & 33.2 & 4.3 & 11.6 & 38.3 & 7.3 \\
\hline January 2003 & 67.7 & 29.9 & 6.2 & 12.5 & 34.9 & 7.1 \\
\hline \multirow[t]{2}{*}{ July $2003^{*}$} & 63.8 & 30.7 & 7.7 & 12.5 & 31.4 & 8.0 \\
\hline & Clothing & $\begin{array}{l}\text { Sport } \\
\text { items }\end{array}$ & $\begin{array}{l}\text { Living, } \\
\text { residence \& } \\
\text { services }\end{array}$ & $\begin{array}{l}\text { Medical, } \\
\text { health \& } \\
\text { services }\end{array}$ & $\begin{array}{l}\text { Gifts \& } \\
\text { services }\end{array}$ & \\
\hline July 2000 & 7.68 & 6.96 & 12.11 & 4.91 & 11.23 & \\
\hline January 2001 & 6.92 & 6.91 & 14.29 & 4.44 & 16.41 & \\
\hline July 2001 & 5.9 & 6.1 & 11.8 & 3.8 & 13.8 & \\
\hline January 2002 & 4.4 & 4.4 & 11.6 & 3.1 & 14.7 & \\
\hline July 2002 & 5.0 & 5.4 & 11.6 & 3.0 & 12,1 & \\
\hline January 2003 & 5.5 & 4.7 & 11.0 & 2.7 & 12.7 & \\
\hline \multirow[t]{2}{*}{ July $2003^{*}$} & 7.8 & 5.4 & 13.5 & 3.7 & 11.8 & \\
\hline & $\begin{array}{l}\text { Financial, } \\
\text { insurance }\end{array}$ & $\begin{array}{l}\text { Education } \\
\text { \& study } \\
\text { services }\end{array}$ & $\begin{array}{l}\text { Ticketing } r \\
\text { services }\end{array}$ & $\begin{array}{l}\text { Hotel } \\
\text { reservation } \\
\text { service }\end{array}$ & Others & \\
\hline July 2000 & 4.64 & 10.15 & 9.62 & n.a. & 11.13 & \\
\hline January 2001 & 3.76 & 13.13 & 8.45 & n.a. & 9.04 & \\
\hline July 2001 & 3.3 & 12.9 & 8.3 & n.a. & 4.1 & \\
\hline Jan. 2002 & 2.6 & 11.8 & 9.7 & n.a. & 3.1 & \\
\hline July 2002 & 2.5 & 9.5 & 7.9 & 5.2 & 1.8 & \\
\hline January 2003 & 2.1 & 9.8 & 7.7 & 4.3 & 2.3 & \\
\hline July $2003^{*}$ & 2.3 & 9.6 & $4.6^{*}$ & 3.8 & 2.0 & \\
\hline
\end{tabular}

Note: * SARS period.

Source: CNNIC Survey

Tang and Liu (2003) have a detailed case study of the online book market in China, the results of which will not be repeated here. Briefly, even the most developed part of the online markets in China (books) is immature.

\section{THE IMPACT OF THE INTERNET ON CHINESE MARKETS}

Internet development in China started far behind other countries and progressed slowly in the early years, mainly due to the political hurdles imposed by the United 
States. From mid 1990s however, it has started to fly, even during the period when the internet bubble burst in the financial markets in other regions of the world.

However, people in China still mainly use Internet for information and leisure activities, rather than for business or governmental activities. Business-to-business electronic commerce in China is far behind other regions, not only because of technological problems, but also because of management and social culture issues.

Ironically, the outbreak of SARS has pushed e-commerce and Internet development in China, since overseas visitors were unwilling to come so an alternative approach had to be in place for orders and transactions. The Chinese government has been very supportive of internet development and heavily financed e-government programs. From this perspective, the market potential in this vast country is enormous, although it would only show up in the medium to long run. The profound impact of Internet development will gradually, and in some cases dramatically, be felt in Chinese society, on its social system, culture and human relationships.

\section{ACKNOWLEDGMENTS}

The work described in this paper was fully supported by a grant from the Research Grants Council of the Hong Kong Special Administrative Region, China (Project No. CUHK4310/02H).

\section{NOTES}

1 According to the authoritative surveys by China Internet Network Information Center (CNNIC), www.cnnic.org.cn.

2 Details in the 12 survey reports are available on www.cnnic.org.cn.

3 Online users number about 655 million globally by the end of 2002, according to the report from the UN Trade and Development Conference.

\section{REFERENCES}

Tang, F-F., 2002. 'What is behind the exceptionally successful broadband market in South Korea?', Web Journal of Chinese Management Review, 5(2):n.p.

Tang, F-F. and Liu, Y., 2003. Development of Online Pricing Efficiency: empirical results from China's book market, Working Paper, Chinese University of Hong Kong, Hong Kong. 


\section{6}

\section{Accession to WTO and foreign pharmaceutical firms' business opportunities}

\section{Yifeng Wu}

\section{AN OVERVIEW}

China is now one of the largest pharmaceuticals producers in the world. During the reform period in the late 1970s, when Chinese authorities began economic reforms, the Chinese pharmaceutical industry has grown rapidly. The ouput of chemical raw medicines rose from 40.7 thousand tonnes in 1978 to 762.2 thousand tonnes in 2001 (Figure 16.1). The output of lactams and vitamins accounts for about 30 per cent of the total world output. China has become the second largest producer of chemical raw medicines in the world. Over the same period, the ouput of traditional Chinese medicines increased sharply from 87 thousand tonnes to 655.9 thousand tonnes (Figure 16.1).

China's pharmaceutical industry is made up of five sub-sectors (Table 16.1)-

- chemical raw medicines

- chemical pharmaceutical preparations

- traditional Chinese medicine and medicinal materials

- animal medicines

- biological products.

The role of the pharmaceutical industry in the Chinese economy has been growing. In 2001, the value of its output reached 204 billion yuan. From 1978-2001, the output value of the industry increased at an annual rate of 16.7 per cent-well 
above the total of all industries, at 11.4 per cent. This industry's profitability was also higher than that of total industry (Figure 16.2).

Chinese authorities permitted Sino-foreign equity joint ventures from 1979, wholly foreign-owned enterprises from 1986, and Sino-foreign contractual joint ventures since 1988. Since the first foreign-funded pharmacy enterprise was set up in 1980, 568 foreign-funded enterprises with sales revenue over 5 million yuan have entered the market. Fifty multinational pharmaceutical firms with advanced productive capacity have established foreign-funded enterprises in China. At present, sales from foreign-funded enterprises account for 22.2 per cent of the total in the Chinese domestic market. By 2001, the accumulated foreign capital invested in the industry reached a total of 9.5 billion yuan with capital from Hong Kong, Macao, and Taiwan reaching 4.8 billion yuan, and contributed 11.7 per cent and 6.0 per cent respectively to the total capital investment in the industry. Direct investment from foreign countries

Figure 16.1 Output of chemical raw medicines and traditional Chinese medicines

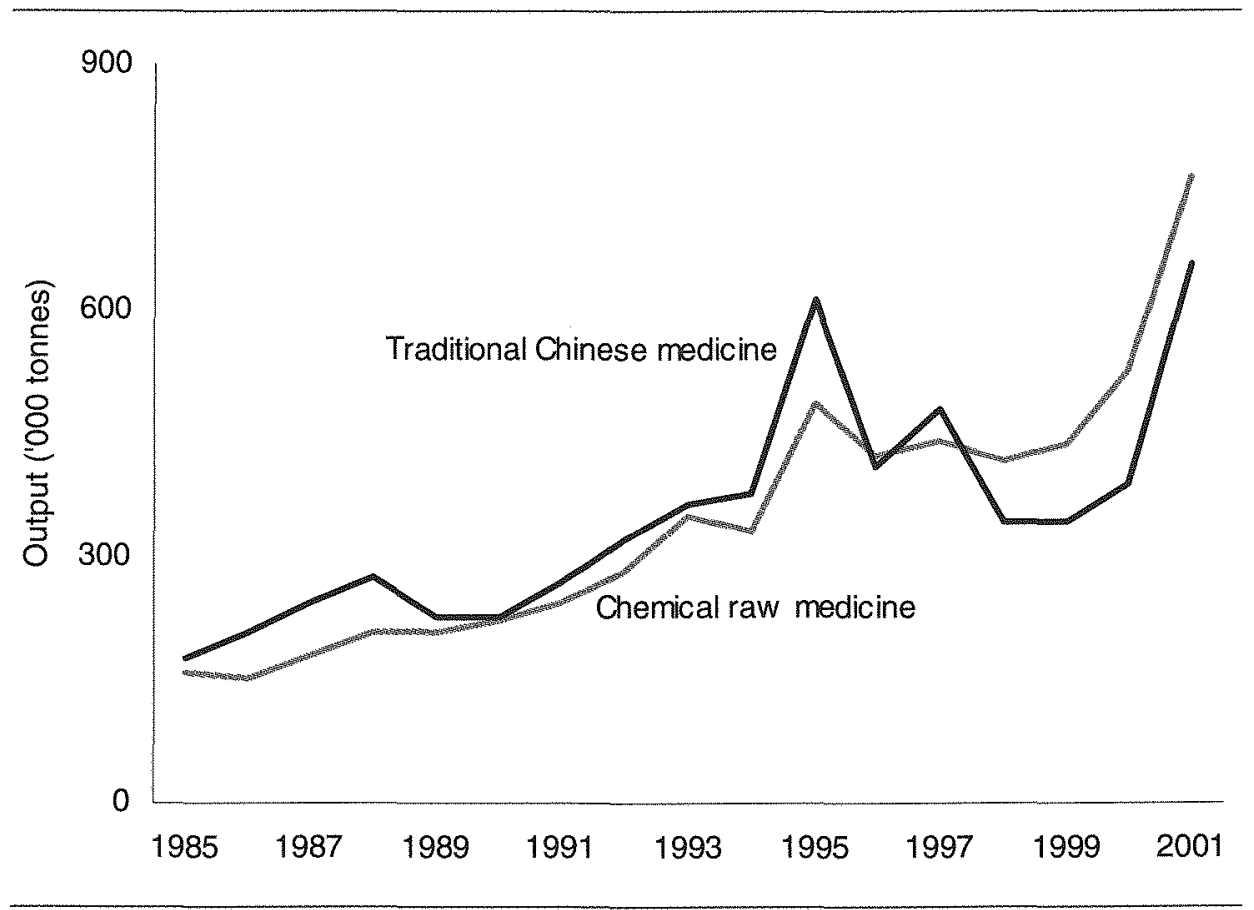

Sources: China State Statistical Bureau, China Statistical Yearbook, 1986-2002 Beijing, China Statistical Publishing House. 
Figure 16.2 Growth rates of net asset profits and output value, pharmaceutical and total industry, 1991-2001

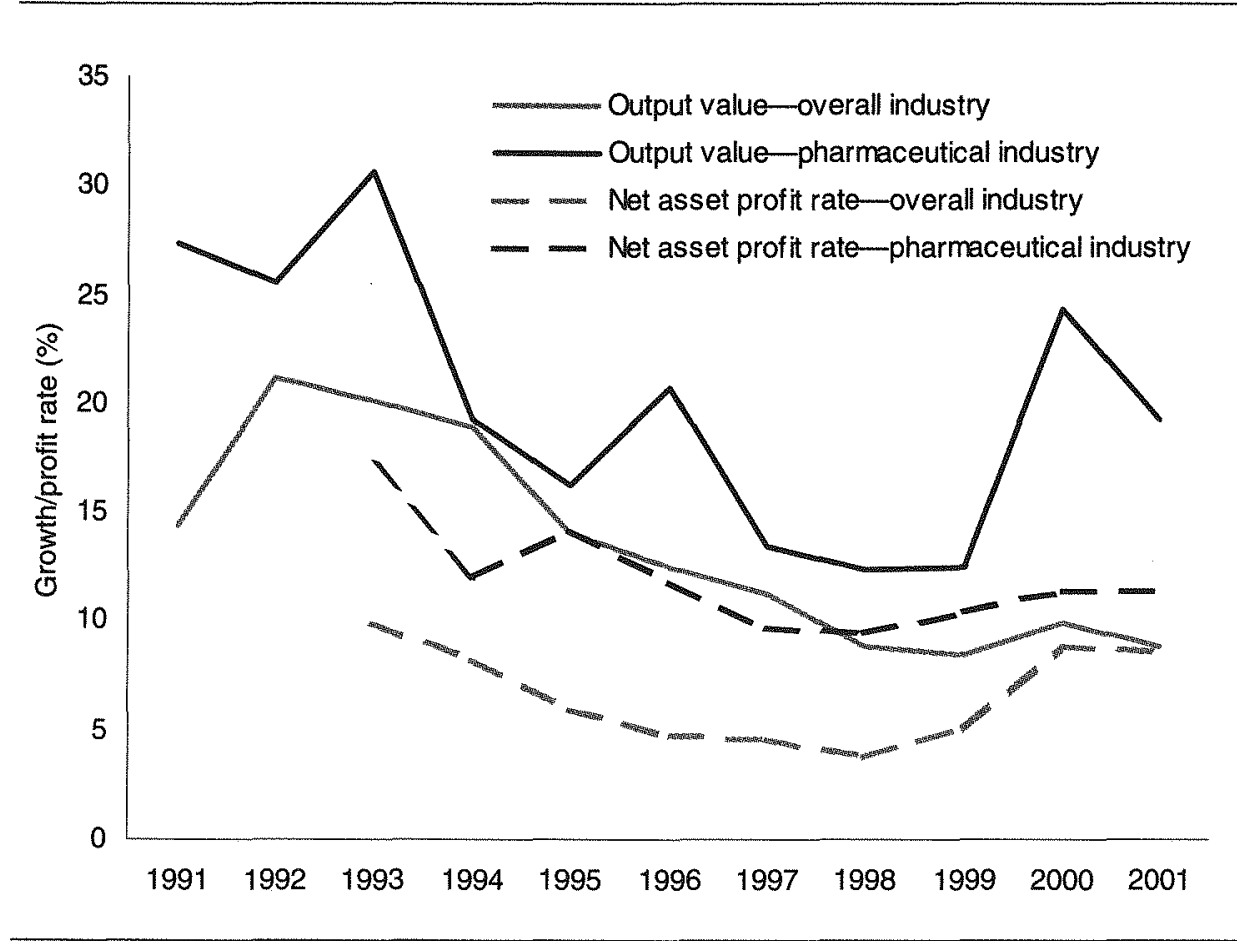

Sources: China State Statistical Bureau, various years, China Statistical Yearbook and China Industrial Economy Statistical Yearbook, China Statistical Publishing House, Beijing.

including Hong Kong, Macao and Taiwan have played an important role in the development of the Chinese pharmaceutical industry.

Official statistics show that since 1992 exports have exceeded imports ofChinese medicines continuously, and China has become a net exporter of medicines (Figure 16.3). During 1992-95, the export value of medicines rose sharply, growing at an annual average rate of 20.1 per cent. In contrast, the import value of medicines fell by 14.4 per cent. Since 1997 , however, the import value of medicines has increased rapidly, growing at an annual average rate of 38.5 per cent.

Although the Chinese pharmaceutical industry as a whole has been growing rapidly, small-scale industries that are widely dispersed are the main characteristics of Chinese pharmaceutical enterprises. At present, there are 3,488 pharmaceutical 
Table 16.1 Structure of the Chinese pharmaceutical industry in 2000

\begin{tabular}{|c|c|c|c|c|c|}
\hline Sub-sector & $\begin{array}{l}\text { Number of } \\
\text { enterprises ( }\end{array}$ & $\begin{array}{l}\text { Output } \\
\text { value } \\
\text { RMB bn yuan) }\end{array}$ & $\begin{array}{c}\text { sub-sectoral } \\
\text { output value/ } \\
\text { total output } \\
\text { value } \\
\text { (per cent) }\end{array}$ & $\begin{array}{l}\text { Sales } \\
\text { revenue } \\
\text { (RMB bn yuan) }\end{array}$ & $\begin{array}{l}\text { Sub-sectoral } \\
\text { sales revenue/ } \\
\text { total sales } \\
\text { revenue } \\
\text { (per cent) }\end{array}$ \\
\hline Chemical raw medicine & 685 & 50.7 & 28.4 & 49.5 & 30.4 \\
\hline $\begin{array}{l}\text { Chemical pharmaceutical } \\
\text { preparation }\end{array}$ & 934 & 57.0 & 32.0 & 50.5 & 31.0 \\
\hline $\begin{array}{l}\text { Traditional Chinese medicin } \\
\text { and medicinal material }\end{array}$ & 1180 & 53.3 & 29.9 & 48.2 & 29.6 \\
\hline Animal medicine & 231 & 3.5 & 1.9 & 3.2 & 1.9 \\
\hline Biological product & 271 & 13.5 & 7.6 & 11.2 & 6.8 \\
\hline Total & 3301 & 178.1 & 100 & 162.7 & 100 \\
\hline
\end{tabular}

Source: State Statistical Bureau, 2000. China Industry Statistical Yearbook 2000, China Statistical Publishing House, Beijing

producers, with only 820 (23 per cent) are classified as large or medium-sized. The sales value by the biggest 60 pharmaceutical enterprises contributes only 35.7 per cent to total sales of this industry. In contrast, the sales value by the biggest 20 multinational pharmaceutical firms in the world produced more than 60 per cent of total sales in the international pharmaceutical market. This comparison shows that the market concentration of Chinese pharmaceutical enterprises is very low.

Duplicated production and lack of autonomic patented products are further characteristics of the industry. For example, generic drugs, gentamycin, vitamin B1, $\rho$-acetaminophemol (paracetanol) and metronidazole are being reproduced in hundreds of factories. New pharmaceuticals, levofloxacin and clarithromyin are also being reproduced in over 30 pharmaceutical factories. Numerous pharmaceutical enterprises are pursuing exorbitant short-term profits rather than long-term interests. Only half of the large and medium-sized pharmaceutical enterprises have established their own institutes of research and development, and many medium and smallsized pharmacy enterprises have not established their own institutes. It is difficult for institutes and universities to find industrialised cooperative partners to turn their research achievements, patents and inventions into production.

Expenditures for research and development have been below 3 per cent of total sales revenue per year, and less than 7 per cent of all employees in large and medium-sized pharmaceutical enterprises have been engaged in research (Table 
Figure 16.3 Imports and exports of Chinese medicines

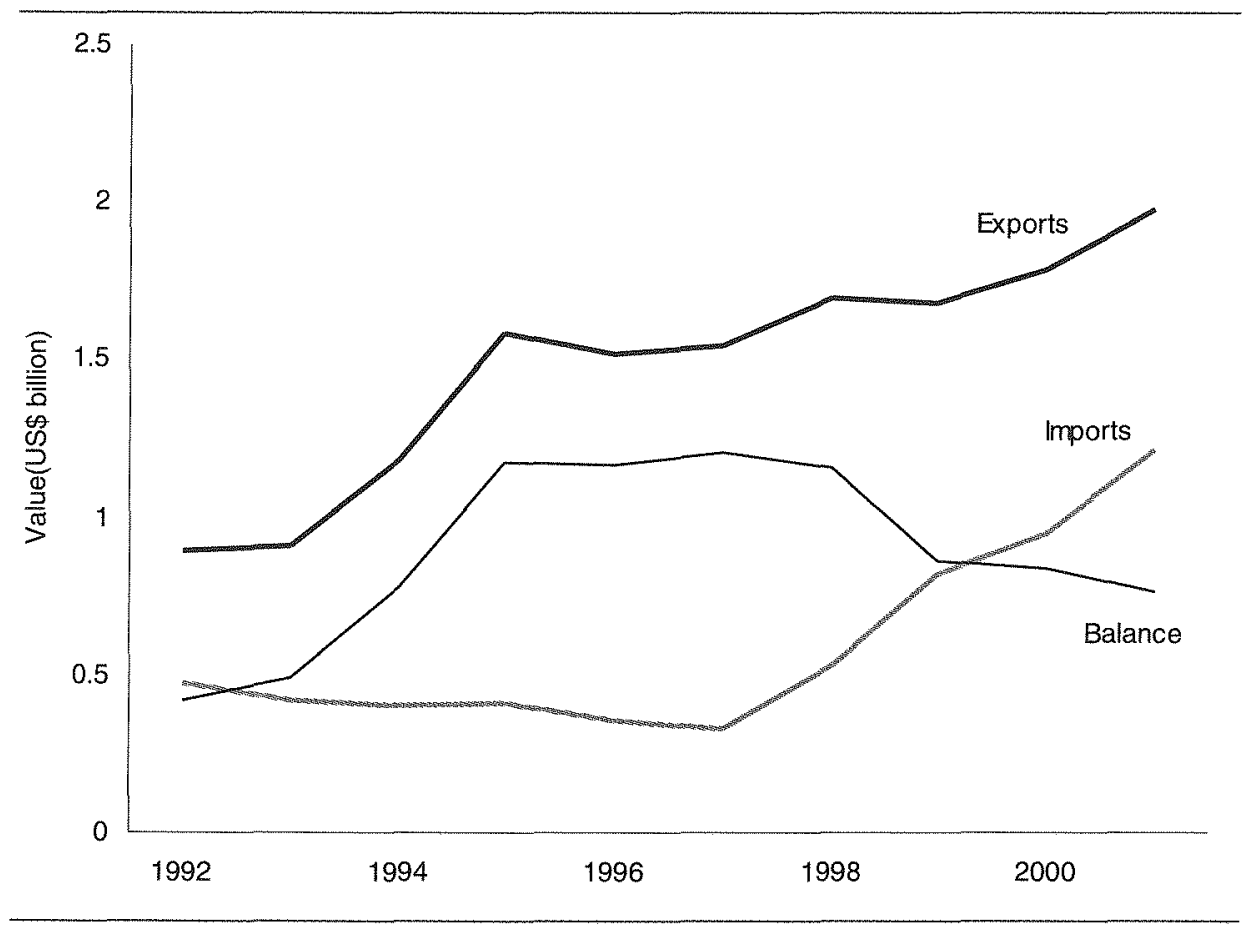

Source: State Statistical Bureau, various years. China Statistical Yearbook, China Statistical Publishing House, Beijing.

16.2). The financial and human resources for research and development are inadequate. Over 1995-2000, Chinese authorities granted new pharmaceutical licenses to 5,043 products, of which 108 were regarded as first class. Even though they were qualified as innovative products, not one was capable of entering the international market. In the field of biological products, over 30 varieties of genetic pharmaceuticals have been permitted by Chinese authorities into the market, of which only Interferon $\mathrm{A} 1 \mathrm{~b}$ is a Chinese invention.

In the field of traditional Chinese medicine, the 'Gingko pill' and 'Salvia miltiorrhiza pill' have passed the US Federal Drug Administration's (FDA) antecedent examination, and are now in the clinical test stage. The export value of traditional Chinese medicines from China accounted for only 3 per cent of the total sales revenue generated by Chinese medicines on the international market. In the field of 
Table 16.2 Research and development expenditures, of large and medium-sized pharmaceutical enterprises

\begin{tabular}{ccccc}
\hline & $\begin{array}{c}\text { No. of } \\
\text { No. of }\end{array}$ & $\begin{array}{c}\text { Researchers/ } \\
\text { enterprises } \\
\text { with own institutes } \\
\text { (per cent) }\end{array}$ & $\begin{array}{c}\text { R\&D expenditures/ } \\
\text { total sales revenue } \\
\text { (per cent) }\end{array}$ \\
1996 & 678 & 466 & 3.9 & 1.7 \\
1997 & 708 & 408 & 5.8 & 1.6 \\
1998 & 726 & 406 & 6.3 & 1.7 \\
1999 & 711 & 418 & 6.1 & 1.7 \\
2000 & 728 & 411 & 6.8 & 2.4 \\
2001 & 820 & 410 & 6.9 & 2.5 \\
\hline
\end{tabular}

Sources: Calculated from original data obtained from China State Statistical Bureau and Ministry of Science and Technology (eds), 2000. China Statistical Yearbook on Science and Technology, 1997-2002, China Statistical Publishing House, Beijing.

chemical medicine, Chinese pharmaceutical enterprises mainly produce cheap imitations. In recent years, 97.4 per cent of the 873 varieties of chemical raw medicines produced by pharmaceutical enterprises were imitations. Chinese pharmaceutical enterprises have limited capabilities in the preparation of pharmaceuticals. In general, they can only prepare three kinds of dosage forms of chemical raw medicine, and the quality of medicaments is unstable. The management structure of Chinese pharmaceutical enterprises is outdated compared with multinational pharmaceutical firms.

\section{INTERNATIONAL TRADING COMPETITIVENESS}

\section{Measuring international trading competitiveness}

The trading competitiveness of pharmaceutical products can be measured using the international trading competitive index and the price index. The international trading competitiveness index can be calculated using the following formula and definition

International trading competitiveness index $=$ (export value - import value)/

(export value + import value)

International trading competitiveness scores close to 1 indicate high trading competitiveness, and scores closer to zero indicate low trading competitiveness. Where the total international trading competitiveness index of overall products in 
particular industry is negative, this industry has a lack of international trading competitiveness, and a deficit of foreign trade occurs.

The price index has the following calculation formula and definition,

Price index $=($ export value/export volume) $/$ (import value/import volume)

The price index reflects the unit parity of a product in the international market. For a lower cost product, a high price index indicates a higher international trading profit margin and a price competitive advantage for that product. The exporter of this product can reduce the export/import unit parity of the product to support the international trading competitiveness of the product. In other words, an exporter with the lower cost product can sacrifice his price advantage to gain strong international trading competitiveness. When the international trading competitive index and the price index of a product drop continuously at the same time, this means that the international trading competitiveness of the product is weakening continuously. Both the international trading competitiveness index and the price index can be used to reveal the international trading competitiveness of a certain kind of product or industry.

In the chemical raw medicines category, hormones, derivatives and steroids used primarily as hormones (HS No. 2937), vegetable alkaloids and their salts, ethers, esters and other derivatives (HS No.2938), glycosides and their salts, ethers, esters and other derivatives (HS No.2939), chemically pure sugars (except sucrose, lactose, maltose, glucose and fructose), sugar ethers, sugar esters and their salts (HS No.2940) have relatively high international trading competitiveness indices of $0.83-$ 0.95 (Tables 16.3 and 16.4). The results reveal that these chemical raw medicines have strong international trading competitiveness. Nucleic acids and their salts; other heterocyclic compounds (HS No.2934), sulfonamides (HS No.2935), provitamins and vitamins used primarily as vitamins (HS No.2936) and antibiotics (HS No.2941) have international trading competitive indices of $0.47-0,70$. These indices have dropped year by year, which shows that these chemical raw medicines have had a certain degree of international trading competitiveness, but this has weakened over time. The international trading competitiveness index of pharmaceutical products (HS No.30) has also fallen over time - pharmaceutical products are gradually losing competitiveness on the international market.

Analysis of the price index reveals that chemical raw medicines that have high international trading competitiveness indices, such as HS No. 2937, 2938, 2939, 2940 , have all suffered year by year falls in those indices. This indicates that the 


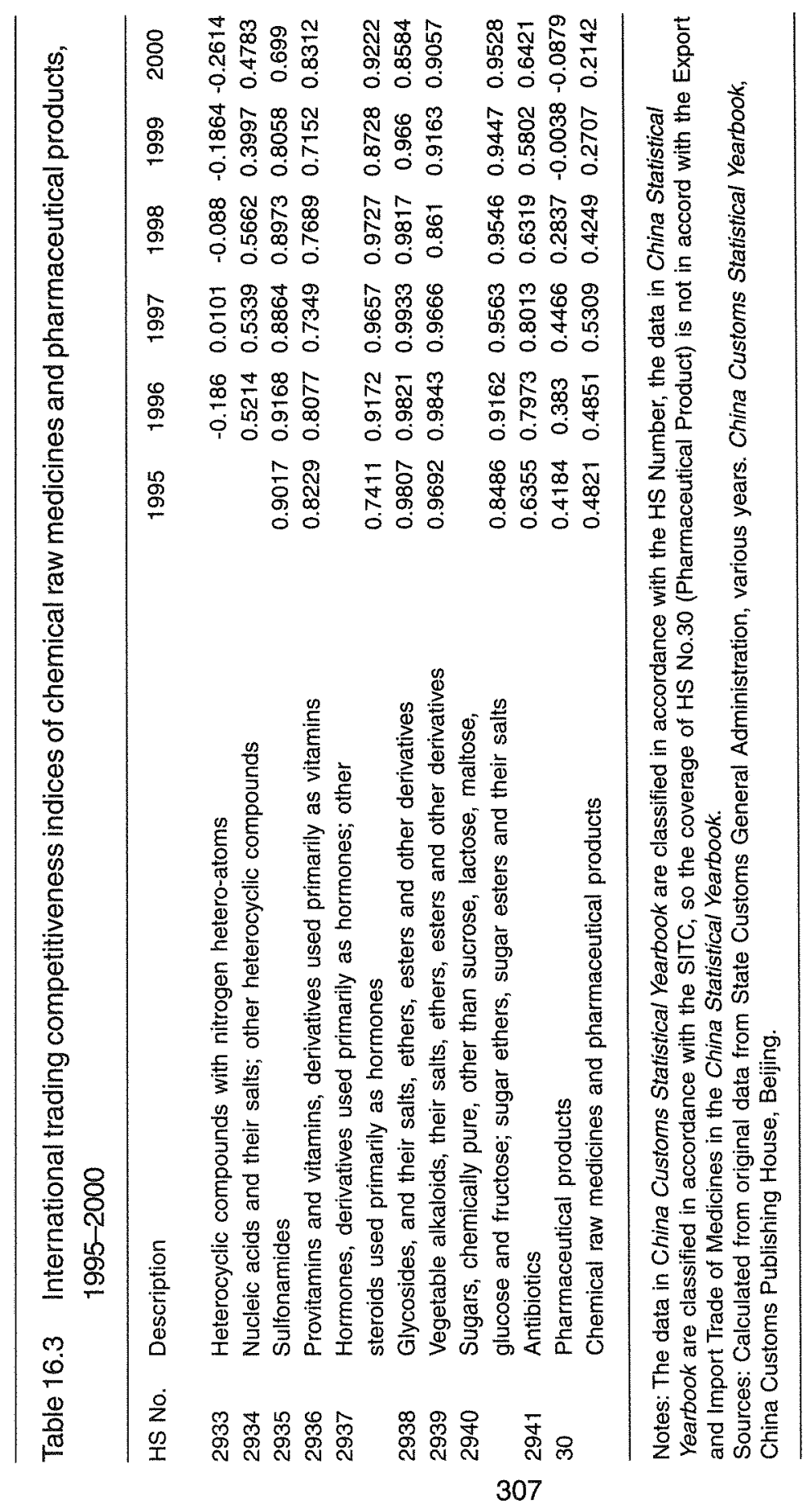




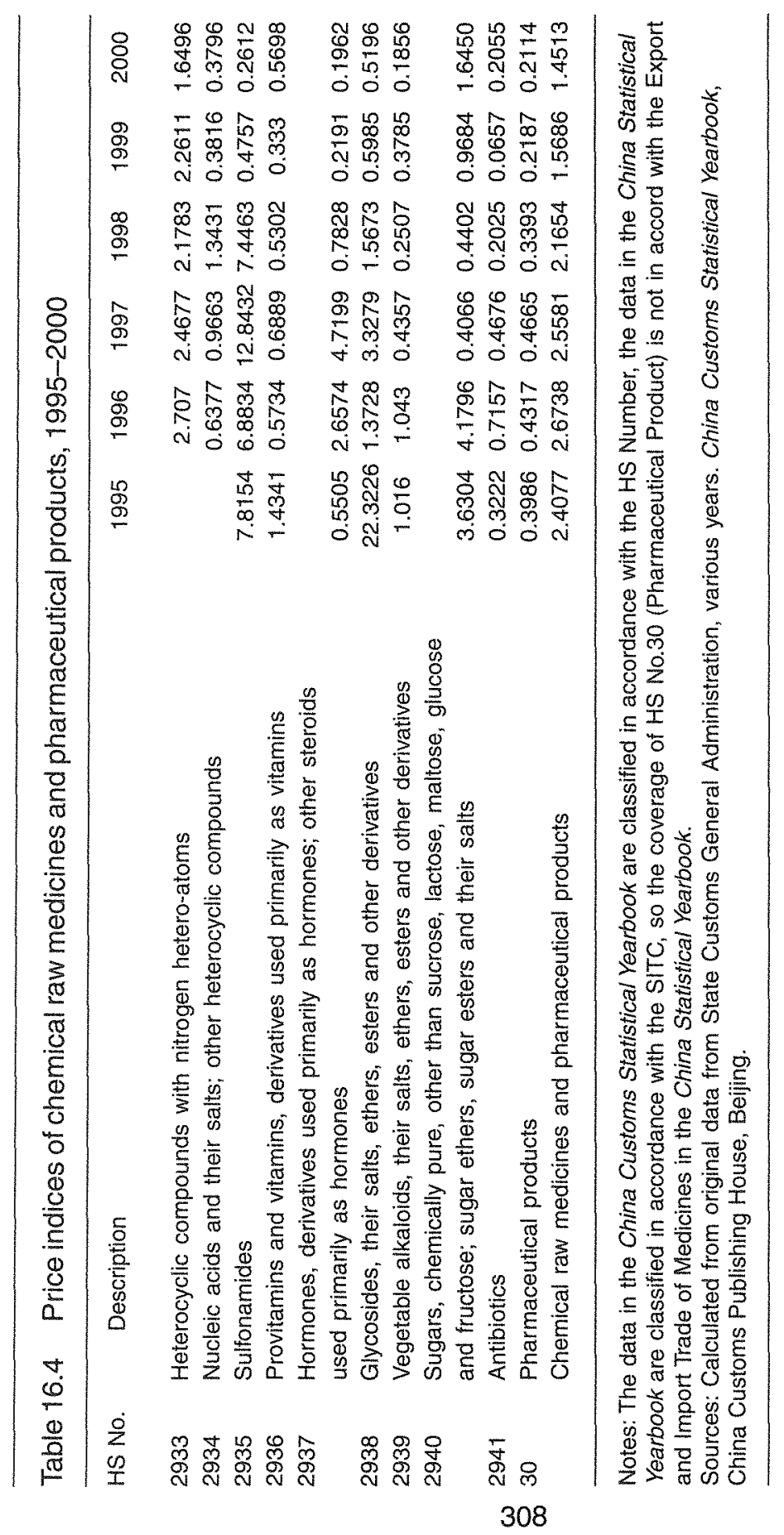


strong international trading competitiveness of chemical raw medicines is being supported at the expense of their price advantage. Chemical raw medicines such as HS No. 2934, 2935, 2936, 2941, have also experienced falling price indices, which reflects diminishing price advantages as well as declining international trading competitiveness. Pharmaceutical products (HS No.30) have been losing both international trading competitiveness and price advantage. So far, the total price index of chemical raw medicines and pharmaceutical products is still higher than 1 , though it has dropped year by year. If the international trading competitiveness indices are compared with the price indices, the following conclusion can be drawn: the Chinese pharmaceutical industry's competitive advantage in international trade is gradually weakening.

\section{POTENTIAL TRADING COMPETITIVENESS}

Potential trading competitiveness depends mainly on an industry's innovative ability. The number of patents is a crucial indicator of the innovation of the pharmaceutical industry. According to International Patent Classification (IPC), patents related to the pharmaceutical industry are mainly in the categories of Medicine A61K and its subgroups-Chemical Medicine A61K31, Traditional Chinese Medicine A61K35 and Pharmaceuticals A61K9. Table 16.5 is an analysis of medicine patent applications, and Figure 16.4 presents the ratio of patents for Chinese medicine applications granted to Chinese and to foreign applicants.

In traditional Chinese medicine, the proportion of patents granted to foreign applicants reached its highest level in 1994 (10 per cent). Since then th proportion has been very low (Table 16.5 and Figure 16.4). In 1999 and 2000, the proportions granted to foreign applicants for traditional Chinese medicine was only 0.8 per cent and 0.5 per cent respectively. China has a strong innovative ability in traditional Chinese medicines. In chemical medicines, foreign applicants dominate, not only in amount of applications but also in the proportion granted. Although the proportion granted dropped after 1992, it remained at about 60 per cent from 1997 to 2000 . In the field of chemical medicines, Chinese producers have lower capability for innovation compared with foreign producers. In recent years, 97.4 per cent of chemical raw medicines produced by Chinese pharmaceutical enterprises have been imitations of foreign products. 
Figure 16.4 Medicine patents in China: proportion granted to foreign applicants (per cent)

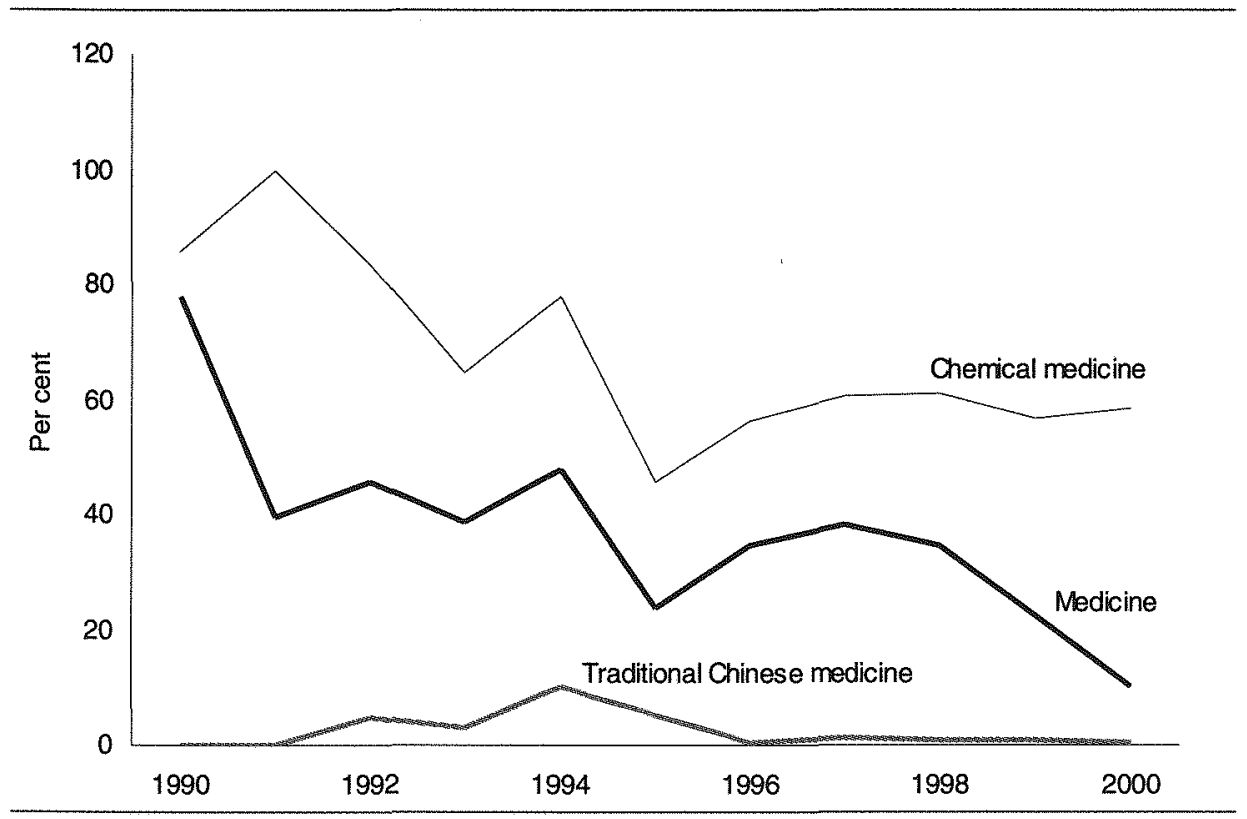

\section{BUSINESS OPPORTUNITIES FOR FOREIGN} PHARMACEUTICAL FIRMS IN CHINA

What factors bring business opportunities to foreign pharmaceutical firms in China? How do these factors affect such opportunities?

Chinese authorities' commitments and administrative measures

China became a member of the WTO on 11 December 2001. According to the WTO Agreement, Chinese authorities made commitments about national treatment, market access and the most-favoured nation tariffs as follows.

- Within three years of China's accession to the WTO, foreign services suppliers will be permitted to engage in the distribution of pharmaceuticals (see Annex 9-Schedule of Specific Commitments on Service of Protocol on the Accession of the People's Republic of China).

- Within three years of China's accession to the WTO, the applied average tariff rate of imported pharmaceuticals will be reduced by 5-6 per cent (see Annex 8-Schedule CLII" of the Protocol on Accession). 
Table 16.5 Number of patent applications in the field of medicine, 1990-2000

\begin{tabular}{|c|c|c|c|c|c|c|}
\hline \multirow[t]{2}{*}{ IPC Group } & \multirow[t]{2}{*}{ Content } & \multirow[t]{2}{*}{ Total } & \multicolumn{2}{|c|}{ Domestic applicants } & \multicolumn{2}{|c|}{ Foreign applicants } \\
\hline & & & Number & $\begin{array}{c}\text { Per cent of } \\
\text { total }\end{array}$ & Number & $\begin{array}{c}\text { Per cent of } \\
\text { total }\end{array}$ \\
\hline $\mathrm{A} 61 \mathrm{~K} 35$ & Traditional Chinese medicine & 10850 & 10631 & 97.98 & 219 & 2.02 \\
\hline $\mathrm{A} 61 \mathrm{~K} 31$ & Chemical medicine & 2703 & 829 & 30.67 & 1874 & 69.33 \\
\hline $\mathrm{A} 61 \mathrm{~K} 9$ & Pharmaceuticals & 1000 & 367 & 36.70 & 633 & 63.30 \\
\hline
\end{tabular}

Source: State Intellectual Property Office, 2000. Annual Report 2000, Intellectual Property Publishing House, Beijing.

After accession to the WTO, Chinese authorities were to adopt a number of administrative measures.

- Pharmaceuticals subject to state pricing covered HS numbers 30011000 to 30066000 , including substances of human or animal origin, heparin and its salts, antisera, other blood fractions and modified immunological products, vaccines, toxins, human and animal blood products, penicillins, cephamycines, insulins, adrenal cortical hormones, quinine or its salts, alkaloids or their derivatives, vitamins, sulpha drugs, biphenyl dicarbxybte, contraceptives, and traditional Chinese medicines.

- Based on the principles of the Sanitary and Phytosanitary Agreement (SPS Agreement) and national treatment, Chinese authorities can implement registration of initial imports of pharmaceuticals according to the Pharmaceutical Management Law of the People's Republic of China. The authorities may also implement GMP and GSP certification for foreign funded pharmacy firms and business distributors according to Chinese GMP and GSP regulations.

In addition, China became a member of the World Intellectual Property Organization in 1980, and the Paris Convention for the Protection of Industrial Property in 1985. Chinese authorities revised their Patent Law in 1992 and 2000 to fulfil the requirements of the TRIPS (Trade-related Intellectual Property) Agreement. Since the enforcement of the first amendment of Patent Law in 1993, pharmaceutical patents granted by members of the Paris Convention from 1986 to 1992 were provided administrative protection with conditionality. Since accession to the WTO, Chinese authorities must implement the new conditions of patent law in full compliance with the TRIPS Agreement, and Chinese pharmaceutical enterprises will no longer be allowed to replicate patented pharmaceuticals while they are still under the protection of foreign 
patents. This will have detrimental effects not only on pharmaceutical enterprises that were producing imitations of patented pharmaceuticals, but also on business opportunities for foreign pharmaceutical firms in China.

\section{Consumer demand for pharmaceutical products}

Consumer demand for pharmaceuticals in China is very large. It is estimated that consumer demand for pharmaceuticals will reach 336 billion yuan by $2005,1.7$ times more than in 2001.

A series of factors underlie such a huge increase in demand.

- China has the largest population in the world. The population will reach 1.33 billion by 2005 .

- The pace of urbanisation is accelerating. In 2001, China had an urban population of 0.48 billion. Since 1995 the annual growth rate of the urban population has remained at around 5.3 per cent, indicating that the urban population will rise to 0.59 billion by 2005 . The demand of an urban person for pharmaceuticals is seven times higher than that of a rural person. The rapid expansion of the urban population therefore promotes the demand for pharmaceuticals

- the Chinese population is aging rapidly. Based on the census statistics, the population over 65 was 8.8 million in 2000 , accounting for 7 per cent of the total population. It is estimated that the annual growth rate of people over 65 will be 3 per cent in the foreseeable future, and the aged population will be over 0.1 billion by 2005 . The sharp growth of the aged population will raise consumer demand for pharmaceuticals.

\section{Factors promoting business opportunities}

The main factors opening up business opportunities for foreign pharmaceutical firms in China are

- a vast consumer demand for pharmaceuticals

- the fiscal decentralisation being implemented by the Chinese authorities under the control of the central government. Such a regime enables local governments to share more of the tax revenue. Granting local governments a bigger stake in the prosperity of the local economy provides an impetus to stimulate the growth of the local economy. Local governments are to establish special economic zones and adopt preferential policies and flexible measures that are attractive to overseas investors. 
- relatively low labour costs. The average worker earns only one-thirtieth to onefortieth of the average wage in industrial countries

- commitments by the Chinese authorities to reduce the average applied tariff rate on imported pharmaceuticals by 5-6 per cent within three years of accession to the WTO. Under this commitment, foreign service suppliers will also be permitted to engage in the distribution of pharmaceuticals

- suspension of the replication of patented pharmaceuticals by traditional pharmaceutical enterprises, in accordance with China's intellectual property protection commitments. A vast market will be opened for foreign pharmaceutical firms holding autonomic patented pharmaceuticals

- the structure of Chinese pharmaceutical enterprises. Chinese pharmaceutical enterprises are characteristically small scale and have scattered layout, poor preparation capability, outdated management structure, low market concentration and a lack of autonomic patented products. Competitive pressure on stateowned pharmacy enterprises is pushing many of them towards bankruptcy. Currently, privatisation of state-owned enterprises is accelerating. Most await purchase, merger or restructure

- the diminishing trade competitiveness of the Chinese pharmaceutical industry. Although the industry has a certain degree of competitive advantage in price, its international trading competitiveness is seriously diminishing.

\section{Business opportunities}

Foreign pharmaceutical manufacturers can capture good business opportunities by establishing wholly foreign-owned pharmaceutical factories and producing pharmaceuticals with autonomic patent rights. However, this requires a large initial investment and further costs to open up the market. Another way is to purchase and merge existing pharmaceutical enterprises, and to produce autonomic patented pharmaceuticals. At present, local governments are selling and auctioning stateowned enterprises within their jurisdiction. Depending on foreign enterprises' bargaining power with local governments, merger and acquisitions could be a lowercost strategy for entering the market.

Setting up a wholly foreign-owned pharmaceutical company or a distributing network is an efficient way to enter the market. This strategy, however, requires large investments, bears a high cost for the developing market and has certain risks. There are still uncertainties about permission for foreign service suppliers to engage 
in distribution of pharmaceuticals. To purchase and merge existing pharmaceutical companies and restructure them with an advanced management structure would be another low cost way to enter the pharmaceutical market.

\section{Profitable fields}

What would be a profitable field for a foreign pharmaceutical firm to invest in? Currently there are shortages of special intermediates for preparing pharmaceuticals, such as 6-aminopenlcillanic acid (6-APA), 7-aminocephalosporianic acid (7-ACA), 7-aminodeacetoxycefanoic acid (7-ADCA), isophytol and trimethylhydroquinone. The production of these intermediates would be profitable.

The current technologies associated with fermentation, separation and extraction of special intermediates for preparing $\beta$-lactams, vitamins, aminoglycosides and macrolides are outdated, so another profitable strategy would be to use DNA recombination or protoplasm hybridisation to breed new species of fungi to improve intermediate fermentation, and use the advanced technologies of ultracritical extraction, macroaperture resin separation and membrane separation to improve intermediate extraction and separation.

Current technologies for pharmaceutical preparation are also outdated. The production of new sustained-release and controlled-release medicaments, as well as targeting and transdermal delivery of medicaments, would also be profitable.

The production of biopharmaceuticals is just beginning, so the biopharmaceutical production of antisera, other blood fractions and modified immunological products, vaccines, toxins prepared for diagnostics, prophylactics, therapeutics for malignant tumours and for cardiovascular and cerebrovascular diseases, diseases of the central nervous system, respiratory system, digestive system, and for AIDS and other immunodeficiency diseases would be highly profitable.

China has abundant resources for preparing natural pharmaceuticals. There are 12,807 species of plants, minerals and animals. However, the techniques for preparing natural pharmaceuticals are primitive. Using the advanced techniques of extraction, purification and separation to produce natural pharmaceuticals would be very profitable.

\section{CONCLUDING REMARKS}

Accession to the WTO has further integrated the Chinese economy into the global economic system, with an accelerated pace of industrial restructuring and increased business opportunities for foreign pharmaceutical firms now appearing in China. In 
order to explore and capture these opportunities, and to enter more profitable fields, foreign firms need to pay attention in number of factors.

- Although China has formally become a member of WTO, the administrative measures adopted by governments are still not fully transparent. This will create uncertainties for foreign firms intending to capture business opportunities in the pharmaceutical industry.

- Even after accession, Chinese authorities have retained pricing control over imported pharmaceuticals, and many have adopted administrative measures that do not accord with the principles of the SPS Agreement and national treatment. Such measures may increase the risks for investment.

- The Chinese market remains an imperfect one. Its operation mechanisms are still very different from the western type of market mechanism. Various interest groups exist, including the lower level of local governments, professional supervisory agencies and industrial groups. For this reason, the pharmaceutical industry and market still retain barriers and distortions for foreign investors. Hope lies in strict implementation of China's WTO commitments-opening up China's market and creating an environment in which both domestic and foreign firms can compete on an equal footing.

\section{REFERENCES}

China State Statistical Bureau, various years. China Statistical Yearbook, China Statistical Publishing House, Beijing.

China State Statistical Bureau, various years. China Industrial Economy Statistical Yearbook, China Statistical Publishing House, Beijing.

China State Statistical Bureau, 2000. China Industry Statistical Yearbook 2000. China Statistical Publishing House, Beijing.

China State Customs General Administration, various years. China Customs Statistical Yearbook, China Customs Publishing House, Beijing.

China State Statistical Bureau and Ministry of Science and Technology, various years. China Statistical Yearbook on Science and Technology, China Statistical Publishing House, Beijing.

State Intellectual Property Office, 2000. Annual Report 2000, Intellectual Property Publishing House, Beijing. 


\section{7 \\ Political capital and wealth accumulation}

\section{Meng Xin}

The economic-well being of individuals during old age, unemployment and sickness is closely related to their private wealth, especially in an economy where government has little ability or desire to redistribute income or provide adequate social insurance. China is in the process of moving from state provision of all social welfare towards a new system that will rely heavily on individual's responsibilities. In this new economic environment, the accumulation and distribution of personal wealth will play an important role. This study investigates changes in private wealth accumulation in urban China. In particular, we are interested in examining the effect of political status in the process of wealth accumulation.

\section{BACKGROUND}

In the pre-reform era in urban China, three important factors discouraged individual households from accumulating personal wealth: 1. a low income level, 2. a wellprovided social welfare system, and 3 . the lack of financial, housing and other important durable goods markets. These three factors have gradually changed with progress in economic reform. Over the last twenty or so years incomes of urban population increased from 343 yuan in 1978 to 5854 yuan in 1999, an annual increase of 14.5 per cent (NSB, 2000). In addition, business opportunities have flourished. In 1999, the proportion of urban workers working in the private sector increased to 51 per cent while this ratio was 0.2 per cent in 1978 (NSB 2000). More 
importantly, since the late 1980s, economic reform gradually swept away almost all aspects of the old social security system at the same time as state-owned enterprises started to lay off large numbers of workers. All these factors have significantly increased households savings. This, in turn, has generated a significant increase in wealth accumulation in urban China.

In addition to the speed of wealth accumulation, the process of wealth accumulation and distribution in urban China has special features. One important feature is the role of political power in the acquisition of wealth. Even though political power has always benefited high-level government and party officials, economic reform has commercialised this power through the distribution of labour and non-labour income (Morduch and Sicular 2000) and the distribution of housing. For example, in the old system, the size and quality of housing was determined by individuals' political power and occupational status. Housing reform introduced in the early 1990 s allowed those who were renting government housing to buy their dwellings at a heavily subsidised price. The subsidy was positively related to the seniority and political positions of household members. Thus, the acquisition of housing, which accounted for more than half of the average household wealth in 1999, is affected by political factors on two accounts-the initial allocation of better housing and larger purchase price discounts. Another example of the influence of political power is the importance of networking in establishing a private business. Those with political power or those well connected to political power find it easier to establish and succeed in private enterprises. Furthermore, widespread corruption during the process of marketisation gives people with political power an extra means to gain non-labour income.

Another unique feature in personal wealth accumulation and distribution in urban China is the way in which inheritance takes place. The lack of wealth among the older generation means that inheritance is not important. Children of important government or party officials, however, can easily inherit business networks and political connections. In addition, in the pre-reform era, children of individuals with political power were normally able to acquire better housing which subsequently could be purchased at highly subsidised prices.

\section{METHODOLOGY AND DATA}

To study wealth accumulation, the specifications used in Carroll and Samwick (1997) and Shamsuddin and DeVoretz (1998) are used as a base model:

$\log W_{i}=\alpha_{0}+\alpha_{1} V_{i}+\alpha_{2} \log P_{i}+\alpha_{3} P$ arty $+X \beta^{W}+u_{i}$ 
where $W_{i}$ is wealth, $V_{i}$ is variance of household income, and $P_{i}$ is an estimate of permanent income, which is defined as weighted average of past incomes. Party is a dummy variable indicating whether or not an individual is a party member or not, and $X_{i}$ is a vector of other exogenous variables.

In this specification $V_{i}$ indicates the effect of precautionary saving, Party ${ }_{i}$ captures the effect of political power. The vector of endogenous variables $X_{i}$ controls for life cycle and bequest effects of wealth accumulation. The variables included in $X_{i}$ are age, number of children, household size, whether the household has unemployed member(s), and household location of residence. The variable 'permanent income', $P_{i}$, normally captures differences in saving behaviour and in wealth acquired from non-saving sources among households with different levels of expected lifetime income. In the West, non-saving wealth accumulation is mainly through inheritance or lotteries. In urban China during the period we are studying, inheritance and lotteries are not important. Rather, direct transfers from state to individuals, such as highly subsidised housing or other forms of non-saving wealth, such as gifts, or even bribes, may form the main part of the non-saving wealth.

One important issue in estimating Equation 17.1 is the possible endogeneity of the variables 'permanent income' and 'the variance of household income'. To endogenise these two variables, a vector of instruments is used. These instruments should be important determinants of permanent income and variance of income but have no predictive power on wealth over and above their effect on these two variables. We include years of schooling for household head and spouse, industry and ownership affiliations of household heads in the vector of the instruments.

The data used in this study are from two Urban Household Income Distribution Surveys (UHIDS) conducted by the Institute of Economics, Chinese Academy of Social Sciences for the years 1995 and 1999. The surveys include 6930, and 4493 households for the two years, respectively. The 1995 survey covers 11 provinces, whereas the 1999 survey covers 6 of the 11 provinces included in the previous surveys. To ensure the consistency of the comparison, only observations from the 6 provinces which are surveyed in both years are included. Excluding missing values, the number of households included in this study vary from 3626 to 3748 for 1995 survey and from 4296 to 4363 for the 1999 survey depending on the group of variables used in each estimation.

Table 17.1 reports summary statistics and measures of inequality of household income, permanent income and different types of wealth for the two survey years. 
Over the 4 year period, real permanent household income increased by 16 per cent per annum and real net wealth increased by 24 per cent per annum. The fact that real wealth growth is much faster than real income growth suggests that either the saving propensity has increased significantly or a large proportion of the wealth accumulation is coming from non-saving sources, or both. Among the total wealth, housing wealth has grown the fastest, at a rate of 42 per cent per annum. This is mainly due to the faster pace of housing reform during this period. Table 17.2 shows that in 1988, hardly any household owned its own house. By 1995, 26 per cent of the households had bought their own house, while this ratio increased to 58 per cent

\section{Table 17.1 Summary statistics and inequality measures of real income and wealth, 1995 and 1999}

\begin{tabular}{lcccc}
\hline & $\begin{array}{c}\text { Permanent } \\
\text { income }\end{array}$ & $\begin{array}{c}\text { Net total } \\
\text { wealth }\end{array}$ & $\begin{array}{c}\text { Financial } \\
\text { wealth }\end{array}$ & $\begin{array}{c}\text { Net housing } \\
\text { wealth }\end{array}$ \\
$1995(1995=100)$ & 6261.24 & 32047.90 & 11673.86 & 10920.41 \\
Mean & 2987.42 & 40436.34 & 23097.01 & 26322.86 \\
Std. Dev. & 0.48 & 1.26 & 1.98 & 2.41 \\
Coefficient of variation & 0.52 & 1.07 & 1.17 & 1.03 \\
Standard deviation of logs & 0.25 & 0.50 & 0.58 & 0.84 \\
Gini coefficient & & & & \\
1999 (1995=100) & 11426.31 & 75515.01 & 22574.62 & 44171.64 \\
Mean & 6626.07 & 85256.71 & 34380.20 & 65768.57 \\
Std. Dev. & 0.58 & 1.13 & 1.52 & 1.49 \\
Coefficient of variation & 0.55 & 1.28 & 1.28 & 0.91 \\
Standard deviation of logs & 0.29 & 0.52 & 0.63 & 0.65 \\
Gini coefficient & & & & \\
Annual growth rate 1995-99 & 16.2 & 23.90 & 17.92 & 41.82 \\
(per cent) & & & & \\
\hline
\end{tabular}

Table 17.2 Effect of housing reform on housing ownership, 1988-99

\begin{tabular}{lcccccc}
\hline & \multicolumn{2}{c}{1988} & \multicolumn{2}{c}{1995} & \multicolumn{2}{c}{1999} \\
Public housing & 3577 & 85.11 & 2436 & 63.31 & 1621 & 36.17 \\
Old self housing & 611 & 14.54 & 419 & 10.89 & 258 & 5.76 \\
Bought after reform & 15 & 0.36 & 993 & 25.81 & 2602 & 58.07 \\
& 4203 & & 3848 & & 4481 & \\
\hline
\end{tabular}

Sources: Household Income Distribution Surveys, 1988, 1995, and 1999, Institute of Economics, the Chinese Academy of Social Sciences. 
in 1999. The majority of houses purchased during the housing reform period were bought at highly subsidised prices, and may account for a large part of the nonsaving wealth accumulation. Nevertheless, the rate of increase in financial wealth (17 per cent per annum) is also faster than the increase in real income, indicating possible non-savings accumulation of financial wealth as well.

Another interesting issue is the difference in the speed of asset accumulation between the rich and the poor. To investigate this issue, we rank household permanent income into percentiles and calculate for each percentile average net household total wealth for 1995 and 1999. Figure 17.1 presents the results as well as the growth rate for each percentile. Over this period net household total wealth increased for households in all percentile of income, but the rate of increase is much higher for the above average rich households than for the poor.

\section{DETERMINANTS OF WEALTH}

To further investigate the determinants of wealth and wealth distribution, Equation 17.1 is estimated using the 1995 and 1999 UHIDS data. The results using IV estimation for the net total wealth, financial wealth, and net housing wealth are reported in Tables 17.3, 17.4, and 17.5, respectively. In each of these tables, the first column presents the results using the 1995 data while the second and the third columns provide results using the 1999 data. Note that in the third column a variable indicating whether the father of the household head is a party member or not is included. Even though important, this variable is not available from the 1995 data. To make it comparable between the two years, we estimated Equation 17.1 with and without this variable for 1999 data.

The first important finding is the difference in the effect of permanent income on wealth between the two years. With regard to net total wealth, the income elasticity of wealth is less than one in 1995 but increased to 1.6 in 1999. The fast change in the elasticity during this period may imply one of three things. First, relative to the poor the rich have been saving much more during this period providing that all wealth is accumulated from savings. However, given the significant increase in wealth during such a short period it is unlikely that all wealth is accumulated through personal savings. Second, the rich may have been given much more wealth than the poor. This wealth may be given in the form of direct wealth, such as housing, or in the form of income, such as gifts or even monetary bribes. If it is in the form of income, our finding suggests that the rich in the sample are under-reporting their 
Figure 17.1 Lorenz curves of wealth

Panel A: Net total assets, 1995 and 1999

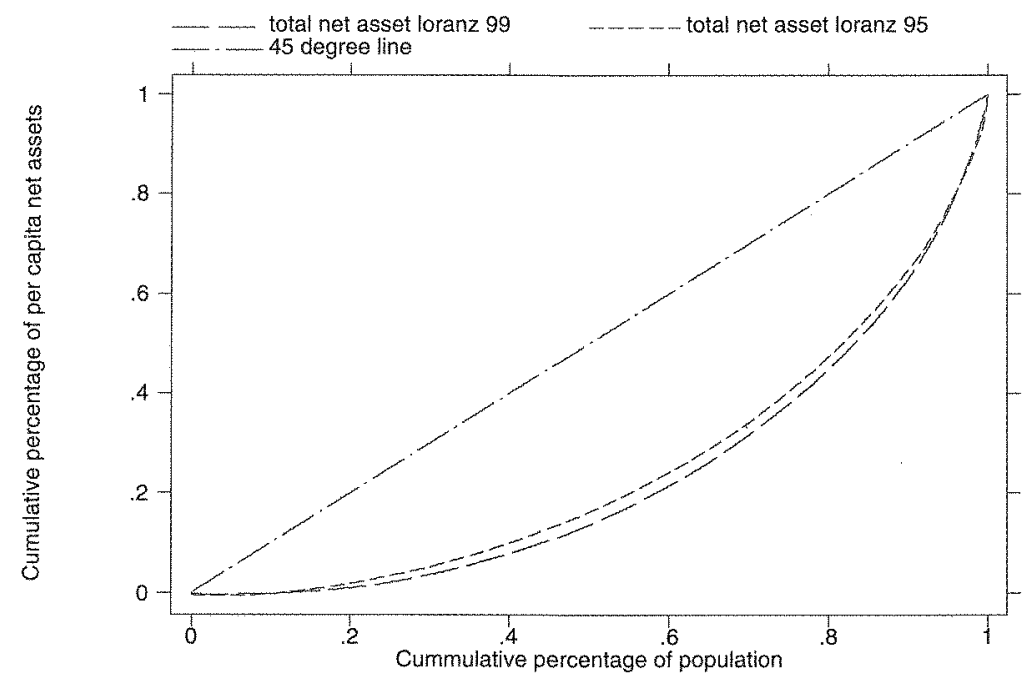

Panel B: Financial assets, 1995 and 1999

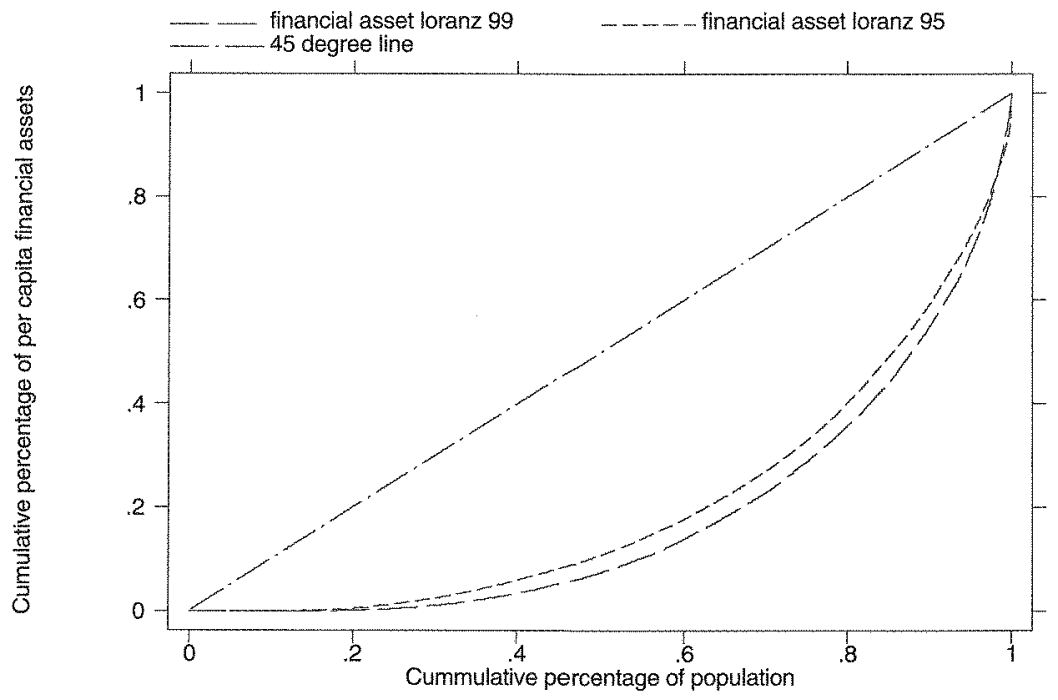


Panel C: Net housing assets, 1995 and 1999

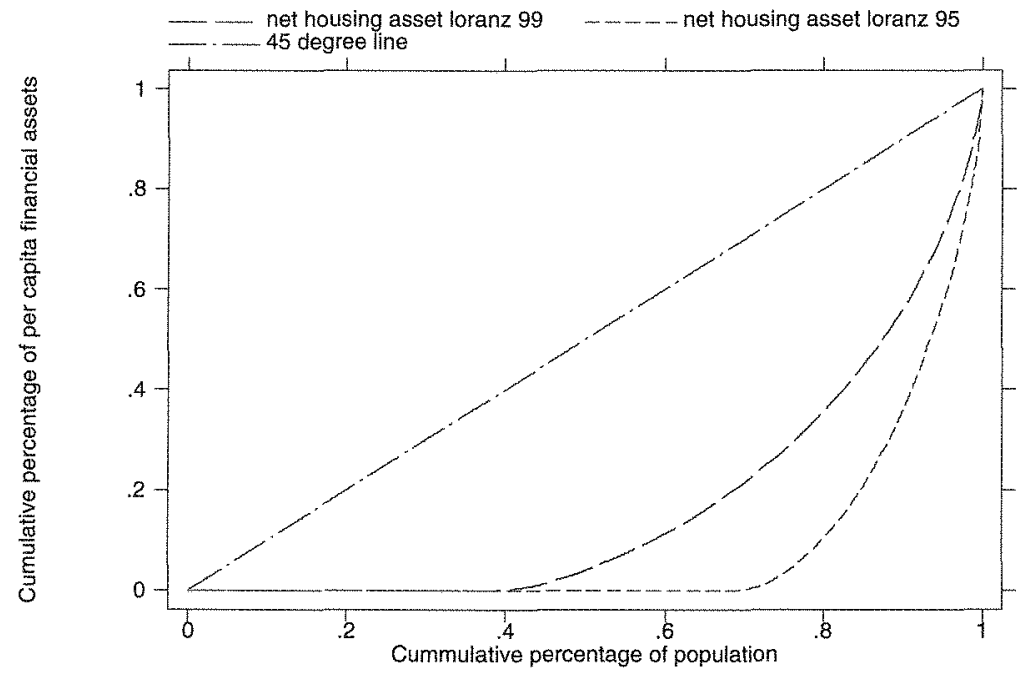

income. Either way, this is an important indication that the rich have been able to accumulate wealth via non-economic means. To provide some evidence, we calculated for each income percentile its annual growth rate in income and saving rate. The net total asset level in 1999 is then projected assuming that net assets are accumulated only through saving. Figure 17.3 shows the result. It clearly indicates that projected wealth is lower than actual wealth for households in all income percentiles. However, the amount of non-saving wealth is much higher for the households with above-average income level, than for the poor. For example, households below the 50 th percentile income level on average acquire 39 per cent of their accumulated wealth from non-saving component, while this ratio for those above the $50^{\text {th }}$ percentile is 50 per cent. The third possibility is that the existing wealth has appreciated at a very high rate. This, however, is unlikely to explain a large part of the difference. The type of wealth which is most likely to have appreciated is housing. According to the China Statistical Yearbook (2002), the commercial housing prices (per square metre) increased by 29 per cent from 1995 to 1999. Taking into account that net housing wealth accounted for 41 per cent of net total wealth in 1999 in our sample, ${ }^{1}$ we projected the effect of housing price appreciation 
Table 17.3 Determinants of net total wealth, 1995 and 1999 (IV estimates)

\begin{tabular}{|c|c|c|c|c|c|c|}
\hline \multirow[b]{3}{*}{ Lntass } & \multirow{2}{*}{\multicolumn{2}{|c|}{1995}} & \multicolumn{4}{|c|}{1999} \\
\hline & & & \multicolumn{2}{|c|}{ without father } & \multicolumn{2}{|c|}{ with father } \\
\hline & Coef. & Std. Err. & Coef. & Std. Err. & Coef. & Std. Err. \\
\hline Constant & 2.50 & 2.99 & $-5.66^{*}$ & 2.56 & $-5.75^{* *}$ & 2.56 \\
\hline Log permanent income & $0.79^{*}$ & 0.41 & $1.62^{\mathrm{mm}}$ & 0.31 & $1.62^{* * n}$ & 0.31 \\
\hline \multicolumn{7}{|l|}{ Variance of household } \\
\hline income/10 $10^{7}$ & -0.20 & 0.18 & $0.05^{*}$ & 0.03 & $0.05^{*}$ & 0.03 \\
\hline $\mathrm{HH}$ being party member & $0.27^{* *}$ & 0.08 & $0.20^{*}$ & 0.09 & $0.19^{*}$ & 0.08 \\
\hline Father of $\mathrm{HH}$ being pty member & & & & & 0.08 & 0.08 \\
\hline No. of unemployed & -0.09 & 0.10 & $-0.23^{\prime *}$ & 0.10 & $-0.23^{*+*}$ & 0.10 \\
\hline $\mathrm{HH}$ age & 0.03 & 0.04 & 0.03 & 0.03 & 0.03 & 0.03 \\
\hline $\mathrm{HH}$ age squared/100 & -0.04 & 0.04 & -0.03 & 0.03 & -0.03 & 0.03 \\
\hline Gender of the $\mathrm{HH}$ & 0.10 & 0.09 & 0.13 & 0.08 & 0.13 & 0.08 \\
\hline Family size & 0.15 & 0.10 & $-0.21^{*}$ & 0.11 & $-0.21^{*}$ & 0.11 \\
\hline No. of children & -0.18 & 0.12 & 0.07 & 0.13 & 0.07 & 0.13 \\
\hline Proportion of elderly members & .0 .45 & 0.71 & 0.02 & 0.64 & 0.00 & 0.64 \\
\hline Proportion of elderly members ${ }^{2}$ & 0.56 & 0.74 & 0.44 & 0.66 & 0.47 & 0.66 \\
\hline Liaoning & -0.37 & 0.23 & $1.01^{\cdots *}$ & 0.17 & $1.00^{\circ+1}$ & 0.17 \\
\hline Jiangsui & -0.26 & 0.24 & $1.05^{\text {k*s }}$ & 0.15 & $1.05^{4+1+}$ & 0.15 \\
\hline Henan & -0.19 & 0.22 & $0.87^{\text {tns }}$ & 0.18 & $0.86^{*+}$ & 0.18 \\
\hline Sichuan & $-1.40^{n+*}$ & 0.21 & $0.95^{\circ *}$ & 0.17 & $0.95^{n+x}$ & 0.17 \\
\hline Gansu & $-1.34^{x+x}$ & * 0.28 & 0.20 & 0.20 & 0.19 & 0.20 \\
\hline No. of observations & 3748 & & 4296 & & 4296 & \\
\hline $\mathrm{R}^{2}$ & 0.070 & & 0.098 & & 0.099 & \\
\hline
\end{tabular}

on net total wealth. It is also plotted in Figure 17.3 (the thicker line). The predicted net total wealth level, taking into account the appreciation in 1999 , is still much lower than the actual level for the middle and high income households.

The second important finding is the change in the effect of the variance in household income on wealth accumulation. In 1995, this variable played no role. A positive effect, however, is observed in 1999, indicating that households which have experienced large income variation over the 5 years prior to the survey year saved more than households which have had more stable incomes. This finding accords well with the reality. The radical state sector reform and social welfare reform during the second half of the 1990s has significantly increased household saving propensity due to the expected increase in unemployment and individual contribution in the areas of medical services, pension, children's education, and housing. In order to 
Table 17.4 Determinants of financial wealth, 1995 and 1999 (IV estimates)

\begin{tabular}{|c|c|c|c|c|c|c|}
\hline \multirow[b]{3}{*}{ Lfass } & \multirow{2}{*}{\multicolumn{2}{|c|}{1995}} & \multicolumn{4}{|c|}{1999} \\
\hline & & & \multicolumn{2}{|c|}{ without father } & \multicolumn{2}{|c|}{ with father } \\
\hline & Coef. & Std. Err. & Coef. & Std. Err. & Coef. & Std. Err. \\
\hline Constant & -12.47 & 3.70 & $-22.87^{*+*}$ & 3.84 & $-23.07^{+50}$ & 3.84 \\
\hline Log permanent income & $2.49^{* * *}$ & 0.51 & $3.32^{\operatorname{snn}}$ & 0.46 & $3.33^{x+*}$ & 0.47 \\
\hline Variance of household income $/ 10^{7}$ & -0.32 & 0.21 & $0.08^{\star}$ & 0.04 & $0.08^{*}$ & 0.04 \\
\hline $\mathrm{HH}$ being party member & $0.42^{* * *}$ & 0.11 & $0.29^{* *}$ & 0.13 & $0.27^{+* *}$ & 0.13 \\
\hline Father of $\mathrm{HH}$ being pty member & & & & & 0.17 & 0.12 \\
\hline No. of unemployed & -0.21 & 0.14 & -0.03 & 0.13 & -0.03 & 0.13 \\
\hline $\mathrm{HH}$ age & 0.04 & 0.04 & 0.06 & 0.04 & 0.06 & 0.04 \\
\hline $\mathrm{HH}$ age squared/100 & -0.05 & 0.05 & $-0.10^{*}$ & 0.04 & $-0.10^{*}$ & 0.04 \\
\hline Gender of the HH & -0.03 & 0.11 & $0.31^{+2 n+}$ & 0.12 & $0.31^{+\infty}$ & 0.12 \\
\hline Family size & -0.20 & 0.14 & $-0.93^{* \times x}$ & 0.18 & $-0.92^{* * *}$ & 0.18 \\
\hline No. of children & -0.04 & 0.16 & $0.62^{* * n}$ & 0.20 & $0.62^{n+*}$ & 0.20 \\
\hline Proportion of elderly members & 0.38 & 0.89 & 1.14 & 1.01 & 1.08 & 1.01 \\
\hline Proportion of elderly members ${ }^{2}$ & -0.04 & 0.97 & -0.12 & 1.04 & -0.07 & 1.04 \\
\hline Liaoning & $-0.65^{\circ *}$ & 0.30 & $1.90^{-* m}$ & 0.26 & $1.88^{+*+1}$ & 0.26 \\
\hline Jiangsui & $-0.55^{*}$ & 0.29 & $2.28^{+* *}$ & 0.20 & $2.27^{+* *}$ & 0.20 \\
\hline Henan & $-0.58^{* * *}$ & 0.29 & $1.69^{x+4}$ & 0.26 & $1.67^{* t *}$ & 0.26 \\
\hline Sichuan & $-1.90^{\text {t*t }}$ & 0.26 & $0.75^{\text {tom }}$ & 0.25 & $0.74^{*+* t}$ & 0.25 \\
\hline Gansu & $-2.03^{*+t}$ & 0.33 & $0.76^{* * *}$ & 0.27 & $0.75^{\text {sm }}$ & 0.27 \\
\hline No. of observations & 3748 & & 4296 & & 4296 & \\
\hline$R^{2}$ & 0.092 & & 0.1426 & & 0.1436 & \\
\hline
\end{tabular}

get access to the similar amount of services previously provided by the government, households have to accumulate personal wealth. Thus, the precautionary saving motive among urban households has become more and more important during this period.

Another interesting finding is the effect of unemployment on wealth accumulation. In 1995 households with unemployed members accumulate less wealth than households without unemployed members, but such differences are not statistically significant. By 1999, a 23 per cent reduction in wealth is observed for this group of households. The reason for this difference may be related to the increase in the duration of unemployment. This is because the large-scale state sector layoffs did not occur until 1994 to 1995 . The survey in 1995 may only include individuals with very short spells of unemployment. By 1999, however, some layoff workers might have been unemployed for sometime and hence may have started the process of dissaving. Note also that the result presented here is from the IV estimates, which 
Table 17.5 Determinants of net housing wealth, 1995 and 1999 (IV estimates)

\begin{tabular}{|c|c|c|c|c|c|c|}
\hline \multirow{4}{*}{$\begin{array}{l}\text { Lnmvhs } \\
\text { Constant }\end{array}$} & \multirow{2}{*}{\multicolumn{2}{|c|}{1995}} & \multicolumn{4}{|c|}{1999} \\
\hline & & & \multirow{2}{*}{\multicolumn{2}{|c|}{$\begin{array}{c}\text { Without father pty } \\
\text { Coef. Std. Err. }\end{array}$}} & \multicolumn{2}{|c|}{ With father pty } \\
\hline & Coef. & Std. Err. & & & Coef. & td. Err. \\
\hline & $15.54^{\text {tats }}$ & 5.12 & $-16.74^{* * *}$ & 5.36 & $-17.01^{*+*}$ & 5.36 \\
\hline Log permanent income & $-2.64^{* * *}$ & 0.71 & $1.70^{+*+*}$ & 0.65 & $1.67^{* *}$ & 0.66 \\
\hline Variance of household income $/ 10^{7}$ & 0.10 & 0.28 & $0.18^{\mathrm{men}}$ & 0.06 & $0.17^{*+*}$ & 0.06 \\
\hline $\mathrm{HH}$ being party member & $0.60^{\text {sse }}$ & 0.17 & $0.79^{+2 n}$ & 0.19 & $0.76^{*+1}$ & 0.19 \\
\hline Father of $\mathrm{HH}$ being pty member & & & & & $0.45^{* *}$ & 0.19 \\
\hline No, of unemployed & $-0,42^{* * *}$ & 0.20 & -0.16 & 0.18 & -0.16 & 0.18 \\
\hline $\mathrm{HH}$ age & $0.26^{*+4}$ & 0.06 & $0.14^{* *}$ & 0.06 & $0.15^{n+1+}$ & 0.06 \\
\hline $\mathrm{HH}$ age squared/100 & $-0.27^{* *}$ & 0.06 & $-0.14^{* *}$ & 0.06 & $-0.15^{\operatorname{six}}$ & 0.06 \\
\hline Gender of the $\mathrm{HH}$ & $0.76^{\text {*in }}$ & 0.16 & $0.36^{\star *}$ & 0.18 & $0.37^{*}$ & 0.18 \\
\hline Family size & $1.05^{*+*}$ & 0.20 & -0.18 & 0.22 & -0.15 & 0.23 \\
\hline No. of children & $-0.74^{n x *}$ & 0.22 & -0.23 & 0.27 & -0.24 & 0.27 \\
\hline Proportion of elderly members & 0.08 & 1.31 & 2.18 & 1.41 & 2.05 & 1.41 \\
\hline Proportion of elderly members ${ }^{2}$ & -0.42 & 1.39 & -1.47 & 1.44 & -1.36 & 1.44 \\
\hline Liaoning & -0.14 & 0.42 & $3.45^{\text {tox }}$ & 0.37 & $3.39^{\text {knt }}$ & 0.37 \\
\hline Jiangsui & $1.98^{*+*}$ & 0.42 & $4.20^{-+\infty}$ & 0.33 & $4.17^{t+1+x}$ & 0.33 \\
\hline Henan & $2.73^{n+x x}$ & 0.43 & $5.20^{\circ * x}$ & 0.36 & $5.16^{* * * x}$ & 0.36 \\
\hline Sichuan & $1.65^{n+x}$ & 0.36 & $5.51^{\text {tit }}$ & 0.33 & $5.49^{\sin }$ & 0.33 \\
\hline Gansu & $1.39^{+4+}$ & 0.48 & $4.36^{+5+1}$ & 0.36 & $4.31^{+*+}$ & 0.36 \\
\hline No. of observations & 3748 & 4296 & 4296 & & & \\
\hline $\mathrm{R}^{2}$ & 0.087 & 0.099 & 0.100 & & & \\
\hline
\end{tabular}

Table 17.6 Direct and indirect effects of unemployment and party membership on wealth, 1995 and 1999

\begin{tabular}{|c|c|c|c|c|c|c|}
\hline \multirow{2}{*}{$\begin{array}{l}\text { Net total wealth } \\
\text { Unemployment }\end{array}$} & \multicolumn{2}{|c|}{1995} & \multicolumn{2}{|c|}{1999} & \multicolumn{2}{|c|}{$\begin{array}{c}1999 \\
\text { with father party } \\
\text { Direct Indirect }\end{array}$} \\
\hline & -0.09 & -0.07 & -0.23 & -0.27 & -0.23 & -0.26 \\
\hline HH party member & 0.27 & 0.02 & 0.20 & 0.17 & 0.19 & 0.17 \\
\hline $\begin{array}{l}\text { Father party member } \\
\text { Financial wealth }\end{array}$ & & & & & 0.08 & 0.06 \\
\hline Unemployment & -0.21 & -0.21 & -0.03 & -0.54 & -0.03 & -0.54 \\
\hline HH party member & 0.42 & 0.08 & 0.29 & 0.35 & 0.27 & 0.34 \\
\hline $\begin{array}{l}\text { Father party member } \\
\text { Net housing wealth }\end{array}$ & & & & & 0.17 & 0.13 \\
\hline Unemployment & -0.42 & 0.23 & -0.16 & -0.28 & -0.16 & -0.27 \\
\hline $\mathrm{HH}$ party member & 0.60 & -0.08 & 0.79 & 0.18 & 0.76 & 0.17 \\
\hline Father party member & & & & & 0.45 & 0.07 \\
\hline
\end{tabular}


Figure 17.2 Net wealth distribution by percentile of permanent income

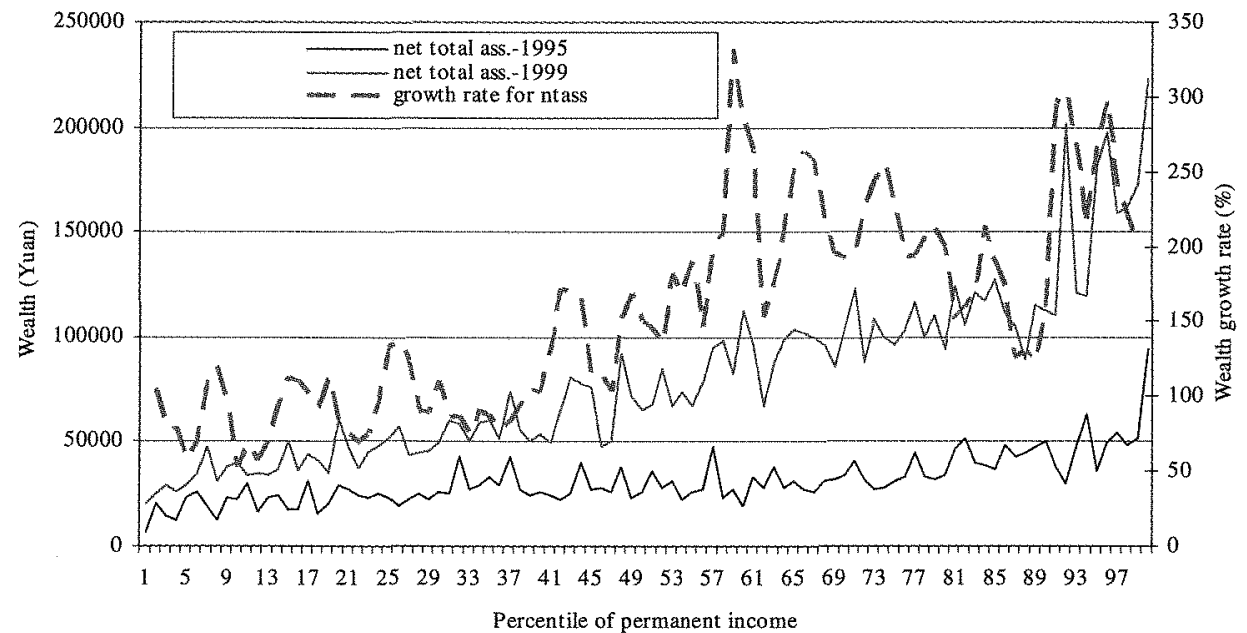

Figure 17.3 Actual and predicted net total wealth by income percentile

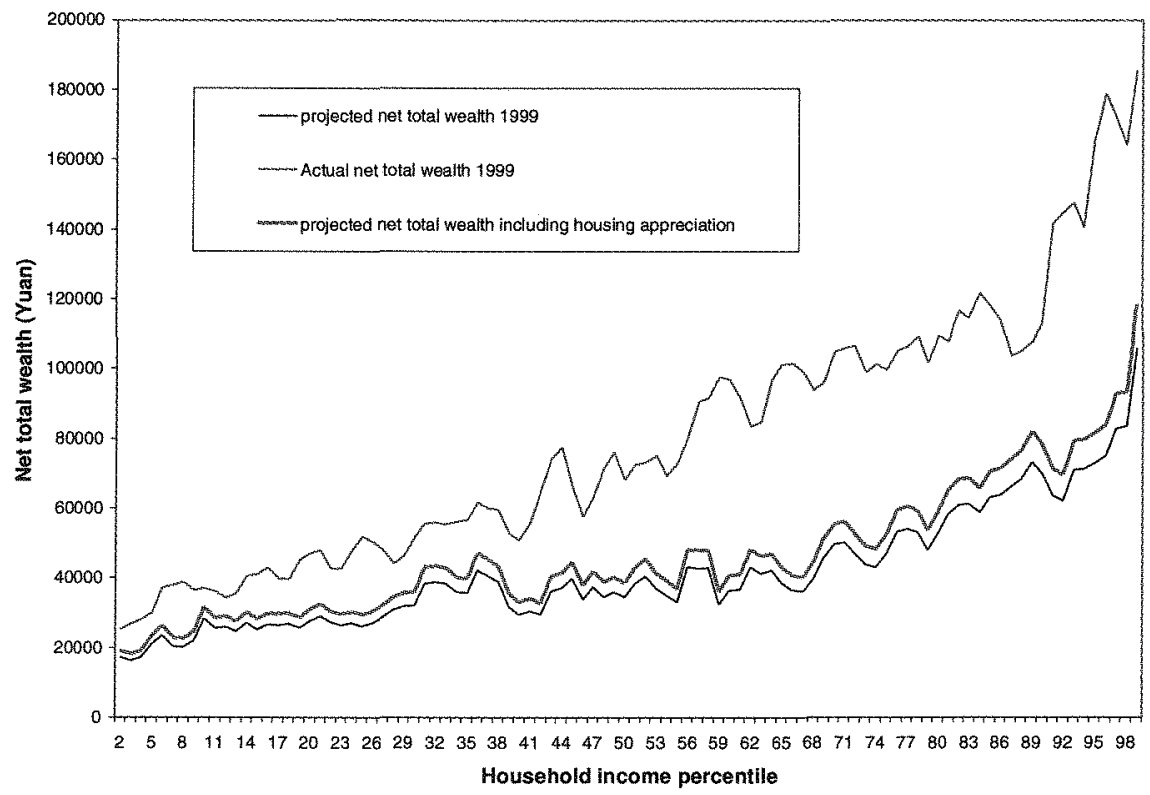


suggests that there are both direct and indirect effect of unemployment on wealth accumulation. The indirect effect is through its effect on household income. Table 17.6 reports the direct and indirect effects. It shows that a higher proportion of unemployed members has a negative effect on household permanent income in both 1995 and 1999, but the effect is twice as big in 1999 as in 1995. Taking into account that the income elasticity of wealth also doubled during this period, the indirect effect of unemployment on wealth reduction in 1999 is around 27 per cent.

The effect of party membership of the household head on wealth also has its direct and indirect components. In 1995, household net total wealth is around 27 per cent higher if a household head is a party member relative to households without a party member head, while its indirect effect through permanent income is around 2 per cent. In 1999, however, the direct effect of party membership on wealth accumulation is 20 per cent, while its indirect effect through permanent income is around 17 per cent. Thus, although the direct effect of party membership on wealth accumulation may have been slightly lower in 1999, its overall effect is actually higher in 1999 than in 1995.

The results from the estimation of the determinants of financial wealth are very similar to those of the net total wealth estimation. One noteworthy difference is that the income elasticity of wealth is very high for financial wealth relative to net total wealth, with the former ranging from 2.5 in 1995 to 3.3 in 1999. Once again, this is similar to that found in Carroll and Samwick (1997). Ruling out the possibility of inheritance, the question still remains as to whether the high saving rate of the rich is enough to explain this high discrepancy between income and wealth among households of different income levels. The answer probably is not.

The result from the net housing wealth equation for 1995 is very unusual with a negative income elasticity of housing wealth. This, however, may not be unreasonable due to a limited housing ownership (one quarter of the total households) at that stage of the housing reform. The majority of households in 1995 did not own a house, including some very rich and powerful families, who had not had the need to buy the house provided to them by the government as heavily subsidised rent lasted until much later.

The most interesting results from the net housing wealth equation is the effect of party membership. Controlling for its impact on income, in 1995 if the household head is a party member the housing asset is about 60 per cent higher than a household without a party member head. This effect increased to 79 per cent in 
1999. What is more interesting is that having a household head whose father is a party member adds another 45 per cent more in household housing assets. These results accord well with the housing distribution process described earlier. Party members and their children acquired larger and better houses before the housing reform and took advantage of the housing reform by getting better houses at substantially subsidised prices. Thus, over and above the contribution of party membership on household income, a substantial effect of party membership on housing wealth is observed together with an additional effect of inherited housing wealth from having a party member as a father is also observed.

\section{CONCLUSIONS}

Several conclusions can be drawn from this paper. First, the rate of growth of wealth is much faster than the growth of real income over the period studied. A large proportion of the increase in wealth accumulation may be through a non-saving channel. Although households at each income percentile have received an increase in non-saving wealth, it is much more so for the rich than for the poor. It is possible, therefore, that economically advantaged households have been receiving larger amounts of non-saving and non-inherited wealth such as housing bought at highly subsidised prices, gifts, or even monetary bribes, than the poor.

Second, party members and their children have benefited significantly from the wealth accumulation process. It is not only that party membership contributes positively to wealth accumulation, having a party member father also adds an additional 50 per cent increment in net housing wealth.

Third, while the precautionary motive is not apparent in the wealth accumulation in 1995, by 1999 households who have experienced large income variations over the 5 year period prior to the survey year have started saving more than households with stable income.

\section{NOTE}

1 The distribution of share of net housing wealth in net total wealth is fairly equal among different income decile, ranging from 36 per cent to 47 per cent. Hence, using average share does not change the story much. 


\section{REFERENCES}

Carroll, C. and Samwick, A.A., 1997. 'The nature of precautionary wealth', Journal of Monetary Economics, 40(1):41-71.

Morduch, J. and Sicular, T, 2000. 'Politics, growth, and inequality in rural China: does it pay to join the party?', Journal of Public Economics, 77(3):331-56.

National Statistical Bureau of China, 2000. China Statistical Yearbook, 2000, China Statistical Publishing House, Beijing.

Shamsuddin, A.F.M. and DeVoretz, D.J., 1998. 'Wealth accumulation of Canadian and foreign-born households in Canada', Review of income and Wealth, 44(4):51533 . 


\section{8}

\section{Reforms and challenges of the social security system}

\section{Qun Shi}

The Chinese social security system is undergoing a series of reforms. These reforms are often the government's short-term responses to imminent financial and social pressure. The long-term impacts, especially those on economic efficiency, are often ignored.

The background of the Chinese social security system reform is unique. Like many other countries (mainly more advanced economies), China is facing an unprecedented demographic transition-an aging population. However, population aging in China is taking place at a much lower level of GDP per capita (Peterson 1999). In the meantime, China is undergoing transition to a market-oriented economy. This is a challenge for the old Chinese social security system and is likely to remain a challenge for many decades.

The old Chinese social security system originated from the command economy era, when the Communist government's development strategy was based on rapid industrialisation. This strategy taxed the agricultural sector, which included 80 per cent of the Chinese population, to cross-subsidise the industrial sector (Wen 2000). The social security system formed at the time was a dual system: a rural system, based on the People's Communes, ${ }^{1}$ that was very elementary, and an urban system that was much more generous and was based on the work unit system. ${ }^{2}$

In rural areas, farmers were organised into People's Communes, and the commune was responsible for providing minimum subsistence to each member. Heavy agricultural taxation, and the need to provide this minimum living, led to a relatively 
equal distribution of available food among members, leaving individual farmers with little incentive to work hard to improve their welfare (Wen 2000). Social security assistance from the government was very limited and only available when the commune could not provide subsistence to its members, such as when there was a natural disaster.

People in cities had much more generous social security provisions and other related welfare benefits. The vast majority of them were guaranteed a job by the government in work units of the public sector and became lifetime employees of the work units. Such jobs also carried generous social security and welfare benefits for the employees and their family members, as specified by the Labour Insurance Regulations (LIR). ${ }^{3}$ By the late 1970 s, the urban social security system was based around the work unit, with individual work units financing the benefits of its members and their families. This was feasible since the government would support them with budgetary appropriations if necessary. Urban residents (and their family members) who were not assigned jobs could receive limited assistance from the Ministry of Civil Affairs (MCA).

This dual system relied heavily on other policies that segregated the rural and urban areas at the time. These policies included the household registration system (HRS), ${ }^{4}$ restrictions on travel, and comprehensive rationing of consumption goods. The HRS was the most important policy and remains in force. These policies effectively curbed domestic migration in general, and rural-to-urban migration in particular (Zhao 2003).

The initiation of transition led to the collapse of the People's Commune system in the early 1980s, a process which essentially destroyed the rural social security system. At present, government-guaranteed access to land is often regarded as the social security provided by the government (Zhao and Wen 1999; Wen 2000). Most reforms to China's social security system have occurred in the urban areas.

Facing demographic and economic transitions, the Chinese government's major social security reform challenge is to transform the old system into a new one that is in line with a market-oriented economy. The new system will have implications for economic efficiency. This chapter will analyse this issue, using selected social welfare programs as case studies. ${ }^{5}$

Economic transition changed the environment of the old urban social security system. First, the previous development policy of cross-subsidising the industrial sector by the agricultural sector was abolished. This meant that the state's control 
and its capacity for mobilising resources from the agricultural to the industrial sector were reduced. As a result, it became increasingly difficult for the central government to subsidise state-owned enterprises (SOEs). ${ }^{6}$

Second, labour market and SOE reforms had gradually undermined the foundation of this work unit-based social security system. Reforms included using labour contracts to replace the previous lifetime employment guarantee by the government (Meng 2000) and policies to transform SOEs into independent economic agents in a market economy. ${ }^{7}$

The 'SOE-based ${ }^{8}$ security system' (LIR) had three major problems

- As an insurance system, it lacked diversifications of risk. The individual SOEbased insurance could not share risks among a large population. This reduced the effectiveness of the system. For example, SOEs with a high retireeemployee ratio had a higher pension burden.

- As a social security program, the scheme had shrinking coverage, when the emerging private sector was left out of the mandatory coverage of the scheme (see Table 18.1).

- The system prevented efficient specification of functions because each SOE had to be a production-based firm, an insurance company and a superannuation fund.

Table 18.1 Employment structure by ownership in urban China, 1980-99 (percentages)

\begin{tabular}{lcccc}
\hline & & & Other & \\
Year & State-owned & Collective-owned & ownership & Total \\
1980 & 76 & 23 & - & 99 \\
1985 & 70 & 26 & - & 96 \\
1990 & 62 & 21 & 1 & 85 \\
1995 & 57 & 16 & 5 & 78 \\
1996 & 55 & 15 & 5 & 75 \\
1997 & 53 & 14 & 5 & 73 \\
1998 & 43 & 9 & 8 & 60 \\
1999 & 40 & 8 & 8 & 56 \\
\hline
\end{tabular}

Note: Figures are based on total urban employment, including all people who worked and received income during the year.

Source: Figures are from State Statistical Bureau, 2001. China Statistical Yearbook, China Statistical Press, Beijing:8, 14 . 
The first two problems diminished the provision of an adequate social safety net to people in need in cities, such as employees in loss-making SOEs and employees in the private sector. The third prevented SOEs from becoming independent firms in a market economy.

Reforms of the urban social security system started in the mid 1980s. However, the major progress was in the 1990s, after the deepening of the SOE reform and the pressure from the large numbers of redundant workers it generated. Although the official number of retrenchments appears to be moderate (Table 18.2), it is estimated that SOEs had about 20-30 million excess employees by the late 1990s (Zhang 1999:69).

\section{THE UNEMPLOYMENT INSURANCE PROGRAM}

Along with the labour contract system, the government established an unemployment insurance program in $1986 .{ }^{9}$ However, this program was only to provide insurance for some redundant SOE employees, especially those who had lost their jobs because of policy changes.

With two further reforms in 1986 and 1999 (Table 18.3), the unemployment program now aims to cover all urban employees (other than public servants). Insurance funds are contributed by employees and employers at the rate of 3 per cent of wages. The government also stands by to provide support if needed. Contributions are collected and pooled at the municipal level, with a provincial adjustment fund. ${ }^{10}$ The unemployment benefits include unemployment relief, medical care subsidies, funeral subsidies, and a lump sum subsidies for the dependants of deceased unemployed workers. The funds are also used to finance training and job-seeking

Table 18.2 Number of retrenched workers of SOEs, 1997-2001 (by year end)

\begin{tabular}{lccccc}
\hline & 1997 & 1998 & 1999 & 2000 & 2001 \\
$\begin{array}{l}\text { Number of retrenched workers } \\
\text { (million persons) }^{\mathrm{a}}\end{array}$ & 6.3 & 6.1 & 6.5 & 6.6 & 5.2 \\
$\begin{array}{l}\text { Total employees in state-owned work units } \\
\text { (millions of persons) }\end{array}$ & 109.5 & 107.7 & 88.1 & 83.3 & 78.8 \\
\hline
\end{tabular}

Note: a Figures do not include reemployed retrenched workers. ${ }^{b}$ State-owned work units include SOEs and other institutes and organisations.

Source: Author's calculations based on figures from MOLSS available online at http:// www.molss.gov.cn.tongji/gb. 
services for the unemployed (Kang and Feng 2000). The details of the benefits are determined by the provincial government. The maximum period of benefits is 24 months for employees with at least 10 years of contributions.

\section{PENSION REFORM}

The pension program is the most expensive scheme among the social security programs specified in the LIR (Figure 18.1).

By the late 1970s, the old pension program had evolved into an individual-SOE based 'pay-as-you-go' (PAYGO) system, where SOEs payed pensions to their retirees from current operating surplus. A series of reforms were introduced in the $1980 \mathrm{~s}$ and 1990s in response to the financial pressures generated by the scheme (Table 18.4).

The first reform involved pooling the pension funds of SOEs at county or city level. It required all SOEs to contribute to a pension fund at a given rate. The fund then distributed the funds back to each SOE according to their pension liabilities.

Figure 18.1 Expenditure of major social security programs in China, 1999

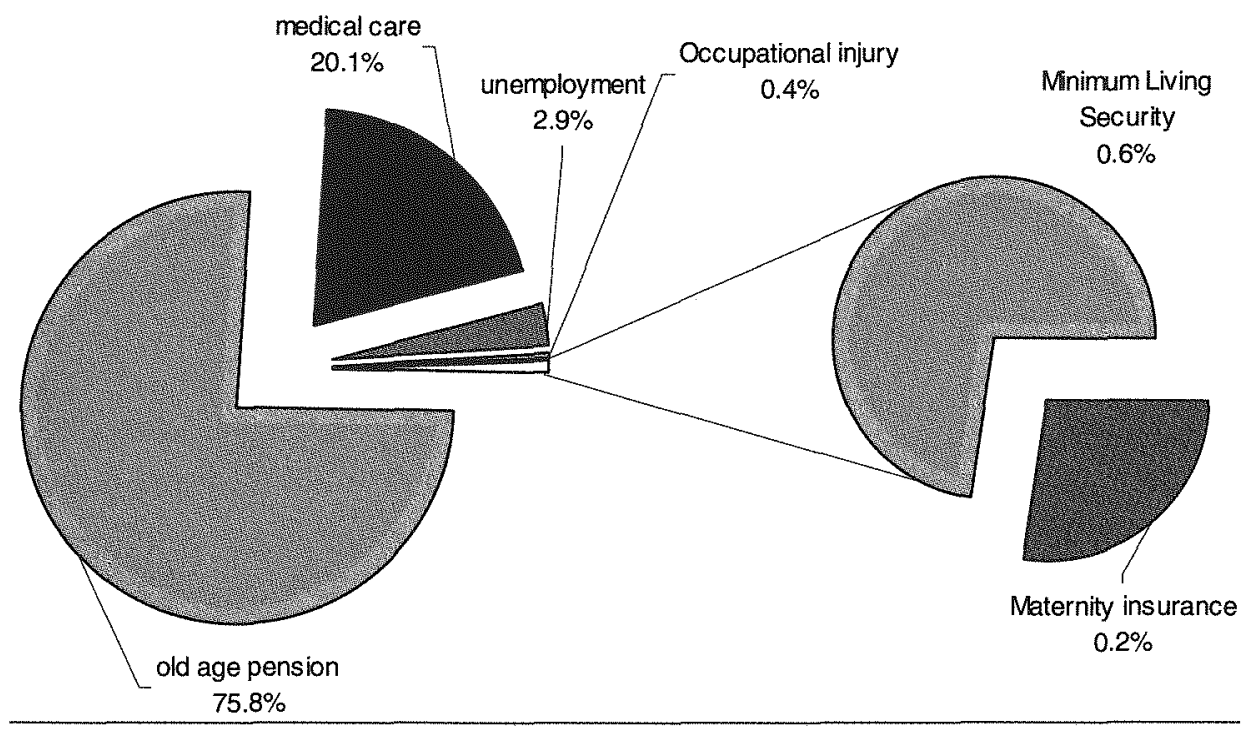

Source: Expenditures on old age pensions, medical care, unemployment insurance, occupational injury and maternity insurance are from State Statistical Bureau 2000. China Statistical Yearbook 2000, China Statistical Press, Beijing. Figures for minimum living security program are from Shi (2000). 
This was the first step towards risk sharing of pension liabilities among SOEs (Han and Jiao 1997, He 2000, Li 2000).

This social pooling of pension funds among SOEs was unsustainable. First, SOEs with a relatively older employee profile had more incentive to contribute, while those with a younger profile had no incentive to contribute. Second, the public sector, which was covered by the pension program, rapidly became 'older', while young people were attracted to the emerging private sector, which was not covered by teh program (Table 18.5). The nature of a PAYGO pension scheme is that it is only stable if it is centrally enforced by regulations. Once the potential for labour mobility was created by the new private sector, young people had an incentive to move into private firms, so as to avoid having to pay for the pensions of the old.

The pension scheme was further reformed in the 1980 s and 1990s (Table 18.4). Reforms at this stage included increasing contributions (employee contributions) and adjusting benefits. By the end of 1990s, the pension scheme had become a three-pillar system with (targeted) coverage of all urban employees.

Table 18.3 Summary of Chinese unemployment insurance reforms in the $1980 \mathrm{~s}$ and 1990s

\begin{tabular}{|c|c|c|c|}
\hline Time & 1986 & 1993 & 1999 \\
\hline Document & $\begin{array}{l}\text { Temporary insurance } \\
\text { regulation for SOE } \\
\text { employees waiting } \\
\text { for jobs }\end{array}$ & $\begin{array}{l}\text { Stipulation of } \\
\text { insurance for SOE } \\
\text { employees waiting for } \\
\text { jobs }\end{array}$ & $\begin{array}{l}\text { Rules of } \\
\text { unemployment } \\
\text { insurance }\end{array}$ \\
\hline Coverage & $\begin{array}{l}\text { Four categories of } \\
\text { ex-employees of SOEs }\end{array}$ & $\begin{array}{l}\text { Seven categories of } \\
\text { ex-employees of SOEs }\end{array}$ & $\begin{array}{l}\text { All urban employees, } \\
\text { except public servants }\end{array}$ \\
\hline Finance & $\begin{array}{l}\text { Employer contribution; } \\
\text { budgetary appropriation }\end{array}$ & $\begin{array}{l}\text { Employer contribution; } \\
\text { budgetary appropriation }\end{array}$ & $\begin{array}{l}\text { Employer contribution; } \\
\text { employee contribution; } \\
\text { budgetary appropriation }\end{array}$ \\
\hline $\begin{array}{l}\text { Unemployment } \\
\text { benefits }\end{array}$ & $\begin{array}{l}\text { Unemployment relief: } \\
\text { between } 50 \text { per cent } \\
\text { to } 75 \text { per cent of } \\
\text { standard wages }\end{array}$ & $\begin{array}{l}\text { Relief: } 20-50 \text { per cent } \\
\text { above social relief, }{ }^{a} \text { plus } \\
\text { medical care subsidy; } \\
\text { funeral subsidy and } \\
\text { dependant allowance; } \\
\text { Other benefits }\end{array}$ & $\begin{array}{l}\text { Unemployment relief } \\
\text { between social relief } \\
\text { and minimum wages; } \\
\text { medical care subsidy; } \\
\text { funeral subsidy and } \\
\text { dependant allowance; } \\
\text { Other benefits }\end{array}$ \\
\hline Duration & $12-24$ months & $12-24$ months & $12-24$ months \\
\hline
\end{tabular}

Note: a Social relief refers to the local poverty line, the minimum living security line, 
The first pillar is a scaled-down PAYGO system that provides the so-called elementary pensions. The second pillar is a compulsory, funded program of individual savings accounts that provides the so-called individual account pensions. The third pillar is a supplementary enterprise pension (Han and Jiao 1997; Liu 2000). It is expected that the first two pillars will provide a basic income-the basic pensionto retirees. ${ }^{11}$

Table 18.4 A summary of public pension reforms in the 1980 s and 1990 s

\begin{tabular}{|c|c|c|}
\hline Major reform & Coverage & Major reforms \\
\hline $\begin{array}{l}\text { Social pooling of } \\
\text { cities; later } \\
\text { pension funds (1984) }\end{array}$ & SOES & $\begin{array}{l}\text { Within a pooling area (initially counties and } \\
\text { provinces), SOEs contributed to a social } \\
\text { pooling fund according to a unified rate. } \\
\text { Pensions were then paid from the social } \\
\text { pool. }\end{array}$ \\
\hline $\begin{array}{l}\text { Fully-funded pension } \\
\text { scheme for contract } \\
\text { workers in SOEs (1986) }\end{array}$ & $\begin{array}{l}\text { Contract workers of } \\
\text { SOEs }\end{array}$ & $\begin{array}{l}\text { Employer: } 15 \text { per cent total wages of } \\
\text { contract workers. Employee: about } 3 \text { per } \\
\text { cent of wages. Contributed into separate } \\
\text { funds from the social pool of permanent } \\
\text { employees }\end{array}$ \\
\hline $\begin{array}{l}\text { Employee contributions } \\
\text { introduced for all } \\
\text { employees of } \\
\text { SOEs (1991) }\end{array}$ & $\begin{array}{l}\text { Employees of SOEs } \\
\text { and state-owned work } \\
\text { units }\end{array}$ & $\begin{array}{l}\text { Employee contribution about } 3 \text { per cent of } \\
\text { wages. Accumulated funds of contract } \\
\text { workers were combined with social } \\
\text { pooling funds of permanent employees of } \\
\text { SOEs. }\end{array}$ \\
\hline $\begin{array}{l}\text { Reforming pension } \\
\text { benefits (1993) }\end{array}$ & SOEs in pilot cities & $\begin{array}{l}\text { Pensions = social pensions+ contribution } \\
\text { pensions. Social pension }=15-25 \text { per cent } \\
\text { of local average wages in the previous } \\
\text { year. Contribution pensions: depend on } \\
\text { contribution years }\end{array}$ \\
\hline $\begin{array}{l}\text { Individual account, a } \\
\text { three-pillar pension } \\
\text { program (1995) }\end{array}$ & All urban employees & $\begin{array}{l}\text { A three-pillar pension system that } \\
\text { comprised: 1) elementary pensions } \\
\text { (PAYGO, social-pooling fund at the city or } \\
\text { county level); 2) individual account pinions } \\
\text { (privately owned individual accounts, fully } \\
\text { funded); and 3) other supplementary } \\
\text { pensions (half-voluntary, at enterprise } \\
\text { level. Still undergoing experiments). }\end{array}$ \\
\hline $\begin{array}{l}\text { Unification of pension } \\
\text { programs within } \\
\text { provinces (1997) }\end{array}$ & All urban employees & $\begin{array}{l}\text { All pension programs within each province } \\
\text { were required to be unified into one } \\
\text { scheme, in terms of contribution rate, } \\
\text { pension benefits, management of social } \\
\text { pooling funds and individual accounts, etc. }\end{array}$ \\
\hline
\end{tabular}


For the PAYGO component, the aim is to establish a social pool at the province level, with funds contributed by employers. The targeted contribution rate is 17 per cent. The elementary pensions-20 per cent of provincial average wages-are paid from this social pool to retirees with at least 15 years' contribution. ${ }^{12}$

For the funded component, funds are accumulated in individual accounts contributed by both employers and employees at a rate of 11 per cent of wages. Of this, employees contribute 8 per cent, and employers contribute 3 per cent. Retirees who contribute for more than 15 years receive monthly individual account pensions equal to $1 / 120$ of total funds in the account at retirement. Other retirees receive the accumulated funds (including credited interest) as a lump sum at retirement.

\section{THE URBAN MINIMUM LIVING SECURITY PROGRAM (UMLS)}

The Urban Minimum Living Security Program (UMLS) program is a new program for social relief. The old social relief program was based on the work unit, since work units looked after the employees and their families. Urban people with no work unit, ${ }^{13}$ no family, and no source of support from relatives-the so-called 'people without the three essentials' (sanwu)-were looked after by the MCA with limited assistance (Wang 1996; Zheng et al. 2000).

Table 18.5 Retiree/employee ratios by ownership structure in China, 1982-98

\begin{tabular}{lcccccc}
\hline & \multicolumn{3}{c}{$\begin{array}{c}\text { Retiree/ } \\
\text { Total } \\
\text { employees } \\
\text { (million) }\end{array}$} & $\begin{array}{c}\text { Total } \\
\text { retirees } \\
\text { (million) }\end{array}$ & $\begin{array}{c}\text { employee } \\
\text { ratio } \\
\text { (per cent) }\end{array}$ & $\begin{array}{c}\text { Retiree/employee ratios } \\
\text { (per cent) }\end{array}$ \\
1982 & 112.8 & 11.1 & 0.10 & 0.10 & 0.09 & state-owned \\
collectives & other units \\
1985 & 123.6 & 16.4 & 0.13 & 0.13 & 0.14 & 0.13 \\
1987 & 132.1 & 19.7 & 0.15 & 0.15 & 0.15 & 0.11 \\
1989 & 137.4 & 22 & 0.16 & 0.16 & 0.16 & 0.08 \\
1990 & 140.6 & 23 & 0.16 & 0.17 & 0.16 & 0.06 \\
1992 & 147.9 & 26 & 0.18 & 0.18 & 0.17 & 0.07 \\
1995 & 149.1 & 30.9 & 0.21 & 0.22 & 0.21 & 0.08 \\
1996 & 148.5 & 32.1 & 0.22 & 0.23 & 0.21 & 0.09 \\
1997 & 146.7 & 33.5 & 0.23 & 0.25 & 0.22 & 0.08 \\
1998 & 123.4 & 36 & 0.29 & 0.32 & 0.32 & 0.12
\end{tabular}

Source: author's calculation based on China Statistical Yearbook, 2001a. China Statistical Press, Beijing. 
During the early and mid 1990s, urban people in need could be broadly classified into three groups:

- residents who had local urban household registrations ${ }^{14}$ and were employed in the public sector

- other urban residents who had local household registrations

- migrants in cities who did not have local household registrations.

This last category included those from other cities, but the majority were from villages (Jiao 2002).

In terms of social relief provisions, the first group received the most generous benefits and were often entitled to be looked after by their work units, although in practice they did not always receive the benefits to which they were entitled. ${ }^{15}$ The second group received minor benefits (the social relief for 'people without the three essentials' from the MCA), while the third group had almost no social safety net. In terms of the need for social support, however, the order was opposite: the most needy were often the third group and the least needy were the first group.

The UMLS program was set up in 1997, designed to provide a guaranteed minimum per capita income for poor urban families (Wang 1999). It covers urban residents who have the local household registrations, but not the third category discussed previously-migrants.

The amount of relief for an UMLS recipient family is calculated by the following formula (all in terms of a month):

Total relief in yuan $=$ Local UMLS line $e^{\star}$ umber of household members

- Total calculated household income

The 'total calculated household income' may not be equal to the 'total actual household income'. The definition often changes slightly from city to city, which may detrimentally affect the poverty relief program.

The city government is responsible for the administration and funding of the program. It determines the local UMLS level and delivers the cash assistance. The provincial government regulates and coordinates the programs of the cities under its jurisdiction. The number of recipients as well as government expenses of the program rose rapidly during the first five years of the program's operation (Table 18.6). 


\section{CHALLENGES FOR THE PENSION SCHEME}

The pension scheme faces a few challenges

- an aging population, which indicates that the PAYGO scheme is not feasible

- financing the pension debt of the old PAYGO scheme in the new funded scheme during the economic transition

- reducing the taxation impact of the funded scheme.

\section{Population aging and the PAYGO pension scheme}

The Chinese population is projected to age rapidly during the first half of the $21^{\text {st }}$ century. This means that the financial burden of supporting the elderly with a PAYGO scheme is going to rise. The old-age dependency ratio-the ratio of the number of retired people to the number of working people--is rising sharply in China compared with other economies (Figure 18.2). In 2000, there were about six working people to support every old person in China. By 2050, there will be fewer than two working people to support each old person.

This population trend means that, in order to finance a defined-benefit (constant pension-wage ratio) PAYGO pension scheme from payroll tax, the tax rate will have to rise. Without other charges, the payroll tax rate in China would have to rise from 13 per cent in 2001 to 53 per cent in 2050 under this scenario (see Figure 18.3). ${ }^{16}$

Such a sharp rise in payroll tax rate would have significant efficiency costs, since the associated deadweight losses increase with the tax rate. A more efficient approach would be to smooth out the future high tax burden over a period of time ${ }^{17}$ by imposing a constant (optimal) tax rate to minimise the overall deadweight losses. Considering various possible future economic growth scenarios, this optimal tax rate needs to finance the old defined-benefit scheme in urban China-about 30 per cent. This tax rate, again, does not appear to be feasible.

The major conclusion of these results ${ }^{18}$ is that, with the rapid aging of the population, financing the old defined-benefit PAYGO pension scheme by collecting payroll tax in urban China is too expensive to be feasible. Even if the tax burden were evened out over a 50-year period, the optimal tax rate would have to be around 30 per cent of wages, which is not feasible either. 


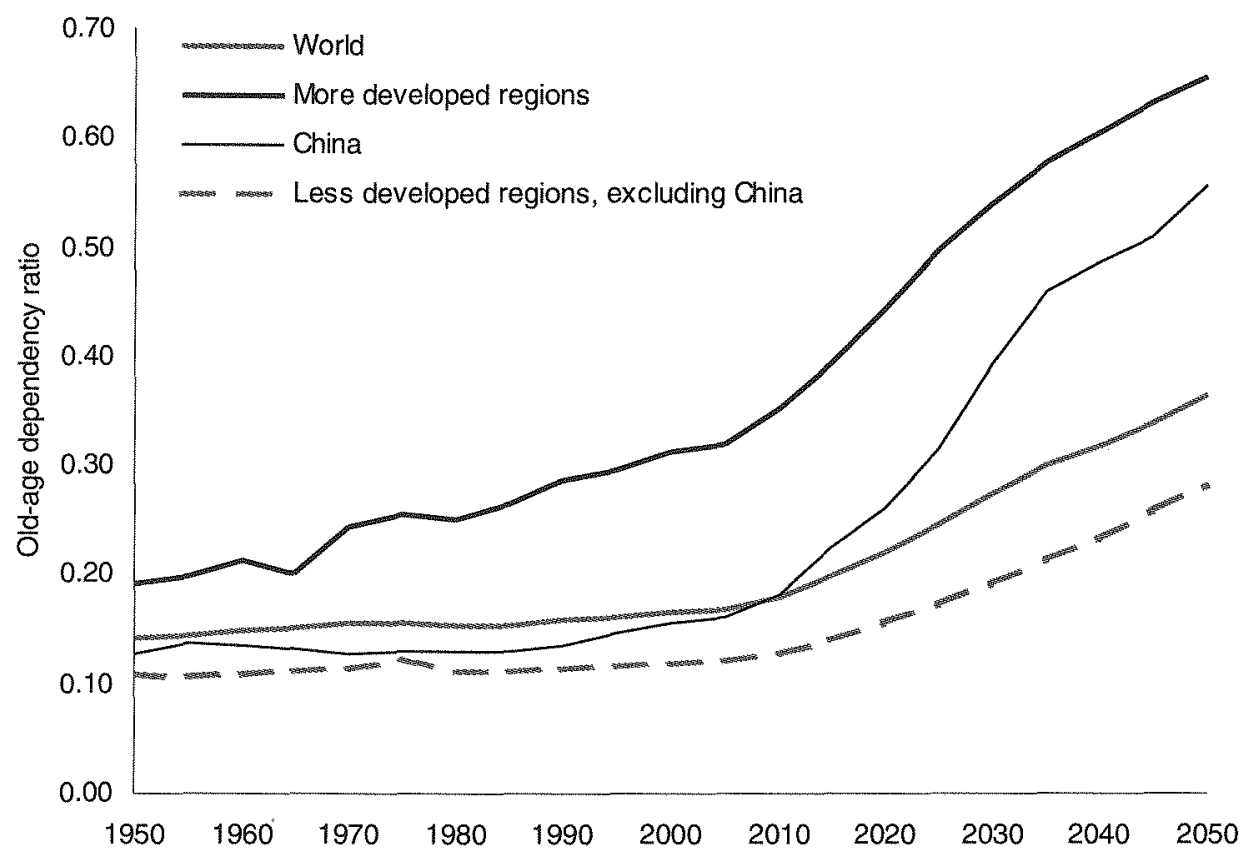

Note: The old-age dependency ratio is defined as the ratio of the number of people aged 60 and over to the number of people aged between 15-59. a The more developed regions comprise Europe, North America, Australia/new Zealand and Japan. ${ }^{b}$ The less developed regions include all regions in Africa, Asia (except Japan), Latin America and the Caribbean plus Melanesia, Micronesia and Polynesia.

Source: Author's construction based on United Nations, 2001. World Population Prospects: the 2000 revision, United Nations, New York

Table 18.6 Selected aggregate figures for the UMLS program, 1998-2002

\begin{tabular}{lccccc}
\hline Year & 1998 & 1999 & 2000 & 2001 & 2002 \\
Recipients (million persons) & 1.84 & 2.66 & 4.03 & 11.71 & 20.64 \\
Share of urban population (per cent) & 0.49 & 0.68 & 0.88 & 2.44 & 4.11 \\
Relief costs (billion yuan) & 0.7 & 2.37 & 3.45 & 5.00 & 10.87 \\
\hline
\end{tabular}

Source: Number of recipients and relief costs figures are from Ministry of Civil Affairs, various years. Urban population figures are from State Statistical Bureau, various years. China Statistical Yearbook, China Statistical Press, Beijing. 


\section{The pension debt, its finance and economic transition}

If the PAYGO pension scheme were reformed into a funded scheme, the government would have to finance the so-called 'transition costs', or the pension debt. This debt is not actually the cost of the pension reform. Instead, it is the implicit government debt accumulated during the PAYGO period, and becomes explicit when the scheme is to be changed to a funded one.

For a given economy, the size of the explicit pension debt depends on factors such as the coverage and benefits in the old PAYGO system and the age structure of the population covered. The pension debt in China is estimated to be low compared with that in countries such as Chile and Argentina when they reformed their systems (World Bank 1997). ${ }^{19}$

One way to examine the burden of the pension debt in China is to simulate the tax rate required to pay this debt. According to the World Bank (World Bank 1997), the scale of China's pension debt was about 50 per cent of GDP in 1996. Suppose the 2000 pension debt level is equal to the level in 2000 and that this pension debt is to be financed by collecting payroll taxe ${ }^{20}$ between 2001 and 2050 . The 50 -year period allows the government to distribute the burden of debt over time in order to minimise the deadweight losses due to the tax. ${ }^{21}$

In the simulation mentioned previously, the Chinese taxation system was assumed to be efficient, that is, one yuan payroll tax collected can be used to pay one yuan pensions, and there was no 'waste' in the taxation system. However, a more realistic assumption for an economy during the transition is to consider a taxation system that is not very efficient initially, but becomes more efficient over time. This is because the command economy had no 'regularised' taxation system (McMillan and Naughton 1992). ${ }^{22}$ A new taxation system needs to be established in a marketoriented economy and it takes time for the new system to begin operating efficiently. With this assumption, the optimal tax rate rises over time instead of being constant. ${ }^{23}$

Bearing in mind these assumptions, ${ }^{24}$ when the taxation system is as inefficient as it was in 2000 , the payroll tax rate for various scenario ${ }^{25}$ ranges from 1 per cent to 4 per cent. If the taxation system becomes more efficient over time, the optimal tax rate is even lower but rises during the 50 year period. Figure 18.4 shows the time path of the tax rate for three different growth rates of urban GDP, when the discount rate is 5 per cent a year. Obviously, when GDP per capita grows faster (and thus the wage rate increases faster), the taxation base for the payroll tax is bigger, and therefore the tax rate required for the pension debt is lower, ceteris paribus. 
These results indicate that the payroll tax burden to finance the pension debt of the old PAYGO scheme in China is not high at all, if the government plans to spread it over a few decades. Faster growth rates of the urban economy tend to reduce the tax rate.

\section{The high tax component of the current pension scheme}

While the current, three-pillar pension scheme is a partially funded program to face the challenge of an aging population, both of the first two pillars need further reforms. The scheme embodies a high tax component and may have a negative impact on economic efficiency.

Figure 18.3 The UN (2001) projected old-age dependency ratio and the PAYGO tax rate

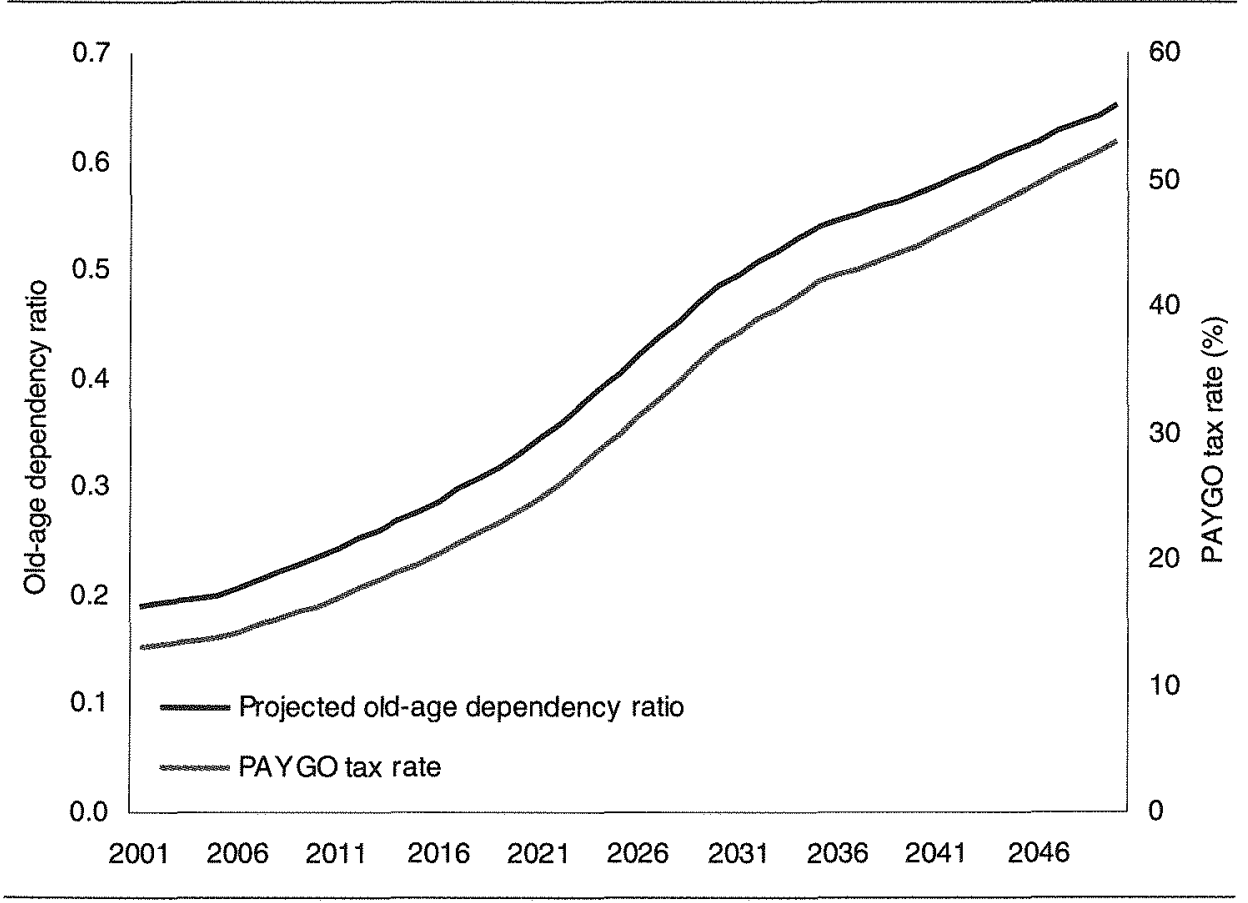

Source: ${ }^{1}$ The old-age dependency ratio is calculated by the author based on UN (2001) projections (medium variant of fertility assumption). It is the number of people at retirement age (males aged $60+$ and females aged 55+) to that at working age (males aged between 15 and 59 , females between 15 and 54). ${ }^{2}$ The year-by-year tax rate is from author's simulation results. Details are available upon requirement. 
First, the social pooling, or the PAYGO component, of the scheme has problems. This PAYGO scheme is unusual since it appears to have both defined benefits and defined contributions: 17 per cent contribution over at least 15 years provides an elementary pensions equal to 20 per cent of provincial average wages. To finance a pension scheme on a PAYGO basis, the fund is financially viable if the following condition holds:

$$
t=\frac{P}{W} * \frac{N_{R}}{N_{W}}
$$

where $P$ is the average pension, $W$ is the average wages, $P / W$ is the aggregate replacement rate; $N_{B}$ is the number of retirees, and $N_{W}$ is the number of workers, $t$ is the contribution rate (as a percentage of total wages).

According to Equation 18.1, a 17 per cent contribution (t) of wages would be sufficient to pay elementary pensions equal to 20 per cent $(P / W)$ of the average wages for a retiree-employee ratio up to 0.85 , if the scheme is financed on a yearby-year basis. This is a very high retiree-employee ratio, and far above the projected old-age dependency ratio of the Chinese population by 2050 .

In fact, the government intends to use this social pooling to finance the implicit pension debt of the old PAYGO scheme (Han and Jiao 1997). But funds in this pool have been insufficient to pay the debt in the past. This has contributed to the 'empty account' problem - some local governments have used funds in individual accounts to pay pensions to current retirees. The central government has had to bail out local governments as well. According to Zhao and Xu (2002:404), '[b]etween 1997 and 2000 , subsidies [by the central government to local governments to pay pensions] doubled every year-from over 5 billion yuan in 1997 to over 10 billion in 1998, over 20 billion in 1999, and over 40 billion in 2000'. In 2001, the subsidy was again 40 billion yuan (Zhao and Xu 2002). In 2002, it was 40.8 billion yuan, which accounted for over 14 per cent of pension payments (Ministry of Labour and Social Security 2003).

Social pooling has other problems. Since only employees with at least 15 years of contribution receive the 20 per cent elementary pension, workers who contribute for less than 15 years lose all their contributions into the social pool-a very high tax on these workers given that the contribution rate is 17 per cent of their wages. In addition, people who only contribute for relatively short periods because they are only employed for short periods may well be the group that most needs the 
Figure 18.4 Optimal payroll tax rate between 2001-50 to pay off historical pension debts up to 2000 , but not beyond*

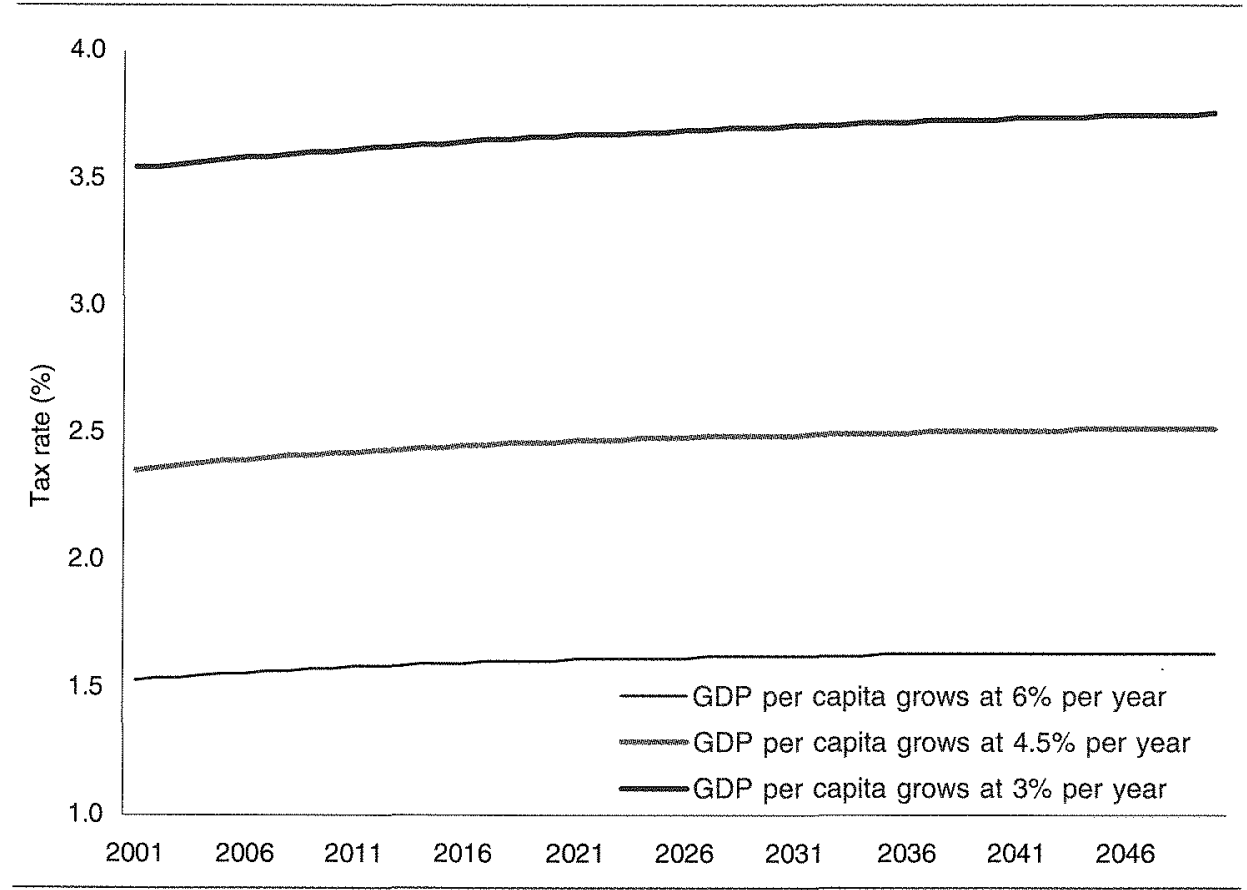

Note: * As explained in the text, this is the optimal tax rate required to collect just enough revenues (in 2000 values) to pay the accumulated pension debt of the old defined-benefit PAYGO scheme. Elasticity of labour supply $=1$; discount rate $=5 \% / y$ r.

Source: Author's simulation results.

government's assistance during retirement, since their lifetime income will probably be low. This income redistribution through the current system of social pooling misses the group who are more likely to be really poor.

Second, the funded component also has problems. To reduce the taxation impact of the contribution to individual accounts, the account must be individually owned, earn market returns and be fully portable. Although individual workers own their individual accounts, including both funds and returns, there is confusion in some regulations and practices regarding this ownership. For instance, in the case of the death of an employee, the relatives may inherit only part of the residual funds in the account-the employee contributions and accumulated interest earnings, but not the employer contributions. 
Currently, funds in individual accounts are not earning a market return. Instead, every year, the provincial government determines a rate of return, the 'accounting interest rate', with reference to bank deposit rates or rates of government bonds (Han and Jiao 1997; Liu 2000). Since the government controls the interest rate, this accounting interest rate tends to be lower than the market return. This implies that employees' labour income is taxed by the pension scheme.

This problem is exacerbated by the fact that provincial governments have an incentive to choose a low interest rate for pension funds. As part of a mandatory public pension scheme operated at the province level, the accounting interest rate affects the future liabilities of the local government. The higher the interest rate chosen to calculate the return on pension funds, the higher the future liabilities of the local government to account owners.

Regulations allow for individual accounts to be fully portable, but how feasible this portability is in practice needs to be monitored closely. This could cause problems if people working in a low-wage province move to a high-wage province owing to the future elementary pensions paid from the social pool.

There are also problems with the management of individual accounts. One example is the 'empty account' problem, when funds in individual accounts are used to pay pensions for current retirees or to invest in local infrastructure, real estate or stocks (Han and Jiao 1997; Li 1998). From an employee's point of view, the key issue is whether or not the local government, as the management authority of their individual accounts, can pay back the money in the account when the employee retires. As long as employees believe that their future pensions from their individual accounts are secure, they will regard the pension contribution into their individual account as part of their deferred payment rather than taxes..$^{26}$ Provided the government's assets, including its future tax revenues, are sufficient to finance its liabilities, they will be all right.

Otherwise, either of the following, or both, may happen: the local government would have to raise taxes or reduce expenditures, or the central government will have to bail out provincial governments in order to keep the scheme running or retirees would receive less than they were promised. In the former case, the government would have to impose more taxes on the private economy, and this would change the nature of the supposedly funded scheme to one that is essentially PAYGO, but with individual accounts. In the latter case, the supposedly individual accounts will turn out not to have been genuinely individual accounts. 
One way to examine the tax component of the current pension scheme is shown in Table 18.7. Suppose there is a hypothetical pension scheme, Scheme $\mathrm{H}$, which has the same contribution rate (28 per cent of wages) as the current scheme, but in which all contributions are accumulated in workers' individual accounts. For simplicity, also assume that, in Scheme $\mathrm{H}$, pensions paid from individual accounts are equal to $1 / 120$ of funds available at retirement, as in the current scheme. The replacement rates of the current Chinese pension scheme and of Scheme $\mathrm{H}$ are listed in Table 18.7. For convenience, the results are calculated for workers whose real wages are equal to the local (provincial) average wage. It is also assumed that the return on funds in individual accounts is the same as the growth rate of wages, and that pensions grow at the same rate as wages. The retirement period is assumed to be ten years. ${ }^{27}$

The comparison between columns $A$ and $B$ shows that, with the same contribution rate, workers receive a higher pension (shown as higher replacement rates) in Scheme $H$ than in the current Chinese pension scheme, regardless of the length of working/ contribution period. In fact, it is clear that the longer the contribution, the more significant the difference is ${ }^{28}$

Table 18.7 Contributions, employment and replacement rate of pensions

\begin{tabular}{|c|c|c|c|c|}
\hline $\begin{array}{l}\text { Years of } \\
\text { employment } \\
\text { contribution }\end{array}$ & $\begin{array}{l}\text { Replacement } \\
\text { rate of the } \\
\text { current Chinese } \\
\text { pension scheme } \\
\text { (per cent)(A) }\end{array}$ & $\begin{array}{c}\text { Replacement } \\
\text { rate of } \\
\text { scheme } H \\
\text { (per cent)(B) }\end{array}$ & $\begin{array}{l}\text { Contribution rate } \\
\text { required for the } \\
\text { same } \\
\text { replacement } \\
\text { rate as }(A) \\
\text { (per cent) }(C)\end{array}$ & $\begin{array}{c}\text { Excess } \\
\text { contribution } \\
\text { rate of the } \\
\text { current Chinese } \\
\text { pension scheme } \\
\text { (percentage points) }\end{array}$ \\
\hline 10 & $11.0^{\mathrm{b}}$ & 28.0 & 11.0 & 17.0 \\
\hline 15 & $36.5^{\mathrm{c}}$ & 42.0 & 24.3 & 3.7 \\
\hline 20 & 42.0 & 56.0 & 21.0 & 7.0 \\
\hline 25 & 47.5 & 70.0 & 19.0 & 9.0 \\
\hline 30 & 53.0 & 84.0 & 17.7 & 10.3 \\
\hline 35 & 58.5 & 98.0 & 16.7 & 11.3 \\
\hline 40 & 64.0 & 112.0 & 16.0 & 12.0 \\
\hline
\end{tabular}

Note: Replacement rate is calculated as the ratio of the first month's (year) pensions to the last month's (year) wages. ${ }^{b}$ Workers with less than 15 years of contribution are not eligible for the 20 per cent local average wage. The number is calculated assuming pensions for the first month of retirement are paid as $1 / 120$ of total funds in the individual account. " This and the following replacement rates in column $A$ include 20 per cent of the local average wage. ${ }^{d} \mathrm{Here}$, all contributions are accumulated in individual accounts.

Source: Author's calculation. 
Another way to see the difference between the two schemes is to look at extra pensions gained with longer years of contribution. While an extra 20 years of contribution (from 15 to 35 years) brings an extra 20 percentage points of replacement rate for workers in the current Chinese pension scheme, it would bring an extra 46 percentage points for the same workers if they were in Scheme $\mathrm{H}$ (comparing columns $A$ and $B$ ).

Column $\mathrm{C}$ in Table 18.7 shows the contribution rate (percentage of wages) required of workers in Scheme $\mathrm{H}$ in order to achieve the same replacement rate as the current Chinese pension scheme. Obviously, the longer the contribution period, the lower the contribution rate required to receive the same pension as in the current Chinese pension system. ${ }^{29}$ This demonstrates that workers bear a higher tax burden the longer they stay in the current Chinese pension system. This is shown in the last column in Table 18.7, where these calculated contribution rates are subtracted from the contribution rate of the current Chinese pension scheme, which is 28 per cent. The results can be regarded as the excess contribution rate of the current Chinese pension scheme compared with Scheme H.

\section{CHALLENGES FACING THE REFORM OF THE UMLS PROGRAM}

\section{The failure of the UMLS to provide a safety net to all residents}

As discussed earlier, the UMLS program only covers people with the local (urban) household registration. This means that a large proportion of people living in cities are not protected by this safety net, although many are poor.

Since the mid 1980s, policies that curbed labour mobility during the pre-reform era have become less effective (Zhao 2003). In the meantime, surplus rural labour has been 'pulled'30 and 'pushed'31 towards cities (Hare 1999; Wang 2001; Zhao 2003). Most of these migrants are not allowed to register as urban households and consequently face discrimination in terms of social and economic entitlements (Meng 2000; Jiao 2002; Zhao 2003). These migrants are often referred to as the 'floating population' (Li2001).

There is no consensus about the size of the floating population in Chinese cities. However, various sources indicate that, during the early 1980s, it accounted for less than 12 per cent of the urban population. ${ }^{32}$ By the mid 1990s, it accounted for 
about 23 per cent (see Rawski and Mead 1998; Wang 2001; Jiao 2002; Rozelle et al. 2002; Jiang 2003). ${ }^{33}$

The limited coverage of the UMLS program has two problems. First, it excludes the poor groups in cities - rural migrants-from the social safety net, even though they contribute to the urban economy. Second, the local household registration requirement, and the difficulty of obtaining it, can reduce labour mobility, especially for urban people. Poor people in one city may choose to rely on the local UMLS relief instead of going to other cities where there are more job opportunities, since they are denied the access of a safety net in these cities.

\section{The high implicit tax of the UMLS program}

The current UMLS program imposes a high tax rate on its recipients. The amount of cash received by the recipient is dependent on household income. When a recipient's household income is increased by one yuan, the recipient household loses one yuan from the UMLS program. This feature effectively imposes a 100 per cent marginal tax rate on recipients' earned income. The recipient is not financially better off by working more and earning more income, so long as they remain a UMLS recipient.

Of course, the 100 per cent marginal tax rate would be less relevant if an effective minimum wage were in place that was much higher than the city's UMLS line, and if part-time work were not available. ${ }^{34}$ On average in 1999 the UMLS line was about 60 per cent of the minimum wage for the capital cities. Taking this figure, suppose that the average family size is three people: two parents and one child. ${ }^{35}$ Suppose only one parent worked in 1999 and received the minimum wage and the family had no other income, then the per capita income of this family would be about 56 per cent of the local UMLS line. Therefore, this family would be eligible for the UMLS poverty relief and would face a tax rate of 100 per cent on any family earnings. That is not sufficient to raise per capita above the local UMLS line.

However, for some unemployed people, the relevant choice is between full-time employment and unemployment. For such people, the effective rate of tax on earned income is less than 100 per cent, particularly if minimum wage rates are actually enforced. For example, using the figures for the UMLS line and provincial minimum wage rates in 1999, a full-time job at the minimum wage for a month would typically pay about 67 per cent more than the monthly UMLS benefit. As a result, the average 
effective tax rate facing a person choosing between the UMLS benefit and full-time employment at the minimum wage would be 60 per cent, not 100 per cent. This is still a very high and distortionary implicit tax.

This high marginal tax rate has a strong negative impact on the labour supply. From the government's point of view, a social safety net that provides a minimum living for the poor is most efficient when the cost is minimised. One way to achieve this object is to minimise the number of people who rely on poverty relief, ceteris paribus. For this purpose, the design of the safety net must consider its negative impact on people's efforts to find jobs.

\section{CONCLUSIONS}

In addition to the problems of rapid population aging, reform of the social security system faces the challenge of the dynamic nature of the economic transition. If the government wishes to explore all possible benefits of the market, reforms to the social security system need to take into consideration ways of minimising the efficiency costs. These costs, such as possible disincentive impacts on labour supply and labor mobility, are particularly significant in the long run.

Some reforms are possible in the current social security system in order to reduce these disincentive effects.

- The contributions to the social pooling funds of pensions need to be reduced or eliminated. This will reduce the tax component of pension contributions on workers.

- The management of individual accounts must be improved to reflect the ownership of the accounts, to raise the return on pension funds to the market return and to minimise the possible impact on labour mobility. This reduces the perceived tax component of contribution to individual accounts.

- The pension debt of the old PAYGO scheme is not high for China. The most efficient way to finance this public debt is to spread the (payroll) tax burden over a long period of time, and to impose lower tax rates when the taxation system is not very efficient, but higher tax rates when it becomes more efficient. Faster economic growth helps to reduce the tax burden.

- For the UMLS program, the high and distortionary tax rate on earned income needs to be abolished. Further reforms of this program also need to consider the provision for migrants and how to reduce the barrier of labour mobility. 


\section{ACKNOWLEDGMENTS}

This paper is based on the author's PhD thesis, completed in June 2003 at the Economics Division, Research School and Pacific and Asian Studies, the Australian National University. The author would like to thank the supervisory panel, including Professor George Fane, Dr. Xin Meng and Professor Ross Garnaut, for their comments on drafts of the thesis

\section{NOTES}

1 The People's Commune was an organisation established by the Communist government. It combined the function of the lowest level government with economic management in rural China. It was the institution that facilitated the role of the agricultural sector in the command economy: a net contributor to the national economy.

2 The work unit was a general name for all sorts of organisations of the command economy, such as schools and factories. It could be state-owned or collective-owned. Each work unit was under the administration of a level of government or its agents. This in turn formed the hierarchy of the work unit system. The work units also combined economic activities with some government social functions, such as social security provisions.

3 The LIR covered state-owned and large collective firms. Employees in other public sectors had social security provisions similar to the LIR.

4 The HRS requires each citizen to register at the local police station, either as rural or non-rural (urban) resident. There are severe restrictions on people living in places other than their registered area.

5 The term 'social security' covers a wide range of programs in China; for example, see Shao and Chen (1991).

6 Wang and $\mathrm{Hu}$ (2001) have an interesting discussion with regard to the declining state fiscal capacity in China since the economic reform.

7 The SOE reforms in China have been well documented, for example, Dong, Tang and Du (1995), Walder (1996), Hay et al. (1994), and Gao (1999).

8 Here 'work units' is replaced with 'SOEs' since most reforms have occurred in SOEs.

$\vartheta$ At the time, the official notation was 'waiting for jobs' rather than 'unemployment' (see Tabie 18.3).

${ }^{10}$ This allows the provincial government to pool the risk among cities under its jurisdiction.

"Policies and detailed regulations with regard to the third pillar are yet to be formalised by the government.

12 This included years of employment acknowledged according to the government rules, which may or may not be equal to the actual working years of the individual (Liu 2000). 
${ }^{13}$ During the pre-reform period, once an individual was allocated to a work unit, the employment relationship was permanent. The work unit was also supposed to take care of the individual and his/her family for lifetime.

${ }_{14}$ This refers to the household registration at the city level, since moving within a city is not restricted by the HRS.

15 This was often due to the financial difficulties of their work units and the reduction of government subsidies to SOEs in deficit during the SOE reform.

${ }^{16}$ This is based on author's simulation, taking into account the difference between urban population aging and overall population aging, and assuming the replacement ratio is the same as the average replacement ratio in 2000 .

17 Barro (1979) shows that the optimal tax rate over time for a given public expenses is a constant tax rate in each period.

18 The author will supply details of the simulation and results of other scenarios of the simulation upon request.

19 The World Bank (1997) estimates that the implicit pension debt in China in 1994 was about 4669 per cent of GDP that year. Compared with 100-200 per cent in most OECD countries, and 40-130 per cent in Chile (depending on the discount rate chosen), the implicit pension debt in China is not very high.

20 Assume this payroll tax is the only tax imposed on the payroll. If there were already other payroll taxes, the tax rate required would be a little higher.

27 In the simulations, this pension debt is rescaled to 2000 values. This approach means that the discount rate matters. In the simulations, several discount rates are used to examine the sensitivity of the results.

22 Government revenues mainly came from the operating surplus of firms it owned (McKinnon 1991).

$\approx$ This can be shown mathematically in the model for the simulations.

${ }^{24}$ It is also assumed that pensions for future retirees of the new funded scheme are financed by accumulated pension contributions, and these contributions are not regarded as tax.

25 These different scenarios include different growth rates of urban GDP per capita and different values of the discount rate.

${ }^{2}$ Assuming the return is the same as the market return.

With this assumption, the formula (for the discrete case) for calculating replacement rate is simplified as

$$
\mathrm{B}=\frac{\mathrm{T}^{*} \tau}{10}
$$


where $B$ is replacement rate, $T$ is number of years of contribution, and $\tau$ is the contribution rate. This formula follows the practice in the current Chinese pension scheme that the first year pensions equal to $1 / 10$ of funds available in the individual account.

${ }^{23}$ Except for the case with only 10 years of contributions, when the worker does not receive the 20 per cent elementary pension from the social pooling fund.

2 With the exception of the case for the shortest contribution period, 10 years.

\$o Farmers are pulled towards cities and villages by, among other things, higher incomes and living standards.

31 Improved agricultural production efficiency and the consequent surplus labour in rural areas are among the factors that pushed farmers to cities.

32 This is calculated by assuming the floating population was 30 million, and those with urban household registration was, on average, 226.1 million between1981-85 (State Statistical Bureau 2000a)

36 This is calculated by assuming the floating population was 80 million in 1995 .

${ }^{34}$ Legislation governing minimum wages in China was issued in 1993 (Kang and Feng 2000).

35 The average family size in 1999 was 3.14 persons (State Statistical Bureau 2000b).

\section{REFERENCES}

Barro, R.,1979. 'On the Determination of the Public Debt', The Journal of Political Economy, 87(5):940-71.

Dong, F.R., Tang, Z.K. and Du, H.Y. (eds), 1995. Studies of Institutional Reform of Chinese State-owned Enterprises, Renmin Publishing House, Beijing.

Gao, S.Q., 1999. Two Decades of Reform in China, World Scientific Press, Singapore. Han, L. and Jiao, K. (eds), 1997. The Unification and Implementation of Enterprise Old Age Pension System, China Human Resource Press, Beijing.

Hare, D., 1999. "Push" and "pull" factors in migration outflows and returns: determinants of migration status and spell duration among China's rural population', Journal Development Studies, 35(3):45-72.

Hay, D.A., Morries, D.J., Liu, G. and Yao, S., 1994. Economic Reform and Stateowned Enterprises in China, 1979-1987, Clarendon Press, Oxford.

He, P., 2000. Choice of the Century: the framework of Chinese social security system, China Labor and Social Security Publishing House, Beijing.

Jiang, X., 2003. 'China perspective: debates initiated by the 'Song of Peasant Workers', BBC News online. Available at http://news.bbc.co.uk/hi/chinese/ china_news/newsid_2857000/28576.stm. 
Jiao, J., 2002. 'From the angle of the rights of the floating population', Population and Economics, 132(3):73-75.

Kang, S. and Feng, W. (eds), 2000. Selected Regulations of Current Social Security System, China Labor and Social Security Publishing House, Beijing.

Li, R., 2001. 'A preliminary study of local regulations of migrants', Population and Economics, 128(5):17-22.

Li, S., 1998. Old Age Pension Scheme and Capital Market, China Development Publishing House, Beiling.

$\mathrm{Li}, \mathrm{S}$., 2000. 'The predicament and way out of old age insurance', Comparative Economic and Social Systems, 3:37-45.

Liu, X. (ed.), 2000. The Old Age Insurance, China Labor and Social Security Publishing House, Beijing.

McKinnon, R.I., 1991. 'Financial control in the transition from classical socialism to a market economy', Journal of Economic Perspectives, 5(4):107-22.

McMillan, J. and Naughton, B., 1992. 'How to reform a planned economy: lessons from China', Oxford Review of Economic Policy, 8(1):130-43.

Meng, X., 2000. Labour Market Reform in China, Cambridge University Press, Cambridge.

Ministry of Civil Affairs, various years. Annual Public Statistical Report for Civil Affairs, Ministry of Civil Affairs, Beijing. Available online at http://www.mca.gov.cn/ news/dibao.

Ministry of Labour and Social Security, 2003. 2003 Annual Public Report of Labour and Social Security Development, MOLSS Report, Beijing. Available online at http://www.molss.gov.cn/tongji/gb.

Peterson, P.G., 1999. Grey Dawn, Random House, New York.

Rawski, T.G. and Mead, R.W., 1998. 'On the trail of China's phantom farmers', World Development, 26(5):767-81.

Rozelle, S., De Brauw, A., Huang, J., Zhang, L. and Zhang, Y, 2002. The Evolution of China's Rural Labour Market during the Reform, Working Paper 02-003, Department of Agricultural and Resource Economics, University of California, Davis.

Shao, L. and Chen, X., 1991. Social Security System Reforms in China, Economic Management Press, Beijing.

Shi, Z., (ed.), 2000. Reports on Chinese Social Welfare and Social Progress in 1999, Social Science Literature Press, Beijing. 
State Statistical Burea, 2001a. China Labour Statistical Yearbook, China Statistical

Press, Beijing.

- 2000b. China Statistical Yearbook, China Statistical Press, Beijing.

United Nations, 2001. World Population Prospects: the 2000 revision, United Nations, New York.

Walder, A.G. (ed.), 1996. China's Transitional Economy, Oxford University Press, Oxford.

Wang, A., Liu, Z., et al. (eds), 1998. Weaving Social Security Net: yesterday, today and tomorrow of the Chinese social security system, Guangxi Normal University Press, Guilin.

Wang, H., 1996. 'Urban Social Relief', in Li, B. and Jiang, W. (eds.), Disaster Relief and Social Relief, China Social Publishing House, Beijing: 145-217.

Wang, $H$. ., 1999. 'An institutional invention of urban social relief in China-The background, contents and implications of the Urban Minimum Living Security System', in D. Xu, Z. Yin and Y. Zheng (eds), Social Security Reform in China: papers selected from the International Forum on Social Security in China, 1998, Beijing, Economic Science Press, Beijing:666-676.

Wang, M., 2001. 'A summary of studies about China's floating rural labour force', in Institute of Population and Labour Economics (ed.), Almanac of China's Population, Almanac of China's Population Press, Beijing:112-20.

Wang, S.G. and Hu, A.G., 2001. The Chinese Economy in Crisis, M.E. Sharpe, New York.

Wen, T.J., 2000. Studies of Fundamental Economic Institutions in Rural China, China Economics Publishing House, Beijing.

World Bank, 1997. Old Age Security: pension reform in China, World Bank, Washington DC.

Zhang, Z., 1999. 'Ownership reforms', in Z. Zhang, F. Huang, and G. Li (eds), Twenty Years of Economic Reform: retrospect and prospect, China Planning Press, Beijing:21-43.

Zhao, Y., 2003. 'Rural to urban labour migration in China: the past and the present', in L. West and Y. Zhao (eds), Chinese Rural Labour Flows, University of California Press, Berkeley.

Zhao, Y. and Xu, J., 2002. 'China's urban pension system: reforms and problems', Cato Journal, 21(3):395-414. 
Zhao, Y. and Wen, G., 1999. 'Chinese rural social security and the land system', in D. Xu, Z. Yin and Y. Zheng (eds), Social Security Reform in China: papers selected from International Forum on Social Security in China, 1998, Beijing, Economic Science Press, Beijing:709-25.

Zheng, B., Wang, C., et al. (eds), 2000. Research of Urban Minimum Living Security Program in Southwest China, Southwest University of Finance and Economics, Chengdu, China, 


\section{9}

\section{The National Social Security Fund}

\section{Tim Murton}

The establishment of the National Social Security Fund (NSSF) is a significant step for China in addressing the magnitude of its current pension problem, and in assisting the Chinese Government to service its pension liabilities. Moreover, it is an important indication of China's desire to encourage the development of institutional investors. Despite this, the NSSF is still shrouded in some mystery. This chapter attempts to provide an insight into the management, funding and operation of the NSSF. The NSSF's role in developing China's fledgling funds management industry will also be considered.

\section{THE NATIONAL SOCIAL SECURITY FUND}

The NSSF, which was set up in the second half of 2000 , was only widely publicised by the Chinese Government in 2001. It was set up to act as a stable, medium to long-term reserve fund, with its main objective to ensure the future sustainability of China's social security system, particularly in relation to the provision of pensions. It is in this context that the Chinese Government hopes that the NSSF will remain untouched for at least 20 years, in order to enable it to accumulate sufficient funds to cover any future shortfalls in social security funding. Many commentators, such as Leckie (2002) and DiBiasio (2002b:28), have noted that the NSSF's role is that of a 'fund of last resort'. As such, the NSSF is expected to reduce the need for budgetary top-ups of the future pension shortfalls of Provincial Governments, particularly as the impact of China's ageing population becomes more severe. Such a view assumes 
that the NSSF is a large fund pool, which will be paid out as required. This chapter assumes that the NSSF is, in fact, a large fund pool that will be used to cover future pension shortfalls as a last resort.

While there is, generally speaking, broad consensus with regard to the role of the National Social Security Fund, other commentators, such as Ogborn, ${ }^{1}$ suggest that the NSSF consists of a multitude of individual accounts. This view is incorrect. The costs associated with managing a range of individual accounts, and keeping them separate from one another to ensure their integrity, would make it too costly for most fund managers to want to be actively involved in the management of such funds. In this way, a structure based around a set of individual accounts would not be attractive to most fund managers, and would defeat the purpose of the Chinese Government in using the NSSF to encourage institutional investors in that country.

In its role as a large fund pool, the NSSF is considered by the Chinese Government to be a kind of Trust Fund.

\section{Management and structure of the National Social Security Fund}

In the context of funds management, the NSSF Council, which reports directly to the State Council, acts as a Board of Trustees. It is the main decision making body, and is made up of representatives from Government, business and academia. Among its members, all of which are appointed by the State Council, are Xiang Huaicheng, the former Minister for Finance and who was recently appointed President of the Council, Gao Xiqing, former Vice Chairman of the China Securities Regulatory Commission and who was recently appointed as the Vice President of the Council, and Liu Yongfu, Vice-Minister for Labour and Social Security, and Feng Jianshen, mentioned below, who are Councillors.

Although the Chinese Government views the NSSF as a Trust Fund, it is doubtful whether this is justified at this time. Generally speaking, Trust Funds are clearly defined and bound by relevant legislation and must specify details regarding sources of funding, how the funds will be invested, and how payments will be made. Information regarding the operation of the National Social Security Fund is available regarding the first two criteria. However, there is a general lack of information available for the last criterion. To date, there has been no clear indication from the Chinese Government of how payments from the NSSF will be made available to provincial governments. 
With regard to its function as a Board of Trustees, the Council of the Chinese National Social Security Fund has appointed a number of custodians and funds management companies to manage part of the NSSF's assets. Of particular relevance to this chapter, the Council has appointed two custodians to oversee the activities of the six funds management companies, which act as investment managers. Those organisations are the Bank of Communications (Jiaotong Yinhang) and the Bank of China (Zhongguo Yinhang). The six funds management companies selected by the Council were Boshi Fund Management, Penghua Fund Management, Nanfang Fund Management, Changsheng Fund Management, Jiashi Fund Management and Huaxia Fund Management.

Under the Council of the NSSF, there is a Secretariat, which is responsible for the day-to-day administration of the Council. It consists of the Administrative Affairs Section, the Finance and Accounting Section, the Investment Management Section, the Stock Management Section, and the Legal and Supervision Section.

In addition to the Secretariat, there are a number of committees directly under the control of the Council of the NSSF. Those committees are the Investment Committee, the Risk Management Committee, and the Specialist Evaluation Committee.

The Chinese Ministries of Finance, and Labour and Social Security, also have a role in the supervision of the NSSF, though that role is still unclear.

The Council of the National Social Security Fund has sought the assistance of consultants to provide advice and training in the areas of asset allocation and risk management. With regard to the role of those consultants, it should be noted that, at present, they do not perform the role of a consultant in the traditional funds management context. The NSSF's consultants do not provide advice directly to the Council of the NSSF regarding the allocation of the fund's assets and which funds management company should be employed to invest the funds, as is their traditional role. At the moment, the NSSF's consultants are largely involved with training staff in funds management principles and techniques, and in a wide range of risk management procedures. The role of consultants in the future remains unclear, though it is possible that they will be able to provide direct advice to the Council of the NSSF. In this way, there is scope for foreign fund managers that specialise in this function to play an active role in developing China's fledgling funds management industry, and in reforming China's social security system. While there are a number of consultants working with the NSSF at present, the three major ones are Principal Insurance, Northern Trust Investor Services and Caisse des Dépots et Placements du Quebec. ${ }^{2}$ 
It is clear that the fund managers report both to the custodians and to the Council (Figure 19.1). The custodians hold title to the assets of the fund managers, and may report to the Council, represented in Figure 19.1 by a dotted arrow. Consultants work with the Council of the NSSF and report to it, as do the Secretariat and its Committees. The diagram makes it clear that the Council of the NSSF itself reports to the State Council. The ministries of Finance and Labour and Social Security only have a supervisory function.

\section{FUNDING OF THE NATIONAL SOCIAL SECURITY FUND}

Although the NSSF, in theory, receives funding from the welfare lottery and the proceeds from the sell off of State shares, its major source of funding is the budgetary finances of the Central Government. The Ministry of Finance provides an undefined amount of money each year, in the form of a special block transfer, to top up the National Social Security Fund, thus ensuring that it 'maintains and increases its value'. The amount of funds provided by the Ministry of Finance is variable, and

Figure 19.1 Reporting structure of the National Social Security Fund

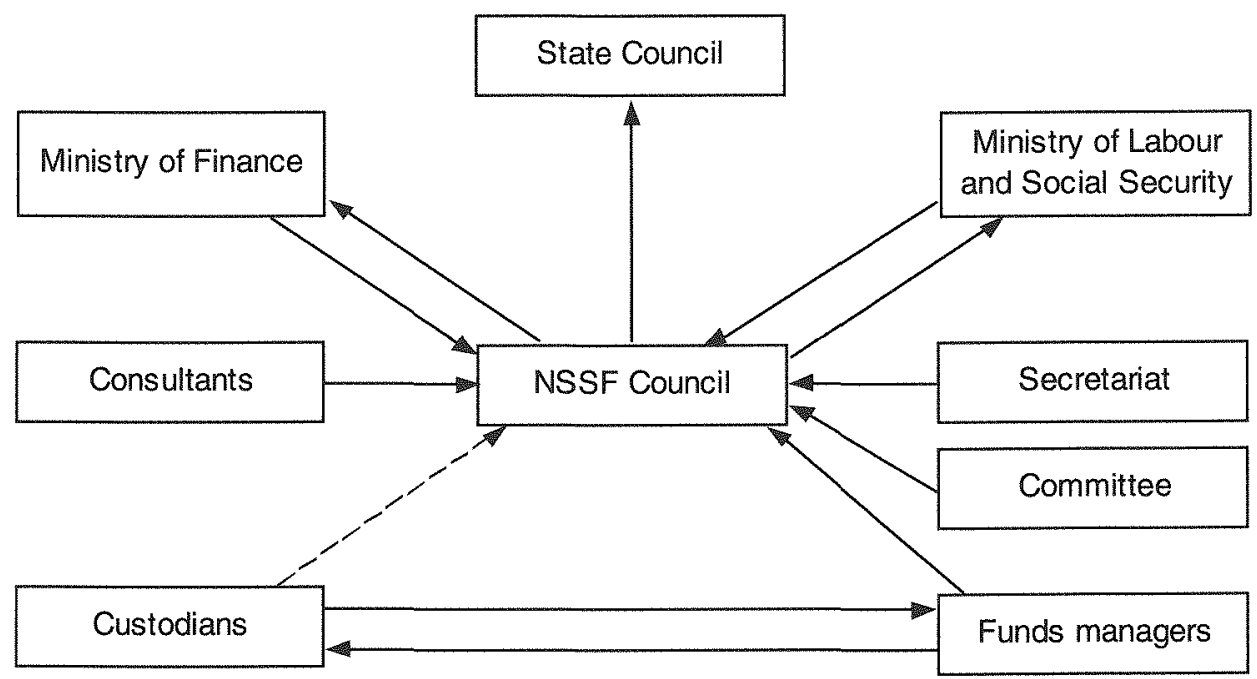


depends largely upon the financial situation regarding the revenues and expenditures of the Central Government's finances towards the end of each financial year.

Although the NSSF currently receives funds from the sell off of State shares, this amount of funding is very limited. The sell off of such shares was halted indefinitely because individual investors in China's stockmarkets feared a flood of shares, which caused them to drop sharply in value. However, State shares still account for some of the funding of the NSSF. An amount equivalent to 10 per cent of the Initial Public Offering or rights issues on those state-owned enterprises that list on overseas stockmarkets must be paid to the NSSF. There has also been speculation that the Chinese Government is considering another sell off of State shares. DiBiasio (2002b:28) comments that it is possible that the Chinese Government will transfer direct ownership of blocks of State shares to the NSSF, which would then sell them off. In this way, the NSSF could bundle them together and sell them off to strategic investors in much the same way as the Tracker Fund in Hong Kong when the Hong Kong government intervened in the stock market after the East Asian financial crisis.

The return on investment is also an important part of the NSSF's funding. Last year, the NSSF achieved a rate of return of 2.75 per cent, up from 2.25 per cent in 2001 (China Labour Net 2003). Although not clearly stated, these are not real rates of return. The rates of return to date indicate that the NSSF is beating price inflation but not salary inflation. At the end of 2002, the funds of the NSSF were invested as follows:

- bank deposits: RMB 93.9 billion, comprising 75.6 per cent of the fund's value;

- bonds: RMB 27.4 billion, comprising 22.1 per cent of the fund's value;

- other equities, including corporate bonds and stocks: RMB 1.05 billion, comprising 1.5 per cent of the fund's value (Xiao 2003).

The value of the National Social Security Fund at the end of 2002 was approximately RMB 124.2 billion (A\$24.84 billion), of which the Ministry of Finance provided RMB 59.526 billion ( $A 11.9$ billion) in the 2001 fiscal year, and RMB 41.6 billion ( $A \$ 8.32$ billion) in 2002 (China Labour Net 2003).

\section{RECENT DEVELOPMENTS}

Following the establishment of the National Social Security Fund in late 2000, it took a long time for the Council to formulate a plan on how the fund would operate. In an important development, Feng Jianshen, one of the councillors of the NSSF, commented at the $35^{\text {th }}$ Asian Development Bank Meeting, held in Shanghai in May 
2002, that the operation of the NSSF had been settled upon. The Chinese Government decided that social security funds in the NSSF would be invested in a more diverse way. From his comments, it is understood that 50 per cent of the funds will remain in Government bonds and bank deposits, which currently remain the only form of approved investments for social security funds, 10 per cent will be invested in enterprise bonds, and the remaining 40 per cent will be able to be invested in stocks, equities and securities ( $X u$ and Chen 2002).

The Chinese Government expects that such a break up of investment streams will provide a higher return for the investment of assets in the NSSF. While this 40 per cent is a positive move, and will help to develop China's fledgling securities and capital markets, it is not clear whether those funds will be able to be invested in overseas markets, especially since the Chinese currency is not convertible. It is also clear from the funding split that the Government appears to favour the use of bonds as an investment mechanism to raise more social security funds, although it could also be said that the Chinese Government is diversifying the scope of the NSSF and is trying to contain risk in the most effective way possible.

Figure 19.2 Funding of the National Social Security Fund

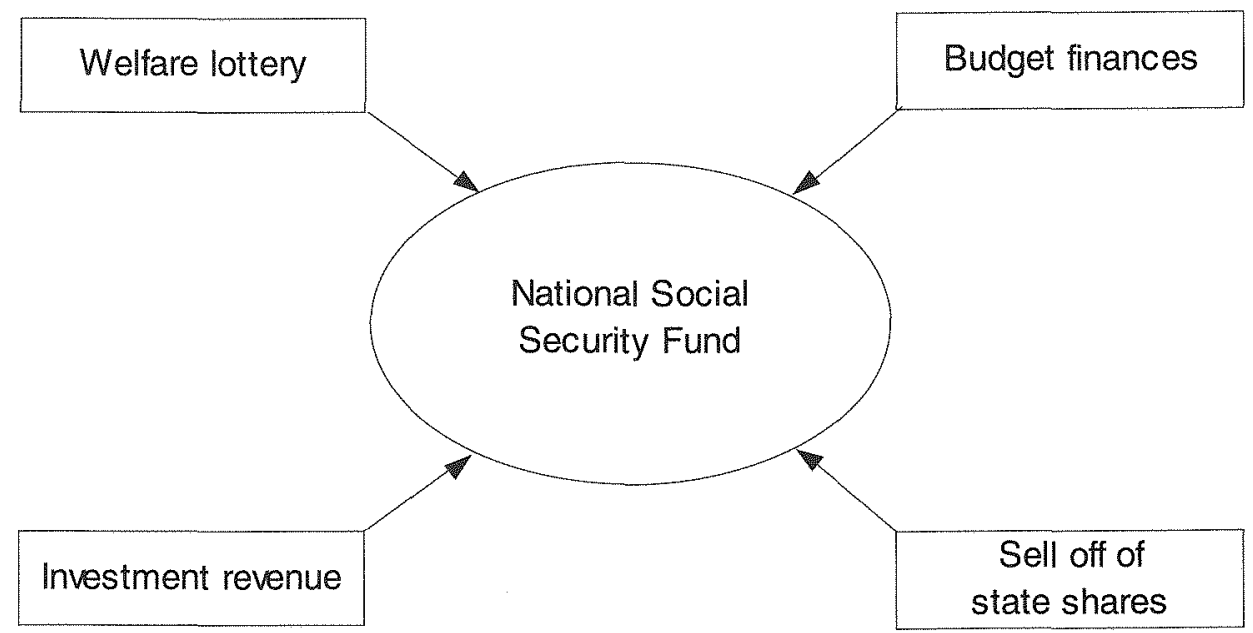


In the current environment, the NSSF's reliance on bonds as the major form of investment appears to be a prudent move, especially since bonds have generally been quite stable in their performance in recent times. However, with the current upturn in stockmarkets all over the world, apart from China, it is increasingly likely that the returns on investments of NSSF assets will become more important over time. Moreover, it is clear that, by diversifying the NSSF's investments in this way, the Chinese Government is looking to the future, and is genuinely making an effort to try to maintain and increase the fund's value.

In July 2001, the NSSF was given permission to invest RMB 300 million ( $A \$ 60$ million) in Sinopec shares on the A-based Share market. The current value of those shares is approximately RMB 900 million ( $\$ \$ 180$ million). Although this move was viewed as a pilot program, the Chinese Government also wanted the NSSF to become a strategic investor in Sinopec. While highlighting the emphasis that the Chinese Government places on developing institutional investors in China's emerging stockmarkets, this investment represented only a small portion of the value of China's stockmarkets, and reflects the insubstantial involvement of institutional investors in those markets at present. At 31 December 2002, the value of all shares in China was valued at approximately US $\$ 500$ billion, while those shares floated on the stock market represent a total value of approximately US $\$ 150$ billion (Leckie 2001). Institutional investment in China's stockmarkets comprises 10 per cent of the market, with fund investments making up 1.7 per cent of the market (Leckie 2001).

The move to encourage institutional investors is widely regarded as a positive one, although it is acknowledged that it will take some time before institutional investors become a dominant force in the stock market, as they have done in many developed economies, such as those of the United States of America and Australia. The involvement of the NSSF in China's stockmarkets, coupled with the recently approved Qualified Foreign Institutional Investor (QFII) scheme, means that the number of institutional investors in China's stockmarkets could increase considerably over the coming years. The QFIl scheme is also an integral part of the Chinese Government's efforts to encourage institutional investment in that country's stockmarkets, though the scheme has been slow on the uptake. Its primary objective is to allow foreign companies to trade in the A-based share market. While the QFII scheme is expected to be successful, there has been some scepticism in the 
scheme because the money is tied up for a period of two to three years, the governance of stockmarkets, particularly in the area of transparency, needs to be improved, and there is a shortage of quality stocks.

In the light of its role as a primary means of encouraging institutional investment in China, there is general consensus that the National Social Security Fund could become one of the largest institutional investors in that country, and, indeed, in the Asian region. Some commentators, such as DiBiasio (2002b:28) have noted that it could become a very significant and influential institutional investor in Asia, with the exception of those investors found in Japan.

In the second half of 2002, the Council of the NSSF invited tenders to manage part of its funds. The tender was open to any company that met the qualifying conditions (See Box 19.1) as laid down in the Temporary Methods for the Investment and Management of the National Social Security Fund, which were issued jointly by the Ministries of Finance and Labour and Social Security. ${ }^{3}$

The tender process clearly favoured domestic Chinese funds management companies, ${ }^{4}$ and excluded the possibility of joint ventures or foreign companies being able to manage NSSF funds because none of them had a two-year track record. It is also important to bear in mind that this tender determined the first group of companies eligible to manage social security funds. It is reasonable to expect that more opportunities to manage these funds will arise in the future, and the

\section{Box 19.1 Qualifying conditions to manage funds in the NSSF}

The qualifying conditions to manage funds in the NSSF are as follows

- Be registered in China or be an investment management organisation of the kind stipulated by the State Council;

- Have a licence from the China Securities Regulatory Commission as a funds management company;

- Possess real capital of not less that RMB 50 million, and, at any time, have not less than RMB 50 million in net assets;

- Have had a representative office in China for more than two years, and possess more than two years experience in securities and investment management in China;

- Be cautious in the management of funds, have a high reputation, and possess a standard international operational structure;

- Have no evidence of illegal behaviour in the last three years;

- Possess a perfected corporate governance structure;

- Have enough competent staff specialised in funds management; and

- Possess a comprehensive and effective internal risk management system, including an independent regulation section. 
Chinese Government has indicated that this will happen (Yang 2003). In the future, it may be possible for foreign funds management companies to have the opportunity to manage NSSF assets, particularly if they exploit the opportunities created by China's recent accession to the World Trade Organization (WTO). However, this will take time. Under the accession rules, foreign funds management companies can own up to 33 per cent of a funds management company immediately, and 49 per cent of the company three years after China's accession to WTO. Moreover, foreign and joint venture funds management companies also will be able to manage pension funds. At present, there are already a number of joint venture funds management companies in China, although it is unclear whether they are currently licensed to manage funds in that country. ${ }^{5}$

The six fund management companies selected to manage part of the NSSF's assets were given formal approval to invest a portion of those funds on the stock market. Before commencing operations, they were required to sign an agreement with the NSSF.

When appointing the funds managers, the Council of the NSSF also discussed the rates of return that it hopes to achieve if the funds managers wish to keep their mandates. Those target rates of return are quite ambitious. They must be at least three percentage points higher than the rate of price inflation, and 120 per cent of the yearly interest rate for a term deposit in a bank (Yang 2003). To clarify the point, it should be noted that these target retums are by no means definite at this stage and are still the subject of much discussion by the Council of the NSSF. If those targets are being considered seriously by the Chinese Government, then it is likely to provide enough of an incentive for the funds managers. It may lead the fund managers to seek positive absolute rates of return for the monies under their control.

In total, RMB 28 billion ( $\mathrm{A} \$ 5.6$ billion) was made available to the fund management companies. Nanfang Fund Management, Boshi Fund Management and Huaxia Fund Management companies each received RMB 6-7 billion (A\$1.2-1.4 billion), while Changsheng Fund Management, Penghua Fund Management and Jiashi Fund Management companies received RMB 3 billion ( $A \$ 600$ million) each to invest. The funds available to each of these funds management companies can only be invested in stocks and bonds (Yang 2003; Xiao 2003). The total amount of funds to be invested will enter the stockmarkets gradually. This is being done, in part, to avoid any perception by individual investors that there is a flood of money going into China's stockmarkets, which could cause prices to rise. It should be recognised that there 
are no guarantees that the entry of the NSSF will boost the value of the stockmarkets. In a recent article, the China Daily (2003) commented that the entry of the fund could not sustain buying momentum on 13 June 2003, and that it is expected to provide a boost in the medium to long term only. Approximately half of the RMB 28 billion ( $\mathrm{A} \$ 5.6$ billion) will enter the stock market within a short space of time and it is understood that RMB 4 billion ( $A \$ 800$ million) will be invested within three months from June 2003 (Xin 2003).

Given the importance of the NSSF for the Chinese Government, there were also a number of restrictions placed upon the funds managers with regard to the investment of NSSF assets. In particular, investment funds managed by funds management companies in China's stockmarkets should not rise above 80 per cent, and investment in bonds must not exceed 20 per cent. The total administrative costs of the six funds management companies must not exceed 10 per cent of the value of assets in the National Social Security Fund, and funds managers cannot hold more than five per cent of a listed company's shares. Such restrictions on the investment of NSSF assets indicate the sensitive nature of the fund, and the Chinese Government's desire for its assets to be invested in a safe and reliable way, while still maintaining and increasing its value. In recent times, there has been discussion within the Chinese Government surrounding the possibility of a Qualified Domestic Institutional Investor (QDII) scheme, which is likely to be an even more sensitive issue than the QFIl scheme, as investments under the QDII scheme are capital outflows. There may be scope for the NSSF to participate in the QDII scheme, but it remains unclear whether it would be allowed to do so.

\section{CONCLUSION}

The chapter has provided a description of the management, funding and operation of China's National Social Security Fund, and the most recent developments in that regard. Its establishment indicates that the Chinese Government is looking to the future, and that it is making an effort to solve China's future pension problems. The most recent developments regarding the NSSF, particularly that of allowing it to hire fund managers to invest in the stockmarket, also suggest that there is a conscious effort on the part of the Chinese Government to maintain and increase its value. In addition, the chapter has demonstrated that it is an important vehicle for the development of the funds management industry in China, and for encouraging institutional investors in that country's stockmarkets. It is also clear that the NSSF 
will assist the Chinese Government in meeting its future pension liabilities. In this context, it is highly likely that the Chinese Government will proceed with great caution to ensure and maintain the integrity of its National Social Security Fund.

\section{ACKNOWLEDGMENTS}

The author wishes to acknowledge the comments of Stuart Leckie, Chairman of the Hong Kong Retirement Schemes Association, for his invaluable comments on a previous version of this chapter. In addition, the author wishes to thank Leon Trainor, Director, Capacity Building, International Branch, and Annabelle Cassells, Assistant Director, Capacity Building, International Branch, Department of Family and Community Services for their support and encouragement.

\section{NOTES}

1 Dr Ogborn, a former employee of the Australian Department of Family and Community Services, was involved in a World Bank funded social security reform project between 1999 and 2002 . His comments were sourced from information obtained by comments he provided on a previous paper by the author.

2 Principal Insurance, a US based company, is training NSSF staff in funds management, and is keen to keep that relationship going after its contract expires, though it is unclear what form that relationship would take (DiBiasio 2002a). Northern Trust Investor Services is providing assistance to the NSSF with regard to its risk management systems, including asset allocation, investment management monitoring, performance reporting (Northern Trust Corporation, 2003). Caisse des Dépots et Placements du Quebec is assisting the NSSF in relation to investment management (DiBiasio 2002b:28).

3 My translation

4 At that time, only ten domestic Chinese companies were in a position to manage NSSF funds. Those companies were: Nanfang Fund Management, Guotai Fund Management, Penghua Fund Management, Fuguo Fund Management, Jiashi Fund Management, Hua'an Fund Management, Boshi Fund Management, Changsheng Fund Management, Dacheng Fund Management and Huaxia Fund Management.

5 At least three foreign funds management companies have set up joint venture funds management companies with Chinese companies, and could, potentially, manage NSSF funds in the future. Those companies are Allianz AG from Germany with Guotai Jun'an Securities, SG Asset Management from France with the Huabao Trust and Investment Company, and ING with China Merchant Securities. 
Joint venture funds management companies in China requires two licences. The first licence gives permission to set up a joint venture funds management company, while the second allows the company to launch funds. As such, approval to set up a joint venture has been given, but it remains unclear whether they have been granted the other license necessary to manage funds (Information obtained from the author's discussion with Stuart Leckie, Chairman of the Hong Kong Retirement Schemes Association).

Of relevance to Australia, Colonial First State, the funds management arm of the Commonwealth Bank of Australia, is awaiting the China Securities Regulatory Commission's approval to participate in a joint venture funds management company with Hantong Securities from Shenzhen (DiBiasio 2003b; Korporaal 2003).

\section{REFERENCES}

China Daily, 2003. 'Entry of welfare fund fails to push up stocks', China Daily, 13 June 2003. Available online at http://www1.chinadaily.com.cn/news/cb/2003-0613/119094.html [Accessed 16 June 2003].

China Fortune Securities, 2003. 'Quanguo Shehui Baozhang Jijin Niandu Baogao (2002 Niandu)', China Fortune Securities Website, 2 June 2003. Available online at http://www.cfs.com.cn/zfzq/content/html/20030602/content002004008 _. 1000652276.html [Accessed 16 July 2003].

China Labour Net, 2003. 'Shebao Jijin Qunian Shouyilu 2.75\%', China Labour Net Website, 2 June 2003. Available online at http://www.labournet.com.cn/ldnews/ fileview.asp?fileno=7201 [Accessed: 3 June 2003].

DiBiasio, J., 2002a. 'China Fund hires principal for training', Finance Asia Magazine, 12 April 2002. Available online http://www.financeasia.com/articles/E7B276544207-11D6-81DE0090277E174B.cfm [Accessed 16 July 2003].

- 2002b. 'With a little help from my friends', Pensions Asia, Summer 2002:28.

_- 2003a. 'China Fund outsources first mandates', Finance Asia Magazine , 7 January 2003. Available online at http://www.financeasia.com/articles/F7FE57011F9C-11D7-81F20090277E174B.cfm [Accessed 12 March 2003].

_ 2003b. 'First State applies for China Fund JV', Finance Asia Magazine, 3 June 2003. Available online at http://www.financeasia.com/articles/C6A0BBC68E83-11D7-81FA0090277E174B.cfm [Accessed 3 June 2003].

Korporaal, G., 2003. 'CBA sets China raising', The Courier Mail, 16 June 2003. Available online at http://www.thecouriermail.news.com.au/common/story_page/ $0,5936,6602176 \% 5 E 462,00$. html [Accessed 16 June 2003]. 
Leckie, S., 2001. Pension Funds in China, Presentation at International Pensions Seminar, Brighton, 6-7 June. Available online at http:/www.actuaries.org/ members/en/events/seminars/Brighton/presentations/leckie.pdf [Accessed 16 July 2003].

- 2002. Retirement Benefits in Hong Kong and China, Presentation to Pensions Policy Initiative for Policy Dialogue Workshop, Sydney, 4 March 2002. Available: online at http:/www.pensions-policy.org/papers/sydney/China.pdf [Accessed: 16 July 2003].

Northern Trust Investor Services, 2003. 'Northern Trust News: Northern Trust to Assist China's National Social Security Fund', Northern Trust Investor Services Website, Chicago. Available online at http://www.ntrs.com/aboutus/news/ 030109.html [Accessed: 16 July 2003].

Liaoning Provincial Government, 2002. Social Security Fund Plans For Larger Amount To Enter Stock Market, Liaoning Provincial Government Website, Liaoning. Available online at http://www.In.gov.cn/zwxx/tx02072306.htm [Accessed 25 July 2002].

Sun, Min, 2003. 'QFlls in no rush to enter markel', China Daily, Hong Kong Edition, 15 January 2003.

Tang, Yuankai, 2003. 'Social security fund debuts on market', Beijing Review, 46 (27):30-31

Xiao, K., 2003. 'Shebao Jijin Touzi Gupiao Fudong Wusun 3.63 Yi Yuan: Shei Lai Mai Dan', Xinhua, 3 June 2003. Available online at http://news.xinhuanet.com/fortune/ 2003-06/03/content_901105.htm [Accessed 5 June 2003].

Xin, Zhiming, 2003. 'Pension fund needs time in market', China Daily, 19-20 July.

$X u, X$. and Chen, Y., 2002. 'Zhongguo Shebao Jijin Yunzuo Moshi Jiben Queli' [Operational model of China's social security fund basically determined], Xinhua News Agency Website, 9 May 2002. Available online at http://news.xinhuanet.com/ newscenter/2002-05/09/content_386622.htm [Accessed 10 May 2001].

Yang, D., 2003. 'Shebao Jijin Shouci Rushi Zong'e Yue 140 Yi: Na Xie Pinzhong Cheng Shou Xuan', Xinhua News Agency Website, 3 June 2003. Available online at http://news.xinhuanet.com/fortune/2003-06/03/content_900603.htm [Accessed 4 June 2003]. 


\section{0}

\section{Building modern enterprises: challenges and requirements}

\section{Mei Wen}

The 14th congress of the Chinese Communist Party was held in October 1992. It was here that Deng Xiaoping officially declared that the aim of China's economic reform was to establish a socialist market system, and since then, China's stateowned enterprises (SOEs) have been reformed. With faster development of markets and the rapid growth of collectives and small private businesses, SOEs were further exposed to market competition in 1992 when dual track prices were merged with market prices.

Different SOEs required different approaches to reform. A variety of contracts were introduced to provide incentives for managers to improve enterprise performance. Some small SOEs were leased to private agents. A number of well-performing SOEs were listed in domestic and international stockmarkets. Many loss-making SOEs experienced liquidation or internal restructuring, and more than 7,000 insolvent SOES went bankrupt. Mergers and acquisition of SOEs were also allowed.

Despite SOEs' poorly-defined property rights of, most Chinese economists did not suggest large-scale privatisation in the earlier economic reform period. Instead, concerns about a possible backlash caused the Chinese government to adopt a piecemeal reform approach and pursue GDP growth.

Recent studies analyse the success of this path to economic reform. For example, (Lau, et al. 2000) and Wen (2002a) claim that keeping major SOEs from privatisation may have helped China evade a decline in industrial output during the earlier period 
of economic reform. Tian (2000) shows that an optimal ownership arrangement is dependent on marketisation. Pure private ownership would not have been welfareoptimal in an economy with very low levels of marketisation. Lau et al. (2000) argue that because China's economic reforms were Pareto-improving, backlash forces were minimised. Yet productivity growth among SOEs indicates that the SOE reforms were at least partially effective (Jefferson, et al. 1999 and Jefferson et al. 1996). And the social safety net function of SOEs has been widely recognised.

Clearly, in almost every facet of its economy, contemporary China is vastly different from the China of the 1980s. While at the beginning of the reform, there were few free markets in major cities for trading agricultural products and small industrial commodities, at the beginning of the 21st century, China not only has networked product markets, but also an imperfect financial market, an imperfect labour market, housing markets, future markets, and even e-commerce. By 1996, less than 10 per cent of commodity categories were under government control. Over 90 per cent of retail prices and 80 per cent of agricultural and producer good prices (as a proportion of output value) were determined by the market.

In addition, major industrial players have changed substantially. At the beginning of economic reform, industrial SOEs contributed over 80 per cent of national industrial output value, with individuals (a type of small private enterprise with fewer than eight employees) and collectives contributed the rest (less than 20 per cent). By 2001 , only 46,767 of the 171,256 of industrial enterprises (with a sales-revenue above 5 million yuan) were either state-owned, or the state had controlling shares in them. These 46,767 enterprises produced 44 per cent of the national industrial output value, contributing 52 per cent to national value added of industry. More than two decades after opening up the economy, foreign and overseas Chinese-funded enterprises (above the designed size) rose from zero in 1978 to 31,423 in 2001, contributing 29 per cent and 25 per cent respectively to gross industrial output value and value added by industry. In addition, there were 31,028 collectives and 5,692 shareholding corporations, which produced 11 and 13 per cent of gross industrial output value, and 9 and 16 per cent of value added of industry.

Since China opened its economy to foreign investors and encouraged the development of private enterprise, firms with different ownership types competed in product markets. This has significantly contributed to China's industrial growth (Wen 2002b). However, there were distortions in the market place. First, changing SOEs from administration units to economic entities did not change their objective to 
pursuing profits, due to poorly-defined property rights and institutional constraints. In fact, because of the lack of a sound social security system, overstaffing in SOEs had been a major obstacle to achieving internal efficiency (Dong et al. 2003 and Wen et al. 2002).

Second, although the increasing power of SOE managers of enabled them to make autonomous decisions based on market information, it also enabled them to strip state assets by pursuing short-run benefits, with SOEs competing more aggressively in the market place than otherwise. This led to a low returns on capital in SOEs and further lowered the accumulation of state assets.

Third, state ownership of major banks meant they were unable to lend to firms according to marginal returns to capital. Loan policies favoured SOEs, which became the major holder of banks' bad loans.

Fourth, to attract foreign investment, tax exemptions and tax reduction policies were given to enterprises with foreign investment and overseas Chinese investment. These preferential policies made taxation for foreign and overseas Chinese invested enterprises much lower than their industrial competitors. ${ }^{1}$

The development of domestic private firms in this distorted market place could be very difficult. Since the late 1990s, increasing international competition, large amounts of state assets stripping, relative poor performance of SOEs, and accumulated bad loans in state banks have led to growing governmental concerns about the maintenance of SOEs and about further reforms in the state sector. Because of the interdependency between the reform of SOEs and that of state banks, and the development of other institutions, the government possibly feels pressured towards further reform, despite the difficulties.

\section{KEY ISSUES IN FURTHER REFORM OF SOES AND STATE BANKS}

Evidence of significant differences in technical efficiency between SOEs and other firms can be seen in the survey data of the third national industrial census (Zhang et al. 2001; Wen et al. 2002). China's competitive industries have problems with internal efficiency, as do industrial market economies and other transitional economies (Wen 2002a). Ownership transformation (zhuanzhior gaizhl) of SOEs in one way or another is desirable to improve the technical efficiency of current SOEs, especially in competitive industries. Although the 'keep the large and let the small go' (Zhuada Fangxiao) policy officially initiated SOE privatisation in China, 
diversification of ownership of SOEs has not yet solved inefficiencies in SOEs and the managing of state assets. There is no unified national account of the sales revenues of small and medium-sized SOEs, and very few comparisons of the different mechanisms used for privatising small and medium-sized SOEs, so it is difficult to estimate the net benefits of 'letting the small go'. Concerns about major state assets and mass unemployment made the government reluctant to change SOE ownership structure substantially.

All Chinese citizens are the nominal owners of state assets, and the various levels of government exercise owners' rights on their behalf. But there are now 1.3 billion Chinese citizens, a very small fraction of the nominal owners can exercise their rights. Because of an imperfect legal enforcement system and tax evasion, central and local governments have been forced to use their own state enterprises for fiscal revenue purposes. Therefore, the vested interests of central and local government officials may have become one of the obstacles to effective diversification of ownership in the reform of large SOES.

Central and local governments are clear about the growth objectives of SOEs. But they are also clear about their low profit-assets ratios and competitive inefficiencies. However, governments have a dilemma because of institutional shortcomings. If SOEs in competitive industries are fully privatised no matter what their size, the government may risk revenue decline if the revenue from selling the SOEs and from increasing taxation is smaller than the revenue from lifetime return to state assets and the costs incurred in social security payments to laid-off workers (ceteris paribus). Meanwhile, maintaining large SOEs in competitive industries in spite of continuing poor performance will certainly result in efficiency losses, and is likely to result in slower development of domestic private enterprises and slower growth of domestic industries.

If the legal enforcement system were effective and there were sound assets markets, after privatising large SOEs in competitive industries, the faster industrial growth and stronger domestic industrial sector would generate more taxation income. This, together with the revenue from selling the SOEs, would create a higher fiscal revenue than keeping these enterprises in government hands. Meanwhile, return to domestic capital would be higher, due to the efficiency gain in industrial enterprises, ceteris paribus.

Establishing an efficient legal enforcement system requires new legislation, which demands political reform and would diminish benefits to government officials. It is 
questionable whether government officials have strong incentives to establish an open and fair auction of those SOEs operating at a loss as opportunities for bribery and corruption would be lost. Illegal personal gains from state asset stripping since the 1990s have resulted in large capital losses. According to Gu (2002) and Zhang (2002), China's annual capital flight increased from US $\$ 10$ billion in 1990 to US $\$ 80$ billion in 2000 . The lack of clearly defined property rights in SOEs means that these SOEs are less attractive as a target for domestic capital in the context of open and competitive industries. The longer-term outcome is that SOEs become undercapitalised, and hence must lean on the government to cover investment shortfalls and financial losses. This places a further burden on the government's fiscal situation and indicates that competitive industry is at the cost of loss of faster growth potential for domestic capital, which will result in loss of long-term fiscal revenue.

Because of these problems, central government has adopted measures to improve the performance of SOEs, including the establishment of a State Asset Supervision and Administration Committee (SASAC), changing performance criteria for the central government-owned SOEs to profits and costs, and strengthening the monitoring of SOEs and the general stress of enterprise governance. According to the 'Temporary Provisions of State Assets Monitoring and Management in Enterprises', State Asset Supervision and Administration Committee can have a say on whether the SOE should undergo further reform towards restructuring, merger, bankruptcy, closing down, changing size or issuing company bonds.

This new system might not solve the problem of high agency costs and it could add new costs for the following reasons. First, normal profits and production costs vary from industry to industry. When one large SOE is reported to have performed so poorly that it should be closed down, arguments about its poor performance could arise, especially in industries where there are only one or two large SOEs. Managers of the SOE could argue their firm may perform better with finance for expansion.

Second, due to a less than accurate accounting system, the risk of loss of employment for managers of poorly-performing SOEs could lead them to expend more effort on manipulating the accounts and lowering product quality. While the regionalism and short sighted-behaviour of some managers of SOEs has caused a lot of redundant investment and excess production capacity in the 1990s, changing the performance criteria of SOEs could result in further short-sighted behaviour by managers. 
Third, like many large SOE managers, SASAC personnel are not the genuine owners of state assets. They are also nominal owners and are appointed by government officials to exercise owners' rights. So there is no guarantee that the SASAC will behave differently from former government officials in charge of large SOEs, especially when final decisions about the fate of a large SOEs is still in the government's hands. If the SASAC were able to help SOEs improve internal efficiency by matching performance with profits and costs, former government offices in charge of large SOEs should be able to do the same.

Fourth, under SASAC monitoring, the selection of managers, one of the most important enterprise governance measures, will not substantially change. It is well known that the selection of most SOEs managers in China was not based on individual business acumen and management capability. If government officials have been reluctant to sack incapable managers because of low profits and high costs, excuses can be found in the large labour force and heavy social burden carried by the SOE.

Fifth, SASAC is already a considerable size, with 20 bureaus as well as the general office. Although former direct government intervention in SOEs apparently became indirect after SASAC was established, increased intervention costs would not necessarily reduce government intervention if these costs were not a concern for government officials. While SASAC might help to collect data on existing state assets, the establishment of SASAC itself will not guarantee an efficiency gain for the state sector. Instead, expectations of SASAC to improve the SOE internal inefficiencies will depend on how SASAC can facilitate diversification of ownership of SOEs, and whether more efficient ownership transformation mechanisms can be adopted for these enterprises.

According to Chen (2003), there are currently about 9,000 SOEs under state government surveillance. The assets of 196 of these are now directly monitored by SASAC. Except for these 196 large SOEs, further reform of the remaining SOEs may involve ownership diversification in one way or another in coming years. Although strong industrial competition, fast development of the non-state sector and high economic growth rates have made issues in the state sector less crucial, many scholars regard reform of SOEs over the past ten years as unsatisfactory. Had the reform of SOEs been more efficient, China's economy may have grown even faster. Institutional shortcomings and the failed efficiency gains to mark the policy of 'keep the large and let the small go'. Accurate evaluation of SOEs assets in is a difficult 
and important issue in ownership diversification. The economic value of these assets always changes with their usage. Potential buyers of assets may know the value to them but may not reveal that value in their bids if the auction is not well designed. ${ }^{2}$ More asset markets should be established with well-designed auction mechanisms.

If the current government objectively reviews the results of 'letting the small go' and learns from past experience, further reform of SOEs may yet move towards more efficiency and fairness. Estimates on the book value of total state assets vary greatly. While Zhao (2003) reports that total state assets was over 11.8 trillion yuan at the end of 2002, Chen (2003) reports total assets of SOEs controlled by the state government at about 17.4 trillion yuan. As the nominal owners of state assets are all Chinese citizens, searching for an optimal reform approach of SOEs and a management approach for state assets should not be limited to approaches of increasing the value of these state assets under government control.

Compared with state government managed assets, further privitisation of SOEs may increase opportunities for more efficient enterprises operation, more even income distribution, and faster growth of domestic capital. This would require more appropriate mechanisms for reforming SOEs in different industries and could be an opportunity to reduce state asset stripping through a fair redistribution of assets and clearer identification of property rights among different interest groups. Yet further ownership diversification of the majority of SOEs (in terms of numbers) need not contradict the fact that keeping some SOEs in non-competitive or crucial industries in the governments' hands would be a sensible strategic tool.

State banks form a large proportion of state assets. In addition to current sole state ownership of the People's Bank of China, now working as China's central reserve bank, and four major commercial banks (Bank of China, Industrial and Commercial Bank, Construction Bank and Agricultural Bank), there are other state banks, and many regional commercial and development banks. In the past, state banks had loan policies favouring SOEs because of ideological discrimination against domestic private entities. Severe industrial competition and high agency costs resulted in the majority of SOEs suffering losses in the 1990s. State banks had to lend funds to many of these SOEs because of the problems associated with mass unemployment and hopes for improving the performance of SOES.

Consequently, state banks accumulated US $\$ 400$ billion in bad assets by 1999 and SOEs were the major holders of NPLs in state banks. In the late 1990s, many foreign banks were allowed to open branches in big cities like Shanghai and Beijing. 
By January 2003, 60 foreign banks were allowed to open branches and to conduct foreign currency businesses without any regional location constraints. Fifty-three foreign banks were approved to open renminbi businesses in nine of the most developed Chinese cities including Shanghai and Shenzhen. Because the loan policies of state banks support the reform of SOEs, soft budget constraints and poor performance resulted in a huge amount of NPLs in state banks. According to Woo (2002), after 170 billion yuan of bad assets were transferred from state banks to the four asset management companies (Huarong, the Great Wall, DongFang, and Xinda) in 1999, the ratio of Non-Performing Loans to total outstanding loans of the four biggest state commercial banks was 0.35 at the beginning of 2002 . This ratio indicates a poor performance of state banks relative to many Western banks, creating concerns for the domestic banking sector with drastic increases in international competition and growing appeal of developing domestic private banks.

The trend for ambitious foreign entries with abundant banking experiences in market economies means that further reform of state banks is both urgent and inevitable for their own survival and for the future of the domestic banking sector. More competition is one way to improve efficiency in the banking sector. As renmimbi businesses have now opened to foreign banks, pending rigorous competition will force state banks into better management structures and lending behaviour to survive. This cannot, however, remove the high principal-agency problem in state banks, or guarantee the fastest increase in the value of the state assets in these banks.

In 2003, foreign investment banks such as Gaosheng and Morgan Stanley were permitted to purchase bad assets from major state commercial banks when the state banks were trying to reduce NPL ratios. Nevertheless, as long as the vicious circle of SOEs and state banks cannot be broken, new NPL will accumulate and state banks will have more bad assets. In fact, rapid changes in market structure in China's banking sector has forced the People's Bank of China to consider exit mechanisms for insolvent banks. Three banking laws ${ }^{3}$ were recently passed. However, if the state banks can move towards ownership diversification (through listing in the stockmarkets within the next few years) and break the ownership link between them and SOES along with the establishment of better governance structure, the efficient reforms of these banks may allow them to gain a first-mover advantage. Recently, domestic private entities and foreign investors have been invited to participate in the ownership diversification of some small and medium-sized regional commercial 
banks. This may significantly increase foreign shares in the banking sector as well as enlarge disparity in income distribution.

In China today, banks incur bad loans due to the lack of effective credit evaluation effective legal enforcement. Although credit evaluation will gradually improve with the increasing collection of information about business and business people, by increasing the number of banks, and having more experienced banks evaluate credit, the system's effectiveness will still be affected by the degree of personal grey and black income in the economy. The forthcoming new provisions in China's constitution for further protection of private property and domestic private businesses could help solve the problem.

Many former SOE workers have been major losers in the reform of SOEs since the 1990s. The hard life of laid-off (Xiagang) and sacked workers has been widely observed (Yin 1998). Lack of social security funds (SSF) and a sound social security system is often regarded as an obstacle to reform. A recent study points out that conditions for maintaining a large proportion of exiting employees in an ex ante SOE often made the buyer ask for discounts on the value of the firm and sometimes even made potential buyers reluctant to purchase the firm. This implies that attaching the labour force to state assets in the sale of SOEs may become an excuse for significant reduction in the value of state assets even though there is no long-term employment guarantee for attached employees.

China is establishing a social security system with economic reform, but current social security is not unified and does not provide the unemployed with enough security. Current unemployment benefits for former SOE employees are from three channels: one third from SOEs, one third from the social insurance system, and one third from the fiscal budget. The unemployment benefit for young unemployed people with little work experience is a minimum payment from the fiscal budget at the poverty line with voluntary work required. Unemployment benefits for young people are available only in some large cities, and not nation wide. ${ }^{4}$ Although there is wide concern about the dramatic increase in the number of laid-off workers from the state sector since 1992, there are few studies focusing on finding the best linkage mechanism for the establishment of a unified social security system with reform of SOES.

This is a topic worthy of many separate studies. Perhaps one approach would be to establish more secondary asset markets and auction state assets openly and 
fairly in the market. Direct transfer to social security funds of part of the revenue from the sales of state assets would be required, plus funds raised from selling state shares of listed SOEs transferred to social security funds, but the employment issue would be separated from ownership transformation in order for the sale of state assets to reach the highest amount. This would raise SSF more rapidly and increase the chance of providing unemployment benefits through a unified social security channel, and different SOEs would have different additional benefits arrangements for their former employees with some regulated cap, depending on the enterprise's financial situation.

\section{INSTITUTIONAL REFORMS FOR FAIRER INCOME AND WEALTH DISTRIBUTION}

The key issues in the further reform of SOEs and state banks are the following

- more efficient operation of existing SOEs and state banks

- sales revenues of state assets

- settlement of sacked workers in a unified social security system

- reduction of opportunity for bribery and state asset stripping

- efficient ownership diversification of some of state banks

- fairer sale of state assets among Chinese citizens for more equal income and wealth distribution both within and across regions.

As the current government has publicly emphasised that it is to serve the Chinese people, and the nominal owner of state assets are all Chinese citizens, an integrated reform package is possible in the coming years. Because SOE and state bank inefficiencies are mainly due to poorly defined property rights and usually accompanied by over-staffing, unemployment may increase in the short term. The development of the non-state sector and fast economic growth will provide more reemployment opportunities. Settlement of former employees of SOEs, state banks, and redundant government officials should be given priority. This would require that part of the revenue raised from further reform of SOEs or state banks ${ }^{5}$ should first be directly transferred to the SSF for covering unemployment benefits.

Only after the required transfer to the SSF had been made could the remaining revenue be kept either by the SASAC for further reinvestment or be partly transferred to the Treasury. Direct transfer to the SSF would help establish a unified social security system, which could provide unemployment benefits to former employees of the state sector, and to unemployed who formerly worked in the non-state sector, 
as well as training programs for re-employment and information services for reemployment. Two important conditions for developing a sound social security system are raising more funds for the SSF and establishing open management of the SSF. ${ }^{6}$ While transparent accounting of the SSF would reduce the risk of mismanagement of the funds, fundraising of the SSF could be closely related to mechanisms used in further reforms. More asset markets and open state asset auctions would clearly help increase revenue from the sale of the assets of SOEs and state banks. These measures would help the government fight corruption reducing discrimination among potential buyers and corruption opportunities through establishing definite objectives for efficient re-allocation of assets.

More small and medium-sized SOEs will be bankrupted, sold directly, or merged (in industries with increasing returns to scale). Ownership diversification of the 196 large SOEs whose assets are currently under the direct administration of the SASAC and ownership diversification of state banks, can proceed in two steps: first, listing those unlisted large SOEs and banks in stockmarkets, and second, reducing state holdings of the shares of these economic entities. As these large enterprises and state banks are major state assets, ownership diversification could provide an excellent opportunity for the government to use market forces to reduce income disparities and improve wealth distribution within and across regions. In many industrial market economies, governments provided equal initial share offerings to their citizens at prices significantly lower than expected market prices, for example, privatisation of the Commonwealth Bank and privatisation of Telstra in Australia. After people begin to trade their shares in the market, an increase in share prices engenders more equal income distribution among citizens. More importantly, this approach fits with prevailing socialist ideology as it provides nominal owners with equal ownership rights of state assets. Citizens become the real owners of large SOEs or state banks and are able to exercise their owners' rights by selling, holding or purchasing shares.

The size of the population would be the basis of objections to this approach. What is stated here is a principle. Actual implementation could be flexible. For example, when we consider diversifying ownership for major state commercial banks, an equal initial share offering of the Bank of China, the Industrial and Commerce Bank, and the Construction Bank could be limited to urban citizens and 49 per cent of total shares (with the state holding the remaining 51 per cent) while an equal initial share offering of the Agricultural Bank could be limited to rural citizens and 70 per cent of 
total shares (with the state holding the remaining 30 per cent). Superficially, this may look like uneven income distribution between urban and rural citizens. But the direct transfer of part of the revenue from the former three banks to the SSF could be made while sales revenue of the Agricultural Bank could be kept by the bank for further investment.

This would bring about appreciation of the shares once they were traded in the market. Together with different initial offering prices of the shares of different banks, it could generate a relatively even income distribution between rural and urban citizens. Interestingly, an asset increase in the Agricultural Bank after partial privatisation could raise more funds for further development of the agricultural sector in the short term. An equal initial share offering of regional state banks could be limited to regional urban and rural citizens. As locations of the 196 large SOEs are geographically uneven, an initial share offering could vary according to the net assets of the enterprises. If net assets are large, the approach used for banks could be adopted. Otherwise, the first-come-first-served principle could be used, with initial offering prices being at a level very close to estimated market prices. It is worth pointing out that while the state could control the speed of ownership diversification through its holding of the shares, this approach does not exclude foreign ownership of state-controlling banks or enterprises. Foreign purchases of shares of these enterprises and banks could be allowed after market trading commences but some different aggregate caps on foreign ownership could be set for different banks and each of the 196 different enterprises. Currently, there are calls for renminbi appreciation. The timing of ownership diversification of state banks and SOEs, the speed of their ownership diversification, and the timing of renminbi appreciation all have strong implications for future domestic wealth.

Like the management of the SSF, open or semi-open management of SASAC would be the most efficient way to battle corruption and state asset stripping. SASAC could hold central records on sales of state assets for each of the major state banks and each of the 196 enterprises, with all details of sales revenues and transfers. These records would facilitate state monitoring and surveillance. Meanwhile, the SASAC should provide public monthly reports on aggregate sales revenue of state assets and major sales. In addition, a public monitoring and reporting system of further reforms could be created so that people would be encouraged to observe monthly reports and reforms closely. With open management of SSF, and open 
accounting of SASAC, together with strong regulation of both SSF and SASAC, public monitoring and enhanced legal enforcement would better protect state assets and would significantly reduce the chances for corruption.

Effectiveness of further reforms of SOEs and state banks will be interdependent as SOEs budgets cannot be hardened with state ownership of major banks. Poor performance of SOEs has been generating huge NPLs for state banks. In further reforms, especially in the ownership diversification of state banks and large SOEs through stockmarkets, government restraint from intervention in the business decisions of these economic entities is important for their ex post efficiency. The establishment of SASAC and semi-open accounting of SASAC would increase the cost of government intervention. The board of directors should be selected according to the 'one share one vote' principle and selection of CEOs should be left to the board of directors for these enterprises and banks to establish a good governance structure. With gradual reduction in state holding shares, more directors will be the genuine owners of the ex post corporations and they will have a stronger incentive to choose CEOs according to their management capability and entrepreneurship.

Development of assets markets is a preliminary condition for the sale of state assets. The sale of state assets, either in whole or in part, can involve different selling mechanisms. The most popular mechanism when the value of a selling item is uncertain is by auction. Auction, a frequently used sale mechanism for achieving high revenue, can achieve efficiency in the allocation of final goods in many circumstances (Dasgupta and Maskin 2000). However, the auction of production capacity in transitional economies has many features that are not considered in the conventional auction literature, which make many usual auction mechanisms inefficient (Wen forthcoming). In transitional economies, either more complicated auction mechanisms need to be designed for achieving efficiency in the presence of an externality, or institutional constraints should be removed for existing auction mechanisms to function effectively. The efficient sale of state assets in China is not a simple issue even theoretically. Expert opinions should be sought in the auction of state assets.

One feasible way would be to employ an expert team (5-10 experts) to choose and design auction mechanisms. The tasks of the expert team would be to review all the major cases of state assets, study appropriate mechanisms, and supervise actual auctions and ownership diversifications. This would not be directly involved in the 
operation of any actual sale. This team could work closely with the SASAC and People's Bank of China in further reforms of SOEs and state banks. Although some funds would be needed to pay their salaries, the efficient auction of the assets of one large SOE or one major state bank would generate enough benefits to justify this. ${ }^{\text {? }}$

The regularity of stockmarkets and their normal operation with less government intervention are important in the whole process. Since the Shenzhen Stock Exchange and Shanghai Stock Exchange were established in 1992, a decade of development of the stockmarket together with legislation of Corporation Lawin 1993 and legislation of Security Law in 1998 have enabled more Chinese enterprises to gain finance through markets. In October 20021,215 corporations listed in domestic stockmarkets and issued $A$ or $B$ shares, and 69 corporations were also listed in foreign stockmarkets, mainly the NYSE. The China Securities Regulatory Commission (CSRC) has been accumulating legislative experience in administration and supervision of company listings, shares issuing, market transactions, for the institutions establishment, funds flowing into the market and future markets.

China's security market is still far from perfect. Unfortunately, because the CSRC is affiliated with the government, it is not able to make impartial judgments. A regulation committee like the CSRC should not be associated with any of the players in the market-that is, it should be independent. But its affiliation with a major market player, the government, means that it cannot fulfil this requirement. China's stock market may gradually improve with further reforms of the state sector and more consistent regulation of the market. Development of the legal enforcement system is crucial if a benign circle between the further development of China's security market and further reform of SOEs and state banks is to be set up.

Opening up China's economy has provided foreigners with opportunities to participate actively in China's economic development. It has also brought China many chances to learn from market economies about advanced technologies and institutions. Since the early 1990s, China has paid great attention to developing its legal system and has legislated a large number of economic and institutional laws. Economic laws in China are similar to economic laws in advanced market economies. However, when an investor gets into trouble in China and has to endure lawsuits, dissatisfaction may arise with legal enforcement, especially for ordinary Chinese, who have little social power or international influence. Lack of rule-of-law is the main reason for corruption. While strengthening legal enforcement is essential for efficiency gains in further reform of the state sector, reforms should also provide opportunities 
to reduce corruption and hence remove some obstacles to the development of legal enforcement.

Vested interest groups (especially government officials) must be treated appropriately. Together with strengthening legal enforcement and reducing opportunities for corruption, an increase in the salary of public servants is necessary, along with gradual changes in local and state government functions in this process of further reforms of SOEs and state banks.

\section{CONCLUDING REMARKS}

China's accession to the WTO and the rapid increase in international competition in its secondary and tertiary industries have made the further reforms of SOEs and state banks crucial and urgent. The effectiveness of further reform of the SOEs and further reform of state banks is interdependent. Appropriate ownership transformation is the most important issue. Efficiency of these reforms requires many other institutional developments, including that of asset markets, a sound social security system, an insurance industry and other service intermediaries, further development of a security market, and reinforcement of legal enforcement. These institutional developments are just part of the whole process of improving China's market, which will further promote economic growth through gains in efficiency and from a more competitive allocation of resources.

As China's income disparity is of great concern, partial privatisation of large SOEs and state banks with a more even income distribution is both socially desirable and ideologically justifiable. While further reforms and institutional developments provide the government with an opportunity to reduce corruption significantly, efficient reforms and institutional development can be part of the fight against illegal economic conduct. If China can be successful in these state-sector reforms and institutional development it will attract more investments because of its rapid increase in per capita GDP, but also by significant improvements in living standards.

\section{NOTES}

1 For example, in 2001, the ratio of the sum of sales tax and extra changes and value added tax to total profit of SOEs and enterprises with the state having controlling shares was about 2.24 times that of foreign funded enterprises, and 2.11 times that of overseas Chinese (from Hong Kong, Taiwan and Macau) funded enterprises. The ratio of value added tax of SOEs and enterprises with the state having controlling shares was about 1.71 times of foreign funded enterprises, and 
1.58 times of overseas Chinese (from Hong Kong, Taiwan and Macau) funded enterprises. The laxation rate of domestic collectives was somewhere between that of the state sector and foreignfunded sector.

2 See Tan (2002) for a survey on Auction Theory and Wen (forthcoming) for comparisons among different SOE reform approaches in an industrial study.

3 They are Revision of the Law of People's Bank of China, Revision of the Law of Commercial Banks and Supervision and Administration Law of Banking Sector.

4 See www.moiss.gov.cn for details of the development of China's social security system.

5 Such as revenue of the assets sale of insolvent SOEs, part of revenue raised from selling small and medium SOEs, and part of the funds raised from ownership diversification of state banks and large SOEs through stock market

6 Development of a sound social security system, development of insurance industry and fast development of the non-state sector can significantly remove worries about further unemployment in further reforms of SOEs and state banks.

7 In a survey conducted by SETC and IFC in 2002, among the 311 firms experienced ownership transformation (gaizhi) in one way or another, auction mechanism is used only for 27 firms.

\section{REFERENCES}

Chen, L, 2003. Perfecting the Counter-Corruption Mechanism in the Administration and Supervision of State Assets', Chinanew.com. Available online at www. Chinanew.com [Accessed 4 August 2003].

Dasgupta, P. and Maskin, E.S., 2000. 'Efficient auctions', Quarterly Journal of Economics, 115(2):341-88.

Dong, $X$. and L. Putterman, L., 2003. 'Soft budget constraint, social burdens, and labor redundancy in China's state industry", Journal of Comparative Economics, $31(1): 110-33$.

Garnaut, R. and Song, L., 2002. China 2002: WTO accession and world recession, Asia Pacific Press, Canberra.

Gu, L., 2002. 'Capital flight-China's hidden financial catastrophe', Guoji Shangwu, 7 [in Chinese].

Jefferson, G.H., Singh, I., Xing, J. and Zhang, S., 1999. 'China's industrial performance: a review of recent findings', in G.H. Jefferson and I. Singh (eds), Enterprise Reform in China: ownership, transition, and performance, Oxford University Press, Oxford:127-52. 
Jefferson, G.H., Rawski, T. and Zheng, Y., 1996. 'Chinese industrial productivity: trends, measurement issues and recent developments', Journal of Comparative Economics, 23(2):146-80.

Lau, L.J., Qian, Y. and Roland, G., 2000. 'Reform without losers: an interpretation of China's dual track approach to transition', Journal of Political Economy, 108(1):120-43.

Qian, Y. and Wu, J., 2002. China transition to a market economy: how far across the river, Working Paper of Department of Economics, University of Maryland, College Park.

Tan, G., 2002. 'Auction theory', in G. Tian (ed.), Frontier Development of Modern Economics and Finance, Shangwu Press, Beijing:267-330.

Tian, G., 2000. 'Property Rights and the Nature of Chinese Collective Enterprises', Journal of Comparative Economics, 28(2):247-68.

Wen, M. (forthcoming), 'Bankruptcy, sale, and mergers as a route to the reform of Chinese SOEs', China Economic Review, n.a.

Development of Modern Economics and Finance, Shangwu Press. Beijing:564609.

- 2002b. 'Competition, ownership diversification and industrial growth of China', in R. Garnaut and L. Song (ed.), China 2002: WTO accession and world recession, Asia Pacific Press, Canberra:63-80.

- Li, D. and Lloyd, P., 2002.'Ownership and technical efficiency-a cross-section study on the third industrial census of China', Economic Development and Cultural Changes, 50(3):709-34.

Woo, W.T., 2002. 'Some unorthodox thoughts on China's unorthodox financial sector', China Economic Review, 13(4):388-93.

Yin, X., 1998. 'The macroeconomic effects of waiting workers in the Chinese economy', Journal of Comparative Economics, 26(1):150-64.

Zhang, A., Zhang, Y. and Zhao, R. 2001. 'Impact of ownership and competition on the productivity of Chinese enterprises', Journal of Comparative Economics, 29(2):327-46.

Zhang, X., 2002. 'Analysis of capital flight from China', Journal of Beijing Polytechnic University (Social Sciences Edition), 2(3):47-51.

Zhao, B., 2003. 'Total state assets now over 11 trillion yuan', Jingii Chankao Bao, 5 June.

Zhou, Xiaochuan, 2002. Organisation Structure of China's Capital Market, Beijing. 


\section{1}

\section{Challenges facing small private enterprises}

\section{Kim Houghton and lan Davies}

This chapter reports on the main findings from a survey of entrepreneurship and small private enterprises in Qingdao (Shandong Province) and Harbin (Heilongjiang Province). The survey ${ }^{1}$ consisted of questionnaires distributed to existing small private enterprises (both Getihuand siying-qiye). Additional information (not reported on here) was obtained from unemployed and laid-off workers (xiagang) on issues relating to establishing and growing a small private enterprise.

The two pilot cities were selected for the following reasons

- Harbin is a large inland capital city with a strong heavy industrial and engineering base and a large-scale state-owned sector which is undergoing major reform and restructuring. The city has a high rate of xiagang unemployment.

- Qingdao is a large coastal city with a busy port, a major development zone, and a focus on trade and service industries. The city has a relatively favourable foreign investment environment, with a much larger non-state sector and lower rates of xiagang and other unemployment.

With China's small private enterprises developing fastest in the coastal regions and central inland regions, the survey findings from these two cities are likely to provide insights to the issues and obstacles facing small private enterprises in wide areas of China. 


\section{POLICY CONTEXT}

\section{Importance of small enterprises in economic reform}

China's economic structure is changing rapidly. Privately owned firms, all but illegal 15 years ago, make up around 30 per cent of the country's economy. In 1997 it was estimated that more than half of Chinese economic activity stemmed from the private or household sector (IFC 2000), and this share could have reached twothirds of economic activity by this year. Small-scale private enterprises (those with fewer than 100 employees) in particular are driving the Chinese restructuring and reform process. The key is employment-with small and medium-sized private enterprises being a policy cornerstone in soaking up unemployment generated by lay-offs in state-owned enterprises (SOEs) and displacement of rural workers. From 1990 to 1999 , employment in private enterprises increased from 1.7 to 20.2 million, an annual growth rate of 31.7 per cent. Over the same period, employment as a whole increased by 1.1 per cent per annum, with employment in SOEs declining by 2.1 per cent per annum.

China's pool of unemployed people continues to grow, as old small and medium SOEs are wound down, restructured, privatised, or merged with foreign investors, and as new school, college and university graduate entrants to the urban labour force peak in 2002-05 at around 8-10 million annually. In October 2002 there were 75.08 million workers employed in SOEs compared with 112 million in 1994-96, with SOE jobs continuing to decrease every year. By the end of 2002, there are reported to have been around 10 million xiagang (or laid-off SOE workers) currently needing new jobs, as well as 7.3 million registered unemployed, and there are over 150 million surplus rural labourers also in need of alternative jobs. ${ }^{2}$ The Chinese Government is beginning to recognise the vital role that the emerging small, private enterprise sector will have in soaking up these jobless workers and new entrants to the labour force and building a new framework for the Chinese economy.

There are also other very important roles for the small to medium enterprise private sector. These include: provision of business service infrastructure required by larger firms - China's traditional mainstay; rapidly expanding and bringing China's services sector into the new millennium; acting as a source of innovation and being an important vehicle for getting new products or services to market; and building a 
broader base for the economy-allowing it to rely less on key enterprises in key industries in particular regions.

\section{Legal structures of private enterprises}

The recent history of economic policy and market reform and its impact on private sector development has been well summarised in the 2000 IFC report, China's Emerging Private Enterprises, and in the companion volume by economists from the Australian National University (Garnaut et al. 2001).

There are two main legal structures for small to medium-sized private enterprises in urban China: individual or household-owned enterprises (Getihu) and small to medium-scale private enterprises (Siying Qiye or limited liability companies). In addition, although numbers are much smaller, there are a variety of other legal structures such as urban collectives and township and village enterprises (most of which have converted or are converting to Siying Qiye), shareholder or public companies listed on the stock market, partnerships, and foreign-invested enterprises (joint equity venture, contractual joint venture and wholly-owned foreign companies).

Getihu are owned and operated by an individual or family and are permitted to hire up to seven people. They operate with total liability but without standard accounting systems, are not required to declare and register Registered Capital, and are subject to a district government-determined income tax based on a certain percentage of estimated revenue in their sector (an average 8 per cent in the cities surveyed).

Siying qiye are limited liability firms with $2-50$ shareholders, can employ more than seven people, and have a variable minimum Registered Capital depending on sector categories. These enterprises operate under 1988 laws, modified in 1994, and are subject to normal Chinese company income tax and a VAT or business tax.

There is also a new legal structure in China for solely-owned private enterprises, with limited liability and minimum registered capital of RMB 1.00, which operate using standard accounting systems, and are subject to company tax. These new enterprises operate under the 1999 Solely-Owned Business Law.

\section{Establishing and developing a small private enterprise}

This survey looks specifically at the small end of the private sector business spectrum in China and the institutional and regulatory challenges facing this sector. One of the compelling reasons for this research was the limited amount of previous research on this end of the market-despite the very large numbers of these enterprises. 
Another reason was the perception in China that very small, new-start enterprises have a significant role as a vehicle for getting the unemployed and xiagang back to work and for employing the great bulk of new entrants to the labour force. This makes this end of the small business sector particularly important in terms of economic and labour policy and social stability.

In China, the perception is that many small enterprises start as Getihucharacterised as a small shop or transport operation run by a husband and wife, or a home-based business. Running your own business is seen as a real option for people who were laid-off from SOEs, or registered as unemployed. Such new-start enterprises often involve the whole family in the early stages, and often use the home as a base of operations as a way of reducing set-up costs. This pathway to employment is important, as China's unemployed and xiagang are typically disadvantaged in the labour market, with low-level qualifications and poor prospects of finding alternative employment.

A compounding positive impact of new business formation, especially new businesses formed by people disadvantaged in the labour market, arises when these new businesses are managed well, and start taking on their own staff. With limited financial backing, these new businesses are generally labour rather than capital intensive, and may well grow to offer employment opportunities for other unemployed and xiagang.

This research focuses on issues facing the starting and developing of small private businesses, as a way of identifying key barriers to start-up and development, and the policy changes and support structures most likely to foster growth.

The number of small private firms in the two survey areas is estimated to be large, and is growing rapidly (Table 21.1).

\section{Survey methodology}

Surveying very small firms is difficult in most countries, and China is no exception. Particular difficulties hinge on access, trust and honesty of feedback. Many newstart business operators are uncomfortable with people they do not know who ask questions about their business, especially when they are 'officials'. They may be uncooperative, or even obtuse in their feedback-saying what they think the interviewer wants to hear.

To reduce these sampling risks, the survey was tested and modified, the survey teams (coordinated by the China Society for Research on Economic Systems Reform 
with help from local SCORES officials) were trained in survey techniques, and particular emphasis was placed on the value of honest responses in helping create a better operating environment for small enterprises.

Two survey modes were used-questionnaires for self-completion, and face-toface interviews. Table 21.2 shows the matrix of responses by business type, survey mode and city. In addition to the business survey responses that are reported here, a sample of unemployed people (of various types) who were planning on starting businesses was also surveyed. The results of those surveys are not covered in this paper.

The businesses surveyed were not selected randomly. Six industry groups were selected for particular attention (information technology, business services, retailing, catering/restaurants, community services, and light manufacturing). Businesses were identified through registers, networks and by their location.

\section{RESPONDENT CHARACTERISTICS}

The survey focused on businesses in six industries (Table 21.3),

- IT (15 per cent of respondents), such as computer software and applications, system support

- business services (16 per cent) such as marketing, legal, accounting and business management and feasibility study advice

- retailing (20 per cent)

- catering/restaurants (15 per cent)

Table 21.1 Siying Qiye and Getihu in Harbin and Qingdao, 2002

\begin{tabular}{|c|c|c|c|c|c|c|c|c|}
\hline \multirow[b]{2}{*}{ Siying Qiye } & \multicolumn{4}{|c|}{ Harbin } & \multicolumn{4}{|c|}{ Qingdao } \\
\hline & Total & $\begin{array}{c}\text { Sole } \\
\text { venture }\end{array}$ & $\begin{array}{l}\text { Partner- } \\
\text { ship }\end{array}$ & $\begin{array}{l}\text { Limited } \\
\text { Liability }\end{array}$ & Total & $\begin{array}{c}\text { Sole } \\
\text { Venture }\end{array}$ & $\begin{array}{c}\text { Partner- } \\
\text { ship }\end{array}$ & $\begin{array}{l}\text { Limited } \\
\text { liability }\end{array}$ \\
\hline & 18,608 & 4,094 & 958 & 13,528 & 32,361 & 4,207 & 6,311 & 21,843 \\
\hline \multirow[t]{2}{*}{ Getihu } & Total & $\begin{array}{c}\text { No. of } \\
\text { employees }\end{array}$ & $\begin{array}{l}\text { Regstrd } \\
\text { capital }^{*}\end{array}$ & $\begin{array}{l}\text { Total } \\
\text { prodn. } \\
\text { value* }\end{array}$ & Total & $\begin{array}{c}\text { No. of } \\
\text { employees }\end{array}$ & $\begin{array}{c}\text { Rgst. } \\
\text { capital* }\end{array}$ & $\begin{array}{l}\text { Total } \\
\text { prodn } \\
\text { value }^{*}\end{array}$ \\
\hline & 205,517 & 406,282 & 422,997 & 280,047 & 166,250 & 236,749 & $27.37 b$ & $1,607,687$ \\
\hline
\end{tabular}

Note: * Unless otherwise noted, the capital unit is 1,000 yuan. 
- community service sector (9 per cent) such as home help, aged care, childcare, deliveries

- light manufacturing (16 per cent) such as clothing, handicrafts and piece work outsourcing.

Two-thirds of the businesses surveyed were under five years old, including 11 per cent less than one year old (Table 21.4). This age profile reflects the rapid growth in the number of Chinese small businesses in recent years. By way of comparison, a similar 14 per cent of small businesses in Australia are under one year old, while a very different 51 per cent are over five years old (Australian Bureau of Statistics 2002). The businesses surveyed in Qingdao were slightly younger than those in Harbin.

The 469 Getihu businesses surveyed employed a total of 1,785 people--an average of just 3.8 people per enterprise. The Siying Qiye businesses were considerably larger, with the 318 businesses surveyed employing a total of 14,872 people-an average of 46.8 people per business.

Table 21.2 Responses by business type and survey mode

\begin{tabular}{lcccccc}
\hline & \multicolumn{3}{c}{ Harbin } & \multicolumn{3}{c}{ Qingdao } \\
Siying Qiye & Questionnaire & Interview & Total & Questionnaire & Interview & Total \\
Getihu & 219 & 28 & 247 & 99 & 24 & 123 \\
Total & 225 & 9 & 234 & 244 & 8 & 252 \\
& 444 & 37 & 481 & 343 & 32 & 375 \\
\hline
\end{tabular}

Source: Small business survey 2002

Table 21.3 Distribution of respondents by industry and legal structure, by city

\begin{tabular}{|c|c|c|c|c|c|c|c|c|c|c|}
\hline & \multicolumn{4}{|c|}{ Harbin } & \multicolumn{4}{|c|}{ Qingdao } & \multicolumn{2}{|c|}{ Total } \\
\hline & \multicolumn{2}{|c|}{ Getihu } & \multicolumn{2}{|c|}{ Siying Qiye } & \multicolumn{2}{|c|}{ Getihu } & \multicolumn{2}{|c|}{ Siying Qiye } & \multirow[b]{2}{*}{ No. } & \multirow[b]{2}{*}{$\%$} \\
\hline & No. & $\%$ & No. & $\%$ & No. & $\%$ & No. & $\%$ & & \\
\hline IT & 48 & 21.3 & 26 & 11.9 & 23 & 9.4 & 21 & 21.2 & 118 & 15.0 \\
\hline Business service & 40 & 17.8 & 27 & 12.3 & 42 & 17.2 & 20 & 20.2 & 129 & 16.4 \\
\hline Retailing & 42 & 18.7 & 24 & 11.0 & 81 & 33.2 & 14 & 14.1 & 161 & 20.5 \\
\hline Catering/restaurant & 19 & 8.4 & 41 & 18.7 & 37 & 15.2 & 21 & 21.2 & 118 & 15.0 \\
\hline Community service & 35 & 15.6 & 10 & 4.6 & 23 & 9.4 & 1 & 1.0 & 69 & 8.8 \\
\hline Light industry/ & & & & & & & & & & \\
\hline processing & 28 & 12.4 & 74 & 33.8 & 14 & 5.7 & 10 & 10.1 & 126 & 16.0 \\
\hline Others & 13 & 5.8 & 17 & 7.8 & 24 & 9.8 & 12 & 12.1 & 66 & 8.4 \\
\hline Total & 225 & 100.0 & 219 & 100.0 & 244 & 100.0 & 99 & 100.0 & 787 & 100.0 \\
\hline
\end{tabular}

Source: Small business survey 2002 
Most of the operators reported that they work long hours-with operators of Getihu businesses working slightly longer than operators of Siying Qiye businesses (Table 21.5). Very few of the businesses surveyed were 'part-time' businesses, with over half the operators surveyed reporting that they work 8 to 12 hours per day. A further 14 per cent reported that they work 12 to 14 hours per day.

Looked at by region, it appears that business operators in faster-growing Qingdao City were working slightly longer hours than their counterparts in Harbin.

Operators were mostly male ( 69 per cent), relatively young ( 57 per cent under 40 years old) and quite well educated (27.9 per cent having university or postgraduate degrees and 37.9 per cent having college qualifications).

On a range of social indicators (car ownership, home ownership and schooling preferences) the small-scale entrepreneurs seemed to be generally reasonably well off, despite their young average age.

Table 21.4 Age of businesses, by city (per cent)

\begin{tabular}{lccc}
\hline & Harbin & Qingdao & Total \\
1 year or less & 12.3 & 9.6 & 11.1 \\
$2-3$ years & 25.2 & 36.3 & 30.0 \\
$3-5$ years & 24.2 & 27.1 & 25.4 \\
$5-10$ years & 25.4 & 19.7 & 23.0 \\
10 years or more & 12.8 & 7.3 & 10.5 \\
& 100.0 & 100.0 & 100.0 \\
\hline
\end{tabular}

Source: Small business survey 2002

Table 21.5 Average hours worked per day, by legal structure (per cent)

\begin{tabular}{lcc}
\hline & Getihu & Siying Qiye \\
Under 6 hours & 2.7 & 4.7 \\
$6-8$ hours & 16.2 & 19.1 \\
$8-12$ hours & 54.1 & 58.3 \\
$12-14$ hours & 17.0 & 12.7 \\
$14-16$ hours & 6.6 & 3.3 \\
Over 16 hours & 3.5 & 1.9 \\
Total & 100.0 & 100.0 \\
\hline
\end{tabular}

Source: Small business survey 2002 


\section{MAIN SURVEY FINDINGS}

The survey was designed to focus on issues relating to establishing and developing a small business in China, particularly as a means to employment for xiagang (laidoff workers). Of the respondent SME operators, 65 per cent used to work for SOEs (that is, are laid-off workers).

The survey findings suggest that, contrary to generally held views, small enterprises (Siying Qiye and Getihu) are generally not home-based businesses, and do not rely heavily on family members as employees. Overall, just under 13 per cent of respondent businesses were based at home, and just under 7 per cent of employees were family members.

One of the biggest issues in setting up a small private enterprise in China is access to start-up capital. A particular impediment is the requirement for lodging proof of Registered Capital for Siying Qiye, whereby new businesses must, as part of their registration process, prove that they have certain minimum amounts of fixed assets and liquid funds available. The amount varies by legal status and industry (for example, from 100,000 yuan for consulting and personal services, to 300,000 yuan for retail businesses and 500,000 yuan for manufacturing and processing), but such registered capital requirement is not needed for Getihu operations. The rationale behind the Registered Capital requirements is not to ensure that new-start businesses have development capital, but rather to ensure that debtors can be paid if the venture bankrupts. Anecdotal evidence suggests that many new-start small entrepreneurs beg and borrow funds from family and friends for just long enough to prove they have the amounts required, then return the borrowed funds.

Problems in raising start-up and Registered Capital are exacerbated by weaknesses in the banking system that make it very difficult for small enterprises to borrow funds, unless they have equivalent funds that can be put up as surety. The survey showed that just 10.5 per cent of respondents used a bank to source their start-up capital (20.6). By far the most important sources were own savings (51.8 per cent), investors (19.8 per cent), and borrowings from friends or family (19.7 per cent).

The high emphasis on own or family finance raises an important question-in the absence of alternatives, is family wealth a prerequisite to starting a business. The amount of start-up capital required for Siying Qiye was often quite large-81 per cent requiring over 50,000 RMB for Registered Capital, including 52.5 per cent requiring over $300,000 \mathrm{RMB}$ (Table 21.7). 
Turnover trends reported by respondents were very positive-which should be expected, given China's high economic growth rate. Perhaps surprisingly, a lower percentage of respondents from Qingdao than Harbin reported increasing turnover over the previous three years, despite Qingdao's recent history of strong economic growth. ${ }^{3}$

The survey asked respondents specifically about barriers they had faced in setting up their business (Table 21.9). The biggest barrier, in both cities, was start-up capital (nominated by a total of 58.4 per cent of respondents). The importance of this issue has also been identified in other surveys (for example, Song 2001 and IFC 2000). The next two barriers related to the difficult bureaucratic environment facing small enterprises in China. Government regulations were nominated as a barrier by 28.8 per cent of respondents. These consisted of (in order of importance): limitations of

Table 21.6 Sources of start-up capital, by city

\begin{tabular}{lcccccc}
\hline & \multicolumn{2}{c}{ Harbin } & \multicolumn{2}{c}{ Qingdao } & \multicolumn{2}{c}{ Total } \\
& Number Per cent & Number & Per cent & Number Per cent \\
Own savings & 236 & 53.2 & 172 & 50.1 & 408 & 51.8 \\
Friends' savings & 41 & 9.2 & 39 & 11.4 & 80 & 10.2 \\
Borrowing from friends & 68 & 15.3 & 87 & 25.4 & 155 & 19.7 \\
Bank & 46 & 10.4 & 37 & 10.8 & 83 & 10.5 \\
Investor & 133 & 30.0 & 23 & 6.7 & 156 & 19.8 \\
Business partner & 69 & 15.5 & 29 & 8.5 & 98 & 12.5 \\
Government grant or loan & 21 & 4.7 & 4 & 1.2 & 25 & 3.2 \\
Others & 6 & 1.4 & 1 & 0.3 & 7 & 0.9 \\
All respondents & 444 & & 343 & & 787 & \\
\hline
\end{tabular}

Note: multiple choices possible.

Source: Small business survey 2002.

Table 21.7 Registered capital, by legal structure, Siying Qiye ('000 yuan)

\begin{tabular}{lcclcc}
\hline '000 yuan & Number & Per cent & '000 yuan & \multicolumn{2}{c}{ Number } \\
Up to 10 & 40 & 8.7 & $201-300$ & 59 & 12.8 \\
$11-30$ & 22 & 4.8 & $301-400$ & 8 & 1.7 \\
$31-50$ & 22 & 4.8 & $401-500$ & 124 & 26.9 \\
$51-100$ & 49 & 10.6 & Over 500 & 110 & 23.9 \\
$101-200$ & 27 & 5.9 & Total & 461 & 100.0 \\
\hline
\end{tabular}

Source: Small business survey 2002. 
city management, complex licencing processes, difficult registration processes, difficulties in providing proof of property and limitations in health, sanitation and environmental services. In addition, 21.1 per cent of respondents nominated government fees and charges as a barrier. These consisted of (in order of importance): high taxation levels, other administrative management fees and charges, and the high level of registered capital required.

The other main types of barriers nominated related to business practices and operational issues, including finding customers ( 17.5 per cent), finding staff (7.1 per cent) and business planning ( 12.1 per cent in total).

The pattern of the barriers nominated was quite similar between the two cities, though there were some interesting differences. Start-up capital seems a bigger issue in inland Harbin (nominated by 66 per cent of respondents) than coastal Qingdao (48.7 per cent). Conversely, Qingdao's vibrant economic environment is probably the major factor behind the lower ranking of customer numbers as a barrier to business growth-nominated by 23.2 per cent of Harbin respondents but by just 10.2 per cent of Qingdao respondents. Similarly, more Harbin respondents had trouble finding skilled staff (9.7 per cent) than Qingdao respondents (3.8 per cent).

Table 21.8 Main barriers in starting up businesses, by city

\begin{tabular}{|c|c|c|c|c|c|c|}
\hline \multirow[b]{2}{*}{ Start-up capital } & \multicolumn{2}{|c|}{$\begin{array}{c}\text { Harbin } \\
\text { Numbers Per cent }\end{array}$} & \multicolumn{2}{|c|}{$\begin{array}{l}\text { Qingdao } \\
\text { Numbers Per cent }\end{array}$} & \multicolumn{2}{|c|}{$\begin{array}{c}\text { Total } \\
\text { Numbers Per cent }\end{array}$} \\
\hline & 293 & 66.0 & 167 & 48.7 & 460 & 58.4 \\
\hline Government regulations & 132 & 29.7 & 95 & 27.7 & 227 & 28.8 \\
\hline Government charges & 92 & 20.7 & 74 & 21.6 & 166 & 21.1 \\
\hline Not enough customers & 103 & 23.2 & 35 & 10.2 & 138 & 17.5 \\
\hline $\begin{array}{l}\text { Difficult to find skilled staff } \\
\text { Difficult to find suitable }\end{array}$ & 43 & 9.7 & 13 & 3.8 & 56 & 7.1 \\
\hline business premises & 27 & 6.1 & 10 & 2.9 & 37 & 4.7 \\
\hline $\begin{array}{l}\text { No clear idea about what } \\
\text { the business would do }\end{array}$ & 14 & 3.2 & 14 & 4.1 & 28 & 3.6 \\
\hline Lack of business plan & 19 & 4.3 & 7 & 2.0 & 26 & 3.3 \\
\hline Lack of business skill & 16 & 3.6 & 6 & 1.7 & 22 & 2.8 \\
\hline $\begin{array}{l}\text { Too low prices of } \\
\text { commodities/services }\end{array}$ & 9 & 2.0 & 10 & 2.9 & 19 & 2.4 \\
\hline Others & 5 & 1.1 & 5 & 1.5 & 10 & 1.3 \\
\hline
\end{tabular}

Note: Multiple choices possible.

Source: Small business survey 2002. 
Red tape is a common concern for small businesses in many countries. The main source of this frustration is the multiple roles of the small business owner, which means the main entrepreneur and manager is also the main administrator. Time spent by the small business owner in dealing with red tape is time away from developing the business. The survey sought information on how much time the small business operators spend on reporting to government, and the average was 1.8 days per month, or 22.8 days per year. With the average annual output value per person of respondent enterprises in the order of 56,500 yuan, the direct value of this time is some 5,083 RMB per year-a significant level for most small businesses.

The survey showed very high levels of concern in China about red tape. By way of comparison, a recent Yellow Pages Business Index Survey ${ }^{4}$ listed the main concerns facing small businesses in Australia as

- lack of work/sales (16 per cent)

- cash flow (9 per cent)

- finding quality staff (8 per cent)

- consumer confidence (6 per cent)

- lack of time/hours in the day (6 per cent)

- GST (6 per cent)

- government financial regulations (5 per cent).

With access to capital being the biggest barrier facing start-up businesses in the two cities, the survey sought more detailed information on the nature of capital required, uses, possible sources, and difficulties in accessing the various sources.

The survey found that 73.2 per cent of respondents will be looking for expansion capital in the next 12 months (67.2 per cent of Harbin respondents and 84.2 per cent of Qingdao respondents). The uses of expansion capital are shown in Table 21.10.

The main uses nominated by respondents were: exploring new markets (39.1 per cent), developing manager's skills (30.5 per cent), developing new products and services (23.7 per cent) and developing staff skills (22.3 per cent). Higher percentages of respondents from Harbin nominated manager and staff skills development than their counterparts in Qingdao.

The sources of expansion capital are shown in Table 21.10. The main source nominated by those who responded to this question was investors ( 33.4 per cent). A further 27.4 per cent will be looking for bank finance-considerably above the share of 10.5 per cent who had used bank finance in establishing their business. Another 24.3 per cent will be looking for capital from family and friends. 
There is considerable difference in the responses from the two cities. Respondents from Harbin favoured investors, while those from Qingdao favoured banks and family/ friends.

Respondents were also invited to comment on the difficulties they expected to run into in accessing expansion capital (Table 21.11). The main difficulties reflect the preferred sources of expansion capital, relating primarily to banks (problems with loan deposits ( 30.1 per cent) and loan guarantees (23.3 per cent)) and problems finding investors (27.5 per cent). Once again, small business operators in Qingdao

Table 21.9 Use for expansion capital in next 12 months, by city

\begin{tabular}{lcccccc}
\hline & \multicolumn{2}{c}{ Harbin } & \multicolumn{2}{c}{ Qingdao } & \multicolumn{2}{c}{ Total } \\
& Number Per cent & Number Per cent & Number Per cent \\
Explore new market & 162 & 37.6 & 119 & 41.3 & 281 & 39.1 \\
Develop manager's skill & 148 & 34.4 & 71 & 24.6 & 219 & 30.5 \\
Develop new products or services & 99 & 23.0 & 71 & 24.6 & 170 & 23.7 \\
Develop staff skills & 120 & 27.9 & 40 & 13.9 & 160 & 22.3 \\
Get new equipment & 78 & 18.1 & 42 & 14.6 & 120 & 16.7 \\
Advertising \& marketing & 64 & 14.9 & 36 & 12.5 & 100 & 13.9 \\
Move into new premises & 30 & 7.0 & 12 & 4.2 & 42 & 5.8 \\
Finance a new partnership or venture & 22 & 5.1 & 11 & 3.8 & 33 & 4.6 \\
Other & 3 & 0.7 & 8 & 2.8 & 11 & 1.5 \\
Total & 431 & 100.0 & 288 & 100.0 & 719 & 100.0 \\
\hline
\end{tabular}

Notes: Multiple choices possible.

Source: Small business survey 2002.

Table 21.10 Sources of expansion capital, by city

\begin{tabular}{lcccccc}
\hline & \multicolumn{2}{c}{ Harbin } & \multicolumn{2}{c}{ Qingdao } & \multicolumn{2}{c}{ Total } \\
& Number Per cent & Number Per cent & Number Per cent \\
Investors & 130 & 40.5 & 27 & 18.1 & 157 & 33.4 \\
Bank & 80 & 24.9 & 49 & 32.9 & 129 & 27.4 \\
Family member or friends & 66 & 20.6 & 48 & 32.2 & 114 & 24.3 \\
Risk capital & 13 & 4.0 & 13 & 8.7 & 26 & 5.5 \\
Government & 19 & 5.9 & 4 & 2.7 & 23 & 4.9 \\
Business union & 10 & 3.1 & 6 & 4.0 & 16 & 3.4 \\
Others & 3 & 0.9 & 2 & 1.3 & 5 & 1.1 \\
Total & 321 & 100.0 & 149 & 100.0 & 470 & 100.0 \\
\hline
\end{tabular}

Source: Small business survey 2002. 
were much less worried about finding investors (nominated by 13.4 per cent) than their colleagues in Harbin ( 38.7 per cent). On the other hand, 12.9 per cent of Qingdao respondents reported poor relationships with banks, compared with 3.2 per cent of those from Harbin.

The final set of issues covered in the survey relates to the development of business skills amongst the operators of small businesses in the two cities. Survey respondents were asked to nominate the types of business skills they would like to develop over the next 12 months. The results describe the 'hot topics' of interest to small entrepreneurs, and provide clear directions for government agencies and private providers interested in fast-tracking small business growth in China.

The responses to the question on business skill needs for the next 12 months are shown in Table 21.12. At the top of the list are the core small business management competencies: marketing and promotion (26.4 per cent), financial management (25 per cent), staff management (23.8 per cent) and customer service (23.8 per cent). The ranking of topics was similar across respondents from the two cities, but operators from Harbin were much more likely to nominate staff management-a finding that fits with earlier results showing staff skills and training to be a significant issue for those operators.

By way of comparison, a survey of 860 home-based businesses in Australia in 1999 (AusIndustry 2000) found that the top five business skills sought were

- marketing (36 per cent)

- computer/lT skills (34 per cent)

- business management (27 per cent)

Table 21.11 Difficulties expected in accessing expansion capital, by city

\begin{tabular}{lcccccc}
\hline & \multicolumn{2}{c}{ Harbin } & \multicolumn{2}{c}{ Qingdao } & \multicolumn{2}{c}{ Total } \\
& Number & Per cent & Number Per cent & Number Per cent \\
Loan deposit required by bank & 70 & 27.7 & 67 & 33.2 & 137 & 30.1 \\
Cannot find interested investors & 98 & 38.7 & 27 & 13.4 & 125 & 27.5 \\
Cannot get loan guarantee & 53 & 20.9 & 53 & 26.2 & 106 & 23.3 \\
Poor relations with banks & 8 & 3.2 & 26 & 12.9 & 34 & 7.5 \\
Bank fees and charges & 14 & 5.5 & 15 & 7.4 & 29 & 6.4 \\
Bank paperwork & 8 & 3.2 & 10 & 5.0 & 18 & 4.0 \\
Other & 2 & 0.8 & 4 & 2.0 & 6 & 1.3 \\
Total & 253 & 100.0 & 202 & 100.0 & 455 & 100.0 \\
\hline
\end{tabular}

Source: Small business survey 2002. 
- financial management ( 25 per cent)

- product or service knowledge (15 per cent).

Respondents were also invited to indicate their preferred mode of acquiring their desired business development skills (Table 21.13). The responses show a marked difference between the cities, with operators in Qingdao clearly showing a preference for face-to-face modes like training and seminars, while a very large 41 per cent of respondents from Harbin nominated books or handbooks. Respondents from both cities rated coaching, mentoring and one-to-one advice very low on the list. This is likely to be due to an almost complete absence of creditable providers of these services in these two cities.

\section{CONCLUSIONS AND RECOMMENDATIONS}

The survey findings show that while the number of small enterprises in China is growing, there are significant impediments to establishing and developing a small private business. Three key themes are bureaucratic obstacles, lack of business skills, and difficulties in accessing finance.

Table 21.12 Business skills sought in next 12 months, by city

\begin{tabular}{lcccccc}
\hline & \multicolumn{2}{c}{ Harbin } & \multicolumn{2}{c}{ Qingdao } & \multicolumn{2}{c}{ Total } \\
& Number & Per cent & Number & Per cent & Number Per cent \\
Marketing and promotion & 147 & 33.1 & 61 & 17.8 & 208 & 26.4 \\
Financial management & 134 & 30.2 & 63 & 18.4 & 197 & 25.0 \\
Staff management & 156 & 35.1 & 31 & 9.0 & 187 & 23.8 \\
Customer service & 128 & 28.8 & 59 & 17.2 & 187 & 23.8 \\
Marketing & 93 & 20.9 & 33 & 9.6 & 126 & 16.0 \\
Computer/information & 68 & 15.3 & 21 & 6.1 & 89 & 11.3 \\
Project management & 44 & 9.9 & 27 & 7.9 & 71 & 9.0 \\
Networking & 40 & 9.0 & 15 & 4.4 & 55 & 7.0 \\
No skills needed & 34 & 7.7 & 13 & 3.8 & 47 & 6.0 \\
Business plan & 34 & 7.7 & 10 & 2.9 & 44 & 5.6 \\
Risk assessment & 27 & 6.1 & 9 & 2.6 & 36 & 4.6 \\
Negotiation & 26 & 5.9 & 10 & 2.9 & 36 & 4.6 \\
Pricing & 12 & 2.7 & 5 & 1.5 & 17 & 2.2 \\
Exporting & 6 & 1.4 & 9 & 2.6 & 15 & 1.9 \\
Balancing family and work & 7 & 1.6 & 5 & 1.5 & 12 & 1.5 \\
Other & 0 & 0.0 & 1 & 0.3 & 1 & 0.1 \\
All Respondents & 444 & 100.0 & 343 & 100.0 & 787 & 100.0 \\
\hline
\end{tabular}

Note: Multiple choices possible.

Source: Small business survey 2002. 


\section{Bureaucracy}

The maze of bureaucratic requirements to establish a business, and the high level of ongoing reporting necessary to run a business need to be addressed if an attractive small business environment is to be created and small private enterprises are to flourish in China. Initiatives like One-Stop-Shops where a business operator can go to have all the necessary registration, license and approval forms processed and stamped in the one location, need to be rolled out across China. City and district planning and management departments should consider the impact on Getihu trade and small businesses and the employment opportunities and services they offer when city/district or street committee authorities try to clean up local markets. The arbitrary consolidation of street market activities into commercial multistorey buildings, often long distances from the original market location, where higher rents are charged, often destroys the basis of the small business, and those Getihu and Siying Qiye made to relocate are ultimately forced out of business and their staff made to join the unemployment queue. Registered Capital requirements for Siying Qiye need to be reviewed nationwide to test whether or not they work, and to determine whether they are an obstacle preventing the growth of small private enterprise startups or are an obstacle to employment growth by hindering the process of graduation from Getihu to Siying Qiye. If they are still considered necessary, any review should reassess the registration capital level to ensure that they are standardised across the country and are set at an appropriate level favourable to business growth.

Table 21.13 Preferred skills training delivery modes, by city

\begin{tabular}{lcccccc}
\hline & \multicolumn{2}{c}{ Harbin } & \multicolumn{2}{c}{ Qingdao } & \multicolumn{2}{c}{ Total } \\
& Number Per cent & Number & Per cent & Number Per cent \\
Book or handbook & 182 & 41.0 & 38 & 11.1 & 220 & 28.0 \\
Training course & 107 & 24.1 & 82 & 23.9 & 189 & 24.0 \\
Seminar with experts & 122 & 27.5 & 61 & 17.8 & 183 & 23.3 \\
Lecture with experts & 49 & 11.0 & 22 & 6.4 & 71 & 9.0 \\
Internet reference material & 44 & 9.9 & 22 & 6.4 & 66 & 8.4 \\
Workshop with experts & 29 & 6.5 & 10 & 2.9 & 39 & 5.0 \\
Business coach or mentor & 21 & 4.7 & 15 & 4.4 & 36 & 4.6 \\
One to one advice & 19 & 4.3 & 12 & 3.5 & 31 & 3.9 \\
Other & 1 & 0.2 & 2 & 0.6 & 3 & 0.4 \\
All respondents & 444 & 100.0 & 343 & 100.0 & 787 & 100.0 \\
\hline
\end{tabular}

Notes: Multiple choices possible

Source: Small business survey 2002 


\section{Business support}

The relative youth of China's small private business sector brings both challenges and opportunities. The challenges are that there is little appreciation of the needs of small business or how to improve the small business operating environment among city government authorities who have direct responsibility for managing Getihu and Siying Qiye. Also, there is little depth of experience among the new entrepreneurs, there are few credible business mentors, coaches and teachers, and the 'business intermediaries'-who should provide professional advice on legal, accounting, business planning and marketing matters-are not very evolved. The opportunities arise from the high levels of demand for building skills in these areas.

Initiatives piloted under the AusAID-funded project to address these shortcomings and impediments to growth include Business Advisory Services and Business Support Centres. Drawing on extensive Australian experience and models, the Business Advisory Services are supported by local and city administrations or are integrated into the operations of model small business support centres to provide help to small and aspiring entrepreneurs in setting up a business and in basic business planning. The Business Advisory Service provides training, referral services and advice to laid-off workers, the unemployed, aspiring entrepreneurs, the selfemployed and small businesses on matters necessary to start, support and maintain the running of a small business, including recruitment of staff and preparation of new enterprise business plans. The Business Advisory Services need to be proactive in publicising their existence and relevance to these target groups.

The Business Support Centres are a Chinese version of 'small business or general (mixed) incubators', offering a mix of office, sales and production space, with onsite business development systems and support. The in-house mentoring services focus on solving business problems and identifying growth opportunities, and they directly contribute to the minimisation of small business failures and the expansion of employment opportunities. In Western economies these facilities are generally public--private partnerships, with the local government providing buildings and facilities free of charge. Field work for this project indicates that Chinese demand for these facilities in the two pilot cities is so strong that they can be run as private, profitmaking ventures in their own right. 


\section{Access to finance}

Improving access to formal financial markets by small private enterprises will be essential if this pivotal sector is to play the necessary role of soaking up structural unemployment in China. It is a complex problem, and a seven-step process to reform small enterprise financing in China is outlined below

- Address the perception by banks that small enterprises are an unacceptable credit risk. This requires training of bank loan assessors and credit managers, more sophisticated assessment processes, working through intermediaries like accountants and business incubators to improve company assets and profit/ loss assessments and reduce business failure rates, and application forms that include requirements for sound business planning.

- Establish city-level small business support funds, possibly linked to employment of a certain level of xiagang and the unemployed.

- Seriously evaluate the performance of the existing SME Credit Guarantee Agency system - followed either by reform (if required) or closure of the Agency and diversion of city funds to other city-based intermediary organisations (since its establishment in 1999, the credit guarantee system has shown itself to be risk-averse, duplicating the services of the state banking sector, and servicing only medium-scale SOEs, not the private sector).

- Policy initiatives to develop small and community-based banks or credit cooperatives to better serve local small enterprises (the five new private banks currently under consideration for approval by the China Banking Regulatory Commission are a start in the creation of a proper capital market in China, but this does not go far enough).

- Attract foreign banks into China by 2005 , under WTO accession rules.

- Introduce and finance urban micro-credit facilities to the small-scale enterprise and Getihu sector-funded by city governments and channelled through city Commercial Banks (the former urban credit cooperatives) and/or intermediary organisations such as business incubators.

- Formalise the large 'grey capital market' in China and partially remove informal (illegal) private household and company lending by initiating or allowing other forms of capital raising. As well, it would be of great benefit to direct some of China's high volumes of household savings through special small enterprise credit facilities, with variable bank interest rates, and to formalise and secure the legal status of contracts. 


\section{NOTES}

1 The survey, conducted in October-November 2002, was part of a larger technical assistance project on developing models of support for small private sector enterprises commissioned by AusAID under its China Capacity Building Program. The project, known as Support for Small Scale Business in the Service Sector and Community Services in China, was undertaken in cooperation with, and with the support and guidance of, the State Council Office for Restructuring the Economic Systems (SCORES), which since March 2003 has been integrated into China's highest level economic and reform policy authority, the restructured National Development Reform Commission. The project also received considerable support from SCORES' municipal offices in Harbin and Qingdao, two cities which were chosen as pilot cities for development of small business support programs.

2 Speech by Mr. Xu Hua, State Development and Reform Commission, to the Dissemination Workshop of the Sino-Australian Project and Promoting the Development of Small and Mediumsized Enterprise (SME) in China, Qingdao, April 2003.

3 Gross regional product growth rates of 11-13 per cent per annum in recent years.

4 Yellow Pages Business Index, Small and Medium Enterprises, Feb 2002.

\section{REFERENCES}

AusIndustry, 2000. Back Yarders and Front Runners: home-based business in two Australian regions, AusIndustry, Canberra. Available online at www.ausindustry.gov.au/smallbusiness/publications.

Australian Bureau of Statistics, 2002. Characteristics of Small Business, Australian Bureau of Statistics, Canberra, March 2002.

International Finance Corporation, 2000. China's Emerging Private Enterprises: prospects for the new century, International Finance Corporation (IFC), Washington, DC.

Garnaut, R., Song, L., Xiaolu, W. and Yang, Y., 2001. Private Enterprises in China, Asia Pacific Press, The Australian National University, Canberra.

Song L., 2001. Key Findings from the Survey of Private Enterprise in Chengdu, Sichuan Province of China, Paper presented at the Building an Enabling Environment for SME Development conference, Chengdu, China, 17-18 May. 


\section{2}

\section{Industrial location and regional development}

\section{Jane Golley}

Rising regional inequality has become an undeniable aspect of China's economic reform and development during the last 25 years. Throughout the 1990 s and into the 2000 s inter-provincial disparities in per capita income have continually increased. It is generally accepted that diverging rates of development in the coastal (or eastern) and interior (or central and western) provinces are a major source of these income disparities (Yang 1997; Démurger 2001; Yao and Zhang 2001; Bao et al. 2002). This divergence, in turn, stems largely from the regional pattern of China's industrial development during the same period (Lyons 1991; Yao 1997; Mody and Wang 1997; Fujita and Hu 2001; Golley 2002). It is this pattern which is the primary focus of this chapter.

Regional development has always been an integral part of the Chinese Communist Party's policy agenda. Soon after their rise to power in 1949, developing China as a major industrial and military power became the number one priority. But distributional and equity goals were also important. In particular, the government sought a more even geographical distribution of industry, claiming that foreign domination had resulted in an 'irrational' pattern of industrial development, in which output capacity was concentrated in coastal China. Mao Zedong was determined to achieve a more balanced geographical distribution of industry for strategic military purposes, and also because, in the long run, growth leading to increasing regional inequalities ran counter to the goal of creating a politically unified and economically integrated nation 
state (Lardy 1978). The relocation of industrial capacity was achieved through the nationalisation of industry and an increasing share of state investment allocated to 'backward', that is, interior, provinces, in what became know as the 'Interior Development Strategy'. While it is widely acknowledged that the strategy was fraught with economic inefficiencies, it is an indisputable fact that the geographical structure of industry was levelled out to some extent: in 1953 the interior accounted for 31 per cent of national gross value of industrial output (GVIO); by 1978 this share had increased to 46 per cent.

Regional development has also been a major component of the economic reforms since they commenced in the late 1970s. The 1980s witnessed a significant shift in regional policy towards the coastal region. The primary focus on efficiency and rapid growth justified the promotion of the more developed coastal region, with Deng Xiaoping (1984:45) arguing that 'since conditions for the country as a whole are not ripe, we can have some areas become rich first. Egalitarianism will not work.' This policy stance was made clear from the onset, with the introduction of the Open Door Policy and the establishment of special economic zones (SEZs) in the coastal provinces of Guangdong and Fujian. The 'Coastal Development Strategy', adopted by the CPC Central Committee and the State Council in March 1988, formally endorsed the shift in policy, calling for development to extend 'progressively from the special economic zones to coastal cities, then to coastal economic regions and finally to interior areas' (Zhao 1987:27). Indeed, it was always the intention that the focus on the coastal region would ultimately shift towards the rest of the country. According to Deng (1986:163), 'The purpose of allowing some regions and some people to become prosperous before others is to enable all of them to prosper eventually. We have to make sure there is no polarisation of society-that's what socialism means.'

In contrast with the Seventh Five-Year Plan (1986-90), which clearly favoured coastal provinces, the Eighth Five-Year Plan (1991-95) advocated an absence of regional favouritism and a more level playing field. This was a political response to increasing discontent and widespread criticisms from interior provinces regarding the divergent levels of development in the first decade of reforms. However, the shift was undermined by Deng Xiaoping's 'southern tour' in 1992, during which he strongly supported more rapid growth in the southeastern provinces, and also by declining revenues, which limited the central government's ability to back its policies with 
fiscal measures. Policy proved inadequate to reverse the trend of the coastal region's share of industrial output, which rose steadily from 55 per cent of the national total in 1978 to 65 per cent in 1995.

The Ninth Five-Year Plan (1996-2000) indicated a further strengthening of the central government's commitment to addressing regional disparities. Numerous fiscal, credit and investment-based measures, combined with policies to encourage foreign trade and investment, and measures to enhance co-operation between coastal and interior provinces were implemented during this period. In 2000 both Prime Minister Zhu Rongji and President Jiang Zemin said that the large-scale development of central and western China was a major policy decision for the new century (Zhu 2000; Zeng Peiyan 2000). During the Tenth Five-YearPlan (2001-05), and now under the new leadership of Hu Jintao, Jiang's 'Western Development Strategy' or 'Go West Campaign' is continuing to receive emphasis, as witnessed by a surge of statements during the Tenth National Party Congress in March 2003 (for example, China Daily, 3 March, 5 March, 6 March, 13 March 2003). Despite this policy strengthening, however, the coast has continued to increase its share of the national gross value of industrial output, reaching 72 per cent in 2001.

The key point to take from all of this is simple: regional development matters to the Chinese government. In particular, the location of industrial development-and its implications for regional patterns of income inequality-matters. ${ }^{2}$ Moreover, the government's approach to regional development is far from laissez faire: its current objective is to alleviate the inequalities that it hitherto helped to create. What combination of policies, if any, would enable the government to succeed in this endeavour, is an extremely complex question that cannot be resolved here. ${ }^{3}$ Instead, the objective is to highlight some of the key issues that need to be taken into account.

\section{'LOCATION' MATTERS}

\section{Background}

The idea that the agglomeration of production in a particular location yields advantages, and that these advantages in turn explain such agglomeration is vital for understanding the spatial unevenness of industry and development. Consider a multi-region economy in which 'transport costs' (interpreted broadly to include not only physical transport costs but also the informational, sales, and support 
complications involved in doing business at a distance) are initially so high that industry is distributed across regions in accordance with population in order to serve isolated local markets (that is, there is no inter-regional trade). Note also that this is not an entirely unreasonable representation of China prior to 1978, when transport development lagged well behind other aspects of national development and provinces were highly self-sufficient.

Now consider an economic reform and development process which leads to a gradual reduction in 'transport costs', thereby eliminating the need to locate production perfectly in line with demand. In the presence of economies of scale and interindustry-or cost and demand-linkages, this draws firms to the larger markets in order to benefit from access to their larger (and hence cheaper) supply of intermediate inputs. In some industries, firms will be drawn to the larger market in order to benefit from externalities associated with knowledge or technological spillovers. As long as there is some degree of inter-regional labour mobility, workers will also be drawn to larger markets in order to access higher wages (as in the case of China's 'floating' population). The result will be industrial agglomeration, which will be accompanied by relatively rapid growth of per capita GDP and hence rising regional inequality. According to Myrdal (1957), exactly where that agglomeration occurs will come down to an 'accident of history'. Regardless of the precise nature of that 'accident', the process of agglomeration in one location, and not another, results in a cumulative process where that location industrialises ahead of the rest. In other words, location matters.

However this process is not boundless. As long as there is some degree of interregional labour immobility (which in China there is), rising wages in the agglomerating region will lead to rising costs, which will offset the reduced costs stemming from more intermediate inputs and other externality-driven benefits. As 'transport costs' continue to fall, wage and other cost differentials may reach a point where it is optimal for firms to relocate to less-developed regions. That is, the benefits of industrial agglomeration in a 'Core' region will eventually 'trickle down' or 'spread' to the 'Periphery'. ${ }^{4}$ In the (theoretical) long run, industry is evenly spaced across the economic landscape and per capita incomes are equalised. Adopting Krugman's (1995) interpretation of 'transport costs' $(\tau)$ as a proxy for economic development, this generates an inverted U-shaped pattern between economic development and industrial agglomeration over time. ${ }^{5}$ There is significant evidence to suggest that China lies on the upside of that $U$, with rising industrial agglomeration in coastal 
provinces and rising coast-interior income inequality. ${ }^{6}$ However it is not quite that clear cut. What is needed is an empirical means of identifying exactly where industrial agglomeration is occurring. This will be in those provinces which have 'locational' advantages for industrial development. This is where shift-share analysis comes in.

\section{Shift-share analysis $^{7}$}

Let $\Delta Y_{i j}$ denote the change in output for the th sector in region $j$ from the base period to the end period. By definition, it is the product of total output of the th sector in region $j$ in the base period, $Y_{i j 0,}$ multiplied by the growth rate of output of the th sector in region jover the whole period, $R_{i j}$;

$$
\Delta Y_{\mathrm{ij}}=Y_{i j} R_{\mathrm{ij}}
$$

Let $R_{k}$ and $R_{i k}$ denote growth rates of output for the country and for the ith sector of the country respectively. Equation 22.1 can then be decomposed into three components:

$$
\Delta Y_{i j}=Y_{j 0} R_{k}+Y_{j 0}\left(R_{i k}-R_{k}\right)+Y_{j 0}\left(R_{i j}-R_{i k}\right)
$$

Figure 22.1 Pattern of agglomeration

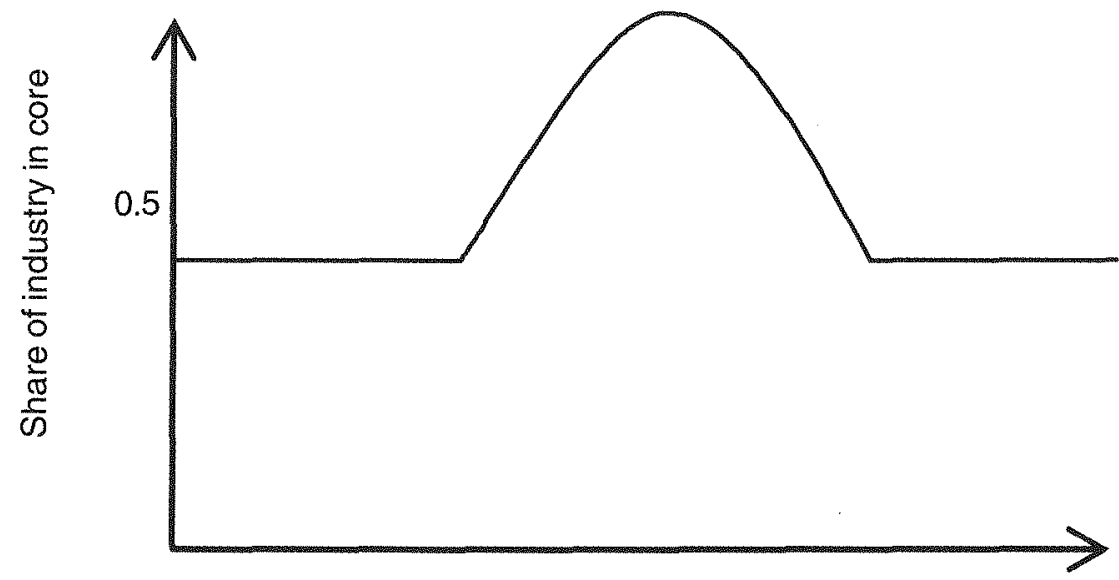


The first term on the right-hand side of Equation 22.2 is called the national component of growth. It shows, ceteris paribus, the growth that would have resulted had sector $i$ in location $j$ exactly matched the national trend $\left(R_{k}\right)$. The second term is the structural component. It calculates the change in the th sector that can be attributed to the region's industry mix. If the region has a 'favourable' mix, comprising more industries that are experiencing rapid growth (higher $R_{i k}$ ), it will, ceteris paribus, experience faster output growth than the rest of the country.

However, having a favourable industrial structure in the base period is neither a necessary nor a sufficient condition for faster growth. The third term on the right hand side is often called the differential (or residual) component, because it is the part of regional growth not explained by the national and structural components. It is a catch-all for measuring the extent to which sector $i$ in region $j$ grew faster or slower than it would have had the local industry experienced the national growth rate (in the former, $R_{i j}>R_{i k}$ so that the value is positive). For this reason, it makes perfect sense to call it the locational component, which is the terminology adopted here.

Finally, Equation 22.2 can be rearranged as follows

$$
\Delta Y_{i j}-Y_{i j 0} R_{k}=Y_{i j 0}\left(R_{i k}-R_{k}\right)+Y_{i j 0}\left(R_{i l}-R_{i k}\right)
$$

The left-hand side is the 'net relative change'(NRC), which is the difference between the actual change and the national component. The NRC shows whether the th sector in region j experienced faster or slower growth of industrial output than the national average, with a positive value reflecting the former. The NRC can therefore be regarded as an index of relative performance, which the right-hand side seeks to explain.

As Equation 22.3 shows, each NRC can be decomposed into its structural and locational components (SC and LC respectively). In total, there are six different combinations of signs on the NRC, SC and LC (Table 22.1).

In Types 1,2 and 3 the NRC is positive, which translates to a growth rate above the national average. Identifying those provinces that record positive NRCs will provide one way of determining where industrial agglomeration is occurring in each sector. In Types 1, 3 and 6, locational factors make a positive contribution to the $\mathrm{NRC}$, that is, to the growth of manufacturing output, which means we can identify which provinces have location working in their favour. A closer look at the actual figures will also provide a measure of the importance of location (as opposed to sectoral structure) in determining provincial industrial performance. This will enable us to establish a clear case that location does indeed matter. 
Table 22.1 NRC, SC and LC combinations

\begin{tabular}{lccc}
\hline Type & NRC & SC & LC \\
1 & + & + & + \\
2 & + & + & - \\
3 & + & - & + \\
4 & - & - & - \\
5 & - & + & - \\
6 & - & - & + \\
\hline
\end{tabular}

\section{EMPIRICAL RESULTS}

Since 1978 China has recorded an average annual rate of real GDP growth of around 10 per cent, a remarkable growth rate by any standards. However, this growth has not been evenly distributed across the country. Provincial rates of real GDP growth between 1978 and 2001 ranged between 13.5 per cent in Fujian (in the East) to 7 per cent in Gansu (in the West) (Table 22.2). Note that the top five provinces in terms of GDP growth are the five Southeastern provinces, Fujian, Guangdong, Zhejiang, Shandong and Jiangsu. It is also interesting to see that Xinjiang (aWestern province) and Henan (a Central province) are the next two provinces in the ranking. Shanghai, on the other hand, ranks second to last, while Liaoning (another coastal province) is also a relatively poor performer in terms of GDP growth.

The table also ranks provinces in terms of changing shares of the gross value of industrial output over the same period. While there is not a one-for-one matching with the GDP ranking, there is a strong correlation (of 0.93 ). The top seven provinces in terms of GDP growth are also the top seven in terms of increases in GVIO shares, while Shanghai and Liaoning both record declining GVIO shares. This correlation follows through to changes in per capita GDP, as shown in the final four columns. Zhejiang's per capita GDP, for example, was 0.87 times the national average in 1978, increasing to 1.94 times the national average in 2001. This implies that Zhejiang recorded the fastest growth of per capita GDP during that period. Again, the same provinces rank in the top seven, while Shanghai remains at the bottom of the ranking. The correlation between per capita GDP growth and growth of GVIO is 0.90 , while the correlation between per capita GDP growth and GDP growth is 0.91 .

It is not surprising that GVIO growth is strongly correlated with growth rates of GDP and per capita GDP. This implies that understanding provincial disparities in 
Table 22.2 Rankings of GDP growth, GVIO shares, and changes in per capita GDP

\begin{tabular}{|c|c|c|c|c|c|c|c|}
\hline Province & $\begin{array}{l}\text { Real GDP } \\
\text { growth } \\
1978-2001\end{array}$ & Province & $\begin{array}{l}\text { Change in } \\
\text { share of } \\
\text { GVIO } \\
1978-2001\end{array}$ & Ratio provincial & $\begin{array}{l}\text { Ratio } \\
1978\end{array}$ & $\begin{array}{l}\text { Ratio } \\
2001\end{array}$ & $\begin{array}{l}\text { apita GDP } \\
\text { Change in } \\
\text { ratio } \\
1978-2001\end{array}$ \\
\hline & & & & & & & \\
\hline Fujian & 13.5 & Guangdong & 10.0 & Zhejiang & 0.87 & 1.94 & 1.07 \\
\hline Guangdong & 12.9 & Zhejiang & 5.3 & Fujian & 0.72 & 1.64 & 0.92 \\
\hline Zhejiang & 12.7 & Jiangsu & 4.3 & Guangdong & 0.97 & 1.82 & 0.85 \\
\hline Shandong & 11.4 & Shandong & 3.1 & Jiangsu & 1.13 & 1.71 & 0.58 \\
\hline Jiangsu & 10.9 & Fujian & 1.7 & Shandong & 0.83 & 1.39 & 0.55 \\
\hline Xinjiang & 10.9 & Henan & 0.3 & Xinjiang & 0.83 & 1.05 & 0.22 \\
\hline Henan & 10.5 & Xinjiang & 0.2 & Henan & 0.61 & 0.79 & 0.17 \\
\hline Hubei & 9.9 & Inner Mongolia & 0.1 & Hubei & 0.88 & 1.04 & 0.16 \\
\hline Hebei & 9.8 & Ningxia & -0.02 & Hebei & 0.96 & 1.11 & 0.15 \\
\hline Yunnan & 9.8 & Yunnan & -0.1 & Yunnan & 0.60 & 0.65 & 0.05 \\
\hline Guangxi & 9.7 & Qinghai & -0.2 & Anhui & 0.64 & 0.69 & 0.05 \\
\hline Anhui & 9.6 & Guizhou & -0.3 & Hunan & 0.75 & 0.80 & 0.05 \\
\hline Hunan & 9.3 & Hubei & -0.4 & Sichuan & 0.67 & 0.71 & 0.04 \\
\hline Inner Mongolia & 9.2 & Anhui & -0.6 & Guangxi & 0.59 & 0.62 & 0.03 \\
\hline Beijing & 9.1 & Guangxi & -0.6 & Inner Mongolia & 0.84 & 0.86 & 0.02 \\
\hline Sichuan & 8.9 & Jiangxi & -0.6 & Jilin & 1.01 & 1.01 & 0.01 \\
\hline Jiangxi & 8.9 & Tianjin & -0.7 & Beijing & 3.40 & 3.38 & -0.02 \\
\hline Jilin & 8.9 & Hebei & -0.8 & Jiangxi & 0.73 & 0.69 & -0.04 \\
\hline Guizhou & 8.6 & Jilin & -0.8 & Guizhou & 0.46 & 0.38 & -0.08 \\
\hline Ningxia & 8.5 & Shaanxi & -0.9 & Shaanxi & 0.77 & 0.67 & -0.10 \\
\hline Shaanxi & 8.5 & Gansu & -0.9 & Liaoning & 1.79 & 1.60 & -0.20 \\
\hline Tianjin & 8.4 & Shanxi & -0.9 & Shanxi & 0.96 & 0.72 & -0.24 \\
\hline Liaoning & 8.3 & Hunan & -1.4 & Heilongjiang & 1.49 & 1.24 & -0.25 \\
\hline Heilongiiang & 7.9 & Beijing & -1.6 & Ningxia & 0.98 & 0.71 & -0.27 \\
\hline Shanxi & 7.9 & Sichuan & -1.8 & Gansu & 0.92 & 0.55 & -0.37 \\
\hline Qinghai & 7.7 & Heilongjiang & -2.4 & Qinghai & 1.13 & 0.76 & -0.37 \\
\hline Shanghai & 7.4 & Liaoning & -4.7 & Tianjin & 3.06 & 2.67 & -0.39 \\
\hline Gansu & 7.0 & Shanghai & -5.6 & Shanghai & 6.59 & 4.96 & -1.64 \\
\hline
\end{tabular}

Source: Figures drawn from State Statistical Bureau (SSB) $(1997,2002)$ and calculated by author. 
industrial performance is a critical component of understanding regional income disparities more generally. It is perhaps more interesting to observe that the standard East-Centre-West and coast-interior regional classifications obscure the fact that each region has some provinces performing well and others performing badly. This is a particularly important point in light of the central government's tendency to focus on these classifications when formulating regional policies.

The empirical analysis that follows draws on a dataset of GVIO for 30 provinces and 28 manufacturing sectors drawn from China Industrial Economic Statistical Yearbooks (State Statistical Bureau 1990, 1995, 2001). Table 22.3 presents gini coefficients for each sector in 1989, 1994 and 2000. Gini coefficients measure the extent of geographical concentration (or agglomeration) in specific manufacturing sectors relative to the level of manufacturing concentration overall. The closer the provincial spread of a particular sector is to the provincial spread of manufacturing overall, the closer the gini is to zero. The more concentrated a certain sector is, the closer the gini is to one. As the table shows, in all but two sectors (wood products and petroleum processing and coking), the gini coefficient rose between 1989 and 2000, suggesting that Chinese industry is indeed becoming more agglomerated. It remains to be seen in which provinces this agglomeration is taking place, and why. Focusing on the period 1994-2000, this is the main task of this section. ${ }^{8}$

Several preliminary points are worth highlighting. First, the coastal region's 74 per cent share of national manufacturing output is far above its population share of 42 per cent. This dominance exists across the board, with the coastal region producing 92 per cent of all clothing, 89 per cent of leather and furs, 97 per cent of cultural, educational and sports goods (CESG) and 90 per cent of electronic and telecommunications equipment (ETE). The region produces more than 60 per cent of output in all but two sectors and at least 80 per cent of output in close to half the sectors.

Second is the dominance of certain provinces. In 2000 Guangdong, with 7 per cent of China's population, produced more than a quarter of its clothes, leather and furs, CESG, furniture, plastics, electronic equipment and machinery (EEM), ETE, and instruments and metres. Jiangsu produced almost a quarter of the nation's chemical fibres, machines and textiles, while Shandong produced more than 20 per cent of its food processing manufactures, rubber products and special purpose equipment. Zhejiang produced 17 per cent of China's textiles and clothing, and neighbouring Shanghai, with less than 2 per cent of the nation's population, produced 
19 per cent of chemical fibres, 14 per cent of transport equipment and 12 per cent of smelting and pressing ferrous metals (SPFM). In combination with Fujian, these six contiguous provinces produced 57 per cent of national manufacturing output in 2000 . This seems to suggest that industry is concentrated at both the regional and provincial levels along China's southeastern coast.

Not only does the coastal region dominate manufacturing production, but its share has risen over time. Between 1994 and 2000, the region increased its share of China's manufacturing output by 5.0 percentage points. This followed an increase of 6.5 percentage points between 1989 and 1994. At the provincial level, Guangdong experienced an increase of 4.4 percentage points during the last six years, on top of 4.1 percentage points in the previous period. Zhejiang, Shandong and Fujian all experienced further increases in their shares, while Liaoning and Guangxi suffered further declines. Shanghai, Beijing, Tianjin and Hebei, in contrast with the early 1990s, also saw their shares increase between 1994 and 2000. The only non-coastal provinces that increased their output shares were Henan, Xinjiang and Tibet. The continuing rise in the coastal region's share of manufacturing over time translates to industrial agglomeration there. ${ }^{9}$ But note that this agglomeration is not benefiting all coastal provinces.

Table 22.4 presents the net relative changes, structural components and locational components for each sector in each province between 1994 and 2000 , classifying each of the 1,108 observations as Types 1-6 following the methodology introduced above. Note first some simple information contained in the table. The final column records the NRCs for total provincial output. In a sense this captures the overall 'locational' value of each province (since the NRC at the provincial level is based solely on the locational components). These will be positive for those provinces in which manufacturing overall grew above the national average, which translates to those provinces which increased their output shares. This is only the case for the provinces mentioned in the previous paragraph, revealing that manufacturing growth is skewed in favour of a small number of provinces. The bottom row of the table records the NRC at the national level for each sector, which is equivalent to the SC (since the LC is zero at the national level). These will be positive for all sectors which grew above the national average.

As Table 22.4 shows, however, there is no guarantee that a positive SC will result in a positive $\mathrm{NRC}$, since locational factors may still manage to drag the growth rate of a given sector in a given province below the national average (Type 5). This is the 
case, for example, in Guangxi's food manufacturing sector, which has a positive SC but a negative NRC. This is because the LC for food manufacturing is negative and large enough to override the positive SC. That is, despite the fact that the sector grew above the national average, when located in Guangxi it dropped to below average. In the furniture sector this is the case for all western provinces other than Xinjiang, while in the transport equipment sector it is the case for all western provinces other than Sichuan. Surely an entrepreneur producing in these sectors would prefer to locate elsewhere.

Table 22.3 Gini coefficients

\begin{tabular}{|c|c|c|c|}
\hline & 2000 & 1994 & 1989 \\
\hline Food processing & 0.316 & 0.236 & .. \\
\hline Food manufacturing & 0.227 & 0.208 & .. \\
\hline Beverages & 0.245 & 0.236 & 0.234 \\
\hline Tobacco & 0.616 & 0.612 & 0.492 \\
\hline Textiles & 0.348 & 0.321 & 0.253 \\
\hline Clothing and other chemical fibres & 0.403 & 0.366 & 0.232 \\
\hline Leather and furs & 0.446 & 0.358 & 0.216 \\
\hline Wood products & 0.234 & 0.308 & 0.403 \\
\hline Furniture & 0.276 & 0.262 & 0.216 \\
\hline Paper making & 0.236 & 0.223 & 0.188 \\
\hline Printing and record medium & 0.272 & 0.182 & 0.187 \\
\hline Cultural, educational and sports articles & 0.501 & 0.462 & 0.499 \\
\hline Petroleum processing and coking & 0.367 & 0.380 & 0.444 \\
\hline Chemical materials & 0.186 & 0.140 & 0.156 \\
\hline Medical and pharmaceutical products & 0.239 & 0.165 & 0.145 \\
\hline Chemical fibres & 0.402 & 0.375 & 0.372 \\
\hline Rubber & 0.301 & 0.233 & 0.162 \\
\hline Plastics & 0.315 & 0.292 & 0.243 \\
\hline Non-metal mineral products & 0.196 & 0.180 & 0.147 \\
\hline Smelting and pressing of ferrous metals & 0.409 & 0.370 & 0.338 \\
\hline Smelting and pressing of non-ferrous metals & 0.396 & 0.367 &.. \\
\hline Metal products & 0.262 & 0.156 & 0.138 \\
\hline Universal machines & 0.299 & 0.195 & 0.118 \\
\hline Special purpose equipment & 0.309 & 0.201 & $\therefore$ \\
\hline Transportation equipment & 0.350 & 0.314 & 0.305 \\
\hline Electric equipment and machinery & 0.270 & 0.239 & 0.206 \\
\hline Electronic and telecommunications equipment & 0.479 & 0.464 & 0.340 \\
\hline Instruments and metres & 0.414 & 0.312 & 0.282 \\
\hline
\end{tabular}

Source: SSB(1990, 1995, 2001) and author's calculations. 
By contrast, an NRC can be positive even though the sector on the whole performed below the national average (Type 3). Take the clothing sector as an example. The negative SC resulted in negative NRCs in virtually all provinces. Only in Jiangsu, Zhejiang, Fujian, Guangdong and Hainan did locational factors override this, resulting in positive NRCs in these provinces. In all other provinces location compounded the performance of the sector and dragged the growth rate further below average (Type 4). The machine-building sector provides a similar example, with only Zhejiang and Guangdong scoring positive NRCs. The point is that these provinces must have something working in their favour.

The results from Table 22.4 are summarised in Table 22.5. There are two main issues of interest. First is the number of sectors in which provinces record positive NRCs (Types 1,2,3), since this equates to above average growth and hence rising industry shares. Guangdong is the frontrunner with positive NRCs in 23 out of its 28 sectors. Zhejiang has 21 such sectors, followed by Fujian and Shanghai with 18 each and then Tianjin and Hebei with 15. Henan and Hubei (neighbouring central provinces) come in just behind with 14 sectors each. With at least half of their sectors growing above average, it is not surprising that these provinces (with the exception of Hubei) increased their shares of national manufacturing output over the period in question. ${ }^{10}$ Moreover, it shows that provincial growth rates are not necessarily contingent on the exceptional growth of one or two boom sectors, but instead derive from above average growth in the majority of sectors. This suggests that location rather than industry structure may be the main determinant of growth.

Building on this point, note that growth is above average in 16 out of the 28 sectors (positive values in the bottom row of Table 22.4). And yet Qinghai, Shaanxi and Inner Mongolia record positive NRCs in only six sectors. This implies that locational factors dragged 22 sectors in each province below average. The two coastal provinces of Liaoning and Guangxi perform even more poorly, recording positive NRCs in only five and three sections respectively. Producing output in sectors that grow above average (which all provinces do) is not enough to ensure above-average provincial growth. That is not to say that a 'lucky' sectoral structure doesn't help. Xinjiang, for example, only records positive NRCs in ten sectors, one of which is petroleum processing and coking, which experienced a growth rate close to double the national average. The fact that close to a third of Xinjiang's manufacturing output is produced in this sector explains Xinjiang's share of manufacturing output overall. This, however, is the exception rather than the rule. ${ }^{11}$ 
The second issue of interest is the number of sectors in which the locational component is positive, that is, location favours growth (Types 1, 3, 6). Guangdong and Zhejiang have 25 and 24 sectors in these three categories respectively, followed by Tianjin and Fujian with 18 each. Most other coastal provinces score highly on this front as well, other than Liaoning and Guangxi. Locating production in either of these provinces made a positive contribution to growth in just two sectors. This placed them behind all western provinces from Ningxia's 11 sectors to Sichuan's five.

For the central provinces, locational advantages tended to exist in relatively few sectors: three in Anhui and Hunan, four in Jiangxi, five in Heilongjiang, and so on. Henan (which increased its share of output) was a favourable location for growth in 15 sectors, placing it above numerous coastal provinces. Hubei also performed relatively well within the central region, with 11 sectors recording positive locational components. These figures are noteworthy from two perspectives. First, the overall performance of the region is well behind that of the East, suggesting that the gains from industrial development in the latter have not yet trickled down, or across as the case may be. However the delineation of East and Centre is somewhat blurry, particularly in light of the relatively strong performances of Henan and Hubei. Second, the average performance of the region in terms of sectors favoured by location is actually worse than the West's (7 sectors versus 8 ), with a significant number of central provinces ranking below their western counterparts. Given the present focus on western development, this is a significant point.

The emphasis here has been on the importance of locational factors in determining rates of manufacturing growth. This is not to say that industrial structure is irrelevant to provincial performance, as that is clearly not the case: those provinces blessed with a 'lucky' industrial structure (that is, relatively more production in sectors that are performing relatively well) will obviously perform better than those that are not. However, structure is simply not enough. In more than 70 per cent of the 1,108 NRC calculations in Table 22.4, the absolute value of the locational component is greater than the absolute value of the structural component. This implies that discrepancies in industrial performances across provinces stem more from discrepancies in provincial 'environments' than from discrepancies in their industrial structures. In other words, location matters. 
$\sqrt[5]{8}$

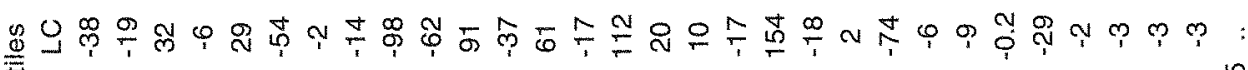

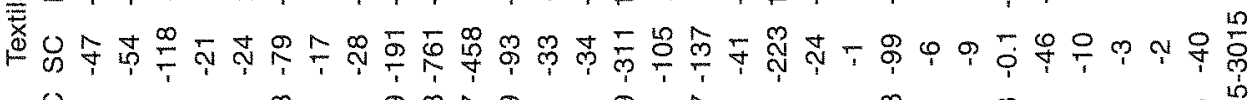

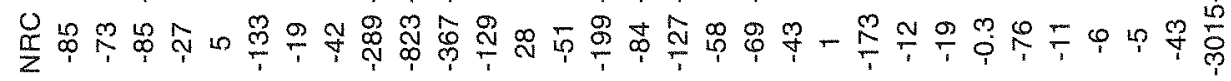

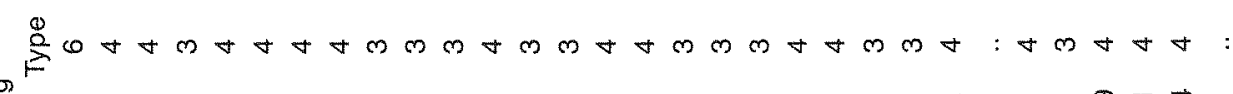

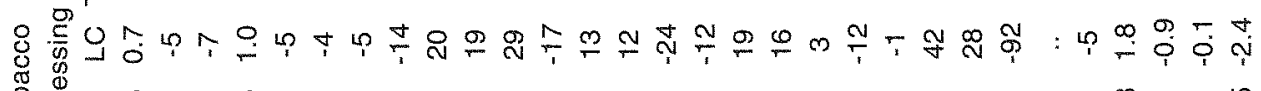

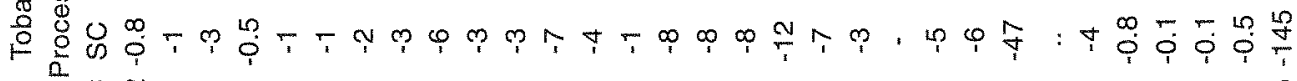

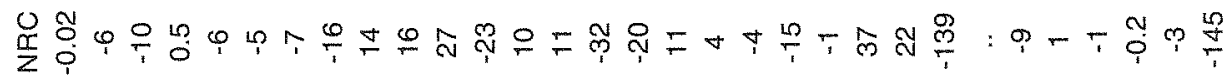
(n) ब.

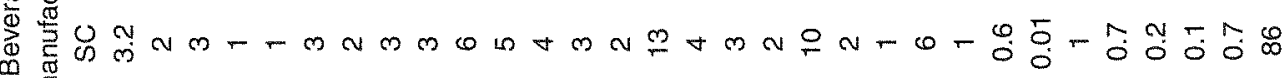

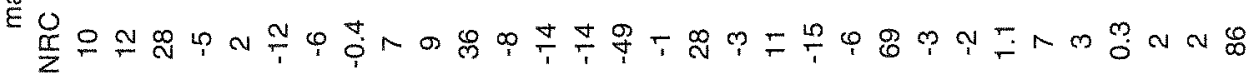
0
0 莺

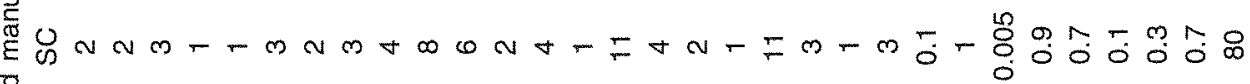

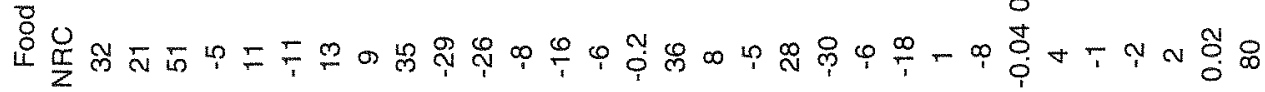

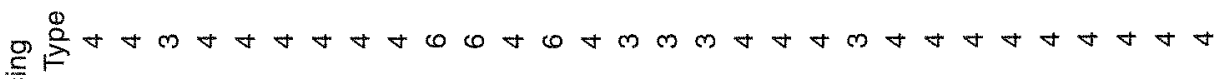
कू 势

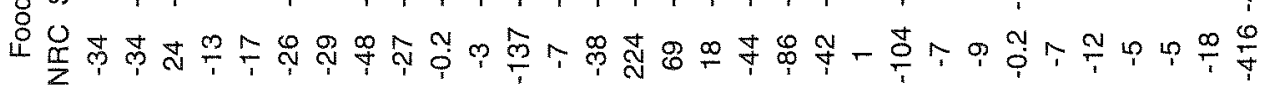


do 产 旁范 茎

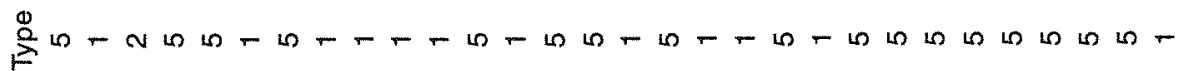

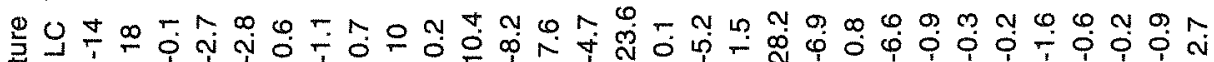

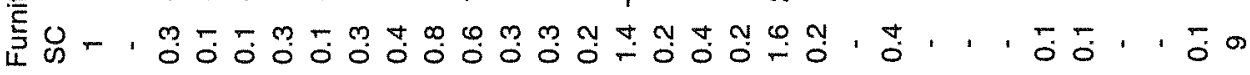
艺

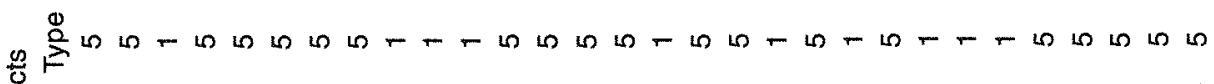

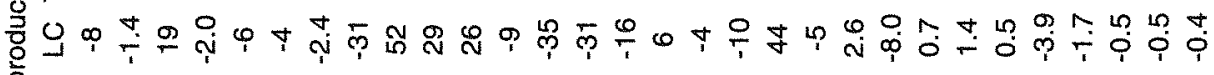
g $U$ 茂

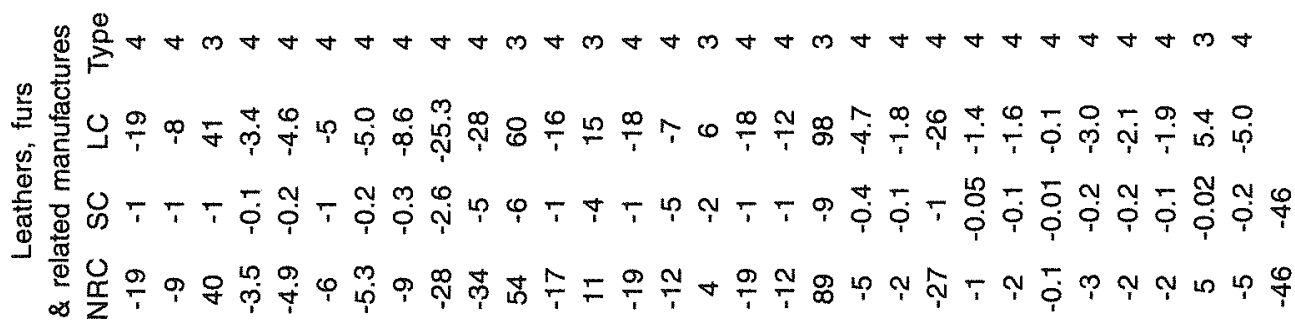

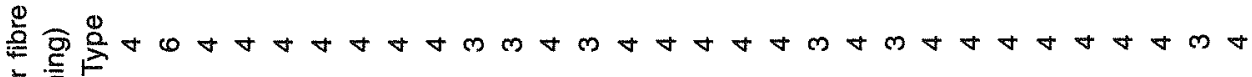

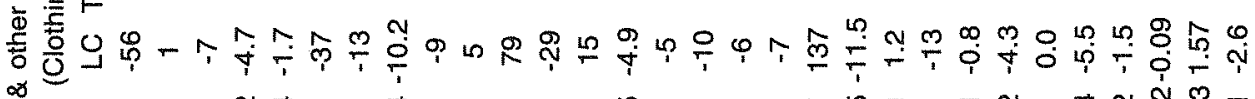

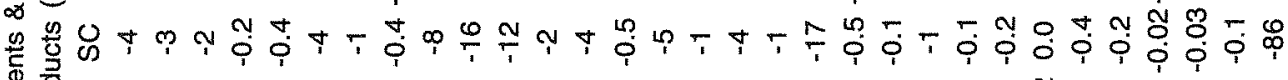

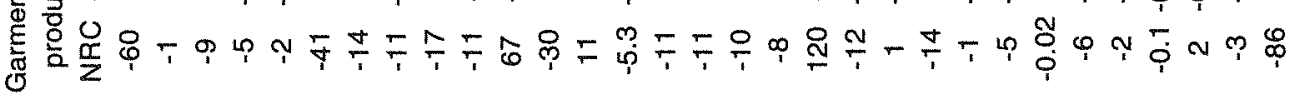

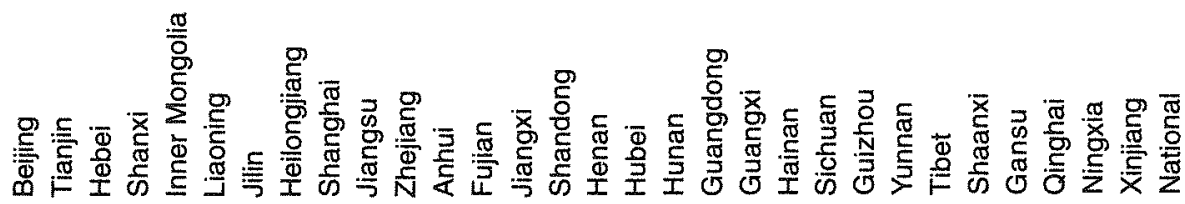




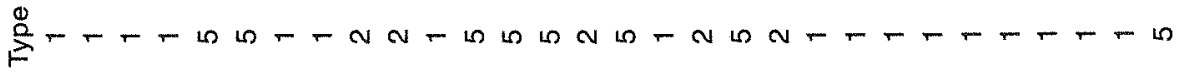

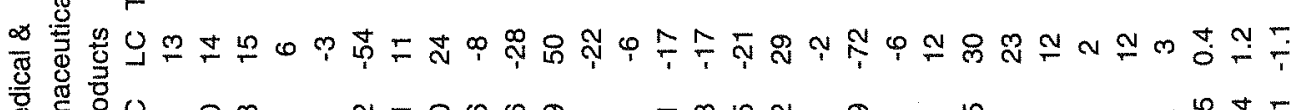

음

夰 $\bar{N}$

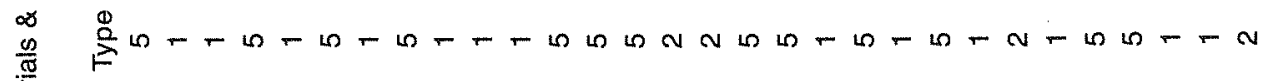

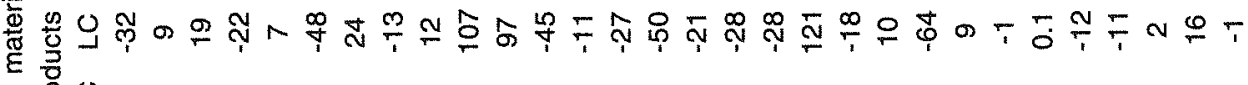
类造品

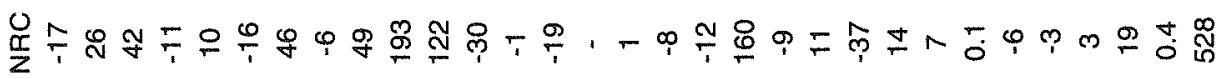

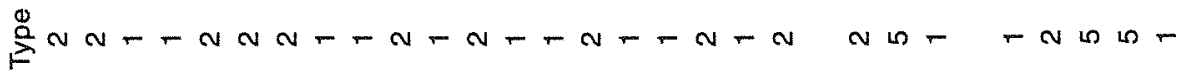

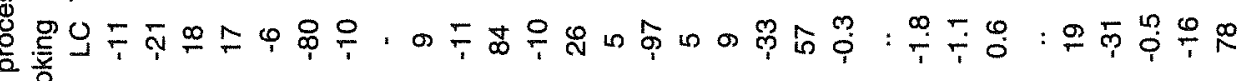

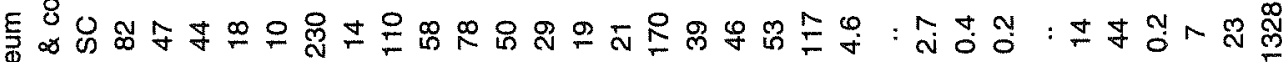

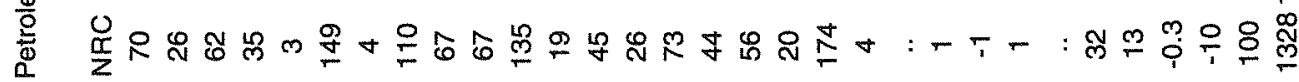

可 跑

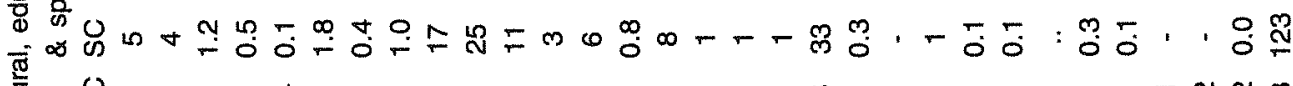

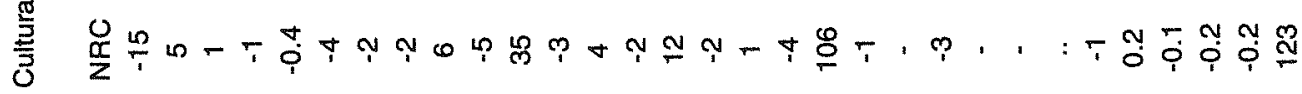

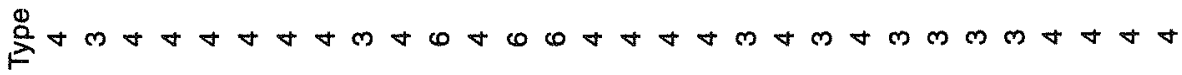

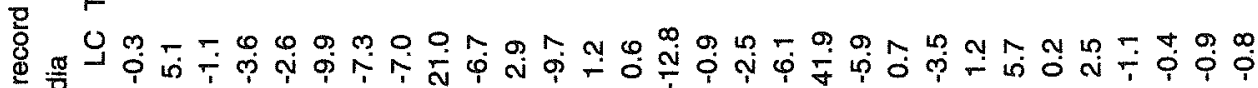

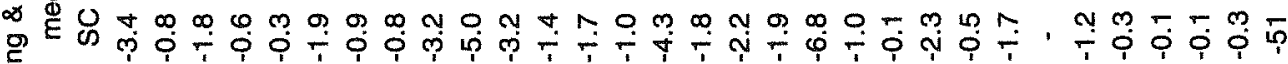
毫

芷

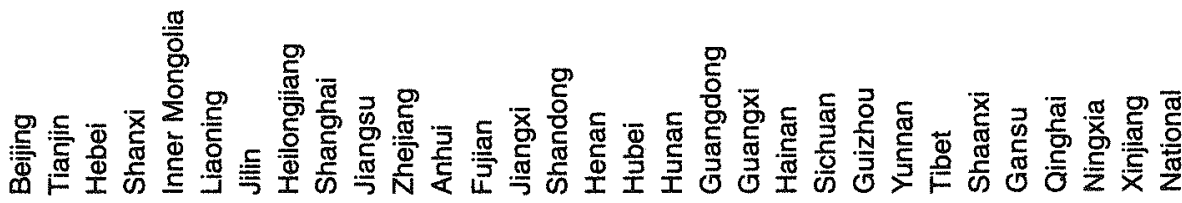




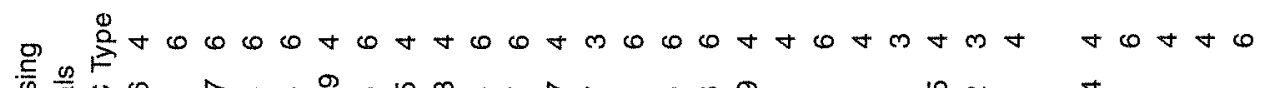

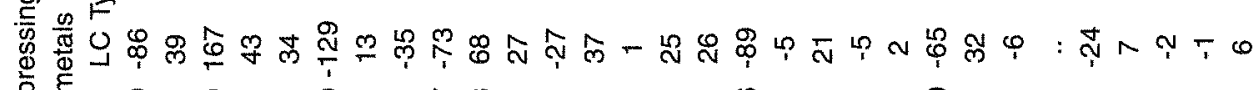

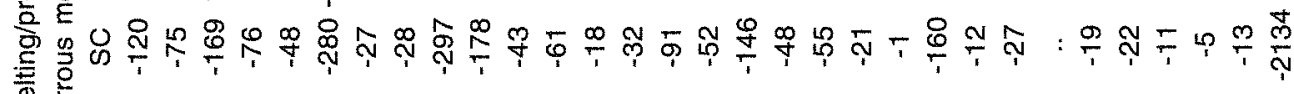
岕 西 厸

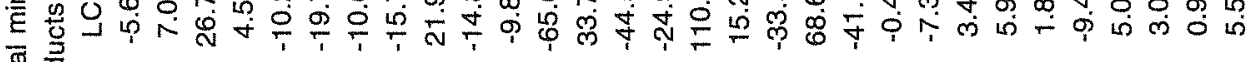
焉吾 है 号

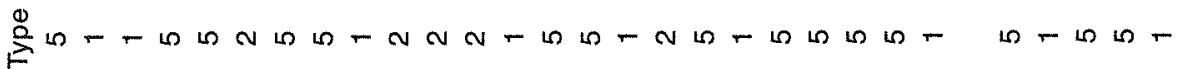

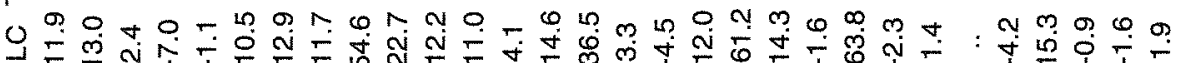
T T $1, T$ T

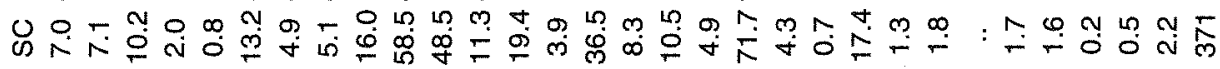

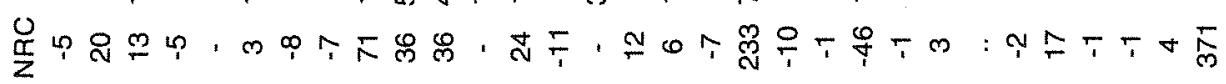

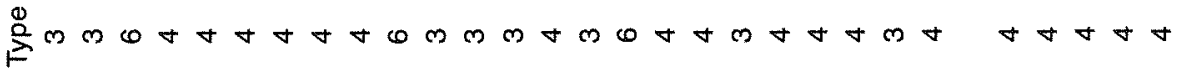

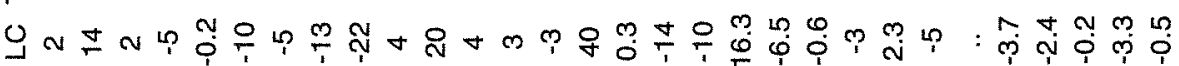

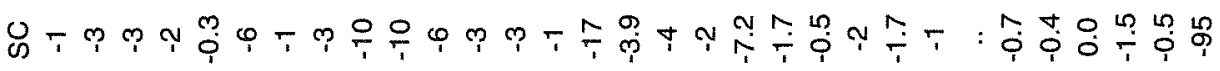

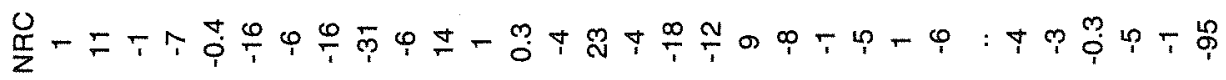

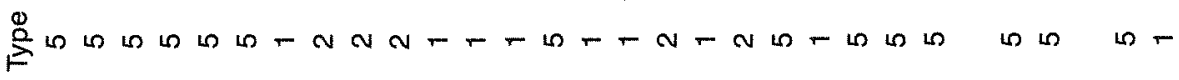
递

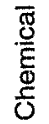

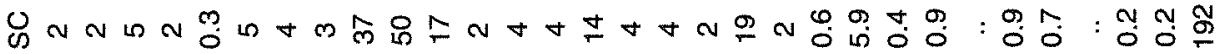

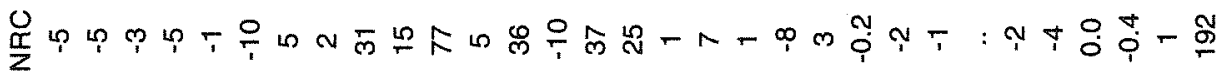

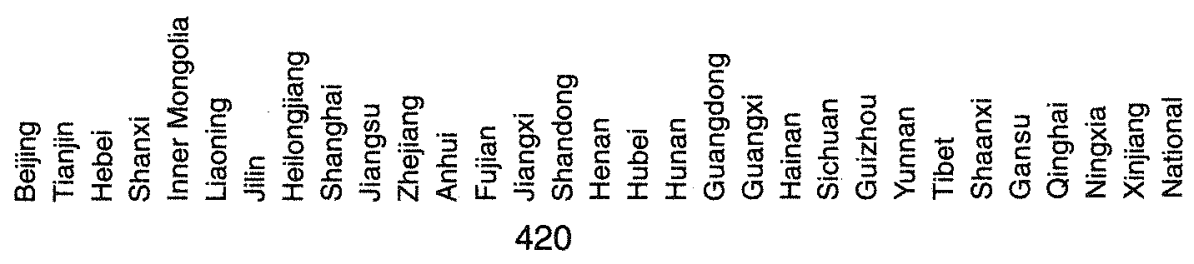




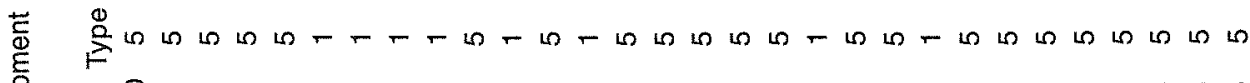
产

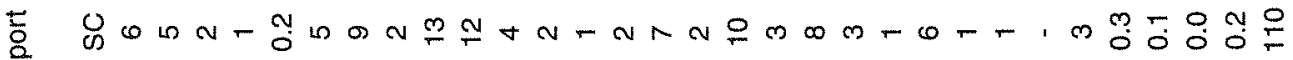

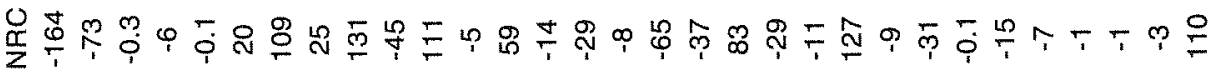

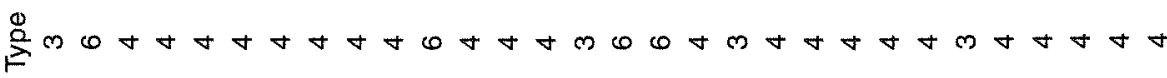
$\%$

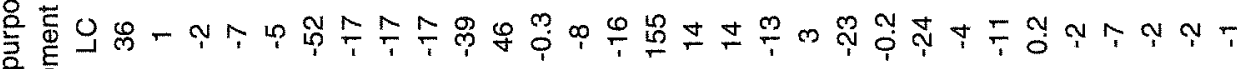

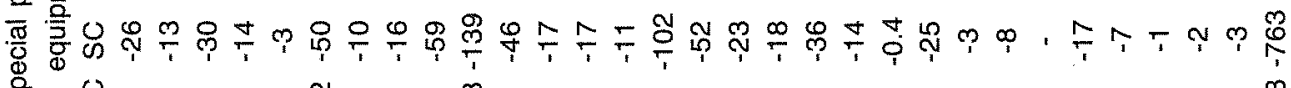

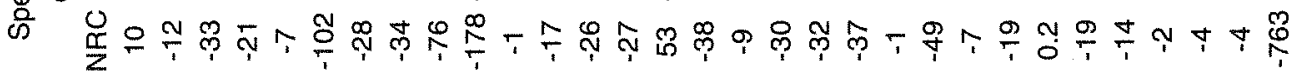
焉

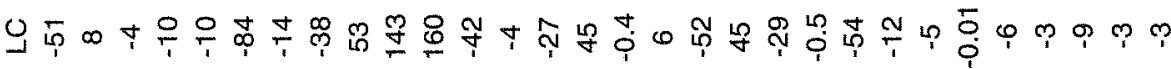

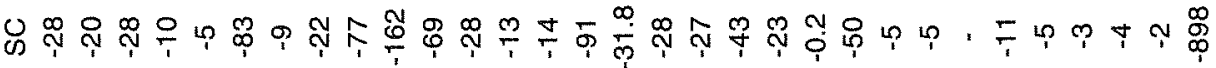

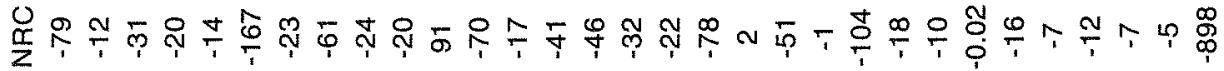

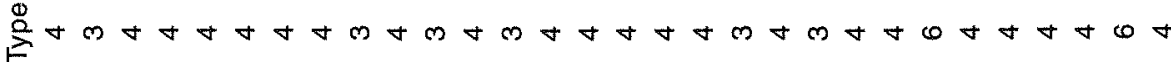

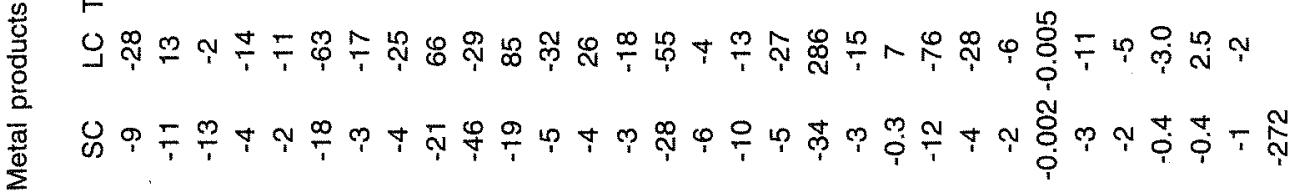
蒙

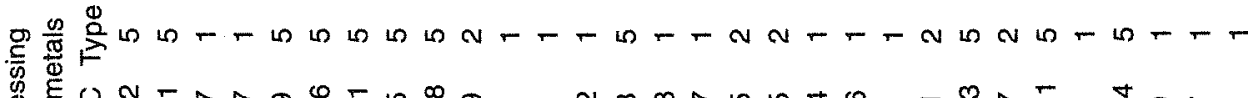

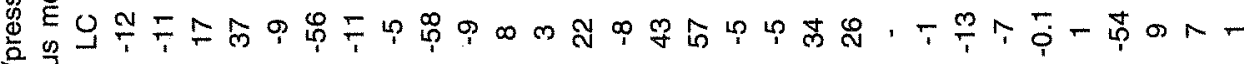
焉递品

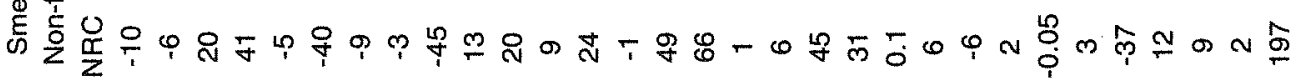

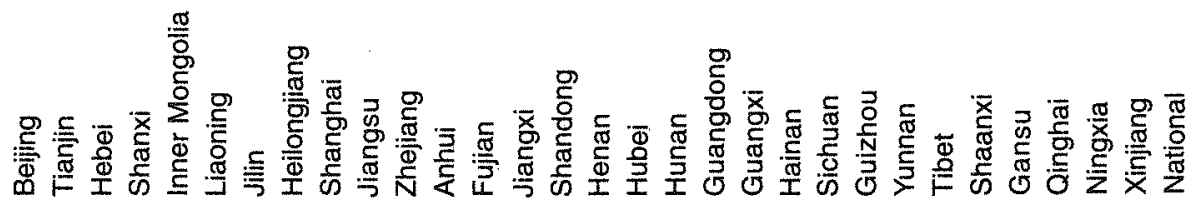




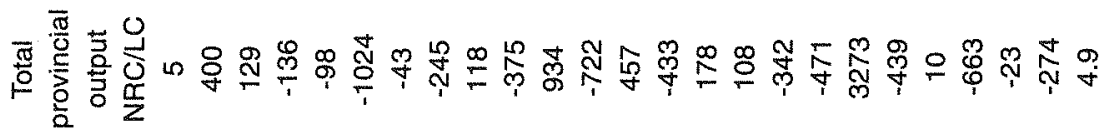

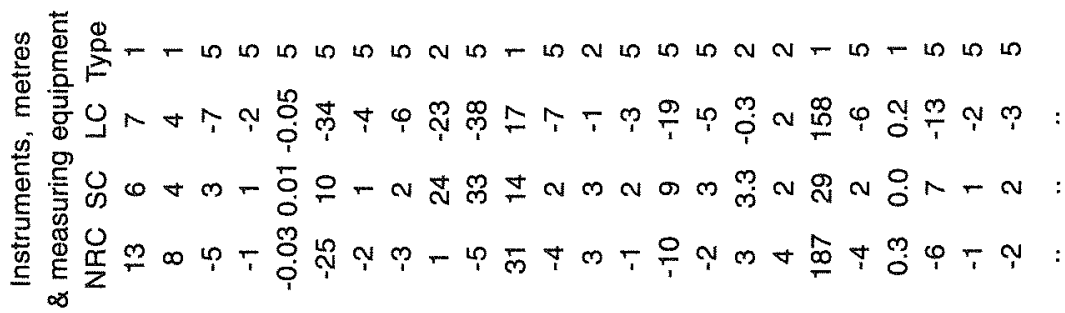

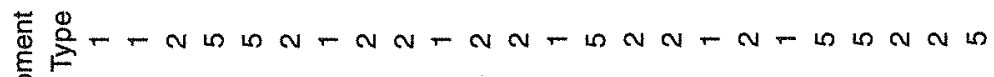

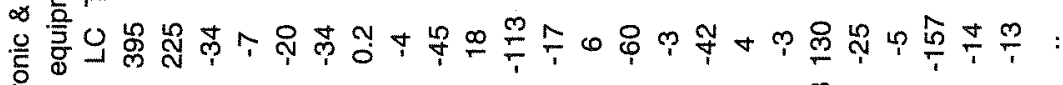

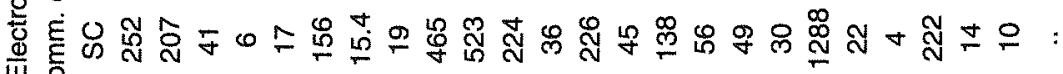

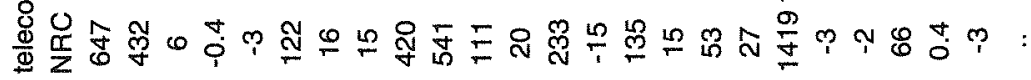

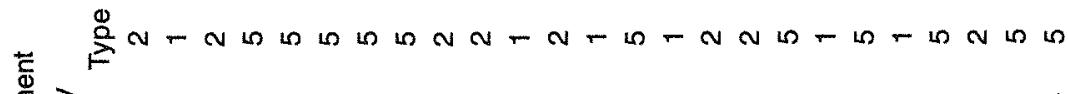

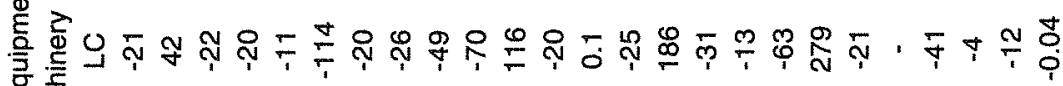

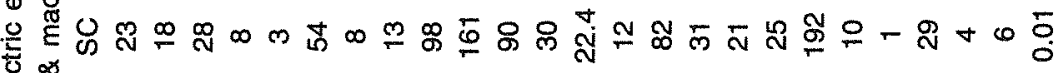

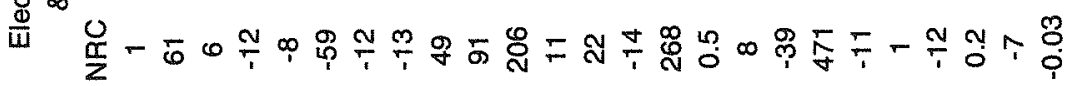

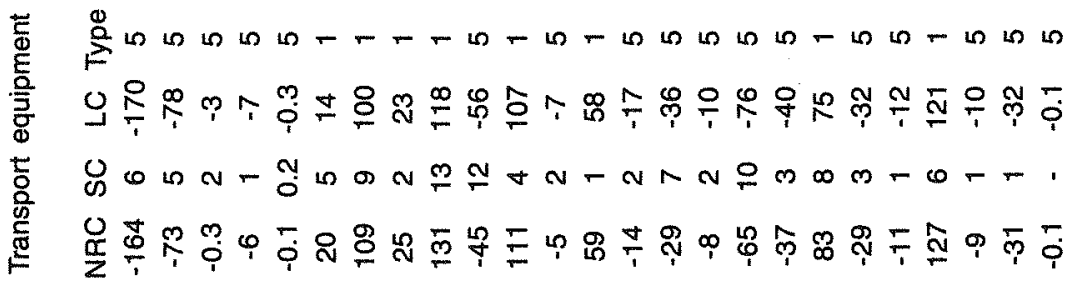

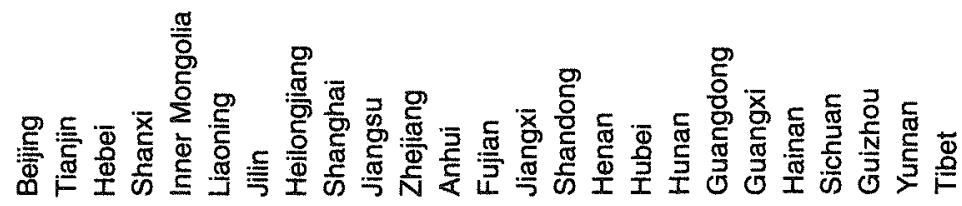
422 


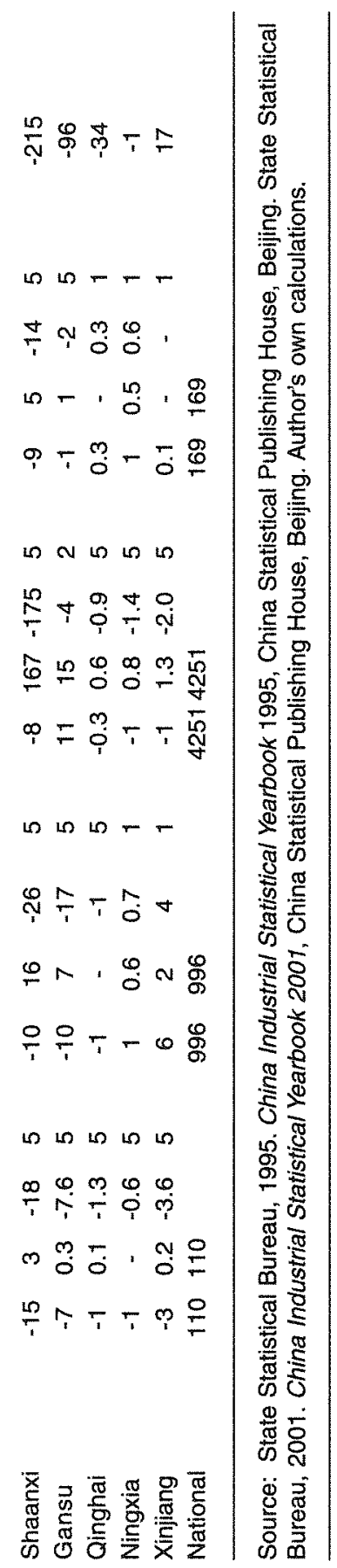




\section{POLICY ISSUES}

Having established that location matters, the crucial question for China's policymakers, which shift-share analysis does not provide any answers to, is whether or not they can influence the locational advantages of individual provinces in order to encourage industrial development in less developed areas. And if this is not the appropriate way to address regional inequality, what is? This section raises some key issues in this regard.

China's immense size and diversity suggest a natural tendency towards regional inequality. With populations ranging from 2.5 million in Tibet to 117 million in Sichuan, and areas ranging from roughly 6,000 square kilometres in Shanghai to 1.7 million square kilometres in Xinjiang, it should be rather obvious that patterns of development would not conform across provinces. This has certainly been the historical experience of China. As long ago as the Song dynasty (960-1279), the economic centre was shifting towards the coastal region. By the end of the Qing dynasty (1644-1911) foreigners began to invest in and establish foreign-run factories along the east coast. The concentration of industrial enterprises in coastal China increased through the second half of the nineteenth century, partly because of the opening of numerous treaty ports there. The Treaty of Nanjing saw the opening of Guangzhou, Fuzhou, Xiamen, Ningbo and Shanghai on the southeast coast to foreign economic activities. ${ }^{12}$ When market forces were re-introduced in the late 1970s, it seemed fairly natural that industrialisation would take up where it had left off prior to the era of command planning. Put simply, 'accidents of history' have favoured China's coastal provinces.

This historical background was clearly recognised by Deng Xiaoping in his Open Door Policy, which was a major initiative underlying the commencement of China's economic reforms. In 1979 four Special Economic Zones (SEZs) were established in Shenzhen, Zhuhai, Shantou (all in Guangdong) and Xiamen (in Fujian). SEZs were granted special administrative and economic powers and enjoyed tax breaks and other privileges. This initial kick-start to development began a cumulative process of industrial agglomeration, by making these provinces more attractive locations for both foreign-invested and domestic industrial production. Rising industrial profits generated higher incomes which, as a result of fiscal decentralisation, remained in provincial hands. Re-investment in infrastructure and other local-level services led to relative cost reductions, which further encouraged firms to locate in areas where success bred success. This process continues today. 
While extremely difficult to quantify, it is difficult to overlook the vital role that government policy has played. Guangdong provides the best example. While it certainly had the geographical advantage of proximity to Hong Kong, initial policy support through the central government's regional policies compounded this advantage, facilitating the rise of reform-minded provincial leaders who in turn came up with innovative local initiatives to obtain foreign capital and technologies and to

Table 22.5 Summary of types

\begin{tabular}{|c|c|c|c|c|c|c|c|c|c|c|}
\hline & \multicolumn{7}{|c|}{$\begin{array}{c}\text { Total number of sectors } \\
\text { in each category }\end{array}$} & \multirow{2}{*}{\multicolumn{2}{|c|}{$\begin{array}{cc}\text { Location Structure } \\
\text { favours } & \text { favours } \\
\text { growth } & \text { growth } \\
1+3+6 & 1+2+5\end{array}$}} & \multirow{2}{*}{$\begin{array}{c}\text { Positive } \\
\text { NRC } \\
1+2+3\end{array}$} \\
\hline & 1 & 2 & 3 & 4 & 5 & 6 & Sum & & & \\
\hline Beijing & 5 & 2 & 2 & 9 & 9 & 1 & 28 & 8 & 16 & 9 \\
\hline Tianjin & 10 & 2 & 3 & 4 & 4 & 5 & 28 & 18 & 16 & 15 \\
\hline Hebei & 9 & 4 & 2 & 6 & 3 & 4 & 28 & 15 & 16 & 15 \\
\hline Shanxi & 3 & - & 1 & 9 & 13 & 2 & 28 & 6 & 16 & 4 \\
\hline Inner Mongolia & 3 & 2 & 1 & 10 & 11 & 1 & 28 & 5 & 16 & 6 \\
\hline Liaoning & 2 & 3 & - & 12 & 11 & - & 28 & 2 & 16 & 5 \\
\hline Jilin & 6 & 1 & - & 11 & 9 & 1 & 28 & 7 & 16 & 7 \\
\hline Heilongjiang & 5 & 2 & - & 12 & 9 & - & 28 & 5 & 16 & 7 \\
\hline Shanghai & 9 & 6 & 3 & 7 & 1 & 2 & 28 & 14 & 16 & 18 \\
\hline Jiangsu & 6 & 6 & 2 & 6 & 4 & 4 & 28 & 12 & 16 & 14 \\
\hline Zhejiang & 13 & 2 & 6 & 1 & 1 & 5 & 28 & 24 & 16 & 21 \\
\hline Anhui & 2 & 4 & 1 & 11 & 10 & - & 28 & 3 & 16 & 7 \\
\hline Fujian & 8 & 3 & 7 & 2 & 5 & 3 & 28 & 18 & 16 & 18 \\
\hline Jiangxi & 1 & - & 1 & 9 & 15 & 2 & 28 & 4 & 16 & 2 \\
\hline Shandong & 5 & 4 & 3 & 6 & 7 & 3 & 28 & 11 & 16 & 12 \\
\hline Henan & 8 & 3 & 3 & 5 & 5 & 4 & 28 & 15 & 16 & 14 \\
\hline Hubei & 5 & 7 & 2 & 6 & 4 & 4 & 28 & 11 & 16 & 14 \\
\hline Hunan & 2 & 5 & 1 & 11 & 9 & - & 28 & 3 & 16 & 8 \\
\hline Guangdong & 14 & 1 & 8 & 1 & 1 & 3 & 28 & 25 & 16 & 23 \\
\hline Guangxi & 1 & 2 & - & 11 & 13 & 1 & 28 & 2 & 16 & 3 \\
\hline Hainan & 9 & 1 & 6 & 5 & 5 & 1 & 27 & 16 & 15 & 16 \\
\hline Sichuan & 3 & 3 & 1 & 10 & 10 & 1 & 28 & 5 & 16 & 7 \\
\hline Guizhou & 4 & 2 & 5 & 7 & 10 & - & 28 & 9 & 16 & 11 \\
\hline Yunnan & 4 & 3 & 2 & 9 & 9 & 1 & 28 & 7 & 16 & 9 \\
\hline Tibet & 4 & - & 3 & 6 & 5 & - & 18 & 7 & 9 & 7 \\
\hline Shaanxi & 5 & - & 1 & 11 & 11 & - & 28 & 6 & 16 & 6 \\
\hline Gansu & 4 & 2 & 1 & 9 & 10 & 2 & 28 & 7 & 16 & 7 \\
\hline Qinghai & 5 & * & 1 & 11 & 10 & 0 & 27 & 6 & 15 & 6 \\
\hline Ningxia & 7 & 1 & 2 & 8 & 8 & 2 & 28 & 11 & 16 & 10 \\
\hline Xinjlang & 8 & 2 & - & 10 & 6 & 2 & 28 & 10 & 16 & 10 \\
\hline National average & 6 & 2 & 2 & 8 & 8 & 2 & 28 & 10 & & 10 \\
\hline
\end{tabular}


promote non-state sector developments (Chung 1997). As a recent article points out, 'Twenty years ago Shenzhen was a small, non-descript area of three square kilometres with a population of 30,000. Ten years later it was a cluster of labourintensive processing workshops. Today it is the most developed and compact hitech area on China's mainland' (China Today, 2003:13). Recently Shenzhen has obtained further rights to experiment with WTO-related reforms ahead of the rest of the country, which should enable the city to continue its role as China's 'pacesetter'. In light of these continuing advantages, no wonder Guangdong remains China's most desirable location for industrial production, with agglomeration there still on the rise.

Guangdong is not the only province to have benefited from preferential treatment by the central government, although the timing of central government support for the reform process varies. Surely not coincidentally, so does the timing of rapid economic growth. The Shanghai people have identified 'policy gifts' from the centre as the crux of the economic reform process. 'Policy is wealth', according to one of their vice-mayors. ${ }^{13}$ As Jacobs (1997) argues convincingly, it is not difficult to see how they have reached this conclusion. At the end of the 1980s Shanghai was still tightly controlled by the central government, in large part due to the centre's heavy reliance on the municipality for revenues. In 1990 the Pudong area-subsequently China's fifth SEZ-was opened, offering incentives such as tax holidays, a freetrade zone, and extended land leases. Following that, Shanghai's enterprise tax rates were lowered and policies permitting the establishment of the stockmarket, futures exchanges and liberal foreign investment policies have attracted funds from both overseas and domestic investors. In other words, Shanghai has benefited from policy rather than funds from centre.

Prior to 1990 Shanghai's share in the gross value of China's industrial output declined continually while growth rates of real GDP and per capita GDP were consistently below average (Table 22.2). However since the early 1990s this situation has reversed, with Shanghai recording annual real GDP growth above the national average between 1993 and 2001. In 2002 Pudong recorded its highest investment in fixed assets and highest materialisation rate of foreign investment to date, with GDP increasing by 16.7 per cent over the previous year. This made 2002 the twelfth consecutive year of two-digit growth for Pudong (China Today April 2003:26-27). The shift-share analysis provides further evidence of this dramatic turnaround for Shanghai. In contrast with a similar analysis conducted between the years 1989 
and 1994, in which only four sectors recorded locational components working in their favour, Shanghai recorded 14 sectors with positive locational components between 1994 and 2000. Similarly, 18 sectors recorded positive NRCs during the period 1994-2000, compared with only seven sectors in the previous period. A similar reversal has clearly not been experienced by Liaoning or Guangxi, coastal provinces which appear to be relatively neglected on the preferential policy front. This is hardly proof that policy is the definitive cause of industrial success, but it certainly suggests that it has a role to play.

Unfortunately the claim that policy has assisted industrial development via creating locational advantages in certain coastal provinces does not lead to an equally valid claim that this could be repeated with success in China's interior. The most significant difference is that Deng's decision to favour the coastal region compounded the natural tendency-stemming from historical, geographical, political, cultural and other factors-towards regional inequality. In contrast, the 'Go West Campaign' appears to be aiming to counteract this natural tendency, making the current task inherently different and also more difficult. But that does not necessarily make it impossible.

The natural process of industrial agglomeration in a market economy is not boundless. Instead, rising costs in industrialising regions, combined with falling transport, transactions and other costs of doing business across regions, should eventually encourage firms to relocate to less developed regions. The shift-share analysis suggests that this process of trickle down remains fairly confined to the coastal provinces and a few neighbouring central provinces. ${ }^{14}$ An equalising regional policy is thus a question of how best to speed up this process.

It is tempting to suggest a set of central government policies which improve the 'locational advantages' of less developed regions. The key idea is that the 'coreperiphery' pattern could be reversed if policy measures were able to tilt the pattern of industrial production in favour of peripheral areas. Preferential policy measures such as investment and credit incentives could reduce the relative costs of producing in Peripheral areas. Subsidies to specific industries in certain regions or expenditure on local infrastructure could, theoretically, serve a similar purpose. Alternatively, direct fiscal transfers from richer to poorer areas should increase expenditure in the latter, thereby strengthening demand linkages there. However, the vast differentials in present industrial capabilities across provinces would require significant expenditure by the central government in order to create locational advantages-or agglomeration 
forces - which could outweigh those already firmly established in the coastal region. Weak central government finances and the sheer size of the problem (that is, western and most of central China), combined with problems such as 'picking winners'either in terms of industries or locations-suggest that in reality such measures are highly unlikely to prove effective. China's entry into the WTO, and the consequent increase in foreign involvement in virtually all industrial sectors alongside various requirements regarding non-discrimination (between state-owned and private firms, and also among provinces), further constrain the central government's options in this category.

A superior set of policy measures focuses on reducing broadly defined 'transport costs'. A key point to observe is that initial reductions in transport costs will actually worsen regional inequality (as we observe in the case of China). In other words, this set of measures necessarily focuses on the medium to long term. The underdeveloped transport system is only one factor contributing to the overall cost of doing business at a distance within China's domestic economy. Expenditure on the national transport system clearly reduces the costs of relocating to distant, peripheral areas. The Qinghai-Tibet Railway project, scheduled for completion by the end of 2006, is one example of this kind. Beyond efforts to reduce physical costs, policy could aim to reduce the informational, sales and support costs of doing inter-regional business by improving the provision and transmission of information. This could be accomplished by expanding telecommunications networks, providing access to computers and the Internet, organising inter-regional trading organisations and so on. Similarly, continued efforts to eliminate administrative and other ad hoc barriers to inter-provincial trade-or to integrate the domestic market-should encourage the dispersal of industry to hitherto underdeveloped provinces. ${ }^{15}$ The central government's call for 'mutually beneficial co-operation' between coastal and interior provinces in the Ninth Five-Year Plan is just one example of a potentially effective policy in this regard. While some of these measures would be costly, if implemented without regional bias they would at least overcome potential problems associated with 'picking winners'. Moreover, rather than attempting to counteract market forces, policy measures in this category simply seek to speed up the process of relocation which is an inherent part of industrial development in an increasingly marketised system.

Aside from central government policies, provincial governments can seek more actively to create economic environments that are conducive to industrial 
development. As one example of this, a recent Beijing Review (20 February 2003:3436) article discusses how in the last two years Qinghai Provincial government has revised its 300 economic laws and regulations in accordance with international practice and formulated a set of preferential policies to protect the interests of foreign investors. It has chosen projects in industries with 'strong potential', including nonferrous metals, salt chemicals and medicine in order to attract foreign investors. (It is perhaps a coincidence that the positive locational component accounted for 66 per cent of the positive NRC on Qinghai's smelting/pressing nonferrous metals and chemical materials, and that its NRC and locational component for medical and pharmaceutical products were also positive). This is more likely to succeed at a provincial level than a national one (although success is far from guaranteed). According to Wu Dawei, Director of the Department of Foreign Trade and Economic Co-operation of Qinghai, the policies have succeeded in bringing substantial increases in foreign investment to the province: foreign-funded enterprises invested US $\$ 270$ million in 2001, a 25 per cent increase over the previous year, and in the first half of 2002 they had already invested US $\$ 347$ million, a 130 per cent increase over the same period in 2001. While this evidence is anecdotal, it does suggest that provinciallevel policies may be important. They would perhaps be even more so in combination with an increased focus on the 'transport cost' category of policies at the central government level.

\section{CONCLUSIONS}

China's current trends in the growth of provincial and regional per capita income, underpinned by a process of industrial agglomeration, suggest that the central government has quite a challenge on its hands given its current objective of alleviating the regional inequalities that it has hitherto helped to promote.

The inverted U-shaped relationship between industrial agglomeration and 'transport costs', which in their very broadest sense provide a proxy for economic development (Krugman 1995) clarifies the notion that these trends are, to a large extent, a natural consequence of economic development in a market economy. On the upside of the $U$, firms and workers choose to locate near other firms in order to benefit from cost and demand linkages and other externalities associated with larger markets, which in turn draws in more and more firms and workers. During this phase, regional inequalities rise. There is ample empirical evidence to suggest that China remains on this side of the process. On the downside of the $U$, firms relocate in order to 
benefit from lower wages and other costs associated with industrial production in hitherto less developed areas. The theoretical endpoint of this process is an even distribution of industry and incomes across space. While this is unlikely to be the case in reality, an equalising regional policy becomes a question of how best to speed up the process of relocation. Although this is a question without obvious or simple answers, the empirical analysis and discussion above provide a few key points.

The shift-share analysis enabled us to identify locations where industrial performance appears to be above average for no reason other than that production was located in that area, and not elsewhere: location matters. The identification of certain coastal provinces as those locations confirmed that industrial agglomeration is an important component of the continuing rise in regional income inequality. But the methodology also enabled us to identify that some coastal provinces, particularly Liaoning and Guangxi, and virtually all the central provinces, were among the worst performers during the period in question. Given the current focus on western development, it is important to recognise the potential for non-western provinces to become areas of neglect in terms of regional policy formulation. Moreover, it is necessary to continually update the analysis in order to pinpoint how the 'winners' and 'losers' are changing over time.

The recognition that regional development is a dynamic process in which the beneficiaries certainly do change over time points to the difficulties a central government would face in trying to pick winners by directing (limited) fiscal resources either to specific industries or provinces. In an increasingly marketised and internationally integrated economy, it is better to leave the decisions of where to invest to the firms themselves, while provincial and lower level governments focus on making their own localities competitive as locations for investment. Central fiscal resources would be much better spent on efforts to reduce the physical and other costs of relocating to distant areas. Policies promoting the integration of the domestic economy fall into this category and would increase the likelihood that the benefits of industrialisation and WTO entry will benefit provinces beyond those in the current industrial Core. While more effort is needed to establish exactly what policies stand the greatest chance of alleviating China's regional inequalities, taking into account the issues addressed here will at least raise the likelihood of success. 


\section{NOTES}

1 This does not imply that the policy goal was successful, as this levelling came at significant cost.

2 Of course industrial development is not the only aspect of development that matters, but it certainly features significantly in China's policy agenda.

3 See Golley (2000) for a much more comprehensive discussion.

4 Hirschman (1958) and Myrdal (1957) introduced the terms 'trickle down' and 'spread' respectively to describe the eventual levelling out of development across regions within a country.

5 See Golley (2000) for a more detailed justification of using 'transport costs' as proxy for China's transition process.

6 See Golley $(2000,2002)$.

7 This method is adapted from Liu, Yao and Zhang (1999).

8 Golley (2002) conducts a similar analysis for the period 1989-94. This section will make reference to some of those results.

9 Further evidence of this claim is provided in Golley $(2000,2002)$.

10. Whether or not total output shares rise clearly depends on how much of their output is derived from sectors growing above average. Space limitations prevent a closer analysis of this point.

1 Again, space limitations prevent a more detailed analysis of sectoral shares in each province, which would validate this point.

12 Golley (2000) discuss these issues in much more detail. See also Yang (1997).

13 Xie Kequiang, quoted in Jacobs (1997:169).

${ }^{14}$ See Brun, Combes and Renard (2002) for further evidence of this.

15 Young (2000) and Poncet (2002) discuss China's lack of domestic market integration.

\section{REFERENCES}

Bao Shuming, Gene Hsin Chang, Sachs, J. and Wing Thye Woo, 2002. 'Geographic factors and China's regional development under market reforms, 1978-1998' China Economic Review, 13(1):89-111.

Brun, J.F., Combes, J.L. and Renard, M.F., 2002. 'Are there spillover effects between coastal and noncoastal regions in China?', China Economic Review, 13(2-3):16169.

Chung, J., 1997. 'Shandong: the political economy of development and inequality', in D.S.G. Goodman (ed.), China's Provincial Reform: class, community and political culture, Routledge, London:127-57. 
Démurger, S., 2001. 'Infrastructure development and economic growth', Journal of Comparative Economics, 29(1):95-117.

Deng Xiaoping, 1984. On SEZs and Opening More Cities to the Outside World, Excerpt from a talk with several senior comrades of the Central Committee of the Chinese Communist Party (CCCCP), Beijing, 24 February. Reprinted in Deng Xiaoping (1987), Fundamental Issues in Present Day China, Foreign Languages Press, Beijing:43-45.

- 1986. Take a Clear Cut Stand Against Bourgeois Liberalisation, Remarks on recent student disturbances made to some leading members of the CCCCP, Beijing, 30 December. Reprinted in Deng Xiaoping (1987), Fundamental Issues in Present Day China, Foreign Languages Press, Beijing:161-66.

_-, 1987. Fundamental Issues in Present Day China, Foreign Languages Press, Beijing.

Fujita, M. and Hu, D., 2001. 'Regional disparity in China 1985-1994: the effects of globalisation and economic liberalisation', Annals of Regional Science, 35(1):337.

Golley, J., 2000. The Dynamics of Regional Development during China's Economic Transition, Dphil Dissertation, Oxford University, Oxford.

- 2002. 'Regional patterns of industrial development during China's economic transition', Economics of Transition, 10(3):761-801.

Goodman, D. (ed.), 1997. China's Provincial Reform: class, community and political culture, Routledge, London.

Hirschman, A., 1958. The Strategy of Economic Development, Yale University Press, New Haven.

Jacobs, B.J., 1997. 'Shanghai: an alternative centre?', in D.S.G. Goodman (ed.), China's Provincial Reform: class, community and political culture, Routledge, London:163-93.

Krugman, P., 1991. Geography and Trade, Leuven University Press and MIT Press, Cambridge, Massachusetts.

- 1995. Development, Geography and Economic Theory, MIT Press, Cambridge, Massachusetts.

Lardy, N., 1978. Economic Growth and Distribution in China, Cambridge University Press, Cambridge.

Liu, A., Yao, S. and Zhang, Z., 1999. 'Economic growth and structural changes in employment and investments in China, 1985-94', Economics of Planning, 32(3):171-90. 
Lyons, T., 1991. "Inter-provincial disparities in China: output and consumption, 19521987', Economic Development and Cultural Change 39(3):471-506.

Myrdal, G., 1957. Economic Theory and Underdeveloped Regions, Gerald Duckworth, Essex.

Mody, A. and Fang-Yi Wang, 1997. 'Explaining industrial growth in coastal China: economic reforms... and what else?", World Bank Economic Review, 11(2):293325.

Poncet, S., 2002. 'Measuring Chinese domestic and international integration', China Economic Review, 14(1):1-22.

State Statistical Bureau, 1997. The Gross Domestic Product of China, 1952-95, Dongbei University of Finance and Economics Press, Dalian.

State Statistical Bureau, various years. Statistical Yearbook of China, China Statistical Publishing House, Beijing.

State Statistical Bureau, various years. China Industrial Economic Statistical Yearbook [Zhongguo Gongye Jinji Tongji Nianjian], China Statistical Publishing House, Beijing.

Yang, D., 1997. Beyond Beijing: liberalization and the regions in China, Routledge, New York.

Yao, S., 1997. 'Industrialisation and spatial income inequality in rural China, 198692', Economics of Transition, 5(1):97-112.

Yao, S. and Zhang, Z., 2001. 'On regional inequality and diverging clubs: a case study of contemporary China', Journal of Comparative Economics, 29(3):46684.

Young, A., 2000. 'The razor's edge: distortions and incremental reform in the People's Republic of China', The Quarterly Journal of Economics, 115(4):1091-135.

Zhao, Z., Documents of the Thirteenth National Congress of the Communist Party of China, Foreign Languages Press, Beijing.

Zeng Peiyan, 2000. Implementing the Strategy for Western Region Development, Interview conducted by Li Rongxia, Beijing Review, 29 May:22-24.

Ziyang, Z., 1987. Documents of the Thirteenth National Congress of the Communist Party of China, Foreign Languages Press, Beijing.

Zhu, R., 2000. Opening Address at the Third Session of the Ninth National People's Congress, Beijing, 5 March. 


\section{3}

\section{Government transfer payments and regional development}

\section{Tingsong Jiang and Zhiyun Zhao}

Rapid economic change in China has been accompanied by worsening regional disparity. The income gap between China's coastal and inland regions ${ }^{1}$ has been widening since the economic reforms began in 1978 (Figure 23.1). Of the three regions, the Eastern coastal region (the richest region) experienced the fastest economic growth in the past two decades. Average per capita GDP in the Eastern region increased sevenfold, while per capita GDP in the Western region (the poorest region) increased less than fivefold. The gap in per capita GDP between the Eastern and Western regions increased from 380.6 yuan in 1978 to $3,354.9$ yuan in 2000 in real terms. This phenomenon has been well documented by many authors, for example, Wu (1999), Sun (2000), Sun and Parikh (2001) and Jiang (2002).

One way to tackle this problem is to use intergovernment transfer payments. ${ }^{2}$ Transfer payments could ease the regional disparity through three channels. First, payments to households in less developed regions could directly narrow the regional income gap. Second, transfer payments to finance more investment in health, education and infrastructure in less developed regions could improve these regions' economic growth potential and ease the disparity in the longer term. Third, transfer payments may reduce the tax burden in the recipient regions and thus give additional stimulation to their economies.

Transfer payments have played an important role in local government budgets in China. In 2001, about 41.3 per cent of local government revenues were transfers 
Figure 23.1 Per capita GDP
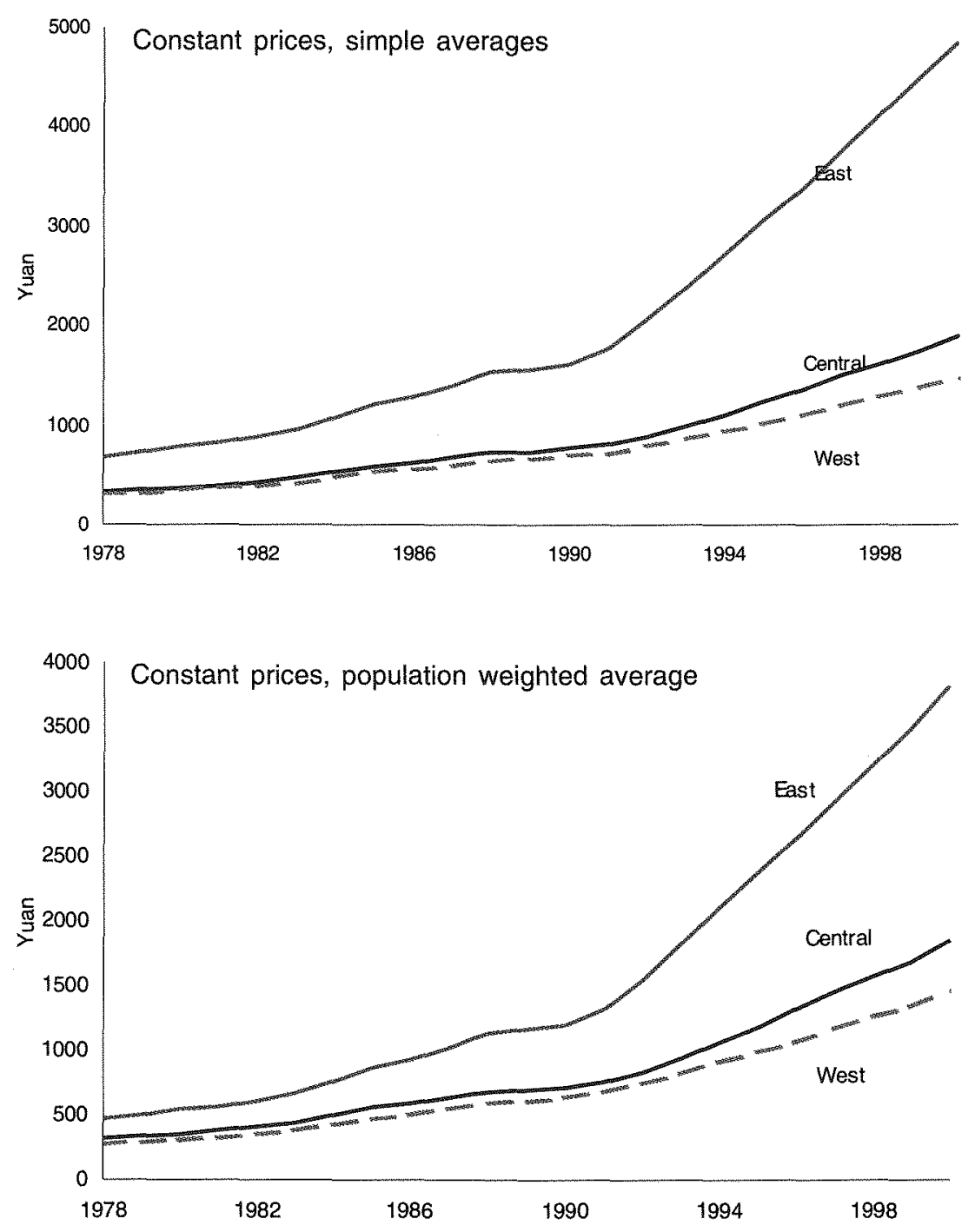

Source: Jiang, T., 2003. 'The impact of China's WTO accession on its regional economies', Australian Agribusiness Review, forthcoming. 


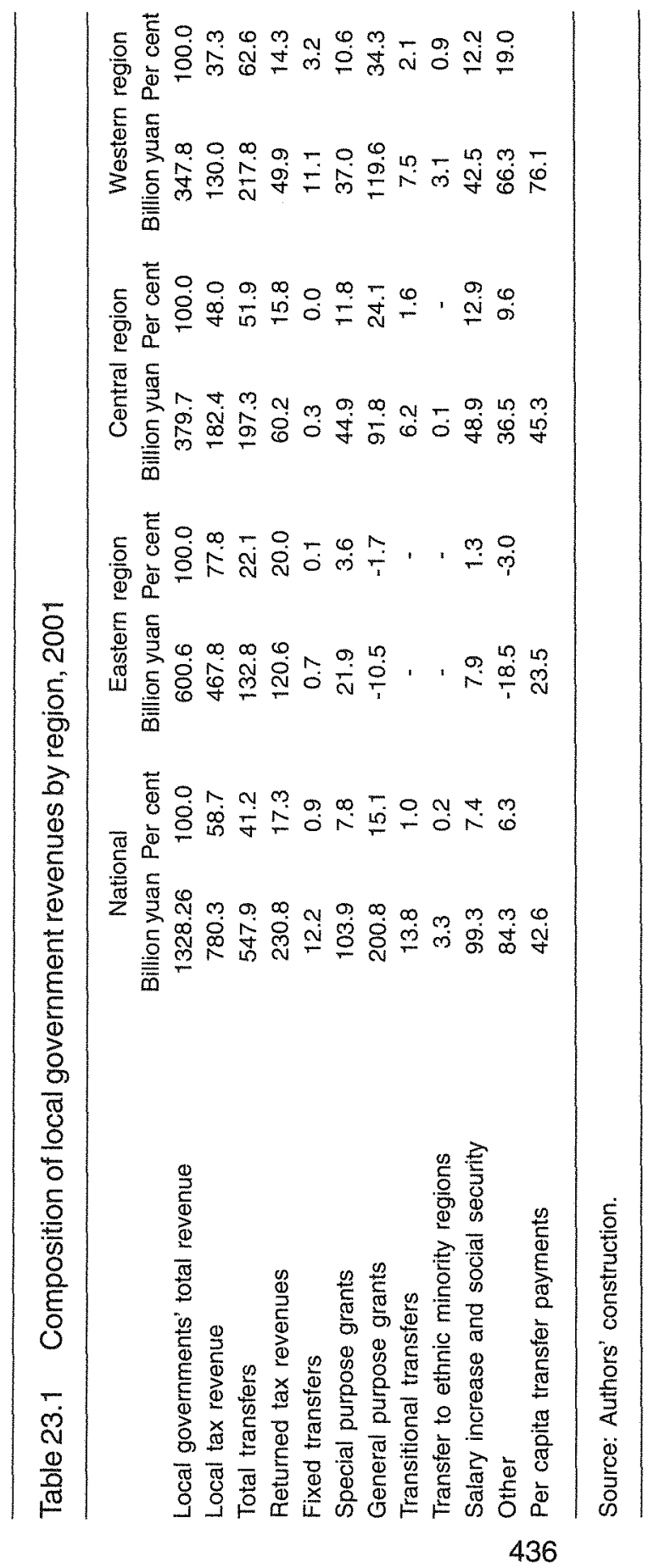


from the central government (Table 23.1). Most of these transfers, however, were purely tax revenues that were redistributed among the central and local governments through the tax sharing system (fen shui zhi). Only a very small proportion of transfers are dedicated to lessening the regional disparity. The share of the 'equalisation transfer' in total transfer payments from the central to the local governments was only 1.8 per cent in 2000 (He 2001). Therefore, many studies find that the transfer system failed to equalise per capita fiscal expenditure and per capita income (for example, Wong 2002a; Ma 2003). ${ }^{3}$

\section{GOVERNMENT TRANSFER PAYMENT SCHEMES}

China's government transfer payment practices have evolved along with its fiscal system. Before the economic reforms of 1978 there were no systematic transfer payments. Transfer payments, as supplementary measures, were made within other fiscal instruments under a centralised fiscal system. Public finances were gradually decentralised under the fiscal contract system (caizheng baogan zi) implemented in the 1980s and early 1990s, until the implementation of the tax sharing system in 1994. The implementation of the Transfer Payment Arrangement during the transitional period in 1996 marked the establishment of a formal and comprehensive program of government transfer payments. Thus, the evolution of transfer payment schemes can be divided into four periods: pre 1979, 1980-93, 1994-95 and post 1996.

\section{Transfer payments before 1979}

Before 1979, the Chinese economy was centrally planned and local governments' finance was strongly controlled by the central government. Revenues were allocated between central and provincial governments according to pre-defined shares. Under this fiscal regime, the central government's transfer payments to local governments took the form of 'deficit subsidy' and 'special purpose grants'.

On the basis of these pre-defined terms, the central government examined local governments' actual revenue and expenditure. Local governments either remitted all their surpluses to, or received full subsidy from, the central government to balance their deficits. The central government also provided grants to local governments in special cases such as natural disasters and large infrastructure projects. 
Although the form of transfer payment was simple during this period, the amount was usually large.

\section{Transfer payments between 1980 and 1993}

Between 1980 and 1993, as part of China's economic reform, government finance was gradually decentralised and a governmental fiscal contract system established. Under this system, the scope and base of revenues and expenditures was defined jointly by the central and local governments and local governments were responsible for the balance of their budgets. Transfer payments occurred in three forms-fixed transier, earmarked special purpose grants, and settlement subsidies.

Fixed transfer was guaranteed by the contract system for those local governments whose base revenues did not cover defined expenditures. The amount of this type of transfer payment was fixed by the level of the deficit in the base year. However, additional settlement subsidies and special purpose grants could still be available. Settlement subsidies were made when items of revenues and/or expenditures defined in the contract were changed, for example, when the ownership of firms transferred from the central government to local governments or vice versa. Special purpose grants were paid in two forms. Some were earmarked to finance special programs, such as agricultural support, large infrastructure projects, and so on. Others were used in the case of natural disasters.

Transfer payments during this period were diversified and informal. In 1988, for example, there were nine forms of fixed transfers, 21 forms of special purpose grants and 15 forms of settlement subsidies. Administrative costs were therefore high, and efficiency low.

\section{Transfer payments between 1994 and 1995}

In 1994, as part of a comprehensive tax reform package, the central government replaced the fiscal-contract system with a tax-sharing system. Under this system, tax revenues received by the central and local governments were clearly defined and collected by different agencies. Tax revenues assigned to the central government included customs duties, excises and value added tax (VAT) on imports; excise; enterprise income tax collected from central government-owned enterprises; taxes collected from railways, headquarters of banks and insurance companies; 75 per cent of domestic VAT; and 91 per cent of security stamp duty. Tax revenues assigned to local governments included 25 per cent of domestic VAT; business tax except 
that collected from railways, banks and insurance companies; company income tax except that collected from central government-owned enterprises; personal income tax; resources tax; urban maintenance and construction tax; real estate tax; agricultural tax and others (Zhang 2002).

As a result of the tax-sharing system, the central government's revenue, and thus the transfer payments, increased significantly. In 1994 and 1995, transfer payments to local governments amounted to 213 and 245 billion yuan, accounting for 78 and 76 per cent of the central government's revenue, and 60 and 52 per cent of local governments' expenditure, respectively (Du 2001:49). Most of the transfer payments were in the form of 'returned revenues', which were designed to ensure that local governments' revenues after the implementation of the tax assignment system did not fall below the 1993 level. The returned revenues, accounting for 77 per cent of total transfer payments in 1995, were not a real increment to the transfer payment as they were originally part of the local governments' revenues. Nevertheless, they provided the central government more room to use fiscal instruments. The remaining transfer payments were equivalent to previous settlement, fixed transfer and special purpose grants.

\section{Transfer payments after 1996}

In 1996, transfer payments were formalised and systematised when the Transfer Payment Arrangement was implemented. These 'transitional' transfer payments consisted of two parts: objective factor-determined transfer payments and policybased transfer payments. The amount of objective factor-determined transfer payments $\left(T O_{i}\right)$ is calculated according to the formula,

$$
T O_{i}=\left(E_{i}-R_{i}\right) \times a
$$

where $E_{i}$ and $R_{i}$ are respectively region is standard fiscal revenues and expenditures, and $a$ is the coefficient of objective factor-determined transfer payment, which is in turn determined by

$$
a=\frac{T-T P}{R-E}
$$

where $T$ is the total amount of transfer payments nationwide, TP is the amount of national policy based transfer payments, and $R$ and $E$ are, respectively, national standard fiscal revenues and expenditures. No objective factor-determined transfer payments are made to regions with more revenues than expenditures. 
Policy-based transfer payments were dedicated to ethnic minority autonomous regions, according to the difference between regional standard fiscal revenue and expenditure. The amount of this type of transfer payment was affected by two factors: the difference of fiscal capacity in the growth rate, and the difference in fiscal capacity per capita, between the nation and the particular region (Ma 1998:94).

In 1998, some changes were made to the Transfer Payment Arrangement, mainly involving the adjustment of the calculation of standard fiscal revenues and expenditures. In 2002, a new decree, the General Transfer Payment Arrangement, was promulgated, mainly to address the issue of transfer payments to the inland regions. General transfer payments were similar to the objective factor-determined transfer payments, except that the transfer payment coefficient differed across regions (Ministry of Finance Budget Department 2003).

However, the 'transitional transfer payment' played a very limited role because it accounted for only a small proportion of total transfer payments, just above 2.5 per cent in 2001 . In the Eastern, Central and Western regions, its share in local governments' total revenues was only $0.01,1.63$ and 2.17 per cent, respectively (Table 23.1).

At present, 41.3 per cent of local governments' total fiscal revenues are from transfer payments from the central government (Table 23.1). These transfers fall into four broad categories-fixed transfer, returned tax revenue, special purpose grants, and general purpose grants. General purpose grants include transitional transfers, transfers to ethnic minority regions, transfers to increase the salaries of public servants and improve social security networks, and other grants, such as settlement subsidies. The shares of these four categories in total transfer payments are shown in Figure 23.2.

\section{AN EVALUATION OF THE TRANSFER PAYMENT SYSTEM}

The impact of transfer payments on regional development can be examined from two aspects-whether the structure of transfer payments is appropriate to address the problem of regional disparity, and whether the transfer payments actually contributed to regional fiscal equalisation and growth convergence.

\section{Are richer provinces receiving more transfer payments?}

It is often argued that the transfer payments in China have failed to ease regional disparity, as richer regions receive even more transfers than poor regions (Ma 2003). This could happen for two reasons. First, the central government collects more 
taxes from the more developed regions, and under the tax-sharing system these regions receive more transfers in the form of returned tax revenue (Table 23.1). Second, the transfer payment system is virtually a negotiable scheme, meaning developed regions can receive fairly large amount of transfers in other forms.

The situation has changed, however, and this concern may no longer be valid. Although richer regions still receive more transfers in the form of returned tax revenues, poorer regions receive more transfers in total. As shown in Table 23.1, the total amount of transfer payments in 2001 to the Central and Western regions was, respectively, double and three times the amount of transfer payments to the Eastern region.

This pattern is also evident at the provincial level. Figure 23.3 plots per capita total transfer payments (23.3a) and per capita transfer payments other than returned revenues (23.3b) received by each province, autonomous region or municipality against its per capita GDP in 2000 . It can be seen from the charts that there is a negative relationship between per capita transfers and per capita GDP.

Figure 23.2 Composition of transfer payments by region, 2001

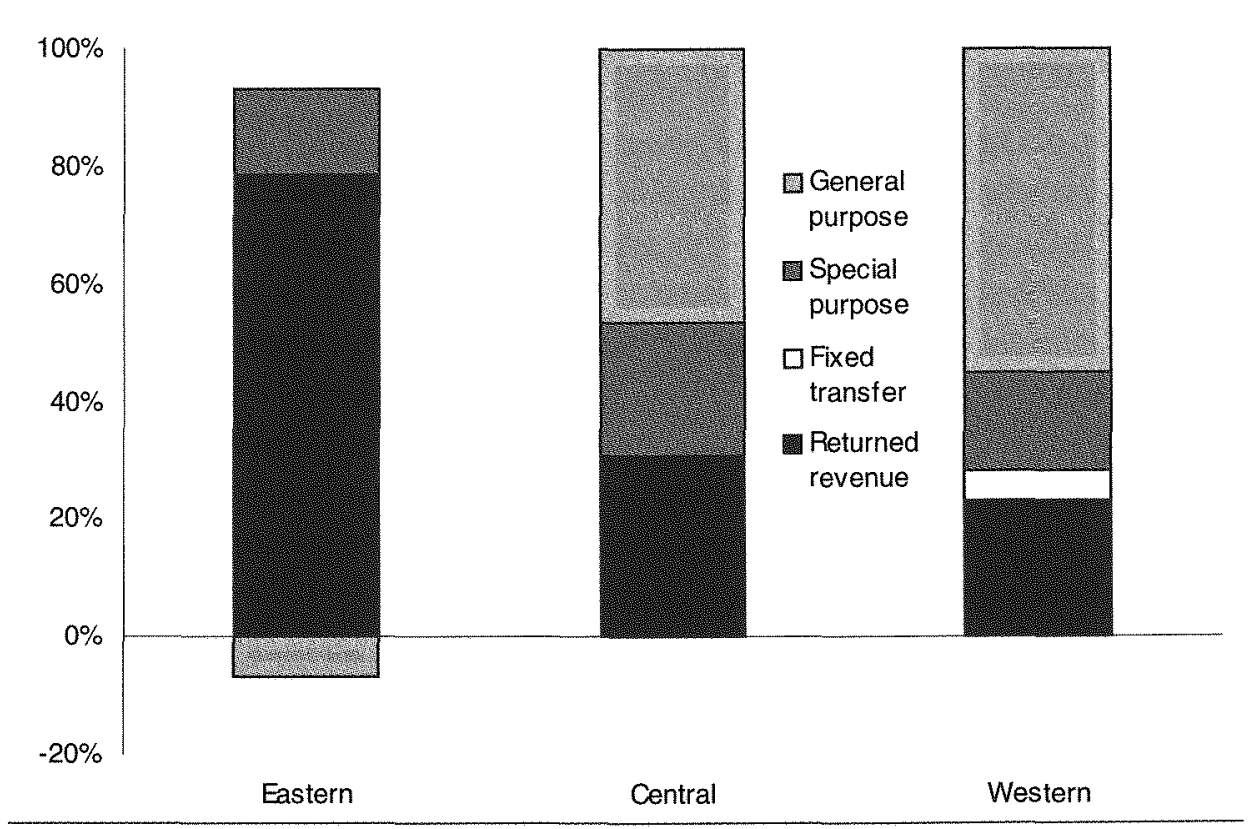

Source: Authors' construction based on statistics 
This is confirmed by the following OLS regressions of per capita transfer payments against per capita GDP:

$$
\begin{aligned}
P_{C T T_{i}=} & 543.359-0.0210 P C G D P_{i} \\
& (5.19) \quad(1.50) \\
\text { PCTO }_{i}= & 533.222-0.0296 P C G D P_{i} \\
(4.29) & (2.56)
\end{aligned}
$$

where $P C T T_{i}, P_{C T O}$ and $P C G D P_{i}$ are, respectively, per capita total transfer payments, per capita transfer payments other than returned revenues, and per capita GDP in province $i$; and numbers in brackets under the equation are t-ratios for estimated coefficients. It can be seen that there is a significant (at 5 per cent level) negative relationship between per capita GDP and other transfers. That is, poorer regions receive more transfers than returned revenues from the central government. There is a weaker negative relationship between per capita total transfer payments and per capita GDP if the outliers-Shanghai, Beijing, Tianjin and Shanghai-are excluded.

This indicates that in recent years poorer regions have received more transfer payments from the central government than richer regions.

\section{TRANSFER PAYMENTS AND REGIONAL FISCAL INEQUALITY}

The pattern of China's regional fiscal inequality has been changing over time while the impact of transfer payments on regional fiscal capacity has been a debatable issue.

Under the fiscal-contract system that prevailed during the 1980 s and early 1990 s, China's fiscal system was decentralised and regional governments were required to finance themselves. Economists have been concerned that regional self-finance may have worsened the inequalities. Jin et al. (1999), however, find that regional fiscal inequality actually improved during the fiscal contract system period.

Table 23.2 reports the coefficients of variation for per capita revenue and expenditure across provinces between 1982 and 1992. It shows that the regional disparity for budgetary and extra-budgetary revenues and expenditures improved over the period. For example, the coefficient of variation for budgetary revenue fell from 1.99 in 1982 to 0.98 in 1992 . On the other hand, the coefficient of variation for per capita budgetary revenue remittance (the difference between budgetary revenue and expenditure) rose from 4.25 in 1982 to 7.78 in 1992, implying greater revenue redistribution from rich to poor provinces. In other words, the transfer payments helped ease regional fiscal inequality during the period. 
Figure 23.3 The relationship between regional income and transfer payments, 2000

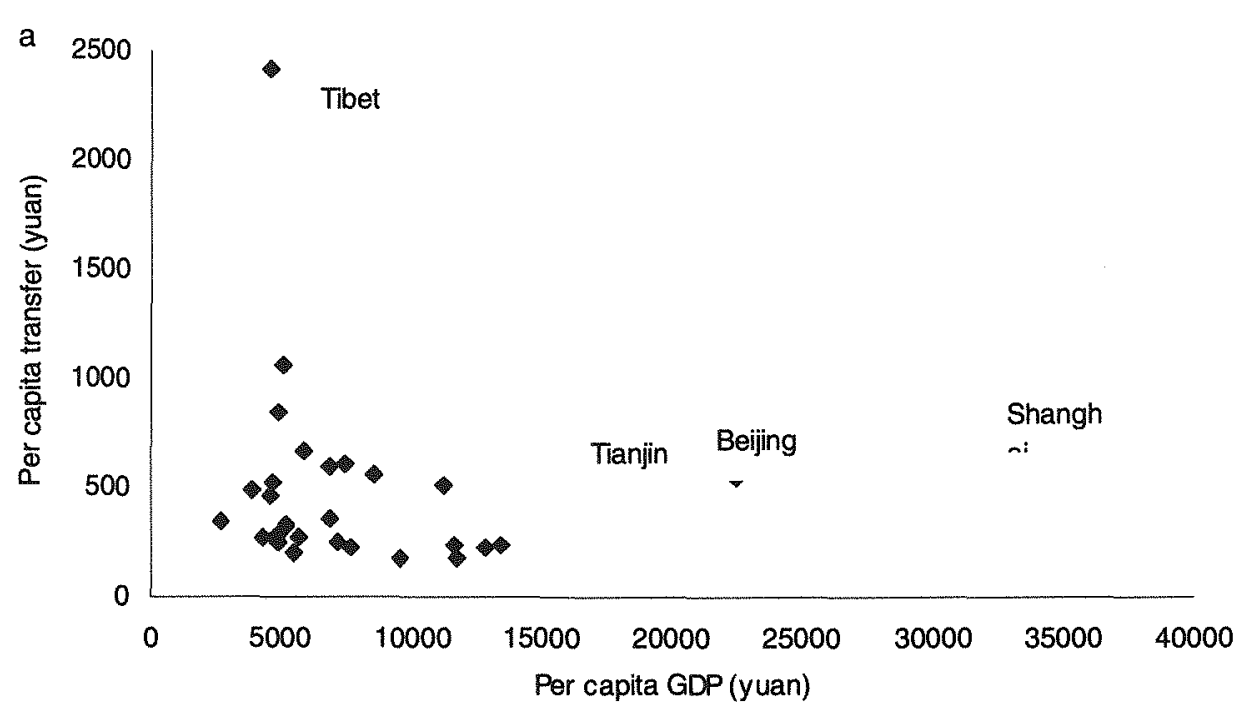

b

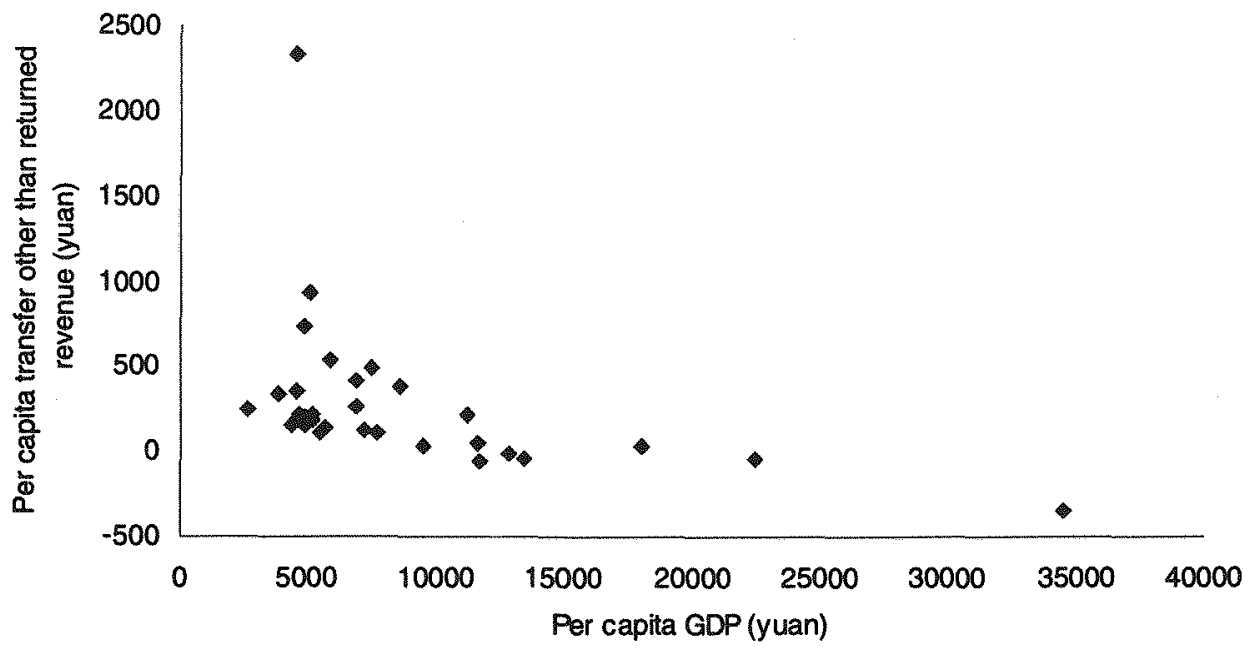

Note: a per capita total transfer payments vs per capita GDP b per capita transfer payments other than returned tax revenues vs per capita GDP 
Wong (2002a) observes that regional fiscal inequality started worsening in 1993. For example, the coefficients of variation for per capita expenditure rose from 0.534 in 1992 to 0.675 in 1998, and the maximum to minimum ratio jumped from 6.6 to 19.1 during the same period (Table 23.3). Based on these observations, Wong argues that the transfer payment system failed to equalise.

However, it seems that regional fiscal inequality has improved in recent years. Both the maximum to minimum ratio and the coefficient of variation for per capita revenue and expenditure were lower in 2001 than in 1998 (Table 23.3). Because our data sources and variable definitions may be different to Wong's (2002a), our results may not be directly comparable with hers. The results for 2000 and 2001, however, are comparable as they have consistent data sources and definition. At least for these two years, there was an improvement in regional fiscal inequality.

Table 23.1 shows that, in 2001, the Eastern, Central and Western regions received $24.2,36.0$ and 39.8 per cent respectively, of the central government's transfer payments. Given that these regions account for $42.5,34.8$ and 23.7 per cent of the Chinese population, respectively, it is clear that the improvement in regional fiscal inequality was a result of increasing transfer payments from the central government to less developed regions.

Table 23.2 The coefficients of variation for per capita revenue and expenditure across provinces, 1982-92

\begin{tabular}{lccccc}
\hline & $\begin{array}{c}\text { Budgetary } \\
\text { revenue }\end{array}$ & $\begin{array}{c}\text { Budgetary } \\
\text { expenditure }\end{array}$ & $\begin{array}{c}\text { Budgetary } \\
\text { revenue } \\
\text { remittance }\end{array}$ & $\begin{array}{c}\text { Extra- } \\
\text { budgetary } \\
\text { revenue }\end{array}$ & $\begin{array}{c}\text { Extra- } \\
\text { budgetary } \\
\text { expenditure }\end{array}$ \\
1982 & 1.9 & 0.6 & 4.2 & 1.0 & 0.8 \\
1983 & 1.8 & 0.6 & 5.0 & 1.0 & 0.9 \\
1984 & 1.7 & 0.6 & 6.1 & 1.0 & 1.0 \\
1985 & 1.6 & 0.6 & 6.9 & 1.0 & 0.9 \\
1986 & 1.5 & 0.6 & 5.3 & 1.0 & 1.0 \\
1987 & 1.3 & 0.5 & 3.9 & 1.0 & 1.0 \\
1988 & 1.2 & 0.5 & 4.5 & 1.0 & 1.0 \\
1989 & 1.0 & 0.5 & 4.8 & 0.9 & 0.9 \\
1990 & 1.0 & 0.5 & 6.2 & 0.9 & 0.9 \\
1991 & 0.9 & 0.5 & 6.1 & 0.9 & 0.9 \\
1992 & 0.9 & 0.5 & 7.7 & 0.8 & 0.8 \\
\hline
\end{tabular}

Source: Jin, H., Quian, Y., and Weingast, B.R., 1999. Regional decentralisation and fiscal incentives: federalism, Chinese style, Stanford University, Stanford, unpublished:Table 22.6. 


\section{TRANSFER PAYMENTS AND REGIONAL ECONOMIC GROWTH}

The ultimate purpose of transfer payments is to stimulate regional economic growth. Jiang (2002) observes a divergence of per capita income in Chinese provinces, autonomous regions and municipalities after 1995. One way to evaluate the impact of transfer payments on regional disparity is to examine whether payments have contributed to this divergence.

$\mathrm{Ma}$ (2003) presents an econometric analysis of the impact of transfer payments on regional growth. He estimates the following regional economic growth equations using regional data from 1995 and 2000

$$
\begin{aligned}
& \ln Y_{i T}-\ln Y_{i 0}=C-\left(1-e^{-\beta T}\right) \ln Y_{i 0}+\varepsilon_{i}, \\
& \ln Y_{i T}-\ln Y_{i 0}=C-\left(1-e^{-\beta T}\right) \ln Y_{i 0}+\gamma T R A N S F_{i}+\varepsilon_{i},
\end{aligned}
$$

where $Y_{i o}$ and $Y_{i T}$ are, respectively, per capita GDP of province $i$ in year 0 and year $T ;$ TRANSF $_{i}$ is the per capita transfer payment received by province $i$ during the

Table 23.3 Trends in the inter-regional distribution of fiscal resources, 1990-2001

\begin{tabular}{ccccccc}
\hline & \multicolumn{3}{c}{ Per capita expenditure (yuan) } & \multicolumn{3}{c}{ Per capita revenue (yuan) } \\
& Max./Min. & Average & Coeff. var. & Max./Min. & Average & Coeff. var. \\
1990 & 6.1 & 241.0 & 0.551 & 17.5 & 227.0 & 1.084 \\
1991 & 6.6 & 268.0 & 0.539 & 16.5 & 256.4 & 1.007 \\
1992 & 6.6 & 282.9 & 0.534 & 15.8 & 271.0 & 0.998 \\
1993 & 8.1 & 355.5 & 0.546 & 15.0 & 360.9 & 0.940 \\
1994 & 9.7 & 417.6 & 0.665 & 15.2 & 271.6 & 0.992 \\
1995 & 16.6 & 512.2 & 0.768 & 16.3 & 333.5 & 1.010 \\
1996 & 18.1 & 612.7 & 0.801 & 15.9 & 413.7 & 1.029 \\
1997 & 19.5 & 708.8 & 0.882 & 16.8 & 486.3 & 1.094 \\
1998 & 19.1 & 817.5 & 0.864 & 16.8 & 558.2 & 1.093 \\
2000 & 7.6 & 1058.1 & 0.705 & 7.7 & 1076.4 & 0.698 \\
2001 & 7.0 & 1326.4 & 0.675 & 7.0 & 1348.3 & 0.675 \\
\hline
\end{tabular}

Note: $1990-98$ indicators are calculated from data of 29 provinces, municipalities and autonomous regions, with Tibet excluded and Chongqing included in Sichuan for 1990-98; 2000-01 indicators are calculated from data of all 31 provinces, municipalities and autonomous regions in mainland China.

Source: 1990-98 figures from Wong, C., 2002. Issues of Equalization in China, presentation to Intergovernmental Fiscal Relations in East Asia Workshop, Bali, 10-11 January. 2000-01 figures from authors' own calculation. 
period from year 0 to year $T$; and $\beta$ is a convergence coefficient. A positive (negative) $\beta$ indicates convergence (divergence); that is, regions with higher per capita GDP level in the base year have a higher (lower) growth rate. Ma finds that the transfer payment variable is not included, $\beta$ is between -0.012 without regional dummy and -0.021 with regional dummy and is statistically significant. If the transfer variable is included, the coefficient of transfer payment $(\gamma)$, is significant and positive, and the value of $\beta$ falls to -0.018 and -0.023 , respectively, without and with regional dummy. From these results, Ma concludes that the 'transfer widens regional gaps'.

We believe, however, that the above results should be interpreted in the opposite direction. Although regional economic growth diverges, transfer payments help to mitigate this trend. In Equation 23.5, $\beta$ captures all the impacts on regional growth, whilst in Equation 23.6 it captures other impacts except transfer payments. As the value of $\beta$ in Equation 23.5 is smaller in absolute value than in Equation 23.6, the regional growth is less divergent if the transfer payments are included than if they are not. This may become clearer from the following derivation.

According to the estimates made earlier, the transfer payment received by a particular region is negatively related to its GDP level. For convenience, this relationship may be written as

$$
\operatorname{TRANSF}_{i}=\bar{T}-\alpha_{i} \ln Y_{i 0}
$$

where $\bar{T}$ is a fixed amount which is independent of regional income, $\alpha_{i}$ is a positive coefficient which is region specific. Replacing TRANSF $F_{i}$ with the above relationship, Equation 23.6 becomes

$$
\ln Y_{i T}-\ln Y_{i 0}=C+\gamma \bar{T}-\left(1-e^{-\beta T}+\gamma \alpha_{i}\right) \ln Y_{i 0}+\varepsilon_{i}
$$

It is clear from comparing Equation 23.5 with Equation 23.6' that $\beta$ in Equation 23.5 includes the effect of transfer payment $\gamma \alpha_{i}$.

The above discussion reveals that, during 1995-2000, regional gaps in per capita incomes were widening at a rate of 1.2-2.1 per cent per annum. However, if there were no transfer payments, the widening rate would have been 1.8-2.3 per cent.

\section{OUTSTANDING ISSUES}

Although the above analysis shows that transfer payments have played a positive role in improving regional disparities in recent years, it does not imply that the system is problem-free. In fact, many imperfections have been associated with this system. 
First, the structure of the transfer payments is problematic. As shown in Table 23.1 and Figure 23.2, general-purpose grants account for only 15 per cent of total transfer payments. Within the category of general-purpose grants, only the transitional transfer', which accounts for less than 7 per cent of general-purpose grants or 1 per cent of total transfer payments, is dedicated for the purpose of 'equalisation'. Most of the grants are still allocated for special purposes. For example, about half of the general purpose grants were used to increase payments to public servants and improve the social security system. This structure gives little flexibility for local governments to arrange the use of transfer payments according to their own needs. Moreover, special purpose grants often require matching funds from the recipient regional governments. This arrangement may have two negative impacts. First, it may in fact increase rather than decrease the tax burden on recipient regions as these regions have to raise the matching funds. Alternatively, the recipient governments may try to divert the earmarked grant to other purposes, thus corrupting the fiscal discipline.

The second problem of the current fiscal and transfer payment system is that it does little to deal with extra-budgetary and off-budget revenues, which include user charges for government provided goods and services, administrative fees for government services and incomes from government-owned enterprises. Local governments have good reason to collect extra-budgetary and off-budget revenues under the tax-sharing system because they are responsible for providing vital public services, such as education, health care, social security and welfare, ${ }^{4}$ but their budgetary revenues are not enough to fund the provision of these services. As a result, the magnitude of extra-budgetary revenues is equivalent to that of budgetary revenues. For example, extra-budgetary and budgetary revenues in 1999 were equivalent to 12 and 14 per cent of GDP respectively (Wong 2001, 2002b). This huge amount of extra-budgetary revenues and expenditures not only makes budgetary management more difficult, but also widens regional gaps in regional government fiscal capacity and government services. For example, in 2001, the World Bank ranked China $61^{\text {st }}$ out of 191 countries in overall quality of health, but $188^{\text {th }}$ in terms of fairness in financial contribution (World Health Report 2000, cited in World Bank 2001). One of the two fieldwork counties referred to in World Bank (2001) could not provide six years of primary schooling.

The third problem is the uneven tax burden on local economies. Figure 23.4 plots each province's average tax rate-the ratio of total taxes collected by the central 
and local governments from a province to that province's total GDP_-against its per capita GDP. The relationship displays a U-shape: the most developed and the least developed provinces have higher tax rates than the middle-income provinces. It becomes clearer if the provinces are grouped into the three regions as shown in Figure 23.5-the Western region has the highest average rate (12 per cent), followed by the Eastern region ( 10.8 per cent) and the Central region ( 9.2 per cent). This tax disparity not only further distorts the economy, but also hinders economic development in the least developed regions.

Finally, those involved in the discussion and design of a transfer payment scheme were preoccupied by equity criteria; although efficiency criteria are also important. Jiang (2003) shows that simply transferring funds from the Eastern coastal region to inland regions may reduce total welfare even though the regional gap might be narrowed. This is because the coastal region has better infrastructure, a higher technology level and a more market-oriented policy environment. Thus returns to resources are higher than those of the inland regions.

\section{STYLISED SIMULATION OF INCREASING TRANSFER PAYMENTS TO INLAND REGIONS}

The above discussion reveals that transfer payments in China have helped slow the trend of worsening regional disparity. However, the effect has been limited by the structure and scope of those programs. This section simulates different programs of increasing transfer payments to inland regions using a general equilibrium model of the Chinese economy with regional details (CERD).

\section{Description of the model}

This subsection gives a brief introduction to the model of the Chinese economy used in the analysis. ${ }^{5}$ (For more details of the model, see Jiang 2003).

As the name suggests, CERD is a multi-regional model of the Chinese economy. In this study a simple version of CERD is used, in which Chinese provinces are grouped into East, Central and West regions, as defined above. ${ }^{6}$

CERD uses the 'bottom-up' approach. Each region in CERD is treated as an open economy with its own agents and behavioural functions (Figure 23.6). Agents in each region make their decisions on the demand for, and supply of, commodities and primary factors, and regional economies are linked through commodity and factor flows. 
Figure 23.4 Provincial average tax rate versus per capita GDP, 2001

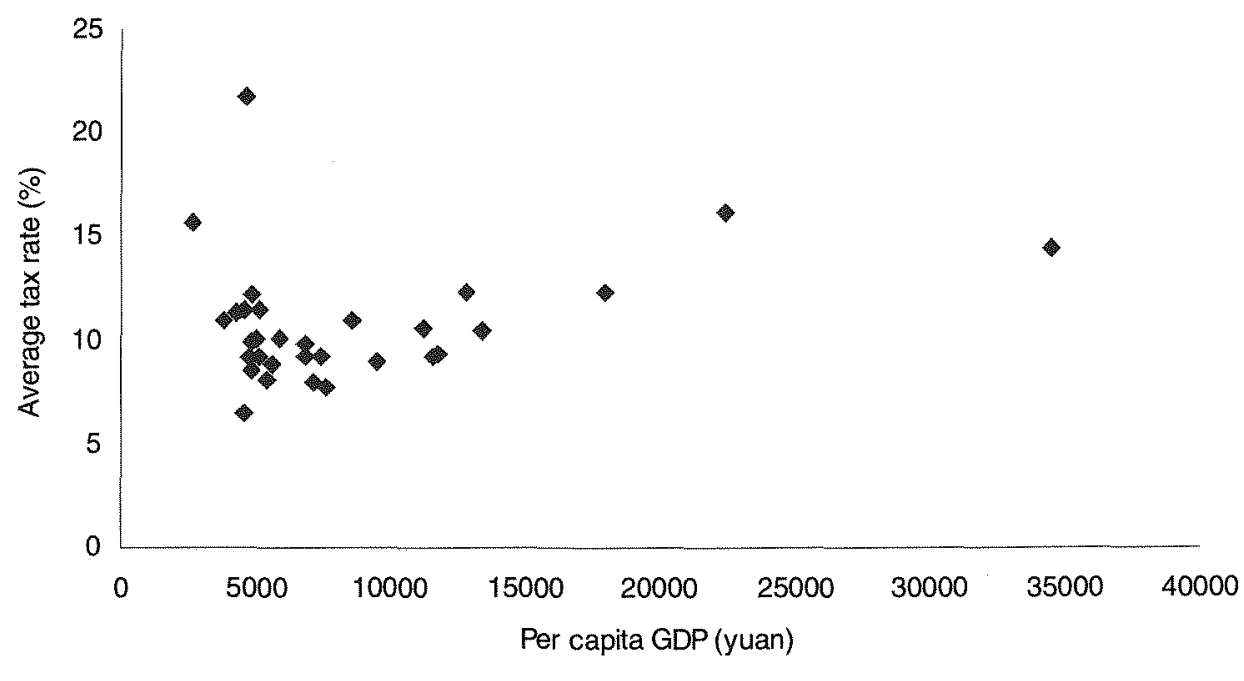

Source: Authors' construction.

Figure 23.5 Regional average tax rate, 2001

14

12

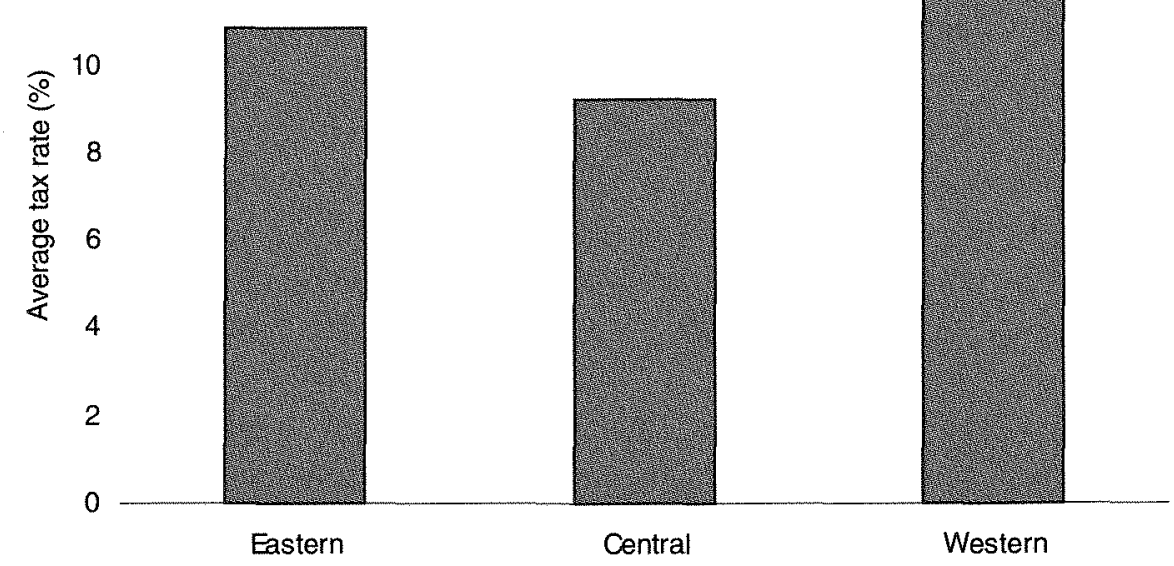

Source: Authors' construction 
It can be seen from the diagram that CERD mimics a global model of multiple regions as in the GTAP model (Hertel 1997). However, it has some peculiar features. First, regional links in CERD are more intensive than in a global model, especially for the movement of primary factors. Four types of labour are identified in CERD: urban labour, rural agricultural labour, rural non-agricultural labour and migrant labour. It is assumed that urban labour and rural migrant labour engage in non-agricultural activities only. CERD also assumes perfect mobility of capital across domestic regions and sectors.

As labour and capital can move across regional boundaries, it is important to distinguish between the usage and ownership of these factors, in order to calculate regional household income and consumption more accurately.

Another feature of CERD is that rural and urban households are distinguished in each region according to their possession of primary factors. This is appropriate for an analysis of the Chinese economy, where rural and urban areas are still separated to some degree because of various restrictions, although significant improvements have been made. For example, the household registration system, which identifies a person as a rural or urban resident, is still in effect and prevents people from freely moving across regions, especially from the countryside to cities.

Another difference between CERD and other global models lies in its treatment of regional links. Ideally, inter-regional flows of commodities and factors would be presented in the model, however, such information is not available as there are no 'customs' in each province to register 'imports' from and 'exports' to other provinces. In order to avoid arbitrary decisions in creating the database, CERD models interregional trade indirectly via a national pool of commodities and factors. Each region sells its excess supply to and buys excess demand from the national pool. For example, as shown in Figure 23.7, migrant labour in the national pool is a constant elasticity of substitution (CES) aggregation of migrant labour supplied by each region. The aggregate migrant labours are then allocated to each region to meet regional demand according to a constant elasticity of transformation (CET) process. The CES and CET processes represent regional differences in migrant labour supply and demand.

CERD also distinguishes between regional and national governments, which allows for the analysis of transfer payments. To simplify the treatment, it is assumed that tax collections (except import tariffs and export taxes), government saving and consumption are made by regional governments, while the central government serves 


\section{Figure 23.6 Structure of CERD}

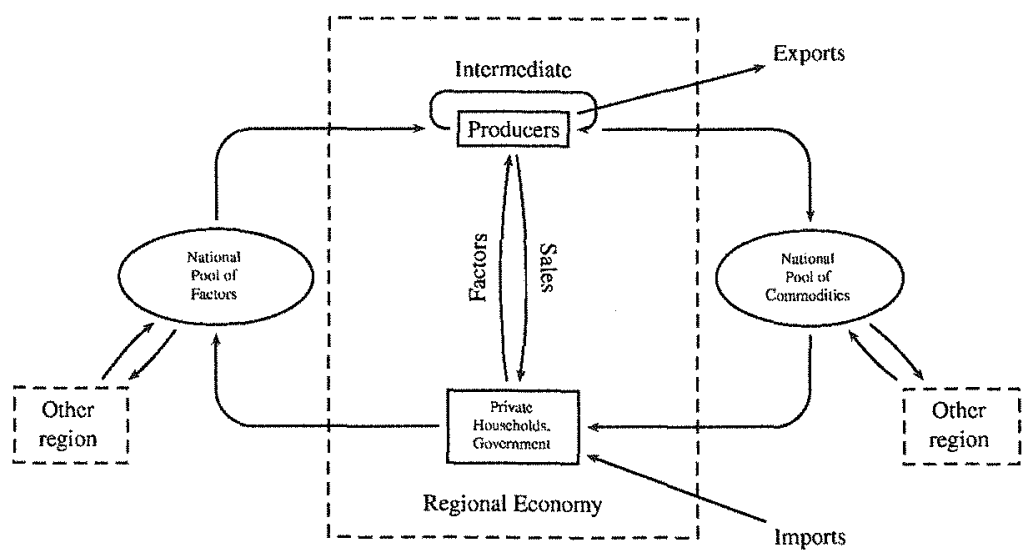

Figure 23.7 National migrant labour market

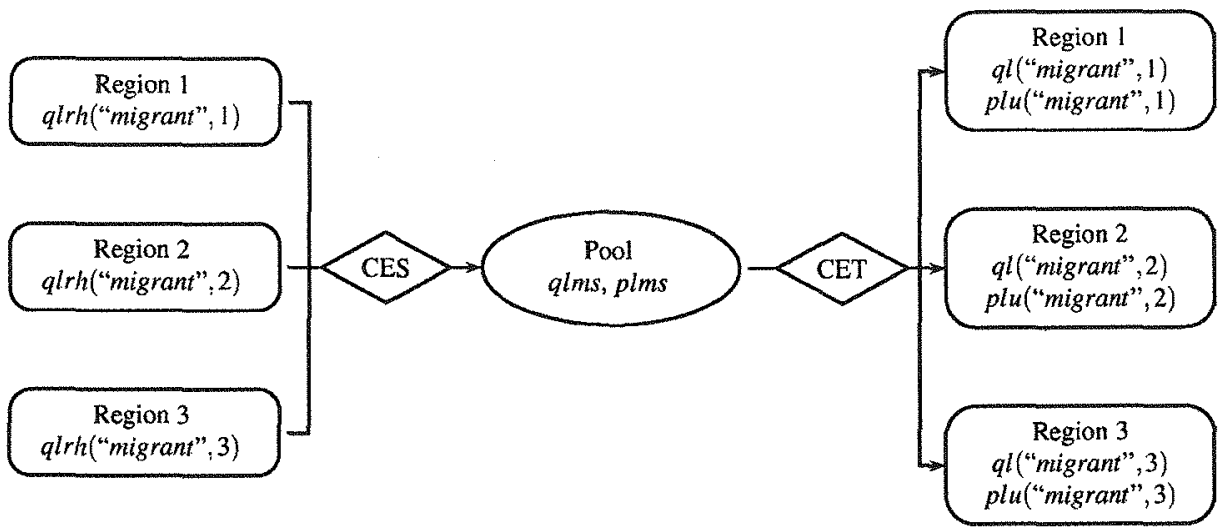


only to transfer payments to regional governments. ${ }^{7}$ Therefore, each regional government's revenue is the regional tax revenues plus transfers from the central government.

There are two closures in modelling regional governments' behaviour, namely, exogenous revenues and exogenous expenditures. In the former closure, regional tax rates and transfer payments are fixed; consequently local governments allocate the resultant revenues to government saving and consumption. On the other hand, in the latter closure, local governments' expenditures on saving and consumption are fixed at pre-defined levels, while the tax rates or the amounts of transfer payment vary to balance their budgets.

CERD gives a reasonably detailed representation of commodities with 44 sectors in each region, including 5 agricultural sectors, 25 industrial sectors, one construction sector, and 13 service sectors.

A particular feature of CERD is that its database has been compiled based on the provincial 44-sector input-output tables for 1997. The 44-sector classification follows the 40-sector classification in the 1997 national input-output table (National Accounts Department 1999) with the agricultural sector further disaggregated into five sectors. In total, there are 28 provincial tables available. ${ }^{8}$ These provincial input-output data have been aggregated into three regions. Other data and parameters are drawn from GTAP database 5, Yang and Huang (1997) and the China Statistics Yearbookseries.

\section{Stylised simulations}

Three stylised changes in transfer payments are simulated using the CERD model described above. All these simulations are centred on increasing transfer payments to the Central and Western regions by 9.2 and 12.0 billion yuan, respectively, or 10 per cent of each region's general purpose grant in 2001. However, different treatments are made in each simulation. A summary of these simulations is given in Table 23.4.

Table 23.4 Summary of simulations

\begin{tabular}{lll}
\hline Simulation 1 & Simulation 2 & Simulation 3 \\
Increase transfer payment to & Changes in transfer & Changes in transfer \\
central and western regions by & payments as set in & payments as set in \\
9.2 and 12.0 billion yuan, & Simulation 1 & Simulation 1 \\
respectively & Fixed government spending & Fixed regional tax rates \\
& Endogenous regional tax rates Improvement in input efficiency \\
& & to prevent welfare loss
\end{tabular}


The first simulation is carried out with an exogenous revenue closure. Regional tax rates are fixed and regional governments' revenues changes along with the changes in transfer payments. ${ }^{9}$

The second simulation is carried out with an exogenous expenditure closure. Regional governments' expenditures are fixed, and the increase in transfers to central and western regions is used to bring down the tax rates in these regions.

The third simulation takes the efficiency issue into consideration. As mentioned above, improving regional disparity through pure transfer payments may actually reduce total welfare. However, it is also possible for transfer payments to increase total welfare through improving the productivity in less developed regions. However,

Table 23.5 Simulation results of increasing transfer payments to inland regions

\begin{tabular}{|c|c|c|c|}
\hline & Simulation 1 & Simulation 2 & Simulation 3 \\
\hline \multicolumn{4}{|c|}{ Equivalent variation (billion yuan) } \\
\hline Eastern & -25.7 & -21.2 & -25.8 \\
\hline Central & 9.9 & 11.2 & 11.8 \\
\hline Western & 12.7 & 15.2 & 13.9 \\
\hline Total & -3.0 & 5.2 & -0.0 \\
\hline \multicolumn{4}{|c|}{ Regional utility (per cent) } \\
\hline Eastern & -0.4 & -0.4 & -0.4 \\
\hline Central & 0.4 & 0.5 & 0.5 \\
\hline Western & 0.8 & 1.0 & 0.9 \\
\hline \multicolumn{4}{|c|}{ Real consumption (per cent) } \\
\hline Eastern & -0.9 & -0.3 & -0.9 \\
\hline Central & 0.3 & 0.4 & 0.4 \\
\hline Western & 0.9 & 1.1 & 0.9 \\
\hline \multicolumn{4}{|c|}{ Regional CPI (per cent) } \\
\hline Eastern & 0.0 & -0.0 & 0.0 \\
\hline Central & 0.1 & 0.1 & 0.1 \\
\hline Western & 0.3 & 0.4 & 0.3 \\
\hline \multicolumn{4}{|c|}{ Real GDP (per cent) } \\
\hline Eastern & 0.0 & -0.4 & 0.0 \\
\hline Central & -0.0 & 0.4 & 0.1 \\
\hline \multirow[t]{2}{*}{ Western } & 0.0 & 1.0 & 0.1 \\
\hline & & (percentage points) efficiency & $\begin{array}{l}\text { Output } \\
\text { efficiency }\end{array}$ \\
\hline Eastern & & 0.1 & 0.0 \\
\hline Central & & -0.1 & 0.0 \\
\hline Western & & -0.4 & 0.0 \\
\hline
\end{tabular}


we do not have sufficient concrete information to establish the relationship between transfer payments and productivity improvement to be included in the CERD. Rather, we proceed in the opposite direction, asking how much productivity improvement is required to offset the inefficiency brought about by transfer payments. This simulation is also carried out with an exogenous revenue closure. The simulation results are summarised in Table 23.5. Several points may be made in relation to these results.

First, increased transfer payments to inland regions can improve regional inequality. For example, in Simulation 1, the Western region benefits the most, with household and government utility increases by 0.89 per cent, followed by the Central region, with utility up by 0.48 per cent, while the Eastern region suffers, with utility down by 0.4 per cent because increased transfer payments to inland regions are financed with decreased transfer payments to the Eastern region.

Second, a pure increase in transfer payments (Simulation 1) is welfare decreasing. Although the equivalent variations (EV) in the Central and Western regions increase by 9.9 and 12.7 billion yuan, respectively, the Eastern region's equivalent variation decreases by 25.7 billion yuan, causing a net loss of 3.0 billion yuan. This is because the inland regions have lower returns to resources. Although the impacts of Simulation 1 are mainly on the demand side and the real GDP virtually does not change, the lower returns in inland regions are represented by lower utility of household and government savings in these regions.

Third, reducing tax rates in inland regions through higher transfer payments may increase total welfare. This is because the reduction in tax rates would provide additional stimulus to the regional economy. For example, tax rates decrease by 0.17 and 0.40 percentage points in the Central and Western regions, respectively, leading to increases in real GDP by 0.42 and 1.03 per cent, respectively.

Finally, a 10 per cent increase in general purpose grants to inland regions requires a 0.04 per cent generic improvement in output efficiency in these regions in order to keep total welfare unchanged.

\section{CONCLUSION}

China's governmental transfer payment scheme has been evolving along with the fiscal regime. The implementation of the Transfer Payment Arrangement during the transitional period in 1996 marked the establishment of a formal and comprehensive program of governmental transfer payments. It has played a positive role in easing regional inequality. However, the scheme has some imperfections. Most importantly, the amount of transfer payments aimed at 'equalisation' is limited. 
Using a general equilibrium model of the Chinese economy with regional dimensions, several approaches to increasing transfer payments to inland regions have been simulated. It was found that a pure transfer payment increment would decrease total welfare, as the decline in the Eastern region's welfare more than offsets the gains in the inland regions. In order to keep the total welfare unchanged, a 0.04 per cent generic improvement in regional output efficiency is required for a 10 per cent increase in general purpose grants to the inland regions.

It was also shown that, if an increase in transfer payment were used to reduce tax rates in the inland regions, total welfare nationwide could be improved. This may have some implications for the so-called 'tax for fee' reform which aimed at reducing the tax (fee) burden by replacing various administrative fee schemes implemented by regional governments with a uniform tax system. As the 'tax for fee' reform usually reduces governments' revenue in less developed regions, the central government should provide enough transfer payments for these governments to fulfil their duties. Otherwise, local governments may simply reduce vital public services.

\section{NOTES}

1 Thirty-one provinces, municipalities and autonomous regions in mainland China are normally classified into three regions--Eastern coastal, Central and Western regions-according to their geographical location and economic development situation. The Eastern coastal region is the most developed region in China and contains 12 provinces and municipalities-Beijing, Tianjin, Hebei, Liaoning, Shanghai, Jiansu, Zhejiang, Fujian, Shandong, Guangdong, Guangxi and Hainan. The Central region includes nine provinces and autonomous regions with a middle degree of economic development: Shanxi, Inner Mongolia, Jilin, Heilongjiang, Anhui, Jiangxi, Henan, Hubei and Hunan. The Western region is the least developed region and contains the remaining six provincesYunnan, Guizhou, Sichuan, Shaanxi, Qinghai and Ganshu; three autonomous regions-Tibet, Ningxia and Xingjiang; and one municipality-Chongqing.

2 This system was intended to reinforce the fiscal power of the central government, which had eroded under the fiscal contract system.

3 Wong (2002) does not give an exact definition of per capita expenditure and revenue. It is conjectured that she includes both budgetary and extra-budgetary expenditure and revenue, which may explain the inconsistency between her numbers and those in Jin el al. (1999).

4 According to the World Bank (2001), governments at county and township level spend 70 per cent of budgetary expenditure on education, and 55-60 per cent on health. Cities at the prefecture and county levels use all expenditures on unemployment benefits and social security. 
5 For more details of the model, see Jiang (2003).

6 The detailed version of the CERD model identifies 28 regions, each of which corresponds to one province, autonomous region or municipality directly under the central government in mainland China, with exceptions where Hainan, Ningxia and Tibet are included in Guangdong, Gansu and Qinghai respectively.

7 If the central government is allowed to consume, it should make decisions about where the commodities it consumes are bought and sold as well as how much of them it consumes. This would unnecessarily increase the burden of computation as it can be embodied in the decisionmaking process of individual regional governments.

8 Three provinces or autonomous regions, Hainan, Ningxia and Tibet, do not have input-output tables. These regions are small in economic scale and their input-output data were constructed on the basis of information about neighbouring regions with similar natural and economic characteristics. Specifically, Hainan is included in Guangdong, Ningxia in Gansu, and Tibet in Qinghai.

9 More accurately, government revenue is endogenous even in this 'exogenous revenue' closure case because it is also affected by the tax base, which is endogenous. The effect, however, would be of second order.

\section{REFERENCES}

Du, F., 2001. Theory and Practices of Intergovernmental Fiscal Transfer Payments, Publishing House of Economic Science, Beijing.

Fan, M. and Zheng, Y., 2000. The Impact of China's Trade liberalisation for WTO Accession: a computable general equilibrium analysis, Paper presented at the Third Annual Conference on Global Economic Analysis, Monash University, Australia, 27-30 June. Available online at http://www.monash.edu.au/policy/conf/ 42fan.pdf.

He, C., 2001. The Main Situations of Inter-governmental Fiscal Transfer Payment in China, Paper presented in the International Symposium on Fiscal Transfer Payments, Kunming, Yunnan, 3-5 September.

Hertel, T.W.(ed.), 1997. Global Trade Analysis: modeling and application. Cambridge University Press, Cambridge and New York.

Jiang, T., 2002. 'WTO accession and regional incomes', in R. Garnaut and L. Song (eds), China 2002: WTO entry and world recession, Asia Pacific Press, Canberra:45-62.

Jiang, T., 2003. 'The impact of China's WTO accession on its regional economies', Australian Agribusiness Review, forthcoming. 
Jin, H., Quian, Y., and Weingast, B.R., 1999. Regional decentralisation and fiscal incentives: federalism, Chinese style, Stanford University, Stanford, unpublished. Ma, J., 1998. Transfer Payments, Publishing House of Economic Science, Beijing. $\mathrm{Ma}, \mathrm{S} ., 2003$. Transfer and narrowing regional gap, Institute of Finance and Trade, Chinese Academy of Social Sciences, Beijing, unpublished.

Ministry of Finance Budget Department, 2003. Intergovernmental Fiscal Relations in China, China Finance and Economics Press, Beijing.

National Accounts Department, State Statistical Bureau, 1999. Input-Output Table of China 1997, China Statistical Press Beijing.

State Statistical Bureau, various issues. China Statistical Yearbook, China Statistical Press, Beijing.

Sun, H., 2000. 'Economic growth and regional disparity in China', Regional Development Studies, 6:43-66.

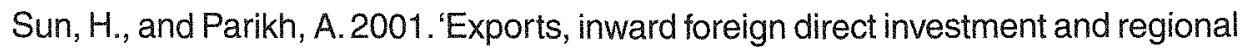
economic growth in China', Regional Studies, 35(3):187-96.

Wong, C., 2001. Fiscal Decentralization in China: the problematic outcomes of unplanned changes in transition towards a market economy, Paper presented to the Asian Development Forum, Bangkok, 11-14 June.

Wong, C., 2002a. Issues of Equalization in China, Paper presented to Intergovernmental Fiscal Relations in East Asia Workshop, Bali, 10-11 January. Wong, C., 2002b. Characteristics of China's Intergovernmental System, Paper presented to Intergovernmental Fiscal Relations in East Asia Workshop, Bali, 10-11 January.

World Bank, 2001. China: provincial expenditure review, World Bank, Washington, DC.

Wu, Yanrui, 1999. Income Disparity and Convergence in China's Regional Economies, Discussion Paper 99-15, Department of Economics, University of Western Australia. Available online at www. econs.ecel.uwa.edu.au/economics/dpapers / DP1999/9.15.pdf [accessed 2 January 2002].

Yang, Y., and Huang, Y., 1997. The Impact of Trade Liberalisation on Income Distribution in China, China Economy Working Paper 97/1, Research School of Pacific and Asian Studies, The Australian National University, Canberra.

Zhang, Z., 2002. Intergovernmental Fiscal Relations in P.R. China, Paper presented to Intergovernmental Fiscal Relations in East Asia Workshop, Bali, 10-11 January. 


\section{4}

\section{A new engine for pragmatism in the international security order?}

\section{Greg Austin}

In 2002 China appointed senior diplomat Wang Shijie as special envoy to the Middle East and in 2003 it approached NATO with a proposal for a formal relationship similar to that which Russia has with the Atlantic alliance. ${ }^{1}$ In recent years China has gradually been resuming its economic aid programs to poorer developing countries at the same time as it has been intensifying its efforts to shape global arms control and proliferation regimes and expanding the reach of its defence diplomacy. China's international security policy has gone global. Is this a gradual accretion of global interests following on the internationalisation of China's economy, or does it represent a more deliberate effort by China to return to an international security strategy with the sort of global reach China pursued in the 1950s and 1960s?

If China were pursuing a global reach now, it would be for far different reasons than in the 1950s and 1960s. But it is worth recalling that era. At that time, China supported wars by national liberation movements in Africa through the provision of military and economic aid, it supported the export of communism in Southeast Asia, and it engaged in proxy wars against both the former Soviet Union and the United States. By 1974, China began abandoning these global aspirations and retreated to a periphery-oriented national security strategy while it undertook important domestic economic and political reforms.

China's leaders now appear to be abandoning the periphery-dominated national security strategy in favour of a new international security strategy with gl obal reach. According to well-placed sources in Beijing, China's leaders decided through the course of 2002 that this was the only choice open to them in the face of continuing 
US strategic pressure on them over Taiwan and in light of the significant changes in the international situation, especially on their periphery. ${ }^{2}$

China's emerging globally-oriented national security strategy has three main characteristics: it is defensive, pragmatic, and gives a low priority to use of military force. In all three respects, it contrasts with the current US national security strategy, which is pre-emptive (offensive), ideological and gives a high priority to use of military force. ${ }^{3}$ It is this contrast, particularly between the pragmatism of China's new global strategy and the ideological pretensions of the US strategy that is the main subject of this chapter.

Five main catalysts have prompted the shift in China's national security strategy

- changes in US national security policy since 11 September

- the subsequent, further deterioration in relations between the Islamic world and the West

- the opening of NATO to a global role and the securitisation of the European Union

- the deepening and intensification of US-Taiwan military relations under a Democratic Progressive Party (DPP) presidency in Taiwan

- the reintroduction of US counter-proliferation military planning for North Korea and the subsequent moves by Japan to upgrade its military posture.

Each of these is, self evidently, sufficient in and of itself to affect Chinese perceptions of the international security order. Together, these five catalysts look likely to have a profound effect on China's fundamental national security strategy. We have seen strong early signs of a shift away from a periphery-based strategy to one with a global compass. It will remain to be seen whether the shift is consolidated. This chapter does not describe the five catalysts separately. Rather, it seeks to draw them together through an overview of the increasing US strategic pressure on China's periphery. It then looks briefly at China's possible responses. It is here that the hypothesis about China as an engine for positive change in the international security order is canvassed. The chapter concludes with some brief musings about the impact of this analysis on some theoretically derived propositions about China.

\section{CHINA'S SENSITIVE AND VULNERABLE PERIPHERY}

China's leaders have appeared to be 'border sensitive' in ways that have often puzzled outside observers. This puzzlement was exacerbated by the extravagant approach taken by China in the 1950s to the limits of 'historical China' and by the 
belligerent approach of China across virtually all of its borders between 1962 and 1969. But, apart from the Cultural Revolution period, China has not had a disposition towards borders and sovereignty that has been all that different from that of other states (Watson 1966:19-20, 212-3). That is, except in one important respect. For China, the final chapter of national territorial unity has yet to be written. The civil war may be over, but for many in China national unity has not yet been restored. China is the only country in the world, and therefore the only major power, that is facing a serious 'secession' problem from a territorial entity with a large economy, powerful armed forces and global diplomatic representation (albeit unofficial). The decades of diplomacy and international noise that have surrounded Taiwan's international status have to a certain extent numbed outside observers to the true sensitivity of this fundamental consideration of China's nationhood. The resumption of Chinese sovereignty over Hong Kong in 1997 and Macao in 1999 has created a new time pressure on leaders in Beijing to reunify China. However these pressures work out (and a peaceful settlement should not be excluded) the defining aspect of China's international relations is now, and will be for coming years, the approach taken by Taiwan to the question of China's national unity and dignity.

What marks out the 1990s as substantially different from the 1970 s and $1980 \mathrm{~s}$ is that China's leaders have begun to be far more conscious and far more defensive of the country's vulnerabilities on its periphery. This mood has been facilitated in some senses by a rise in China's physical capacity to control its borders as defined in a legal, technical sense but it has also been provoked by a growing sense of incapacity to contain and control threats in other dimensions. For China's leaders, the boundaries of their power-their international borders in both physical and social senses-are now facing multiple and intensifying threats. In some areas, the threat is one of legal, technical separation (as in Taiwan), while in others (such as Tibet and Xinjiang), the threat is seen only as one of resisting and repudiating the remit of the central state.

For 16 years (1979-95), China was prepared to assign a lower priority to borders as a source of threat relative to a vision of borders as a source of opportunity, or even of economic necessity. As Chinese scholar Tianbao Zhu pointed out in a recent article, Chinese leaders must now choose whether they will continue to accept that prioritisation (Zhu 2001). They are being pushed in the direction of change both by rising nationalist conceptions of the country's borders and by an unambiguous and radical stepping up of international and domestic repudiation of 
the leadership's remit. As Jiang Zemin noted in the concluding four paragraphs of his report to the $16^{\text {th }}$ Communist Party Congress in November 2002, "it is essential... to bring about the great rejuvenation of the Chinese nation', a formula which he repeated one paragraph later, before noting in the third paragraph that China had to be "keenly aware of the rigorous challenges brought about by the ever-sharpening international competition'. ' He noted earlier in the speech that 'uncertainties affecting peace and development are on the rise' and that 'hegemonism and power politics have new manifestations'. And that the Party had faced a number of 'unexpected challenges bearing on China's sovereignty and security' since $1989 .{ }^{5}$

The December 2002 Defence White Paper noted that a 'new serious disequilibrium has occurred in the balance of military power' (PRC State Council Information Office 2002)-a reference to US military pre-eminence. The White Paper listed periphery security as one of the few internationally oriented tasks of the country's security policy ('striving for a favourable environment in China's periphery'). The Paper also reported that Taiwan separatists remain the biggest threat to security in the Taiwan Strait (and hence on China's periphery), and that they were being encouraged by a few countries selling weapons to Taiwan. It reported that 'China resolutely opposes... any country entering into a military alliance with Taiwan'. Jiang's speech called on China to 'strengthen state security, keeping vigilance against infiltrative, subversive and separatist activities'.

\section{Geopolitics of the China periphery and the US political challenge}

In Taiwan, Tibet and Xinjiang, China's leaders have for many years seen themselves as facing threats to the country's national integrity and territorial sovereignty. Except at the most general level, these three problems have not really been linked either in concrete practicalities or in perceptions since the CIA abandoned its covert political agitation inside China some three decades ago. The specific circumstances of Taiwan, Tibet and Xinjiang remain quite different and there has been little reason to see them as connected. But strategic policymakers in Beijing are beginning to see these once distinct problems as having new common threads that make them together a much higher order of security problem than any of the three cases had represented individually.

The single most important thread in this evolving perception is the view that, since President George W. Bush came to power in January 2001, the United States has been positioning itself to limit China's potential strategic power and has been 
using developments in these three areas to do that. Even to the non-specialist eye, this challenging trend in US policy has been relatively conspicuous in connection with Taiwan, especially in the rejuvenation of the US-Taiwan military relationship to levels unprecedented since 1979, and now little different from the alliance that was abandoned in that year.

But, as this chapter contends, it can be seen also in the cases of Tibet and Xinjiang, albeit in more complex or attenuated ways. The insertion into Central Asia in late 2001 of a potentially permanent US military presence can only magnify the vulnerability and risk that China feels in light of increased US military support for Taiwan. China's leaders do see the US military presence in Central Asia as positive in that it contributed to the removal of the Taliban, but they see it on balance as negative in that it will position the United States better to influence and challenge China's management of its internal affairs in Xinjiang. This reflects the essentially political nature of the new US challenge on China's periphery. And it is the political dimension that is evident in new US positioning on Tibet. There is no US military involvement in Tibetan 'separatism', nor is there likely to be much potential for such involvement. But China's leaders see even US political pressure on Tibet issues as gathering momentum, and as an intensification of US pressure on China as a whole for 'peaceful evolution' of China domestically and for containment of it on the international stage.

The evolution of US-China relations through 2002 has been sufficiently positive to dampen some of the more visible forms of tension between the two nations. In particular, the US need for China's support in Security Council votes on possible war with Iraq in late 2002 overshadowed and even contained some of the emerging negative trends in US-China security relations that were so visible in 2001. But this chapter contends that the underlying fundamentals remain negative. China's support for the US (and UK) position in the UN Security Council is based on shared values to some degree but is also part of China's strategy for responding to the new US strategic challenge that is emerging on its periphery.

The history of international relations shows convincingly that strategic pressure by one major power on another's periphery areas is a recipe for instability in international order. Where the power being subjected to pressure is a rising power, with not just a history but a historiography premised on recovery from national humiliation or fragmentation, the risk of strategic instability is even greater. This sort of consideration was prominent in the ideology of aggression advocated by the 
regimes in Germany and Japan prior to the Second World War. Thus, recent US positioning on each of the three problem areas arguably presents a new security challenge not just for China but for the international community as a whole. As a recent study from a US ally put it, our 'interest in a stable, cooperative, prosperous future for Asia is threatened by the possibility that America and China might drift into animosity or even war in coming years. The risk of this outcome is not high, but it is real and significant' (Australian Strategic Policy Institute 2002).

Each of China's three periphery problems (Taiwan, Tibet and Xinjiang) is becoming more bound up with US global strategic power, an expansion of US regional alliances, and a reorientation of US military strategy and force deployments. The Bush Administration has vigorously followed up on the Clinton Administration's commitment to 'democratic expansion'. And Bush's first review of strategic policy in 2001 concluded that the most likely potential threat for major war in the future would come from China. As a result, the United States has been undertaking more and more concrete measures in both political and military strategy that directly impinge on China's periphery.

Over the last decade, there has been an escalating contest of ideas in Beijing, Washington and Tokyo about the future balance of power in East Asia. With both China and the United States seeing the resolution of Taiwan's status as reflecting seriously on their credibility as great powers, US planning for Taiwan-related contingencies is not just about Taiwan's status but has become part of a bigger balance of power contest with global ramifications. In February 2002, the Director of the CIA, George Tenet, told a Congressional committee that China's cooperation with the United States in the war against terrorism changed none of the fundamentals of the long-term strategic competition between the United States and China. That cooperation, he said, would not deflect China's bid to emerge as a power likely to challenge US strategic pre-eminence in Asia; and China's cooperation did not reduce the need for the United States to prepare for the contingency of military confrontation with it. ${ }^{6}$ There are other statements by senior US officials that explicitly discuss the need to contain China's rising power.

The September 2002 National Security Strategy of the United States represented a further challenge to China, not because of the changes in military deployment that it foreshadowed, but for the return by the United States to a Kennedy-esque ambition of going anywhere and paying any price to to defend freedom. For China, the reference in the Strategy to the US intention to 'defend the peace by fighting 
terrorists and tyrants', was a reference (in the second word 'tyrants') to the Chinese leadership (Government of the United States of America 2002). The suggestion in that document that '[i]n time, they [China's leaders] will find that social and political freedom is the only source of national greatness' is reasonable enough. But until they do accept liberal pluralism, language like the following seems to place them at odds with the main thrust of the US strategy: 'We seek...to create a balance of power that favours human freedom: conditions in which all nations and all societies can choose for themselves the rewards and challenges of political and economic liberty'; and 'The United States will stand beside any nation determined to build a better future by seeking the rewards of liberty for its people' (Government of the United States of America 2002:n.p.).

We can diasgaree on what these words mean, but over the last decade there has been an unambiguous intensification in US national security strategy of measures premised on the need to prepare for the contingency of military confrontation with China as a possible evolution either of an emerging balance of power contest in Asia or as a result of some Taiwan crisis. According to veteran China-watcher, Jonathan Pollack, what we are seeing in the United States is not threat-based planning, not capabilities-based planning, but 'possibilities-based planning'.7

\section{Taiwan and the Western Pacific}

Beginning in 1995, China has undertaken a series of military manoeuvres designed to intimidate Taiwan and its international supporters into reversing Taiwan's move away from the 'one China' principle. Resort to such a drastic measure was evidence that, even then, China felt that it was losing ground on Taiwan. In its White Paper on Taiwan, issued in 2000, China imposed a new condition that indicated its continuing sense of losing ground. China insisted for the first time that Taiwan could face use of force if it sought to put off reunification indefinitely. In November 2002, President Jiang said bluntly that China was looking for a positive move towards reunification 'at an early date'. ${ }^{8}$ As two prominent US scholars observed in 1999, 'Taiwan is perhaps the only external issue where raw emotion and nationalist fervour trumps the realpolitik calculations that normally govern China's external policy' (Lampton and May 1999). The reason for this is that the 'Beijing leadership believes it could not remain in power if it buckled on an issue central to Chinese nationalism'. By late 2002, Taiwan was not backing down and it had more international support than ever, especially from the United States. In response, China was determined to show its 
resolve and refused to back down. In mid October 2002, it signalled a possible expansion of its military pressure on Taiwan by dispatching one of its warships on an unprecedented cruise parallel to the east coast of Taiwan.

The United States and its allies in the Western Pacific, especially Japan and Australia, are now positioning themselves, in political and strategic terms, for a new confrontation between the United States and China over Taiwan. The United States and its allies reacted strongly to China's military intimidation of Taiwan in 1995 and 1996. The United States deployed two aircraft carriers, Japan hurriedly completed a number of measures with the United States to extend US military access to its territory, and Australia's Defence Minister declared his country's readiness to join combat alongside the United States if hostilities broke out. While these reactions were appropriate, there is little doubt that this military response by the United States and its allies was seen by Beijing as an unacceptable intervention in its 'domestic' Taiwan problem and only encouraged China in subsequent years to intensify its military readiness opposite Taiwan.

The eight years since 1995 have seen a gradual escalation in military preparation by China and the United States for the contingency of military hostilities of some sort associated with Taiwan. For example, China has deployed some 300 mediumrange missiles to its coastal areas opposite Taiwan, and reliable sources estimate that the number will rise to 800 by 2006. In the same period, China has conducted large-scale military exercises in the Taiwan Strait. For its part, the United States has been consistently enhancing its military capabilities in the Western Pacific. While this has not so far seen dramatic increases in US military forces permanently deployed to the region, the United States has steadily improved its infrastructure and operational readiness by

- reactivating military facilities on Guam to provide forward-basing options for China-related contingencies

- conducting carrier battle group exercises in the South China Sea (on one occasion at least involving two carriers)

- carrying out US carrier transits of the Taiwan Strait

- extending US-Japan mutual support arrangements for Korea-related and Chinarelated contingencies in the second half of the 1990s (Austin 1997)

- rejuvenating the military alliance with the Philippines during the Clinton Administration (Austin 2003) 
- notifying of its intent to withdraw from the ABM treaty (this was not directed at China but is seen by it as a threat since it opens the way to develop theatre missile defence technologies which China suspects will be transferred to Taiwan).

The forced landing on Hainan Island in April 2001 of a US military intelligence aircraft that had been involved in a mid-air collision with a Chinese air force fighter highlighted publicly the intensity of US military intelligence collection efforts against China. And that was even before the new Bush Administration had completed its first review of US strategic policy, which elevated the possibility of major war with China to a central plank of long-term US strategic planning.

Citing China's continuing military intimidation of Taiwan as the justification, the Bush Administration took US policy towards Taiwan on a more confrontational path by radically enhancing its military relationship with Taiwan. In the second week of March 2002, the United States permitted a visit by Taiwan's Defence minister to participate in public and private discussions of his official portfolio interests, even though the United States sought to pass off the visit as 'unofficial'. ${ }^{9}$ This visit was the first substantive one by a Taiwanese foreign affairs or security minister since 1979. The minister held a 100-minute meeting with Deputy Secretary of Defense Paul Wolfowitz. Also in March 2002, news broke of a Pentagon document detailing a nuclear posture review by the Bush Administration that called for US planning for the use of nuclear weapons in a Taiwan Strait contingency-a report that Chinese officials predictably described as 'shocking' (Arkin 2002). Other moves include

- new arrangements for military exchanges with Taiwan

- normalisation of the timing and manner in which the United States approved arms sales to Taiwan

- expansion of the scope of arms sales to Taiwan

- committing to pursuing combat interoperability between US and Taiwanese armed forces

- committing to supporting substantial reform in Taiwan's administration of defence policy and development of joint force operational capability.

\section{Tibet, India and US policy trends}

In contrast to the relationship between Beijing and Taipei, the situation in Tibet is far less dramatic for the Chinese leadership on a day-to-day basis. Despite this, it is no less threatening. On the one hand, Beijing controls the territory in Tibet and has in place a highly developed system of public administration. This is backed by a large 
number of uniformed personnel and residents who are not of Tibetan origin, but are migrants (or the children of the migrants) sent there in the past four decades by Beijing to provide a substantial population base for continued rule by China. The enemy for Beijing in Tibet is the authority of a religious leader who commands no armed forces, who is not supported by any quasi-military alliance with the United States, and who preaches non-violence. There is therefore no question of Tibet as a political entity continuing to resist Beijing's efforts to control it physically, as with Taiwan. This is not an issue of re-unification.

On the other hand, there is a Tibetan government in exile, located in Dharamsala in northern India. The spiritual leader of the Tibetans, the Dalai Lama, vigorously cultivates international support for his resistance to Beijing's rule, without ever really being too precise about his long-term political ambition for Tibet. He says he is interested in increased autonomy for the local (non-Chinese) Tibetan community, but Beijing fears that he really wants independence. And the Dalai Lama has recently rebuked Beijing publicly for lack of response to his conciliatory approach, a rebuke that carries with it the implication for Beijing that the Tibetan government in exile will more directly advocate total independence from Beijing. The authorities in Beijing continue to suppress the collective activities of Buddhist monks in Tibet, and thereby continue to fuel not only resistance by Tibetans to its rule but also international support for this resistance. Thus, while this is not an issue of reunification, it is for Beijing an issue of national integrity and internal security on almost the same level of complexity as the Taiwan problem.

For Beijing, the Tibetan problem is getting worse. Sentiment in Western countries in favour of Tibetan independence continues to snowball. The number of legislative resolutions or other measures taken in Western parliaments to register disapproval of Beijing's style of rule continues to grow. The Dalai Lama has extended his international profile. China's main assets (physical control and transmigrants) offer no guarantee of any sort in the absence of other fundamental changes in the loyalty of the local population. The cases of the former Soviet republics, especially Estonia, where the former Soviet Union had military and internal security forces and where some 40 per cent of the population identified as ethnically Russian, do not reassure Chinese leaders that their possession of such assets in Tibet offers any ultimate protection against eventual political separation.

Where is the US hand in propping up or bolstering Tibetan resistance to Chinese rule? One scholar has rightly observed that it has been the Congress and not the 
Administration that has maintained interest in the 'Tibet cause' in the United States (Knaus 2000). There is certainly no public evidence of direct use by the US Administration of any military strategic instrument, and the Administration's public face on Tibet is one of acceptance of Chinese sovereignty. A series of Congressional initiatives on Tibet were taken most visibly in 1987 after the Dalai Lama addressed the Congressional Human Rights Caucus (Knaus 2000). But President Bush Senior initiated the 'drop-in' meetings between the Dalai Lama and the President in the White House, a practice continued by Clinton and George W. Bush.

With the emphasis in the Clinton Administration on the expansion of democracy, new moves were taken by parts of the US government to support Tibetan resistance to Chinese rule. For example, when Clinton visited India, he signed a joint declaration with the Indian Prime Minister which provided for the opening of an office there of the US National Endowment for Democracy (NED), an office which has provided low levels of funding to Tibetan exile groups. ${ }^{10}$ Some Chinese sources refer to the NED as a CIA front. In the Clinton period, the US Senate passed on 9 March 2000 a bill to designate 10 March as the 'national day' of Tibet (China Daily Online, 9 March 2001).

The political contest between Washington and Beijing over Tibet has escalated under the Administration of George W. Bush. In May 2001, the US Congress (both houses) passed the Tibet Policy Act, which declared Tibet-including Tibetan nationality areas in parts of four neighbouring Chinese provinces--to be an 'occupied country, ${ }^{11}$ and called on the US government to undertake a range of measures including

- reappointment of a Special Coordinator for Tibetan Issues within the State Department

- annual reporting to Congress on progress in US efforts to get a Tibet-China negotiation on autonomy under way

- imposition of conditions on US-supported multilateral aid projects in Tibetan areas of China

- application of best efforts to establish a State Department office in Lhasa

- stepping up advocacy by the US State Department of an end to 'all interference' by Beijing 'in the religious affairs of the Tibetan people'

- increasing the visibility of Tibetan groups and Tibetan issues within the United Nations. 
The Act also provides for Tibet to be an issue of discussion between the USEuropean Interparliamentary Group. In response, on 17 May 2001, the Bush Administration gave to Undersecretary of State for Global Affairs Ms Paula Dobriansky the assignment of US Special Coordinator for Tibetan Affairs. Her duties are to 'help preserve Tibet's unique cultural, religious, and linguistic heritage'. Dobriansky is the highest-ranking official to hold this post since it was set up in 1997.12

On 5 March 2002, a Resolution was introduced into the House of Representatives by 42 members calling on the Bush administration to 'give serious consideration to recognising the authorities of Tibet who are currently exiled in Dharamsala, India, as the legitimate representatives of Tibet' if they cannot reach an agreement with Beijing within three years that 'provides for the political autonomy of Tibet'. ${ }^{13}$

So, at many levels, the Act and other recent Congressional moves on Tibet represent a significant expansion of the 'internationalisation' of the Tibet issue, something which Beijing has always opposed. If one takes as a precedent the way in which Congressional opinion on Taiwan has helped to shape US Administration policy in the last decade, then these Congressional measures on Tibet will only be viewed in Beijing with great concern.

\section{Xinjiang and the shifting alliances of Central Asia}

Some members of the Uighur community and some other Turkic ethnic groups have been waging a low-level campaign of sabotage and murder against the Chinese government in support of claims for independence from China. Their violent resistance to Chinese rule first resurfaced between 1989 and $1993,{ }^{14}$ died down somewhat in 1994-95, and again intensified after February 1997 (South Asia Analysis Group 1999). The rise in armed Uighur nationalism can be attributed in part to the service in Afghanistan during the 1980s of Chinese citizens of Uighur nationality; and in part to the relatively easy interchange that had existed between radicals in Pakistan and Western China. A number of the violent activists in Xinjiang have been trained in Pakistan.

The Xinjiang Uighur Autonomous Region (XUAR) retains many appearances of a colony of China. ${ }^{15}$ Except in the capital and a few other places, it has highly segregated and mutually antagonistic populations. It has a violent (though low intensity) rebellion of the indigenous population, and an irrational and highly centralised 
system of economic exploitation, through the Xinjiang Production and Construction Corps (somewhat reminiscent of the British East India Company in its heyday). ${ }^{16}$ There are marked differences between northern parts of the XUAR, including cities like Urumqi and Turfan, which are 'Sinicised', have quite high proportions of Han Chinese, and are less troublesome, and the southwestern parts around Kashgar, where the Uighur community accounts for 90 per cent of the population, where modernisation has not been profound, where there are deep-seated inter-communal tensions, and where there is a pervasive 'wild west' atmosphere (Kemenade 1998:403-4).

According to sources in Beijing, the Chinese government now feels it is losing the fight against the Moslem rebels. The reasons cited for this by Beijing sources are as follows. ${ }^{17}$ There is now a net outflow of Han Chinese from Xinjiang. This has come about because the policy of migration of Han Chinese to Xinjiang was a policy of forced migration, when jobs were assigned by the Party and people had little choice but to go where they were sent. Now that China effectively has a free labour market and its controls on residency have largely evaporated, many of the forced migrants to the West are returning to their original homes (for family reasons) or to other places in the richer provinces (for economic reasons). Even a number of Han Chinese born in the west find it more attractive for economic reasons to migrate eastwards. This net outward migration is a long-term problem for the Chinese leadership, and though it can be corrected over time with special incentives, the issue bears heavily on leadership calculations of the nature of the problem. There are other indirect signs that China is losing control, and these include a rapid increase in the number of illegal mosques and religious schools.

The rebellion in Western China weighs even more heavily on Chinese leadership perceptions of internal security because official sources in Beijing believe that China has lost control of infiltration across the borders with Tajikistan and Kyrgyzstan, two tiny countries of Central Asia facing immense problems of governance and armed incursions of their own. China has significantly increased its military relations with Kyrgyzstan at least and is providing support to the development of its border surveillance programs. But these programs are at a low level and the flow of weapons, money and drugs to support the operations of the rebels in Xinjiang has increased in recent years. Chinese sources make it clear that China does not have the capacity to seal its borders in the west. Chinese military and police assets even now have to rely on citizen support for surveillance of the borders. Since long stretches of the 
border are in very sparsely populated areas, the citizens are not much help-even if they were well disposed to Beijing or the government, and most in southwestern Xinjiang are not.

China supported US military intervention in Afghanistan to attack and root out AlQaeda and Taliban forces. China had also supported a series of Security Council resolutions beginning in 1998 calling on the Taliban to stop harbouring (and to hand over) indicted terrorists. ${ }^{18}$ So, it could be argued that the arrival of US military forces in Central Asia in the war against terrorism is not of great concern to Beijing and is indeed welcomed. At one level this is true and it is not difficult to find commentaries in the Chinese media to this effect.

But the leadership view is more likely negative on balance, taking much the same view as has often appeared in Chinese open source commentaries. ${ }^{19}$ While the more negative public commentaries were published prior to China's more fulsome welcoming of the US military action in Afghanistan, they are still useful as a reflection of the basic instincts of at least some Chinese leaders. Much earlier commentaries were quite strong, painting US strategic intentions in Central Asia in a negative light, suggesting that the United States was trying to bring the region 'under its security system', and that it was trying to gain control of the region's energy resources. ${ }^{20}$

China's military leaders in particular are not happy with the expansion of Europe (OSCE and NATO Partnership for Peace) to their western borders. They are even less content about the new US presence in Central Asia after 11 September 2001. It should be noted that the main requirement from China's point of view in support of a temporary US presence in Central Asia at that time was an internal security one. China had to put aside its geo-political concerns in the interests of eliminating the threat of the export of revolution to Xinjiang from Afghanistan, Pakistan and some of the Central Asian states. China also no doubt saw virtue in being seen to be friendly to the United States in its moment of great need from the point of view of trying to make a dent in US public opinion. But now that the immediate threat of export of revolution has been reduced significantly, the geopolitical concerns will almost certainly begin to re-emerge.

Until the US military presence arrived in Central Asia, China had been quite successful in shaping the geopolitics of the region. Along with the former Soviet Union, China had established in 2001 the Shanghai Cooperation Organisation, an outgrowth of the multilateral border negotiating forum, the Shanghai Five, that had 
been in place since the collapse of the USSR ${ }^{21}$ China's active leadership in formation of the Shanghai Cooperation Organisation (SCO), which included Jiang Zemin attending a summit meeting in Dushanbe, the capital of Tajikistan, is one of the most visible manifestations of the seriousness with which China views the geopolitics of the region. The SCO has both regional and global ambitions. At the regional level, it provides a formal legal framework for cooperation in anti-terrorism and border security, among other regional security issues such as the illegal arms trade. At the global level, it has the ambition of providing the foundation for a new international order ${ }^{22}$ premised on multipolarity and the 'renunciation of unilateral military superiority in contiguous areas'. ${ }^{23}$ But the organisation gives priority in the security sector to regional security. In this sphere, the determination of both China and Russia to apply maximum resources consistent with political constraints, such as sensitivity about deploying troops across borders, should not be underestimated. In forming the SCO, both China and Russia saw the existing and emerging threats in Afghanistan and Central Asia as among the most serious they then faced.

But in geopolitical terms, the fate of the SCO now seems to hang in the balance and the organisation will have to go through the next few years under competing pressures. On the one hand, leaders of all member states share China's very hardline approach to internal security and national unity. It would appear at first glance that they should easily be able to continue to cooperate on internal security matters. But under the influence of the rapid and large scale US strategic insertion into Central Asia after 11 September, cleavages are beginning to show. Uzbekistan failed to attend the last SCO summit, and Russia made a dramatic strategic tilt towards the United States and Europe that can only compromise the embryonic strategic partnership that was emerging between China and Russia. The energy aspect of the Russian strategic tilt, embodied in President Putin's agreement to consult with the United States on oil prices, is one area where this may be felt most keenly by China. After 11 September, China is reported to have taken a decision to establish a strategic oil reserve, partly out of fear of an interruption of Persian Gulf supply, but partly out of concern about long-term access to Central Asian reserves.

The insertion into Central Asia of a potentially permanent US military presence can only aggravate the sense of vulnerability and risk that China feels about the US military support for Taiwan. This has three dimensions. First, a mooted US military presence on China's western border had been portrayed in some Chinese commentaries before 11 September in classic geopolitical terms as encirclement, 
even if that was not the primary motivation for the US deployment once it took place. Second, Chinese leaders could be forgiven for viewing the new US military presence in Central Asia as giving the United States a second theatre option for a military confrontation with China over Taiwan. Third, the US military presence in Central Asia brings with it the inevitable pressure from the United States for political reform and liberalisation in the neo-Communist states there. Chinese leaders almost certainly see this link in Central Asia as likely to lead to more pressure from the United States on China over the political order in western Xinjiang.

\section{CHINA'S INTERNATIONAL RESPONSES: CHALLENGE WORLD ORDER OR SOFTEN ITS EDGES?}

The circumstances analysed in this chapter raise big questions about future directions in Chinese strategic policy. Will these common threads to distinct periphery problems push China's leaders to a different strategic choice than the one they have accepted in the last two decades? Will they hold to the 1989 injunction of Deng Xiaoping of 'First, observing coolly; second, securing our position; third, dealing with things calmly'? (Austin 1998:239). Can China make the domestic political adjustments (significant political liberalisation) to contain its growing problems? Or will they begin to accept that 'strategic breakout' is the only option, and begin to probe in one or other area of the periphery as a means of forcing a realignment of US international alliances on key China issues, especially the status of Taiwan. Or can China go further? Can it begin to contemplate a more comprehensive challenge to US power through a new global rivalry that pits a China-led coalition of non-democratic Third World states against a US-led coalition of democratic industrialised Western states?

For Tibet and Western Xinjiang, China's possible responses stretch across a wide area of domestic policy (nationalities policy, religious policy, political pluralism, regional development programs, legal and police responses). And for all three periphery problems, there is a variety of international policy options (security treaties, economic cooperation, trade and investment, or even coercive diplomacy). China has been trying a mix of policies, including both carrots and sticks, in all three cases and will continue to do so. By 1999, Chinese leaders had agreed to increase their reliance on coercive diplomacy in international policy and increased police repression in domestic policy.

But the four years since the end of the 1990s, when China tilted in the direction of more confrontational responses, have seen only a deterioration in China's domestic 
and international security situations. Relations with the United States and Japan have worsened, as both countries have more openly prepared themselves for military contingencies involving China (or North Korea). In response, as discussed at the outset, there is evidence that China's leaders have decided to shift their national security strategy away from the confrontational choices that rose most visibly to the surface in 1999 and early 2000. China appears to have decided that, if it can't challenge world order, it will soften it.

This has been evident in the change in China's strategy toward Taiwan from a threat-based one to a largely incentive-based one. China now relies on the military threat only as part of a broader political strategy. China has signalled its willingness for the two sides to move forward in cooperative moves on concrete areas of policy without Taiwan's total surrender on the issue of its status. ${ }^{24}$ China is moving more towards treating Taiwan as an equal, at least in negotiating terms if not in formal legal terms. This position is reflected in China's formulation, now a couple of years old, that the 'mainland and Taiwan are parts of one China', a phrase intended to repudiate China's earlier position that Taiwan is a province of China. China wants to give the impression that it is no longer proceeding on the view that it should be the dominant partner. Through 2003, China has shown new determination to find some common ground with Taiwan, going so far as to open the first ever talks at officials' level at the WTO in Geneva in December 2002.

But China's new push to soften the international security order is visible in other ways, not least in its determination to avoid a new military clash on the Korean peninsula and its refusal to take side in crucial votes in the UN Security Council. The appointment of China's first special envoy to the Middle East is another example. China may now have gone somewhat beyond the parameters of Deng's admonition of securing China's position by observing coolly. China appears now to have set itself the positive mission of reducing international tensions through a vigorous globally-oriented security policy of a type not seen in China since 1974.

\section{CONCLUSION}

In the early 1990s, the academic community was divided on China's emerging position in international security affairs. Would its new wealth and power line up behind previous Chinese impulses towards aggression or empire? Or would China become a cooperative member of the international system? Few scholars or 
commentators outside China were prepared then to contemplate a third scenario: China as an engine for positive changes in the international security order.

One decade later, the dominant view in scholarly analysis is that China has recorded an unambiguous commitment to cooperative and stabilising international regimes. Remnants of the 'China-threat' thesis can still be found in the United States, both in scholarly analysis and in positions of power, including the Pentagon, the CIA and the Congress. But most observers are still reluctant to consider China as a potential locomotive force for positive change in the international security order.

It is the contention of this chapter that China is now demonstrating the potential to be such a force for positive change. But the main cause of this does not flow as directly from China's own wealth and growing power, especially its military power, as much from other factors, some of which reflect China's relative military weaknesses. There have been three main factors

- China's perception of a growing US threat to its periphery

- China's perception of its inability to counter that threat militarily

- China's understanding of its capacity to alter the balance of power in its favour through a peaceful settlement with Taiwan.

Thus, in the normal logic of action and reaction in international affairs-as ironic as it seems-China is looking to influence peaceful change in the international security order because of the strategic pressure applied on it by the United States, especially over Taiwan, but in a positive way.

At a superficial level at least, this response seems to suggest that the neorealists and the 'China-threat' advocates might have been right. It does appear, at least at first glance, as though dealing with China from a position of strength has produced positive outcomes. But since the basis of the neo-realist assumption was China's power, not its weakness, something fundamental was wrong in their positioning. Moreover, the neo-realists had premised their argument largely on the need to discipline China and contain it within the existing international security order. They never quite imagined this more complete evolution, with China seeking to change that order by peaceful means.

This author's assessment of China's shift to new global security strategy is partly intuitive, and for this reason the assessment might be challenged on an evidentiary basis. After all, direct access to the strategic thinking of the highest level Chinese leadership is hard to come by. But, whatever the correct assessment of changed 
Chinese strategic perceptions, it is important to note the significant, unambiguous and factually incontestable changes in international security order during the last two to three years and to ask whether they have been sufficiently far-reaching to produce a profound change in China's security policy. If the answer is yes, was the change more likely to be of the sort hypothesised in this chapter or one of a more belligerent nature? Any objective assessment of China's weaknesses in the face of US strengths and power could only find in favour of the former: a determination to work actively around the world to soften existing international confrontations in order to reduce the escalating potential for military confrontation between China and the United States.

\section{ACKNOWLEDGMENTS}

The author would like to thank Dr Willem Van Der Geest and the European Institute for Asian Studies for their support during the research for this chapter.

\section{NOTES}

1 Information provided by a member of staff of the office of the European Union's High Representative for the Common Foreign and Security Policy, Javier Solana, May 2003.

2 Interviews, Beijing, November 2002.

3 These characterisations of US national security strategy should not necessarily be seen as negatives. Rather, as discussed later in the chapter, they are just what the September 2002 National Security Strategy released by President Bush describes.

4 Embassy of the People's Republic of China in Australia, Full text of Jiang Zemin's Report at 16th Party Congress, www.chinaembassy.org.au/eng/37883.html

5 This reference is to the date of Jiang's appointment as Secretary General of the CCP in the immediate aftermath of the Tian An Men suppressions in June of that year.

6 Tenet told the Senate Select Committee on Intelligence on 6 February 2002 that 'China is developing an increasingly competitive economy and building a modern military force with the ultimate objective of asserting itself as a great power in East Asia. And, although Beiling joined the coalition against terrorism, it remains deeply sceptical of US intentions in South Asia. It fears we are gaining influence at China's expense, and views our encouragement of a Japanese military role in counterterrorism as support for Japanese rearmament-something the Chinese oppose:

7 Comments made to the author.

8 Report at $16^{\text {th }}$ Party Congress. 
9 In its 1979 communiqué with China on normalisation, the United States 'recognises the government of the People's Republic of China as the sole legal government of China'. The next sentence in the same article says that '[w]ithin this context, the people of the United States will maintain cultural, commercial, and other unofficial relations with the people of Taiwan'. Even though the United States broke off its formal defence relations with Taiwan at that time, it was understood between the United States and China at the time that the question of the US-Taiwan military relationship, especially arms sales, would be a subject of further US-China discussions. At any rate, the United States made plain in its December 1978 statement on normalisation its expectation that the Taiwan question will be settled peacefully by the Chinese themselves. (This was in contrast to the December 1978 statement of China on normalisation, which said that the Taiwan question "has now been resolved between the two sides')

10 NED was established under President Reagan and is funded by Congress. In 2000, it gave the following small grants to Tibetan groups: 'International Campaign for Tibet- $\$ 30,000$-to support meetings, symposia, speeches, publications and articles designed to improve communication between Tibetans and Chinese; Tibetan Literary Society- $\$ 20,000$-to publish the Tibet Times, a Tibetan language newspaper providing in-depth coverage of Tibetan, local and international issues for Tibetans in Tibet, international audiences and Tibetan exiles; Tibetan Multimedia Centre$\$ 30,000$ - to disseminate news and information about the struggle for a democratic Tibet inside Tibet and China, among Chinese democrats throughout the world, throughout the exile communities of Tibetans in India, and to the Indian public; Tibetan Review $-\$ 20,000$ - to publish and distribute Tibetan Review, a monthly English language news magazine, throughout the Tibetan community in exile and international community'.

1 A measure echoing similar resolutions in earlier years.

12 Her predecessor, Julia Taft, had the rank of Assistant Secretary of State.

${ }^{13}$ See State Dept website, http://usinfo.state.gov/regional/ea/uschina/rez357.htm

${ }^{14}$ Between 1944 and 1950 in the area around Yining, Uighur nationalists managed to establish an independent East Turkestan.

${ }^{15}$ A recent study of Xinjiang in the 1990s, albeit one based on fieldwork mostly conducted several years ago, supports the general thrust of the assessment this paper is suggesting, though it differs on some of the causes. The study by Nicholas Becquelin (2000:54, 90) concludes that the '1990s led to a very major shift in relations between the state and society in Xinjiang'. The system had changed, the author suggested, from one that discriminated (presumably positively) on the basis of nationality to one that segregated on the basis of nationality. The study identified major risks in Beijing's current strategy in the XUAR, and described the heightening of inter-ethnic 
conflicts-and in southern Xinjiang in particular, a renewed repressive climate and increased segregation. (The Becquelin study appears to differ from this paper in its emphasis on new Han migration into Xinjiang, whereas this paper has reported a net outflow of Han Chinese. Becquelin does note that 'information on recent Han arrivals is extremely difficult to verify'.)

${ }^{16}$ See Seymour (2000). Seymour notes that the Corps is a 'major institution for the ethnic Han (Chinese) colonisation of Xinjiang'. 'Although quasi-military in origin, its military role is now eclipsed by its economic role. Traditionally it was primarily a collection of state farms, but in recent years its industrial enterprises have expanded. It has also played a role in imprisoning convicts from eastern China. Largely destroyed during the Cultural Revolution, it was actually abolished for a few years beginning in 1975. But the perceived need to project Chinese influence into the area, and to protect against ethnic unrest and Soviet pressures, persuaded the authorities that the Corps should be revived. Today the Corps has 2.8 million members, or 14 per cent of Xinjlang's population, and plays a significant role in the region's economy'. According to the Uighur American Association, the Corps has a special legal status that subordinates it to Beijing, not to the Autonomous Regional government; the Corps plays an integral part in Beijing's strategies for control of the region; and the Corps' exploitative activities are the main source of the 'ethnic' rebellion in the XUAR (Uyghur American Association n.d.).

${ }^{17}$ Interviews with the author, October 2000.

18 UNSC Resolution 1214, 8 December 1998; Resolution 1267, 15 October 1999; Resolution 1333, 19 December 2000.

19 See, for example, Ba Ren (2001:n.p.). Two excerpts are indicative: 'To China, it means that the US fills the last gap in the northeast of its ring of encirclement (or at least hammers in a wedge). If the US uses the opportunity to occupy Afghanistan, or set up a puppet government in that country, the US military stationed in Afghanistan and in the Persian Gulf will take up two corners, and possibly use national and religious factors to give strategic pressure on China's western region. China will feel prickles down his back...To summarise the above, if the US military marches into Afghanistan, the strategic situation as a result of the military actions will greatly change, accelerate the demolition of the original power balance in Central Asia, and make Central Asia a region with a prominently unbalanced security mechanism in the world. We should attach enough importance and be vigilant to this possible variable of the international security situation that has an effect on China.'

o See, for example, Xinhua Domestic Service, 3 August 1997, carried in FBIS-CHI-97-217: 'US Central Asian strategy faces challenges'.

27. The members are China, Russia, Tajikistan, Kyrgyzstan, Kazakhstan (the original Shanghai Five) and Uzbekistan. The negotiations built on significant progress that had been made between China and the USSR before 1991. 
2 See Article 2 of the Declaration on the Creation of the Shanghai Cooperation Organisation.

${ }^{23}$ See Article 5.

${ }^{24}$ See International Crisis Group (2003). The present author was the principal author of that ICG report.

\section{REFERENCES}

Arkin, W.M., 2002. 'Secret plan outlines the unthinkable', Los Angeles Times, 10 March.

Austin, G., 1997. 'The Taiwan issue in Japanese domestic politics', in Austin, G. (ed.), 1997. Missile Diplomacy and Taiwan's Future: Innovations in Politics and military power, Canberra Papers in Strategy and Defence, Strategic and Defence Studies Centre, The Australian National University, Canberra.

- 1998. China's Ocean Frontier: international law, military force and national development, Allen \& Unwin, St Leonards.

- 2003. 'Philippines Spratly policy as a case study in conflict enhancement', Security Dialogue, 34(1):41-54.

Australian Strategic Policy Institute, Beyond Bali: ASPI's strategic assessment, 2002, Australian Strategic Policy Institute, Canberra. Available online at http:// www.aspi.org.au/beyondbali/2.html.

Ba Ren, 2001. 'The United States meddles with Afghanistan to kill three birds with one stone: on the White House's military deployment and variable of Central Asian strategic patterns', Ta kung pao (Internet version), 24 September. Reprinted in FBIS-CHI-2001-0924.

Becquelin, N., 2000. 'Xinjiang in the 1990s', China Journal, 44:65-90.

Embassy of the People's Republic of China in Australia, 2002. Full text of Jiang Zemin's Report at $16^{\text {th }}$ Party Congress, Chinese Embassy to Australia, Canberra. Available online at www.chinaembassy.org.au/eng/37883.html.

Government of the United States of America, 2002. The National Security Strategy of the United States, White House, Washington, DC. Available online at http:// www.whitehouse.gov/nsc/nssall.html [accessed September 2002].

International Crisis Group, 2003. Taiwan Strait III: the path to peace, International Crisis Group, Brussels. Available online at www.crisisweb.org [accessed June 2003].

Kemenade, W.V. and Webb, D., 1998. China, Hong Kong, Taiwan, Inc, Vintage, New York. 
Knaus, J.K., 2000. 'An uncertain ally: the US government and Tibet', Harvard Asia Quarterly, 4(3):n.p. Available online at www.fas.harvard.edu.

Lampton, D.M. and May, G.C., 1999. Managing US-China Relations in the TwentyFirst Century, The Nixon Center, Washington, DC. Available online at www.nixoncenter.org.

PRC State Council Information Office, 2002. China's National Defense in 2002, Full Text of White Paper issued by the PRC State Council Information Office, 9 December. Reprinted by FBIS-CHI-2002-1209: 'Full Text of China's National Defense White Paper'.

Seymour, J.D., 2000. 'Xinjiang's production and construction corps, and the sinification of Eastern Turkestan', Inner Asia, 2(2):171-93.

South Asia Analysis Group, 1999. Continuing Unrest in Xinjiang: an update, South Asia Analysis Group, Noida. Available online at www.saag.org/papers [accessed 14 March 1999].

Uyghur American Association, n.d. Bingtuan: Xinjiang production and construction Corp, Uyghur American Association, Virginia. Available online at http:// www.uyghuramerican.org/ET/bintuan/mainpage.html.

Watson, F., 1966. The Frontiers of China, Chatto and Windus, London.

Zhu, T., 2001. 'Nationalism and Chinese foreign policy', The China Review, 1(1):127. 